\title{
RISKIND Verification and Benchmark Comparisons
}

by B.M. Biwer, J.J. Arnish, S. Kamboj, and S.Y. Chen

Environmental Assessment Division,

Argonne National Laboratory, 9700 South Cass Avenue, Argonne, Illinois 60439

\section{DISCLAIMER}

This report was prepared as an account of work sponsored by an agency of the United States Government. Neither the United States Government nor any agency thereof, nor any of their employees, makes any warranty, express or implied, or assumes any legal liability or responsibility for the accuracy, completeness, or usefulness of any information, apparatus, product, or process disclosed, or represents that its use would not infringe privately owned rights. Reference herein to any specific commercial product, process, or service by trade name, trademark, manufacturer, or otherwise does not necessarily constitute or imply its endorsement, recommendation, or favoring by the United States Government or any agency thereof. The views and opinions of authors expressed herein do not necessarily state or reflect those of the United States Government or any agency thereof.

August 1997

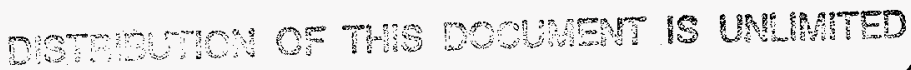<smiles>c1ccccc1</smiles>

Work sponsored by U.S. Department of Energy, Office of Environmental Maragement 
6ry

This report is printed on recycled paper. 


\section{DISCLAMIER}

Portions of this document may be illegible in electronic image products. Images are produced from the best available original document. 


\section{CONTENTS}

ACKNOWLEDGMENTS.

ix

ABSTRACT

1 INTRODUCTION.

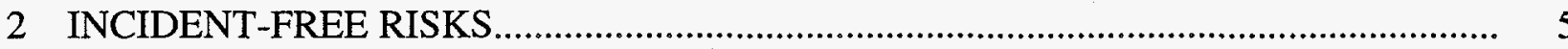

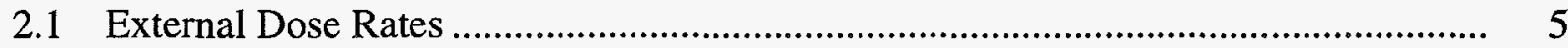

2.1.1 Gamma Radiation............................................................................. 5

2.1.2 Neutron Radiation ........................................................................... 9

2.1.3 Dose Rate Curve Normalization ...................................................... 11

2.1.4 Shape Factor Correction ................................................................... 13

2.2 External Dose from a Passing Spent Fuel Shipment......................................... 15

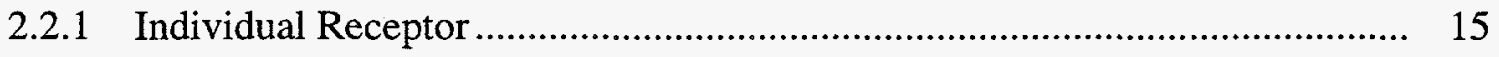

2.2.2 Population Receptor ........................................................................... 16

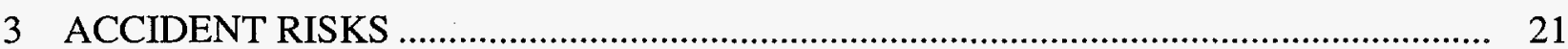

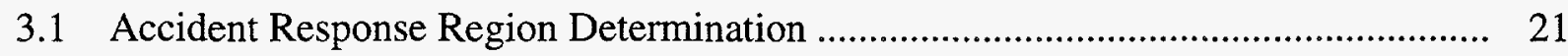

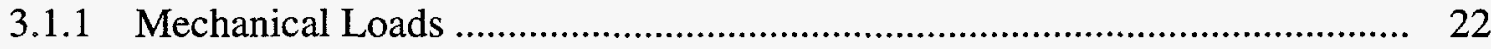

3.1.2 Thermal Loads............................................................................ 25

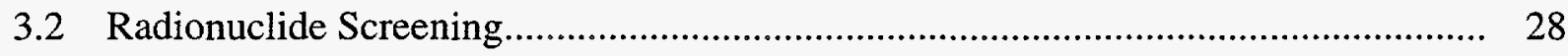

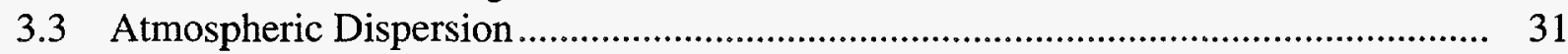

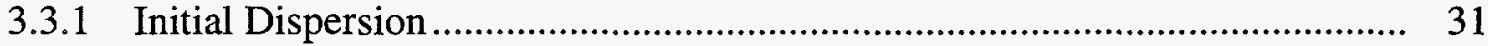

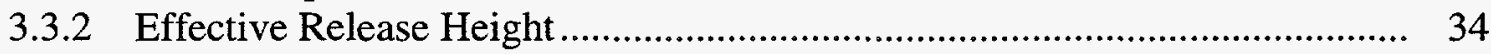

3.3.3 Ground-Level Air Concentrations........................................................ 34

3.3.3.1 Comparison with GENII ......................................................... 34

3.3.3.2 Comparison with CAP88-PC ......................................................... 39

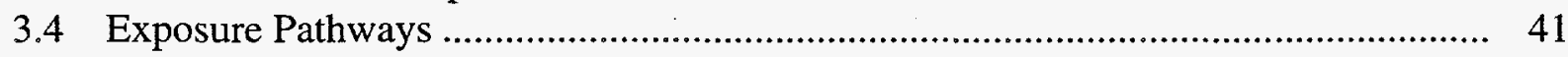

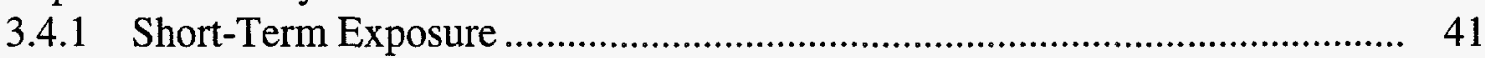

3.4.2 Long-Term Exposure ...................................................................... 43

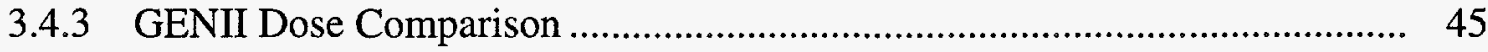

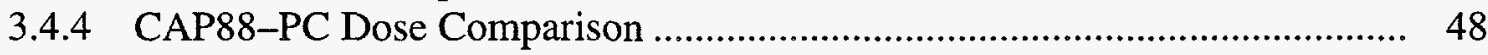

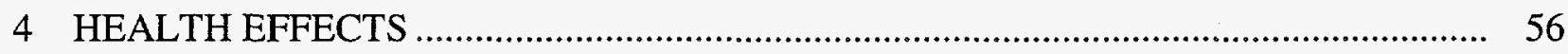

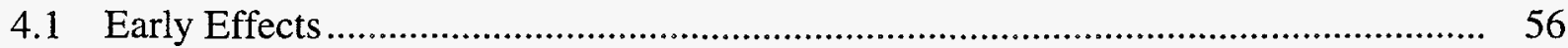

4.1.1 External Exposure ...................................................................... 56

4.1.2 Inhalation Exposure........................................................................ 60

4.1.3 Lethality Risk ........................................................................ 60

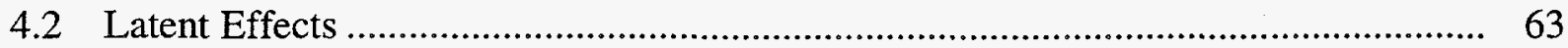




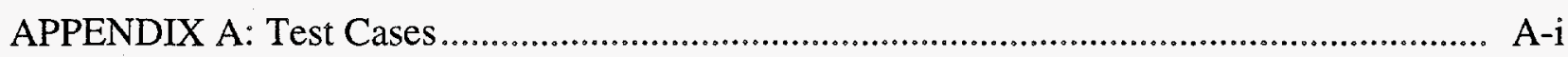

APPENDIX B: Dose Comparison Cases ................................................................. B-i

APPENDIX C: Definitions of Variables Presented in the Spreadsheet Calculations............... C-i

\section{TABLES}

1.1 RISKIND Calculations Verified in This Study ................................................... 3

1.2 RISKIND Benchmark Comparisons Made in This Study ........................................ 4

2.1 Gamma Dose Rates as a Function of Distance Estimated by MicroShield, MCNP, NUREG-0170, and RISKIND.

2.2 Neutron Dose Rates as a Function of Distance Estimated by MCNP and RISKIND...... 10

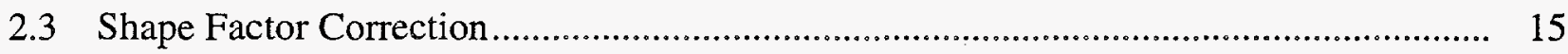

2.4 Calculation of Dose to an Individual from a Passing Shipment ............................. 15

2.5 Gamma Dose Rate Curve Coefficients for Input into RISKIND to Fit the NUREG-0170 Dose Rate Curve

2.6 Comparison of RISKIND, NUREG-0170, and RADTRAN 4 Incident-Free Gamma Radiation Off-Link Population Dose.

2.7 Comparison of RISKIND and RADTRAN 4 Incident-Free Neutron Radiation Off-Link Population Dose

3.1 Impact Velocities Required to Attain 0.2\%, 2\%, and 30\% Strain Levels for Objects Impacted in Highway and Railway Accidents

3.2 Response Region Determination with Variation in Cask Velocity.

3.3 Response Region Determination with Variation in Cask Impact Angle 26

3.4 Response Region Determination with Variation in Cask Orientation Angle 26 


\section{TABLES (Cont.)}

3.5 Heat Flux Factors for Flame Temperatures.

3.6 Fire Duration Required to Reach the Four Levels of Lead Midlayer Thickness

Temperatures for a 1,200 K Engulfing Fire

3.7 Radionuclide Screening Value for Case 2

3.8 Comparison of RISKIND and GENII Air Concentration Calculations

3.9 Comparison of RISKIND and CAP88-PC Air Concentration Calculations.

3.10 Calculated Doses from Short-Term Exposure

3.11 Time-Integrated Ground and Resuspended Air Concentrations for Use in Long-Term Exposure Calculations

3.12 Calculated Individual Doses from Long-Term Exposure to External Radiation from Ground Contamination and to External and Internal Radiation from Resuspended Air Contamination

3.13 Calculated Radionuclide Concentrations in Vegetables, Meat, and Milk.

3.14 Calculated Individual Doses from Ingestion of Vegetables, Meat, and Milk 48

3.15 Contaminated Drinking Water Radionuclide Concentrations and Doses from Individual Consumption.

3.16 Comparison of RISKIND and GENII Dose Calculations for a 1-Ci

Cs-137 Release

3.17 Comparison of RISKIND and GENII Individual Dose Calculations

for a Hypothetical Spent Fuel Transportation Accident.

3.18 Comparison of RISKIND and CAP88-PC Doses Calculated for a 1-Ci

Cs-137 Release

3.19 Comparison of RISKIND and CAP88-PC Individual Doses Calculated for a Hypothetical Spent Fuel Transportation Accident.

4.1 Brief Doses to the Bone Marrow, Gastrointestinal Tract, and Lungs....

4.2 Brief Dose Rates to the Bone Marrow, Gastrointestinal Tract, and Lungs. 


\section{TABLES (Cont.)}

4.3 Protracted Inhalation Doses and Dose Rates from the Exposure of Bone Marrow, Gastrointestinal Tract, and Lungs to Radionuclides

4.4 Latent Health Risks for an Individual

\section{FIGURES}

2.1 Comparison of RISKIND, MicroShield, MCNP, and NUREG-0170

Gamma Dose Rates

2.2 Comparison of RISKIND, MicroShield, MCNP, and NUREG-0170

Gamma Dose Rates When the Receptor Is Near the Source.

2.3 Comparison of RISKIND and MCNP Neutron Dose Rates

2.4 Comparison of RISKIND and MCNP Neutron Dose Rates

When the Receptor Is Near the Source

2.5 Dose Rate Curve Normalization Calculations for Case 1

2.6 Dose Rate Shape Factor Calculations for Case 1 .................................................... 14

2.7 Method for Estimating the Dose from a Passing Shipment ......................................... 16

2.8 Area Used by RISKIND to Predict Incident-Free Off-Link Population Risks ................ 17

3.1 Matrix of Cask Response Regions and Probabilities of Occurrence for Combined Mechanical and Thermal Loads

3.2 Three Impact Loading Parameters Considered in the Response Analysis for Impacts on Surfaces.

3.3 Radionuclide Screening Calculations for Cs-137 ................................................... 30

3.4 Initial Pasquill-Gifford Horizontal and Vertical Dispersion Parameter Estimates ........... 33

3.5 Initial Briggs Horizontal and Vertical Virtual Distance Estimates ................................. 33

3.6 Effective Release Height Calculation in RISKIND ....................................................... 35

3.7 Pasquill-Gifford Dispersion Coefficient Calculations ................................................ 36 


\section{FIGURES (Cont.)}

3.8 Briggs Dispersion Coefficient Calculations

3.9 Ground-Level Air Concentration for Radionuclide $i$ by Using Pasquill-Gifford

Dispersion Coefficients without Plume Reflection

3.10 Ground-Level Air Concentration for Radionuclide $i$ by Using Pasquill-Gifford

Dispersion Coefficients with Plume Reflection

3.11 Ground-Level Air Concentration for Radionuclide $i$ by Using Briggs Dispersion Coefficients without Plume Reflection

3.12 Dose Calculations for Short-Term Exposure to Cs-137.

3.13 Time-Integrated Ground and Resuspended Air Concentration Calculations

for Long-Term Exposure to Cs-137

3.14 Groundshine, Cloudshine, and Inhalation Dose Calculations for Long-Term Exposure to Cs-137

3.15 Vegetable Ingestion Dose Calculations for Exposure to Cs-137.

3.16 Initial and Long-Term Cs-137 Concentrations in Vegetation for Animal Consumption

3.17 Meat Ingestion Dose Calculations for Exposure to Cs-137

3.18 Milk Ingestion Dose Calculations for Exposure to Cs-137.

3.19 Water Consumption Dose Calculations for Exposure to Cs-137.

4.1 Short-Term External Dose and First-Year Inhalation Dose to the Bone Marrow from Cs-137

4.2 Short-Term External Dose and First-Year Inhalation Dose to the Gastrointestinal Tract from Cs-137.

4.3 Short-Term External Dose and First-Year Inhalation Dose to the Lungs from Cs-137.

4.4 One-Year Retention Function Calculation for Cs-137 in Bone Marrow

4.5 Inhalation Dose Calculations for the Early Effects from the Exposure of Bone Marrow to Cs-137 


\section{FIGURES (Cont.)}

4.6 Inhalation Dose Calculations for the Early Effects from the Exposure of the Gastrointestinal Tract to Cs-137

4.7 Inhalation Dose Calculations for the Early Effects from the Exposure of the Lungs to Cs-137

4.8 Lethality Hazard Calculations for Bone Marrow . 68

4.9 Lethality Hazard Calculations for the Gastrointestinal Tract 69

4.10 Lethality Hazard Calculations for the Lungs 70

4.11 Lethality Risk Calculations for Case 3. 


\section{ACKNOWLEDGMENTS}

The authors wish to express their thanks to their colleagues David LePoire and Frederick Monette for providing internal review and valuable suggestions. Thanks are also extended to the program managers within the Environmental Assessment Division who provided opportunities to use the code in various environmental programs and also provided support for this study: Halil Avci, Kenneth Cornelius, Marsha Goldberg, and Frederick Monette. Finally, we thank Marita Moniger for editorial assistance and the Information and Publishing Division Document Processing and Control Center for document preparation.

The authors also wish to thank the U.S. Department of Energy, Office of Civilian Radioactive Waste Management, for the original funding of this project to produce RISKIND (v. 1.11). 


\title{
RISKIND VERIFICATION AND BENCHMARK COMPARISONS
}

\author{
by
}

\author{
B.M. Biwer, J.J. Arnish, S. Kamboj, and S.Y. Chen
}

\begin{abstract}
This report presents verification calculations and benchmark comparisons for RISKIND, a computer code designed to estimate potential radiological consequences and health risks to individuals and the population from exposures associated with the transportation of spent nuclear fuel and other radioactive materials. Spreadsheet calculations were performed to verify the proper operation of the major options and calculational steps in RISKIND. The program is unique in that it combines a variety of well-established models into a comprehensive treatment for assessing risks from the transportation of radioactive materials. Benchmark comparisons with other validated codes that incorporate similar models were also performed. For instance, the external gamma and neutron dose rate curves for a shipping package estimated by RISKIND were compared with those estimated by using the MCNP and MicroShield 4 codes and NUREG-0170 methodology. Doses from external radiation from a passing shipment estimated by RISKIND were compared with those estimated by using the RADTRAN 4 code and NUREG-0170 methodology. Atmospheric dispersion of released material and dose estimates related to potential transportation accidents were compared with estimates from the GENII and CAP88-PC codes. Verification results have shown the program to be performing its intended function correctly. The benchmark results indicate that the predictions made by RISKIND are within acceptable limits when compared with predictions from similar existing models.
\end{abstract}

\section{INTRODUCTION}

The RISKIND computer code was developed at Argonne National Laboratory (ANL) under the auspices of the U.S. Department of Energy (DOE), Office of Civilian Radioactive Waste Management, to address public concerns with regard to the transportation of spent nuclear fuel (SNF) (Yuan et al. 1993). A revision to the RISKIND program (Yuan et al. 1995) added a number of new features, including the capability to assess the risks from transporting SNF and other radioactive materials. RISKIND is used to assess the risks to a nearby person or a group of people from the external radiation emanating from a shipping package of radioactive materials during routine, incident-free transport or from the possible release of radioactive material as the result of potential accidents. Its primary objective is to evaluate the risks to specific individuals and population subgroups by using local, site-specific input data. RISKIND provides answers to the "what if" situations postulated by those concerned about shipments passing through their area of interest. 
To answer these types of questions by stakeholders, a modified version of the original program was used for a number of past environmental impact statements (EISs), including the Department of Energy Programmatic Spent Nuclear Fuel Management and Idaho National Engineering Laboratory Environmental Restoration and Waste Management Programs Final Environmental Impact Statement (DOE 1995), Final Environmental Impact Statement on a Proposed Nuclear Weapons Nonproliferation Policy Concerning Foreign Research Reactor Spent Nuclear Fuel (DOE 1996), and Final Waste Management Programmatic Environmental Impact Statement (DOE 1997). Proper operation of the code was independently documented (Maheras and Pippen 1995).

This acceptance of RISKIND by stakeholders has increased its use for transportation risk analysis in other areas. For example, the latest version of RISKIND (version 1.11) is also being applied at the state level for oversight of transportation activities (Deng et al. 1996; Baepler et al. 1996). It is therefore important to assure users that the program is performing properly.

The study discussed in this report had two objectives: (1) verify the proper operation of the code and (2) benchmark the code against previously accepted codes to show that the results are reasonable. We performed independent verification by using calculations external to the RISKIND code; Microsoft Excel (version 7) spreadsheets were used to verify all the major portions of the program discussed in this report. We conducted this verification on a step-by-step basis and used several test cases as templates, since all possible options could not be considered in a single analysis. The files used as input to and output from RISKIND (version 1.11) are provided in Appendix A. We introduced each test case for the verification as needed. The types of calculations we investigated are listed in Table 1.1. The calculations are presented as figures throughout this document. The equation numbers shown next to the calculations correspond with the numbers in the RISKIND manual (Yuan et al. 1995). In addition to verifying each major calculational step in the model, we benchmarked a set of results from the model against results from similar models in other programs, if available. Table 1.2 lists the benchmark comparisons made for this study.

The purpose of the benchmark cases was to help check the proper operation of the code and help validate the new code. In general, the various models incorporated in RISKIND are well established and needed little, if any, validation. The unique feature of RISKIND is that it combines these models into a comprehensive program for assessing risks from the transportation of SNF and other radioactive materials. The benchmark cases also helped provide a better understanding of the models incorporated in the code. A model's applicability and limitations become apparent when it is compared with known solutions or other estimates based on previously validated models (codes). The cases discussed in this report exercise the major options available in RISKIND. 


\section{TABLE 1.1 RISKIND Calculations Verified in This Study}

Incident-free calculations

- Dose rate curve normalization

- Shape factor adjustment for package size

- Individual dose from a stationary shipment

- Individual dose from a passing shipment

- Population dose from a passing shipment

\section{Accident calculations}

- Accident response region determination

- Radionuclide screening

- Atmospheric dispersion

$\checkmark$ Effective wind speed and release height

$\checkmark \quad$ Initial puff size and virtual distances

$\checkmark$ Buoyancy induced dispersion

$\checkmark$ Pasquill-Gifford and Briggs dispersion coefficients

$\diamond$ Ground-level air concentrations

- Individual dose from short-term exposure

$\checkmark$ External dose from passing cloud

$\diamond$ External dose from contaminated ground

$\diamond$ Internal dose from inhalation during cloud passage

- Individual dose from long-term exposure

$\diamond$ External dose from resuspended contamination

$\diamond$ External dose from contaminated ground

$\checkmark$ Internal dose from inhalation of resuspended contamination

$\diamond \quad$ Internal dose from ingestion of contaminated food and water

- Individual fatality risk from acute health effects

- Individual risk from long-term health effects 
TABLE 1.2 RISKIND Benchmark Comparisons Made in This Study

Type of

Calculation

Incident-free

Default gamma dose rate curve

Default neutron dose rate curve

Shape factor correction

Gamma and neutron doses from a passing shipment

Accident

$$
\text { Ground-level air concentrations }
$$

Short-term inhalation, cloudshine, and groundshine doses

Ingestion doses

Short-term inhalation and cloudshine doses
Model Used for Comparison

MCNP, MicroShield, and NUREG-0170

MCNP

MicroShield

NUREG-0170/RISKIND, RADTRAN 4

GENII (Pasquill-Gifford coefficients) and CAP88-PC (Briggs coefficients)

GENII

GENII

CAP88-PC 


\section{INCIDENT-FREE RISKS}

Risks from the routine transport of radioactive material result from the external radiation emanating from the shipping package in the vicinity of the transport vehicle. The nature of the radiation can be gamma rays or neutrons that penetrate their package walls and escape to the outside. Alpha or beta particles do not contribute to such radiation since they are unable to penetrate container walls. Therefore, the magnitude of the risk involved depends on the (1) external dose rates of the shipping package from gamma rays and neutrons, (2) distance of any potential receptors from the package, and (3) amount of time spent near the package by a receptor.

The calculation of routine risks requires that the gamma and neutron dose rates be determined as a function of distance (dose rate curves). The model's default dose rate curves must then be scaled to match the dose rate input by the user for a receptor located 1 or $2 \mathrm{~m}$ from the source. Sections 2.1.1 and 2.1.2 compare the default dose rate curves in RISKIND with those of other models. However, RISKIND allows users to provide their own specific gamma and neutron dose rate curves as input.

Section 2.1.3 introduces a routine risk analysis, test case 1, and discusses how the scaling process is verified through sample spreadsheet calculations. The default dose rate curves in RISKIND are for an SNF uranium/water-shielded cask of specific dimensions that contains spent PWR fuel. An option is available to adjust the dose rates for different size casks by using a cylindrical surface source model. Section 2.1.4 shows spreadsheet calculations used to verify the proper operation of this model within the code.

\subsection{EXTERNAL DOSE RATES}

The external dose of radiation received by a receptor from a stationary shipment depends on the distance of separation between the receptor and radiation source and the magnitude of the source's radiation. The external gamma and neutron dose rate curves used by RISKIND were developed specifically for a spent fuel cask (Chen and Yuan 1988). The dose rates were obtained by using a three-dimensional (3-D) Monte Carlo method that considered air and ground scattering. The dose rate curves were then normalized to match the dose rate to a receptor located 1 or $2 \mathrm{~m}$ from the waste package of interest. Dose rates were determined for a cylindrical package $5.46 \mathrm{~m}$ long with a radius of $0.56 \mathrm{~m}$ (RISKIND default shipping cask dimensions).

\subsubsection{Gamma Radiation}

The default gamma dose rate curve supplied with RISKIND was compared with those estimated by the MicroShield 4TM (Negin and Worku 1992a,b), MCNPTM (Briesmeister 1993), and Nuclear Regulatory Commission (NRC 1977) models. Data from this comparison are shown in Table 2.1 and plotted in Figures 2.1 and 2.2. All gamma dose rates were normalized to 
TABLE 2.1 Gamma Dose Rates (mrem/h) as a Function of Distance Estimated by MicroShield, MCNP, NUREG-0170, and RISKINDa

\begin{tabular}{cccccc}
\hline $\begin{array}{c}\text { Distance } \\
(\mathrm{m})\end{array}$ & $\begin{array}{c}\text { RISKIND } \\
\text { Default }\end{array}$ & MicroShield & MCNP & $\begin{array}{c}\text { Roint } \\
\text { Source }\end{array}$ & $\begin{array}{c}\text { NUREG- } \\
0170\end{array}$ \\
\hline 1 & $2.1 \mathrm{E}+01$ & $2.2 \mathrm{E}+01$ & $2.0 \mathrm{E}+01$ & $3.9 \mathrm{E}+01$ & $4.0 \mathrm{E}+01$ \\
2 & $1.0 \mathrm{E}+01$ & $1.0 \mathrm{E}+01$ & $1.0 \mathrm{E}+01$ & $1.0 \mathrm{E}+01$ & $1.0 \mathrm{E}+01$ \\
5 & $2.6 \mathrm{E}+00$ & $2.5 \mathrm{E}+00$ & $2.7 \mathrm{E}+00$ & $1.7 \mathrm{E}+00$ & $1.6 \mathrm{E}+00$ \\
7 & $1.5 \mathrm{E}+00$ & $1.4 \mathrm{E}+00$ & $1.5 \mathrm{E}+00$ & $8.7 \mathrm{E}-01$ & $8.1 \mathrm{E}-01$ \\
10 & $7.8 \mathrm{E}-01$ & $7.2 \mathrm{E}-01$ & $7.7 \mathrm{E}-01$ & $4.3 \mathrm{E}-01$ & $3.9 \mathrm{E}-01$ \\
15 & $3.6 \mathrm{E}-01$ & $3.4 \mathrm{E}-01$ & $3.5 \mathrm{E}-01$ & $1.9 \mathrm{E}-01$ & $1.7 \mathrm{E}-01$ \\
20 & $2.0 \mathrm{E}-01$ & $1.9 \mathrm{E}-01$ & $1.9 \mathrm{E}-01$ & $1.0 \mathrm{E}-01$ & $9.7 \mathrm{E}-02$ \\
30 & $8.8 \mathrm{E}-02$ & $8.5 \mathrm{E}-02$ & $8.6 \mathrm{E}-02$ & $4.4 \mathrm{E}-02$ & $4.2 \mathrm{E}-02$ \\
50 & $2.9 \mathrm{E}-02$ & $3.1 \mathrm{E}-02$ & $2.8 \mathrm{E}-02$ & $1.4 \mathrm{E}-02$ & $1.5 \mathrm{E}-02$ \\
70 & $1.3 \mathrm{E}-02$ & $1.5 \mathrm{E}-02$ & $1.3 \mathrm{E}-02$ & $6.6 \mathrm{E}-03$ & $7.1 \mathrm{E}-03$ \\
100 & $5.7 \mathrm{E}-03$ & $7.0 \mathrm{E}-03$ & $5.5 \mathrm{E}-03$ & $2.8 \mathrm{E}-03$ & $3.3 \mathrm{E}-03$ \\
150 & $2.0 \mathrm{E}-03$ & $2.7 \mathrm{E}-03$ & $1.8 \mathrm{E}-03$ & $9.7 \mathrm{E}-04$ & $1.3 \mathrm{E}-03$ \\
200 & $8.8 \mathrm{E}-04$ & $1.3 \mathrm{E}-03$ & $7.5 \mathrm{E}-04$ & $4.2 \mathrm{E}-04$ & $6.4 \mathrm{E}-04$ \\
300 & $2.3 \mathrm{E}-04$ & $3.6 \mathrm{E}-04$ & $1.5 \mathrm{E}-04$ & $1.1 \mathrm{E}-04$ & $2.2 \mathrm{E}-04$ \\
400 & $7.6 \mathrm{E}-05$ & $1.2 \mathrm{E}-04$ & $4.2 \mathrm{E}-05$ & $3.7 \mathrm{E}-05$ & $9.5 \mathrm{E}-05$ \\
500 & $2.8 \mathrm{E}-05$ & $4.2 \mathrm{E}-05$ & $1.1 \mathrm{E}-05$ & $1.3 \mathrm{E}-05$ & $4.6 \mathrm{E}-05$ \\
600 & $1.1 \mathrm{E}-05$ & $1.5 \mathrm{E}-05$ & $4.1 \mathrm{E}-06$ & $5.3 \mathrm{E}-06$ & $2.4 \mathrm{E}-05$ \\
700 & $4.5 \mathrm{E}-06$ & $5.9 \mathrm{E}-06$ & $1.1 \mathrm{E}-06$ & $2.2 \mathrm{E}-06$ & $1.3 \mathrm{E}-05$ \\
800 & $2.0 \mathrm{E}-06$ & $2.3 \mathrm{E}-06$ & $3.2 \mathrm{E}-07$ & $9.4 \mathrm{E}-07$ & $7.3 \mathrm{E}-06$ \\
\hline
\end{tabular}

a Normalized to $10 \mathrm{mrem} / \mathrm{h}$ at $2 \mathrm{~m}$.

$10 \mathrm{mrem} / \mathrm{h}$ at a distance of $2 \mathrm{~m}$ from the cask surface. The MicroShield and MCNP calculations assumed a shipping package having the same shape and size as those of the RISKIND default package (cylinder $5.46 \mathrm{~m}$ long with a $0.56-\mathrm{m}$ radius). The dose rate curve described in NUREG0170, the NRC (1977) report, is for a point source (rather than a cylindrical source) model. Therefore, a second RISKIND curve that used an approximation for a point source was generated for comparison; the cask length and radius were both set to $0.0001 \mathrm{~m}$ (a value of $0.001 \mathrm{~m}$ produces the same result).

MicroShield is an analytical point-source kernel model program for estimating gamma radiation shielding and exposure. Its validation and verification have been well-documented (Negin and Worku 1992a,b). For MicroShield, a cylindrical surface source model was used, and the same gamma energy spectrum (ranging from 0.3 to $2 \mathrm{MeV}$ ) that was used to generate the RISKIND curve was input (RSIC 1981). In general, approximately $98 \%$ of the gamma radiation from the surface of a spent fuel cask is within the 0.4-0.9 MeV range (Sandquist et al. 1985). MicroShield calculations take air attenuation and buildup into account, but the code does not address ground scattering. As can be seen in Figures 2.1 and 2.2, the agreement between the 


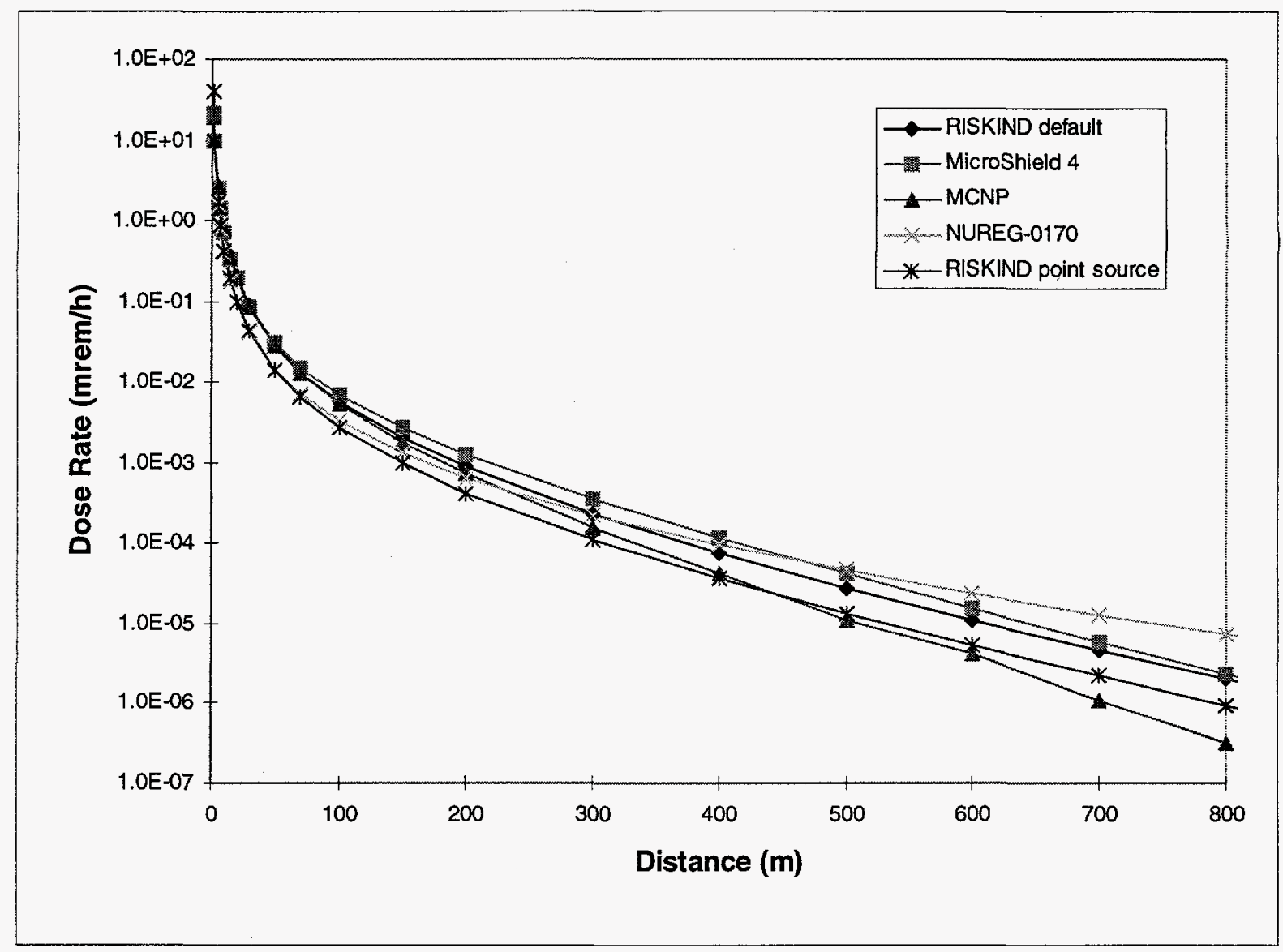

FIGURE 2.1 Comparison of RISKIND, MicroShield, MCNP, and NUREG-0170 Gamma Dose Rates

MicroShield and RISKIND results was quite good; the RISKIND curve stayed within $35 \%$ of the MicroShield results at the maximum deviation at distances of approximately 300 to $400 \mathrm{~m}$.

MCNP is a general-purpose, Monte Carlo, photon and neutron transport code (Briesmeister 1993). It has been successfully benchmarked against experimental data for both photon (Whalen et al. 1991a) and neutron (Whalen et al. 1991b) transport. The MCNP calculations also used a cylindrical surface source having the same size and gamma spectrum as those used for the RISKIND and MicroShield calculations. Calculations took ground scattering (concrete) into account because ground scattering is considered in the default RISKIND dose rates. Figure 2.2 shows that the agreement between RISKIND and MCNP was excellent within the first $100 \mathrm{~m}$. A difference of only about $5 \%$ or less in the dose rates was observed within this range. At further distances, where the inherent uncertainties in the Monte Carlo scattering calculations are magnified for both codes because of fewer photons, MCNP calculations resulted in slightly lower dose rates; the difference between MCNP and RISKIND reached a factor of about six at $800 \mathrm{~m}$. 


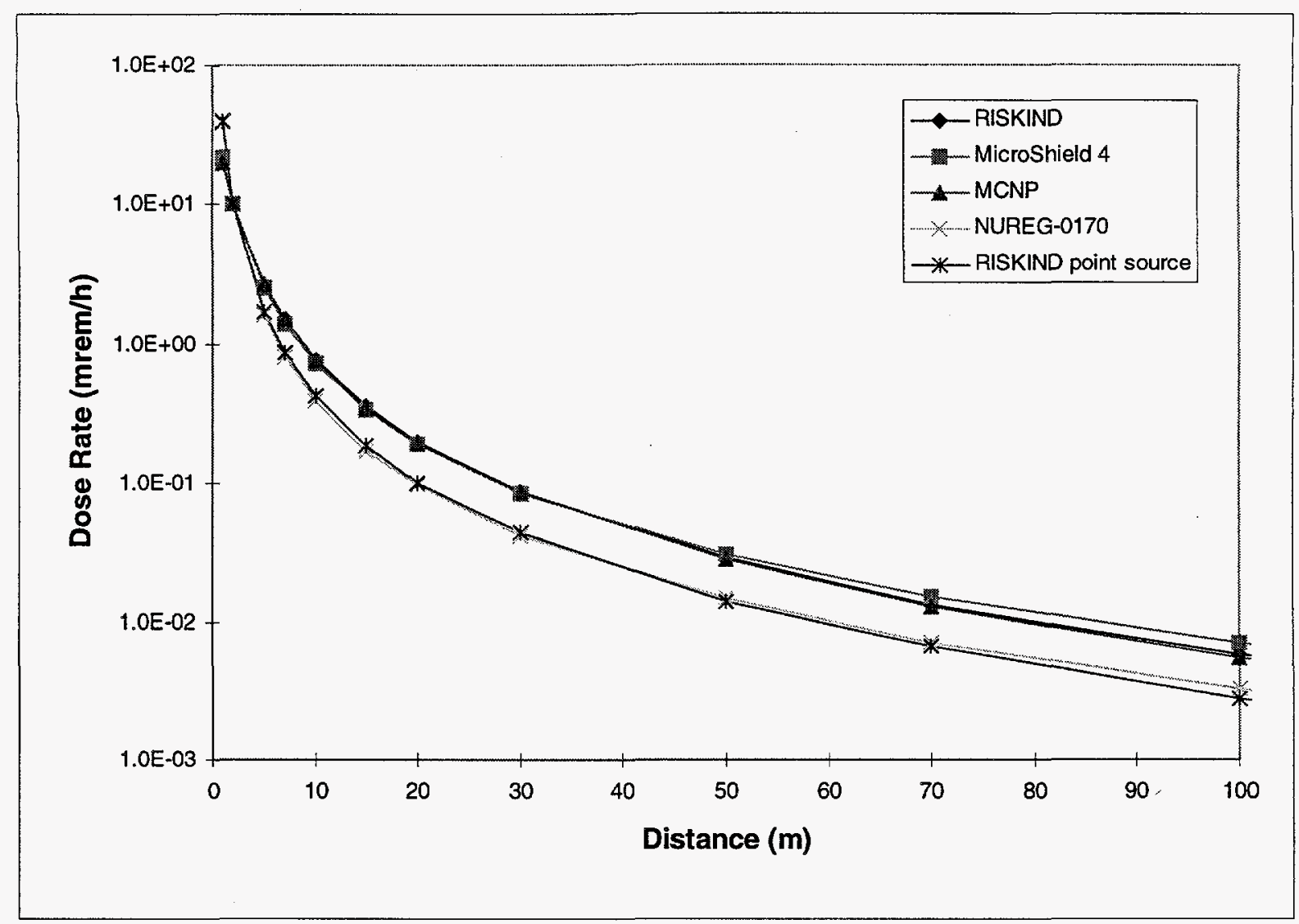

FIGURE 2.2 Comparison of RISKIND, MicroShield, MCNP, and NUREG-0170 Gamma Dose Rates When the Receptor Is Near the Source

Statistical errors for the RISKIND default curve were estimated to be less than $20 \%$ at distances less than $100 \mathrm{~m}$ and can be as high as about $50 \%$ at $800 \mathrm{~m}$ when generated by using the MORSE Monte Carlo transport code (Chen and Yuan 1988). For the MCNP calculations, the statistical errors were expected to be less than $2 \%$ at distances less than $100 \mathrm{~m}$ and were as high as about $20 \%$ at $800 \mathrm{~m}$. At the far distances, the number of photons available for scattering decreases drastically, resulting in pronounced uncertainties. However, because of the good agreement at near distances and the sharp decrease in dose rates at far distances, the uncertainties were not expected to affect the overall consequences in any significant manner.

The NRC report, NUREG-0170, describes a point-source model that uses a gamma dose rate curve for analyzing risk associated with the transportation of radioactive materials. The dose rate incorporates air attenuation and buildup and is of the following form:

$$
D(d)=\frac{K e^{-\mu d} B(d)}{d^{2}},
$$

where: 


$$
\begin{aligned}
\mathrm{D}(\mathrm{d}) & =\text { dose rate at distance } \mathrm{d}(\mathrm{mrem} / \mathrm{h}) \\
\mathrm{d} & =\text { distance from the source }(\mathrm{ft}) ; \\
\mu & =\text { absorption coefficient for air }\left(0.00118 \mathrm{ft}^{-1}\right) ; \\
\mathrm{B}(\mathrm{d}) & =\text { Berger buildup factor in air, } \mathrm{B}(\mathrm{d})=0.0006 \mathrm{~d}+1 \text { (dimensionless); and } \\
K & =\text { dose rate factor }\left(\mathrm{mrem}^{-\mathrm{ft}^{2}} / \mathrm{h}\right) .
\end{aligned}
$$

Normalized to $10 \mathrm{mrem} / \mathrm{h}$ at $2 \mathrm{~m}$, the value for $\mathrm{K}$ was taken to be $432 \mathrm{mrem}-\mathrm{ft}^{2} / \mathrm{h}$. Figures 2.1 and 2.2 compare this NRC model with a RISKIND point-source approximation. The agreement was excellent within the first $70 \mathrm{~m}$; there was less than $5 \%$ difference at any point, despite a decrease in the dose rate of more than three orders of magnitude. Agreement between the two models diverged at distances beyond $100 \mathrm{~m}$. The NUREG-0170 values became increasingly more conservative, differing from the RISKIND results by a factor of about eight at a distance of $800 \mathrm{~m}$.

It can be seen from the model comparison in Figures 2.1 and 2.2 that the gamma dose rate curve for RISKIND is quite reasonable. RISKIND's default dose rate curve is in excellent agreement (within a difference of about $5 \%$ ) with those of the other cylindrical surface models (MCNP and MicroShield) at near distances, where dose rates are highest. At further distances, RISKIND's default dose rate curve tends to stay within the limits defined by the MicroShield and MCNP results. Even when RISKIND is compared with the simple point-source model used in NUREG-0170, excellent agreement occurs at near distances and results diverge slightly at distances greater than about $100 \mathrm{~m}$. At far distances, however, NUREG-0170 exhibits a conservative trend. For instance, at $800 \mathrm{~m}$, NUREG-0170's estimated dose rate reaches a level eight times higher than RISKIND's.

\subsubsection{Neutron Radiation}

A comparison of RISKIND and MCNP neutron dose rates was made (Briesmeister 1993). RISKIND's and MCNP's estimated neutron dose rates as a function of distance are compared in Table 2.2 and plotted in Figures 2.3 and 2.4. All dose rates were normalized to $10 \mathrm{mrem} / \mathrm{h}$ at a distance of $2 \mathrm{~m}$ from the cask surface.

The same neutron energy spectrum (ranging from 0.1 to $15 \mathrm{MeV}$ ) that was used to generate the RISKIND default curve (RSIC 1981) was input to MCNP. The MCNP calculations also used the same size cylindrical surface source as that used for the RISKIND calculations (RSIC 1981). The MCNP calculations considered ground scattering (concrete), as do the RISKIND calculations. Figures 2.3 and 2.4 show good agreement (about 15\% or less difference) between RISKIND and MCNP within the first $200 \mathrm{~m}$ and differences of $25 \%$ or less out to a distance of $600 \mathrm{~m}$. Because both the RISKIND and MCNP results were based on Monte Carlo 
TABLE 2.2 Neutron Dose Rates as a Function of Distance Estimated by MCNP and RISKINDa

\begin{tabular}{ccc}
\hline $\begin{array}{c}\text { Distance } \\
(\mathrm{m})\end{array}$ & $\begin{array}{c}\text { RISKIND } \\
(\mathrm{mrem} / \mathrm{h})\end{array}$ & $\begin{array}{c}\mathrm{MCNP} \\
(\mathrm{mrem} / \mathrm{h})\end{array}$ \\
\hline $2.0 \mathrm{E}+00$ & $1.0 \mathrm{E}+01$ & $1.0 \mathrm{E}+01$ \\
$5.0 \mathrm{E}+00$ & $2.7 \mathrm{E}+00$ & $3.0 \mathrm{E}+00$ \\
$7.0 \mathrm{E}+00$ & $1.5 \mathrm{E}+00$ & $1.7 \mathrm{E}+00$ \\
$1.0 \mathrm{E}+01$ & $7.7 \mathrm{E}-01$ & $8.8 \mathrm{E}-01$ \\
$1.5 \mathrm{E}+01$ & $3.5 \mathrm{E}-01$ & $4.1 \mathrm{E}-01$ \\
$2.0 \mathrm{E}+01$ & $2.0 \mathrm{E}-01$ & $2.3 \mathrm{E}-01$ \\
$3.0 \mathrm{E}+01$ & $9.0 \mathrm{E}-02$ & $1.1 \mathrm{E}-01$ \\
$5.0 \mathrm{E}+01$ & $3.1 \mathrm{E}-02$ & $3.5 \mathrm{E}-02$ \\
$7.0 \mathrm{E}+01$ & $1.5 \mathrm{E}-02$ & $1.7 \mathrm{E}-02$ \\
$1.0 \mathrm{E}+02$ & $6.4 \mathrm{E}-03$ & $7.1 \mathrm{E}-03$ \\
$1.5 \mathrm{E}+02$ & $2.3 \mathrm{E}-03$ & $2.3 \mathrm{E}-03$ \\
$2.0 \mathrm{E}+02$ & $1.1 \mathrm{E}-03$ & $9.9 \mathrm{E}-04$ \\
$3.0 \mathrm{E}+02$ & $2.9 \mathrm{E}-04$ & $3.9 \mathrm{E}-04$ \\
$4.0 \mathrm{E}+02$ & $9.1 \mathrm{E}-05$ & $1.1 \mathrm{E}-04$ \\
$5.0 \mathrm{E}+02$ & $3.0 \mathrm{E}-05$ & $3.4 \mathrm{E}-05$ \\
$6.0 \mathrm{E}+02$ & $9.6 \mathrm{E}-06$ & $1.3 \mathrm{E}-05$ \\
$7.0 \mathrm{E}+02$ & $3.0 \mathrm{E}-06$ & $4.5 \mathrm{E}-06$ \\
$8.0 \mathrm{E}+02$ & $9.4 \mathrm{E}-07$ & $2.8 \mathrm{E}-06$ \\
\hline
\end{tabular}

a Normalized to $10 \mathrm{mrem} / \mathrm{h}$ at $2 \mathrm{~m}$.

scattering calculations, the uncertainties increased with distance, resulting in greater differences in the dose rates at greater distances. At $800 \mathrm{~m}, \mathrm{MCNP}$ values were higher than the RISKIND results by a factor of about three.

Similar to the gamma dose rate results discussed in Section 2.1.1, statistical errors for the RISKIND default curve are estimated to be less than $20 \%$ at distances less than $100 \mathrm{~m}$ and can be as high as approximately $50 \%$ at $800 \mathrm{~m}$ when generated by using the MORSE Monte Carlo transport code (Chen and Yuan 1988). For the MCNP calculations, the statistical errors were expected to be less than $2 \%$ at distances less than $100 \mathrm{~m}$ and were as high as approximately $20 \%$ at $800 \mathrm{~m}$. At the far distances, the number of neutrons available for scattering decreases drastically, resulting in pronounced uncertainties. However, because of the good agreement at near distances and the sharp decrease in dose rates at far distances, the uncertainties were not expected to affect the overall consequences in any significant manner. 


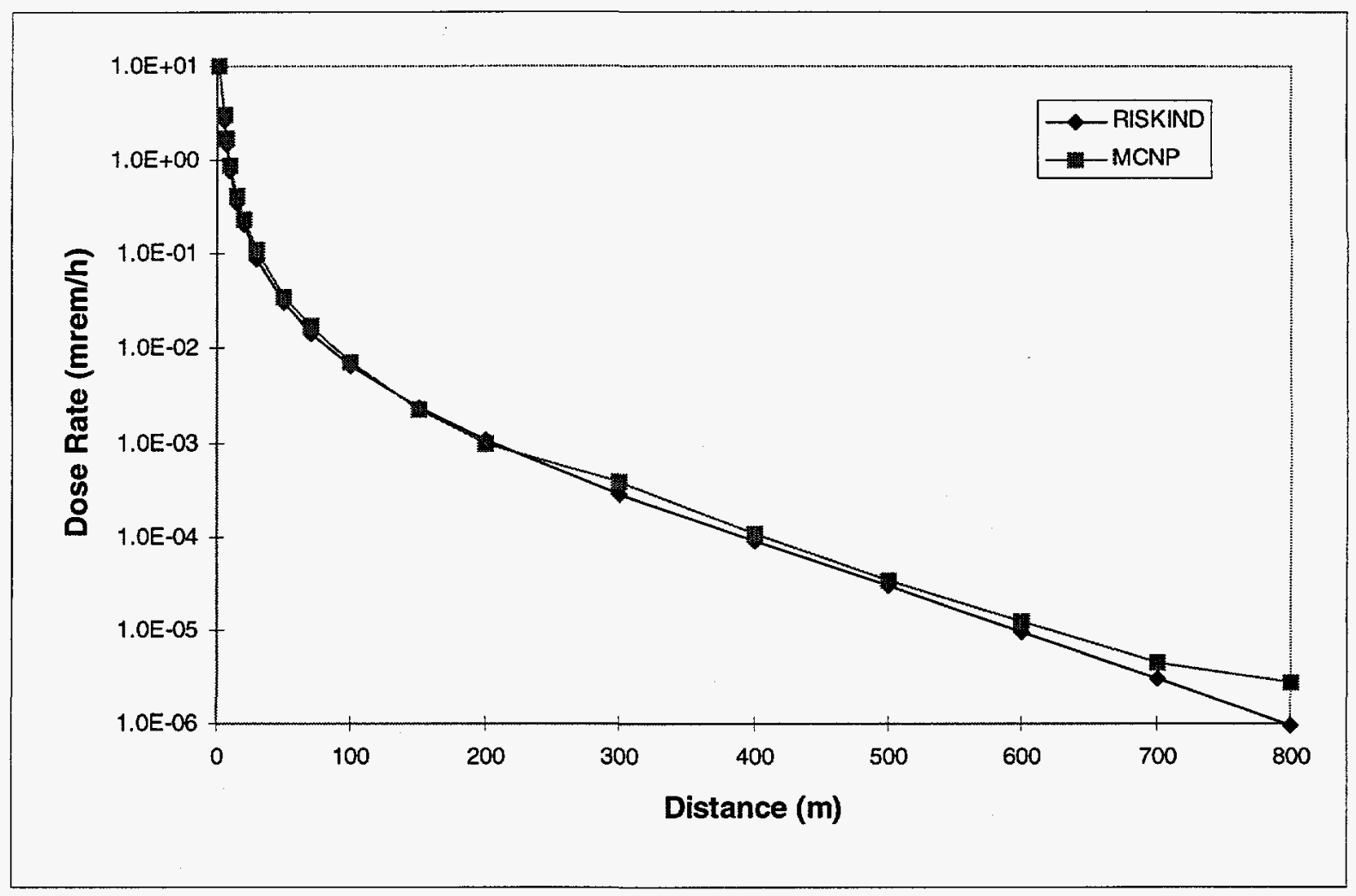

FIGURE 2.3 Comparison of RISKIND and MCNP Neutron Dose Rates

\subsubsection{Dose Rate Curve Normalization}

The calculations shown in this section and Sections 2.1 .4 and 2.2 were performed to verify the proper operation of the RISKIND code in estimating the impacts to an individual from the routine transport of an SNF cask. The following input parameters defined the problem:

Distance of individual from SNF transport route: $30 \mathrm{~m}$,

- Length of SNF cask: $4 \mathrm{~m}$,

- Radius of SNF cask: $0.45 \mathrm{~m}$,

- Dose rate at $1 \mathrm{~m}$ from cask surface: $11 \mathrm{mrem} / \mathrm{h}$,

- Gamma radiation fraction of dose rate: 0.6 ,

- Neutron radiation fraction of dose rate: 0.4 , and

- Speed of passing shipment: $24 \mathrm{~km} / \mathrm{h}$. 


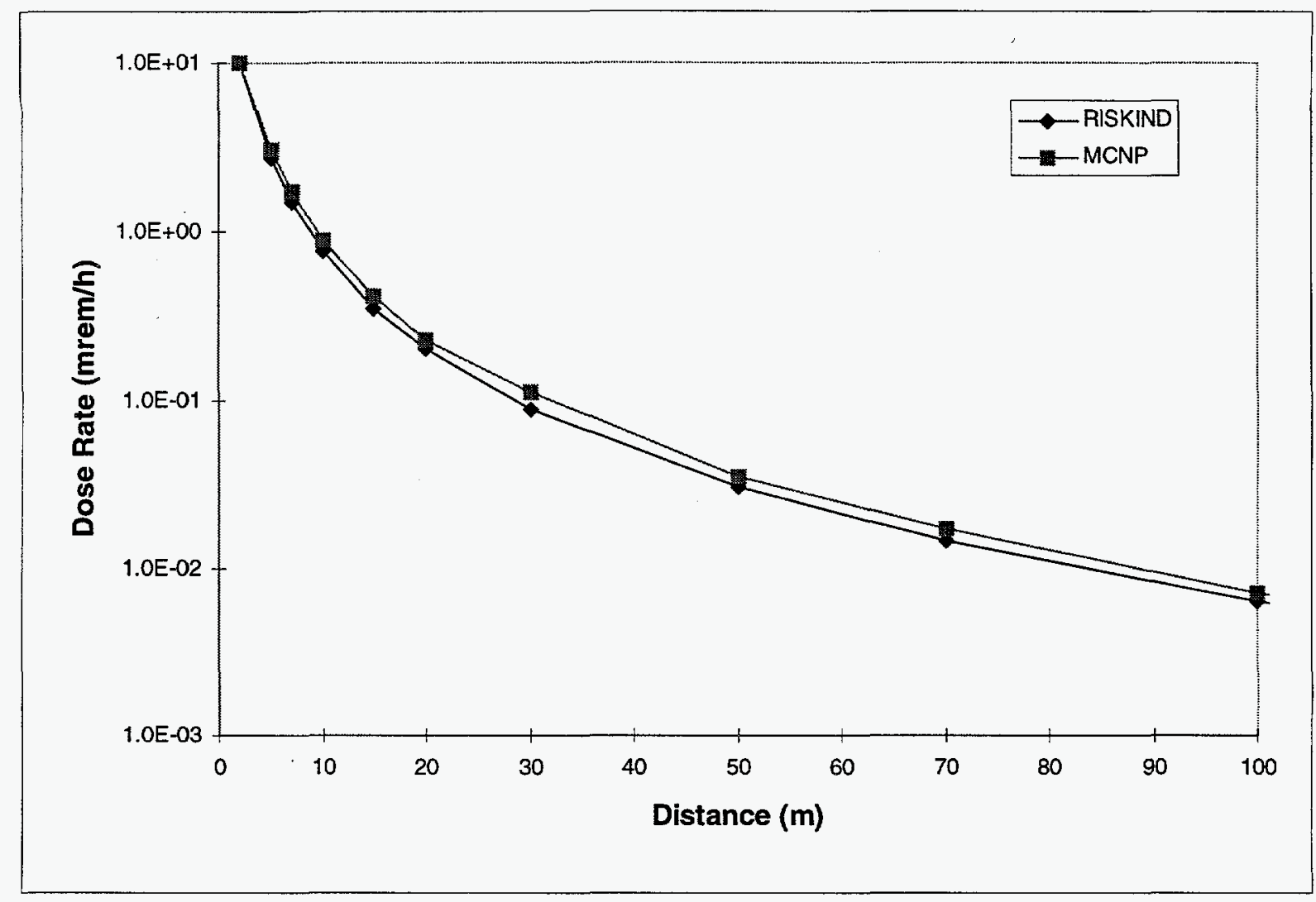

FIGURE 2.4 Comparison of RISKIND and MCNP Neutron Dose Rates When the Receptor Is Near the Source

This analysis is defined in the case 1 RISKIND input file, and the results are found in the case 1 output file, both of which are provided in Appendix A.

The first step in calculating impacts from external radiation was to normalize the dose rate curve to match the dose rate that was input for the problem. Figure 2.5 lists the calculations used to estimate the total dose rate at the receptor distance by normalizing the default dose rate curves for both gamma and neutron radiation. The shape factor correction calculated is shown in Section 2.1.4.

Normalization of the gamma and neutron dose rate curves consists of determining the first coefficient $\left(A_{o g}\right.$ or $\left.A_{o n}\right)$ in the equation for the appropriate curve. The empirical form of the equation used in RISKIND to model the dose rate curves makes this a simple calculation, in which the first coefficient is the logarithm of the measured dose rate at $1 \mathrm{~m}$ from the shipping package. The logarithms of the gamma and neutron dose rates are then calculated separately. Finally, the two results are combined to obtain the total dose rate at the receptor. 


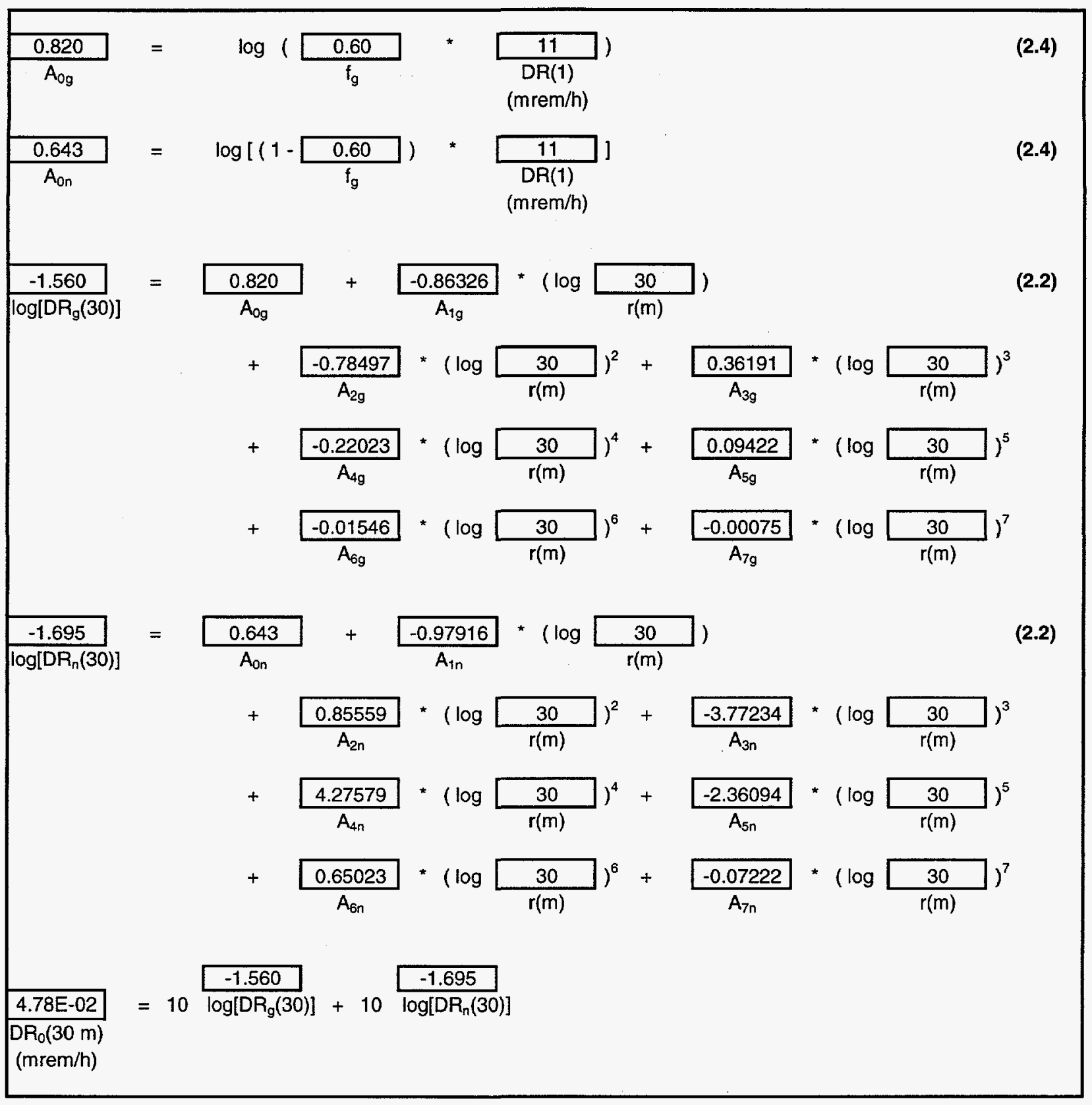

FIGURE 2.5 Dose Rate Curve Normalization Calculations for Case 1

\subsubsection{Shape Factor Correction}

The dose rate at the receptor shown in Section 2.1.3 was calculated for a shipping package with the dimensions of the default cask. Figure 2.6 lists the additional calculations used to correct for the size of the shipping package specified by the user. As explained in Appendix B of the RISKIND manual, the correction to the dose rate at a given distance is the ratio of the true dose rate to the default cask dose rate. This ratio is determined by means of geometric 


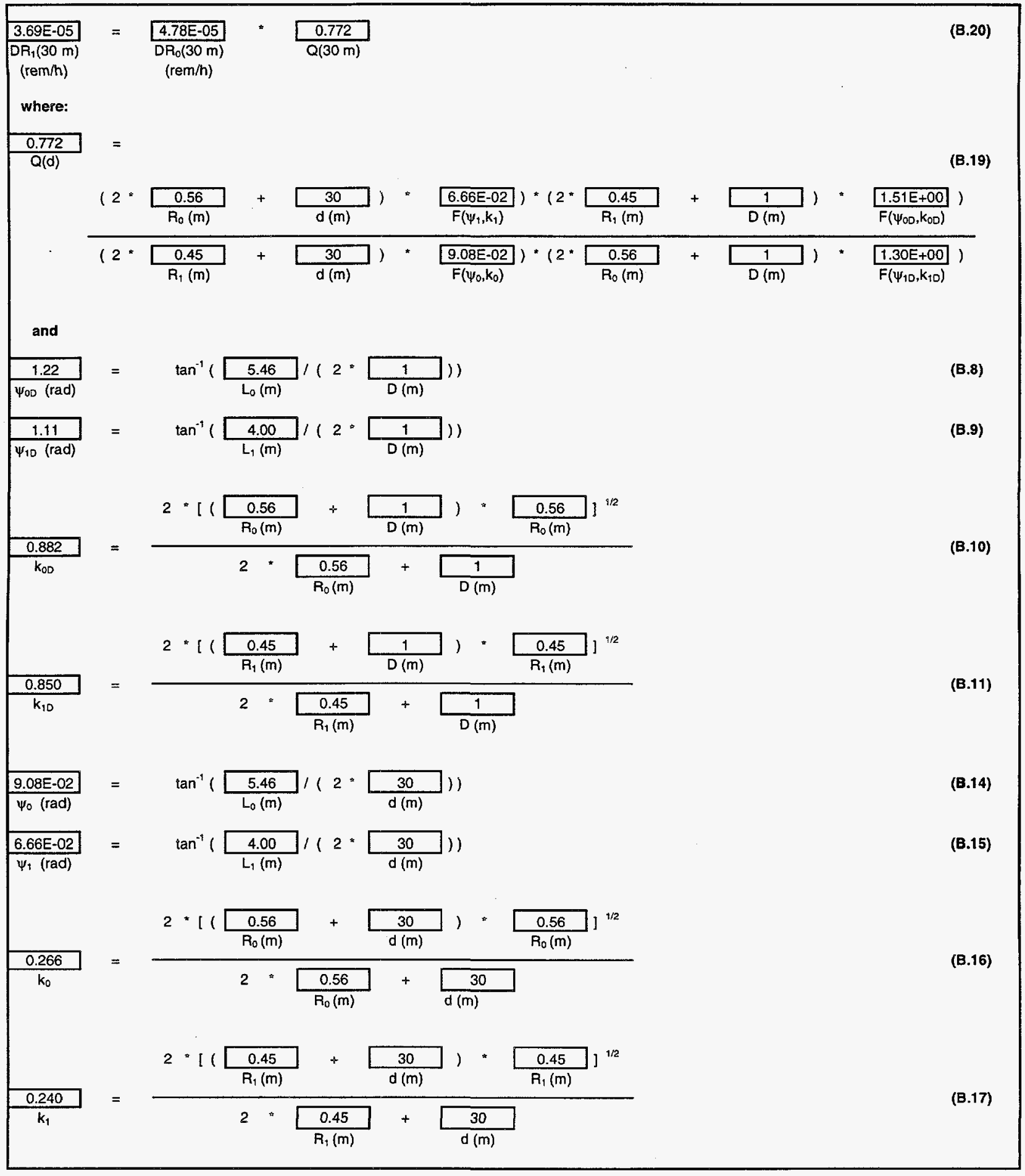

\section{FIGURE 2.6 Dose Rate Shape Factor Calculations for Case 1}


considerations and assumes that the nearest distance between the cask and the receptor is always measured from the midpoint of the cask.

In case 1 , the exposure time for the stop dose to the individual receptor was set to $1 \mathrm{~h}$. The calculated value of $3.7 \times 10^{-5}$ rem (Appendix A, pg. A-6) was therefore the dose rate per hour that agreed with the final dose rate calculation in Figure 2.6.

In addition to this verification, the RISKIND shape factor correction was also benchmarked against MicroShield. The correction was the ratio of the dose received when the user input cask size is used to the dose received when the reference cask dimensions (RISKIND default values) are assumed. Table 2.3 presents these ratios for a receptor located $70 \mathrm{~m}$ from the shipping cask, as calculated by using RISKIND and MicroShield. As seen in Table 2.3, the results from the two codes were in good agreement; results were within a $7 \%$ difference when scaling down to a 3-m cask, and they were the same when scaling up to a 7-m cask.

\subsection{EXTERNAL DOSE FROM A PASSING SPENT FUEL SHIPMENT}

\subsubsection{Individual Receptor}

Case 1 modeled a shipment that passes by an individual at a speed of $24 \mathrm{~km} / \mathrm{h}(15 \mathrm{miles}$ per hour or $\mathrm{mph}$ ) at a distance of $30 \mathrm{~m}$. Gamma radiation was assumed to account for $60 \%$ of the dose, and neutron radiation was assumed to account for the remaining $40 \%$ of the dose at a distance of $1 \mathrm{~m}$. The dose to that individual estimated by using RISKIND was thus $1.2 \times 10^{-7}$ rem (Appendix A,pg. A-6).

At any one instant in time, the dose rate to an individual from a passing shipment can be estimated in the same way as the rate from a stationary shipment is estimated. At a fixed rate of

TABLE 2.3 Shape Factor Correctiona

\begin{tabular}{ccc} 
& & \\
Cask Size & \multicolumn{2}{c}{ Dose Ratio to Default Cask } \\
\cline { 2 - 3 } Length $\times$ Radius & & \\
$(\mathrm{m})$ & RISKIND & MicroShield \\
\hline & & \\
$3 \times 0.3$ & 0.74 & 0.69 \\
$5.46 \times 0.56$ & 1 & 1 \\
$7 \times 0.7$ & 1.2 & 1.2 \\
\hline
\end{tabular}

TABLE 2.4 Calculation of Dose to an Individual from a Passing Shipment

\begin{tabular}{ccc}
\hline $\begin{array}{c}\text { Segment } \\
\text { Distance (m) }\end{array}$ & $\begin{array}{c}\text { Number of } \\
\text { Segments }\end{array}$ & $\begin{array}{c}\text { Dose } \\
\text { (rem) }\end{array}$ \\
\hline 100 & 21 & $1.77 \times 10^{-7}$ \\
50 & 41 & $1.30 \times 10^{-7}$ \\
25 & 81 & $1.23 \times 10^{-7}$ \\
1 & 2001 & $1.23 \times 10^{-7}$ \\
\hline
\end{tabular}

a Gamma dose rates were normalized to $10 \mathrm{mrem} / \mathrm{h}$ at $2 \mathrm{~m}$ and compared at a distance of $70 \mathrm{~m}$. 
speed, the dose received while the shipment travels a short distance (a segment) can be approximated by the dose rate at the midpoint of the segment multiplied by the time taken to travel that distance (Figure 2.7). This approximation is similar to the numerical integration routine used by RISKIND to calculate the dose from a passing shipment. Table 2.4 summarizes the results when segment distances of $1,25,50$, and $100 \mathrm{~m}$ were used. The estimated dose converged to the value of $1.2 \times 10^{-7}$ rem calculated by RISKIND as the number of segments increased, indicating proper operation of the code.

For comparison, the RADTRAN 4 transportation risk assessment code (Neuhauser and Kanipe 1992) was used. In RADTRAN 4, the dose for a maximally exposed individual is calculated as part of the incident-free risks from a shipment. The maximally exposed individual is always assumed to be at the nearest distance of $30 \mathrm{~m}$ from the route, and the passing shipment is always assumed to travel at a speed of $24 \mathrm{~km} / \mathrm{h}$. This distance and speed were the same as those used above. The package dimension, dose rate at $1 \mathrm{~m}$, and fraction of gamma and neutron radiation present were set to equal the values used above. The dose to the maximally exposed individual was estimated to be $3.79 \times 10^{-7} \mathrm{rem}$. This result was approximately three times higher than the value of $1.2 \times 10^{-7}$ rem calculated by RISKIND. The higher value calculated by RADTRAN 4 can be attributed primarily to the conservatism of the line source model it uses (Weiner and Neuhauser 1992), which is further demonstrated in the following section.

\subsubsection{Population Receptor}

Persons residing along the shipment route are exposed to low levels of external radiation as the shipment passes through populated areas (off-link population dose). In RISKIND, the collective population dose is estimated by integrating the dose received by one individual, as calculated above, over an area that is bounded by the nearest distance to the route,

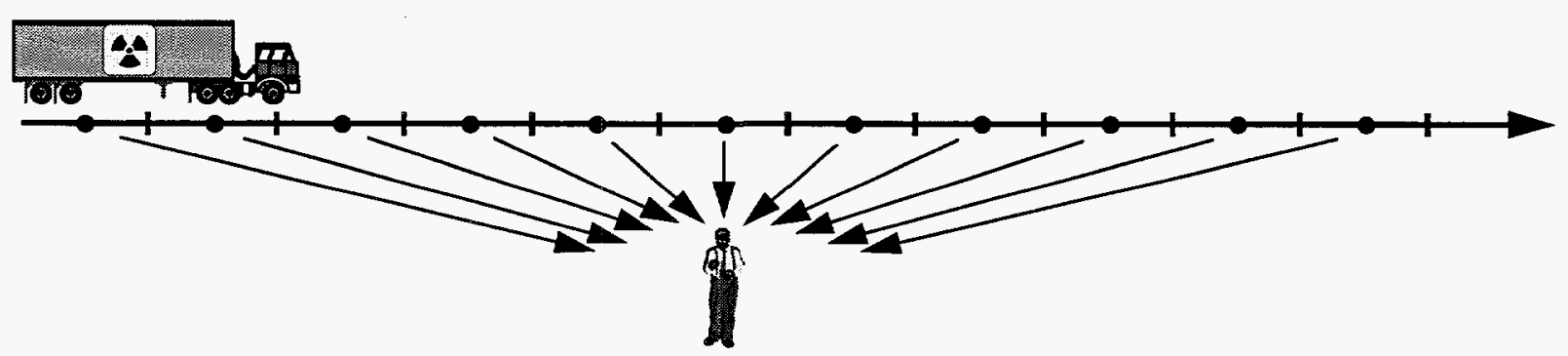

Dose from passing shipment $=\Sigma_{n} D_{i} \times t_{i}$

$\mathrm{n}$ - number of segments

$D_{i}$ - dose rate at midpoint of segment $i$ (mrem/hr)

$t_{i}$ - time within segment boundary $=$ segment distance/speed

FIGURE 2.7 Method for Estimating the Dose from a Passing Shipment 
furthest distance to the route, and distance traveled (Figure 2.8). The collective dose is calculated by using an average population density and includes one side of the route along the region of interest.

The routine risk to populations along the route from gamma radiation was estimated from two sources: a point source and a 3-m cask. A comparison was made of RISKIND when it uses its default gamma dose rate curve, RISKIND when it uses the NUREG-0170 curve as input, and RADTRAN 4. Although the areas of integration are fixed in RADTRAN 4, when the population zone and shielding factors are judiciously selected, population doses for specific distances from the transport route can be estimated for comparison. Table 2.5 presents the dose rate curve coefficients used in RISKIND to fit the NUREG-0170 dose rate curve for a point source. To approximate a point source in RISKIND, a value of $0.001 \mathrm{~m}$ was used for both cask length and radius; the calculated results were not affected if a value of $0.0001 \mathrm{~m}$ was used for these dimensions. In RADTRAN 4, a point source was approximated by using a value of $0.25 \mathrm{~m}$ for the package dimension, use of smaller values with the regulatory maximum dose rate of $10 \mathrm{mrem} / \mathrm{h}$ at $2 \mathrm{~m}$ caused the program to override the dose rate, because the dose rate at the package surface was estimated to exceed the regulatory maximum of $200 \mathrm{mrem} / \mathrm{h}$.

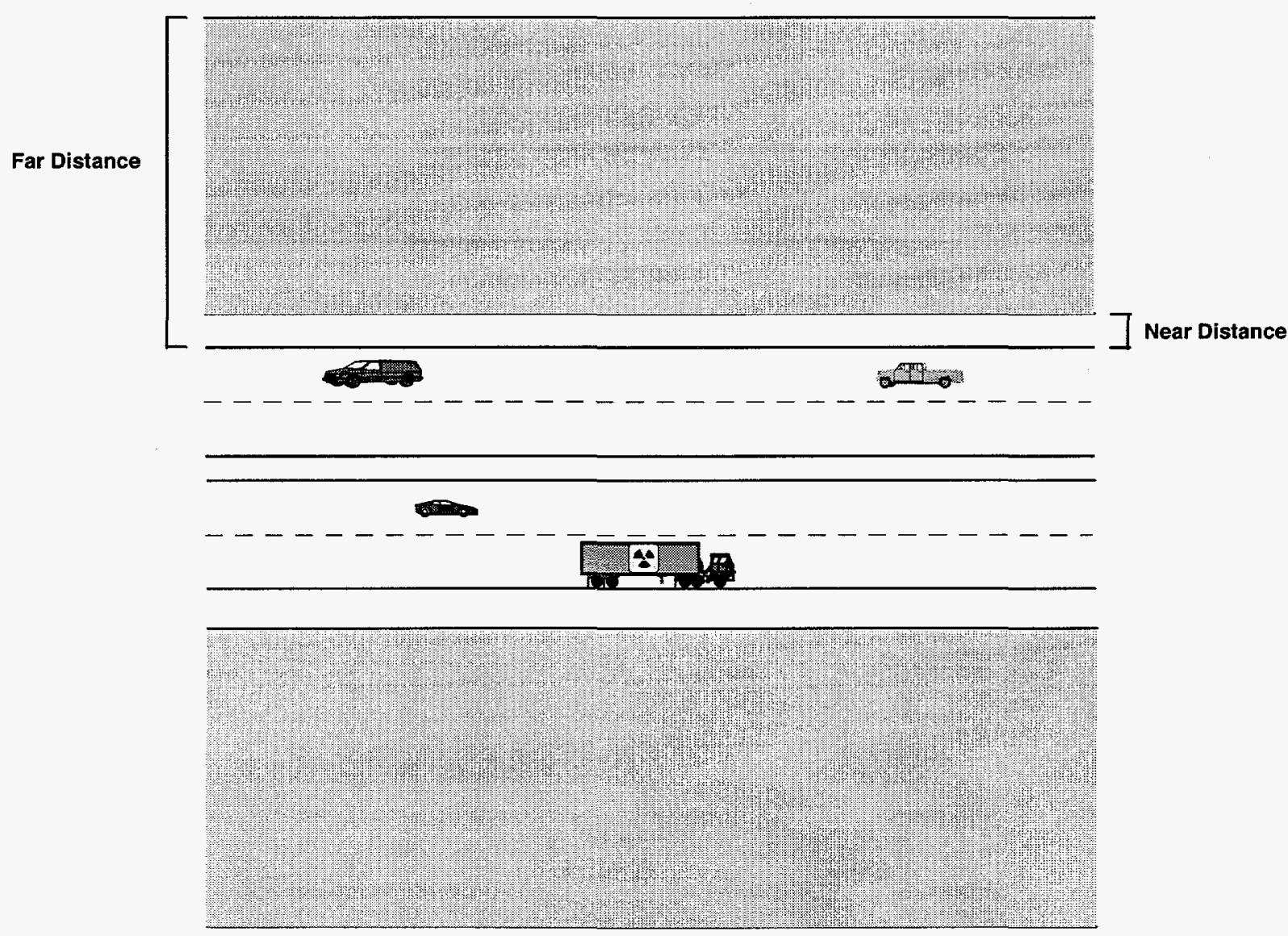

FIGURE 2.8 Area Used by RISKIND to Predict Incident-Free Off-Link Population Risks 
TABLE 2.5 Gamma Dose Rate Curve Coefficients for Input into RISKIND to Fit the NUREG-0170

Dose Rate Curvea

\begin{tabular}{cccc}
\hline $\begin{array}{c}\text { Gamma } \\
\text { Coefficient }\end{array}$ & Value & $\begin{array}{c}\text { Gamma } \\
\text { Coefficient }\end{array}$ & Value \\
\hline $\mathrm{A}_{\mathrm{Og}}$ & 1.60319 & $\mathrm{~A}_{4 \mathrm{~g}}$ & 0.134010 \\
$\mathrm{~A}_{1 \mathrm{~g}}$ & -2.00868 & $\mathrm{~A}_{5 \mathrm{~g}}$ & -0.0948845 \\
$\mathrm{~A}_{2 \mathrm{~g}}$ & 0.0369240 & $\mathrm{~A}_{6 g}$ & 0.0334039 \\
$\mathrm{~A}_{3 \mathrm{~g}}$ & -0.103879 & $\mathrm{~A}_{7 \mathrm{~g}}$ & -0.00496503 \\
\hline
\end{tabular}

a Normalized to $10 \mathrm{mrem} / \mathrm{h}$ at $2 \mathrm{~m}$ for a point source.

The off-link population doses from a shipment with a gamma dose rate of $10 \mathrm{mrem} / \mathrm{h}$ at $2 \mathrm{~m}$ are shown in Table 2.6. The shipment was assumed to travel at $24 \mathrm{~km} / \mathrm{h}$ through an area with a unit population density of 1 person $/ \mathrm{km}^{2}$. Relatively good agreement (approximately $40 \%$ difference in the worst case at $30-800 \mathrm{~m}$ ) occurred among the three cases for the point source model. The RADTRAN 4 values increased with respect to those of the other two cases when the distances considered were increased. RADTRAN 4's increase can be attributed to its conservative assumptions, such as not taking credit for attenuation (Neuhauser and Kanipe 1995). For the cylindrical source (Table 2.6), the RISKIND default and RISKIND (NUREG-0170) cases were in relatively good agreement. Again, the conservative nature of RADTRAN 4's line source model produced results that were up to about four times higher than the RISKIND default values for the $30-\mathrm{m}$ to $800-\mathrm{m}$ region. Such differences are unavoidable because RADTRAN 4's line source model is generic in nature so it can accommodate a wide variety of packaging. On the other hand, the RISKIND values can also be made smaller or larger, depending on the cask's radius. For example, if the radius were increased to $1.5 \mathrm{~m}$, the dose to the $30-\mathrm{m}$ to $800-\mathrm{m}$ region would almost double $\left(1.60 \times 10^{-8}\right.$ person-rem $\left./ \mathrm{km}\right)$.

Table 2.7 presents a comparison similar to that presented for the gamma radiation case. It compares the off-link population doses from a shipment with a neutron dose rate of $10 \mathrm{mrem} / \mathrm{h}$ at $2 \mathrm{~m}$ as estimated by RISKIND when it uses its default dose rate curve and RADTRAN 4. Good agreement (20\% or less difference) was again obtained when a point-source configuration was used for both models. In this case, the RADTRAN 4 values always remained slightly lower than the RISKIND values. The RADTRAN 4 values did not become progressively larger relative to the RISKIND values with increasing distance, as they did for the gamma radiation case, because the neutron model in RADTRAN 4 accounts for attenuation (Neuhauser and Kanipe 1995). A comparison of the cylindrical source values again shows the conservative nature of the RADTRAN 4 line source approximation: the RADTRAN 4 value was about two times greater than the RISKIND value for the $30-\mathrm{m}$ to $800-\mathrm{m}$ zone. 
TABLE 2.6 Comparison of RISKIND, NUREG-0170, and RADTRAN 4 Incident-Free Gamma Radiation Off-Link Population Dose (person rem/km)a

\begin{tabular}{llll}
\hline $\begin{array}{c}\text { Near and Far } \\
\text { Distance }(\mathrm{m})\end{array}$ & RISKIND & $\begin{array}{c}\text { RISKIND } \\
\text { (NUREG-0170) }^{\mathrm{b}}\end{array}$ & RADTRAN 4 $^{\text {RUR }}$ \\
\hline Point source & & & \\
$5-8$ & $2.17 \times 10^{-9}$ & $2.01 \times 10^{-9}$ & $1.49 \times 10^{-9}$ \\
$27-30$ & $4.15 \times 10^{-10}$ & $4.11 \times 10^{-10}$ & $3.33 \times 10^{-10}$ \\
$30-800$ & $6.02 \times 10^{-9}$ & $8.28 \times 10^{-9}$ & $1.04 \times 10^{-8}$ \\
$5-800$ & $1.49 \times 10^{-8}$ & $1.69 \times 10^{-8}$ & $1.60 \times 10^{-8}$ \\
& & & \\
Cylindrical sourcec & & & \\
$5-8$ & $2.96 \times 10^{-9}$ & $2.96 \times 10^{-9}$ & $5.45 \times 10^{-9}$ \\
$27-30$ & $6.00 \times 10^{-10}$ & $6.04 \times 10^{-10}$ & $1.22 \times 10^{-9}$ \\
$30-800$ & $8.80 \times 10^{-9}$ & $1.22 \times 10^{-8}$ & $3.79 \times 10^{-8}$ \\
$5-800$ & $2.14 \times 10^{-8}$ & $2.48 \times 10^{-8}$ & $5.85 \times 10^{-8}$ \\
\hline
\end{tabular}

a Assumes a unit population density of 1 person $/ \mathrm{km}^{2}$ for comparison purposes. Doses are for a zone on one side of the transport route.

b NUREG-0170 dose rate curve used in RISKIND.

c Cylindrical source $3 \mathrm{~m}$ in length with a $0.3-\mathrm{m}$ radius was assumed. A 3-m package dimension is used in RADTRAN. 
TABLE 2.7 Comparison of RISKIND and

RADTRAN 4 Incident-Free Neutron Radiation

Off-Link Population Dose (person-rem/ $/ \mathbf{k m})^{a}$

\begin{tabular}{lll}
\hline $\begin{array}{l}\text { Near and Far } \\
\text { Distance }(\mathrm{m})\end{array}$ & RISKIND & RADTRAN 4 \\
\hline Point source & & \\
$5-8$ & $2.16 \times 10^{-9}$ & $1.72 \times 10^{-9}$ \\
$27-30$ & $4.32 \times 10^{-10}$ & $4.21 \times 10^{-10}$ \\
$30-800$ & $6.76 \times 10^{-9}$ & $6.00 \times 10^{-9}$ \\
$5-800$ & $1.58 \times 10^{-8}$ & $1.29 \times 10^{-8}$ \\
& & \\
Cylindrical source & & \\
$5-8$ & $2.95 \times 10^{-9}$ & $6.25 \times 10^{-9}$ \\
$27-30$ & $6.26 \times 10^{-10}$ & $1.54 \times 10^{-9}$ \\
$30-800$ & $9.89 \times 10^{-9}$ & $2.19 \times 10^{-8}$ \\
$5-800$ & $2.26 \times 10^{-8}$ & $4.71 \times 10^{-8}$ \\
\hline
\end{tabular}

a Assumes a unit population density of 1 person $/ \mathrm{km}^{2}$ for comparison purposes. Doses are for a zone on one side of the transport route.

b Cylindrical source $3 \mathrm{~m}$ in length with a $0.3-\mathrm{m}$ radius was assumed. A 3-m package dimension is used in RADTRAN. 


\section{ACCIDENT RISKS}

Risks from potential accidents are associated with the release and dispersal of radioactive material. Potential accident conditions can result in a release of radioactive material to the atmosphere, and nearby individuals can be exposed through a number of pathways. If contamination is released to the air, it is first dispersed through atmospheric transport and eventually deposited on the ground. The exposure pathways considered in RISKIND include inhalation of the passing plume immediately following the accident, inhalation of resuspended contamination in the time following the accident, external radiation from the passing plume and from ground contamination, and ingestion of contaminated water and foodstuffs.

Most of the major accident risk algorithms were exercised in test case 2. Case 2 involved the estimation of impacts to an individual who is $1 \mathrm{~km}$ downwind of a potential SNF accident site in a rural population zone. Accident conditions such as vehicle speed at the time of impact, cask orientation parameters, and fire considerations were input by the user so the program could determine the accident severity. The consequences from an accident in the calculated accident response region were determined on the basis of a given set of weather conditions. The consequences included consideration of the ingestion and water pathways. The calculations began with a determination of the accident response region that specified the fractions of the shipment inventory released (Section 3.1). Section 3.2 examines the radionuclide screening process to determine the major contributors to the impacts. Section 3.3 covers atmospheric dispersion, and the various exposure pathways are discussed in Section 3.4.

\subsection{ACCIDENT RESPONSE REGION DETERMINATION}

An accident's severity determines the potential amount of radioactive material that could be released in the accident. RISKIND permits users to directly input radionuclide inventories and release fractions for a given situation. When analyzing SNF shipments, the program has the added capability of estimating release amounts on the basis of potential accident conditions. It estimates the potential amount of radioactive material that could be released on the basis of the accident response region in which the potential accident is categorized. The work discussed in this section was designed to check that the RISKIND procedures for determining the accident response region for SNF shipments operate properly.

The accident response region determination in the RISKIND model is an implementation of the NRC modal study of SNF casks (LLNL 1987). The spectrum of accident severities - from high probability with no radioactive release to very low probability with some release - is covered by 20 regions. A region is selected on the basis of two criteria: (1) the mechanical load on the cask due to impact forces and (2) the thermal load imparted to the cask as a result of a potential fire. There are four regions of mechanical response and five regions of thermal response, yielding a total of 20 potential regions. Figure 3.1 shows the region matrix. 


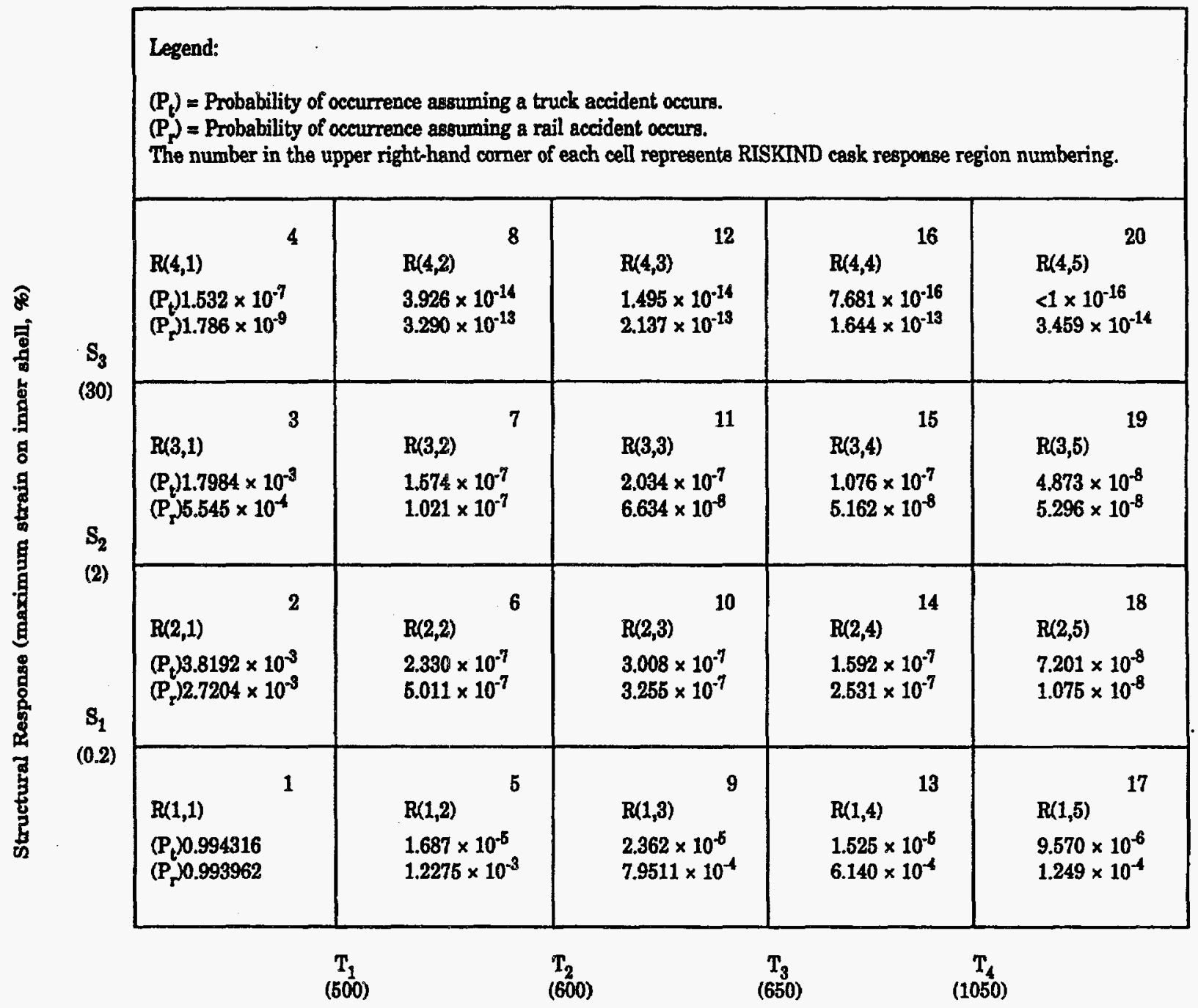

Thermal Response (lead midlayer thickness temperature, ${ }^{\circ} \mathrm{F}$ )

FIGURE 3.1 Matrix of Cask Response Regions and Probabilities of Occurrence for Combined Mechanical and Thermal Loads (Source: LLNL 1987)

\subsubsection{Mechanical Loads}

The mechanical response of the shipping cask to an impact is characterized by four input parameters:

1. Hardness of the object impacted (IHARD $=1-4$, unyielding to very soft),

2. Velocity of the cask (VCASK $=0-150 \mathrm{mph}[0-241 \mathrm{~km} / \mathrm{h}]$ ), 
3. Cask impact angle $\left(\mathrm{ALPHA}=0-90^{\circ}\right)$, and

4. Cask orientation angle $\left(B E T A=0-90^{\circ}\right)$, see Figure 3.2 .

In case 2, the input values were (Appendix A, pg. A-18) as follows: IHARD $=1$, $\mathrm{VCASK}=60 \mathrm{mph}(97 \mathrm{~km} / \mathrm{h}), \mathrm{ALPHA}=45^{\circ}$, and BETA $=45^{\circ}$. The mechanical response region is determined by calculating the impact velocity (impact velocity $=$ VCASK $\times \operatorname{SIN}($ ALPHA)) and locating its relative position in Table 3.1. The hardness of the object impacted was unyielding for case 2 for truck transport, so the top line in Table 3.1 was used. Because an orientation angle of $45^{\circ}$ was used, the impact velocity had to be less than $35 \mathrm{mph}(0.2 \%$ strain) to be in mechanical response region 1 , less than $49 \mathrm{mph}$ ( $2 \%$ strain) to be in region 2 , less than 113 mph (30\% strain) to be in region 3 , or greater than or equal to $113 \mathrm{mph}$ to be in region 4 . The impact velocity for case 2 was $42.4 \mathrm{mph}$ :

$$
\begin{gathered}
\text { Impact velocity }=\text { VCASK } \times \operatorname{SIN~}(\text { ALPHA }) \\
42.4 \mathrm{mph}=60 \mathrm{mph} \times \sin \left(45^{\circ}\right) \quad(\text { E. } 1 \text { in Manual })
\end{gathered}
$$
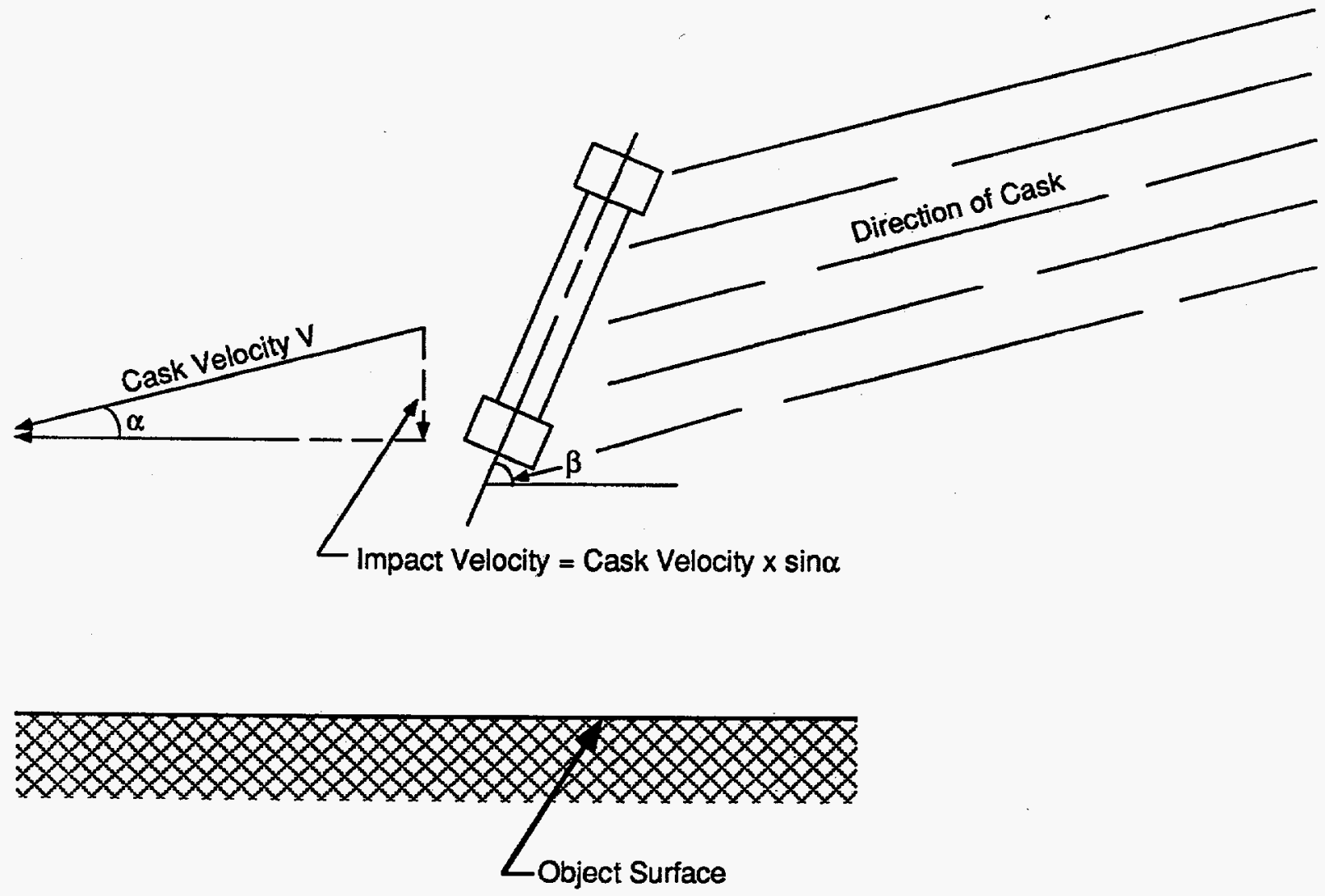

FIGURE 3.2 Three Impact Loading Parameters Considered in the Response Analysis for Impacts on Surfaces (Modified from LLNL 1987, Figure 2.1) 
TABLE 3.1 Impact Velocities Required to Attain $0.2 \%, 2 \%$, and 30\% Strain Levels for Objects Impacted in Highway and Railway Accidents

\begin{tabular}{|c|c|c|c|c|c|c|c|c|c|}
\hline \multirow{3}{*}{$\begin{array}{l}\text { Accident Type/ } \\
\text { Object Hardness }\end{array}$} & \multicolumn{9}{|c|}{ Impact Velocity $(\mathrm{km} / \mathrm{h})$ at Various Strain Levels and Orientation Angles ${ }^{\mathrm{a}}$} \\
\hline & \multicolumn{3}{|c|}{$0.2 \%$ Strain at Three Angles } & \multicolumn{3}{|c|}{$2 \%$ Strain at Three Angles } & \multicolumn{3}{|c|}{$30 \%$ Strain at Three Angles } \\
\hline & $0^{\circ}$ & $45^{\circ}$ & $90^{\circ}$ & $0^{\circ}$ & $45^{\circ}$ & $90^{\circ}$ & $0^{\circ}$ & $45^{\circ}$ & $90^{\circ}$ \\
\hline \multicolumn{10}{|l|}{ Highway } \\
\hline Unyielding & $51.5(32)$ & $56.3(35)$ & $61.1(38)$ & $82.1(51)$ & $78.8(49)$ & $74.0(46)$ & $>241(>150)$ & $182(113)$ & $122(76)$ \\
\hline Median & $51.5(32)$ & $56.3(35)$ & $61.1(38)$ & $82.1(51)$ & $78.8(49)$ & $74.0(46)$ & $241(>150)$ & $241(>150)$ & $241(>150)$ \\
\hline Soft & $51.5(32)$ & $933(58)$ & $135(84)$ & $82.1(51)$ & $163(101)$ & $241(>150)$ & $241(>150)$ & $241(>150)$ & $241(>150)$ \\
\hline Very soft & $67.6(42)$ & $>241(>150)$ & $61.1(38)$ & $94.9(59)$ & $241(>150)$ & $103(64)$ & $241(>150)$ & $241(>150)$ & $241(>150)$ \\
\hline \multicolumn{10}{|l|}{ Railway } \\
\hline Unyielding & $88.5(55)$ & $75.6(47)$ & $61.1(38)$ & $116(72)$ & $96.5(60)$ & $77.2(48)$ & $241(>150)$ & $206(128)$ & $169(105)$ \\
\hline Median & $88.5(55)$ & $75.6(47)$ & $61.1(38)$ & $116(72)$ & $96.5(60)$ & $77.2(48)$ & $241(>150)$ & $206(128)$ & $169(105)$ \\
\hline Soft & $88.5(55)$ & $75.6(47)$ & $64.4(40)$ & $116(72)$ & $111(69)$ & $105(65)$ & $241(>150)$ & $241(>150)$ & $241(>150)$ \\
\hline Very soft & $88.5(55)$ & $>241(>150)$ & $61.1(38)$ & $116(72)$ & $241(>150)$ & $96.5(60)$ & $241(>150)$ & $241(>150)$ & $241(>150)$ \\
\hline
\end{tabular}

a In the modal study (LLNL 1987), $150 \mathrm{mph}(241 \mathrm{~km} / \mathrm{h})$ is defined as the maximum credible velocity. Numbers in parentheses indicate mph.

Source: LLNL (1987). 
Because the calculated impact velocity was greater than $35 \mathrm{mph}$ but less than $49 \mathrm{mph}$, the scenario fell into the second impact region. When the second impact region was combined with the estimated thermal response region of 3 , as discussed in the following section, the scenario fell into RISKIND response region 10. This determination is reflected in the case 2 output file (Appendix A,pg. A-18).

It would not have been practical to check every possible combination of the four input parameters for this study. However, a spot check of a few well-chosen combinations was done to demonstrate the proper operation of most of the calculational steps. Variations in the cask velocity, impact angle, and orientation angle were investigated. Table 3.2 shows the response regions determined when only the cask velocity was changed. The effects from varying the impact angle at a cask velocity of $114 \mathrm{mph}$ are shown in Table 3.3. Effects from varying the cask orientation angle (BETA) are shown in Table 3.4 for a cask velocity of $70 \mathrm{mph}$. When BETA equalled $45^{\circ}$, the estimated impact velocity was $49.5 \mathrm{mph}$. The impact velocity limit in Table 3.4 is the cutoff velocity between impact regions 2 and 3. This limit is obtained by interpolation when BETA is some value other than $0^{\circ}, 45^{\circ}$, or $90^{\circ}$.

\subsubsection{Thermal Loads}

The thermal response region is determined on the basis of four discrete temperatures (response levels) of the midlayer of the cask's lead shield $-500,600,650$, and $1,050^{\circ} \mathrm{F}-$ corresponding to five regions. The midlayer temperature is related to three input parameters:

1. Fire duration (DFIRE),

2. Flame temperature (TFLAME), and

3. Fire location (FLOC).

A $1,700^{\circ} \mathrm{F}$ engulfing fire was used as a reference point for estimates in the modal study. Results are extrapolated to other scenarios by using the following calculation:

$$
\mathrm{d}_{\mathrm{F}}(\mathrm{t}, \mathrm{l})=\delta(\mathrm{t}) \mathrm{d}_{\mathrm{F}}\left(1700^{\circ} \mathrm{F}\right) \delta(\mathrm{l}), \quad(\mathrm{E} .2 \text { in Manual })
$$

where:

$$
\begin{aligned}
& \mathrm{t}= \text { cask midlayer temperature }\left({ }^{\circ} \mathrm{F}\right) ; \\
& 1= \text { fire location }(\mathrm{ft}) ; \\
& \mathrm{d}_{\mathrm{F}}(\mathrm{t}, \mathrm{l})= \text { fire duration corresponding to cask midlayer temperature } \mathrm{t} \text { and } \\
& \text { fire location } \mathrm{l} ; \\
& \delta(\mathrm{t})= \begin{array}{l}
\text { multiplication factor to adjust for flame temperature other than } \\
\end{array} \\
&\left.1,700^{\circ} \mathrm{F} \text { (Table } 3.5\right) ;
\end{aligned}
$$


TABLE 3.2 Response Region Determination with Variation in Cask Velocity

\begin{tabular}{ccccc}
\hline $\begin{array}{c}\text { Cask } \\
\text { Velocity } \\
(\mathrm{mph})\end{array}$ & $\begin{array}{c}\text { Impact } \\
\text { Velocity } \\
(\mathrm{mph})\end{array}$ & $\begin{array}{c}\text { Impact } \\
\text { Region }\end{array}$ & $\begin{array}{c}\text { Fire } \\
\text { Region }\end{array}$ & $\begin{array}{c}\text { RISKIND } \\
\text { Region }\end{array}$ \\
\hline 20 & 14.1 & 1 & 3 & 9 \\
40 & 28.3 & 1 & 3 & 9 \\
60 & 42.4 & 2 & 3 & 10 \\
80 & 56.6 & 3 & 3 & 11 \\
100 & 70.7 & 3 & 3 & 11 \\
120 & 84.9 & 3 & 3 & 11 \\
140 & 99.0 & 3 & 3 & 11 \\
\hline
\end{tabular}

TABLE 3.3 Response Region Determination with Variation in Cask Impact Angle

\begin{tabular}{ccccc}
\hline $\begin{array}{c}\text { Impact } \\
\text { Angle, } \alpha \\
\text { degrees) }\end{array}$ & $\begin{array}{c}\text { Impact } \\
\text { Velocity } \\
\text { (mph) }\end{array}$ & $\begin{array}{c}\text { Impact } \\
\text { Region }\end{array}$ & $\begin{array}{c}\text { Fire } \\
\text { Region }\end{array}$ & $\begin{array}{c}\text { RISKIND } \\
\text { Region }\end{array}$ \\
\hline 0 & 0.0 & 1 & 3 & 9 \\
15 & 29.5 & 1 & 3 & 9 \\
30 & 57.0 & 3 & 3 & 11 \\
45 & 80.6 & 3 & 3 & 11 \\
60 & 98.7 & 3 & 3 & 11 \\
75 & 110.1 & 3 & 3 & 11 \\
90 & 114.0 & 4 & 3 & 12 \\
\hline
\end{tabular}

TABLE 3.4 Response Region Determination with Variation in Cask Orientation Angle

\begin{tabular}{ccccc}
\hline $\begin{array}{c}\text { Orientation } \\
\text { Angle, } \beta \\
\text { (degrees) }\end{array}$ & $\begin{array}{c}\text { Impact } \\
\text { Velocity } \\
\text { Limit } \\
(\mathrm{mph})\end{array}$ & $\begin{array}{c}\text { Impact } \\
\text { Region }\end{array}$ & $\begin{array}{c}\text { Fire } \\
\text { Region }\end{array}$ & $\begin{array}{c}\text { RISKIND } \\
\text { Region }\end{array}$ \\
\hline 0 & 51.0 & 2 & 3 & 10 \\
15 & 50.3 & 2 & 3 & 10 \\
30 & 49.7 & 2 & 3 & 10 \\
45 & 49.0 & 3 & 3 & 11 \\
60 & 48.0 & 3 & 3 & 11 \\
75 & 47.0 & 3 & 3 & 11 \\
90 & 46.0 & 3 & 3 & 11 \\
\hline
\end{tabular}


TABLE 3.5 Heat Flux Factors for Flame

Temperatures (engulfing fire)

\begin{tabular}{cccccccc}
\hline \multicolumn{3}{c}{$\begin{array}{c}\text { Flame } \\
\text { Temperature, } \mathrm{t}\end{array}$} & & \multicolumn{3}{c}{$\begin{array}{c}\text { Flame } \\
\text { Temperature, } \mathrm{t}\end{array}$} \\
\cline { 1 - 4 } \cline { 5 - 8 } $\mathrm{K}$ & ${ }^{\circ} \mathrm{F}$ & $\delta(\mathrm{t})$ & & $\mathrm{K}$ & ${ }^{\circ} \mathrm{F}$ & $\delta(\mathrm{t})$ \\
\cline { 1 - 5 } 1,030 & 1,400 & 1.72 & & 1,370 & 2,000 & 0.64 \\
1,090 & 1,500 & 1.43 & & 1,420 & 2,100 & 0.56 \\
1,140 & 1,600 & 1.21 & & 1,480 & 2,200 & 0.49 \\
1,200 & 1,700 & 1.0 & & 1,530 & 2,300 & 0.44 \\
1,260 & 1,800 & 0.86 & & 1,590 & 2,400 & 0.39 \\
1,310 & 1,900 & 0.73 & & & & \\
\hline
\end{tabular}

Source: LLNL (1987).

$\mathrm{d}_{\mathrm{F}}\left(1700^{\circ} \mathrm{F}\right)=$ duration of $1,700^{\circ} \mathrm{F}$ fire $($ Table 3.6 has the fire durations necessary to reach the four response levels for both truck and rail casks); and

$\delta(1)=$ multiplication factor to adjust for cask distance away from fire location ( $1=0$ corresponds to an engulfing fire);

$$
\begin{gathered}
\delta(1)=0.78 \exp (0.7732+0.06287 \mathrm{l}) \text { for truck } \\
\text { when } 1 \text { is }>1.5 \mathrm{ft} \quad \text { (E.3 in Manual) } \\
\delta(1)=0.78 \exp (0.62874+0.08471 \text { l) for rail } \\
\text { when } \mathrm{l} \text { is }>4 \mathrm{ft} \quad \text { (E.4 in Manual) }
\end{gathered}
$$

For case 2 , DFIRE was $1.5 \mathrm{~h}$, TFLAME was $1,850^{\circ} \mathrm{F}(1,283 \mathrm{~K})$, and FLOC was $0 \mathrm{ft}$. The flame temperature multiplication factor, $\delta(t)$, which can be obtained by interpolating between the values for $1,800^{\circ}$ and $1,900^{\circ} \mathrm{F}$ in Table 3.5 , was a value of 0.81 . Since an engulfing fire was present, the distance multiplication factor, $\delta(1)$, was 0 . The fire duration adjusted for a $1,700^{\circ} \mathrm{F}$ flame temperature was:

$$
\mathrm{d}_{\mathrm{F}}(\mathrm{t}, 1) / \delta(\mathrm{t})=1.5 \mathrm{~h} / 0.81=1.9 \mathrm{~h}
$$

This time fell between the time needed to result in midlayer temperatures of 600 and $650^{\circ} \mathrm{F}$, the third thermal response region (Table 3.6). As discussed in the impact response section, the combined results of the impact response and thermal response placed the case 2 scenario in RISKIND response region 10, as noted in the case 2 output file (Appendix A, pg. A-18). 
TABLE 3.6 Fire Duration Required

to Reach the Four Levels of Lead

Midlayer Thickness Temperatures

for a $1,200 \mathrm{~K}\left(1,700^{\circ} \mathrm{F}\right)$ Engulfing Fire

\begin{tabular}{ccccc}
\hline \multicolumn{2}{c}{ Temperature } & & \multicolumn{2}{c}{ Duration (h) } \\
\cline { 1 - 2 } \cline { 5 - 5 } $\mathrm{K}$ & ${ }^{\circ} \mathrm{F}$ & & Truck Cask & Rail Cask \\
\hline \multirow{2}{*nnny}{530} & 500 & & 1.1 & 1.2 \\
590 & 600 & & 1.4 & 1.8 \\
616 & 650 & & 2.1 & 2.7 \\
839 & 1,050 & & 3.3 & 5.1 \\
\hline
\end{tabular}

Source: LLNL (1987).

\subsection{RADIONUCLIDE SCREENING}

Since an SNF shipment could contain more than 100 radionuclides, the number of potential radionuclides used in the risk calculations can be screened so that only those radionuclides responsible for the largest impacts are used. Radionuclides are screened with regard to their potential hazard via three pathways. Pathway $I$ is short-term exposure from inhalation and air immersion during plume passage; pathway II is long-term external radiation exposure from contaminated ground; and pathway III is long-term internal exposure due to ingestion. A radionuclide is retained for calculations if its relative contribution to any of the three pathways is greater than the hazard limit set by the user, HZLM. Screening should not be used if there is a potential for acute effects, because the screening does not account for acute impacts. No screening is performed if HZLM is set to 0 .

The relative importance of each radionuclide with regard to pathway I exposure can be written as:

$$
F I(i)=\frac{D I(i)}{\sum_{i} D I(i)}=\frac{\sum_{j=1,2} Q(i) \operatorname{RS}(i) \operatorname{DFI}(i, j)}{\sum_{i} \sum_{j=1,2} Q(i) \operatorname{RS}(i) \operatorname{DFI}(i, j)} \quad \text { (C.2, C.3 in Manual) }
$$

where:

$\mathrm{Q}(\mathrm{i})=$ source inventory for radionuclide $\mathrm{i}$,

RS(i) = release fraction for radionuclide $\mathrm{i}$, and

$\operatorname{DFI}(i, j)=$ dose conversion factor for radionuclide $\mathrm{i}$ for either inhalation or air immersion $(\mathrm{j}=1$ or 2$)$. 
The relative importance of each radionuclide with regard to pathway II exposure can be written as:

$$
\text { FII(i) }=\frac{\mathrm{DII}(\mathrm{i})}{\sum_{\mathrm{i}} \mathrm{DII}(\mathrm{i})}=\frac{\mathrm{Q}(\mathrm{i}) \mathrm{RS}(\mathrm{i}) \mathrm{V}_{\mathrm{d}}(\mathrm{i}) \mathrm{TG}(\mathrm{i}) \mathrm{DFII}(\mathrm{i})}{\sum_{\mathrm{i}} \mathrm{Q}(\mathrm{i}) \mathrm{RS}(\mathrm{i}) \mathrm{V}_{\mathrm{d}}(\mathrm{i}) \mathrm{TG}(\mathrm{i}) \operatorname{DFII}(\mathrm{i})} \quad \text { (C.7, C.8 in Manual) }
$$

where:

$$
\begin{aligned}
\mathrm{V}_{\mathrm{d}}(\mathrm{i})= & \text { deposition velocity for radionuclide } \mathrm{i} ; \\
\mathrm{DFII}(\mathrm{i})= & \text { dose conversion factor for radionuclide } \mathrm{i} \text { for ground external } \\
\mathrm{TG}(\mathrm{i})= & \left\{1-\exp \left[-\lambda_{\mathrm{g}}(\mathrm{i}) \mathrm{T}\right]\right\} / \lambda_{\mathrm{g}}(\mathrm{i})(\mathrm{C} .6 \text { in Manual); } \\
\lambda_{\mathrm{g}}(\mathrm{i})= & \lambda(\mathrm{i})+\lambda_{\mathrm{w}}, \text { effective removal constant for radionuclide } \mathrm{i} \text { (accounts } \\
& \text { for radioactive decay and weathering); and } \\
\mathrm{T}= & \text { total time period for ground external exposure. }
\end{aligned}
$$
written as:

The relative importance of each radionuclide with regard to pathway III exposure can be

$$
\begin{gathered}
F I I(i)=\frac{D I I I(i)}{\sum_{i} D I I I(i)}=\frac{Q(i) R S(i) V_{d}(i) T G(i) D F I I I(i) B_{v}(i)[F 1(i)+F 2(i)+F 3(i)]}{\sum_{i} Q(i) R S(i) V_{d}(i) T G(i) D F I I(i) B_{v}(i)[F 1(i)+F 2(i)+F 3(i)]} \\
(\text { C.13, C.14 in Manual) }
\end{gathered}
$$

where:

$$
\begin{aligned}
B_{v}(i) & =\text { soil-to-vegetation transfer factor for radionuclide } i ; \\
F 1(i) & =F_{b}(i) Q_{a} U_{b} / \rho \quad(C .10 \text { in Manual }) ; \\
F 2(i) & =F_{m}(i) Q_{a} U_{m} / \rho \quad(C .11 \text { in Manual }) ; \\
F 3(i) & =0.5 U_{v} / \rho \quad(C .12 \text { in Manual }) \\
F_{b}(i) & =\text { meat transfer factor for radionuclide } i ; \\
F_{m}(i) & =\text { milk transfer factor for radionuclide } i ; \\
Q_{a} & =\text { animal pasture grass ingestion rate for meat cattle and milk cows; }
\end{aligned}
$$




$$
\begin{aligned}
\mathrm{U}_{\mathrm{b}}, \mathrm{U}_{\mathrm{m}}, \mathrm{U}_{\mathrm{v}} & =\begin{array}{l}
\text { human food ingestion rate for meat, milk, and vegetables, } \\
\text { respectively; and }
\end{array} \\
\rho & =\text { vegetation yield density of pasture land or vegetable garden. }
\end{aligned}
$$

A set of example calculations for case 2 is given in Figure 3.3 for one of the more significant radionuclides, Cs-137. It was estimated to contribute to less than $10 \%$ of the acute dose, $\mathrm{FI}(\mathrm{Cs}-137)=0.069$ but to more than $50 \%$ of the long-term ground exposure dose and $90 \%$ of the ingestion dose ( $\mathrm{FII}=0.58$ and $\mathrm{FIII}=0.945$, respectively). These values are rough estimates only and do not represent the final contributions calculated by using the full methodology for each exposure pathway.

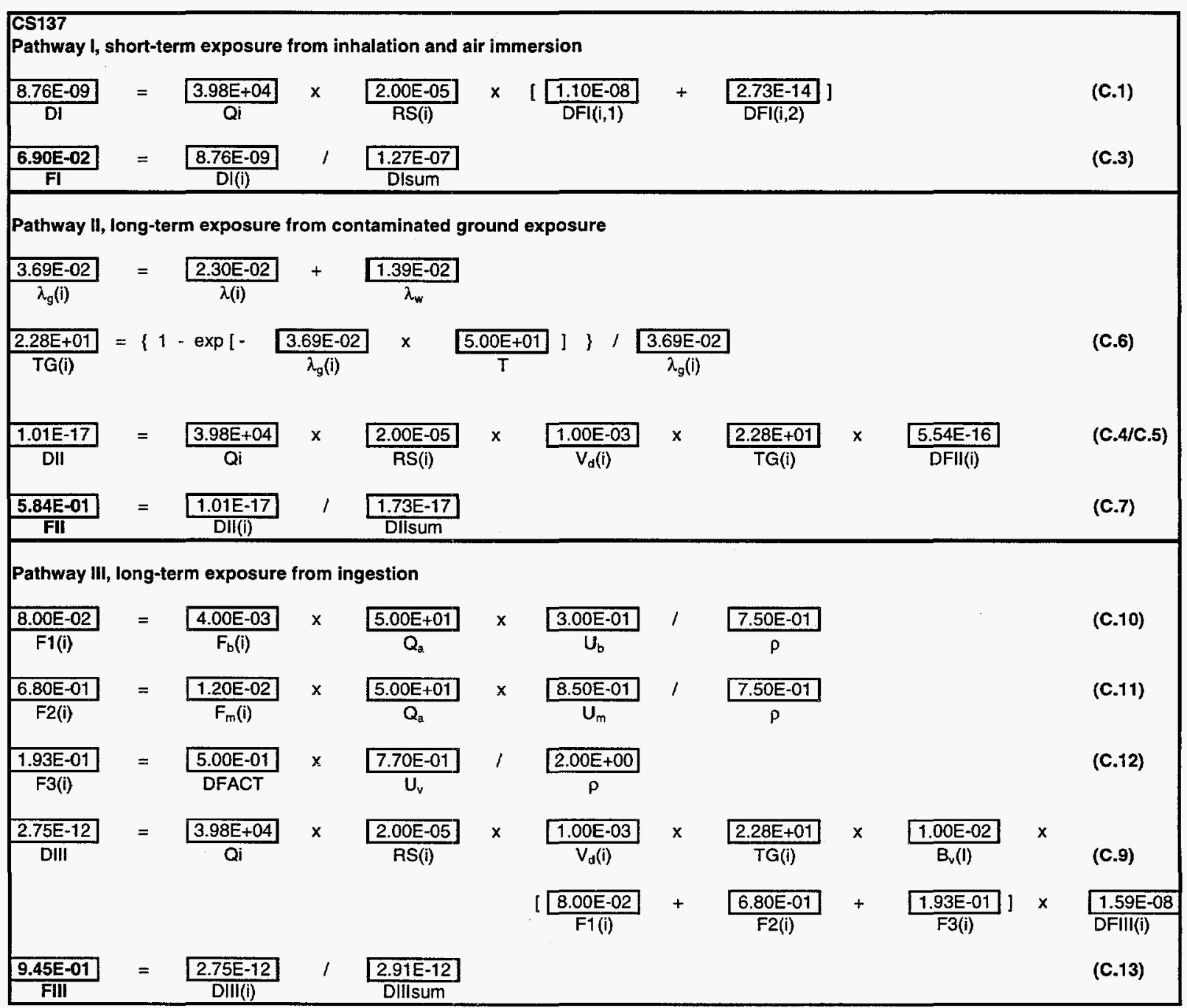

FIGURE 3.3 Radionuclide Screening Calculations for Cs-137 
Table 3.7 provides the intermediate and final values for the relationships described above for case 2 . It shows which radionuclides provide significant doses relative to the hazard limit of 0.005 . Those radionuclides selected match those provided in the case 2 output file (Appendix A, pg. A-19).

\subsection{ATMOSPHERIC DISPERSION}

Once a radioactive material is released from its packaging after an accident, any aerosolized component may be dispersed by the prevailing weather conditions. The air concentrations lead directly to the inhalation and external radiation (cloudshine) exposure pathways covered in Section 3.4 and are intermediate values in the estimation of ground deposition. In turn, the calculated values for ground concentrations are required to estimate exposure to external radiation from the contaminated ground surface (groundshine) and resuspended inhalation, and they are used as input to the food and water ingestion pathways.

\subsubsection{Initial Dispersion}

RISKIND uses a simple Gaussian dispersion model that assumes a point source as the origin of a puff release. Since estimates of downwind concentrations depend on the size of the puff at a given location, adjustments are made to account for the initial size of the puff and to correct for this initial size at further locations downwind.

Following an accident, turbulent air flow around the packaging mixes the released material with the surrounding air. Therefore, the initial release of material from its packaging will result in a small puff whose cross section is roughly proportional to the size of the packaging, even if only a small breach is present. The size of the initial source is first estimated in the form of values for the initial horizontal and vertical dispersion coefficients, $\sigma_{\mathrm{y} 0}$ and $\sigma_{\mathrm{z} 0}$, respectively.

Once the initial size of the puff is estimated, the Gaussian dispersion model is corrected for downwind concentration estimates by adding an additional length to the distance downwind from the source in the calculations. This additional virtual distance is the distance necessary for the puff to grow from a point source to its estimated initial size.

RISKIND provides an option to use one of two sets of dispersion coefficients in the Gaussian plume equations: the Pasquill-Gifford dispersion coefficients (Eimutis and Konicek 1972) or the Briggs dispersion coefficients (Briggs 1974). The Pasquill-Gifford dispersion coefficients are based on ground-level release data, and their use with elevated releases is discouraged. The Briggs dispersion coefficients are based on elevated releases. Briggs does not recommend their use for heights greater than $100 \mathrm{~m}$. 
TABLE 3.7 Radionuclide Screening Values for Case 2

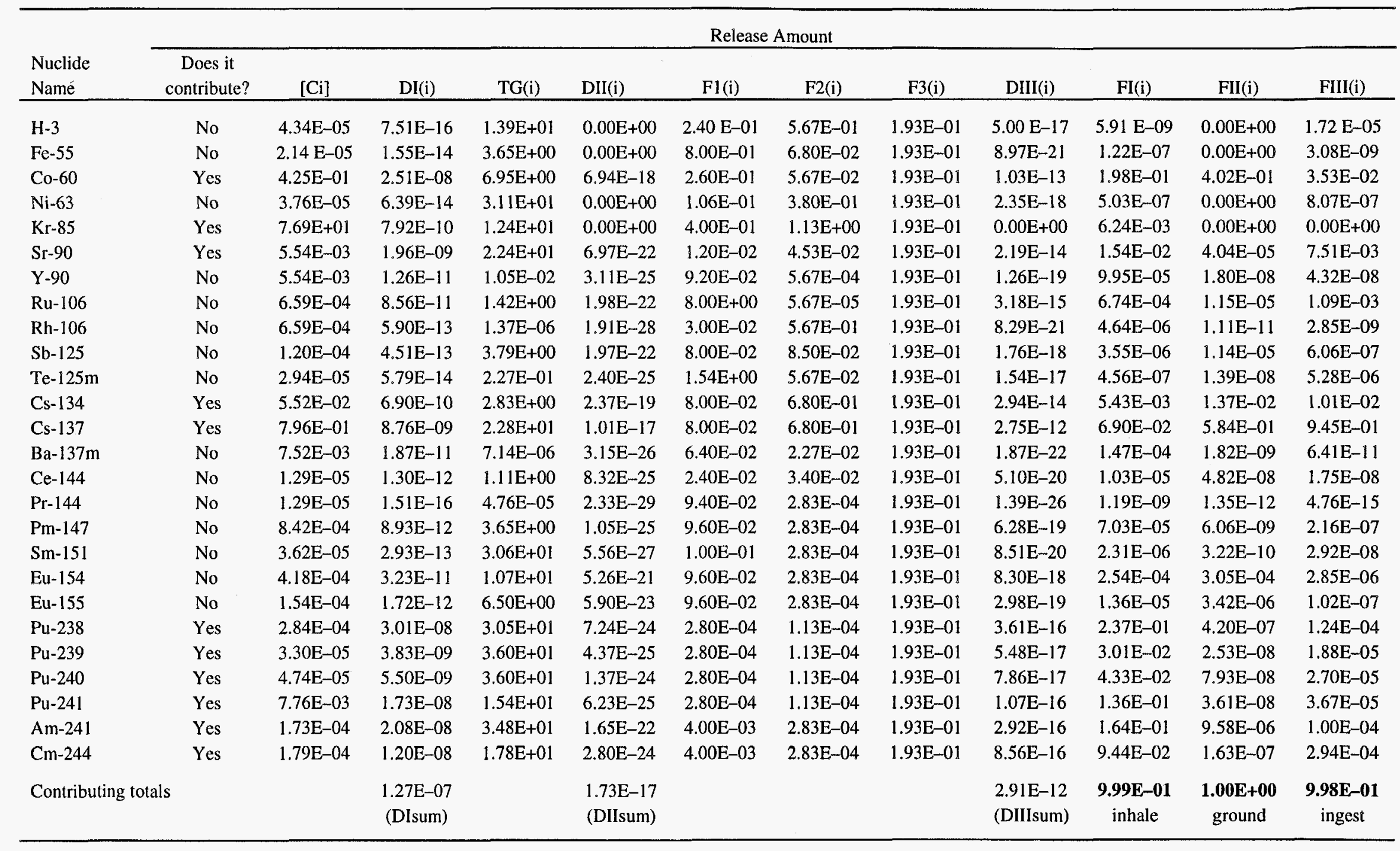


The Pasquill-Gifford dispersion coefficients were used in case 2. The estimated values for the initial dispersion coefficients and the virtual distances are presented in Figure 3.4 for the horizontal and vertical coefficients, respectively. Note that the Pasquill-Gifford coefficients used for determining the virtual distance for $\sigma_{\mathrm{z} 0}$ are for an $\mathrm{x}$ that is less than $100 \mathrm{~m}$, since the initial size of the plume is assumed to be smaller than it would be if the plume originated from a point source and traveled further than $100 \mathrm{~m}$. If the Briggs coefficients were selected for case 2 , the resulting virtual distances would be those shown in Figure 3.5.

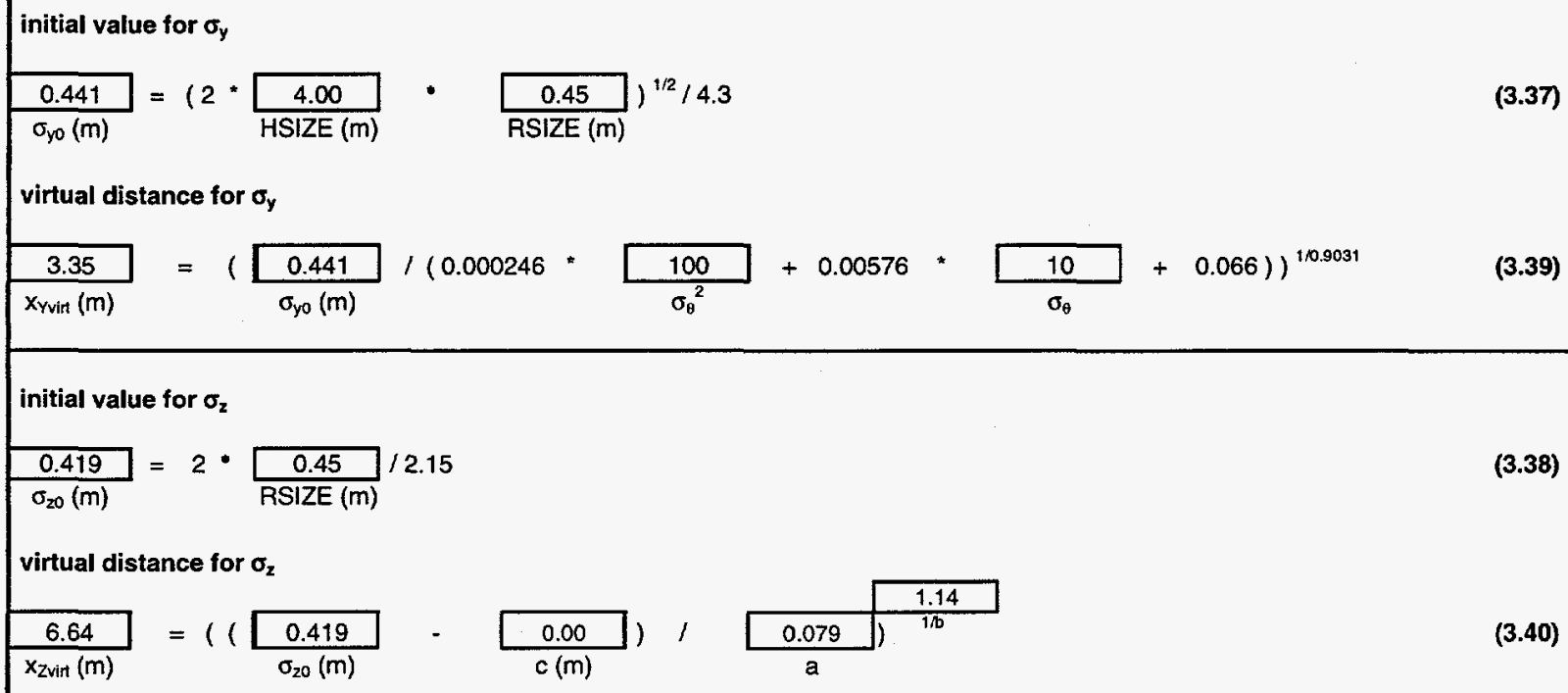

FIGURE 3.4 Initial Pasquill-Gifford Horizontal and Vertical Dispersion Parameter Estimates

$$
\begin{aligned}
& \text { virtual distance for } \sigma_{y}
\end{aligned}
$$

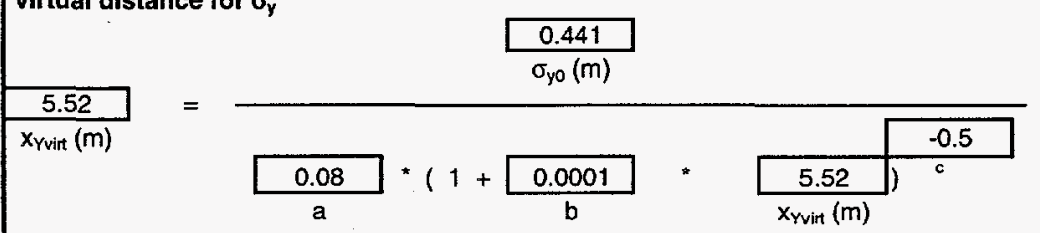

$$
\begin{aligned}
& \text { virtual distance for } \sigma_{\mathbf{z}}
\end{aligned}
$$

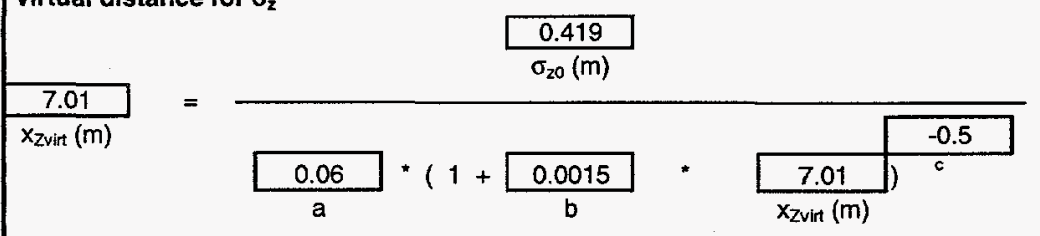




\subsubsection{Effective Release Height}

Another initial factor in addition to dispersion geometry that will affect downwind concentrations is the effective release height. The effective release height is the actual physical release height above the ground, adjusted for thermally induced plume rise and the terrain height of the receptor. The plume rise calculations depend on the effective wind speed, which depends, in turn, on the effective release height. This circular dependency requires iteration among the equations for effective release height, plume rise $(\Delta \mathrm{h})$, and effective wind speed. The calculations for case 2 are presented in Figure 3.6. The resulting effective release height of $11.3 \mathrm{~m}$ agrees with the $11.2 \mathrm{~m}$ value found in the case 2 output file (Appendix A, pg. A-19).

\subsubsection{Ground-Level Air Concentrations}

To estimate the ground-level air concentrations at a given location from the release point, the effective dispersion coefficients must be calculated. Figure 3.7 presents the PasquillGifford dispersion coefficients for case 2 calculated by using the results from Section 3.3.1 adjusted for buoyancy-induced dispersion. These data are in agreement with the case 2 program output (Appendix A, pg. A-19). The parallel calculations for Briggs dispersion coefficients are given in Figure 3.8.

As the plume migrates downwind, it is eventually restricted by an upper layer of stable air. This restriction results in reflection of the plume back toward the ground and eventually a homogenous vertical distribution. Figure 3.9 presents the calculations performed to estimate the time-integrated ground-level air concentration $\left(\mathrm{C}_{\mathrm{a}}\right)$ of radionuclide $i$ for a release of $1 \mathrm{Ci}$ when the plume has not yet been restricted by a stable upper air layer. The value of $5.27 \times 10^{-5} \mathrm{Ci}$-s $/ \mathrm{m}^{3}$ agrees with the $\chi / \mathrm{Q}\left(\mathrm{Chi} / \mathrm{Q} ; \mathrm{C}_{\mathrm{a}} / \mathrm{Q}_{\mathrm{xi}}\right.$ ) on page 10 of the case 2 output (Appendix A, pg. A-19) for gases that are assumed to not undergo plume depletion. Values of $\chi / Q$ for the other radionuclide types are slightly less than those for gases since they are assumed to undergo dry deposition. As a check, Figure 3.10 presents the ground-level air calculation when plume reflection occurs. This latter result of $2.15 \times 10^{-7} \mathrm{Ci}-\mathrm{s} / \mathrm{m}^{3}$ can be obtained by using RISKIND if the case 2 input parameters for the receptor distance are changed from 1 to $10 \mathrm{~km}$ and the weather stability category is changed from $D$ to $B$. The gas $\chi / Q$ value in the program output is $2.16 \times 10^{-7} \mathrm{~s} / \mathrm{m}^{3}$. As an additional check, Figure 3.11 presents the ground-level air concentration calculations for the case 2 conditions, except the Briggs dispersion coefficients have been selected for input. The $4.43 \times 10^{-5} \mathrm{Ci}-\mathrm{s} / \mathrm{m}^{3}$ end result agrees with the RISKIND output of $4.45 \times 10^{-5} \mathrm{~s} / \mathrm{m}^{3}$ for the gas $\chi / \mathrm{Q}$ if case 2 is run with the Briggs dispersion coefficients selected.

\subsubsection{Comparison with GENII}

The GENII computer code (Napier et al. 1988) uses a similar Gaussian plume model for accidental radioactive releases and is implemented with the Pasquill-Gifford dispersion coefficients. Plume centerline $(\mathrm{y}=0) \chi / \mathrm{Q}$ values for a number of distances downwind were estimated by using RISKIND and GENII. Point source releases were modeled to compare codes, since the model in GENII assumes a point source configuration. The cask length was set to 


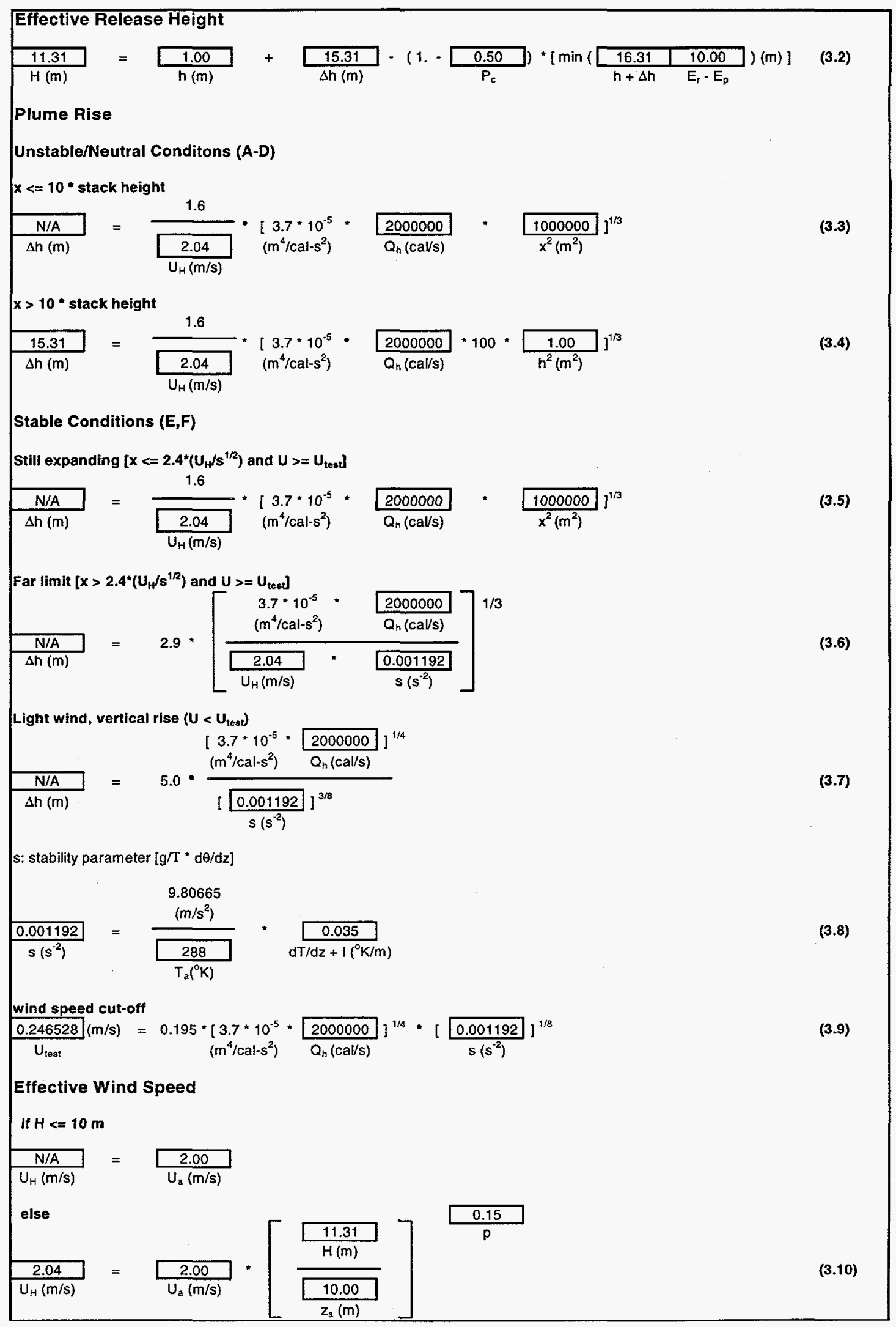

FIGURE 3.6 Effective Release Height Calculation in RISKIND 


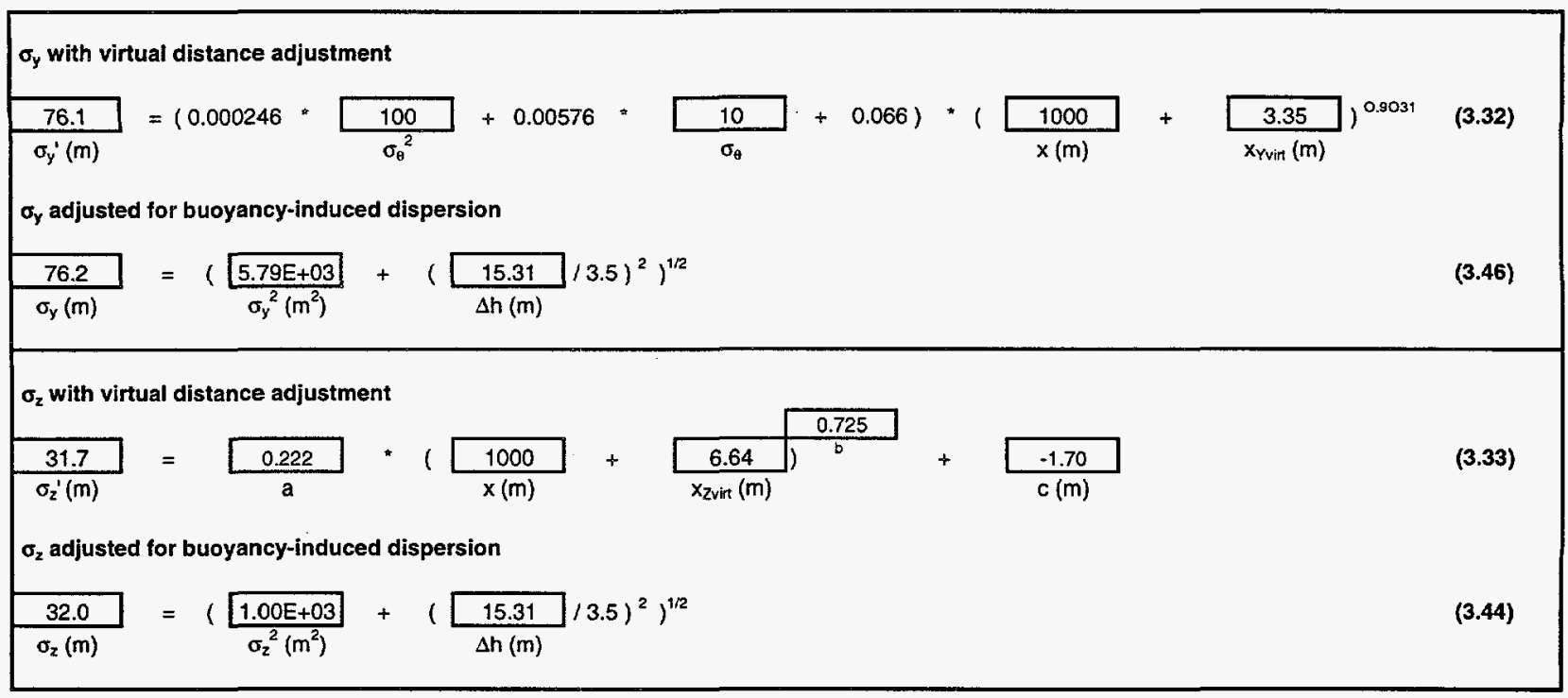

FIGURE 3.7 Pasquill-Gifford Dispersion Coefficient Calculations

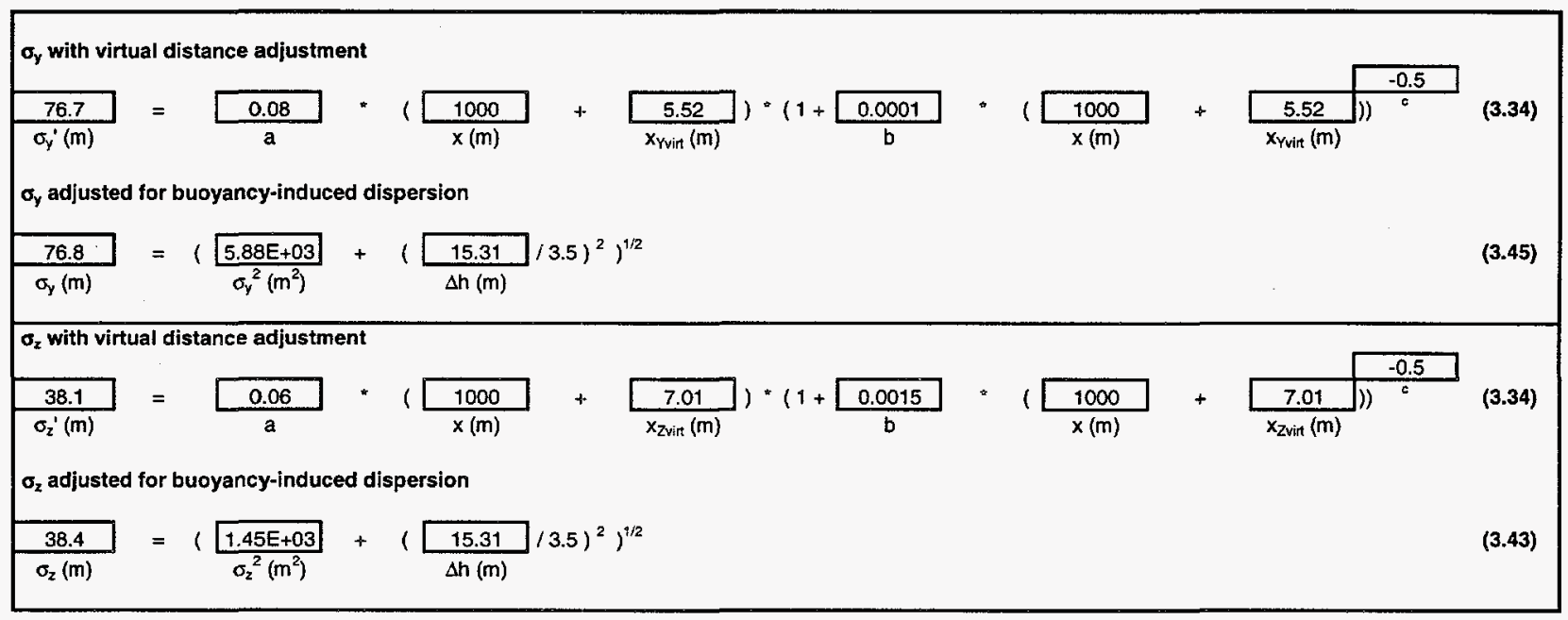

\section{FIGURE 3.8 Briggs Dispersion Coefficient Calculations}

$0.01 \mathrm{~m}$ and the radius to $0.01 \mathrm{~m}$ in RISKIND. (The RISKIND results did not change if a value of $0.1 \mathrm{~m}$ was used instead for the cask dimensions.) The release height was fixed at $10 \mathrm{~m}$, and average weather conditions were assumed. The Pasquill D stability category was used in conjunction with an average wind speed of $4 \mathrm{~m} / \mathrm{s}$.

As presented in Table 3.8, the time-integrated $\chi / Q$ air concentration values at groundlevel for distances from 0.1 to $80 \mathrm{~km}$ were the same for the GENII results and for the RISKIND values when there was no plume depletion (inert gases). The GENII implementation is 


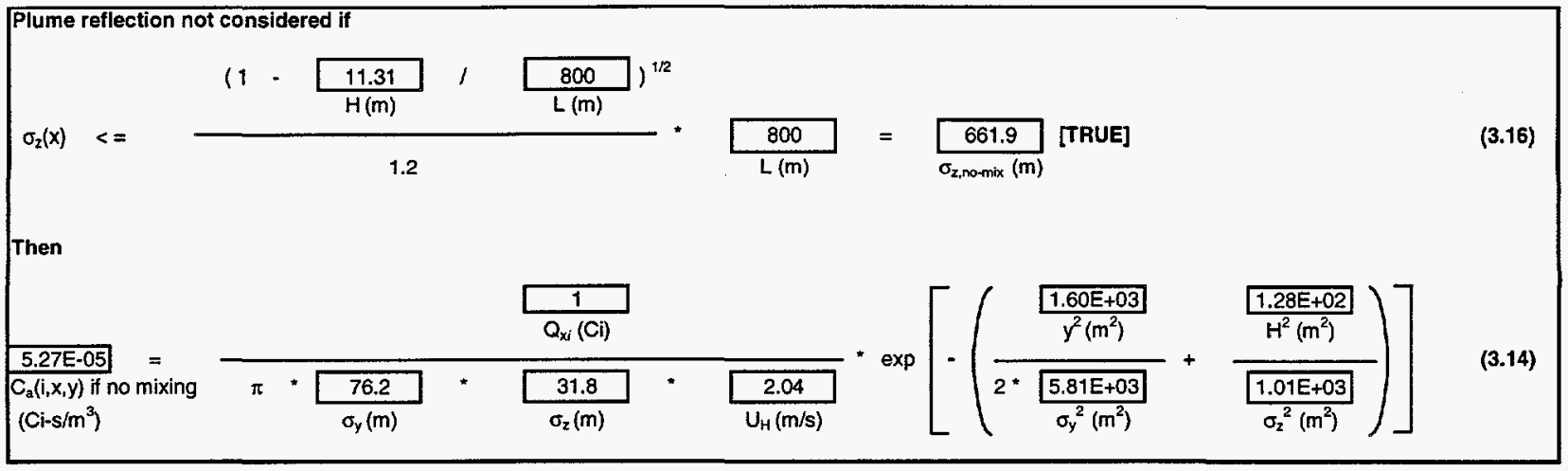

FIGURE 3.9 Ground-Level Air Concentration for Radionuclide $i$ by Using Pasquill-Gifford Dispersion Coefficients without Plume Reflection

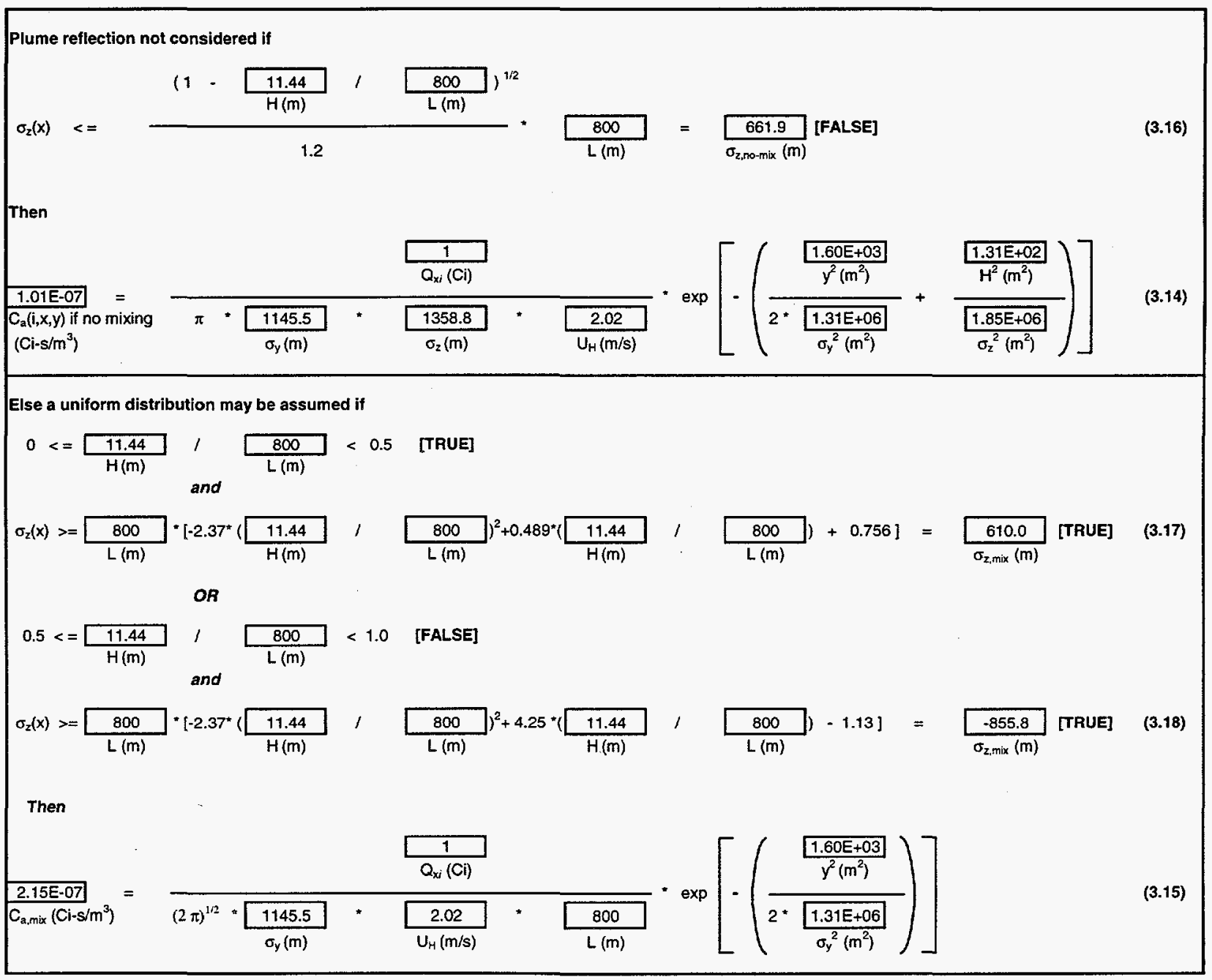

FIGURE 3.10 Ground-Level Air Concentration for Radionuclide $i$ by Using Pasquill-Gifford Dispersion Coefficients with Plume Reflection 


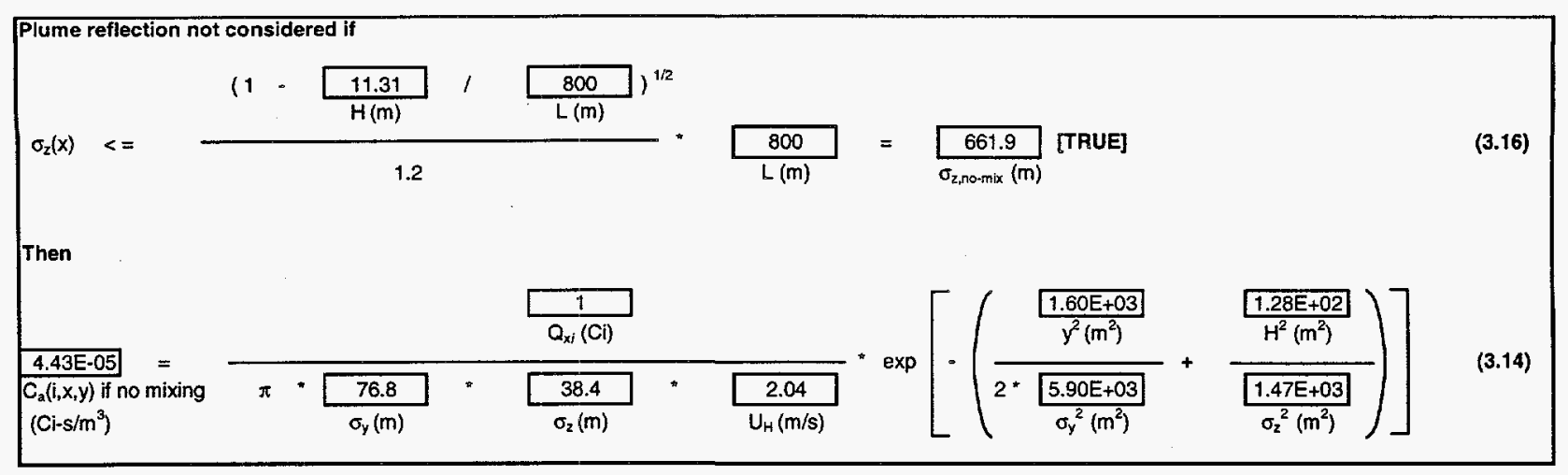

FIGURE 3.11 Ground-Level Air Concentration for Radionuclide $i$ by Using Briggs Dispersion Coefficients without Plume Reflection

TABLE 3.8 Comparison of RISKIND and GENII Air Concentration Calculations

\begin{tabular}{cccc}
\hline & \multicolumn{3}{c}{$\chi / \mathrm{Q}\left(\mathrm{s} / \mathrm{m}^{3}\right)$} \\
\cline { 2 - 4 } $\begin{array}{c}\text { Distance } \\
(\mathrm{km})\end{array}$ & GENII & $\begin{array}{c}\text { RISKIND } \\
\text { (gases) }\end{array}$ & $\begin{array}{c}\text { RISKIND } \\
\text { (particulates) }\end{array}$ \\
\hline 0.1 & $1.7 \mathrm{E}-04$ & $1.66 \mathrm{E}-04$ & $1.66 \mathrm{E}-04$ \\
0.2 & $2.7 \mathrm{E}-04$ & $2.66 \mathrm{E}-04$ & $2.63 \mathrm{E}-04$ \\
0.3 & $1.8 \mathrm{E}-04$ & $1.82 \mathrm{E}-04$ & $1.78 \mathrm{E}-04$ \\
0.4 & $1.3 \mathrm{E}-04$ & $1.26 \mathrm{E}-04$ & $1.22 \mathrm{E}-04$ \\
0.5 & $9.3 \mathrm{E}-05$ & $9.20 \mathrm{E}-05$ & $8.81 \mathrm{E}-05$ \\
0.6 & $7.1 \mathrm{E}-05$ & $7.01 \mathrm{E}-05$ & $6.66 \mathrm{E}-05$ \\
0.7 & $5.6 \mathrm{E}-05$ & $5.54 \mathrm{E}-05$ & $5.22 \mathrm{E}-05$ \\
0.8 & $4.5 \mathrm{E}-05$ & $4.50 \mathrm{E}-05$ & $4.21 \mathrm{E}-05$ \\
0.9 & $3.8 \mathrm{E}-05$ & $3.74 \mathrm{E}-05$ & $3.47 \mathrm{E}-05$ \\
1 & $3.2 \mathrm{E}-05$ & $3.17 \mathrm{E}-05$ & $2.92 \mathrm{E}-05$ \\
2.5 & $7.8 \mathrm{E}-06$ & $7.73 \mathrm{E}-06$ & $6.66 \mathrm{E}-06$ \\
5 & $2.8 \mathrm{E}-08$ & $2.73 \mathrm{E}-06$ & $2.20 \mathrm{E}-06$ \\
10 & $9.9 \mathrm{E}-07$ & $9.83 \mathrm{E}-07$ & $7.24 \mathrm{E}-07$ \\
20 & $3.6 \mathrm{E}-07$ & $3.58 \mathrm{E}-07$ & $2.33 \mathrm{E}-07$ \\
30 & $2.0 \mathrm{E}-07$ & $1.99 \mathrm{E}-07$ & $1.19 \mathrm{E}-07$ \\
40 & $1.3 \mathrm{E}-07$ & $1.31 \mathrm{E}-07$ & $7.37 \mathrm{E}-08$ \\
50 & $9.6 \mathrm{E}-08$ & $9.51 \mathrm{E}-08$ & $5.04 \mathrm{E}-08$ \\
60 & $7.4 \mathrm{E}-08$ & $7.32 \mathrm{E}-08$ & $3.69 \mathrm{E}-08$ \\
70 & $5.9 \mathrm{E}-08$ & $5.86 \mathrm{E}-08$ & $2.82 \mathrm{E}-08$ \\
80 & $4.9 \mathrm{E}-08$ & $4.84 \mathrm{E}-08$ & $2.23 \mathrm{E}-08$ \\
\hline & & &
\end{tabular}


conservative, because it does not model plume depletion. The last column in Table 3.8 lists the ground-level $\chi / Q$ values when plume depletion from dry deposition was considered in RISKIND and the default deposition velocity of $0.01 \mathrm{~m} / \mathrm{s}$ was used for everything except gases. Approximately $50 \%$ of the plume was depleted at a distance of $80 \mathrm{~km}$.

\subsubsection{Comparison with CAP88-PC}

The CAP88-PC computer code (EPA 1992) is used to show compliance with the National Emission Standards for Hazardous Air Pollutants (NESHAPS) air monitoring requirements (Code of Federal Regulations, Title 40, Part 61, Subpart H). This code uses the Briggs dispersion coefficients (Briggs 1974) for open country (rural area) in a Gaussian plume model similar to that used in RISKIND. CAP88-PC estimates exposures from chronic releases, but the Gaussian dispersion equation used to estimate ground-level air concentrations for these chronic exposures is identical in form to that for acute exposures. (For more information, compare equations 3.116 [continuous] and 3.158 [puff] in Slade [1968].) The main exception is in the definitions and dimensions of the source terms (constant release rate for continuous exposure; one-time total release for puff) and the air concentrations (constant instantaneous air concentration for continuous exposure; integrated over time for puff). The exposures in CAP88-PC are therefore given in dose per unit time rather than as a single (acute) dose.

The comparison between RISKIND and CAP88-PC used point sources at a release height of $20 \mathrm{~m}$ with average weather conditions of Pasquill stability category D in conjunction with an average wind speed of $4.37 \mathrm{~m} / \mathrm{s}$ (the average wind speed of the third wind speed category in STAR files as used by CAP88-PC). The first two columns in Table 3.9 present the groundlevel air $\chi / Q$ values as calculated by the two programs. The values from RISKIND are more than twice the values from CAPP88-PC primarily because CAP88-PC uses a modified form of the Gaussian plume equation that produces a sector-averaged value at the plume centerline $(y=0)$. Plume reflection is not an issue in this problem, so the RISKIND value is evaluated by using the following calculation:

$$
\bar{C}_{a}(i, x, y)=\frac{Q_{x i}}{\pi \sigma_{y} \sigma_{z} u_{H}}\left[\exp -\left(\frac{y^{2}}{2 \sigma_{y}^{2}}+\frac{H^{2}}{2 \sigma_{z}^{2}}\right)\right] \quad \text { (3.14 in Manual) }
$$

When $\mathrm{y}=0$, this equation reduces to one that provides the basis for the CAP88-PC sectoraverage derivation:

$$
\bar{C}_{a}(i, x, y)=\frac{Q_{x i}}{\pi \sigma_{y} \sigma_{z} u_{H}}\left[\exp -\left(\frac{H^{2}}{2 \sigma_{z}^{2}}\right)\right]
$$

The inclusion of sector averaging results in the final form of the equation that is used in CAP88-PC when the atmospheric lid height has not been reached (EPA 1992): 
TABLE 3.9 Comparison of RISKIND and CAP88-PC Air Concentration Calculations

\begin{tabular}{ccccc}
\hline & \multicolumn{3}{c}{$\chi / \mathrm{Q}$ (gases) $\left(\mathrm{s} / \mathrm{m}^{3}\right)$} \\
\cline { 2 - 4 } $\begin{array}{c}\text { Distance } \\
(\mathrm{km})\end{array}$ & RISKIND & CAP88-PC & $\begin{array}{c}\text { CAP88-PC } \\
\text { without Sector } \\
\text { Averaging }\end{array}$ & RISKIND/ \\
CAP88-PC \\
\hline 0.1 & $2.79 \mathrm{E}-06$ & $1.06 \mathrm{E}-06$ & $2.11 \mathrm{E}-06$ & 1.32 \\
0.2 & $7.19 \mathrm{E}-05$ & $2.70 \mathrm{E}-05$ & $5.41 \mathrm{E}-05$ & 1.33 \\
0.3 & $8.42 \mathrm{E}-05$ & $3.70 \mathrm{E}-05$ & $7.45 \mathrm{E}-05$ & 1.13 \\
0.4 & $7.01 \mathrm{E}-05$ & $3.36 \mathrm{E}-05$ & $6.79 \mathrm{E}-05$ & 1.03 \\
0.5 & $5.57 \mathrm{E}-05$ & $2.78 \mathrm{E}-05$ & $5.66 \mathrm{E}-05$ & 0.98 \\
0.6 & $4.46 \mathrm{E}-05$ & $2.27 \mathrm{E}-05$ & $4.64 \mathrm{E}-05$ & 0.96 \\
0.7 & $3.63 \mathrm{E}-05$ & $1.87 \mathrm{E}-05$ & $3.83 \mathrm{E}-05$ & 0.95 \\
0.8 & $3.02 \mathrm{E}-05$ & $1.55 \mathrm{E}-05$ & $3.20 \mathrm{E}-05$ & 0.94 \\
0.9 & $2.55 \mathrm{E}-05$ & $1.31 \mathrm{E}-05$ & $2.71 \mathrm{E}-05$ & 0.94 \\
1 & $2.19 \mathrm{E}-05$ & $1.11 \mathrm{E}-05$ & $2.31 \mathrm{E}-05$ & 0.95 \\
2.5 & $5.67 \mathrm{E}-06$ & $2.70 \mathrm{E}-06$ & $5.98 \mathrm{E}-06$ & 0.95 \\
5 & $2.13 \mathrm{E}-06$ & $9.45 \mathrm{E}-07$ & $2.30 \mathrm{E}-06$ & 0.93 \\
10 & $8.50 \mathrm{E}-07$ & $3.35 \mathrm{E}-07$ & $9.41 \mathrm{E}-07$ & 0.90 \\
20 & $3.64 \mathrm{E}-07$ & $1.17 \mathrm{E}-07$ & $4.02 \mathrm{E}-07$ & 0.91 \\
30 & $2.28 \mathrm{E}-07$ & $6.32 \mathrm{E}-08$ & $2.51 \mathrm{E}-07$ & 0.91 \\
40 & $1.65 \mathrm{E}-07$ & $4.08 \mathrm{E}-08$ & $1.81 \mathrm{E}-07$ & 0.91 \\
50 & $1.29 \mathrm{E}-07$ & $2.90 \mathrm{E}-08$ & $1.41 \mathrm{E}-07$ & 0.91 \\
60 & $1.06 \mathrm{E}-07$ & $2.20 \mathrm{E}-08$ & $1.15 \mathrm{E}-07$ & 0.92 \\
70 & $9.00 \mathrm{E}-08$ & $1.74 \mathrm{E}-08$ & $9.75 \mathrm{E}-08$ & 0.92 \\
80 & $7.81 \mathrm{E}-08$ & $1.42 \mathrm{E}-08$ & $8.44 \mathrm{E}-08$ & 0.93 \\
\hline
\end{tabular}

$\chi=\frac{Q}{0.15871 \pi x \sigma_{z} u_{H}}\left[\exp -\left(\frac{H^{2}}{2 \sigma_{z}^{2}}\right)\right]$ (Equation 12 in EPA 1992)

where $\chi=C_{a}(i, x, y)$ and $\mathrm{Q}=\mathrm{Q}_{\mathrm{xi}}$. To provide a fair comparison between RISKIND and CAP88-PC, the value for the original form of the Gaussian equation can be obtained by multiplying the CAP88-PC result (Equation 3.15) by $0.15871 * \mathrm{x} / \sigma_{\mathrm{y}}$ (to obtain Equation 3.14, the RISKIND result), where $\mathrm{x}$ is the distance from the release point to the receptor and $\sigma_{\mathrm{y}}$ is the horizontal dispersion coefficient in the Briggs form for $\mathrm{D}$ weather stability in a rural area:

$$
\sigma_{y}=\frac{0.08 x}{\sqrt{1+0.0001 x}} \text { (specific case of Equation } 3.34 \text { in the Manual) }
$$

The third column in Table 3.9 provides the modified CAP88-PC results, and the fourth column provides the ratio of the RISKIND and modified CAP88-PC results for comparison. Disagreement is greater than $10 \%$ at distances less than $0.5 \mathrm{~km}$ because of CAP88-PC's use of modified Briggs coefficients: 


$$
\sigma_{y}=\frac{x^{A}}{C}
$$

and

$$
\sigma_{z}=\frac{x^{D}}{F}
$$

rather than the form of Equation 3.16 as originally proposed by Briggs (1974). For example, at $200 \mathrm{~m}$, the $\chi / \mathrm{Q}$ value estimated by CAP88-PC was $2.7 \times 10^{-5} \mathrm{~s} / \mathrm{m}^{3}$. This calculation used a $\sigma_{\mathrm{z}}$ value of $9.57 \mathrm{~m}$, obtained by using $\mathrm{D}=0.8061$ and $\mathrm{F}=7.48$ in Equation 3.18. If CAP88-PC had used:

$$
\sigma_{z}=\frac{0.06 x}{\sqrt{1+0.0015 x}}
$$

as did RISKIND, $\sigma_{\mathrm{z}}$ would have been 10.52 , and $\chi / \mathrm{Q}$ would have been $3.58 \times 10^{-5} \mathrm{~s} / \mathrm{m}^{3}$. Removing the sector averaging from this value (multiplying by $0.15871 * \mathrm{x} / \sigma_{\mathrm{y}}$, as discussed above) would have yielded the $7.19 \times 10^{-5} \mathrm{~s} / \mathrm{m}^{3}$ result given by RISKIND for a receptor at $200 \mathrm{~m}$ (Table 3.9).

\subsection{EXPOSURE PATHWAYS}

The air concentrations calculated in Section 3.3 lead directly to the inhalation and cloudshine exposure pathways and are intermediate values in the estimation of ground deposition. The calculated ground concentrations are required, in turn, to estimate exposure from groundshine and resuspended inhalation and are used as input to the food and water ingestion pathways.

\subsubsection{Short-Term Exposure}

During passage of a radioactive cloud following an accident, individuals downwind from the accident may be exposed to external radiation from the radioactive material in the cloud, internal radiation from inhalation of the radioactive material in the cloud, and external radiation from radioactive material deposited on the ground. The calculated doses resulting from short-term exposure to the passing radioactive cloud are shown in Table 3.10. Figure 3.12 presents the individual calculations for exposure to Cs-137. The estimated ground concentration for calculating the groundshine dose is obtained by multiplying the air concentration calculated in Section 3.3 .3 by the radionuclide deposition velocity (Equation 3.19 in the Manual). A comparison between Table 3.10 and page 11 of the case 2 output file (Appendix A, page A-20) shows proper operation of the code in calculating the total short-term (acute) doses received from cloudshine, groundshine, and inhalation. 
TABLE 3.10 Calculated Doses from Short-Term Exposure (rem)

\begin{tabular}{lccc}
\hline & \multicolumn{2}{c}{ External } & \\
\cline { 2 - 3 } Radionuclide & Cloudshine & Groundshine & $\begin{array}{c}\text { Internal } \\
\text { Inhalation }\end{array}$ \\
\hline $\mathrm{Kr}-85$ & $1.61 \mathrm{E}-06$ & $0.00 \mathrm{E}+00$ & $3.93 \mathrm{E}-05$ \\
$\mathrm{Co}-60$ & $8.11 \mathrm{E}-06$ & $4.84 \mathrm{E}-06$ & $1.07 \mathrm{E}-03$ \\
$\mathrm{Sr}-90$ & $1.66 \mathrm{E}-10$ & $1.51 \mathrm{E}-10$ & $8.36 \mathrm{E}-05$ \\
$\mathrm{Cs}-134$ & $6.32 \mathrm{E}-07$ & $4.07 \mathrm{E}-07$ & $2.94 \mathrm{E}-05$ \\
$\mathrm{Cs}-137$ & $3.29 \mathrm{E}-06$ & $2.14 \mathrm{E}-06$ & $3.73 \mathrm{E}-04$ \\
$\mathrm{Pu}-238$ & $2.09 \mathrm{E}-13$ & $1.15 \mathrm{E}-12$ & $1.28 \mathrm{E}-03$ \\
$\mathrm{Pu}-239$ & $2.12 \mathrm{E}-14$ & $5.87 \mathrm{E}-14$ & $1.63 \mathrm{E}-04$ \\
$\mathrm{Pu}-240$ & $3.40 \mathrm{E}-14$ & $1.84 \mathrm{E}-13$ & $2.34 \mathrm{E}-04$ \\
$\mathrm{Pu}-241$ & $2.58 \mathrm{E}-13$ & $1.96 \mathrm{E}-13$ & $7.39 \mathrm{E}-04$ \\
Am-241 & $2.14 \mathrm{E}-11$ & $2.30 \mathrm{E}-11$ & $8.86 \mathrm{E}-04$ \\
$\mathrm{Cm}-244$ & $1.33 \mathrm{E}-13$ & $7.62 \mathrm{E}-13$ & $5.12 \mathrm{E}-04$ \\
Total & $1.36 \mathrm{E}-05$ & $7.38 \mathrm{E}-06$ & $5.41 \mathrm{E}-03$ \\
\hline
\end{tabular}

\begin{tabular}{|c|c|c|c|c|c|c|c|c|c|c|}
\hline Cloudshine & \multirow{3}{*}{$=$} & \multirow{3}{*}{\begin{tabular}{|c|}
$7.95 E-01$ \\
$Q_{x}(C i)$
\end{tabular}} & \multirow{3}{*}{$=$} & \multirow{3}{*}{\begin{tabular}{|l|}
$4.55 \mathrm{E}-05$ \\
$\chi / \mathrm{Q}\left(\mathrm{sec} / \mathrm{m}^{3}\right)$
\end{tabular}} & \multirow{3}{*}{$\begin{array}{c}2.73 E-14 \\
D C F_{\text {Air }}(\mathrm{Cs}-137) \\
\left(\mathrm{Sv}-\mathrm{m}^{3} / \mathrm{Bq}-\mathrm{s}\right)\end{array}$} & \multirow{3}{*}{ * } & & \multirow{3}{*}{$\therefore$} & \multirow{3}{*}{$3.7 \times 10^{12}$ ren } & \multirow{3}{*}{$\mathrm{n}-\mathrm{B} q / \mathrm{Sv}-\mathrm{Ci}$} \\
\hline $3.29 \mathrm{E}-06$ & & & & & & & 0.9 & & & \\
\hline $\mathrm{D}_{\text {Airst }}(\mathrm{rem})$ & & & & & & & $\mathrm{SF}_{\text {AirST }}$ & & & \\
\hline \multicolumn{11}{|l|}{ Groundshine } \\
\hline $2.14 \mathrm{E}-06$ & \multirow[t]{2}{*}{$=$} & $7.95 E-01$ & \multirow[t]{2}{*}{ * } & $4.55 \mathrm{E}-07$ & $5.54 \mathrm{E}-16$ & \multirow[t]{2}{*}{ - } & 2 & \multirow[t]{2}{*}{ * } & 0.4 & (3.48) \\
\hline$D_{\text {GndST }}$ (rem) & & $Q_{x}(\mathrm{Ci})$ & & $x / Q_{\text {gnd }}\left(m^{-2}\right)$ & $\begin{array}{c}\text { DCF }_{\text {Gnd }}(\mathrm{Cs}-137) \\
\left(\mathrm{Sv}-\mathrm{m}^{2} / \mathrm{Bq}-\mathrm{s}\right)\end{array}$ & & $T_{E x t}(h r)$ & & $\mathrm{SF}_{\text {GndST }}$ & $1.332 \times 10^{16} \mathrm{rem}-\mathrm{Bq}-\mathrm{s} / \mathrm{Sv}-\mathrm{Ci}-\mathrm{h}$ \\
\hline \multicolumn{11}{|l|}{ Inhalation } \\
\hline $3.73 E-04$ & $=$ & $7.95 \mathrm{E}-01$ & * & $4.55 \mathrm{E}-05$ & $1.10 \mathrm{E}-08$ & * & 8000 & $=$ & 1.0 & $(3.50)$ \\
\hline$D_{\text {Inhst }}(\mathrm{rem})$ & & $Q_{x}(C i)$ & & $x^{/ Q}\left(\mathrm{sec} / \mathrm{m}^{3}\right)$ & $D C F_{\text {inh }}\left(C_{s-137}\right)$ & & $\mathrm{BR}\left(\mathrm{m}^{3} / \mathrm{yr}\right)$ & & $\overline{S F_{\text {InisT }}}$ & $1.172 \times 10^{5} \mathrm{rem}-\mathrm{Bq}-\mathrm{yr} / \mathrm{Sv}-\mathrm{Ci}-\mathrm{s}$ \\
\hline
\end{tabular}

FIGURE 3.12 Dose Calculations for Short-Term Exposure to Cs-137 


\subsubsection{Long-Term Exposure}

For the long-term period following an accident, individuals may be exposed to external radiation from the radionuclides remaining on the ground, internal radiation from inhalation of resuspended radionuclides, external radiation from resuspended radionuclides, and ingestion of contaminated food and water. Data on time-integrated contaminant ground concentrations and resuspended air concentrations are needed to estimate these long-term exposure doses. The calculations for Cs-137 concentrations are presented in Figure 3.13. The values for the other radionuclides are given in Table 3.11 .

Individual dose calculations for long-term groundshine, cloudshine, and inhalation exposure to Cs-137 are shown in Figure 3.14 for case 2. Table 3.12 presents the results for the other radionuclides and the cumulative totals. The total individual long-term exposure doses given in Table 3.12 agree with those calculated by RISKIND for case 2, as shown on page 11 of the output file (Appendix A, pg. A-20).

RISKIND estimates ingestion doses in two parts. The first part, if selected by the user, consists of doses calculated for the first year following an accident. Estimated doses for this first year are generally higher than they are for following years, because direct deposition from the passing radioactive cloud results in higher radionuclide concentrations in vegetation eaten by humans and animals. For individual doses, first-year doses are calculated by assuming a 365-day supply of contaminated food. For the second part of the ingestion calculations, plant contamination is dominated by the root uptake pathway. Ingestion doses are calculated for human consumption of vegetables, meat, and milk.

TABLE 3.11 Time-Integrated Ground and Resuspended Air Concentrations for Use in LongTerm Exposure Calculations

\begin{tabular}{lll}
\hline & $\begin{array}{l}\text { Ground } \\
\text { Radionuclide } \\
\left(\mathrm{Ci}-\mathrm{s} / \mathrm{m}^{2}\right)\end{array}$ & $\begin{array}{l}\text { Air } \\
\left(\mathrm{Ci}-\mathrm{s} / \mathrm{m}^{3}\right)\end{array}$ \\
\hline $\mathrm{Kr}-85$ & $0.00 \mathrm{E}+00$ & $0.00 \mathrm{E}+00$ \\
$\mathrm{Co}-60$ & $4.24 \mathrm{E}+01$ & $1.18 \mathrm{E}-05$ \\
$\mathrm{Sr}-90$ & $1.79 \mathrm{E}+00$ & $1.58 \mathrm{E}-07$ \\
$\mathrm{Cs}-134$ & $2.24 \mathrm{E}+00$ & $1.47 \mathrm{E}-06$ \\
$\mathrm{Cs}-137$ & $2.61 \mathrm{E}+02$ & $2.26 \mathrm{E}-05$ \\
$\mathrm{Pu}-238$ & $1.24 \mathrm{E}-01$ & $8.11 \mathrm{E}-09$ \\
$\mathrm{Pu}-239$ & $1.71 \mathrm{E}-02$ & $9.50 \mathrm{E}-10$ \\
$\mathrm{Pu}-240$ & $2.44 \mathrm{E}-02$ & $1.36 \mathrm{E}-09$ \\
$\mathrm{Pu}-241$ & $1.72 \mathrm{E}+00$ & $2.19 \mathrm{E}-07$ \\
$\mathrm{Am}-241$ & $8.65 \mathrm{E}-02$ & $4.98 \mathrm{E}-09$ \\
$\mathrm{Cm}-244$ & $4.59 \mathrm{E}-02$ & $5.07 \mathrm{E}-09$ \\
\hline
\end{tabular}

TABLE 3.12 Calculated Individual Doses (rem) from Long-Term Exposure to External Radiation from Ground Contamination and to External and Internal Radiation from Resuspended Air Contamination

\begin{tabular}{lccc}
\hline & \multicolumn{2}{c}{ Resuspended Air } & \\
\cline { 2 - 3 } & & & Ground \\
Radionuclide & $\begin{array}{c}\text { Internal } \\
\text { Inhalation }\end{array}$ & External & External \\
\hline Kr-85 & $0.00 \mathrm{E}+00$ & $0.00 \mathrm{E}+00$ & $0.00 \mathrm{E}+00$ \\
$\mathrm{Co}-60$ & $4.89 \mathrm{E}-04$ & $3.02 \mathrm{E}-06$ & $1.29 \mathrm{E}-01$ \\
$\mathrm{Sr}-90$ & $3.92 \mathrm{E}-05$ & $6.33 \mathrm{E}-11$ & $1.30 \mathrm{E}-05$ \\
$\mathrm{Cs}-134$ & $1.29 \mathrm{E}-05$ & $2.25 \mathrm{E}-07$ & $4.41 \mathrm{E}-03$ \\
$\mathrm{Cs}-137$ & $1.75 \mathrm{E}-04$ & $1.26 \mathrm{E}-06$ & $1.87 \mathrm{E}-01$ \\
$\mathrm{Pu}-238$ & $6.05 \mathrm{E}-04$ & $8.04 \mathrm{E}-14$ & $1.34 \mathrm{E}-07$ \\
$\mathrm{Pu}-239$ & $7.75 \mathrm{E}-05$ & $8.20 \mathrm{E}-15$ & $8.12 \mathrm{E}-09$ \\
$\mathrm{Pu}-240$ & $1.11 \mathrm{E}-04$ & $1.32 \mathrm{E}-14$ & $2.54 \mathrm{E}-08$ \\
$\mathrm{Pu}-241$ & $3.44 \mathrm{E}-04$ & $9.78 \mathrm{E}-14$ & $1.16 \mathrm{E}-08$ \\
Am-241 & $4.20 \mathrm{E}-04$ & $8.28 \mathrm{E}-12$ & $3.07 \mathrm{E}-06$ \\
$\mathrm{Cm}-244$ & $2.39 \mathrm{E}-04$ & $5.07 \mathrm{E}-14$ & $5.21 \mathrm{E}-08$ \\
Total & $2.51 \mathrm{E}-03$ & $4.50 \mathrm{E}-06$ & $3.20 \mathrm{E}-01$ \\
\hline
\end{tabular}




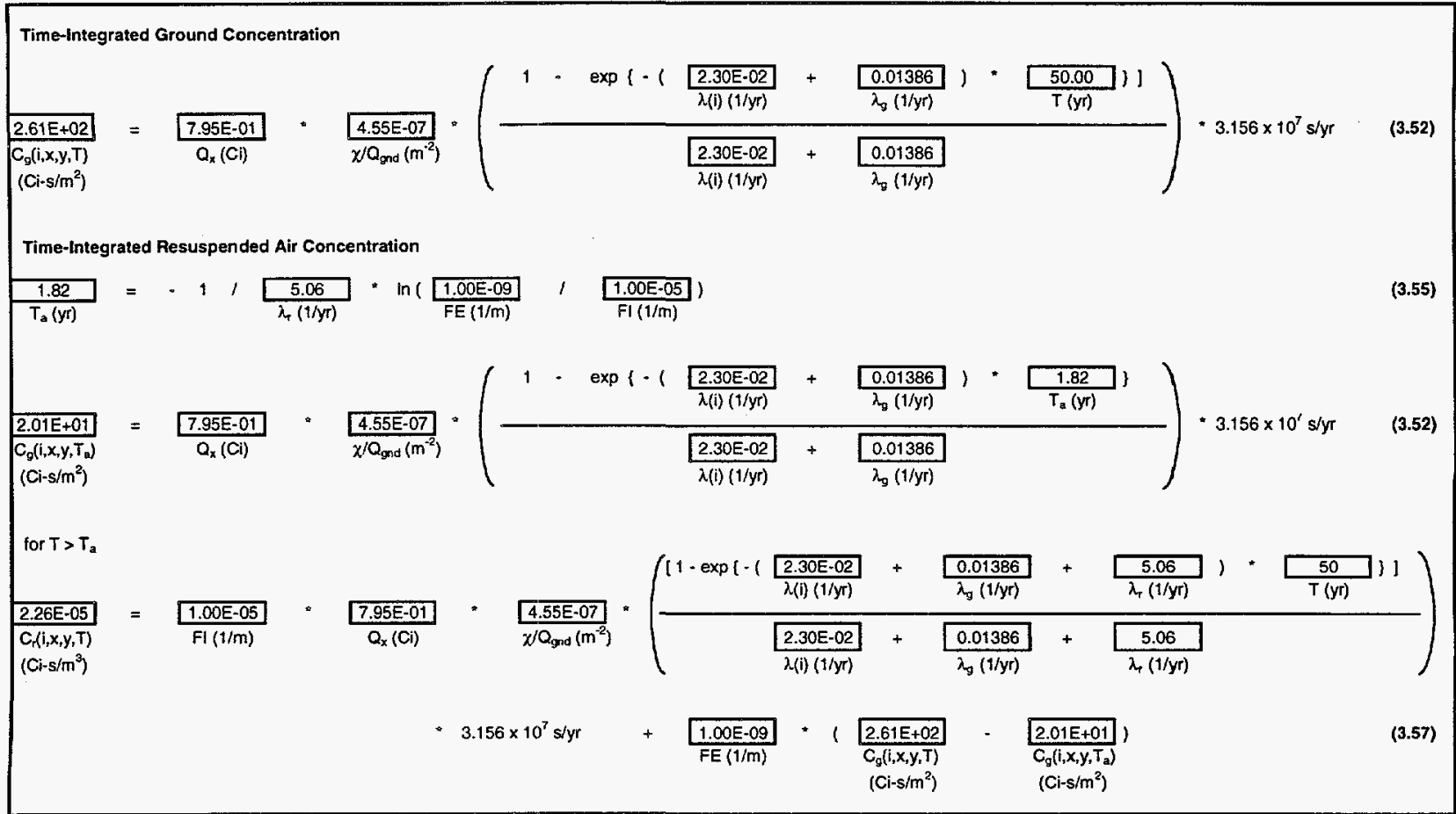

FIGURE 3.13 Time-Integrated Ground and Resuspended Air Concentration Calculations for Long-Term Exposure to Cs-137

$$
\begin{aligned}
& \text { Cloudshine from Resuspended Contamination }
\end{aligned}
$$

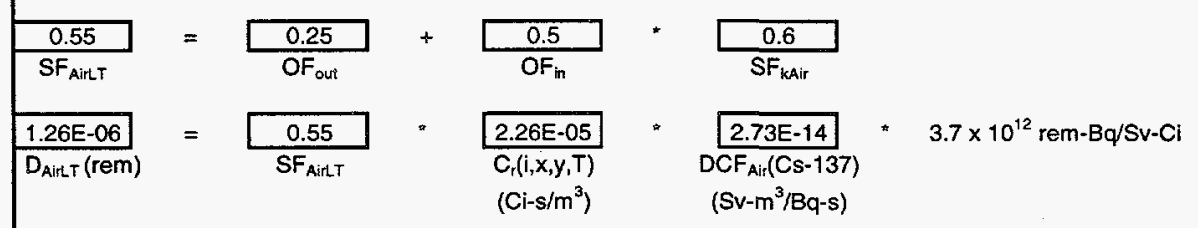

$$
\begin{aligned}
& \text { Groundshine }
\end{aligned}
$$

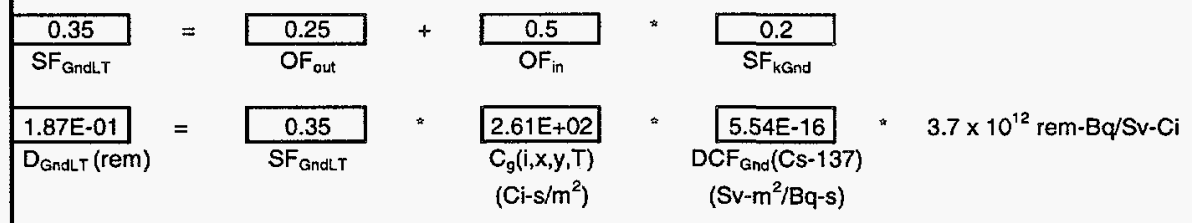

Inhalation from Resuspended Contamnation

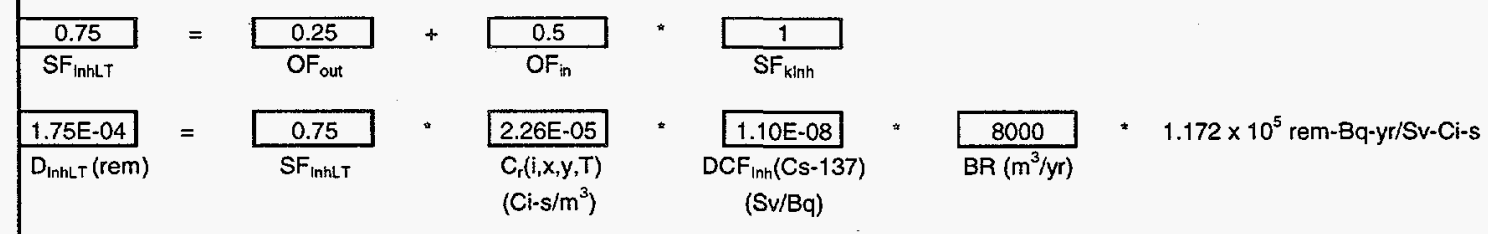

FIGURE 3.14 Groundshine, Cloudshine, and Inhalation Dose Calculations for Long-Term Exposure to Cs-137 
Individual dose calculations for first-year and long-term exposure to Cs-137 resulting from vegetable ingestion are shown in Figure 3.15 for case 2 . Table 3.13 presents the results for radionuclide concentrations found in vegetables meant for animal and human consumption and in meat and milk meant for human consumption that are to be used to calculate first-year and longterm exposures. Table 3.14 presents the radionuclide doses and the cumulative totals for consumption of vegetables, meat, and milk. Cs-137 concentrations in vegetation meant for animal consumption are calculated in Figure 3.16. Individual dose calculations for first-year and long-term exposure to Cs-137 from meat and milk ingestion are presented in Figures 3.17 and 3.18 , respectively. The total dose values presented in Table 3.14 agree with the doses calculated by RISKIND, shown on page 11 of the case 2 output file (Appendix A, pg. A-20).

The case 2 input problem also specified the calculation to estimate exposure to contaminated drinking water. Radionuclide concentrations in contaminated water and individual doses from consuming this water are presented in Table 3.15. Figure 3.19 shows the calculations necessary to estimate the dose received from Cs-137 in the drinking water. The dose from drinking water exposure calculated here agrees with that given on page 11 of the case 2 RISKIND output file (Appendix A,pg. A-20).

\subsubsection{GENII Dose Comparison}

A hypothetical release of Cs-137 (1 Ci) was modeled by RISKIND and GENII to compare their estimated doses to an individual $1 \mathrm{~km}$ downwind. A point source at a release height of $10 \mathrm{~m}$, Pasquill stability category D weather conditions, and a wind speed of $4 \mathrm{~m} / \mathrm{s}$ were assumed. The receptor was assumed to be exposed without shielding to the passing radioactive cloud immediately following the release. A Cs-137 deposition velocity of $0.001 \mathrm{~m} / \mathrm{s}$ was used for determining the contaminated ground concentration. Long-term exposure to groundshine (unshielded for $0.5 \mathrm{yr}$ ) and ingestion (1 yr) were compared. The output file for each program is listed in Appendix B, Section B.1.1. As shown in Section 3.3.1, RISKIND and GENII calculate the same ground-level air concentrations for the same release conditions. Therefore the exposure calculations used to compare dose estimates started with the same air concentrations at the receptor location.

The results of the dose comparison are shown in Table 3.16. Differences were generally within one order of magnitude. Except for the ingestion exposure pathway, as shown in the last three columns of Table 3.16, these differences can be ascribed to the different dose conversion factors used by the two programs rather than any differences in methodology. To determine ingestion exposure, human ingestion rates for vegetables, meat, and milk were set to the RISKIND defaults in GENII, and agricultural productivity was matched between the two models as closely as possible.

The differences in the ingestion doses, approximately an order of magnitude at most, are not unreasonable considering the differences in the models. The ingestion doses of $0.155 \mathrm{rem}$ from RISKIND and 0.21 rem from GENII following contamination of crops at the end of the growing season are in relatively good agreement. However, there is an order-of-magnitude 


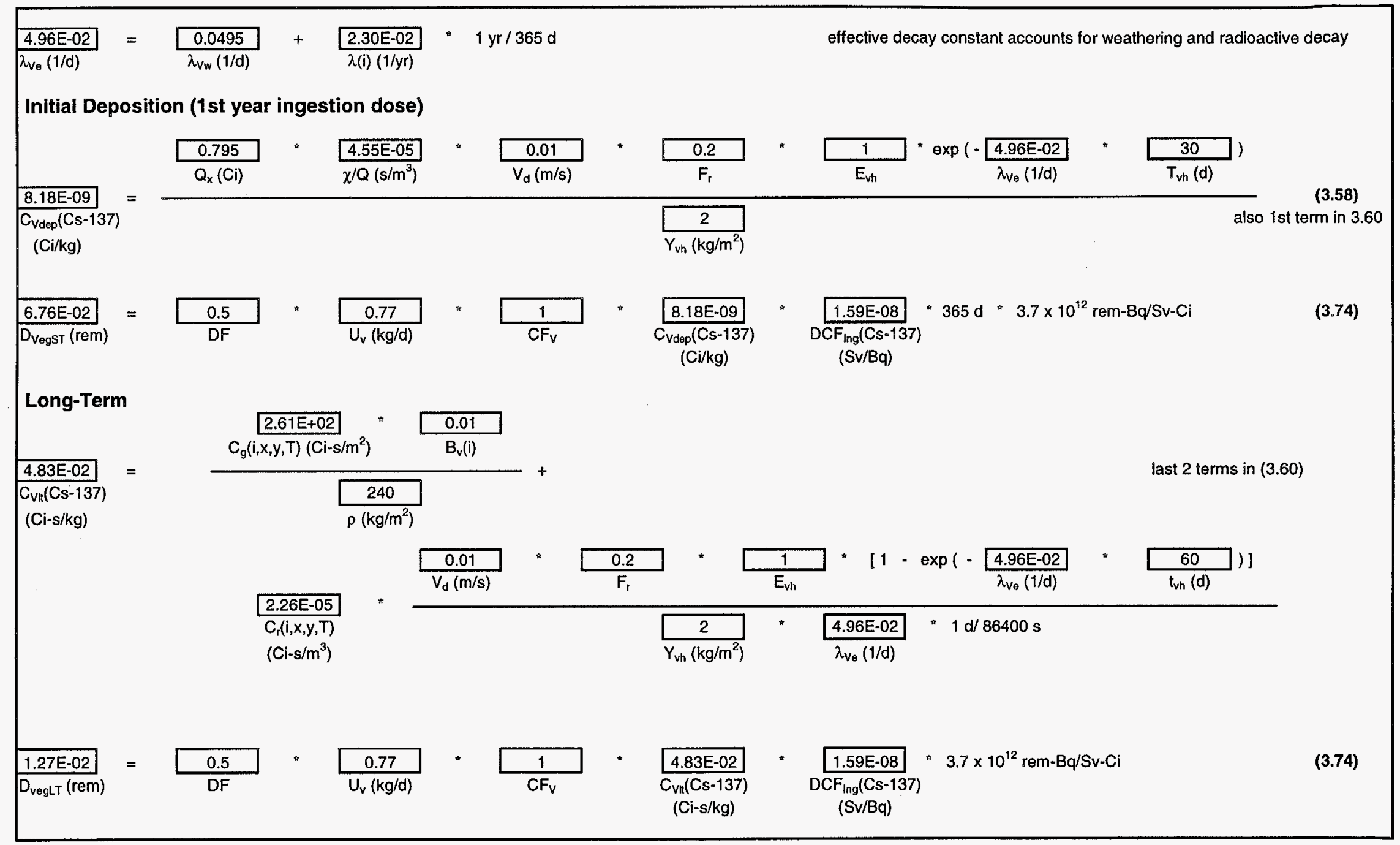

FIGURE 3.15 Vegetable Ingestion Dose Calculations for Exposure to Cs-137 
TABLE 3.13 Calculated Radionuclide Concentrations in Vegetables, Meat, and Milk

\begin{tabular}{|c|c|c|c|c|c|c|c|c|}
\hline \multirow[b]{3}{*}{ Radionuclide } & \multirow{2}{*}{\multicolumn{2}{|c|}{$\begin{array}{c}\text { Animal Consumption } \\
\text { Vegetable } \\
\end{array}$}} & \multicolumn{6}{|c|}{ Human Consumption } \\
\hline & & & \multicolumn{2}{|c|}{ Vegetable } & \multicolumn{2}{|c|}{ Meat } & \multicolumn{2}{|c|}{ Milk } \\
\hline & $\begin{array}{c}\text { First Year } \\
(\mathrm{Ci} / \mathrm{kg})\end{array}$ & $\begin{array}{l}\text { Long Term } \\
(\mathrm{Ci}-\mathrm{s} / \mathrm{kg})\end{array}$ & $\begin{array}{c}\text { First Year } \\
(\mathrm{Ci} / \mathrm{kg})\end{array}$ & $\begin{array}{c}\text { Long Term } \\
(\mathrm{Ci}-\mathrm{s} / \mathrm{kg})\end{array}$ & $\begin{array}{c}\text { First Year } \\
(\mathrm{Ci} / \mathrm{kg})\end{array}$ & $\begin{array}{c}\text { Long Term } \\
\text { (Ci-s/kg) }\end{array}$ & $\begin{array}{l}\text { First Year } \\
(\mathrm{Ci} / \mathrm{kg})\end{array}$ & $\begin{array}{c}\text { Long Term } \\
(\mathrm{C}-\mathrm{i} / \mathrm{kg})\end{array}$ \\
\hline $\mathrm{Kr}-85$ & $0.00 \mathrm{E}+00$ & $0.00 \mathrm{E}+00$ & $0.00 \mathrm{E}+00$ & $0.00 \mathrm{E}+00$ & $0.00 \mathrm{E}+00$ & $0.00 \mathrm{E}+00$ & $0.00 \mathrm{E}+00$ & $0.00 \mathrm{E}+00$ \\
\hline Co-60 & $2.44 \mathrm{E}-08$ & $4.38 \mathrm{E}-02$ & $4.33 \mathrm{E}-09$ & $2.10 \mathrm{E}-02$ & $1.59 \mathrm{E}-08$ & $2.85 \mathrm{E}-02$ & $1.22 \mathrm{E}-09$ & $2.19 \mathrm{E}-03$ \\
\hline $\mathrm{Sr}-90$ & $3.20 \mathrm{E}-10$ & $6.95 \mathrm{E}-04$ & $5.71 \mathrm{E}-11$ & $3.88 \mathrm{E}-04$ & $9.61 \mathrm{E}-12$ & $2.08 \mathrm{E}-05$ & $1.28 \mathrm{E}-11$ & $2.78 \mathrm{E}-05$ \\
\hline Cs-134 & $3.14 \mathrm{E}-09$ & $5.31 \mathrm{E}-03$ & $5.53 \mathrm{E}-10$ & $2.48 \mathrm{E}-03$ & $6.29 \mathrm{E}-10$ & $1.06 \mathrm{E}-03$ & $1.89 \mathrm{E}-09$ & $3.19 \mathrm{E}-03$ \\
\hline Cs-137 & 4.59E-08 & $9.23 \mathrm{E}-02$ & $8.18 \mathrm{E}-09$ & $4.83 \mathrm{E}-02$ & $9.17 \mathrm{E}-09$ & $1.85 \mathrm{E}-02$ & $2.75 \mathrm{E}-08$ & $5.54 \mathrm{E}-02$ \\
\hline $\mathrm{Pu}-238$ & $1.63 \mathrm{E}-11$ & 2.93E-05 & $2.91 \mathrm{E}-12$ & $1.36 \mathrm{E}-05$ & $1.14 \mathrm{E}-14$ & 2.05E-08 & $1.63 \mathrm{E}-15$ & $2.93 \mathrm{E}-09$ \\
\hline Pu-239 & $1.91 \mathrm{E}-12$ & $3.44 \mathrm{E}-06$ & $3.40 \mathrm{E}-13$ & $1.59 \mathrm{E}-06$ & $1.33 \mathrm{E}-15$ & $2.41 \mathrm{E}-09$ & $1.91 \mathrm{E}-16$ & $3.44 \mathrm{E}-10$ \\
\hline $\mathrm{Pu}-240$ & $2.73 \mathrm{E}-12$ & $4.93 \mathrm{E}-06$ & $4.87 \mathrm{E}-13$ & $2.28 \mathrm{E}-06$ & $1.91 \mathrm{E}-15$ & 3.45E-09 & $2.73 \mathrm{E}-16$ & $4.93 \mathrm{E}-10$ \\
\hline $\mathrm{Pu}-241$ & $4.48 \mathrm{E}-10$ & $7.90 \mathrm{E}-04$ & $7.98 \mathrm{E}-11$ & 3.64E-04 & $3.13 E-13$ & 5.53E-07 & $4.48 \mathrm{E}-14$ & $7.90 \mathrm{E}-08$ \\
\hline Am-241 & $9.99 \mathrm{E}-12$ & $1.80 \mathrm{E}-05$ & $1.78 \mathrm{E}-12$ & 8.33E-06 & $9.99 \mathrm{E}-14$ & $1.80 \mathrm{E}-07$ & $2.50 \mathrm{E}-15$ & $4.50 \mathrm{E}-09$ \\
\hline $\mathrm{Cm}-244$ & $1.03 \mathrm{E}-11$ & $1.87 \mathrm{E}-05$ & $1.84 \mathrm{E}-12$ & $8.86 \mathrm{E}-06$ & $1.03 \mathrm{E}-13$ & $1.87 \mathrm{E}-07$ & $2.58 \mathrm{E}-15$ & 4.68E-09 \\
\hline
\end{tabular}


TABLE 3.14 Calculated Individual Doses (rem) from Ingestion of Vegetables, Meat, and Milk

\begin{tabular}{|c|c|c|c|c|c|c|}
\hline \multirow[b]{2}{*}{ Radionuclide } & \multicolumn{2}{|c|}{ Vegetable } & \multicolumn{2}{|c|}{ Meat } & \multicolumn{2}{|c|}{ Milk } \\
\hline & First Year & Long Term & First Year & Long Term & First Year & Long Term \\
\hline $\mathrm{Kr}-85$ & $0.00 \mathrm{E}+00$ & $0.00 \mathrm{E}+00$ & $0.00 \mathrm{E}+00$ & $0.00 \mathrm{E}+00$ & $0.00 \mathrm{E}+00$ & $0.00 \mathrm{E}+00$ \\
\hline $\mathrm{Co}-60$ & $1.64 \mathrm{E}-02$ & $2.52 \mathrm{E}-03$ & $4.68 \mathrm{E}-02$ & $2.66 \mathrm{E}-03$ & $1.02 \mathrm{E}-02$ & $5.81 \mathrm{E}-04$ \\
\hline Sr-90 & $1.23 \mathrm{E}-03$ & $2.65 \mathrm{E}-04$ & $1.61 \mathrm{E}-04$ & $1.11 \mathrm{E}-05$ & $6.09 \mathrm{E}-04$ & $4.19 \mathrm{E}-05$ \\
\hline Cs-134 & $5.70 \mathrm{E}-03$ & $8.10 \mathrm{E}-04$ & $5.05 \mathrm{E}-03$ & $2.70 \mathrm{E}-04$ & $4.29 \mathrm{E}-02$ & $2.30 \mathrm{E}-03$ \\
\hline Cs-137 & $6.76 \mathrm{E}-02$ & $1.27 \mathrm{E}-02$ & $5.91 \mathrm{E}-02$ & 3.77E-03 & $5.03 \mathrm{E}-01$ & $3.20 \mathrm{E}-02$ \\
\hline $\mathrm{Pu}-238$ & $1.31 \mathrm{E}-03$ & $1.93 \mathrm{E}-04$ & $4.01 \mathrm{E}-06$ & $2.28 \mathrm{E}-07$ & $1.62 \mathrm{E}-06$ & $9.23 \mathrm{E}-08$ \\
\hline $\mathrm{Pu}-239$ & $1.69 \mathrm{E}-04$ & $2.51 \mathrm{E}-05$ & $5.17 \mathrm{E}-07$ & $2.96 \mathrm{E}-08$ & $2.09 \mathrm{E}-07$ & $1.20 \mathrm{E}-08$ \\
\hline $\mathrm{Pu}-240$ & $2.42 \mathrm{E}-04$ & $3.59 \mathrm{E}-05$ & $7.41 \mathrm{E}-07$ & 4.24E-08 & $3.00 \mathrm{E}-07$ & $1.71 E-08$ \\
\hline $\mathrm{Pu}-241$ & $7.68 \mathrm{E}-04$ & $1.11 \mathrm{E}-04$ & $2.35 \mathrm{E}-06$ & $1.31 \mathrm{E}-07$ & $9.52 \mathrm{E}-07$ & 5.32E-08 \\
\hline Am-241 & $9.13 \mathrm{E}-04$ & $1.35 \mathrm{E}-04$ & $3.98 \mathrm{E}-05$ & $2.28 \mathrm{E}-06$ & $2.82 \mathrm{E}-06$ & $1.61 \mathrm{E}-07$ \\
\hline $\mathrm{Cm}-244$ & $5.21 \mathrm{E}-04$ & $7.96 \mathrm{E}-05$ & $2.28 \mathrm{E}-05$ & $1.31 \mathrm{E}-06$ & $1.62 \mathrm{E}-06$ & $9.28 \mathrm{E}-08$ \\
\hline Total & $9.49 \mathrm{E}-02$ & $1.68 \mathrm{E}-02$ & $1.11 \mathrm{E}-01$ & $6.72 \mathrm{E}-03$ & $5.56 \mathrm{E}-01$ & $3.50 \mathrm{E}-02$ \\
\hline
\end{tabular}

disparity between the models ( $4.96 \times 10^{-4}$ rem for RISKIND and $3.4 \times 10^{-5}$ rem for GENII) when direct deposition on crops does not occur and root uptake is the main route for crop contamination. Although the programs use different food transfer factors, the main difference occurs because of GENII's estimate for contaminated ground concentration. GENII redistributes the deposited radionuclide(s) within a top surface layer $(0.15 \mathrm{~m}$ is the default used here) to account for weathering and leaching of the deposited contamination to subsurface soil levels, lowering soil concentrations and thereby lowering dose estimates. This approach is also reflected in the groundshine dose conversion factor used by GENII, as seen in Table 3.16; RISKIND uses a more conservative value.

A hypothetical SNF accident could release a number of radionuclides simultaneously. Such a potential release was also modeled by RISKIND and GENII; the same exposure parameters as those used above for the $1-\mathrm{Ci} \mathrm{Cs}-137$ release were used. The program output files are listed in Appendix B, Section B.1.2. The results are presented in Table 3.17. The general trends in the relative doses were the same as those observed for the Cs-137 release.

\subsubsection{CAP88-PC Dose Comparison}

A hypothetical release of Cs-137 (1 Ci) was modeled by RISKIND and CAP88-PC to compare their estimated doses to an individual. As discussed in Section 3.3.3.2, RISKIND's downwind air concentrations from an acute release (time-integrated, $\mathrm{Ci}-\mathrm{s} / \mathrm{m}^{3}$ ) and CAP88-PC's chronic release (instantaneous, $\mathrm{Ci} / \mathrm{m}^{3}$ ) are the same except for the unit of time. Thus, inhalation and cloudshine exposure to a 1-Ci puff release (RISKIND) should be the same as a 1-year exposure to a $1-\mathrm{Ci} / \mathrm{yr}$ release (CAP88-PC) when the $\chi / \mathrm{Q}$ value is the same for the two programs. However, the two programs' groundshine and ingestion doses are not comparable because of the time-dependence of the calculations. 


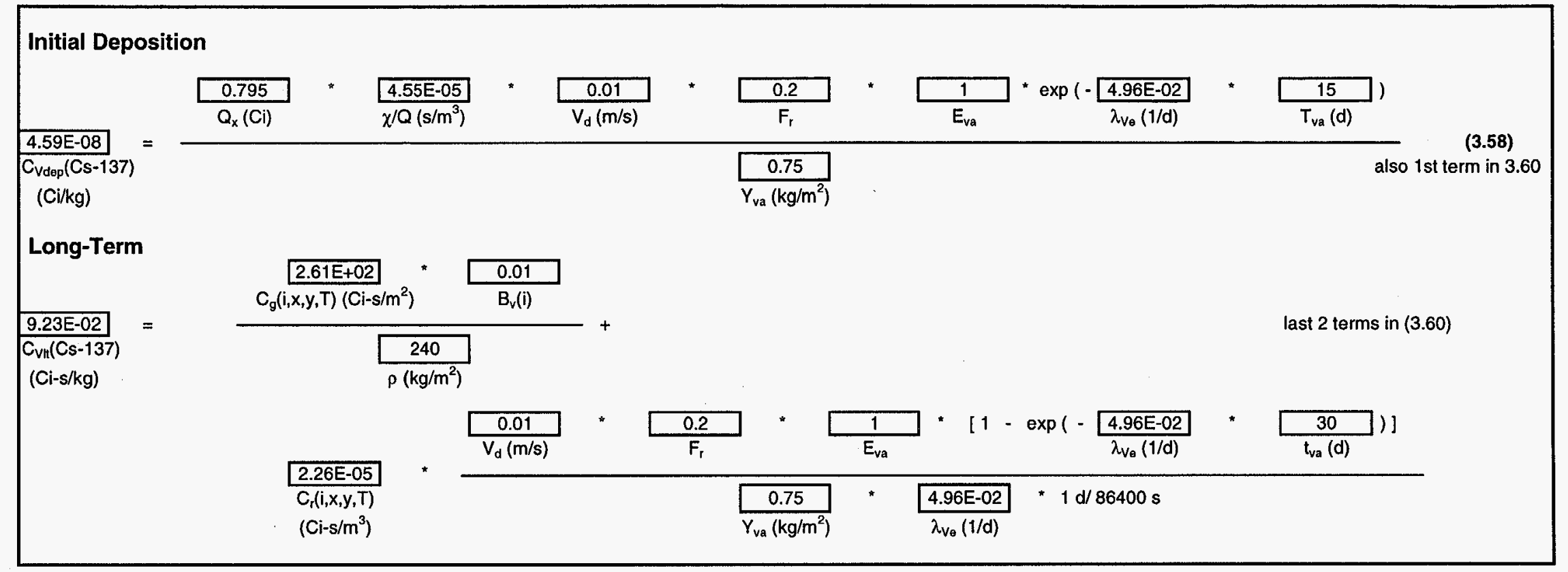

FIGURE 3.16 Initial and Long-Term Cs-137 Concentrations in Vegetation for Animal Consumption 


\begin{tabular}{|c|c|c|c|c|c|c|c|c|c|}
\hline \multicolumn{10}{|c|}{ Initial Deposition (1st year ingestion dose) } \\
\hline $\begin{array}{l}9.17 \mathrm{E}-09 \\
\mathrm{C}_{\mathrm{bl}}(\mathrm{i}, \mathrm{T}) \\
(\mathrm{Ci} / \mathrm{kg})\end{array}$ & $=$ & $\begin{array}{c}4.59 \mathrm{E}-08 \\
\mathrm{C}_{\text {Vdep }}(\mathrm{Cs}-137) \\
\text { (Ci/kg) }\end{array}$ & , & \begin{tabular}{|c|}
50 \\
$Q_{a}(k g / d)$
\end{tabular} & * & \begin{tabular}{|l|}
$4.00 \mathrm{E}-03$ \\
$F_{b}(i)(\mathrm{d} / \mathrm{kg})$
\end{tabular} & & & (3.61) \\
\hline $\begin{array}{l}5.91 \mathrm{E}-02 \\
D_{\text {MeatsT }}(\mathrm{i}) \\
\text { (rem) }\end{array}$ & $=$ & \begin{tabular}{|c|}
0.3 \\
$U_{0}(\mathrm{~kg} / \mathrm{d})$
\end{tabular} & . & $\frac{1}{\mathrm{CF}_{\mathrm{b}}}$ & * & \begin{tabular}{|c|}
$9.17 \mathrm{E}-09$ \\
$\mathrm{C}_{\mathrm{b}}(\mathrm{i}, \mathrm{T})$ \\
$(\mathrm{C} / \mathrm{kg})$
\end{tabular} & $* \begin{array}{c}1.59 \mathrm{E}-08 \\
\mathrm{DCF} \\
(\mathrm{ISV} / \mathrm{Bq}) \\
(\mathrm{Cs}-137)\end{array}$ & * $365 \mathrm{~d} * 86,400 \mathrm{~s} / \mathrm{d} \quad * 4.282 \times 10^{7} \mathrm{rem}-\mathrm{Bq}-\mathrm{d} / \mathrm{Sv}-\mathrm{Ci}-\mathrm{s}$ & (3.75) \\
\hline \multicolumn{10}{|c|}{ Long-Term } \\
\hline $\begin{array}{l}1.85 E-02 \\
\mathrm{C}_{\mathrm{bLT}}(\mathrm{i}, \mathrm{T}) \\
(\mathrm{Ci}-\mathrm{S} / \mathrm{kg})\end{array}$ & $=$ & $\begin{array}{c}9.23 \mathrm{E}-02 \\
\mathrm{C}_{\mathrm{VIt}}(\mathrm{Cs}-137) \\
(\mathrm{C} / \mathrm{kg})\end{array}$ & * & \begin{tabular}{|c|}
50 \\
$Q_{a}(\mathrm{~kg} / \mathrm{d})$
\end{tabular} & * & \begin{tabular}{|l|}
$4.00 \mathrm{E}-03$ \\
$\mathrm{~F}_{\mathrm{b}}(\mathrm{i})(\mathrm{d} / \mathrm{kg})$
\end{tabular} & & & (3.61) \\
\hline $3.77 \mathrm{E}-03$ & $=$ & 0.3 & * & 1 & $*$ & $1.85 \mathrm{E}-02$ & $1.59 \mathrm{E}-08$ & $4.282 \times 10^{7} \mathrm{rem}-\mathrm{Bq}-\mathrm{d} / \mathrm{Sv}-\mathrm{Ci}-\mathrm{s}$ & (3.75) \\
\hline $\begin{array}{l}D_{\text {MeatLT }}(\mathrm{i}) \\
(\mathrm{rem})\end{array}$ & & $U_{0}(\mathrm{~kg} / \mathrm{d})$ & & $\mathrm{CF}_{\mathrm{b}}$ & & $\begin{array}{l}\mathrm{C}_{\mathrm{bLT}}(\mathrm{i}, \mathrm{T}) \\
(\mathrm{Ci}-\mathrm{s} / \mathrm{kg})\end{array}$ & $\begin{array}{c}\mathrm{DCF}_{\text {Ing }}(\mathrm{Cs}-137) \\
(\mathrm{Sv} / \mathrm{Bq})\end{array}$ & & \\
\hline
\end{tabular}

FIGURE 3.17 Meat Ingestion Dose Calculations for Exposure to Cs-137 


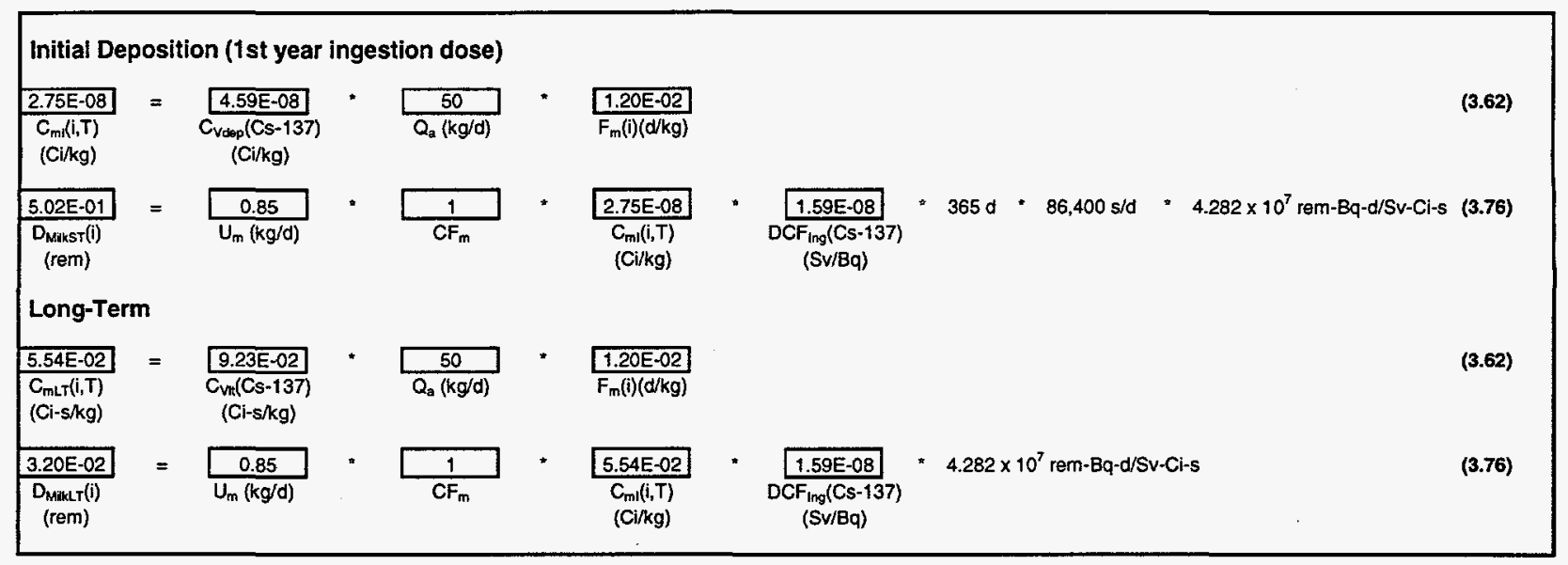

FIGURE 3.18 Milk Ingestion Dose Calculations for Exposure to Cs-137

TABLE 3.15 Contaminated Drinking

Water Radionuclide Concentrations

and Doses from Individual

Consumption

\begin{tabular}{lcc}
\hline Radionuclide & $\begin{array}{c}\text { Concentration } \\
\left(\mathrm{Ci}-\mathrm{yr} / \mathrm{m}^{3}\right)\end{array}$ & $\begin{array}{c}\text { Dose } \\
(\mathrm{rem})\end{array}$ \\
\hline $\mathrm{Kr}-85$ & $0.00 \mathrm{E}+00$ & $0.00 \mathrm{E}+00$ \\
$\mathrm{Co}-60$ & $4.73 \mathrm{E}-08$ & $4.66 \mathrm{E}-04$ \\
$\mathrm{Sr}-90$ & $6.82 \mathrm{E}-10$ & $3.82 \mathrm{E}-05$ \\
$\mathrm{Cs}-134$ & $5.19 \mathrm{E}-09$ & $1.39 \mathrm{E}-04$ \\
$\mathrm{Cs}-137$ & $9.78 \mathrm{E}-08$ & $2.10 \mathrm{E}-03$ \\
$\mathrm{Pu}-238$ & $3.53 \mathrm{E}-11$ & $4.13 \mathrm{E}-05$ \\
$\mathrm{Pu}-239$ & $4.15 \mathrm{E}-12$ & $5.36 \mathrm{E}-06$ \\
$\mathrm{Pu}-240$ & $5.95 \mathrm{E}-12$ & $7.69 \mathrm{E}-06$ \\
$\mathrm{Pu}-241$ & $9.33 \mathrm{E}-10$ & $2.33 \mathrm{E}-05$ \\
$\mathrm{Am}-241$ & $2.17 \mathrm{E}-11$ & $2.89 \mathrm{E}-05$ \\
$\mathrm{Cm}-244$ & $2.17 \mathrm{E}-11$ & $1.60 \mathrm{E}-05$ \\
Total & & $2.87 \mathrm{E}-03$ \\
\hline
\end{tabular}




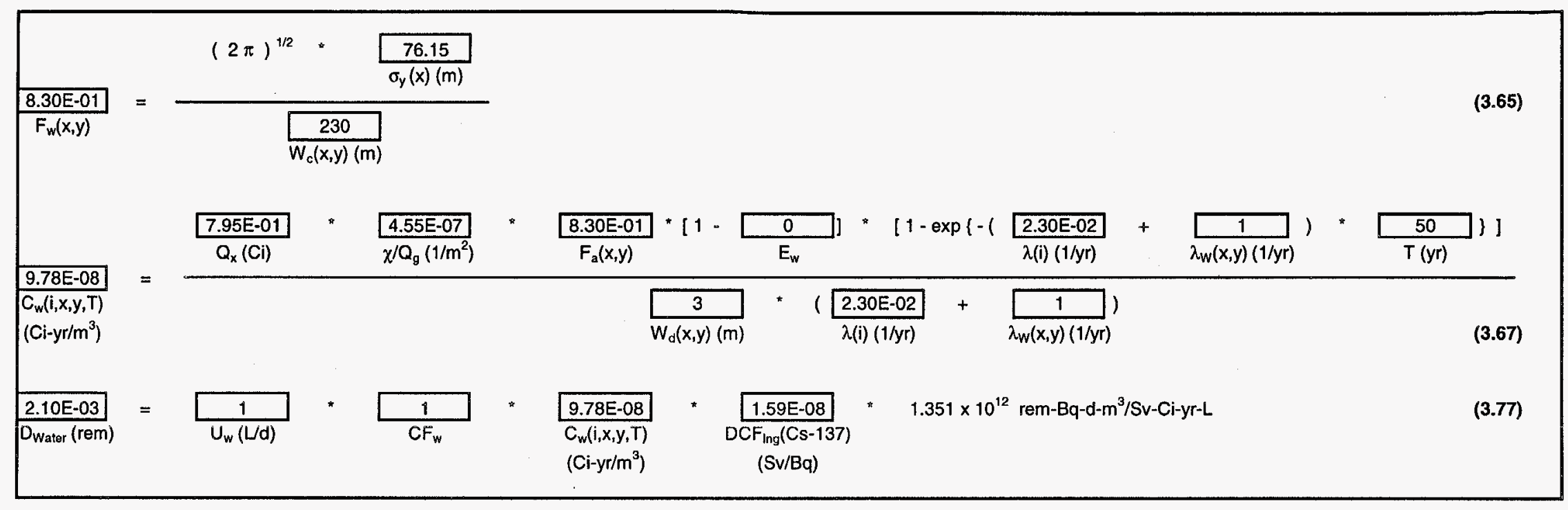

FIGURE 3.19 Water Consumption Dose Calculations for Exposure to Cs-137 
TABLE 3.16 Comparison of RISKIND and GENII Dose Calculations for a 1-Ci Cs-137 Release

\begin{tabular}{|c|c|c|c|c|c|c|}
\hline \multirow[b]{2}{*}{ Pathway } & \multicolumn{2}{|c|}{ Dose (rem) } & \multirow{2}{*}{$\begin{array}{c}\text { Dose Ratio } \\
\text { RISKIND/ } \\
\text { GENII }\end{array}$} & \multicolumn{2}{|c|}{ Dose Conversion Factor } & \multirow{2}{*}{$\begin{array}{c}\text { Factor Ratio } \\
\text { RISKIND/ } \\
\text { GENII } \\
\end{array}$} \\
\hline & RISKIND & GENII & & RISKIND $^{\mathbf{a}}$ & $\mathrm{GENII}^{\mathrm{b}}$ & \\
\hline $\begin{array}{l}\text { Inhalation from } \\
\text { plume passage }\end{array}$ & $3.21 \times 10^{-4}$ & $2.4 \times 10^{-4}$ & 1.3 & $\begin{array}{c}1.1 \times 10^{-8} \\
\mathrm{~Sv} / \mathrm{Bq}\end{array}$ & $\begin{array}{c}7.9 \times 10^{-9} \text { to } \\
9.1 \times 10^{-9} \mathrm{~Sv} / \mathrm{Bq}\end{array}$ & $\sim 1.2$ \\
\hline $\begin{array}{l}\text { Cloudshine from } \\
\text { plume passage }^{c}\end{array}$ & $3.14 \times 10^{-6}$ & $3.6 \times 10^{-6}$ & 0.87 & $\begin{array}{l}2.73 \times 10^{-14} \\
\mathrm{~Sv} / \mathrm{s} / \mathrm{Bq} / \mathrm{m}^{3}\end{array}$ & $\begin{array}{l}3.12 \times 10^{-14} \\
\mathrm{~Sv} / \mathrm{s} / \mathrm{Bq} / \mathrm{m}^{3}\end{array}$ & 0.875 \\
\hline Groundshine $^{\mathrm{d}}$ & $9.87 \times 10^{-4}$ & $2.2 \times 10^{-4}$ & 4.49 & $\begin{array}{l}5.54 \times 10^{-16} \\
\mathrm{~Sv} / \mathrm{s} / \mathrm{Bq} / \mathrm{m}^{2}\end{array}$ & $\begin{array}{l}1.19 \times 10^{-16} \\
\mathrm{~Sv} / \mathrm{s} / \mathrm{Bq} / \mathrm{m}^{2}\end{array}$ & 4.66 \\
\hline Ingestion $^{\mathrm{e}}$ & $\begin{array}{c}4.96 \times 10^{-4} \\
\text { to } 0.155\end{array}$ & $\begin{array}{c}3.4 \times 10^{-5} \\
\text { to } 0.21\end{array}$ & 15 to 0.74 & $\begin{array}{c}1.59 \times 10^{-8} \\
\mathrm{~Sv} / \mathrm{Bq}\end{array}$ & $\begin{array}{c}1.3 \times 10^{-8} \text { to } \\
1.4 \times 10^{-8} \mathrm{~Sv} / \mathrm{Bq}\end{array}$ & $\sim 1.2$ \\
\hline
\end{tabular}

a RISKIND DCFs are from Eckerman et al. (1988) and Eckerman and Ryman (1993).

b The internal doses from inhalation and ingestion are estimated in GENII by using weighted organ doses, in which each internal organ has its own dose conversion factor.

c Inhalation and cloudshine doses are from exposure to passage of the radioactive cloud immediately following an accident.

d Groundshine doses are for exposure without shielding to external radiation from contaminated ground for $0.5 \mathrm{yr}$.

e Ingestion doses from RISKIND do not include initial contamination of the crops and do include direct deposition from the radioactive cloud following an accident, respectively. The GENII ingestion doses are from the "winter" and "autumn" portion of the output; these are comparable to the RISKIND doses, since "winter" assumes no direct deposition on crops (none are assumed to be growing at the time of the accident), and "autumn" assumes the accident occurs at the end of the growing season.

Note that $1 \mathrm{Ci}$ of $\mathrm{Ba}-137 \mathrm{~m}$ (the short-lived progeny radionuclide of $\mathrm{Cs}-137$ assumed to be in secular equilibrium with Cs-137) was also released in the CAP88-PC calculations. The dose conversion factors for Cs-137 in RISKIND (and GENII) account for the Ba-137m, whereas those in CAP88-PC do not. For the calculations, a point source at a release height of $20 \mathrm{~m}$, Pasquill stability category D weather conditions, and a wind speed of $4.373 \mathrm{~m} / \mathrm{s}$ were used. The receptor was assumed to be exposed without shielding to the passing radioactive cloud immediately following the release. For dose comparison purposes, the receptor distances from the release point were different for each program in order to start the exposure calculations with the same $\chi / Q$ value at the receptor locations. The output for each program is listed in Appendix B, Section B.2.1.

The results of the inhalation and cloudshine dose comparisons are shown in Table 3.18. Differences can be directly attributed to differences in the dose conversion factors used by the two programs. The Cs-137 inhalation dose conversion factor is orders of magnitude larger than the $\mathrm{Ba}-137 \mathrm{~m}$ factor, while the reverse situation is true for the cloudshine dose conversion factors. Therefore, the Cs-137 inhalation and Ba-137m cloudshine dose conversion factors are shown for CAP88-PC in Table 3.18. 
TABLE 3.17 Comparison of RISKIND and GENII Individual Dose Calculations for a Hypothetical Spent Fuel Transportation Accident

\begin{tabular}{|c|c|c|c|}
\hline \multirow[b]{2}{*}{ Pathway } & \multicolumn{2}{|c|}{ Dose (rem) } & \multirow{2}{*}{$\begin{array}{c}\text { Dose Ratio of } \\
\text { RISKIND to } \\
\text { GENII }\end{array}$} \\
\hline & RISKIND & GENII & \\
\hline Inhalation from plume passage ${ }^{a}$ & $3.68 \times 10^{-3}$ & $3.6 \times 10^{-3}$ & 1.0 \\
\hline Cloudshine from plume passage & $9.15 \times 10^{-6}$ & $1.0 \times 10^{-5}$ & 0.92 \\
\hline Groundshine $^{b}$ & $2.60 \times 10^{-3}$ & $5.8 \times 10^{-4}$ & 4.5 \\
\hline Ingestion ${ }^{c}$ & $\begin{array}{c}4.98 \times 10^{-4} \\
\text { to } 0.155\end{array}$ & $\begin{array}{c}5.6 \times 10^{-5} \\
\text { to } 0.22\end{array}$ & 8.9 to 0.70 \\
\hline
\end{tabular}

a Inhalation and cloudshine doses are from exposure to passage of the radioactive cloud immediately following an accident.

b Groundshine doses are for exposure without shielding to external radiation from contaminated ground for $0.5 \mathrm{yr}$.

c Ingestion doses from RISKIND do not include initial contamination of the crops and do include direct deposition from the radioactive cloud following an accident, respectively. The GENII ingestion doses are from the "winter" and "autumn" portion of the output; these are comparable to the RISKIND doses, since "winter" assumes no direct deposition on crops (none are assumed to be growing at the time of the accident), and "autumn" assumes the accident occurs at the end of the growing season.

A hypothetical SNF accident could release a number of radionuclides simultaneously. Such a potential release was also modeled by RISKIND and CAP88-PC; the same exposure parameters as those used above for the 1-Ci Cs-137 release were used. The program output files are listed in Appendix B, Section B.2.2. The results are presented in Table 3.19. The general trends in the relative doses were the same as those for the Cs-137 release; RISKIND was more conservative for both inhalation and cloudshine exposures. 
TABLE 3.18 Comparison of RISKIND and CAP88-PC Doses Calculated for a 1-Ci

\section{Cs-137 Release}

\begin{tabular}{|c|c|c|c|}
\hline \multirow[b]{2}{*}{ Pathway } & \multicolumn{2}{|c|}{ Dose (rem) } & \multirow{2}{*}{$\begin{array}{l}\text { Dose Ratio of } \\
\text { RISKIND to } \\
\text { CAP88-PC }\end{array}$} \\
\hline & RISKIND & CAP88-PC & \\
\hline Inhalation from plume passage ${ }^{a}$ & $3.84 \times 10^{-4}$ & $2.92 \times 10^{-4}$ & 1.32 \\
\hline \multirow[t]{2}{*}{ Cloudshine from plume passage ${ }^{a, b, c}$} & $3.74 \times 10^{-6}$ & $2.61 \times 10^{-6}$ & $1.43 \times 0.733=1.05$ \\
\hline & \multicolumn{2}{|c|}{ Dose Conversion Factor } & Factor Ratio of \\
\hline Pathway & RISKIND & CAP88-PC & CAP88-PC \\
\hline Inhalation from plume passage & $1.10 \times 10^{-8} \mathrm{~Sv} / \mathrm{Bq}$ & $8.38 \times 10^{-9} \mathrm{~Sv} / \mathrm{Bq}$ & 1.31 \\
\hline Cloudshine from plume passage $e^{a, b, c}$ & $\frac{2.73 \times 10^{-14} \mathrm{~Sv} / \mathrm{s}}{\mathrm{Bq} / \mathrm{m}^{3}}$ & $\frac{2.60 \times 10^{-14} \mathrm{~Sv} / \mathrm{s}}{\mathrm{Bg} / \mathrm{m}^{3}}$ & 1.05 \\
\hline
\end{tabular}

a For inhalation and cloudshine doses, the time-integrated air concentrations for exposure to a 1-Ci puff release used in RISKIND are equivalent to a 1-yr exposure to the 1-Ci/yr release used in CAP88-PC.

b The factor of 0.733 in the dose ratio accounts for the difference between the Cs-137 and Ba- $137 \mathrm{~m}$ concentrations at the receptor location calculated by CAP88-PC. CAP88-PC calculates radionuclide decay during plume travel.

c The CAP88-PC cloudshine dose conversion factor is for Ba- $137 \mathrm{~m}$, the short-lived progeny radionuclide of Cs-137.

TABLE 3.19 Comparison of RISKIND and CAP88-PC Individual Doses

Calculated for a Hypothetical Spent Fuel Transportation Accident

\begin{tabular}{|c|c|c|c|}
\hline \multirow[b]{2}{*}{ Pathway } & \multicolumn{2}{|c|}{ Dose (rem) } & \multirow{2}{*}{$\begin{array}{l}\text { Dose Ratio of } \\
\text { RISKIND to } \\
\text { CAP88-PC }\end{array}$} \\
\hline & RISKIND & CAP88-PC & \\
\hline Inhalation from plume passage & $4.39 \times 10^{-3}$ & $3.99 \times 10^{-3}$ & 1.10 \\
\hline Cloudshine from plume passage ${ }^{a}$ & $1.09 \times 10^{-5}$ & $9.02 \times 10^{-6}$ & 1.21 \\
\hline
\end{tabular}

a For inhalation and cloudshine doses, the time-integrated air concentrations for exposure to a 1-Ci puff release used in RISKIND are equivalent to a 1-yr exposure to the $1-\mathrm{Ci} / \mathrm{yr}$ release used in CAP88-PC. 


\section{HEALTH EFFECTS}

RISKIND calculates potential early health effects from acute, short-term exposure to high dose rates received from a hypothetical severe accident, as well as potential latent health effects from short- and long-term exposures to low dose rates received during routine transport or from potential accident events.

\subsection{EARLY EFFECTS}

When using RISKIND, radionuclide screening (Section 3.2) should be turned off $(\mathrm{HAZLM}=0$ ) to assess early health effects properly, since early effects are not considered in the screening process.

Calculations of early effects were performed to verify the RISKIND results for case 3. Case 3 involved a receptor $25 \mathrm{~m}$ downwind from a spent fuel rail accident with a severity in response region 4 (Figure 3.1), one of the most severe accident regions. The scenario assumptions were a 1-m release height, no fire, and unfavorable weather conditions (stability = $\mathrm{F}$, wind speed $=1 \mathrm{~m} / \mathrm{s}$ ), which do little to disperse the released and aerosolized material. Such a release might occur if a rail cask were traveling at a speed of more than about $170 \mathrm{~km} / \mathrm{h}$ (105 mph) into an unyielding surface (LLNL 1987).

The early effects model is based on the NRC health effects study (Evans et al. 1985; Abrahamson et al. 1989, 1991). Fatalities are estimated on the basis of the responses of the bone marrow, gastrointestinal (GI) tract, and lungs to high dose rates. The acute dose received is considered in two parts, brief and protracted. The brief dose consists of the inhalation dose received within the first $24 \mathrm{~h}$ of a release and external radiation received from the passing radioactive cloud, the radionuclide-contaminated ground surface, or loss of cask shielding. The protracted dose consists of the exposure from inhaled radionuclides for periods up to one year, depending on the target organ, following an accident.

\subsubsection{External Exposure}

The calculation of external exposure to the bone marrow, GI tract, and the lungs is a straightforward modification of the calculations performed in Section 3.4.1 for whole body exposure. Equations 3.47 and 3.48 in the RISKIND manual for external radiation exposure from radionuclides in the passing radioactive cloud and deposited on the ground, respectively, are modified slightly by replacing the whole body dose conversion factors (DCFs) with organ-specific DCFs (Eckerman and Ryman 1993). In addition, the radiation trauma (physical damage) induced by the high dose rates is measured in terms of absorbed dose (units of Gy) rather than the effective dose equivalent (units of $\mathrm{Sv}$ or rem, $1 \mathrm{~Sv}=100 \mathrm{rem}$ ) applied in Section 3. Figures $4.1,4.2$, and 4.3 provide the calculations of early effects from doses of Cs- 137 to the bone marrow, GI tract, and lungs, respectively. For Cs-137, the absorbed inhalation dose is the same as the effective dose equivalent (1 Gy is equivalent to $1 \mathrm{~Sv}$ since the quality factor for 


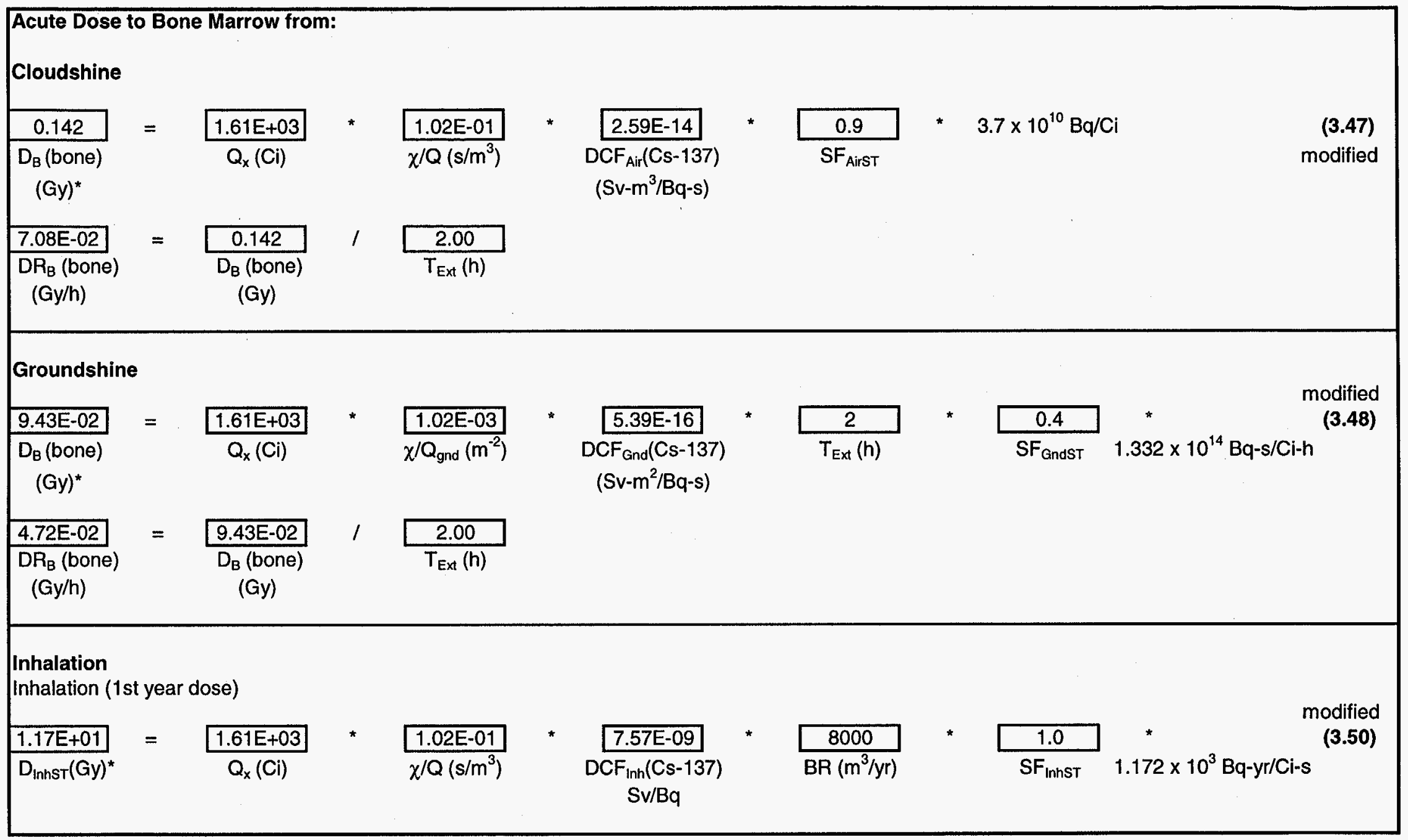

FIGURE 4.1 Short-Term External Dose and First-Year Inhalation Dose to the Bone Marrow from Cs-137 


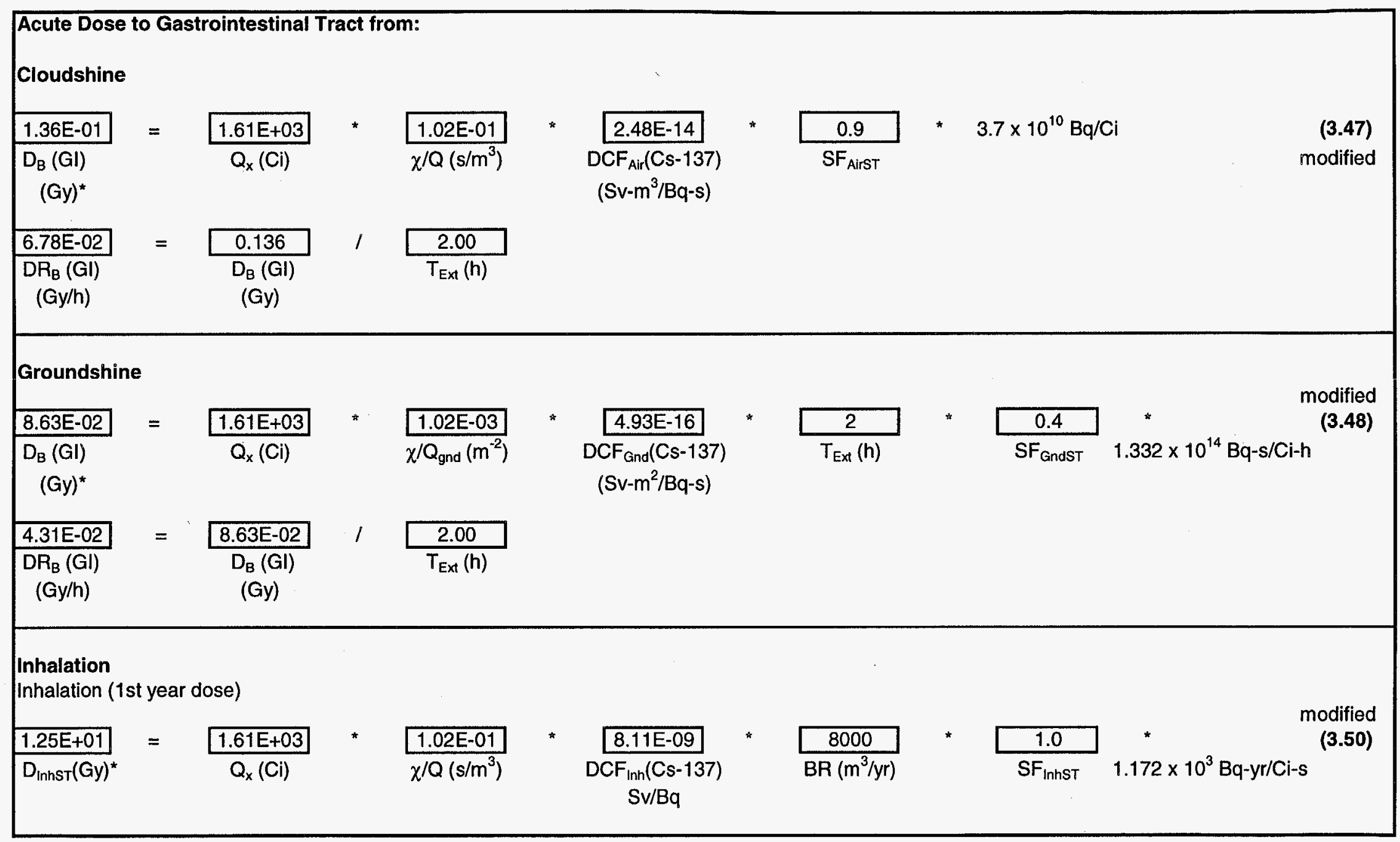

FIGURE 4.2 Short-Term External Dose and First-Year Inhalation Dose to the Gastrointestinal Tract from Cs-137 


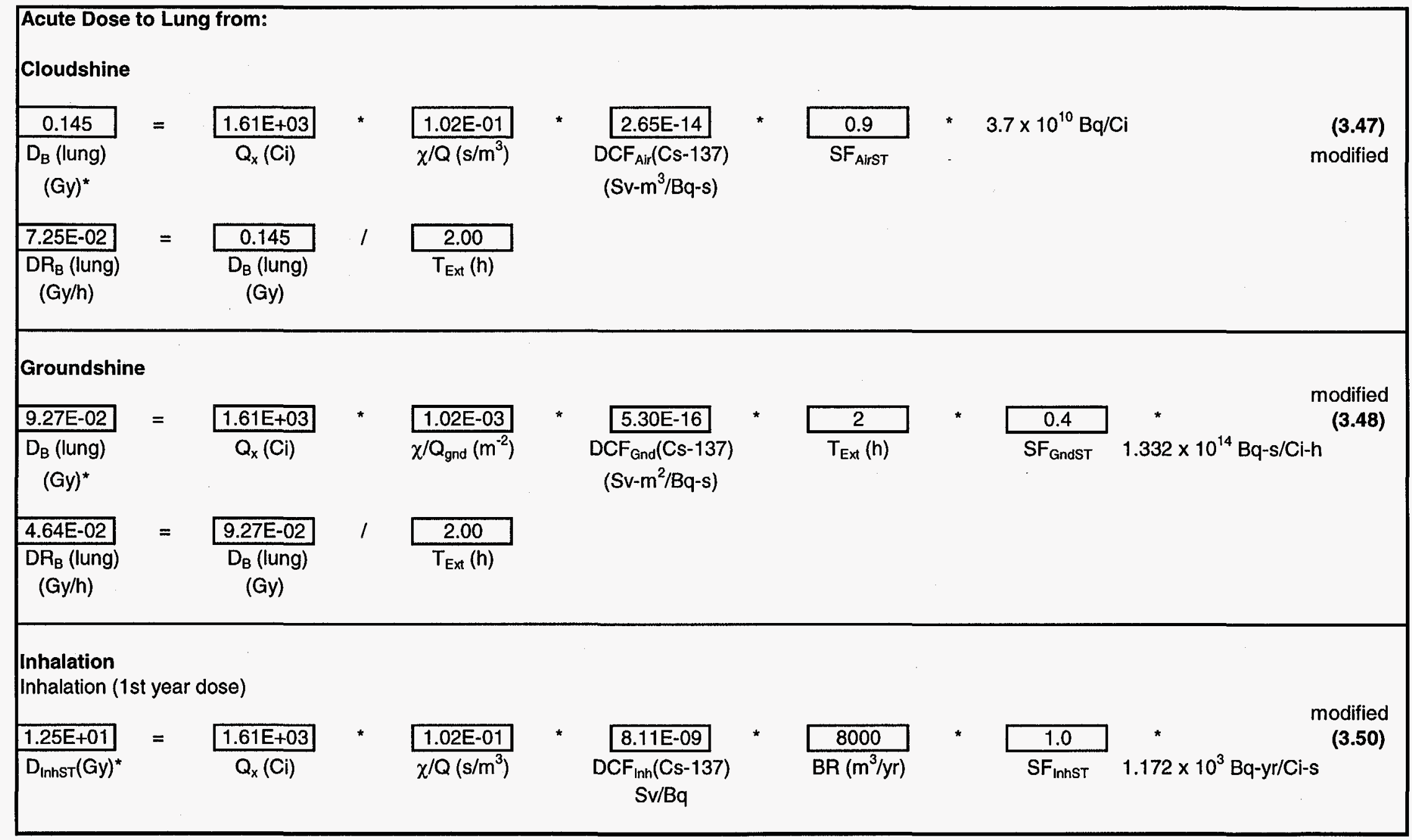

FIGURE 4.3 Short-Term External Dose and First-Year Inhalation Dose to the Lungs from Cs-137 
CS-137 is 1). The calculated dose rates to each organ are also shown because this information is needed when estimating the lethality hazard. Tables 4.1 and 4.2 provide the calculated doses and dose rates, respectively, for the other radionuclides.

\subsubsection{Inhalation Exposure}

Estimation of brief and protracted doses from inhalation exposure is more difficult because internal DCFs are unavailable for the target organs for the time periods of interest. To estimate the appropriate DCFs, RISKIND multiplies the 1-yr DCFs from Dunning (1986) by the ratio of retention functions for the organ under consideration (the retention function for the time period of interest divided by that for a 1-yr period). Figure 4.4 presents the 1-yr Cs-137 retention function, and Figure 4.5 presents the subsequent calculations of inhalation doses and dose rates to bone marrow from exposure to Cs-137. The calculations for the GI tract and lungs, respectively, are given in Figures 4.6 and 4.7. Tables 4.1 and 4.2 present the brief inhalation doses and dose rates, respectively, for the other radionuclides. The protracted inhalation doses and dose rates for the other radionuclides are presented in Table 4.3. The total protracted inhalation doses and dose rates agreed with the RISKIND calculations shown on page 9 of the case 3 output (Appendix A, pg. A-34).

\subsubsection{Lethality Risk}

In RISKIND, the lethality risk is the probability of fatality from a radiation dose received immediately following a potential accident. A hazard function approach that follows the methodology in Evans et al. (1985) and Abrahamson et al. (1989) is used. A hazard function was calculated for each of the three major organs considered: bone marrow, GI tract, and lungs, as presented in Figures 4.8, 4.9, and 4.10, respectively. For each organ, the total brief dose received and the brief dose rate from inhalation, cloudshine, and groundshine were first calculated from the individual exposure pathway totals found in Tables 4.1 and 4.2. The total brief doses and dose rates estimated in Figures 4.8 to 4.10 agreed with those presented on page 9 of the case 3 output (Appendix A, pg. A-34).

The hazards were then calculated on the basis of median lethal dose estimates. The hazards calculated in Figures 4.8, 4.9, and 4.10 agreed with the RISKIND output (Appendix A, pg. A-34), although there was a little more deviation between these verification calculations and the RISKIND output resulting from round-off errors because of the rather sharp fatality threshold estimates used (the exponential rise) in the acute effects model. The deviations were still less than 5\%: 0.308 versus 0.299 for bone marrow, $1.02 \times 10^{4}$ versus $1.07 \times 10^{4}$ for the lungs, and 883 versus 844 for the GI tract.

The calculations for the lethality risk from each organ and the combined risk are shown in Figure 4.11. Again, the calculated risks for each organ were in relatively good agreement with the RISKIND output values for "Acute Risk" (Appendix A, pg. A-34). 
TABLE 4.1 Brief Doses (Gy) to the Bone Marrow, Gastrointestinal Tract, and Lungs

\begin{tabular}{|c|c|c|c|c|c|c|c|c|c|}
\hline \multirow[b]{2}{*}{ Radionuclide } & \multicolumn{3}{|c|}{ Bone Marrow } & \multicolumn{3}{|c|}{ Gastrointestinal Tract } & \multicolumn{3}{|c|}{ Lungs } \\
\hline & Inhalation & Ext. Gnd. & Ext. Cloud & Inhalation & Ext. Gnd. & Ext. Cloud & Inhalation & Ext. Gnd. & Ext. Cloud \\
\hline $\mathrm{H}-3$ & $0.00 \mathrm{E}+00$ & $0.00 E+00$ & $0.00 \mathrm{E}+00$ & $1.28 \mathrm{E}-06$ & $0.00 \mathrm{E}+00$ & $0.00 \mathrm{E}+00$ & $1.35 \mathrm{E}-06$ & $0.00 \mathrm{E}+00$ & $0.00 \mathrm{E}+00$ \\
\hline $\mathrm{Fe}-55$ & $1.45 \mathrm{E}-08$ & $0.00 \mathrm{E}+00$ & $0.00 \mathrm{E}+00$ & 4.87E-06 & $5.71 \mathrm{E}-10$ & $9.30 \mathrm{E}-11$ & $1.51 \mathrm{E}-07$ & $0.00 \mathrm{E}+00$ & $0.00 \mathrm{E}+00$ \\
\hline $\mathrm{Co}-60$ & $1.42 \mathrm{E}-02$ & $5.09 \mathrm{E}-02$ & $8.36 \mathrm{E}-02$ & $1.09 E+00$ & $4.22 \mathrm{E}-02$ & $7.54 \mathrm{E}-02$ & $1.30 \mathrm{E}-01$ & 4.93E-02 & $8.42 \mathrm{E}-02$ \\
\hline $\mathrm{Ni}-63$ & $1.52 \mathrm{E}-10$ & $0.00 \mathrm{E}+00$ & $0.00 \mathrm{E}+00$ & 2.09E-08 & $0.00 \mathrm{E}+00$ & $0.00 \mathrm{E}+00$ & $1.46 \mathrm{E}-09$ & $0.00 \mathrm{E}+00$ & $0.00 \mathrm{E}+00$ \\
\hline $\mathrm{Kr}-85$ & $0.00 \mathrm{E}+00$ & $0.00 \mathrm{E}+00$ & $1.13 \mathrm{E}-02$ & $0.00 \mathrm{E}+00$ & $0.00 \mathrm{E}+00$ & $9.91 \mathrm{E}-03$ & $0.00 \mathrm{E}+00$ & $0.00 \mathrm{E}+00$ & $1.18 \mathrm{E}-02$ \\
\hline Sr-90 & $1.37 \mathrm{E}-04$ & $5.50 \mathrm{E}-06$ & $6.05 \mathrm{E}-06$ & $1.64 \mathrm{E}-01$ & $0.00 \mathrm{E}+00$ & $0.00 \mathrm{E}+00$ & $3.71 \mathrm{E}-02$ & $5.74 \mathrm{E}-06$ & $6.62 \mathrm{E}-06$ \\
\hline$Y-90$ & $5.55 \mathrm{E}-05$ & $5.27 \mathrm{E}-06$ & $5.83 \mathrm{E}-06$ & $1.24 \mathrm{E}-01$ & $0.00 \mathrm{E}+00$ & $0.00 \mathrm{E}+00$ & $3.93 \mathrm{E}-02$ & $5.48 \mathrm{E}-06$ & $6.37 \mathrm{E}-06$ \\
\hline $\mathrm{Ru}-106$ & $1.66 \mathrm{E}-05$ & $2.71 \mathrm{E}-05$ & $4.01 \mathrm{E}-05$ & $3.88 \mathrm{E}-02$ & $2.37 \mathrm{E}-05$ & $3.69 \mathrm{E}-05$ & $5.41 \mathrm{E}-03$ & $2.67 \mathrm{E}-05$ & $4.15 \mathrm{E}-05$ \\
\hline Rh-106 & $2.99 \mathrm{E}-04$ & $2.71 \mathrm{E}-05$ & $4.01 \mathrm{E}-05$ & 1.32E-03 & $2.37 \mathrm{E}-05$ & $3.69 \mathrm{E}-05$ & $2.99 \mathrm{E}-04$ & $2.67 \mathrm{E}-05$ & $4.15 \mathrm{E}-05$ \\
\hline Sb-125 & $5.03 \mathrm{E}-10$ & $1.15 \mathrm{E}-05$ & $1.67 \mathrm{E}-05$ & 7.72E-07 & $1.08 \mathrm{E}-05$ & $1.61 \mathrm{E}-05$ & 5.88E-07 & $1.14 \mathrm{E}-05$ & $1.73 E-05$ \\
\hline $\mathrm{Te}-125 \mathrm{~m}$ & $1.93 \mathrm{E}-10$ & $9.50 \mathrm{E}-08$ & $4.03 \mathrm{E}-08$ & $1.39 \mathrm{E}-07$ & $1.23 \mathrm{E}-07$ & 8.88E-08 & $2.80 \mathrm{E}-08$ & $1.23 \mathrm{E}-07$ & $4.83 E-08$ \\
\hline Cs-134 & $1.47 \mathrm{E}-02$ & $1.99 \mathrm{E}-02$ & $3.03 \mathrm{E}-02$ & $1.44 E+00$ & $1.81 \mathrm{E}-02$ & $2.88 \mathrm{E}-02$ & $1.28 \mathrm{E}+00$ & $1.97 \mathrm{E}-02$ & $3.10 \mathrm{E}-02$ \\
\hline Cs- 137 & $1.27 \mathrm{E}-01$ & $9.43 \mathrm{E}-02$ & $1.42 \mathrm{E}-01$ & $1.19 E+01$ & $8.63 \mathrm{E}-02$ & $1.36 \mathrm{E}-01$ & $1.25 \mathrm{E}+01$ & $9.27 \mathrm{E}-02$ & $1.45 \mathrm{E}-01$ \\
\hline $\mathrm{Ba}-137 \mathrm{~m}$ & $3.97 \mathrm{E}-04$ & $9.42 \mathrm{E}-04$ & $1.41 \mathrm{E}-03$ & $0.00 \mathrm{E}+00$ & $8.62 \mathrm{E}-04$ & $1.35 \mathrm{E}-03$ & $3.97 \mathrm{E}-04$ & $9.25 \mathrm{E}-04$ & $1.45 \mathrm{E}-03$ \\
\hline $\mathrm{Ce}-144$ & 8.67E-08 & $1.14 \mathrm{E}-07$ & $1.71 \mathrm{E}-07$ & 5.83E-04 & $3.92 \mathrm{E}-08$ & 5.17E-08 & $8.00 \mathrm{E}-05$ & $1.16 \mathrm{E}-07$ & $1.79 \mathrm{E}-07$ \\
\hline Pr-144 & $3.62 \mathrm{E}-10$ & $7.84 \mathrm{E}-08$ & $1.26 \mathrm{E}-07$ & $4.07 \mathrm{E}-10$ & $5.44 \mathrm{E}-08$ & $1.02 \mathrm{E}-07$ & $1.78 \mathrm{E}-06$ & 7.73E-08 & $1.28 \mathrm{E}-07$ \\
\hline Pm-147 & $6.08 \mathrm{E}-07$ & 2.83E-09 & 2.12E-09 & $2.07 \mathrm{E}-03$ & $5.30 \mathrm{E}-10$ & $7.37 \mathrm{E}-10$ & $2.72 \mathrm{E}-04$ & $3.35 \mathrm{E}-09$ & 2.59E-09 \\
\hline $\mathrm{Sm}-151$ & $7.87 \mathrm{E}-10$ & $1.15 \mathrm{E}-11$ & $2.93 \mathrm{E}-12$ & $6.03 \mathrm{E}-08$ & $3.70 \mathrm{E}-11$ & $1.01 \mathrm{E}-11$ & $4.49 \mathrm{E}-09$ & $8.39 \mathrm{E}-12$ & $1.85 \mathrm{E}-12$ \\
\hline Eu-154 & $6.83 \mathrm{E}-08$ & $1.24 \mathrm{E}-04$ & $1.96 \mathrm{E}-04$ & 8.25E-06 & $1.10 \mathrm{E}-04$ & $1.85 \mathrm{E}-04$ & $7.89 \mathrm{E}-07$ & $1.22 \mathrm{E}-04$ & $2.00 \mathrm{E}-04$ \\
\hline Eu-155 & 4.16E-09 & $1.94 \mathrm{E}-06$ & $2.38 \mathrm{E}-06$ & $5.49 \mathrm{E}-07$ & $2.49 \mathrm{E}-06$ & $3.11 \mathrm{E}-06$ & $5.04 \mathrm{E}-08$ & $2.19 \mathrm{E}-06$ & $2.85 \mathrm{E}-06$ \\
\hline $\mathrm{Pu}-238$ & $3.16 \mathrm{E}-05$ & $1.70 \mathrm{E}-08$ & $4.59 \mathrm{E}-09$ & $1.09 \mathrm{E}-03$ & $6.42 \mathrm{E}-08$ & $1.03 \mathrm{E}-08$ & $1.40 \mathrm{E}-02$ & $6.88 \mathrm{E}-09$ & 2.89E-09 \\
\hline $\mathrm{Pu}-239$ & $2.18 \mathrm{E}-06$ & $7.90 \mathrm{E}-10$ & $5.54 \mathrm{E}-10$ & $7.53 \mathrm{E}-05$ & $2.15 \mathrm{E}-09$ & $7.26 \mathrm{E}-10$ & $1.02 \mathrm{E}-03$ & $5.23 \mathrm{E}-10$ & $5.50 \mathrm{E}-10$ \\
\hline $\mathrm{Pu}-240$ & $3.41 E-06$ & $1.96 \mathrm{E}-09$ & $5.40 \mathrm{E}-10$ & $1.18 \mathrm{E}-04$ & 7.30E-09 & $1.20 \mathrm{E}-09$ & $1.59 \mathrm{E}-03$ & $8.12 \mathrm{E}-10$ & $3.54 \mathrm{E}-10$ \\
\hline $\mathrm{Pu}-241$ & 1.35E-05 & 7.63E-09 & $9.99 \mathrm{E}-09$ & $2.16 \mathrm{E}-03$ & $0.00 \mathrm{E}+00$ & $0.00 \mathrm{E}+00$ & $4.80 \mathrm{E}-03$ & 7.96E-09 & $1.14 \mathrm{E}-08$ \\
\hline Am-241 & $2.18 \mathrm{E}-04$ & $6.98 \mathrm{E}-07$ & $6.76 \mathrm{E}-07$ & $5.18 \mathrm{E}-04$ & $1.05 \mathrm{E}-06$ & $1.04 \mathrm{E}-06$ & $1.05 \mathrm{E}-02$ & 8.30E-07 & $8.75 \mathrm{E}-07$ \\
\hline $\mathrm{Cm}-244$ & $4.79 \mathrm{E}-04$ & $1.72 \mathrm{E}-08$ & 3.85E-09 & $1.15 \mathrm{E}-03$ & $5.99 \mathrm{E}-08$ & 9.41E-09 & $2.26 \mathrm{E}-02$ & $7.59 \mathrm{E}-09$ & $1.86 \mathrm{E}-09$ \\
\hline $\mathrm{Cd}-113 \mathrm{~m}$ & 7.57E-08 & $9.87 \mathrm{E}-11$ & $8.68 \mathrm{E}-11$ & $1.89 \mathrm{E}-08$ & $0.00 \mathrm{E}+00$ & $0.00 \mathrm{E}+00$ & 1.39E-09 & $1.13 \mathrm{E}-10$ & $1.03 \mathrm{E}-10$ \\
\hline Totals & $1.58 \mathrm{E}-01$ & $1.66 \mathrm{E}-01$ & $2.68 \mathrm{E}-01$ & $1.48 \mathrm{E}+01$ & $1.48 \mathrm{E}-01$ & $2.51 \mathrm{E}-01$ & $1.40 \mathrm{E}+01$ & $1.63 \mathrm{E}-01$ & $2.74 \mathrm{E}-01$ \\
\hline
\end{tabular}


TABLE 4.2 Brief Dose Rates (Gy/h) to the Bone Marrow, Gastrointestinal Tract, and Lungs

\begin{tabular}{|c|c|c|c|c|c|c|c|c|c|}
\hline \multirow[b]{2}{*}{ Radionuclide } & \multicolumn{3}{|c|}{ Bone Marrow } & \multicolumn{3}{|c|}{ Gastrointestinal Tract } & \multicolumn{3}{|c|}{ Lungs } \\
\hline & Inhalation & Ext. Gnd. & Ext. Cloud & Inhalation & Ext. Gnd. & Ext. Cloud & Inhalation & Ext. Gnd. & Ext. Cloud \\
\hline $\mathrm{H}-3$ & $0.00 \mathrm{E}+00$ & $0.00 \mathrm{E}+00$ & $0.00 \mathrm{E}+00$ & $5.35 \mathrm{E}-08$ & $0.00 \mathrm{E}+00$ & $0.00 \mathrm{E}+00$ & 7.78E-08 & $0.00 \mathrm{E}+00$ & $0.00 \mathrm{E}+00$ \\
\hline $\mathrm{Fe}-55$ & $6.04 \mathrm{E}-10$ & $0.00 \mathrm{E}+00$ & $0.00 \mathrm{E}+00$ & 2.03E-07 & $2.86 \mathrm{E}-10$ & $4.65 \mathrm{E}-11$ & $6.30 \mathrm{E}-09$ & $0.00 \mathrm{E}+00$ & $0.00 \mathrm{E}+00$ \\
\hline Co-60 & 5.93E-04 & $2.54 \mathrm{E}-02$ & $4.18 \mathrm{E}-02$ & $4.53 \mathrm{E}-02$ & $2.11 \mathrm{E}-02$ & 3.77E-02 & $5.40 \mathrm{E}-03$ & $2.47 \mathrm{E}-02$ & $4.21 \mathrm{E}-02$ \\
\hline $\mathrm{Ni}-63$ & $6.35 \mathrm{E}-12$ & $0.00 \mathrm{E}+00$ & $0.00 \mathrm{E}+00$ & $8.69 \mathrm{E}-10$ & $0.00 E+00$ & $0.00 \mathrm{E}+00$ & $6.10 \mathrm{E}-11$ & $0.00 \mathrm{E}+00$ & $0.00 \mathrm{E}+00$ \\
\hline $\mathrm{Kr}-85$ & $0.00 \mathrm{E}+00$ & $0.00 \mathrm{E}+00$ & $5.63 \mathrm{E}-03$ & $0.00 \mathrm{E}+00$ & $0.00 \mathrm{E}+00$ & 4.95E-03 & $0.00 \mathrm{E}+00$ & $0.00 \mathrm{E}+00$ & $5.89 \mathrm{E}-03$ \\
\hline Sr-90 & $5.71 \mathrm{E}-06$ & $2.75 \mathrm{E}-06$ & $3.02 \mathrm{E}-06$ & $6.85 \mathrm{E}-03$ & $0.00 \mathrm{E}+00$ & $0.00 \mathrm{E}+00$ & $1.55 \mathrm{E}-03$ & $2.87 \mathrm{E}-06$ & $3.31 \mathrm{E}-06$ \\
\hline$Y-90$ & $2.31 \mathrm{E}-06$ & $2.63 \mathrm{E}-06$ & $2.92 \mathrm{E}-06$ & $5.16 \mathrm{E}-03$ & $0.00 \mathrm{E}+00$ & $0.00 \mathrm{E}+00$ & $1.64 \mathrm{E}-03$ & $2.74 \mathrm{E}-06$ & $3.19 \mathrm{E}-06$ \\
\hline Ru-106 & $6.92 \mathrm{E}-07$ & $1.35 \mathrm{E}-05$ & $2.01 \mathrm{E}-05$ & $1.62 \mathrm{E}-03$ & $1.18 \mathrm{E}-05$ & $1.85 \mathrm{E}-05$ & $2.25 \mathrm{E}-04$ & $1.33 \mathrm{E}-05$ & $2.08 \mathrm{E}-05$ \\
\hline Rh-106 & $2.49 \mathrm{E}-02$ & $1.35 \mathrm{E}-05$ & 2.01E-05 & $1.10 \mathrm{E}-01$ & $1.18 \mathrm{E}-05$ & $1.85 \mathrm{E}-05$ & $2.49 \mathrm{E}-02$ & $1.33 \mathrm{E}-05$ & 2.08E-05 \\
\hline $\mathrm{Sb}-125$ & $2.10 \mathrm{E}-11$ & $5.74 \mathrm{E}-06$ & 8.33E-06 & $3.22 \mathrm{E}-08$ & $5.38 \mathrm{E}-06$ & 8.07E-06 & $2.45 \mathrm{E}-08$ & $5.72 \mathrm{E}-06$ & $8.64 \mathrm{E}-06$ \\
\hline $\mathrm{Te}-125 \mathrm{~m}$ & $8.06 \mathrm{E}-12$ & $4.75 \mathrm{E}-08$ & $2.02 \mathrm{E}-08$ & $5.78 \mathrm{E}-09$ & 6.17E-08 & 4.44E-08 & $1.16 \mathrm{E}-09$ & $6.14 \mathrm{E}-08$ & $2.42 \mathrm{E}-08$ \\
\hline Cs- 134 & $6.14 \mathrm{E}-04$ & $9.97 \mathrm{E}-03$ & $1.51 \mathrm{E}-02$ & $5.99 \mathrm{E}-02$ & $9.03 \mathrm{E}-03$ & 1.44E-02 & $7.40 \mathrm{E}-02$ & $9.84 \mathrm{E}-03$ & $1.55 \mathrm{E}-02$ \\
\hline Cs- 137 & $5.29 \mathrm{E}-03$ & 4.72E-02 & $7.08 \mathrm{E}-02$ & $4.97 \mathrm{E}-01$ & $4.31 \mathrm{E}-02$ & $6.78 \mathrm{E}-02$ & $7.21 \mathrm{E}-01$ & 4.64E-02 & $7.25 \mathrm{E}-02$ \\
\hline $\mathrm{Ba}-137 \mathrm{~m}$ & 6.34E-03 & 4.71E-04 & 7.05E-04 & $0.00 \mathrm{E}+00$ & $4.31 \mathrm{E}-04$ & $6.74 \mathrm{E}-04$ & $6.34 \mathrm{E}-03$ & 4.63E-04 & 7.23E-04 \\
\hline Ce-144 & $3.61 \mathrm{E}-09$ & $5.68 \mathrm{E}-08$ & $8.53 \mathrm{E}-08$ & $2.43 \mathrm{E}-05$ & $1.96 \mathrm{E}-08$ & $2.59 \mathrm{E}-08$ & 3.33E-06 & $5.81 \mathrm{E}-08$ & 8.97E-08 \\
\hline Pr- 144 & 8.67E-10 & 3.92E-08 & $6.29 \mathrm{E}-08$ & $9.76 \mathrm{E}-10$ & 2.72E-08 & $5.09 \mathrm{E}-08$ & 4.27E-06 & $3.86 \mathrm{E}-08$ & 6.39E-08 \\
\hline Pm-147 & $2.53 \mathrm{E}-08$ & $1.42 \mathrm{E}-09$ & $1.06 \mathrm{E}-09$ & $8.63 \mathrm{E}-05$ & $2.65 \mathrm{E}-10$ & $3.69 \mathrm{E}-10$ & $1.13 \mathrm{E}-05$ & 1.67E-09 & $1.30 \mathrm{E}-09$ \\
\hline Sm-151 & $3.28 \mathrm{E}-11$ & $5.77 \mathrm{E}-12$ & $1.47 \mathrm{E}-12$ & $2.51 \mathrm{E}-09$ & $1.85 \mathrm{E}-11$ & $5.07 \mathrm{E}-12$ & $1.87 \mathrm{E}-10$ & $4.19 \mathrm{E}-12$ & $9.25 \mathrm{E}-13$ \\
\hline Eu-154 & $2.85 \mathrm{E}-09$ & $6.20 \mathrm{E}-05$ & $9.81 \mathrm{E}-05$ & $3.44 \mathrm{E}-07$ & $5.51 \mathrm{E}-05$ & $9.26 \mathrm{E}-05$ & $3.29 \mathrm{E}-08$ & $6.10 \mathrm{E}-05$ & $1.00 \mathrm{E}-04$ \\
\hline Eu-155 & $1.73 \mathrm{E}-10$ & $9.68 \mathrm{E}-07$ & $1.19 \mathrm{E}-06$ & $2.29 \mathrm{E}-08$ & $1.24 \mathrm{E}-06$ & $1.55 \mathrm{E}-06$ & $2.10 \mathrm{E}-09$ & $1.10 \mathrm{E}-06$ & $1.43 \mathrm{E}-06$ \\
\hline $\mathrm{Pu}-238$ & $1.32 \mathrm{E}-06$ & $8.48 \mathrm{E}-09$ & 2.29E-09 & $4.54 \mathrm{E}-05$ & $3.21 \mathrm{E}-08$ & $5.15 \mathrm{E}-09$ & $5.82 \mathrm{E}-04$ & $3.44 \mathrm{E}-09$ & $1.45 \mathrm{E}-09$ \\
\hline $\mathrm{Pu}-239$ & $9.07 \mathrm{E}-08$ & $3.95 \mathrm{E}-10$ & $2.77 \mathrm{E}-10$ & $3.14 \mathrm{E}-06$ & $1.08 \mathrm{E}-09$ & $3.63 \mathrm{E}-10$ & $4.24 \mathrm{E}-05$ & $2.61 E-10$ & $2.75 \mathrm{E}-10$ \\
\hline $\mathrm{Pu}-240$ & $1.42 \mathrm{E}-07$ & $9.78 \mathrm{E}-10$ & $2.70 \mathrm{E}-10$ & $4.91 \mathrm{E}-06$ & 3.65E-09 & $6.00 \mathrm{E}-10$ & $6.64 \mathrm{E}-05$ & $4.06 \mathrm{E}-10$ & $1.77 \mathrm{E}-10$ \\
\hline $\mathrm{Pu}-241$ & 5.62E-07 & $3.82 \mathrm{E}-09$ & $4.99 \mathrm{E}-09$ & $9.01 \mathrm{E}-05$ & $0.00 \mathrm{E}+00$ & $0.00 \mathrm{E}+00$ & $2.00 \mathrm{E}-04$ & $3.98 \mathrm{E}-09$ & $5.68 \mathrm{E}-09$ \\
\hline Am-241 & $9.08 \mathrm{E}-06$ & $3.49 \mathrm{E}-07$ & $3.38 \mathrm{E}-07$ & $2.16 \mathrm{E}-05$ & $5.23 E-07$ & $5.19 \mathrm{E}-07$ & $4.36 \mathrm{E}-04$ & $4.15 \mathrm{E}-07$ & 4.37E-07 \\
\hline $\mathrm{Cm}-244$ & $2.00 \mathrm{E}-05$ & $8.60 \mathrm{E}-09$ & $1.92 \mathrm{E}-09$ & $4.78 \mathrm{E}-05$ & 2.99E-08 & 4.70E-09 & $9.43 \mathrm{E}-04$ & $3.80 \mathrm{E}-09$ & $9.32 \mathrm{E}-10$ \\
\hline Cd-113m & $3.15 \mathrm{E}-09$ & $4.93 \mathrm{E}-11$ & $4.34 \mathrm{E}-11$ & $7.85 \mathrm{E}-10$ & $0.00 \mathrm{E}+00$ & $0.00 \mathrm{E}+00$ & $5.80 \mathrm{E}-11$ & $5.63 \mathrm{E}-11$ & $5.14 \mathrm{E}-11$ \\
\hline Totals & $3.78 \mathrm{E}-02$ & $8.31 \mathrm{E}-02$ & $1.34 \mathrm{E}-01$ & $7.26 \mathrm{E}-01$ & $7.38 \mathrm{E}-02$ & $1.26 \mathrm{E}-01$ & $8.38 \mathrm{E}-01$ & 8.14E-02 & $1.37 \mathrm{E}-01$ \\
\hline
\end{tabular}




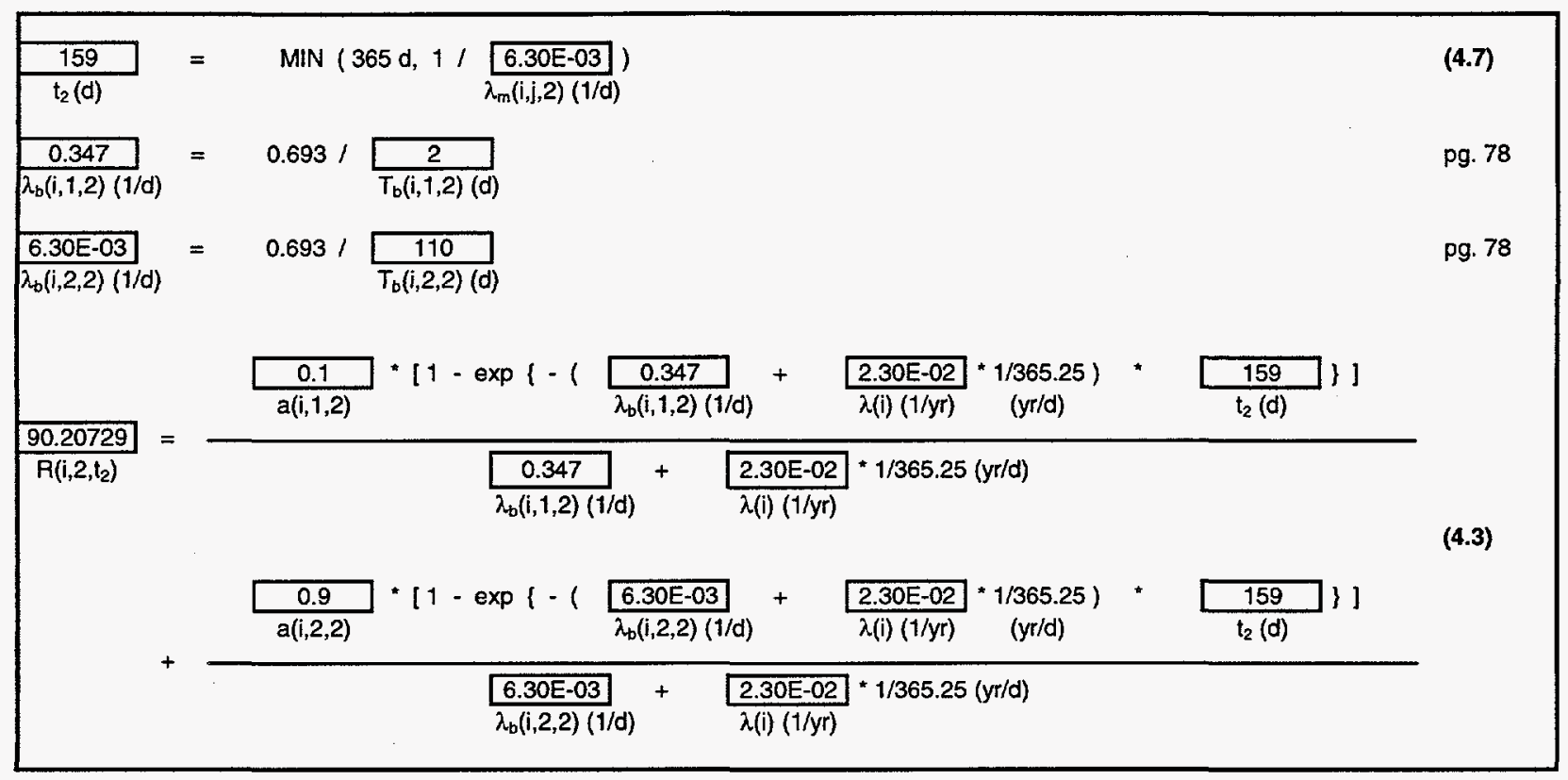

FIGURE 4.4 One-Year Retention Function Calculation for Cs-137 in Bone Marrow

\subsection{Latent Effects}

Latent effects may occur following cumulative short-term and long-term routine and accidental exposures to radiation. Three latent health effects are considered in RISKIND: (1) nonfatal cancer occurrence, (2) fatal cancer occurrence, and (3) genetic effects manifested in the exposed individual's descendants. These effects are calculated in RISKIND by using dose to risk conversion factors recommended by the ICRP (ICRP 1991).

The estimated latent health effects are presented in Table 4.4 for the individuals exposed in cases 1 and 2. Case 1 involved risks to a member of the public. with the associated DCFs as shown in the output file (Appendix A, page A-5). This individual received a routine passing dose of $1.2 \times 10^{-7}$ rem. Multiplying this dose by the appropriate DCF resulted in the estimated risks shown in Table 4.4, which match the respective values shown in the output file (Appendix A, pg. A-6) within round-off errors. Case 2 involved risks to a worker exposed as the result of an accident, and the associated DCFs are shown in the output file (Appendix A, pg. A-11). Multiplying the 1.15-rem dose received by the appropriate DCF results in the estimated risks shown in Table 4.4, which matched the respective values shown in the output file (Appendix A, pg. A-20). 


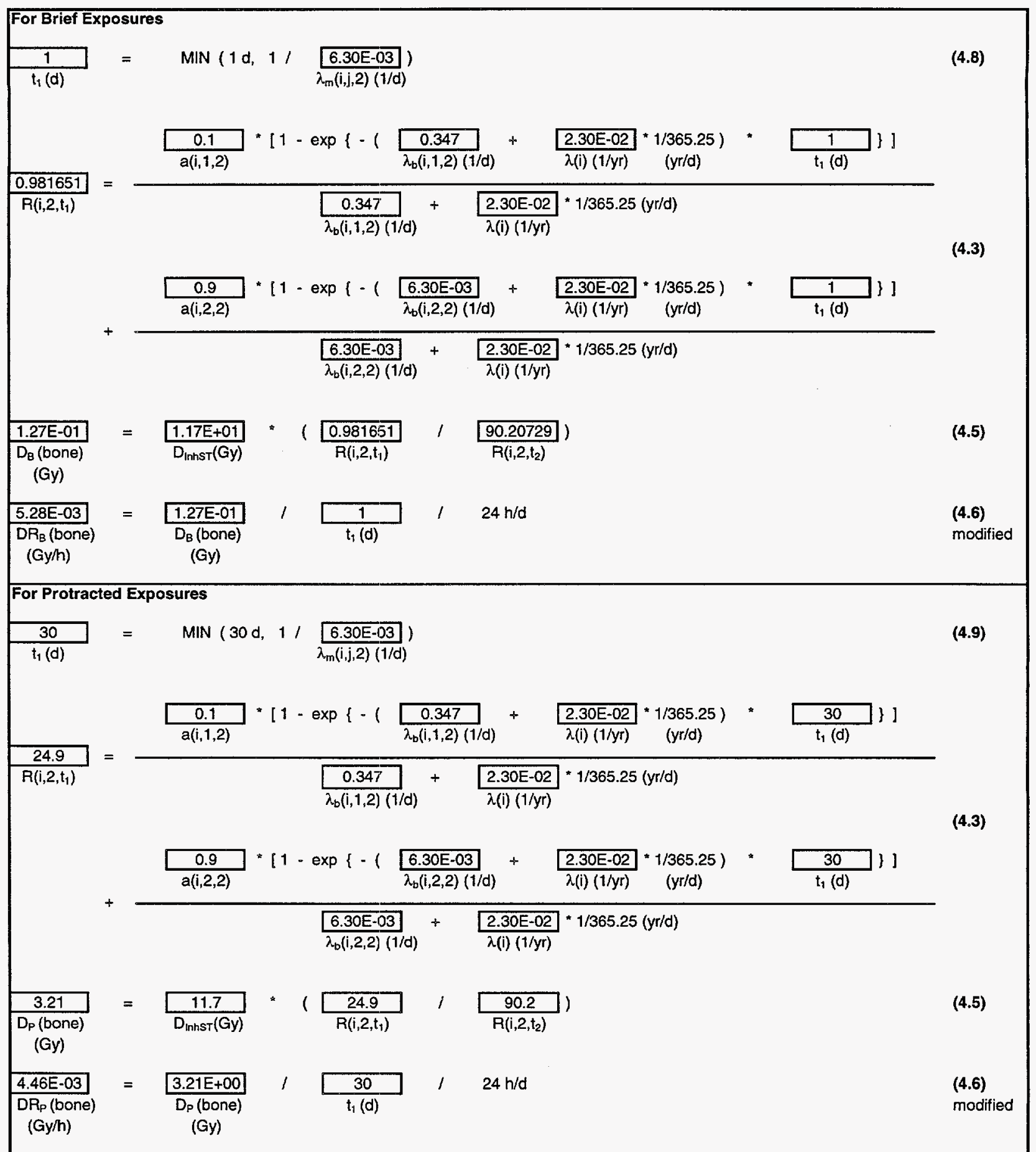

FIGURE 4.5 Inhalation Dose Calculations for the Early Effects from the Exposure of Bone Marrow to Cs-137 


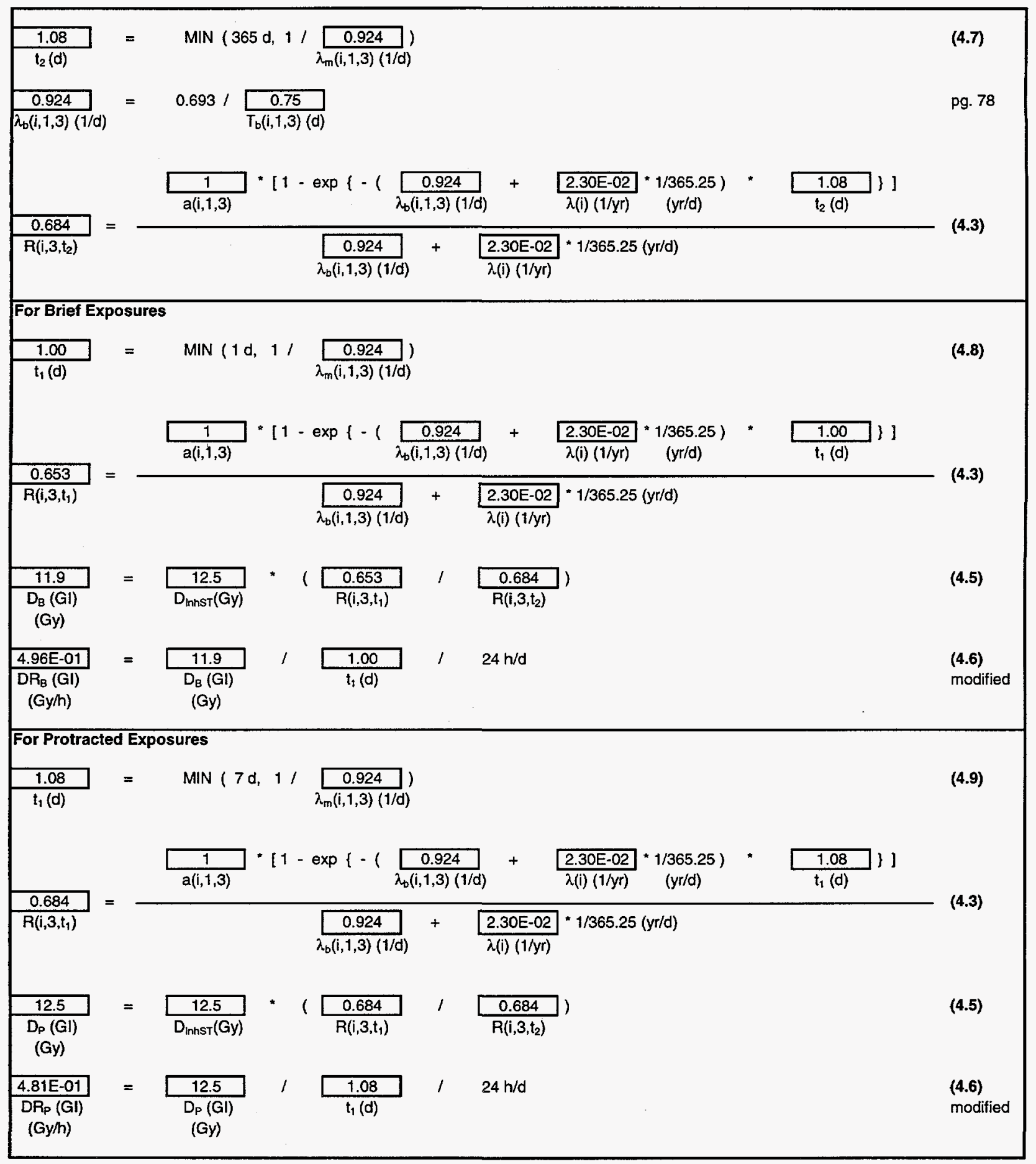

FIGURE 4.6 Inhalation Dose Calculations for the Early Effects from the Exposure of the Gastrointestinal Tract to Cs-137 


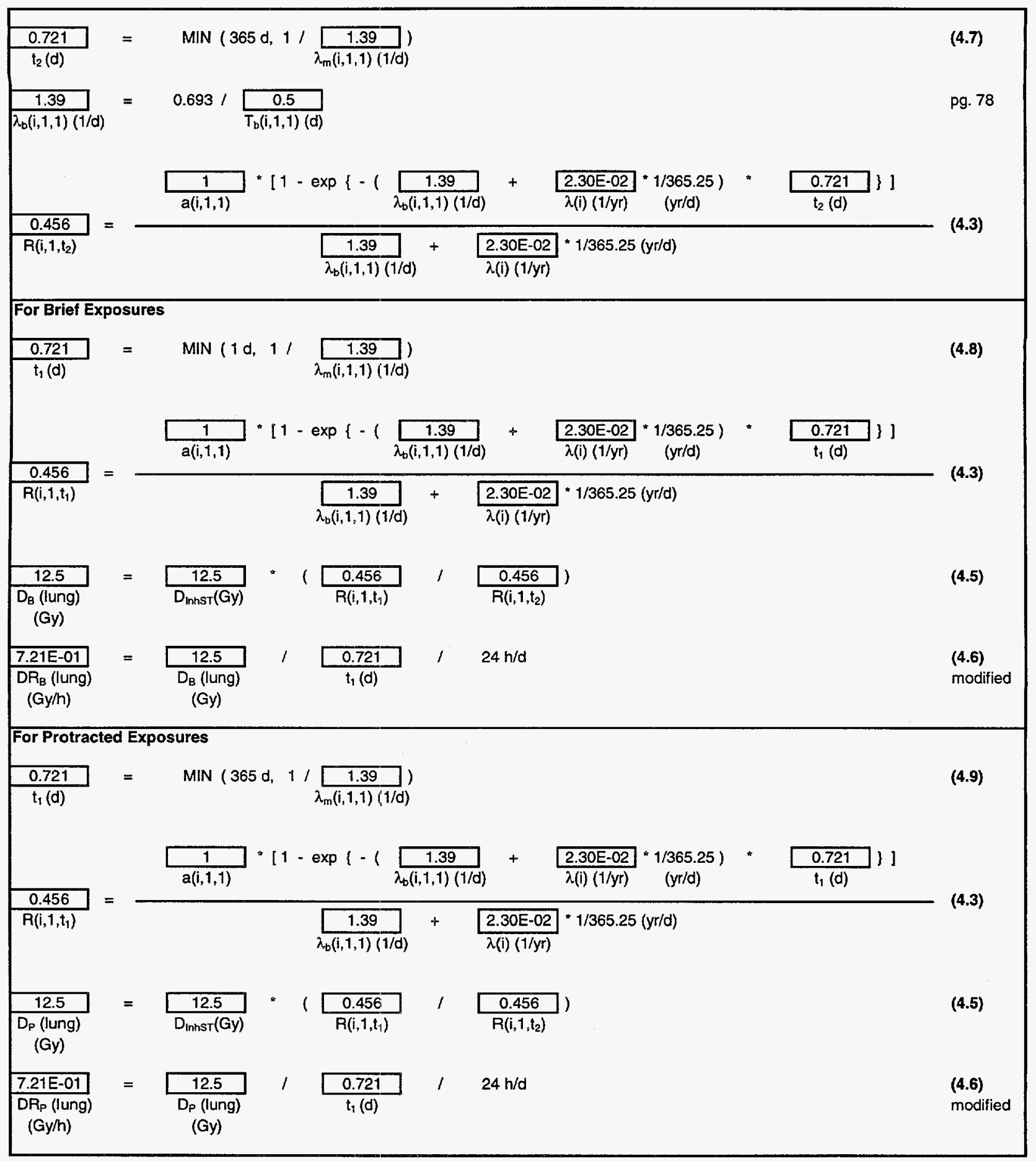

FIGURE 4.7 Inhalation Dose Calculations for the Early Effects from the Exposure of the Lungs to $\mathrm{Cs}-137$ 
TABLE 4.3 Protracted Inhalation Doses and Dose Rates from the Exposure of Bone Marrow, Gastrointestinal Tract, and Lungs to Radionuclides

\begin{tabular}{|c|c|c|c|c|c|c|}
\hline \multirow[b]{2}{*}{ Radionuclide } & \multicolumn{2}{|c|}{ Bone Marrow } & \multicolumn{2}{|c|}{ Gastrointestinal Tract } & \multicolumn{2}{|c|}{ Lungs } \\
\hline & $\begin{array}{l}\text { Dose } \\
\text { (Gy) }\end{array}$ & $\begin{array}{c}\text { Dose Rate } \\
\text { (Gy) }\end{array}$ & $\begin{array}{l}\text { Dose } \\
\text { (Gy) }\end{array}$ & $\begin{array}{c}\text { Dose Rate } \\
\text { (Gy) }\end{array}$ & $\begin{array}{l}\text { Dose } \\
\text { (Gy) }\end{array}$ & $\begin{array}{c}\text { Dose Rate } \\
\text { (Gy) }\end{array}$ \\
\hline $\mathrm{H}-3$ & $0.00 \mathrm{E}+00$ & $0.00 \mathrm{E}+00$ & $1.35 \mathrm{E}-06$ & $5.19 \mathrm{E}-08$ & $1.35 \mathrm{E}-06$ & $7.78 \mathrm{E}-08$ \\
\hline $\mathrm{Fe}-55$ & $4.28 \mathrm{E}-07$ & $5.94 \mathrm{E}-10$ & $5.11 \mathrm{E}-06$ & $1.97 \mathrm{E}-07$ & $4.68 \mathrm{E}-06$ & $2.70 \mathrm{E}-09$ \\
\hline Co-60 & $2.35 \mathrm{E}-01$ & $3.27 \mathrm{E}-04$ & $1.14 \mathrm{E}+00$ & $4.38 \mathrm{E}-02$ & $2.37 \mathrm{E}+01$ & $2.71 E-03$ \\
\hline $\mathrm{Ni}-63$ & $4.53 \mathrm{E}-09$ & $6.30 \mathrm{E}-12$ & $2.19 \mathrm{E}-08$ & $8.42 \mathrm{E}-10$ & $2.83 \mathrm{E}-07$ & $3.24 \mathrm{E}-11$ \\
\hline $\mathrm{Kr}-85$ & $0.00 \mathrm{E}+00$ & $0.00 \mathrm{E}+00$ & $0.00 \mathrm{E}+00$ & $0.00 \mathrm{E}+00$ & $0.00 \mathrm{E}+00$ & $0.00 \mathrm{E}+00$ \\
\hline Sr-90 & $1.48 \mathrm{E}-03$ & $2.06 \mathrm{E}-06$ & $1.72 \mathrm{E}-01$ & $6.64 \mathrm{E}-03$ & $7.13 \mathrm{E}+00$ & $8.14 \mathrm{E}-04$ \\
\hline$Y-90$ & $1.53 \mathrm{E}-04$ & $1.66 \mathrm{E}-06$ & $1.29 \mathrm{E}-01$ & $4.96 \mathrm{E}-03$ & 9.32E-02 & $1.01 \mathrm{E}-03$ \\
\hline $\mathrm{Ru}-106$ & $3.01 \mathrm{E}-04$ & $4.18 \mathrm{E}-07$ & $4.06 \mathrm{E}-02$ & $1.56 \mathrm{E}-03$ & $7.83 \mathrm{E}-01$ & 8.93E-05 \\
\hline Rh-106 & $2.99 \mathrm{E}-04$ & $2.49 \mathrm{E}-02$ & $1.32 \mathrm{E}-03$ & $1.10 \mathrm{E}-01$ & $2.99 \mathrm{E}-04$ & $2.49 \mathrm{E}-02$ \\
\hline Sb-125 & $4.33 \mathrm{E}-09$ & $6.01 \mathrm{E}-12$ & $8.09 \mathrm{E}-07$ & $3.11 \mathrm{E}-08$ & $1.82 \mathrm{E}-05$ & $1.05 \mathrm{E}-08$ \\
\hline $\mathrm{Te}-125 \mathrm{~m}$ & $3.14 \mathrm{E}-09$ & $4.53 \mathrm{E}-12$ & $1.45 \mathrm{E}-07$ & $5.59 \mathrm{E}-09$ & $6.41 \mathrm{E}-07$ & $3.70 \mathrm{E}-10$ \\
\hline $\mathrm{Cs}-134$ & $3.69 \mathrm{E}-01$ & $5.13 \mathrm{E}-04$ & $1.51 E+00$ & $5.80 \mathrm{E}-02$ & $1.28 \mathrm{E}+00$ & $7.40 \mathrm{E}-02$ \\
\hline Cs-137 & $3.21 \mathrm{E}+00$ & $4.46 \mathrm{E}-03$ & $1.25 E+01$ & $4.81 \mathrm{E}-01$ & $1.25 \mathrm{E}+01$ & $7.21 \mathrm{E}-01$ \\
\hline $\mathrm{Ba}-137 \mathrm{~m}$ & $3.97 \mathrm{E}-04$ & $6.34 \mathrm{E}-03$ & $0.00 \mathrm{E}+00$ & $0.00 \mathrm{E}+00$ & $3.97 \mathrm{E}-04$ & $6.34 \mathrm{E}-03$ \\
\hline $\mathrm{Ce}-144$ & $2.50 \mathrm{E}-06$ & $3.48 \mathrm{E}-09$ & $6.11 \mathrm{E}-04$ & $2.35 \mathrm{E}-05$ & $1.07 \mathrm{E}-02$ & $1.22 \mathrm{E}-06$ \\
\hline Pr- 144 & $3.62 \mathrm{E}-10$ & $8.67 \mathrm{E}-10$ & $4.07 \mathrm{E}-10$ & $9.76 \mathrm{E}-10$ & $1.78 \mathrm{E}-06$ & 4.27E-06 \\
\hline Pm-147 & $1.80 \mathrm{E}-05$ & $2.50 \mathrm{E}-08$ & $2.17 \mathrm{E}-03$ & $8.35 \mathrm{E}-05$ & $4.70 \mathrm{E}-02$ & $5.37 \mathrm{E}-06$ \\
\hline Sm-151 & $2.35 \mathrm{E}-08$ & $3.27 \mathrm{E}-11$ & $6.32 \mathrm{E}-08$ & $2.43 \mathrm{E}-09$ & $8.70 \mathrm{E}-07$ & $9.93 \mathrm{E}-11$ \\
\hline Eu-154 & $2.04 \mathrm{E}-06$ & $2.83 \mathrm{E}-09$ & $8.65 \mathrm{E}-06$ & 3.33E-07 & $1.48 \mathrm{E}-04$ & $1.69 \mathrm{E}-08$ \\
\hline Eu-155 & $1.24 \mathrm{E}-07$ & $1.72 \mathrm{E}-10$ & $5.75 \mathrm{E}-07$ & $2.21 \mathrm{E}-08$ & $9.19 \mathrm{E}-06$ & $1.05 \mathrm{E}-09$ \\
\hline $\mathrm{Pu}-238$ & $9.48 \mathrm{E}-04$ & $1.32 \mathrm{E}-06$ & $1.14 \mathrm{E}-03$ & $4.40 \mathrm{E}-05$ & $2.70 \mathrm{E}+00$ & $3.09 \mathrm{E}-04$ \\
\hline Pu-239 & $6.53 \mathrm{E}-05$ & $9.07 \mathrm{E}-08$ & $7.89 \mathrm{E}-05$ & $3.04 \mathrm{E}-06$ & $1.98 \mathrm{E}-01$ & $2.26 \mathrm{E}-05$ \\
\hline $\mathrm{Pu}-240$ & $1.02 \mathrm{E}-04$ & $1.42 \mathrm{E}-07$ & $1.24 \mathrm{E}-04$ & $4.76 \mathrm{E}-06$ & $3.09 \mathrm{E}-01$ & $3.53 \mathrm{E}-05$ \\
\hline $\mathrm{Pu}-241$ & $4.04 \mathrm{E}-04$ & 5.61E-07 & $2.27 \mathrm{E}-03$ & $8.72 \mathrm{E}-05$ & $9.13 \mathrm{E}-01$ & $1.04 \mathrm{E}-04$ \\
\hline Am-241 & $6.53 \mathrm{E}-03$ & $9.08 \mathrm{E}-06$ & $5.43 \mathrm{E}-04$ & $2.09 \mathrm{E}-05$ & $3.31 \mathrm{E}-01$ & $1.91 \mathrm{E}-04$ \\
\hline $\mathrm{Cm}-244$ & $1.43 \mathrm{E}-02$ & $1.99 \mathrm{E}-05$ & $1.20 \mathrm{E}-03$ & $4.63 \mathrm{E}-05$ & $7.13 \mathrm{E}-01$ & $4.12 \mathrm{E}-04$ \\
\hline Cd-113m & $1.98 \mathrm{E}-07$ & $2.28 \mathrm{E}-09$ & $1.98 \mathrm{E}-08$ & $7.61 \mathrm{E}-10$ & $2.64 \mathrm{E}-07$ & $3.01 \mathrm{E}-11$ \\
\hline Totals & $3.84 \mathrm{E}+00$ & $3.66 \mathrm{E}-02$ & $1.55 \mathrm{E}+01$ & $7.06 \mathrm{E}-01$ & $5.07 \mathrm{E}+01$ & 8.32E-01 \\
\hline
\end{tabular}




$$
\begin{aligned}
& \text { Brief Exposure }
\end{aligned}
$$

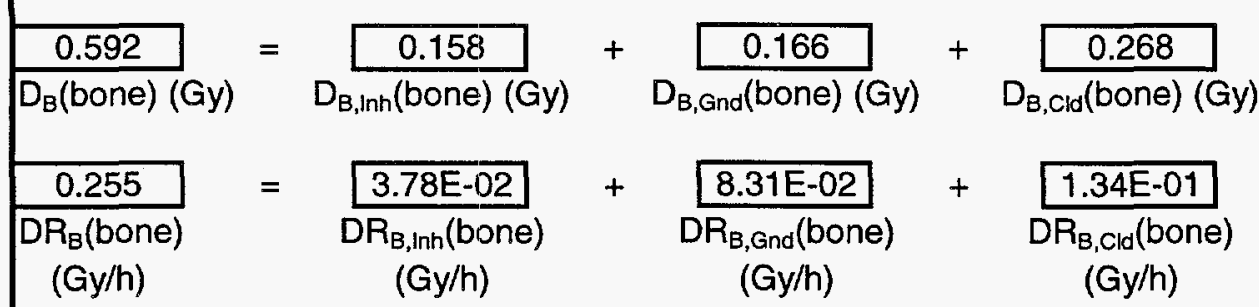

High dose rate section, if dose rate $>=0.06 \mathrm{~Gy} / \mathrm{hr}$

[True]

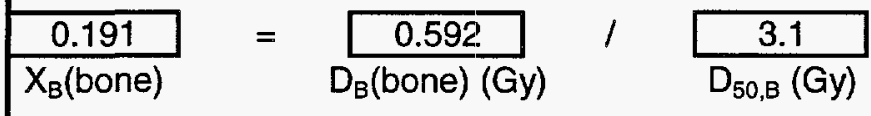

Protracted Exposure

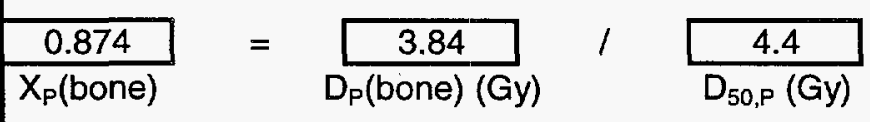

\section{Bone Marrow Hazard}

Threshold effect, if $X_{B}$ (bone) $<0.5, X_{B}$ (bone) $=0$

Threshold effect, if $X_{P}($ bone $)<0.5, X_{P}($ bone $)=0$

$$
\begin{aligned}
& \frac{0.874}{\mathrm{X} \text { (bone) }}=\frac{\frac{0}{\mathrm{X}_{\mathrm{B}} \text { (bone) }}+\frac{0.874}{\mathrm{X}_{\mathrm{P}} \text { (bone) }}}{\frac{1}{\text { treatment factor }}}
\end{aligned}
$$

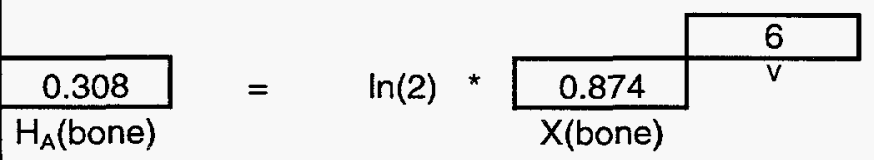

FIGURE 4.8 Lethality Hazard Calculations for Bone Marrow 


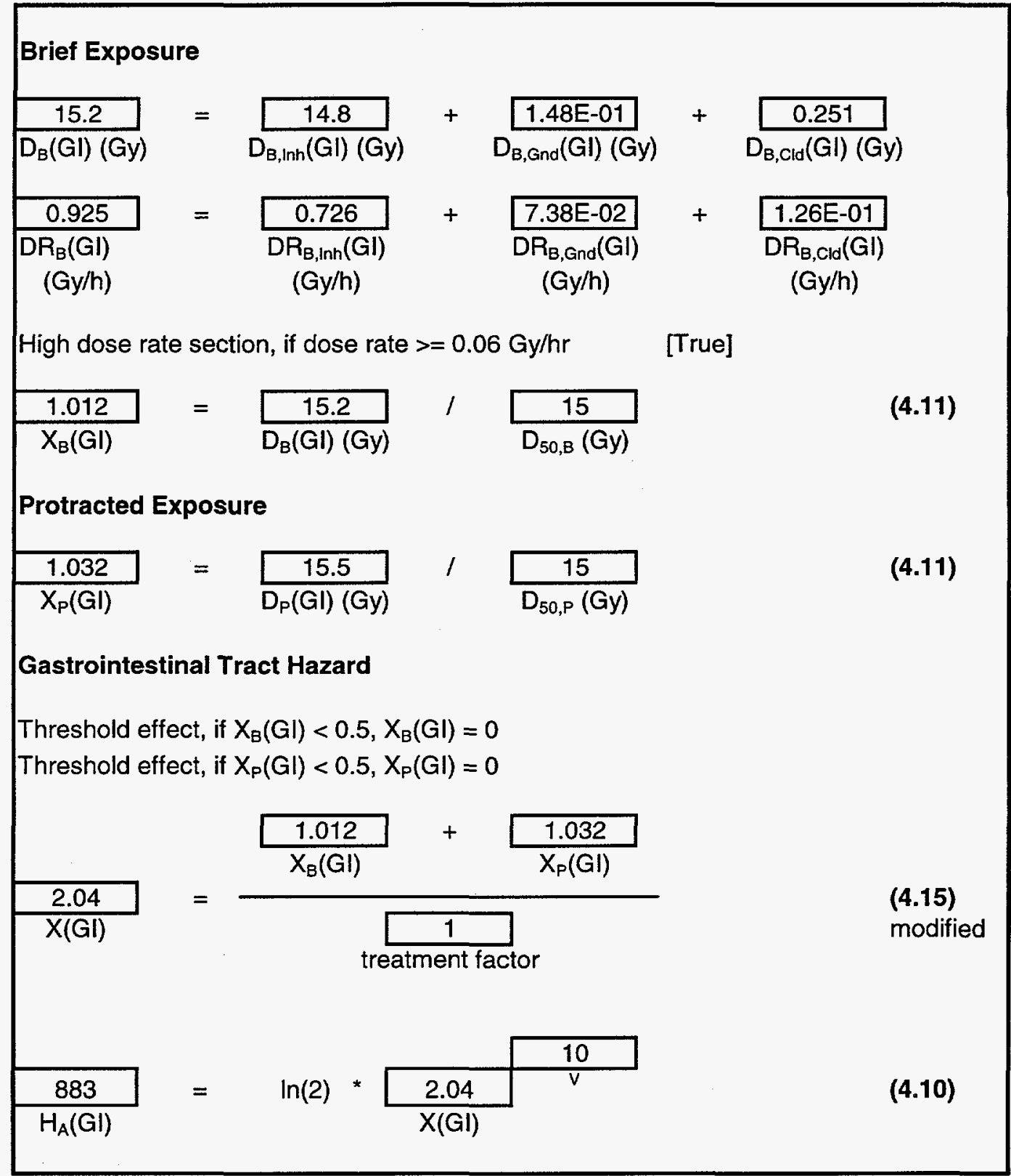

FIGURE 4.9 Lethality Hazard Calculations for the Gastrointestinal Tract 


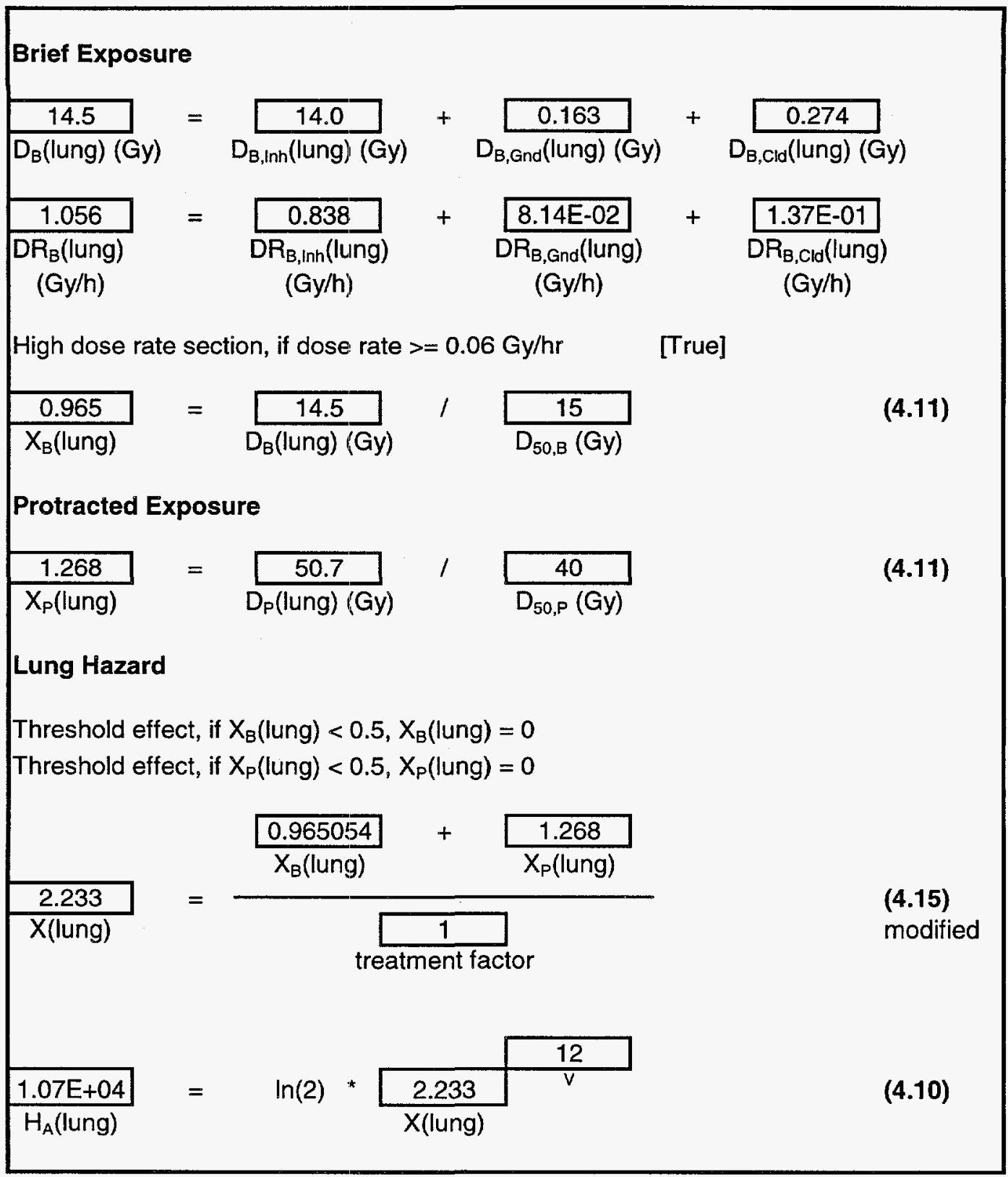

FIGURE 4.10 Lethality Hazard Calculations for the Lungs 


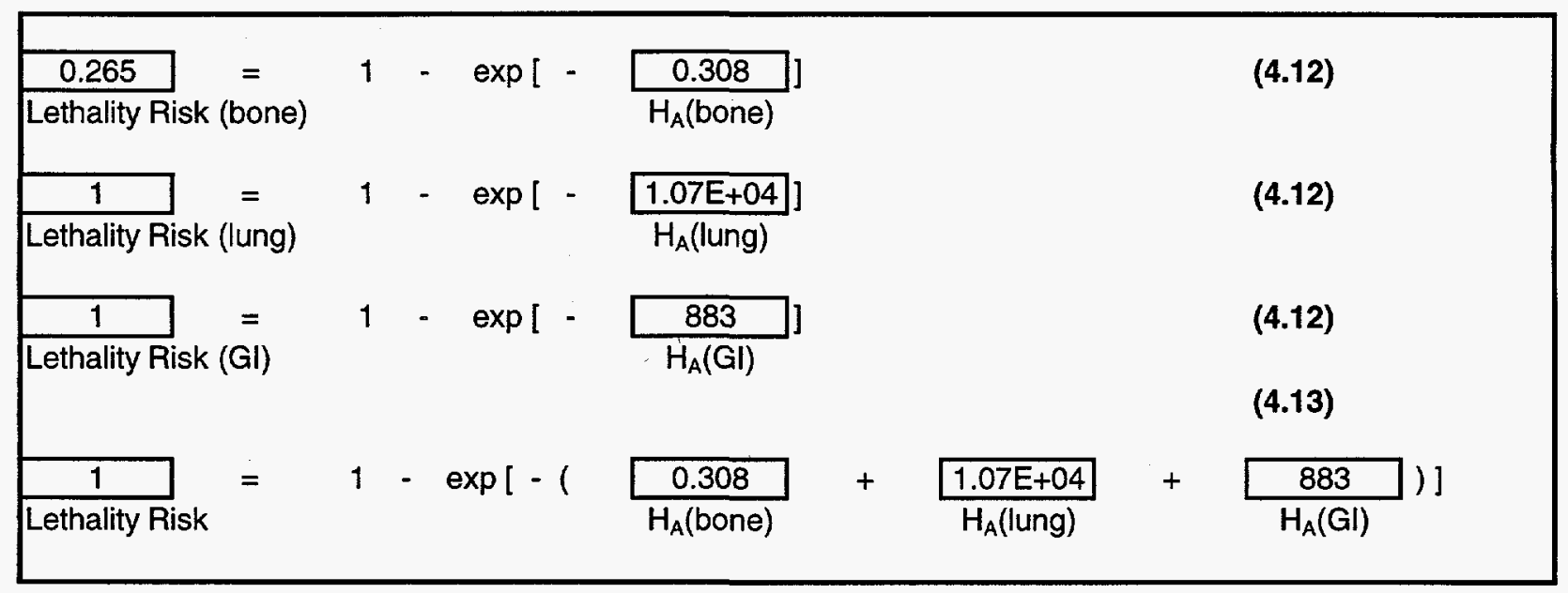

FIGURE 4.11 Lethality Risk Calculations for Case 3

TABLE 4.4 Latent Health Risks for an Individual

\begin{tabular}{|c|c|c|c|c|}
\hline \multirow[b]{2}{*}{ Latent Health Effect } & \multicolumn{2}{|c|}{$\begin{array}{c}\text { Case } 1 \\
\text { Dose of } 1.2 \times 10^{-7} \mathrm{rem} \\
\end{array}$} & \multicolumn{2}{|c|}{$\begin{array}{c}\text { Case } 2 \\
\text { Dose of } 1.15 \mathrm{rem}\end{array}$} \\
\hline & $\mathrm{DCF}^{\mathrm{a}}$ & Risk $^{\mathrm{b}}$ & $\mathrm{DCF}^{\mathrm{a}}$ & Risk $^{\mathrm{b}}$ \\
\hline Nonfatal cancer & $1.0 \times 10^{-4}$ & $1.2 \times 10^{-11}$ & $8.0 \times 10^{-5}$ & $9.2 \times 10^{-5}$ \\
\hline Fatal cancer & $5.0 \times 10^{-4}$ & $6.0 \times 10^{-11}$ & $4.0 \times 10^{-4}$ & $4.6 \times 10^{-4}$ \\
\hline Genetic effects & $1.3 \times 10^{4}$ & $1.6 \times 10^{-11}$ & $8.0 \times 10^{-5}$ & $9.2 \times 10^{-5}$ \\
\hline
\end{tabular}

a Source: ICRP (1991).

b Lifetime risk of experiencing nonfatal or fatal cancer or risk of genetic effects occurring in descendants. 


\section{REFERENCES}

Abrahamson, S., et al., 1989, Health Effects Model for Nuclear Power Accident Consequence Analysis, Low LET Radiation, Rev. 1, NUREG/CR-4214, U.S. Nuclear Regulatory Commission, Washington, D.C.

Abrahamson, S., et al., 1991, Health Effects Model for Nuclear Power Accident Consequence Analysis, Modifications of Models Resulting from Recent Reports on Health Effects of Ionizing Radiation, Rev. 1, Part II, Addendum 1, NUREG/CR-4214, U.S. Nuclear Regulatory Commission, Washington, D.C.

Baepler, D., et al., 1996, Preliminary Risk Assessment DOE Sites in Nevada, Nevada Risk Assessment/Management Program, Harry Reid Center for Environmental Studies, University of Nevada, Las Vegas, Nev., Dec。

Briesmeister, J.F. (editor), 1993, MCNPTM - A General Monte Carlo N-Particle Transport Code, Version 4A, LA-12625-M, Los Alamos National Laboratory, Los Alamos, N.M., Nov.

Briggs, G.A., 1974, Diffusion Estimation for Small Emissions, Environmental Research Laboratories, Atmospheric Turbulence and Diffusion Laboratory 1973 Annual Report, Report ATDL-106, National Oceanic and Atmospheric Administration, Washington, D.C.

Chen, S.Y., and Y.C. Yuan, 1988, "Calculation of Radiation Dose Rates from a Spent Nuclear Fuel Shipping Cask," Transactions of the American Nuclear Society 56:110-112.

Deng, C., et al., 1996, "Risk Assessments for Transporting Radioactive Material within Idaho," Radwaste, July.

DOE, 1995, Department of Energy Programmatic Spent Nuclear Fuel Management and Idaho National Engineering Laboratory Environmental Restoration and Waste Management Programs Final Environmental Impact Statement, DOE/EIS-0203-F, U.S. Department of Energy, Office of Environmental Management, Idaho Operations Office, Idaho Falls, Idaho, Apr.

DOE, 1996, Final Environmental Impact Statement on a Proposed Nuclear Weapons Nonproliferation Policy Concerning Foreign Research Reactor Spent Nuclear Fuel; Appendix E: Evaluation of Human Health Effects of Overland Transportation, Vol. 2, DOE/EIS-0218F, U.S. Department of Energy, Assistant Secretary for Environmental Management, Washington, D.C., Feb.

DOE, 1997, Final Waste Management Programmatic Environmental Impact Statement for Managing Treatment, Storage, and Disposal of Radioactive and Hazardous Waste, DOE/EIS0200-F, U.S. Department of Energy, Office of Environmental Management, Washington, D.C., May. 
Dunning, D.E., 1986, Estimates of Internal-Dose Equivalent from Inhalation and Ingestion of Selected Radionuclides, WIPP-DOE-176, prepared for U.S. Department of Energy, Washington, D.C., by Westinghouse Electric Corporation, Albuquerque, N.M.

Eckerman, K.F., and J.C. Ryman, 1993, External Exposure to Radionuclides in Air, Soil, and Water: Exposure to Dose Coefficients for General Applications Based on the 1987 Federal Radiation Protection Guidance, EPA 402-R-93-076, Federal Guidance Report No. 12, prepared by Oak Ridge National Laboratory, Oak Ridge, Tenn., for U.S. Environmental Protection Agency, Office of Radiation and Indoor Air, Washington, D.C.

Eckerman, K.F., et al., 1988, Limiting Values of Radionuclide Intake and Air Concentration and Dose Conversion Factors for Inhalation, Submersion, and Ingestion, EPA-520/1-88-020, Federal Guidance Report No. 11, prepared by Oak Ridge National Laboratory, Oak Ridge, Tenn., for U.S. Environmental Protection Agency, Office of Radiation Programs, Washington, D.C.

Eimutis, E.C., and M.G. Konicek, 1972, "Derivation of Continuous Functions for the Lateral and Vertical Dispersion Coefficients," Atmospheric Environment 6:859-863.

EPA, 1992, User's Guide for CAP88-PC, Version 1.0, 402-B-92-001, U.S. Environmental Protection Agency, Washington, D.C.

Evans et al., 1985, Health Effects Model for Nuclear Power Accidents Consequence Analysis, NUREG/CR-4214, U.S. Nuclear Regulatory Commission, Washington, D.C.

ICRP, 1991, 1990 Recommendations of the International Commission on Radiological Protection, Publication 60, International Commission on Radiological Protection, Pergamon Press, New York, N.Y.

LLNL, 1987, Shipping Container Response to Severe Highway and Railway Accident Conditions, NUREG/CR-4829, UCID-20733, prepared by Lawrence Livermore National Laboratory, Livermore, Calif., for U.S. Nuclear Regulatory Commission, Feb.

Maheras, S.J., and H.K. Pippen, 1995, Validation of the Transportation Computer Codes HIGHWAY, INTERLINE, RADTRAN 4, and RISKIND, prepared by Science Applications International Corp., Idaho Falls, Idaho, for U.S. Department of Energy, ES Project Office, Idaho Operations Office, Idaho Falls, Idaho, May.

Napier, B.A., et al., 1988, GENII - The Hanford Environmental Radiation Dosimetry Software System, PNL-6584, prepared by Pacific Northwest Laboratory, Richland, Wash., for U.S. Department of Energy, Dec.

Negin, C.A., and G. Worku, 1992a, MicroShield, Version 4, User's Manual, Grove 92-2, Grove Engineering, Inc., Rockville, Md.

Negin, C.A., and G. Worku, 1992b, MicroShield 4 Verification and Validation, Grove 92-3, Grove Engineering, Inc., Rockville, Md. 
Neuhauser, K.S., and F.L. Kanipe, 1992, RADTRAN 4: Volume 3, User Guide, SAND89-2370, Sandia National Laboratories, Albuquerque, N.M., Jan.

Neuhauser, K.S., and F.L. Kanipe, 1995, RADTRAN 4: Volume 2, Technical Manual, SAND892370, Sandia National Laboratories, Albuquerque, N.M., March.

NRC, 1977, Final Environmental Impact Statement on the Transportation of Radioactive Material by Air and Other Modes, NUREG-0170, U.S. Nuclear Regulatory Commission, Office of Standards Development, Washington, D.C., Dec.

RSIC, 1981, CASK-81: 22 Neutron, 18 Gamma-Ray Group, P3, Cross Sections for Shipping Cask Analysis, DLC-23F, Radiation Shielding Information Center, Oak Ridge National Laboratory, Oak Ridge, Tenn.

Sandquist, G.M. et al., 1985, Exposures and Health Effects from Spent Fuel Transportation, RAE-8339/12-1, prepared by Rogers and Associates Engineering Corporation, Salt Lake City, Utah, for U.S. Department of Energy, Office of Civilian Radioactive Waste Management, Washington, D.C., Nov.

Slade, D.H. (editor), 1968, Meteorology and Atomic Energy 1968, TID 24190, prepared by Air Resources Laboratories, Research Laboratories, Environmental Science Services Administration, U.S. Department of Commerce, for Division of Reactor Development and Technology, U.S. Atomic Energy Commission, July.

Weiner, R.F., and K.S. Neuhauser, 1992, "Conservatism of RADTRAN Line-Source Model for Estimating Worker Exposures," in PATRAM '92, 10 th International Symposium on the Packaging and Transportation of Radioactive Materials, Yokohama City, Japan, Sept. 13-18.

Whalen, D.J., et al., 1991a, MCNP: Photon Benchmark Problems, LA-12196, Los Alamos National Laboratory, Los Alamos, N.M.

Whalen, D.J., et al., 1991b, MCNP: Neutron Benchmark Problems, LA-12212, Los Alamos National Laboratory, Los Alamos, N.M.

Yuan, Y.C., et al., 1993, RISKIND - A Computer Program for Calculating Radiological Consequences and Health Risks from Transportation of Spent Nuclear Fuel, ANL/EAIS-6, Rev. 0, Argonne National Laboratory, Argonne, Ill., Feb.

Yuan, Y.C., et al., 1995, RISKIND - A Computer Program for Calculating Radiological Consequences and Health Risks from Transportation of Spent Nuclear Fuel, ANL/EAD-1, Argonne National Laboratory, Argonne, Ill., Nov. 


\section{APPENDIX A:}

TEST CASES 


\section{CONTENTS}

A.1 Case 1: Routine Risk to Individual ............................................................... A-1

A.1.1 Case 1 Input File ................................................................................ A-1

A.1.2 Case 1 Output File.................................................................................... A-4

A.2 Case 2: Accident Risk to Individual ................................................................. A-7

A.2.1 Case 2 Input File ............................................................................... A-7

A.2.2 Case 2 Output File.................................................................................. A-10

A.3 Case 3: Acute Health Effects........................................................................... A-22

A.3.1 Case 3 Input File .................................................................................. A-22

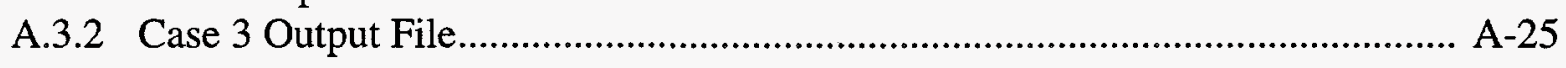




\section{APPENDIX A: TEST CASES}

\section{A.1 Case 1: Routine Risk to Individual}

\section{A.1.1 Case 1 Input File}

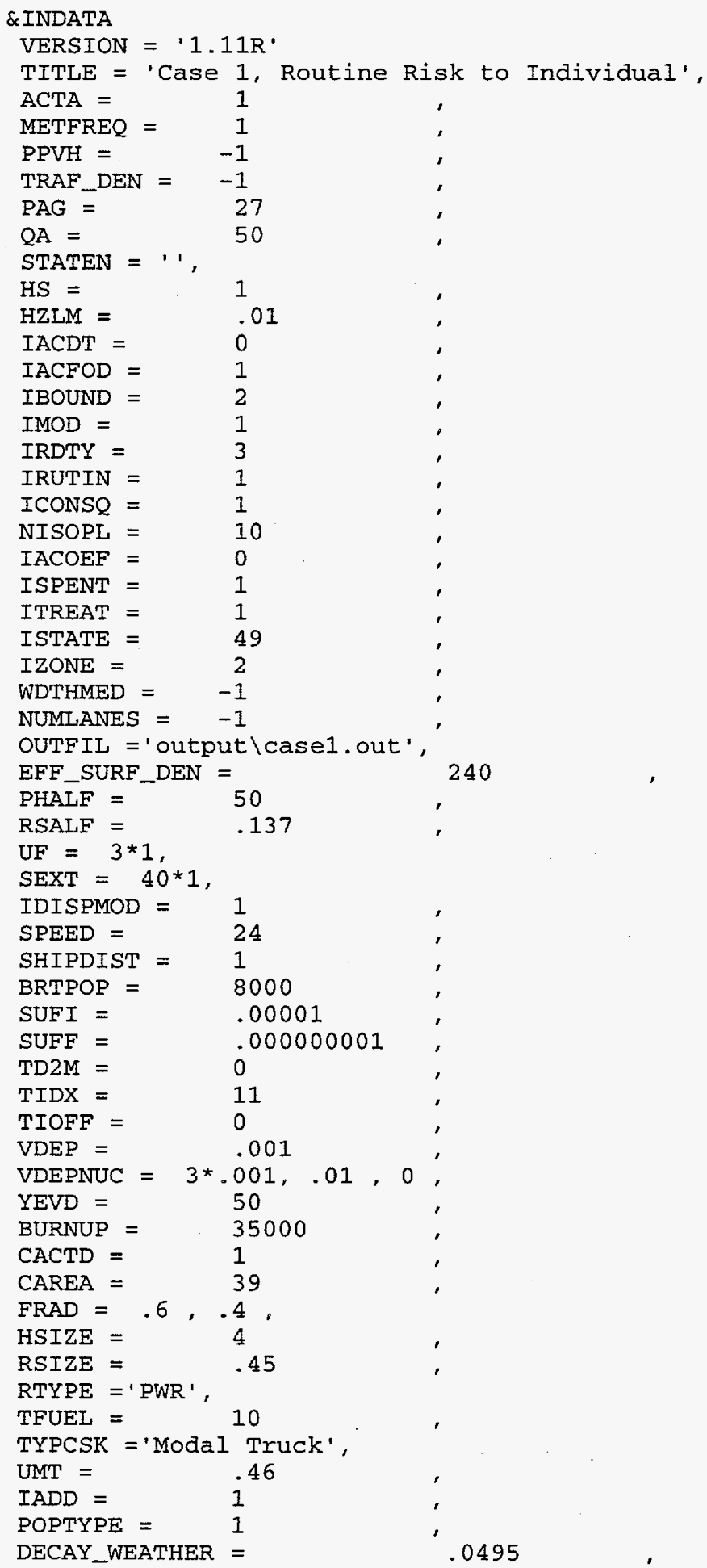




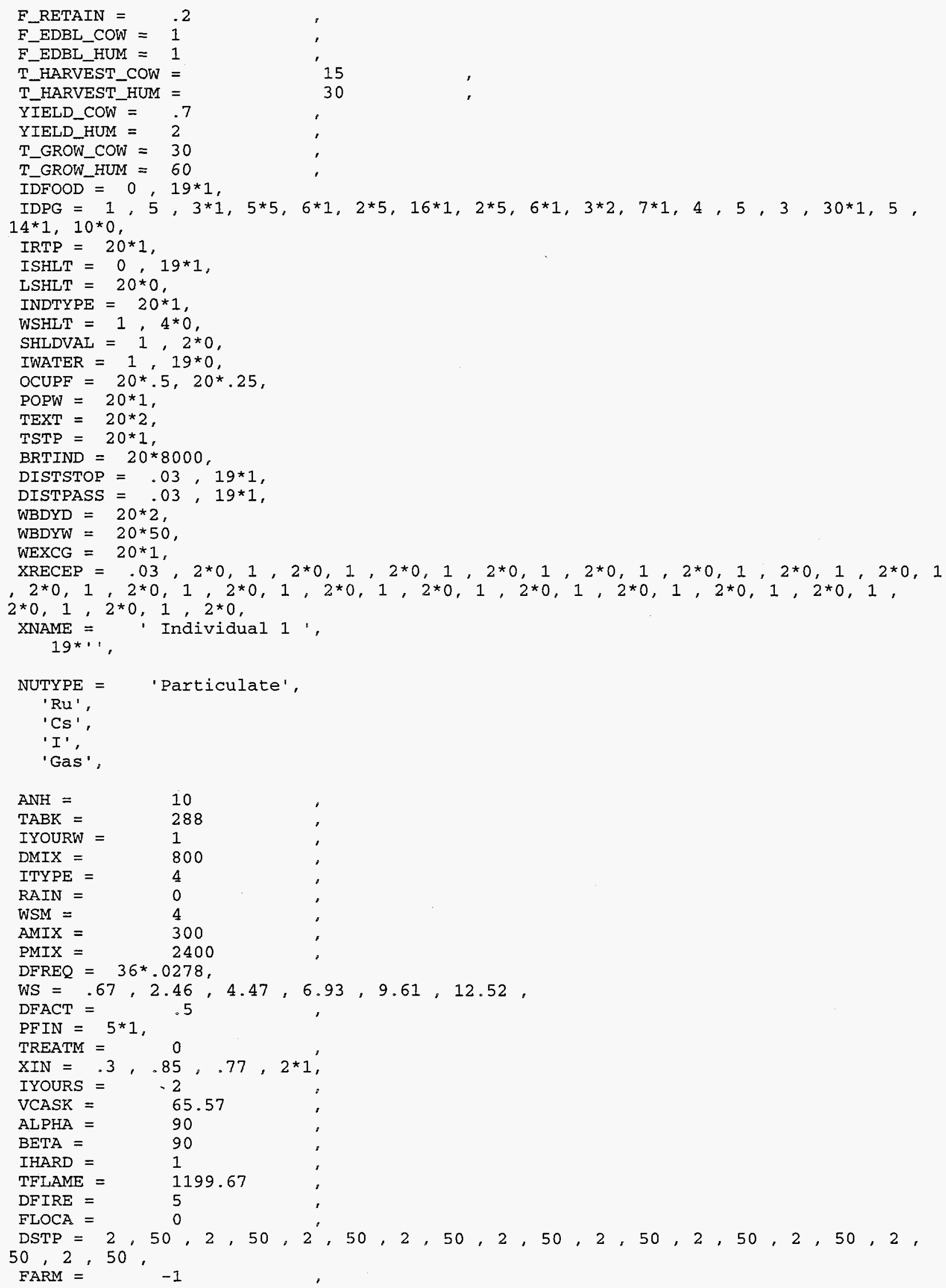




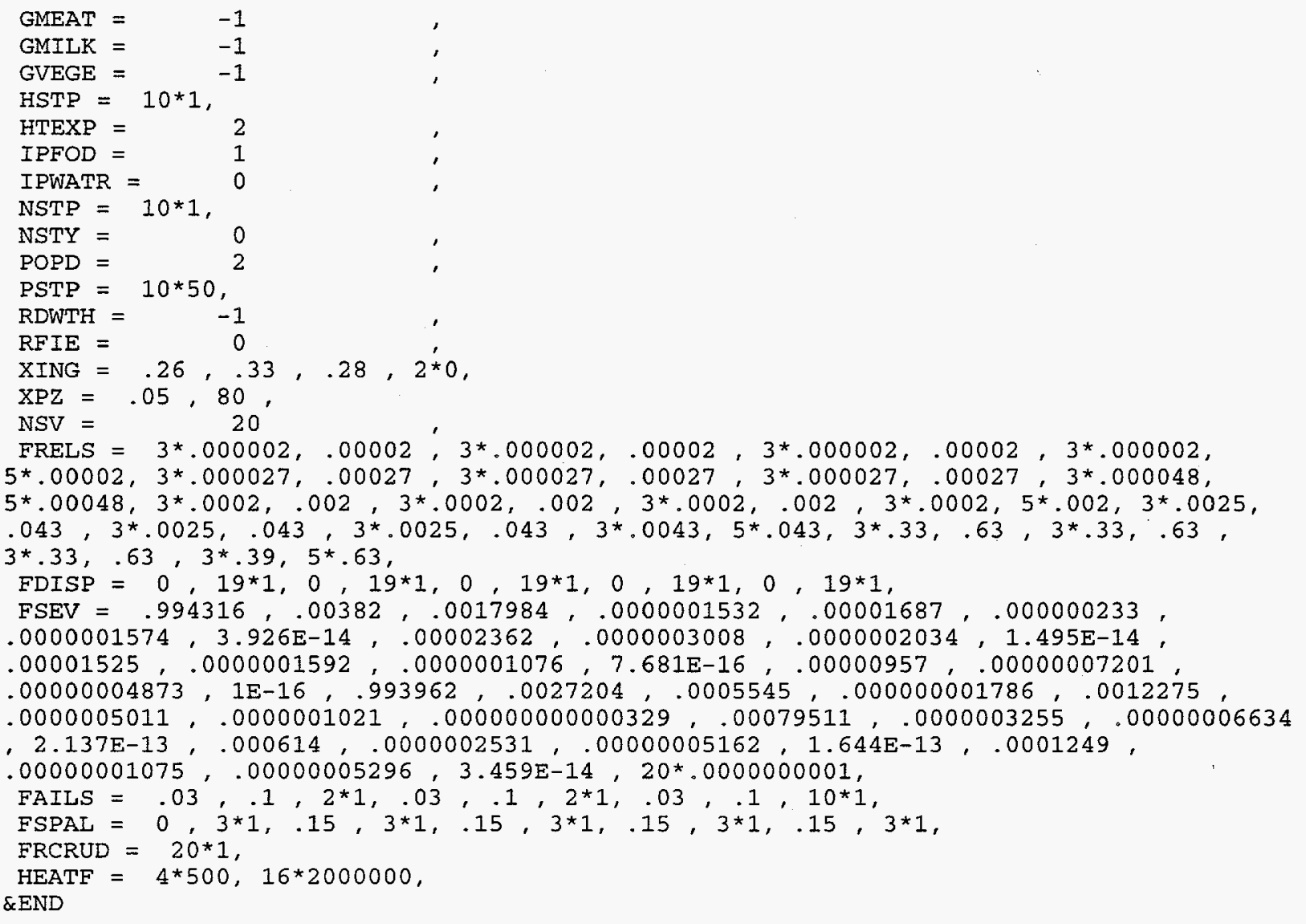




\title{
A.1.2 Case 1 Output File
}

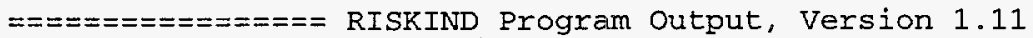 \\ =ニニニニニニ= Page: \\ 1 \\ Title \\ - Case 1, Routine Fisk to Individual \\ Date/Time \\ : $11 / 27 / 9513: 57$ \\ Input File: c:\riskind input \casel.inp \\ output File: outputlcasel.out

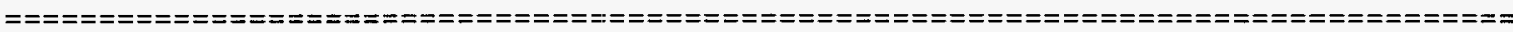

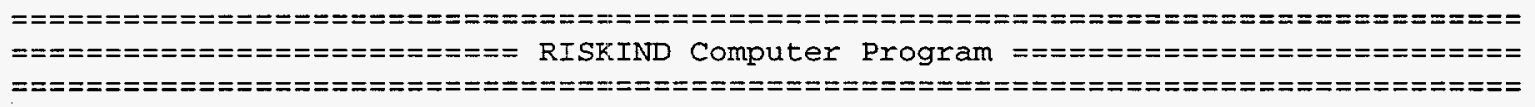

Problem Description

Individual Receptors

Routine Calculatjons

Note: * next to input description signifies

a data dependent default value 


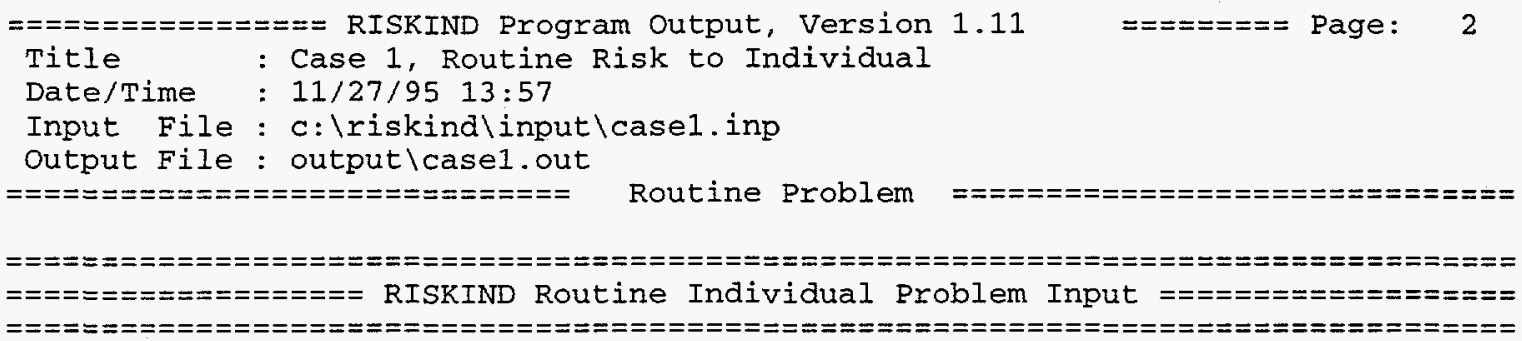

Transport Mode [IMOD] : Truck Population Zone [IZONE] : Suburban Dose at $1 \mathrm{~m}$ [TIDX] : $11.00 \mathrm{mrem} / \mathrm{hr}$ Measurement offset [TIOFF]: $0.00 \mathrm{~m}$

Gamma Fraction [FRAD(1)]: 0.60

Neutron Fraction [FRAD (2)]: 0.40

Cask Length [HSIZE]:

Cask Radius [RSIZE] : 0.45

Traveling speed [SPEED]: 24.00

Individual type [INDTYPE]: Public Risk Conversion Factors

Non-Fatal Cancers/rem: 1.0E-04

Fatal Cancers/rem: 5.0E-04 Genetic Effects/rem: 1.3E-04

\begin{tabular}{lllccc}
\hline & $\begin{array}{c}\text { Stop } \\
\text { Distance } \\
\text { [DISTSTOP] } \\
\text { [ Ifm] }\end{array}$ & $\begin{array}{c}\text { Stop } \\
\text { Time } \\
\text { [TSTP] } \\
{[\mathrm{hr}]}\end{array}$ & $\begin{array}{c}\text { Passing } \\
\text { Distance } \\
\text { [DISTPASS } \\
{[\mathrm{km}]}\end{array}$ \\
\hline 1 & Individual 1 & $3.0 \mathrm{E}-02$ & 1.00 & $3.0 \mathrm{E}-02$
\end{tabular}




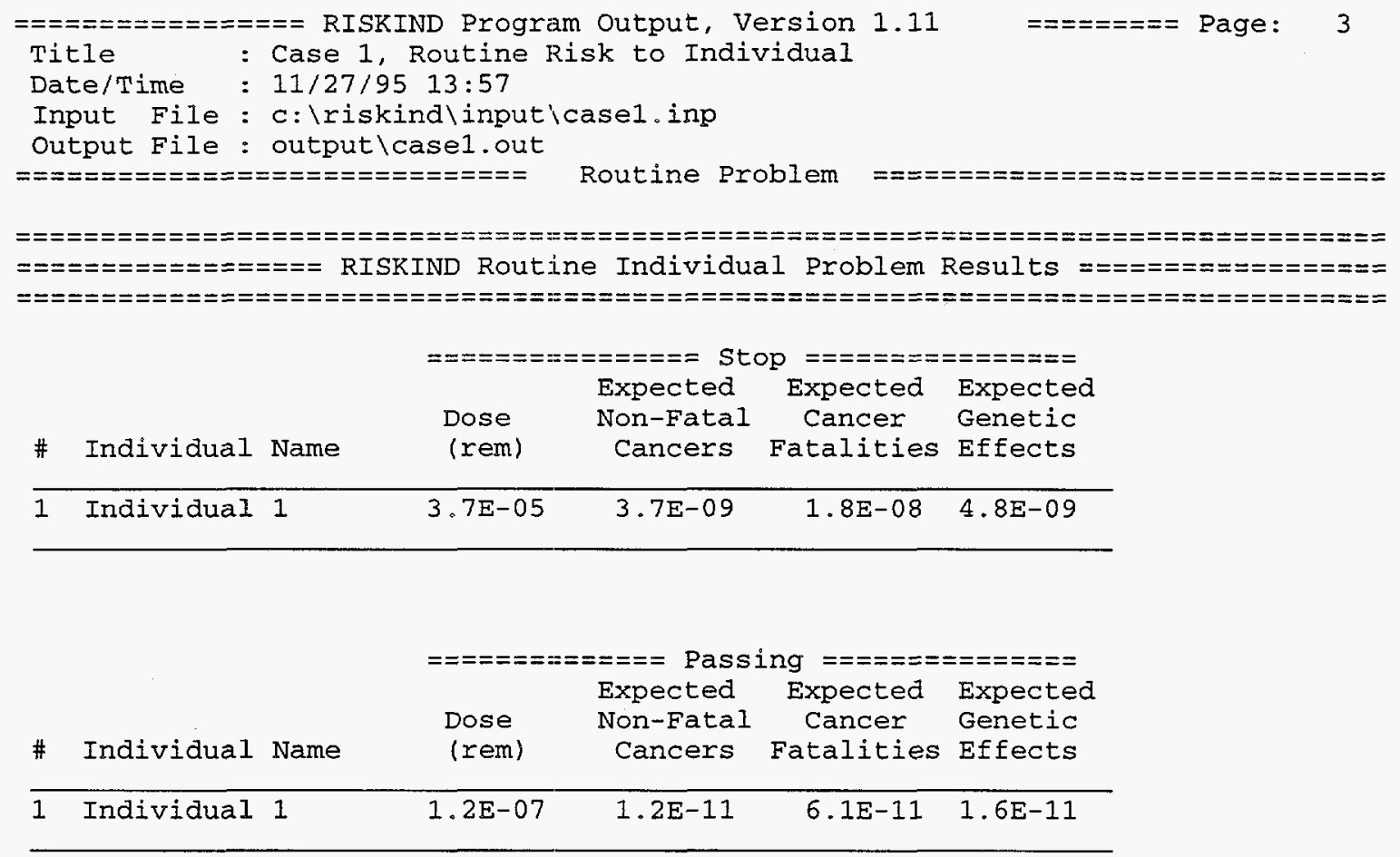




\section{A.2 Case 2: Accident Risk to Individual}

\section{A.2.1 Case 2 Input File}

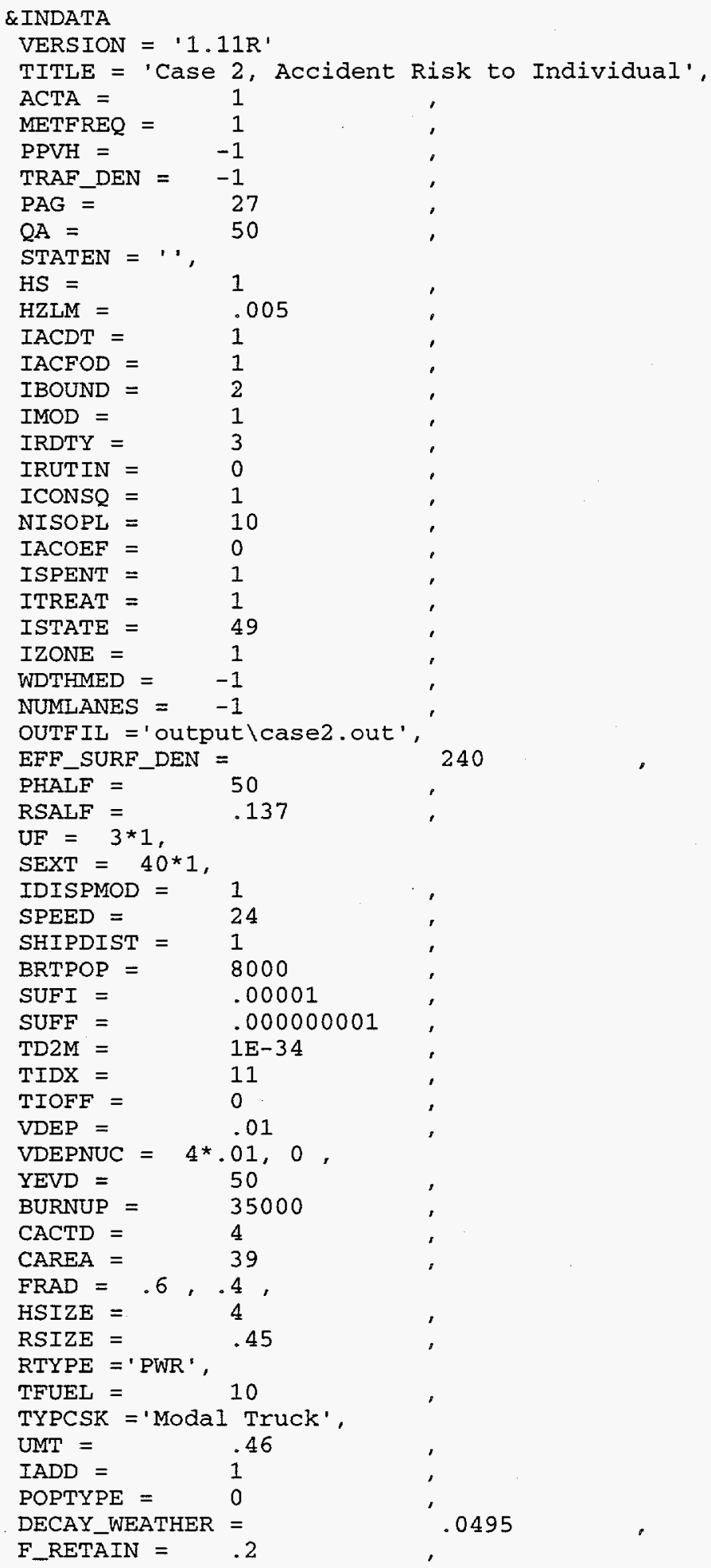




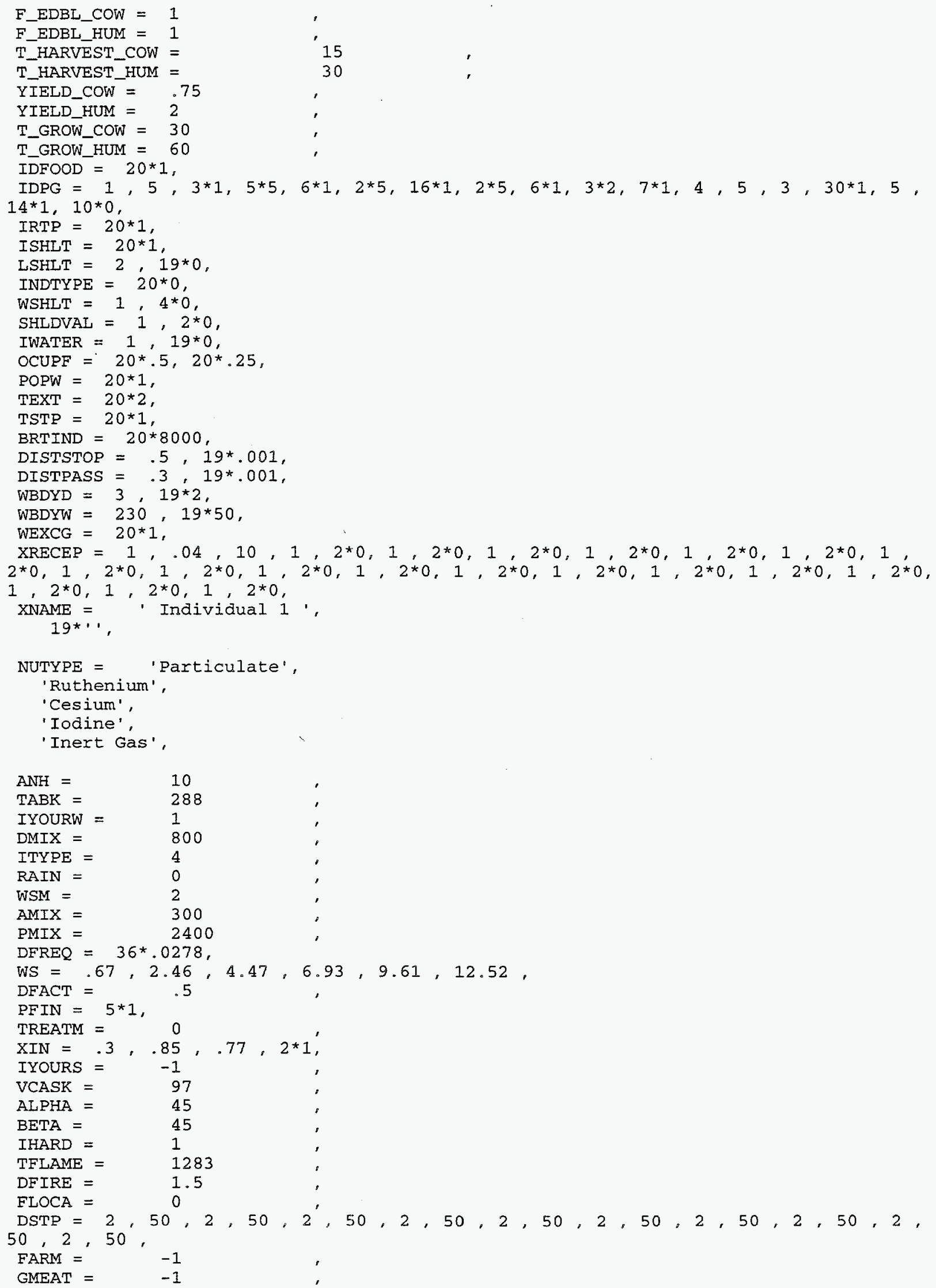




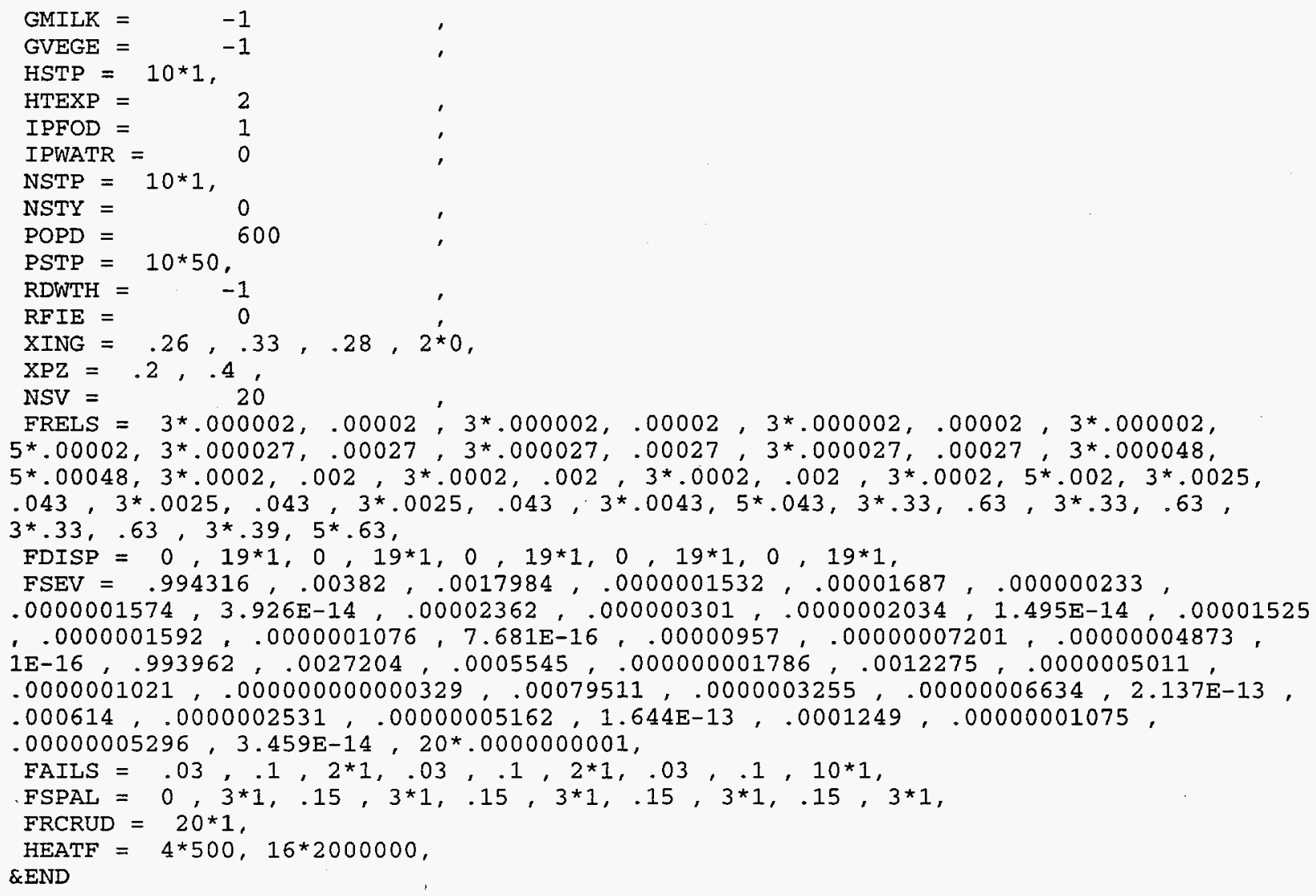




\section{A.2.2 Case 2 Output File}

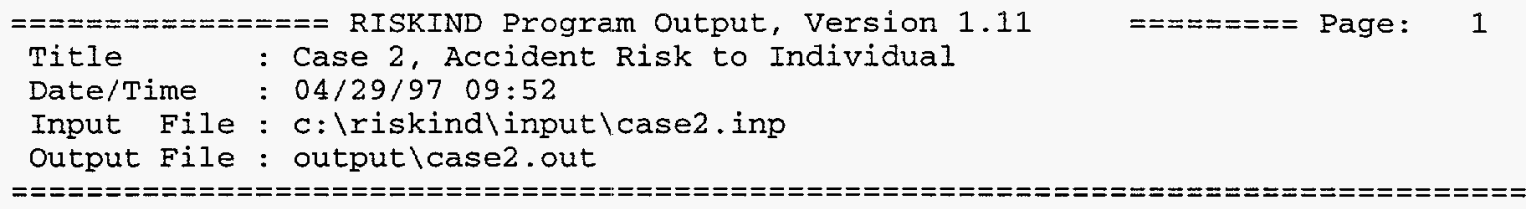

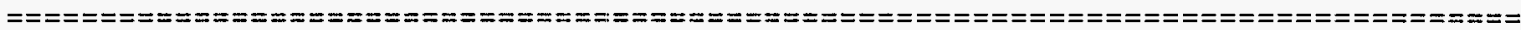

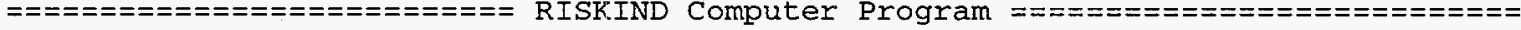

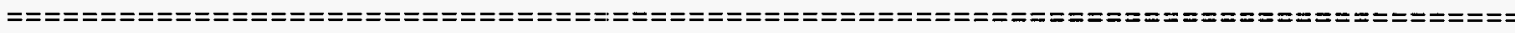

Problem Description

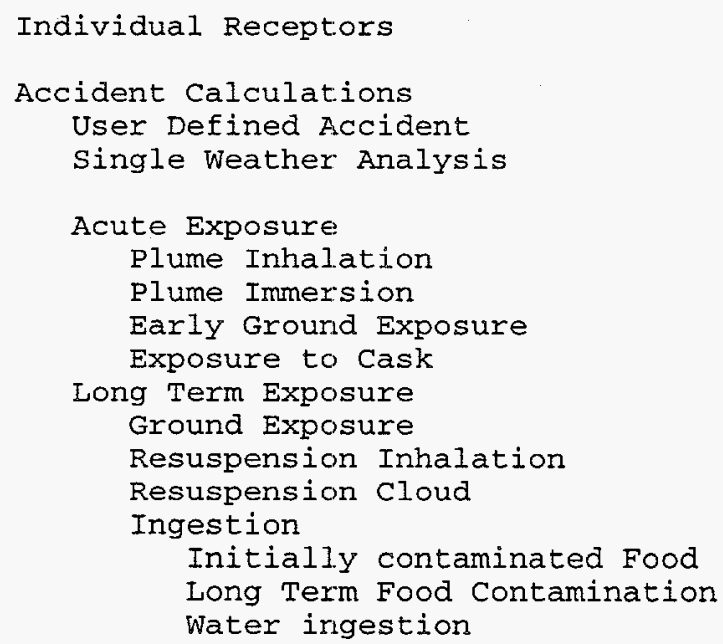

Note: * next to input description signifies

a data dependent default value 
Title : Case 2, Accident Risk to Individual

Date/Time : 04/29/97 09:52

Input File : c:\riskind \input\case2.inp

Output File : outputicase2.out

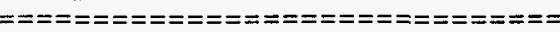

Input Parameters

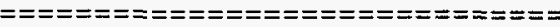

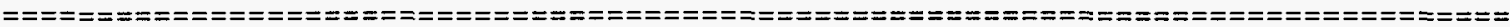

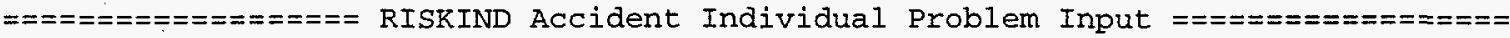

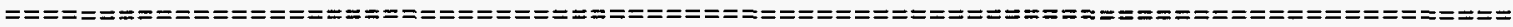

Individual Accident Parameters

State: US

Population Zone: Rural

Long-Term Exposure Duration [YEVD]: 5.00E+01

yr

Average Breathing Rate [BRTIND]: $8.00 \mathrm{E}+03 \mathrm{~m} 3 / \mathrm{yr}$ Individual type [INDTYPE] : Worker

Risk Conversion Factors

Non-Fatal Cancers/rem: 8.0E-05

Fatal Cancers/rem: 4.0E-04

Genetic Effects/rem: 8.0E-05

\begin{tabular}{|c|c|c|c|c|c|c|}
\hline $\begin{array}{l}\text { Individual Name } \\
\text { [XNAME] }\end{array}$ & $\begin{array}{c}====== \\
\text { Down } \\
\text { Wind } \\
{[\mathrm{km}]}\end{array}$ & $\begin{array}{c}\text { Location } \\
\text { Cross } \\
\text { wind } \\
\text { [km] } \\
\text { [XRECEP] }\end{array}$ & $\begin{array}{c}===== \\
\text { Elevation } \\
\text { [m] }\end{array}$ & $\begin{array}{c}\text { Acute } \\
\text { Exposure } \\
\text { Time } \\
\text { [hr] } \\
\text { [TEXT] }\end{array}$ & $\begin{array}{l}\text { Long Term } \\
\text { Exposure } \\
\text { [IRTP] }\end{array}$ & $\begin{array}{l}\text { Food } \\
\text { Ingestion } \\
\text { [IDFOOD] }\end{array}$ \\
\hline Individual 1 & $1.00 \mathrm{E}+00$ & $4.00 \mathrm{E}-02$ & $1.00 \mathrm{E}+01$ & $2.00 \mathrm{E}+00$ & Yes & Yes \\
\hline
\end{tabular}

\begin{tabular}{|c|c|c|c|c|c|c|c|c|c|c|}
\hline \multirow[b]{2}{*}{ Individual } & \multicolumn{2}{|c|}{$\begin{array}{l}\text { Shielding } \\
\text { Type }\end{array}$} & \multicolumn{2}{|c|}{$\begin{array}{l}\text { Long- } \\
\text { Term }\end{array}$} & \multicolumn{6}{|c|}{$\begin{array}{c}====\begin{array}{c}\text { Shielding Factors }==== \\
\text { Acute: }\end{array} \text { Long-Term: }\end{array}$} \\
\hline & Short & Long & In & out & Inh & cld & Ext & Inh & cld & Ext \\
\hline Individual 1 & Trame & $c k$ & 0.50 & 0.25 & 1.00 & 0.90 & 0.40 & 0.75 & 0.55 & 0.35 \\
\hline
\end{tabular}

Ingestion Parameters

\begin{tabular}{ccc}
\hline & $\begin{array}{c}\text { Individual } \\
\text { Consumption Rate } \\
{[\mathrm{kg} / \mathrm{d}]}\end{array}$ & $\begin{array}{c}\text { Contaminated } \\
\text { Fraction }\end{array}$ \\
\hline Food Type & {$[\mathrm{XIN}]$} & {$[\mathrm{PFIN}]$} \\
Meat & $3.00 \mathrm{E}-01$ & $1.00 \mathrm{E}+00$ \\
Milk & $8.50 \mathrm{E}-01$ & $1.00 \mathrm{E}+00$ \\
Vegetable & $7.70 \mathrm{E}-01$ & $1.00 \mathrm{E}+00$ \\
Water & $1.00 \mathrm{E}+00$ & $1.00 \mathrm{E}+00$ \\
\hline
\end{tabular}




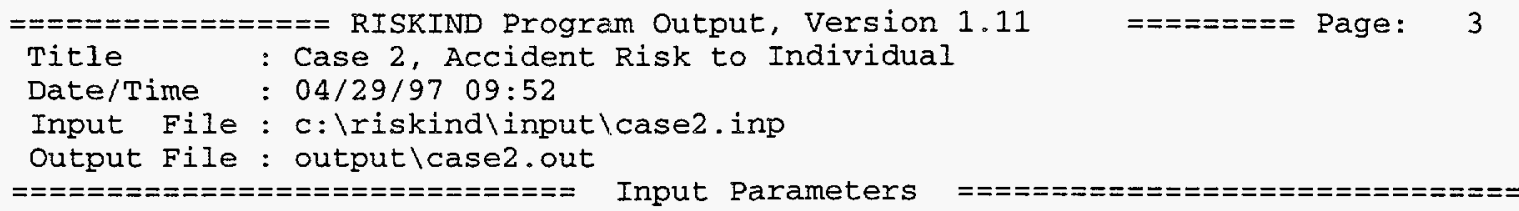

Meteorological Parameters

Dry deposition rates [VDEPNUC]

Particulates

Ruthenium

Cesium

Iodine

Gases

Rain fall rate [RAIN]

Anemometer height [ANH] :

Ambient Temperature [TABK] :

Mixing height [DMIX]:

wind at anemometer [WSM] :

Pasquill stability cat. [ITYPE] :
: $1.00 \mathrm{E}-02$

$: 1.00 \mathrm{E}-02$

$1.00 E-02$

$1.00 E-02$

$0.00 E+00$

$0.00 E+00$

10.00

288.00

800.00

2.00

D
$\mathrm{m} / \mathrm{s}$
$\mathrm{m} / \mathrm{s}$
$\mathrm{m} / \mathrm{s}$
$\mathrm{m} / \mathrm{s}$
$\mathrm{m} / \mathrm{s}$
$\mathrm{mm} / \mathrm{h}$
m
$\mathrm{m}$
$\mathrm{m} / \mathrm{s}$

Transportation Mode [IMOD] : Dose at $1 \mathrm{~m}$ [TIDX] : Measurement offset [TIOFF] : Gamma Fraction [FRAD(1)]: Neutron Fraction [FRAD(2)]: Cask Length [HSIZE]: Cask Raclius [RSIZE] : Amount of Uranium [UMT]: Reactor TYPe [RTYPE]: Reactor Burnup [BURNUP]: Fuel cooling T'ime [TFUEL]: Total Surface Area of Cask [CAREA]: Crud Surface Activity Density [CACTD]:
Truck

11.00

0.00

0.60

0.40

4.00

0.45

0.46

PWR

3. $50 \mathrm{E}+04$

10.00

39.00

4.00 $\mathrm{mrem} / \mathrm{hr}$

m

$\mathrm{m}$

MTU

MWD

Yr

$\mathrm{uCi} / \mathrm{cm} 2$ 


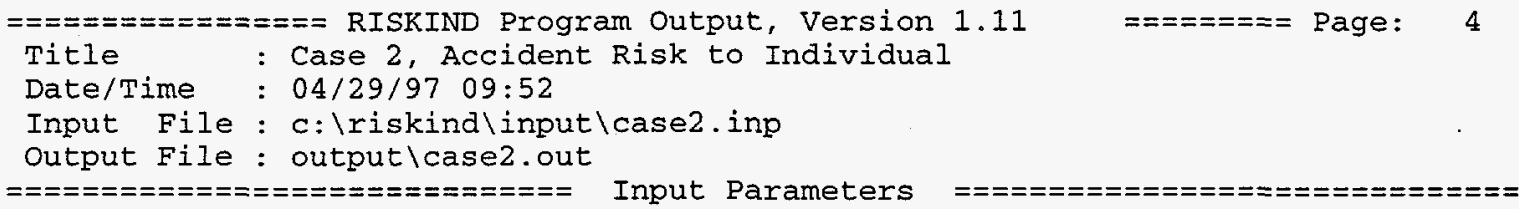

Long-Term Environmental Parameters

$\begin{array}{lrr}\text { Removal half-life from soil [PHALF] : } & 50.00 & \mathrm{yr} \\ \text { Initial resuspension factor [SUFI] : } 1.00 \mathrm{E}-05 & 1 / \mathrm{m} \\ \text { Final Resuspension factor [SUFF] : } 1.00 \mathrm{E}-09 & 1 / \mathrm{m} \\ \text { Resus. factor decay halflife [RSAL] : } 1.37 \mathrm{E}-01 & \mathrm{yr}\end{array}$

Water Pathway Parameters

Water Treatment Cleanup [TREATM]: 0.00

\begin{tabular}{|c|c|c|c|}
\hline $\begin{array}{c}\text { Individual } \\
\text { [XNAME] }\end{array}$ & $\begin{array}{r}\text { Water Bodies } \\
\text { Depth } \\
{[\mathrm{m}]} \\
{[\text { WBDYD }]}\end{array}$ & $\begin{array}{l}\text { Water Body } \\
\text { Width } \\
\text { [m] } \\
\text { [WBDYw] }\end{array}$ & $\begin{array}{c}\text { Exhange Rate } \\
\text { [1/Yr] } \\
\text { [WEXCG] }\end{array}$ \\
\hline Individual 1 & $3.00 \mathrm{E}+00$ & $2.30 E+02$ & $1.00 \mathrm{E}+00$ \\
\hline
\end{tabular}

Food Production Parameters

\begin{tabular}{|c|c|c|}
\hline Food decontamination factor [DF & 0.50 & \\
\hline Cow's ingestion rate of grass $[\mathrm{QA}]$ : & 50.00 & $\mathrm{~kg} / \mathrm{d}$ \\
\hline Yield of pasture grass [YIELD_COW] : & $7.50 \mathrm{E}-01$ & $\mathrm{~kg} / \mathrm{m} 2$ \\
\hline $\begin{array}{c}\text { Yield of edible vegetation [YIELD_HUM] : } \\
\text { Time to first harvest }\end{array}$ & $2.00 E+00$ & $\mathrm{~kg} / \mathrm{m} 2$ \\
\hline Pasture grass [T_HARVEST_COW] : & 15.00 & da \\
\hline Vegetation [T_HARVEST_HUM] : & 30 & day \\
\hline Pasture grass grow time [T_GROW_COW] & 30.00 & day \\
\hline Vegetation grow time [T_GROW_HUM] & 60.00 & days \\
\hline Deposition retention fraction [F_RETAIN] & 0.20 & \\
\hline Edible vegetation fraction [F_EDBL_HUM] & 1.00 & \\
\hline Edible pasture fraction [F_EDBL_COW] : & 1.00 & \\
\hline Weathering decay const. [DECAY_WEATHER] & $4.95 E-02$ & $1 /$ \\
\hline Effective Surface Density [EFF_SURF_DEN] & 240.00 & $\mathrm{~kg} / \mathrm{m} 2$ \\
\hline
\end{tabular}




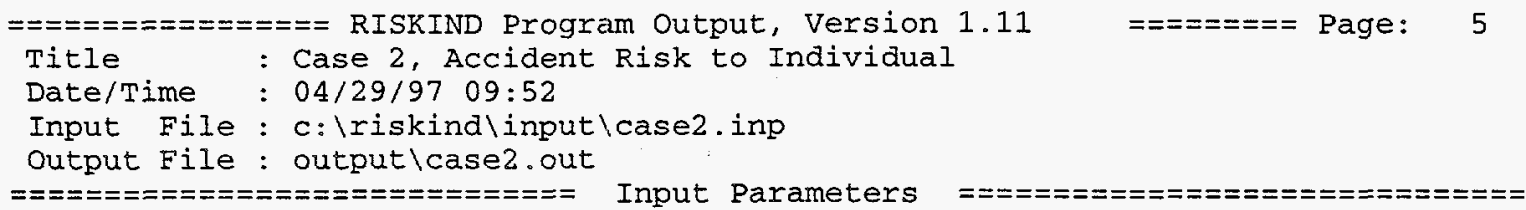

Nuclide Parameters

\begin{tabular}{|c|c|c|c|c|c|c|c|}
\hline \multirow[b]{2}{*}{$\begin{array}{l}\text { Nuclide } \\
\text { Name }\end{array}$} & \multicolumn{7}{|c|}{ Nuclide Inventory and DCFs } \\
\hline & $\begin{array}{c}\text { Inventory } \\
\text { Amount } \\
\text { [Ci] }\end{array}$ & $\begin{array}{c}======\text { Do } \\
\text { Inhalation } \\
{[\mathrm{Sv} / \mathrm{Bq}]}\end{array}$ & $\begin{array}{l}\text { ose Convers } \\
\text { Ingestion } \\
{[\mathrm{Sv} / \mathrm{Bq}]}\end{array}$ & $\begin{array}{c}\text { sion Fact } \\
\text { Cloud } \\
{[\mathrm{Sv} / \mathrm{s}]} \\
{[\mathrm{Bg} / \mathrm{m} 3]}\end{array}$ & $\begin{array}{c}\text { rs }===== \\
\text { Ground } \\
{[\mathrm{Sv} / \mathrm{s}]} \\
{[\mathrm{Bg} / \mathrm{m} 2]}\end{array}$ & $\begin{array}{l}\text { Nucl. } \\
\text { Class }\end{array}$ & $\begin{array}{l}\text { Decay } \\
\text { Const. } \\
{[1 / y r]}\end{array}$ \\
\hline H 3 & $2.17 E+02$ & $1.73 \mathrm{E}-11$ & $1.73 \mathrm{E}-11$ & $0.00 \mathrm{E}+00$ & $0.00 \mathrm{E}+00$ & Particul & $5.60 \mathrm{E}-02$ \\
\hline FE 55 & 1. $07 E+02$ & $7.26 \mathrm{E}-10$ & 1. $64 \mathrm{E}-10$ & $0.00 E+00$ & $0.00 E+00$ & Particul & $2.60 \mathrm{E}-01$ \\
\hline $\mathrm{CO} 60$ & $1.10 \mathrm{E}+03$ & $5.91 E-08$ & $7.28 E-09$ & $1.26 E-13$ & $2.35 E-15$ & Particul & $1.30 \mathrm{E}-01$ \\
\hline NI 63 & $1.88 \mathrm{E}+02$ & $1.70 E-09$ & $1.56 \mathrm{E}-10$ & $0.00 \mathrm{E}+00$ & $0.00 E+00$ & Particul & $6.90 E-03$ \\
\hline $\mathrm{KR} 85$ & $2.33 E+03$ & 1. $03 E-11$ & $1.03 E-11$ & $1.19 \mathrm{E}-16$ & $2.64 \mathrm{E}-18$ & Inert $\mathbf{G a}$ & $6.50 E-02$ \\
\hline SR 90 & $2.77 E+04$ & $3.53 E-07$ & $4.14 E-08$ & $1.97 \mathrm{E}-16$ & $5.61 \mathrm{E}-18$ & Particul & $2.40 E-02$ \\
\hline Y 90 & $2.77 E+04$ & $2.28 \mathrm{E}-09$ & $2.91 \mathrm{E}-09$ & $1.90 \mathrm{E}-16$ & $5.33 E-18$ & Particul & $9.50 E+01$ \\
\hline RU106 & $2.44 E+02$ & $1.30 E-07$ & $8.30 E-09$ & 1. $04 \mathrm{E}-14$ & $2.12 E-16$ & Rutheniu & $6.90 E-01$ \\
\hline RH106 & $2.44 E+02$ & $8.95 E-10$ & $8.95 E-10$ & $1.04 \mathrm{E}-14$ & $2.12 E-16$ & Rutheniu & $7.30 E+05$ \\
\hline SB125 & $6.01 E+02$ & $3.75 E-09$ & $9.85 E-10$ & $2.02 \mathrm{E}-14$ & $4.33 E-16$ & Particul & $2.50 \mathrm{E}-01$ \\
\hline TE125M & 1. $47 \mathrm{E}+02$ & $1.97 \mathrm{E}-09$ & $9.92 \mathrm{E}-10$ & $4.53 E-16$ & $3.61 \mathrm{E}-17$ & Particul & $4.40 E+00$ \\
\hline $\operatorname{CS} 134$ & $2.76 E+03$ & $1.25 E-08$ & 1. $98 E-08$ & $7.56 \mathrm{E}-14$ & $1.52 \mathrm{E}-15$ & Cesium & $3.40 E-01$ \\
\hline $\operatorname{cs} 137$ & $3.98 E+04$ & $1.10 E-08$ & $1.59 E-08$ & $2.73 E-14$ & $5.54 \mathrm{E}-16$ & Cesium & $2.30 \mathrm{E}-02$ \\
\hline BA137M & $3.76 E+04$ & $2.49 E-09$ & $2.49 E-09$ & $2.88 E-14$ & $5.86 E-16$ & Particul & 1. $40 E+05$ \\
\hline CE144 & $6.45 E+01$ & $1.01 E-07$ & $5.71 E-09$ & $2.80 \mathrm{E}-15$ & $5.83 E-17$ & Particul & $8.90 E-01$ \\
\hline PR144 & $6.45 E+01$ & $1.17 \mathrm{E}-11$ & 3. $15 E-11$ & $1.94 \mathrm{E}-15$ & $3.79 E-17$ & Particul & $2.10 E+04$ \\
\hline PM147 & $4.21 E+03$ & $1.06 \mathrm{E}-08$ & $2.83 E-10$ & $6.92 \mathrm{E}-19$ & 3. $40 E-20$ & Particul & $2.60 \mathrm{E}-01$ \\
\hline SM151 & $1.81 E+02$ & $8.10 E-09$ & 1. $05 E-10$ & $3.61 E-20$ & $5.02 E-21$ & Particul & $7.70 \mathrm{E}-03$ \\
\hline EU154 & $2.09 E+03$ & $7.73 E-08$ & $2.58 E-09$ & $6.14 \mathrm{E}-14$ & $1.18 \mathrm{E}-15$ & Particul & $7.90 \mathrm{E}-02$ \\
\hline EU155 & $7.69 E+02$ & $1.12 \mathrm{E}-08$ & $4.13 E-10$ & $2.49 E-15$ & $5.90 E-17$ & Particul & 1. $40 E-01$ \\
\hline PU238 & 1. $42 \mathrm{E}+03$ & $1.06 \mathrm{E}-04$ & $8.65 E-07$ & $4.87 E-18$ & $8.37 E-19$ & Particul & $7.90 E-03$ \\
\hline PU239 & $1.65 E+02$ & $1.16 \mathrm{E}-04$ & $9.56 \mathrm{E}-07$ & $4.24 E-18$ & $3.67 E-19$ & Particul & $2.90 E-05$ \\
\hline PU240 & $2.37 E+02$ & $1.16 \mathrm{E}-04$ & $9.56 \mathrm{E}-07$ & $4.75 E-18$ & $8.02 \mathrm{E}-19$ & Particul & $1.10 E-04$ \\
\hline PU241 & $3.88 E+04$ & $2.23 E-06$ & $1.85 \mathrm{E}-08$ & $2.19 E-19$ & $5.20 E-21$ & Particul & $4.80 E-02$ \\
\hline AM2 41 & $8.66 \mathrm{E}+02$ & $1.20 \mathrm{E}-04$ & $9.84 \mathrm{E}-07$ & $8.18 E-16$ & $2.74 \mathrm{E}-17$ & Particul & $1.60 E-03$ \\
\hline CM244 & $8.95 \mathrm{E}+02$ & $6.70 E-05$ & $5.45 \mathrm{E}-07$ & $4.91 \mathrm{E}-18$ & $8.78 E-19$ & Particul & $3.80 E-02$ \\
\hline
\end{tabular}




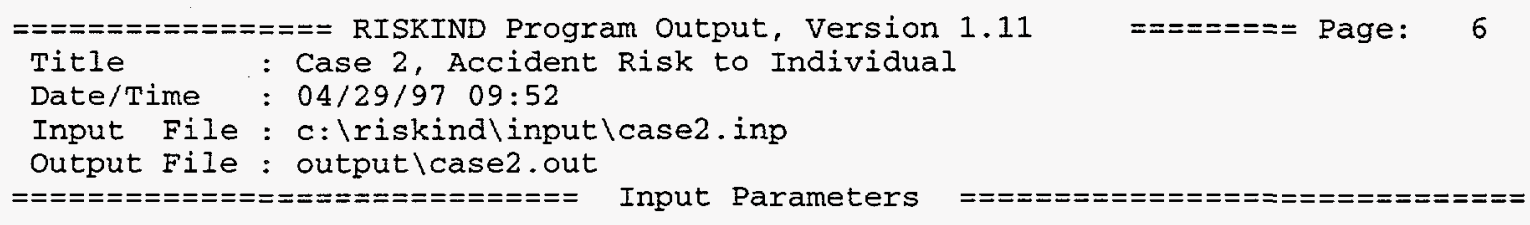

\begin{tabular}{|c|c|c|c|}
\hline \multicolumn{4}{|c|}{ Nuclide Food Transfer Parameters } \\
\hline $\begin{array}{l}\text { Nuclide } \\
\text { Name }\end{array}$ & $\begin{array}{l}\text { Soil-to-Plant } \\
\text { [unitless] }\end{array}$ & $\begin{array}{c}\text { Grass-to-Meat } \\
{[\text { day } / \mathrm{kg}]}\end{array}$ & $\begin{array}{c}\text { Grass-to-Milk } \\
{[\mathrm{day} / \mathrm{L}]}\end{array}$ \\
\hline $\mathrm{H} 3$ & $4.80 \mathrm{E}+00$ & $1.20 \mathrm{E}-02$ & $1.00 E-02$ \\
\hline FE 55 & $6.60 \mathrm{E}-04$ & $4.00 \mathrm{E}-02$ & $1.20 E-03$ \\
\hline $\mathrm{CO} 60$ & $9.40 E-03$ & $1.30 \mathrm{E}-02$ & $1.00 E-03$ \\
\hline NI 63 & $1.90 E-02$ & $5.30 E-03$ & $6.70 E-03$ \\
\hline $\mathrm{KR} \quad 85$ & $3.00 E+00$ & $2.00 \mathrm{E}-02$ & $2.00 E-02$ \\
\hline SR 90 & $1.70 \mathrm{E}-02$ & $6.00 \mathrm{E}-04$ & $8.00 E-04$ \\
\hline Y 90 & $2.60 \mathrm{E}-03$ & $4.60 \mathrm{E}-03$ & 1. $00 \mathrm{E}-05$ \\
\hline RU106 & $5.00 E-02$ & $4.00 E-01$ & $1.00 \mathrm{E}-06$ \\
\hline RH106 & 1. $30 E+01$ & $1.50 \mathrm{E}-03$ & 1. $00 \mathrm{E}-02$ \\
\hline SBI25 & 1. $10 E-02$ & $4.00 E-03$ & $1.50 E-03$ \\
\hline TE125M & 1. $30 \mathrm{E}+00$ & $7.70 \mathrm{E}-02$ & $1.00 E-03$ \\
\hline $\operatorname{CS} 134$ & 1. $00 \mathrm{E}-02$ & $4.00 E-03$ & 1.20E-02 \\
\hline $\operatorname{cs} 137$ & 1. $00 \mathrm{E}-02$ & $4.00 E-03$ & 1.20E-02 \\
\hline $\mathrm{BA} 137 \mathrm{M}$ & $5.00 E-03$ & $3.20 E-03$ & $4.00 E-04$ \\
\hline CE144 & $2.50 \mathrm{E}-03$ & 1. $20 \mathrm{E}-03$ & $6.00 \mathrm{E}-04$ \\
\hline PR144 & $2.50 \mathrm{E}-03$ & $4.70 \mathrm{E}-03$ & $5.00 E-06$ \\
\hline PM147 & $2.50 \mathrm{E}-03$ & $4.80 \mathrm{E}-03$ & $5.00 E-06$ \\
\hline SM151 & $2.50 E-03$ & $5.00 E-03$ & $5.00 E-06$ \\
\hline EU154 & $2.50 E-03$ & $4.80 E-03$ & $5.00 \mathrm{E}-06$ \\
\hline EU155 & $2.50 E-03$ & $4.80 E-03$ & $5.00 E-06$ \\
\hline PU238 & $2.50 E-04$ & 1. $40 E-05$ & $2.00 E-06$ \\
\hline PU239 & $2.50 E-04$ & $1.40 \mathrm{E}-05$ & $2.00 E-06$ \\
\hline PU2 40 & $2.50 \mathrm{E}-04$ & 1. $40 \mathrm{E}-05$ & $2.00 E-06$ \\
\hline PU241 & $2.50 E-04$ & 1. $40 \mathrm{E}-05$ & $2.00 E-06$ \\
\hline AM241 & $2.50 E-04$ & $2.00 E-04$ & $5.00 E-06$ \\
\hline CM244 & $2.50 E-03$ & $2.00 E-04$ & $5.00 E-06$ \\
\hline
\end{tabular}


$=================$ RISKIND Program Output, Version 1.11

Title : Case 2, Accident Risk to Individual

Date/Time : 04/29/97 09:52

Input File: c: \riskind

Output File: outputlcase2. out

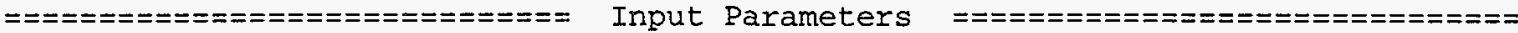

\begin{tabular}{|c|c|c|c|c|c|c|c|}
\hline \multirow{2}{*}{$\begin{array}{l}\text { Nuclide } \\
\text { Name }\end{array}$} & \multicolumn{7}{|c|}{ 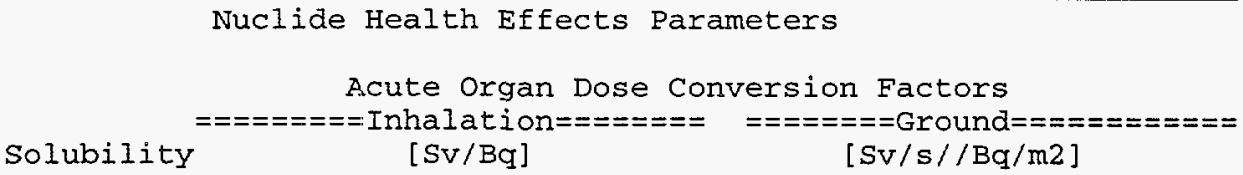 } \\
\hline & Class & Marrow & Lung & Intestine & Marrow & Lung & Intestine \\
\hline H 3 & $D$ & $1.62 E-11$ & $1.62 E-11$ & $1.62 \mathrm{E}-11$ & $0.00 E+00$ & $0.00 E+00$ & $0.00 E+00$ \\
\hline FE 55 & W & 1. $65 \mathrm{E}-10$ & $1.76 \mathrm{E}-10$ & 1. $92 \mathrm{E}-10$ & $0.00 E+00$ & $0.00 \mathrm{E}+00$ & $1.89 E-19$ \\
\hline CO 60 & $Y$ & $6.22 E-09$ & $1.24 \mathrm{E}-07$ & $5.95 E-09$ & $2.34 E-15$ & $2.27 E-15$ & $1.94 E-15$ \\
\hline NI 63 & $Y$ & 1. $05 \mathrm{E}-12$ & $5.95 E-12$ & $9 E-13$ & $0.00 E+00$ & $0.00 E+00$ & $0.00 \mathrm{E}+00$ \\
\hline KR 85 & $D$ & $0.00 \mathrm{E}+00$ & $0.00 E+00$ & $0.00 E+00$ & $2.43 E-18$ & $2.45 E-18$ & $1.97 E-18$ \\
\hline SR 90 & $Y$ & 1. $08 \mathrm{E}-09$ & $7.03 E-07$ & $1.70 E-08$ & $7 E-18$ & -18 & $E+00$ \\
\hline Y 90 & $Y$ & $1.51 E-11$ & $9.19 E-09$ & $1.27 E-08$ & $4.57 E-18$ & $4.76 E-18$ & $0 E+00$ \\
\hline RU106 & $Y$ & 1. $05 E-09$ & $6.76 E-07$ & $3.51 E-08$ & $2.06 E-16$ & $2.03 E-16$ & $E-16$ \\
\hline RH106 & $Y$ & $2.58 E-10$ & $2.58 E-10$ & 1.14E-09 & $2.06 \mathrm{E}-16$ & $2.03 E-16$ & -16 \\
\hline SB125 & W & $2.41 \mathrm{E}-14$ & $7.30 \mathrm{E}-11$ & $3.24 \mathrm{E}-12$ & $4.05 \mathrm{E}-16$ & $4.03 E-16$ & $3.79 \Xi-16$ \\
\hline TE125M & W & $5.14 E-14$ & $1.05 \mathrm{E}-11$ & $2.38 E-12$ & $1.37 \mathrm{E}-17$ & $1.77 \mathrm{E}-17$ & $1.78 \mathrm{E}-17$ \\
\hline $\operatorname{CS} 134$ & $\mathrm{D}$ & $1.08 E-08$ & $1.08 \mathrm{E}-08$ & $1.27 E-08$ & $1.48 E-15$ & $1.46 \mathrm{E}-15$ & $1.34 \mathrm{E}-15$ \\
\hline CS137 & D & $7.57 \mathrm{E}-09$ & $8.11 E-09$ & $8.11 \mathrm{E}-09$ & $5.39 E-16$ & $5.30 \mathrm{E}-16$ & $4.93 \mathrm{E}-16$ \\
\hline BA137M & $\mathrm{D}$ & $2.73 E-11$ & $2.73 E-11$ & $0.00 E+00$ & $5.70 \mathrm{E}-16$ & $5.60 \mathrm{E}-16$ & $5.22 E-16$ \\
\hline CEI44 & $Y$ & $1.08 \mathrm{E}-09$ & $5.68 \mathrm{E}-07$ & $3.24 E-08$ & $5.31 \mathrm{E}-17$ & $5.43 E-17$ & $1.83 E-17$ \\
\hline PR144 & $Y$ & $1.92 \mathrm{E}-14$ & $9.46 \mathrm{E}-11$ & $2.16 \mathrm{E}-14$ & $3.66 \mathrm{E}-17$ & $3.61 \mathrm{E}-17$ & $2.54 E-17$ \\
\hline PM147 & $Y$ & $1.41 \mathrm{E}-10$ & $3.51 \mathrm{E}-08$ & $1.62 \mathrm{E}-09$ & $1.86 \mathrm{E}-20$ & $2.20 \mathrm{E}-20$ & $3.48 \mathrm{E}-21$ \\
\hline SM151 & $\mathrm{Y}$ & $3.78 E-12$ & $1.19 \mathrm{E}-11$ & $8.65 \mathrm{E}-13$ & $1.39 \mathrm{E}-21$ & $1.01 \mathrm{E}-21$ & $4.45 \mathrm{E}-21$ \\
\hline EU154 & $\mathrm{Y}$ & $2.46 \mathrm{E}-11$ & 1. $57 \mathrm{E}-10$ & $9.19 \mathrm{E}-12$ & $1.16 \mathrm{E}-15$ & $1.14 \mathrm{E}-15$ & $1.03 E-15$ \\
\hline EU155 & $\mathrm{Y}$ & $3.78 \mathrm{E}-12$ & $2.54 \mathrm{E}-11$ & $1.59 \mathrm{E}-12$ & $4.71 \mathrm{E}-17$ & $5.34 \mathrm{E}-17$ & $6.05 E-17$ \\
\hline PU238 & $Y$ & $2.97 E-07$ & $7.03 E-05$ & $2.97 \mathrm{E}-08$ & $1.94 \mathrm{E}-19$ & $7.87 E-20$ & $7.35 E-19$ \\
\hline PU239 & $Y$ & $2.70 \mathrm{E}-07$ & $6.76 \mathrm{E}-05$ & $2.70 \mathrm{E}-08$ & $1.19 \mathrm{E}-19$ & $7.87 E-20$ & $3.24 E-19$ \\
\hline PU240 & $\mathrm{Y}$ & $2.70 E-07$ & $6.76 E-05$ & $2.70 \mathrm{E}-08$ & $1.88 \mathrm{E}-19$ & $7.81 E-20$ & $7.02 E-19$ \\
\hline PU241 & $Y$ & $2.97 \mathrm{E}-10$ & $5.68 E-08$ & $1.41 \mathrm{E}-10$ & $4.18 \mathrm{E}-21$ & $4.36 E-21$ & $0.00 \mathrm{E}+00$ \\
\hline AM2 41 & W & $4.32 E-06$ & $1.81 E-05$ & $2.97 \mathrm{E}-08$ & $1.68 \mathrm{E}-17$ & $2.00 \mathrm{E}-17$ & $2.52 \mathrm{E}-17$ \\
\hline CM244 & $w$ & $4.59 E-06$ & $1.92 \mathrm{E}-05$ & $3.24 \mathrm{E}-08$ & $2.04 E-19$ & $9.00 E-20$ & $7.10 E-19$ \\
\hline
\end{tabular}




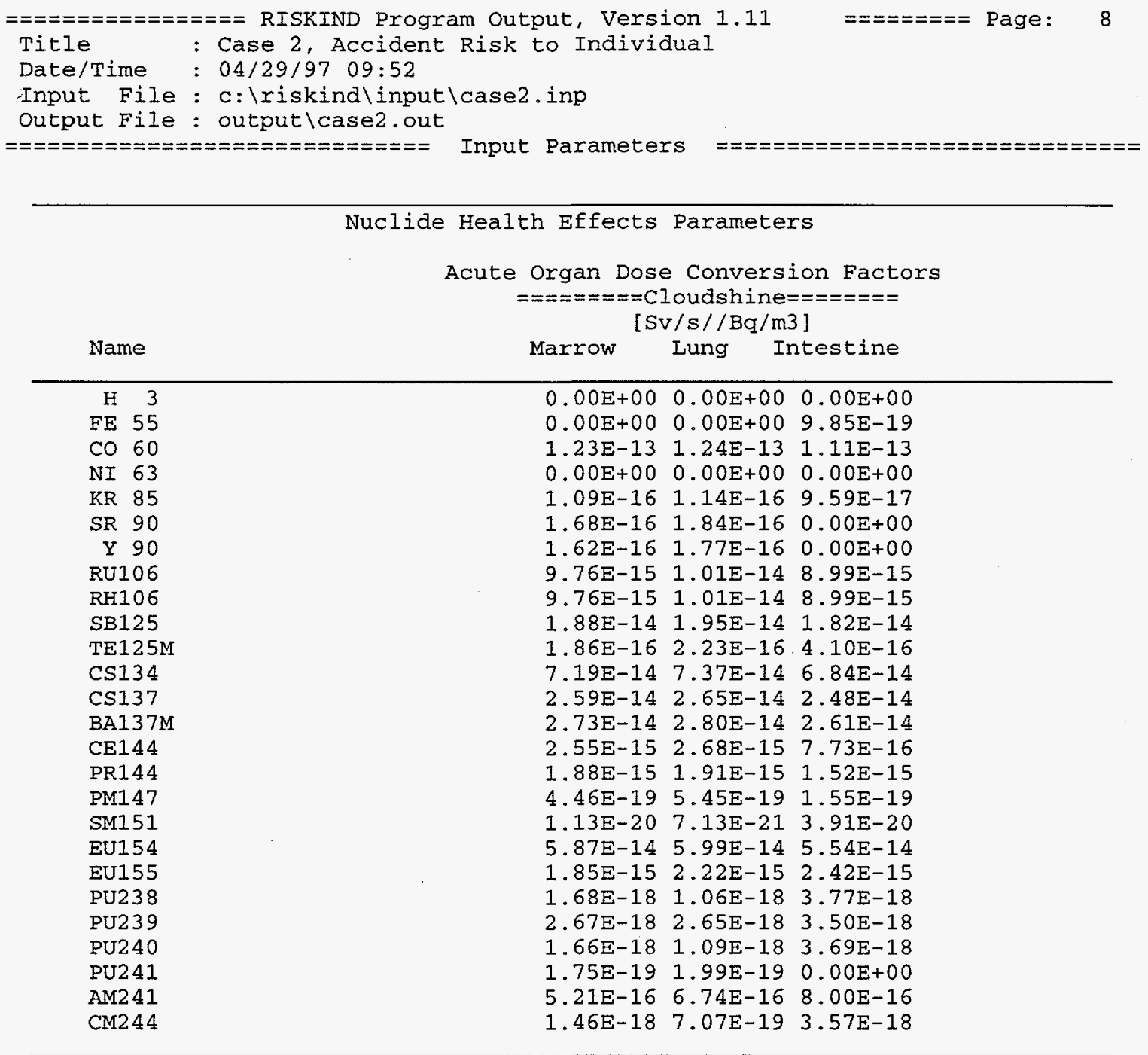




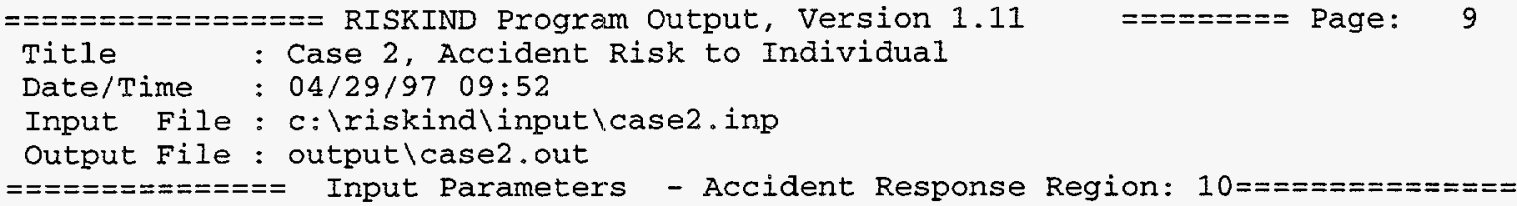

Accident Parameters

Physical Release Height [HS]:

$$
1.00 \mathrm{~m}
$$

Dispersion Model Coefficients [IDISPMOD] : Pasquill-Gifford

Accident Analysis Type: Consequence

Accident Response Region Determined By

Accident Cask Velocity [VCASK] : Cask Impact Angle [ALPHA] :

Cask orientation Angle [BETA]: Impact object Hardriess [IHARD] :

Flame Temperature [TFLAME]: Fire Duration [DFIRE] : Fire Location [FLOCA] :

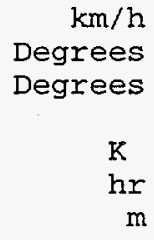

$\mathrm{km} / \mathrm{h}$

45.00

1.00

0.00

$\mathrm{K}$

$\mathrm{m}$

Accident Response Region Parameters

Response Regjon [IYOURS]: 10 Region Conditional Probabjlity [FSEV]: 3.01E-07 Heat Flux [HEATF] : 2.00E+06 Loss of Cask Shielding Factor [SEXT]

Gamma: $\quad 1.00$

Neutron: $\quad 1.00$

Failure Rate [FAILS] : 1.00E-01

Crud Spallation Rate [FSPAL]: 1.00E+00

Crud Release Rate [FRCRUD]: 1.00E+00

\begin{tabular}{lccc}
\hline $\begin{array}{c}\text { Nuclide } \\
\text { Class } \\
\text { [NUTYPE] }\end{array}$ & $\begin{array}{c}\text { Conditional } \\
\text { Release } \\
\text { Fraction } \\
\text { [FRELS] }\end{array}$ & $\begin{array}{c}\text { Dispersion } \\
\text { Fraction } \\
\text { [FDISP] }\end{array}$ & $\begin{array}{c}\text { Released and Dispersed } \\
\text { Fraction } \\
\text { (FRELS*FAILS*FDISP) }\end{array}$ \\
\hline Particulate & $2.00 \mathrm{E}-06$ & $1.00 \mathrm{E}+00$ & $2.00 \mathrm{E}-07$ \\
Ruthenium & $2.70 \mathrm{E}-05$ & $1.00 \mathrm{E}+00$ & $2.70 \mathrm{E}-06$ \\
Cesium & $2.00 \mathrm{E}-04$ & $1.00 \mathrm{E}+00$ & $2.00 \mathrm{E}-05$ \\
Iodine & $2.50 \mathrm{E}-03$ & $1.00 \mathrm{E}+00$ & $2.50 \mathrm{E}-04$ \\
Inert Gas & $3.30 \mathrm{E}-01$ & $1.00 \mathrm{E}+00$ & $3.30 \mathrm{E}-02$ \\
\hline
\end{tabular}




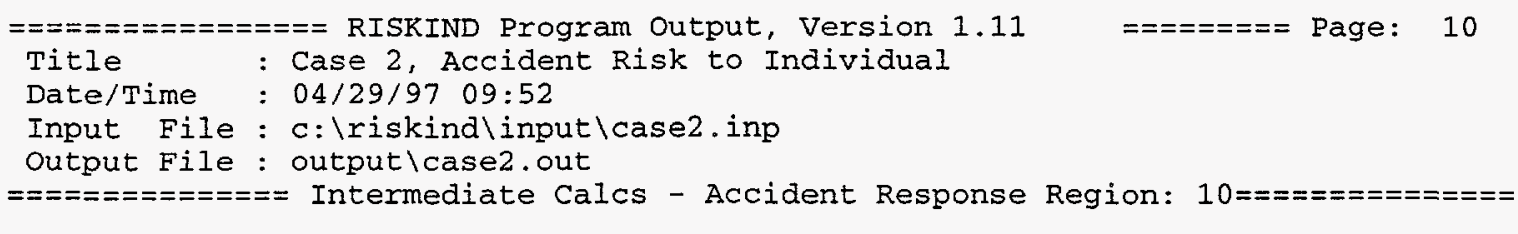

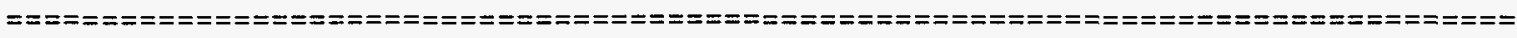

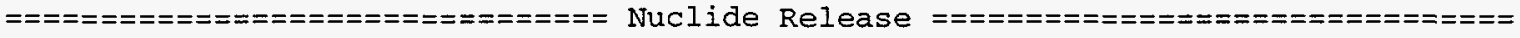

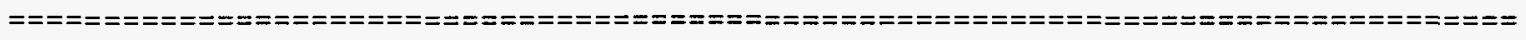

\begin{tabular}{|c|c|c|c|c|}
\hline $\begin{array}{c}\begin{array}{c}\text { Nuclide } \\
\text { Name }\end{array} \\
\text { CO } 60\end{array}$ & $\begin{array}{c}\begin{array}{c}\text { Release } \\
\text { Amount } \\
\text { [Ci] }\end{array} \\
4.25 E-01\end{array}$ & \multicolumn{3}{|c|}{ 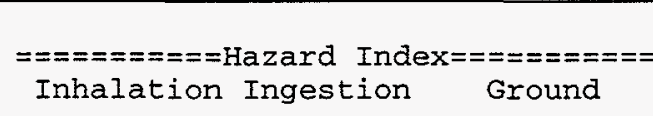 } \\
\hline $\begin{array}{l}\text { CO } 60 \\
\text { KR } 85 \\
\text { SR } 90 \\
\text { CS134 } \\
\text { CS137 } \\
\text { PU238 } \\
\text { PU239 } \\
\text { PU2 } 40 \\
\text { PU241 } \\
\text { AM2 } 41 \\
\text { CM2 } 44\end{array}$ & $\begin{array}{l}4.25 E-01 \\
7.70 E+01 \\
5.55 E-03 \\
5.52 E-02 \\
7.95 E-01 \\
2.83 E-04 \\
3.30 E-05 \\
4.73 E-05 \\
7.77 E-03 \\
1.73 E-04 \\
1.79 E-04\end{array}$ & $\begin{array}{l}1.99 E-01 \\
6.52 E-03 \\
1.54 E-02 \\
5.55 E-03 \\
6.94 E-02 \\
2.36 E-01 \\
3.01 E-02 \\
4.31 E-02 \\
1.36 E-01 \\
1.63 E-01 \\
9.42 E-02\end{array}$ & $\begin{array}{l}4.26 \mathrm{E}-02 \\
0.00 \mathrm{E}+00 \\
1.27 \mathrm{E}-02 \\
9.98 \mathrm{E}-03 \\
9.33 \mathrm{E}-01 \\
2.43 \mathrm{E}-04 \\
3.71 \mathrm{E}-05 \\
5.30 \mathrm{E}-05 \\
7.23 \mathrm{E}-05 \\
1.95 \mathrm{E}-04 \\
5.71 \mathrm{E}-04\end{array}$ & $\begin{array}{l}4.03 E-01 \\
0.00 E+00 \\
4.05 E-05 \\
1.37 E-02 \\
5.83 E-01 \\
4.19 E-07 \\
2.53 E-08 \\
7.92 E-08 \\
3.61 E-08 \\
9.59 E-06 \\
1.62 E-07\end{array}$ \\
\hline Total & $7.83 E+01$ & $9.99 \mathrm{E}-01$ & $9.99 \mathrm{E}-01$ & $1.00 \mathrm{E}+00$ \\
\hline
\end{tabular}

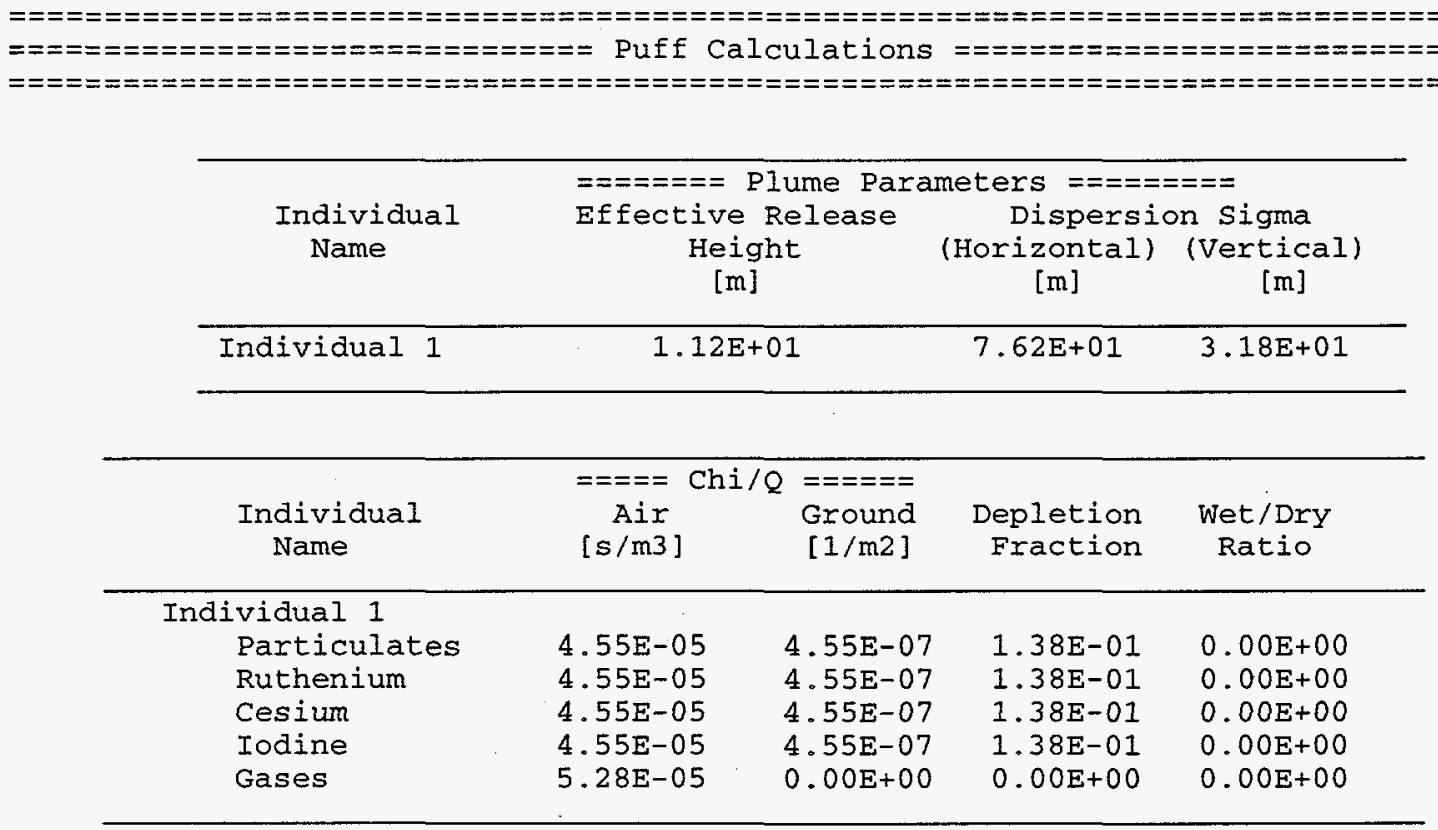


$================$ RISKIND Program Output, Version 1.11 : Case 2, Accident Risk to Individual

Date/Time

: 04/29/97 09:52

Input File : c: \riskindlinput lcase2.inp

Output File: output \case2.out

$=============\quad$ Results

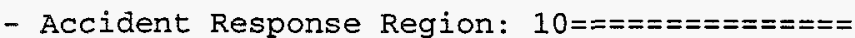

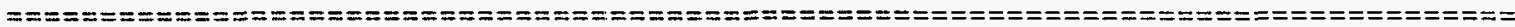

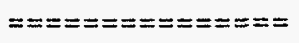

Accident Dose to : Individual 1

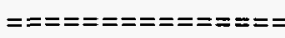

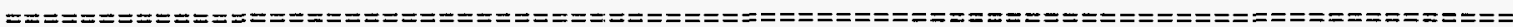

\begin{tabular}{|c|c|c|}
\hline Individual Summary Resul & Per Accident & \\
\hline $\begin{array}{l}\text { Committed Effective Dose Equivalent } \\
\text { Expected Genetic Effects } \\
\text { Expected Non-fatal Cancers } \\
\text { Expected Cancer Fatalities } \\
\text { Acute Risk (Expected fatalities) }\end{array}$ & $\begin{array}{l}1.15 E+00 \\
9.23 E-05 \\
9.23 E-05 \\
4.62 E-04 \\
0.00 E+00\end{array}$ & rem \\
\hline
\end{tabular}

\begin{tabular}{|c|c|c|c|c|}
\hline Pathway & & Doses (rem) & & \\
\hline Acute & $5.44 E-03$ & & & \\
\hline Cask & & $8.69 E-11$ & & \\
\hline Ground Shine & & $7.40 E-06$ & & \\
\hline Inhalation & & $5.42 \mathrm{E}-03$ & & \\
\hline Cloud Shine & & $1.37 E-05$ & & \\
\hline Long-Term & 1. $15 E+00$ & & & \\
\hline Ground Shine & & $3.21 \mathrm{E}-01$ & & \\
\hline Inhalation & & $2.52 \mathrm{E}-03$ & & \\
\hline Cloud Shine & & $4.51 \mathrm{E}-06$ & & \\
\hline Ingestion & & $8.25 E-01$ & & \\
\hline Initial Year & & & $7.64 \mathrm{E}-01$ & \\
\hline Vegetable & & & & $9.51 E-02$ \\
\hline Meat & & & & $1.11 \mathrm{E}-01$ \\
\hline $\operatorname{Milk}$ & & & & $5.57 E-01$ \\
\hline Long-Term & & & $6.15 \mathrm{E}-02$ & \\
\hline Vegetable & & & & $1.69 \mathrm{E}-02$ \\
\hline Meat & & & & $6.73 E-03$ \\
\hline Milk & & & & $3.50 \mathrm{E}-02$ \\
\hline Water & & & & $2.87 E-03$ \\
\hline
\end{tabular}

\begin{tabular}{lcccc}
\hline Exposure Parameter & Organ $\begin{array}{c}\text { Exposure } \\
\text { Marrow }\end{array}$ & Lung & Intestine & Gonads \\
\hline Long-Term Dose [rem] & $1.12 \mathrm{E}+00$ & $1.07 \mathrm{E}+00$ & $1.10 \mathrm{E}+00$ & $7.81 \mathrm{E}+01$ \\
Brief Dose [Gy] Time [d] & $2.49 \mathrm{E}-07$ & $3.35 \mathrm{E}-06$ & $4.17 \mathrm{E}-06$ & $1.00 \mathrm{E}+00$ \\
Brief Exposure Tim [Gy/hr] & $1.00 \mathrm{E}+00$ & $1.00 \mathrm{E}+00$ & 1.007 \\
Brief Dose Rate [Gy] & $1.04 \mathrm{E}-07$ & $2.82 \mathrm{E}-07$ & $2.57 \mathrm{E}-07$ \\
Prolonged Dose [G] & $1.01 \mathrm{E}-06$ & $2.81 \mathrm{E}-05$ & $4.18 \mathrm{E}-06$ \\
Prolong Exposure Time [d] & $3.00 \mathrm{E}+01$ & $3.65 \mathrm{E}+02$ & $7.00 \mathrm{E}+00$ \\
Prolong Dose Rate [Gy/hr] & $1.40 \mathrm{E}-09$ & $1.77 \mathrm{E}-07$ & $1.61 \mathrm{E}-07$ \\
Hazard & $0.00 \mathrm{E}+00$ & $0.00 \mathrm{E}+00$ & $0.00 \mathrm{E}+00$ \\
Acute Risk [Expected fatalities] & $0.00 \mathrm{E}+00$ & $0.00 \mathrm{E}+00$ & $0.00 \mathrm{E}+00$ \\
\hline
\end{tabular}


Individual Accident Dose Summary Results Consequences

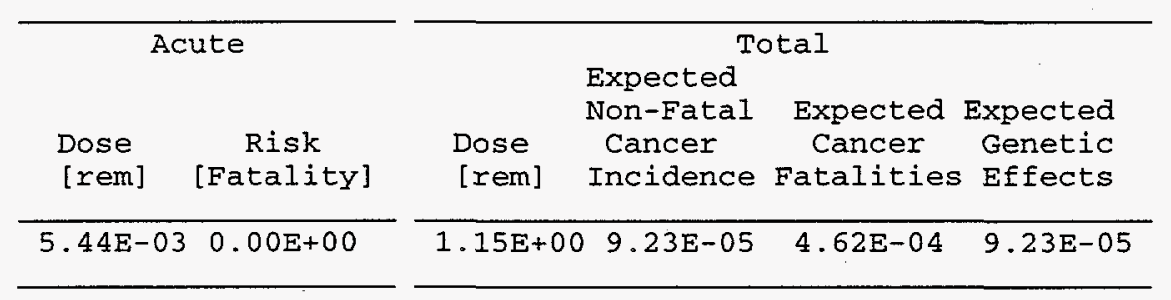




\section{A.3 Case 3: Acute Health Effects}

\section{A.3.1 Case 3 Input File}

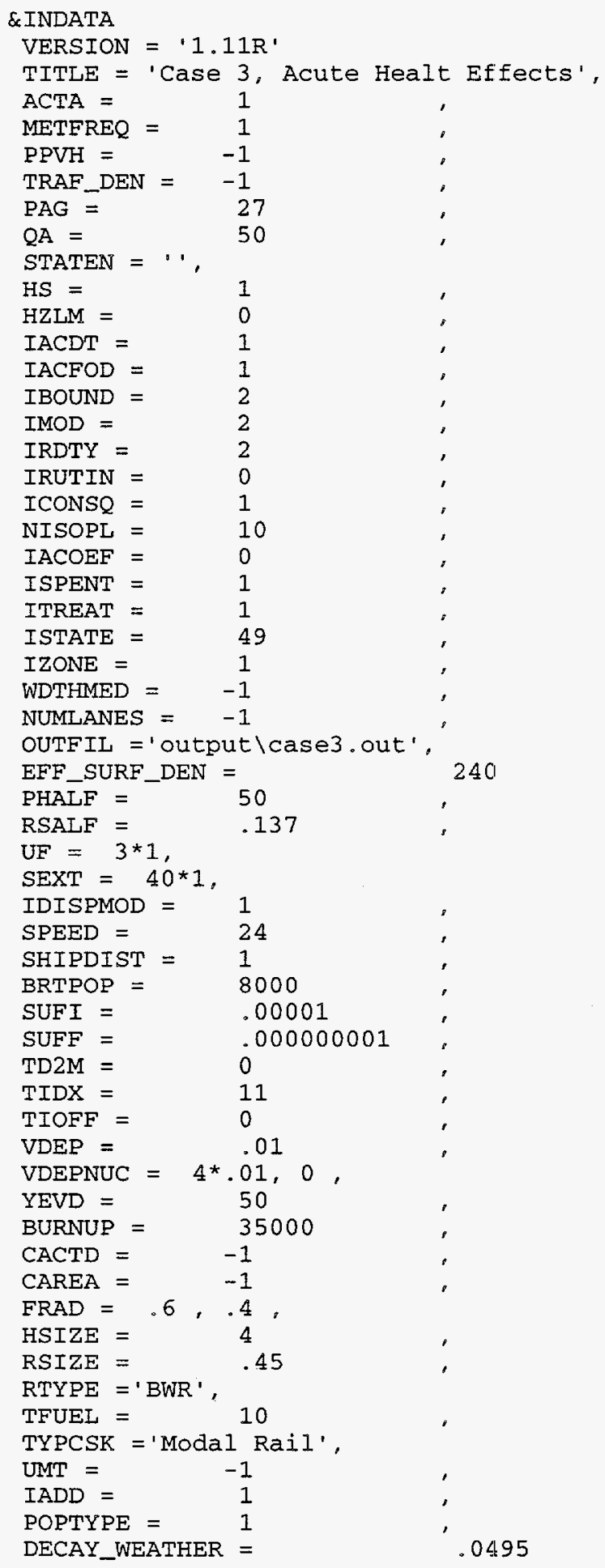




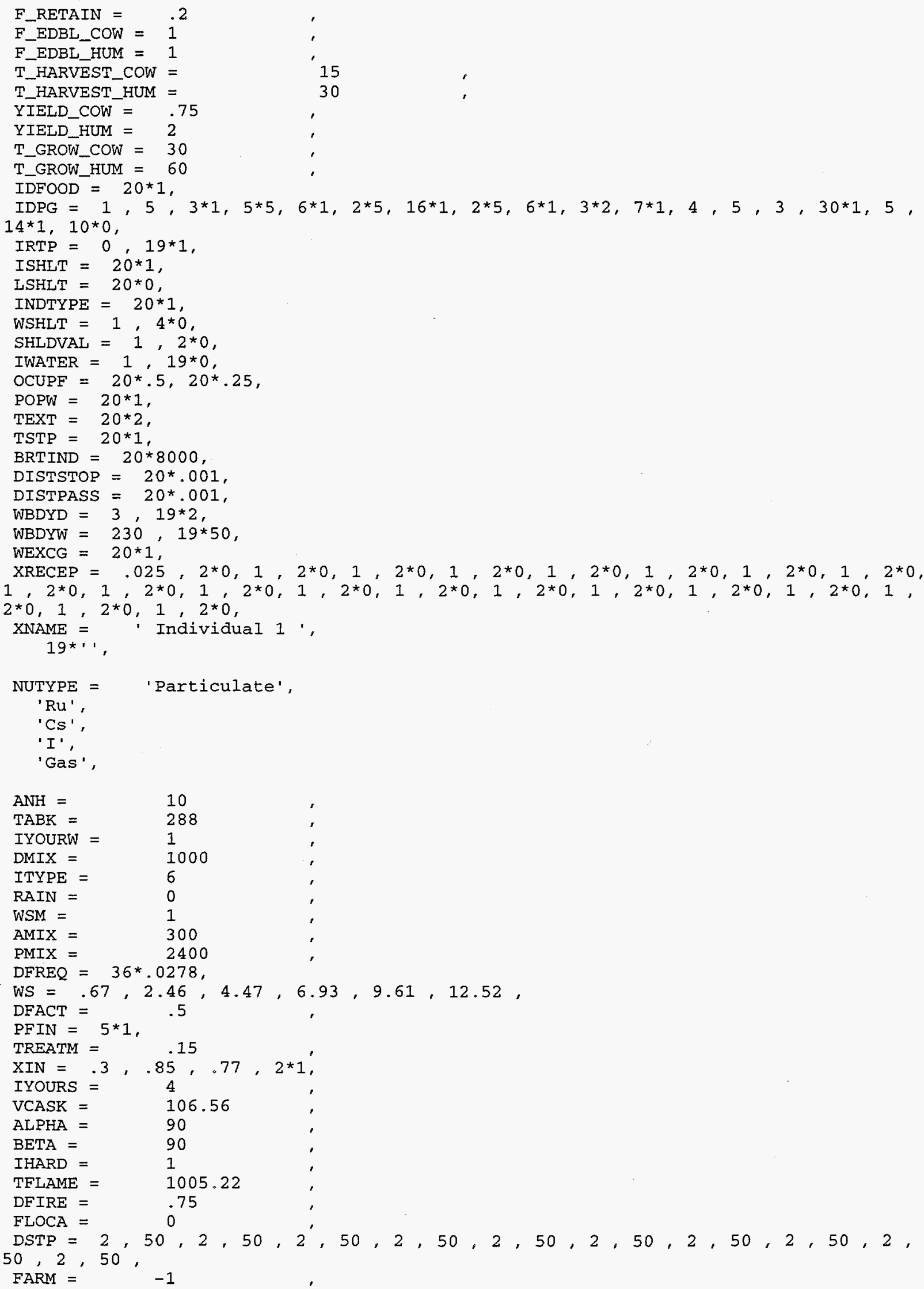




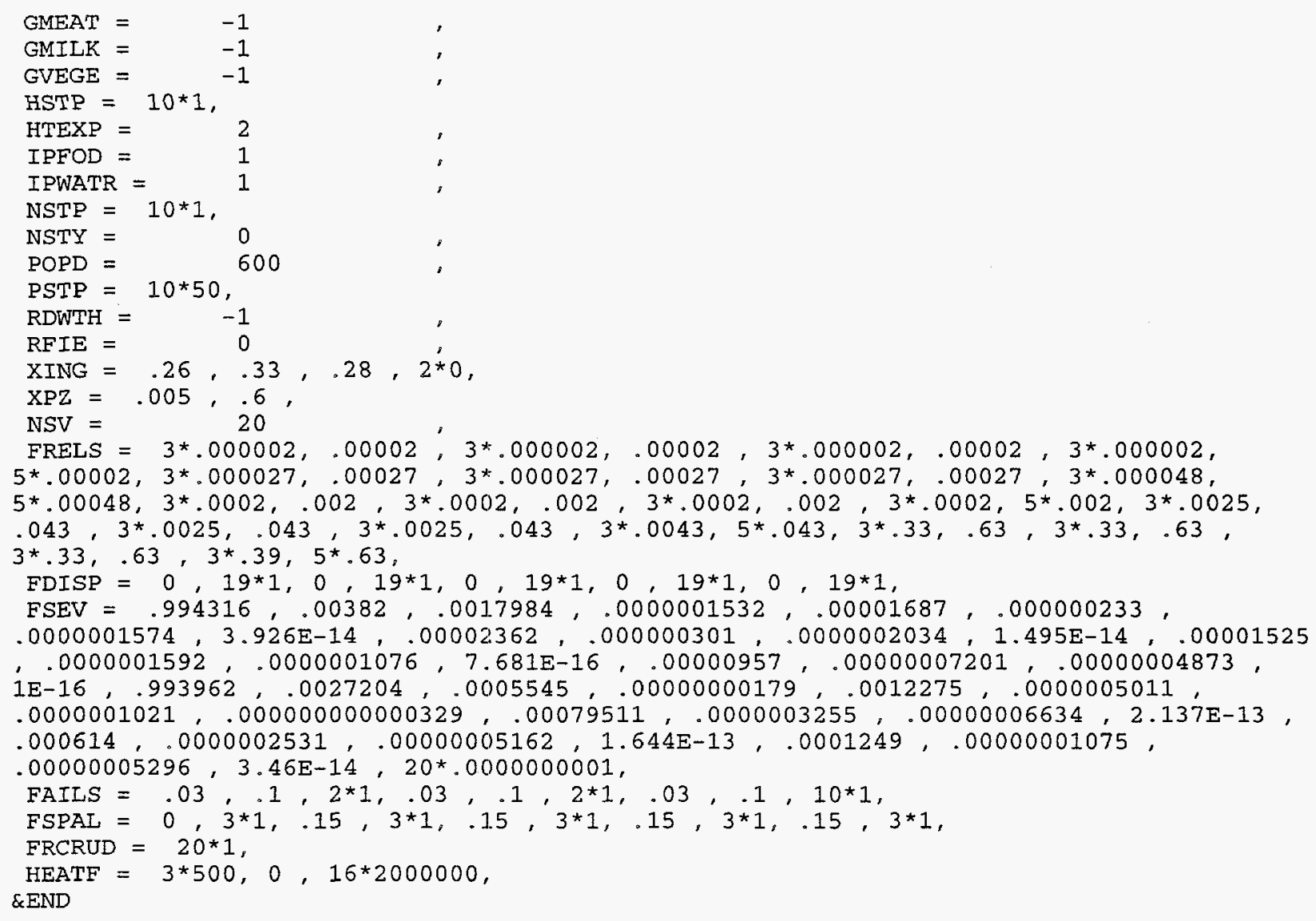




\title{
A.3.2 Case 3 Output File
}

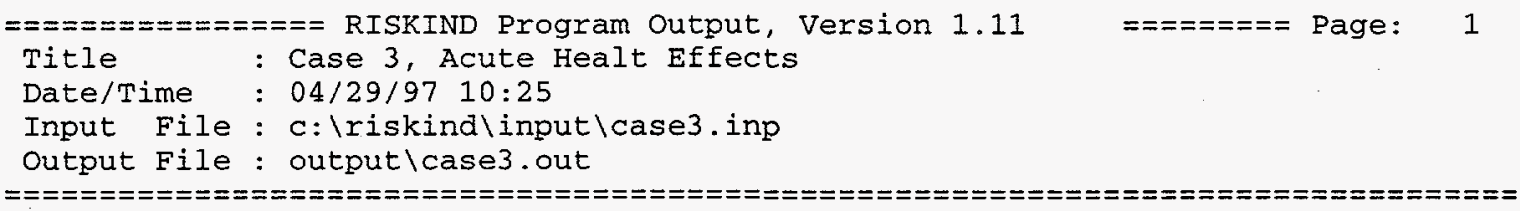

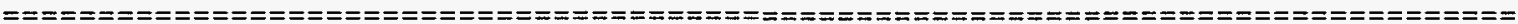

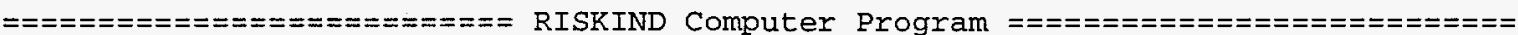

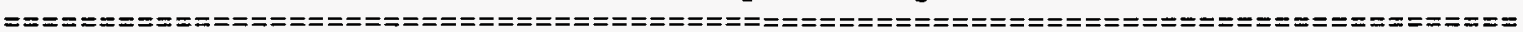

Problem Description

\author{
Individual Receptors \\ Accident Calculations \\ Single Accident Analysis \\ Single Weather Analysis \\ Acute Exposure \\ Plume Inhalation \\ Plume Immersion \\ Early Ground Exposure \\ Exposure to Cask
}

Note: * next to input description signifies

a data dependent default value 
$======== \pm========$ RISKIND Program Output, Version 1.11

Title

: Case 3, Acute Healt Effects

Date/Time

04/29/97 10:25

Input File : c: $\backslash r i s k i n d \backslash$ input $\backslash c a s e 3 . i n p$

Output File: output \case3.out

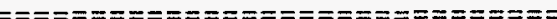

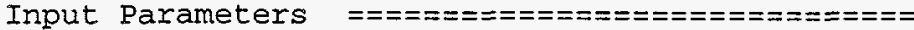

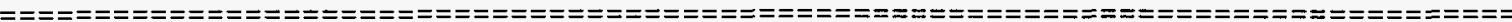

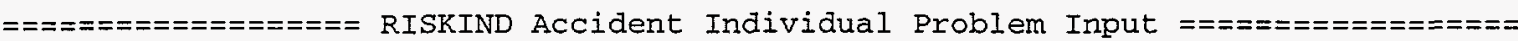

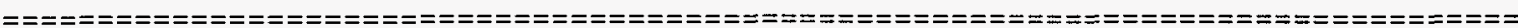

Individual Accident Parameters

State: US

Population Zone: Rural

Average Breathing Rate [BRTIND]: $8.00 \mathrm{E}+03 \mathrm{~m} 3 / \mathrm{yr}$ Individual type [INDTYPE]: Public

Risk Conversion Factors

Non-Fatal Cancers/rem: 1.0E-04

Fatal Cancers/rem: 5.0E-04

Genetic Effects/rem: 1.3E-04

\begin{tabular}{|c|c|c|c|c|c|c|}
\hline $\begin{array}{l}\text { Individual Name } \\
\text { [XNAME] }\end{array}$ & $\begin{array}{l}====== \\
\text { Down } \\
\text { Wind } \\
{[\mathrm{km}]}\end{array}$ & $\begin{array}{c}\text { Location } \\
\text { Cross } \\
\text { wind } \\
\text { [km] } \\
\text { [XRECEP] }\end{array}$ & $\begin{array}{c}===== \\
\text { Elevation } \\
{[\mathrm{m}]}\end{array}$ & $\begin{array}{c}\text { Acute } \\
\text { Exposure } \\
\text { Time } \\
\text { [hr] } \\
\text { [TEXT] }\end{array}$ & $\begin{array}{l}\text { Long Term } \\
\text { Exposure } \\
\text { [IRTP] }\end{array}$ & $\begin{array}{l}\text { Food } \\
\text { Ingestion } \\
\text { [IDFOOD] }\end{array}$ \\
\hline Individual 1 & $2.50 \mathrm{E}-02$ & $20.00 E+00$ & $0.00 E+00$ & $2.00 E+00$ & Non & No \\
\hline
\end{tabular}

\begin{tabular}{|c|c|c|c|c|c|c|c|c|c|}
\hline \multirow[b]{2}{*}{ Individual } & \multicolumn{2}{|c|}{$\begin{array}{c}\text { Shielding } \\
\text { Type }\end{array}$} & \multicolumn{2}{|c|}{$\begin{array}{l}\text { Long- } \\
\text { Term }\end{array}$} & \multicolumn{5}{|c|}{$\begin{array}{c}=====\text { Shielding Factors }==== \\
\text { Acute: } \quad \text { Long-Term: }\end{array}$} \\
\hline & Short & Long & In & out & Cla & Ext & Inh & cld & Ext \\
\hline Individual 1 & Frame & & 0.50 & 0.25 & 1.000 .90 & 0.40 & 0.75 & 0.75 & 0.75 \\
\hline
\end{tabular}




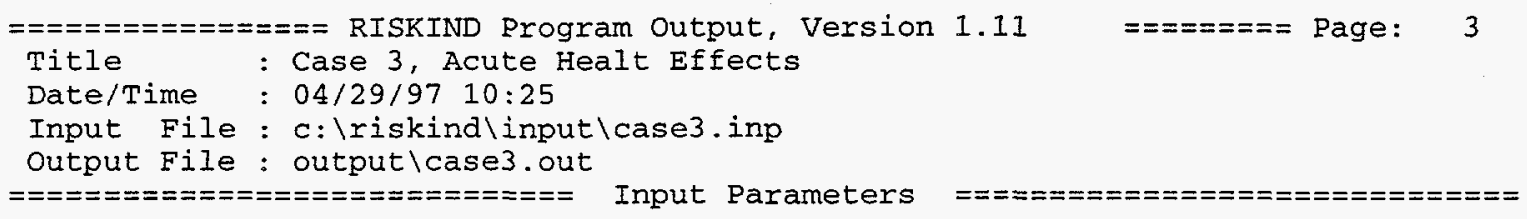

Meteorological Parameters

Dry deposition rates [VDEPNUC] Particulates Ruthenium $: 1.00 \mathrm{E}-02$ Cesium Iodine Gases

Rain fall rate [RAIN]: 0.00E+00 Anemometer height [ANH]: Ambient Temperature [TABK] : Mixing height [DMIX]:

wind at anemometer [WSM] : Pasquill stability cat. [ITYPE]:

$$
\text { : }
$$$$
\text { : } 1.00 \mathrm{E}-02
$$$$
\text { - } 1.00 \mathrm{E}-02
$$$$
\text { : } 1.00 \mathrm{E}-02
$$$$
0.00 E+00
$$$$
10.00
$$$$
288.00
$$$$
1000.00
$$

1.00

F

$$
\begin{aligned}
& \text { Transportation Mode [IMOD]: } \\
& \text { Dose at } 1 \mathrm{~m} \text { [TIDX] : } \\
& \text { Measurement offset [TIOFF] : } \\
& \text { Gamma Fraction [FRAD(1)]: } \\
& \text { Neutron Fraction [FRAD(2)]: } \\
& \text { Cask Length [HSIZE]: } \\
& \text { Cask Radius [RSIZE] : } \\
& \text { Amount of Uranium [UMT] *: } \\
& \text { Reactor Type [RTYPE]: } \\
& \text { Reactor Burnup [BURNUP] : } 3.50 \mathrm{E}+04 \\
& \text { Fuel Cooling Time [TFUEL]: } 10.00 \\
& \text { Total Surface Area of Cask [CAREA] * } 209.50 \\
& \text { Crud Surface Activity Density [CACTD] * : } 350.00
\end{aligned}
$$




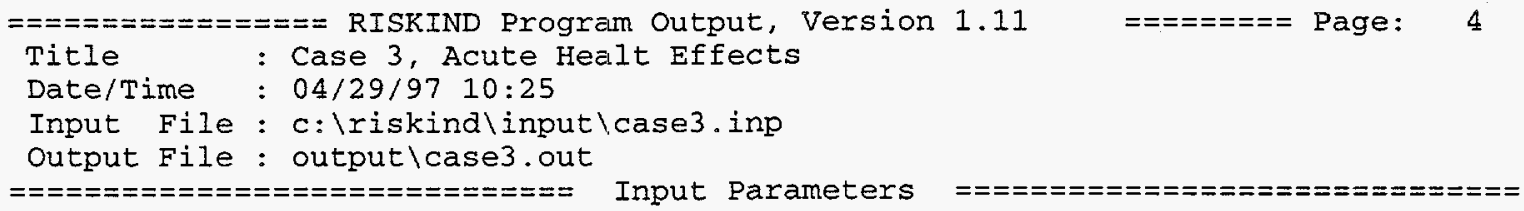

Nuclide Parameters

\begin{tabular}{|c|c|c|c|c|c|c|c|}
\hline \multirow[b]{2}{*}{$\begin{array}{l}\text { Nuclide } \\
\text { Name }\end{array}$} & \multicolumn{7}{|c|}{ Nuclide Inventory and DCFs } \\
\hline & $\begin{array}{c}\text { Inventory } \\
\text { Amount } \\
\text { [Ci] }\end{array}$ & $\begin{array}{c}\text { Inhalation } \\
{[\mathrm{Sv} / \mathrm{Bq}]}\end{array}$ & $\begin{array}{c}\text { Ingestion } \\
{[\mathrm{Sv} / \mathrm{Bq}]}\end{array}$ & $\begin{array}{c}\text { ion Fact } \\
\text { Cloud } \\
{[\mathrm{Sv} / \mathrm{s}]} \\
{[\mathrm{Bq} / \mathrm{m} 3]}\end{array}$ & $\begin{array}{c}c===== \\
\text { Ground } \\
{[\mathrm{Sv} / \mathrm{s}]} \\
{[\mathrm{Bq} / \mathrm{m} 2]}\end{array}$ & $\begin{array}{l}\text { Nucl. } \\
\text { Class }\end{array}$ & $\begin{array}{l}\text { Decay } \\
\text { Const. } \\
\text { [1/yr] }\end{array}$ \\
\hline $\mathrm{H}$ & $4.35 \mathrm{E}+03$ & $1.73 \mathrm{E}-11$ & $1.73 \mathrm{E}-11$ & $0.00 \mathrm{E}+00$ & $0.00 \mathrm{E}+00$ & Particul & $5.60 \mathrm{E}-02$ \\
\hline FE 55 & 1. $39 E+03$ & $7.26 \mathrm{E}-10$ & $1.64 \mathrm{E}-10$ & $0.00 \mathrm{E}+00$ & $0.00 E+00$ & Particul & $2.60 \mathrm{E}-01$ \\
\hline CO 60 & $1.74 E+04$ & $5.91 E-08$ & $7.28 E-09$ & $1.26 \mathrm{E}-13$ & $2.35 \mathrm{E}-15$ & Particul & $1.30 E-01$ \\
\hline NI 63 & $2.49 \mathrm{E}+03$ & $1.70 \mathrm{E}-09$ & $1.56 \mathrm{E}-10$ & $0.00 \mathrm{E}+00$ & $0.00 \mathrm{E}+00$ & Particul & $6.90 E-03$ \\
\hline KR 85 & $4.39 E+04$ & $1.03 E-11$. & $1.03 E-11$ & $1.19 E-16$ & 2. $64 \mathrm{E}-18$ & Gas & $6.50 \mathrm{E}-02$ \\
\hline SR 90 & $5.31 E+05$ & $3.53 E-07$ & $4.14 E-08$ & $1.97 E-16$ & $5.61 \mathrm{E}-18$ & Particul & $2.40 E-02$ \\
\hline Y 90 & $5.31 E+05$ & $2.28 E-09$ & $2.91 E-09$ & $1.90 E-16$ & $5.33 \mathrm{E}-18$ & Particul & $9.50 E+01$ \\
\hline RU106 & $4.49 E+03$ & $1.30 E-07$ & $8.30 E-09$ & $1.04 \mathrm{E}-14$ & $2.12 \mathrm{E}-16$ & Ru & $6.90 E-01$ \\
\hline RH106 & $4.49 E+03$ & $8.95 E-10$ & $8.95 E-10$ & $1.04 \mathrm{E}-14$ & $2.12 \mathrm{E}-16$ & Ru & $7.30 \mathrm{E}+05$ \\
\hline SB125 & 1. $31 E+04$ & $3.75 \mathrm{E}-09$ & $9.85 E-10$ & $2.02 E-14$ & $4.33 E-16$ & Particul & $2.50 \mathrm{E}-01$ \\
\hline TE125M & $3.19 E+03$ & $1.97 \mathrm{E}-09$ & $9.92 E-10$ & $4.53 E-16$ & $3.61 \mathrm{E}-17$ & Particul & $4.40 \mathrm{E}+00$ \\
\hline $\operatorname{CS} 134$ & $6.19 E+04$ & $1.25 \mathrm{E}-08$ & $1.98 E-08$ & $7.56 \mathrm{E}-14$ & $1.52 \mathrm{E}-15$ & $\mathrm{Cs}$ & $3.40 \mathrm{E}-01$ \\
\hline $\operatorname{cs} 137$ & $8.03 E+05$ & $1.10 \mathrm{E}-08$ & $1.59 E-08$ & $2.73 \mathrm{E}-14$ & $5.54 \mathrm{E}-16$ & $\mathrm{Cs}$ & $2.30 \mathrm{E}-02$ \\
\hline BA137M & $7.60 \mathrm{E}+05$ & $2.49 E-09$ & $2.49 E-09$ & $2.88 E-14$ & $5.86 \mathrm{E}-16$ & Particul & $1.40 \mathrm{E}+05$ \\
\hline CE144 & $9.83 E+02$ & $1.01 \mathrm{E}-07$ & $5.71 \mathrm{E}-09$ & $2.80 E-15$ & $5.83 E-17$ & Particul & $8.90 E-01$ \\
\hline PR144 & $9.83 E+02$ & $1.17 \mathrm{E}-11$. & 3. $15 \mathrm{E}-11$ & $1.94 \mathrm{E}-15$ & $3.79 \mathrm{E}-17$ & Particul & $2.10 E+04$ \\
\hline PM147 & $6.99 E+04$ & $1.06 \mathrm{E}-08$ & $2.83 E-10$ & $6.92 E-19$ & $3.40 E-20$ & Particul & $2.60 E-01$ \\
\hline SM151 & $3.82 E+03$ & $8.10 E-09$ & $1.05 \mathrm{E}-10$ & $3.61 \mathrm{E}-20$ & $5.02 \mathrm{E}-21$ & Particul & $7.70 E-03$ \\
\hline EU154 & $4.92 E+04$ & $7.73 E-08$ & $2.58 E-09$ & $6.14 \mathrm{E}-14$ & $1.18 \mathrm{E}-15$ & Particul & $7.90 E-02$ \\
\hline EU155 & $1.89 E+04$ & $1.12 E-08$ & $4.13 E-10$ & $2.49 E-15$ & $5.90 E-17$ & Particul & $1.40 \mathrm{E}-01$ \\
\hline PU238 & $4.02 E+04$ & $1.06 \mathrm{E}-04$ & $8.65 E-07$ & $4.87 \mathrm{E}-18$ & $8.37 E-19$ & Particul & $7.90 \mathrm{E}-03$ \\
\hline PU239 & $3.06 E+03$ & $1.16 \mathrm{E}-04$ & $9.56 \mathrm{E}-07$ & $4.24 E-18$ & $3.67 \mathrm{E}-19$ & Particul & $2.90 E-05$ \\
\hline PU240 & $4.79 E+03$ & $1.16 \mathrm{E}-04$ & $9.56 \mathrm{E}-07$ & $4.75 \mathrm{E}-18$ & $8.02 \mathrm{E}-19$ & Particul & $1.10 \mathrm{E}-04$ \\
\hline PU241 & $8.39 E+05$ & $2.23 E-06$ & $1.85 \mathrm{E}-08$ & $2.19 E-19$ & $5.20 E-21$ & Particul & $4.80 E-02$ \\
\hline AM2 41 & $1.91 \mathrm{E}+04$ & $1.20 E-04$ & $9.84 \mathrm{E}-07$ & $8.18 E-16$ & $2.74 \mathrm{E}-17$ & Particul & $1.60 \mathrm{E}-03$ \\
\hline CM244 & $3.88 E+04$ & $6.70 \mathrm{E}-05$ & $5.45 \mathrm{E}-07$ & $4.91 E-18$ & $8.78 E-19$ & Particul & $3.80 E-02$ \\
\hline CD113M & $2.55 E+02$ & $4.13 E-07$ & $4.35 E-08$ & $6.93 E-18$ & $2.63 E-19$ & Particul & $5.10 \mathrm{E}-02$ \\
\hline
\end{tabular}




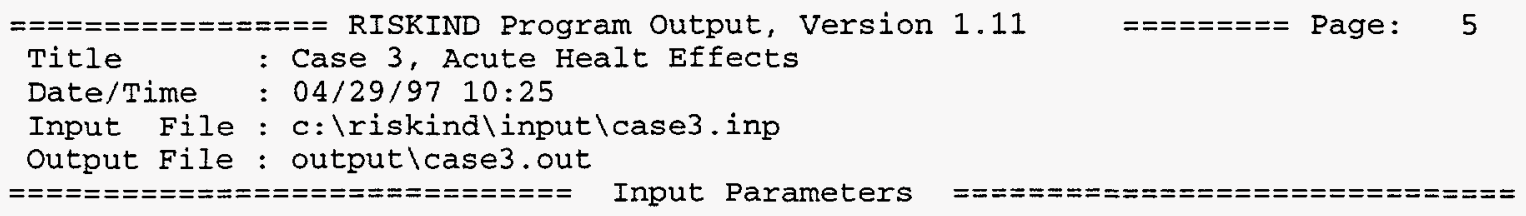

\begin{tabular}{|c|c|c|c|c|c|c|c|}
\hline \multirow{3}{*}{$\begin{array}{l}\text { Nuclide } \\
\text { Name }\end{array}$} & \multicolumn{7}{|c|}{ Nuclide Health Effects Parameters } \\
\hline & \multirow{2}{*}{ Solubility } & \multicolumn{6}{|c|}{ 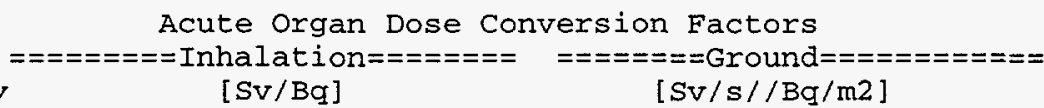 } \\
\hline & & Marrow & Lung & Intestine & Marrow & Lung & Intestine \\
\hline H & $\bar{D}$ & $1.62 \mathrm{E}-11$ & $1.62 \mathrm{E}-11$ & $1.62 \mathrm{E}-11$ & $0.00 E+00$ & $0.00 \mathrm{E}+00$ & $0.00 E+00$ \\
\hline FE 55 & W & $1.65 \mathrm{E}-10$ & $1.76 \mathrm{E}-10$ & $1.92 E-10$ & $0.00 E+00$ & $0.00 \mathrm{E}+00$ & $1.89 \mathrm{E}-19$ \\
\hline $\mathrm{CO} 60$ & $\mathrm{Y}$ & $6.22 \mathrm{E}-09$ & $1.24 \mathrm{E}-07$ & $5.95 \mathrm{E}-09$ & $2.34 E-15$ & $2.27 E-15$ & $1.94 \mathrm{E}-15$ \\
\hline NI 63 & Y & $1.05 \mathrm{E}-12$ & $5.95 \mathrm{E}-12$ & $4.59 E-13$ & $0.00 E+00$ & $0.00 \mathrm{E}+00$ & $0.00 \mathrm{E}+00$ \\
\hline KR 85 & $\mathrm{D}$ & $0.00 E+00$ & $0.00 \mathrm{E}+00$ & $0.00 \mathrm{E}+00$ & $2.43 E-18$ & $2.45 \mathrm{E}-18$ & $1.97 \mathrm{E}-18$ \\
\hline SR 90 & $Y$ & $1.08 \mathrm{E}-09$ & $7.03 E-07$ & $1.70 E-08$ & $4.77 E-18$ & $4.98 E-18$ & $0.00 \mathrm{E}+00$ \\
\hline Y 90 & $Y$ & $1.51 \mathrm{E}-11$ & $9.19 E-09$ & $1.27 E-08$ & $4.57 E-18$ & $4.76 \mathrm{E}-18$ & $0.00 \mathrm{E}+00$ \\
\hline RU106 & $\mathrm{Y}$ & $1.05 \mathrm{E}-09$ & $6.76 \mathrm{E}-07$ & $3.51 E-08$ & $2.06 \mathrm{E}-16$ & $2.03 E-16$ & $1.80 \mathrm{E}-16$ \\
\hline RH106 & $Y$ & $2.58 \mathrm{E}-10$ & $2.58 \mathrm{E}-10$ & $1.14 \mathrm{E}-09$ & $2.06 \mathrm{E}-16$ & $2.03 E-16$ & $1.80 \mathrm{E}-16$ \\
\hline SB125 & W & $2.41 \mathrm{E}-14$ & $7.30 \mathrm{E}-11$ & 3. $24 \mathrm{E}-12$ & $4.05 E-16$ & $4.03 E-16$ & $3.79 \mathrm{E}-16$ \\
\hline TE125M & $W$ & $5.14 \mathrm{E}-14$ & 1. $05 \mathrm{E}-11$ & $2.38 E-12$ & 1. $37 \mathrm{E}-17$ & $1.77 \mathrm{E}-17$ & $1.78 \mathrm{E}-17$ \\
\hline CS134 & D & $1.08 \mathrm{E}-08$ & $1.08 \mathrm{E}-08$ & $1.27 E-08$ & $1.48 \mathrm{E}-15$ & $1.46 \mathrm{E}-15$ & $1.34 E-15$ \\
\hline $\operatorname{cs} 137$ & D & $7.57 \mathrm{E}-09$ & $8.11 E-09$ & $8.11 \mathrm{E}-09$ & $5.39 \mathrm{E}-16$ & $5.30 \mathrm{E}-16$ & $4.93 E-16$ \\
\hline BA137M & D & $2.73 E-11$ & $2.73 E-11$ & $0.00 E+00$ & $5.70 E-16$ & $5.60 \mathrm{E}-16$ & $5.22 \mathrm{E}-16$ \\
\hline CE144 & $\mathrm{Y}$ & $1.08 \mathrm{E}-09$ & $5.68 E-07$ & $3.24 E-08$ & $5.31 \mathrm{E}-17$ & $5.43 E-17$ & $1.83 \mathrm{E}-17$ \\
\hline PR144 & $\mathrm{Y}$ & $1.92 \mathrm{E}-14$ & $9.46 \mathrm{E}-11$ & $2.16 E-14$ & $3.66 E-17$ & $3.61 \mathrm{E}-17$ & $2.54 \mathrm{E}-17$ \\
\hline PM147 & $Y$ & $1.41 \mathrm{E}-10$ & $3.51 E-08$ & $1.62 E-09$ & $1.86 E-20$ & $2.20 E-20$ & $3.48 E-21$ \\
\hline SM151 & $\mathrm{Y}$ & $3.78 \mathrm{E}-12$ & 1. $19 \mathrm{E}-11$ & $8.65 E-13$ & 1. $39 E-21$ & 1.01E-21 & $4.45 \mathrm{E}-21$ \\
\hline EU154 & $\mathrm{Y}$ & $2.46 \mathrm{E}-11$ & $1.57 E-10$ & $9.19 \mathbf{E}-12$ & $1.16 E-15$ & $1.14 \mathrm{E}-15$ & $1.03 E-15$ \\
\hline EU155 & $Y$ & $3.78 \mathrm{E}-12$ & $2.54 \mathrm{E}-11$ & $1.59 E-12$ & $4.71 E-17$ & $5.34 E-17$ & $6.05 E-17$ \\
\hline PU238 & $Y$ & $2.97 \mathrm{E}-07$ & $7.03 E-05$ & $2.97 E-08$ & $1.94 \mathrm{E}-19$ & $7.87 \mathrm{E}-20$ & $7.35 E-19$ \\
\hline PU239 & $Y$ & $2.70 E-07$ & $6.76 E-05$ & $2.70 E-08$ & $1.19 E-19$ & $7.87 E-20$ & $3.24 E-19$ \\
\hline PU240 & $\mathrm{Y}$ & $2.70 \mathrm{E}-07$ & $6.76 E-05$ & $2.70 \mathrm{E}-08$ & $1.88 \mathrm{E}-19$ & $7.81 \mathrm{E}-20$ & $7.02 \mathrm{E}-19$ \\
\hline PU241 & $\mathrm{Y}$ & $2.97 \mathrm{E}-10$ & $5.68 E-08$ & $1.41 E-10$ & $4.18 \mathrm{E}-21$ & $4.36 E-21$ & $0.00 E+00$ \\
\hline $\mathrm{AM} 241$ & $w$ & $4.32 \mathrm{E}-06$ & $1.81 E-05$ & $2.97 E-08$ & $1.68 E-17$ & $2.00 E-17$ & $2.52 E-17$ \\
\hline CM244 & $w$ & $4.59 E-06$ & $1.92 \mathrm{E}-0.5$ & 3. $24 E-08$ & $2.04 E-19$ & $9.00 E-20$ & $7.10 \mathrm{E}-19$ \\
\hline CD113M & $\mathrm{Y}$ & $4.05 \mathrm{E}-11$ & $5.41 E-11$ & $4.05 E-12$ & $1.78 E-19$ & $2.03 E-19$ & $0.00 \mathrm{E}+00$ \\
\hline
\end{tabular}




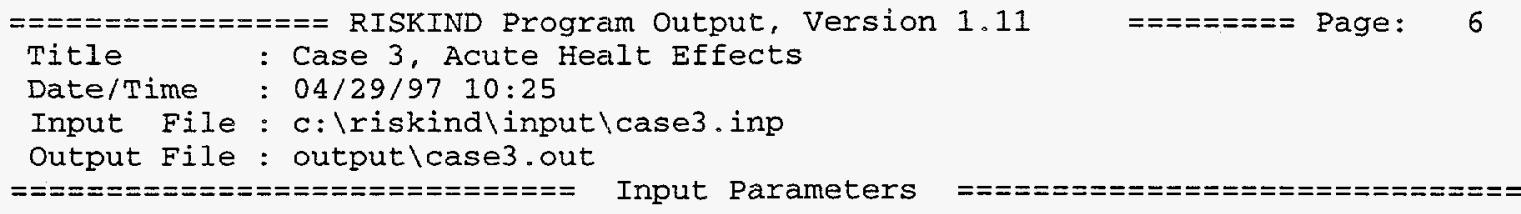

Nuclide Health Effects Parameters

Acute Organ Dose Conversion Factors

$=========$ Cloudshine== = = = = =

Name

[ $\mathrm{Sv} / \mathrm{s} / / \mathrm{Bg} / \mathrm{m} 3$ ]

Marrow Lung Intestine

\begin{tabular}{|c|c|c|c|}
\hline H 3 & $0.00 E+00$ & $0.00 E+00$ & $0.00 \mathrm{E}+00$ \\
\hline FE 55 & $0.00 \mathrm{E}+00$ & $0.00 \mathrm{E}+00$ & $9.85 E-19$ \\
\hline CO 60 & $1.23 \mathrm{E}-13$ & $1.24 \mathrm{E}-13$ & $1.11 \mathrm{E}-13$ \\
\hline NI 63 & $0.00 \mathrm{E}+00$ & $0.00 \mathrm{E}+00$ & $0.00 \mathrm{E}+00$ \\
\hline KR 85 & $1.09 \mathrm{E}-16$ & $1.14 \mathrm{E}-16$ & $9.59 \mathrm{E}-17$ \\
\hline SR 90 & $1.68 \mathrm{E}-16$ & $1.84 \mathrm{E}-16$ & $0.00 \mathrm{E}+00$ \\
\hline Y 90 & $1.62 \mathrm{E}-16$ & $1.77 \mathrm{E}-16$ & $0.00 \mathrm{E}+00$ \\
\hline RU106 & $9.76 \mathrm{E}-15$ & $1.01 E-14$ & $8.99 \mathrm{E}-15$ \\
\hline RH106 & $9.76 \mathrm{E}-15$ & $1.01 E-14$ & $8.99 E-15$ \\
\hline SB125 & $1.88 \mathrm{E}-14$ & $1.95 \mathrm{E}-14$ & $1.82 \mathrm{E}-1$ \\
\hline TE125M & $1.86 \mathrm{E}-16$ & 2. $23 E-16$ & $4.10 \mathrm{E}-1$ \\
\hline $\operatorname{Cs} 134$ & $7.19 \mathrm{E}-14$ & $7.37 E-14$ & $6.84 \mathrm{E}-1$ \\
\hline CS137 & $2.59 \mathrm{E}-14$ & $2.65 \mathrm{E}-14$ & $2.48 \mathrm{E}-14$ \\
\hline BA137M & $2.73 E-14$ & $2.80 E-14$ & $2.61 \mathrm{E}-1$ \\
\hline CE144 & $2.55 E-15$ & $2.68 E-15$ & $7.73 E-1$ \\
\hline PR144 & $1.88 \mathrm{E}-15$ & $1.91 \mathrm{E}-15$ & 1. $52 \mathrm{E}-1$ \\
\hline PM147 & $4.46 \mathrm{E}-19$ & $5.45 E-19$ & $1.55 \mathrm{E}-1$ \\
\hline SM151 & $1.13 \mathrm{E}-20$ & $7.13 E-21$ & $3.91 \mathrm{E}-2$ \\
\hline EU154 & $5.87 E-14$ & $5.99 \mathrm{E}-14$ & $5.54 \mathrm{E}-1$ \\
\hline EU155 & $1.85 E-15$ & $2.22 \mathrm{E}-15$ & $2.42 \mathrm{E}-1$ \\
\hline PU238 & 1. $68 \mathrm{E}-18$ & $1.06 \mathrm{E}-18$ & $3.77 \mathrm{E}-1$ \\
\hline PU239 & $2.67 \mathrm{E}-18$ & $2.65 E-18$ & $3.50 \mathrm{E}-1$ \\
\hline PU240 & $1.66 \mathrm{E}-18$ & $1.09 E-18$ & $3.69 E-1$ \\
\hline PU241 & 1. $75 \mathrm{E}-19$ & $1.99 \mathrm{E}-19$ & $0.00 \mathrm{E}+0$ \\
\hline AM2 41 & $5.21 E-16$ & $6.74 \mathrm{E}-16$ & $8.00 E-1$ \\
\hline CM2 44 & $1.46 \mathrm{E}-18$ & $7.07 E-19$ & $3.57 E-1$ \\
\hline CD113M & $5.01 \mathrm{E}-18$ & $5.93 E-18$ & $0.00 E+0$ \\
\hline
\end{tabular}




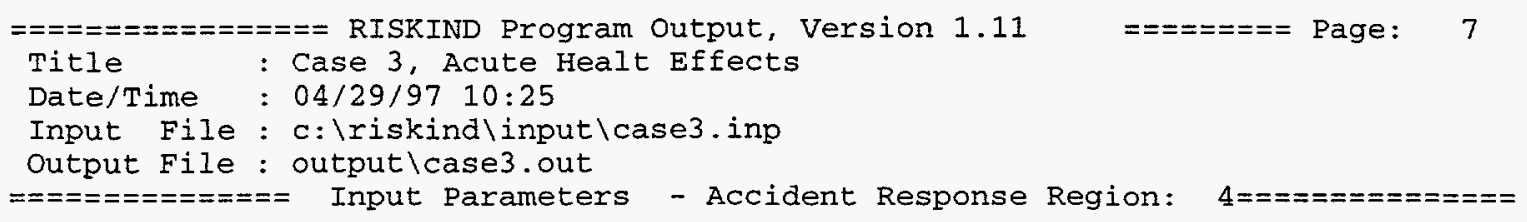

Accident Parameters

Physical Release Height [HS]: $1.00 \mathrm{~m}$

Dispersion Model Coefficients [IDISPMOD]: Pasquil1-Gifford

Accident Analysis Type: Consequence

Accident Response Region Parameters

Response Region [TYOURS]:

Region Conditional Probability [FSEV]: 1.79E-09

$$
\text { Heat Flux [HEATF] : } 0.00 \mathrm{E}+00 \mathrm{cal} / \mathrm{s}
$$

Loss of Cask Shielding Factor [SEXT]

$$
\begin{aligned}
\text { Gamma: } & 1.00 \\
\text { Neutron: } & 1.00
\end{aligned}
$$

Failure Rate [FAILS]: 1.00E+00

Crud Spallation Rate [FSPAL]: $1.00 \mathrm{E}+00$

Crud Release Rate [FRCRUD]: 1.00E+00

\begin{tabular}{lccc}
\hline $\begin{array}{c}\text { Nuclide } \\
\text { Class } \\
\text { [NUTYPE] }\end{array}$ & $\begin{array}{c}\text { Conditional } \\
\text { Release } \\
\text { Fraction } \\
\text { [FRELS] }\end{array}$ & $\begin{array}{c}\text { Dispersion } \\
\text { Fraction } \\
\text { [FDISP] }\end{array}$ & $\begin{array}{c}\text { Released and Dispersed } \\
\text { Fraction } \\
\text { (FRELS*FAILS*FDISP) }\end{array}$ \\
\hline Particulate & $2.00 \mathrm{E}-05$ & $1.00 \mathrm{E}+00$ & $2.00 \mathrm{E}-05$ \\
Ru & $2.70 \mathrm{E}-04$ & $1.00 \mathrm{E}+00$ & $2.70 \mathrm{E}-04$ \\
Cs & $2.00 \mathrm{E}-03$ & $1.00 \mathrm{E}+00$ & $2.00 \mathrm{E}-03$ \\
I & $4.30 \mathrm{E}-02$ & $1.00 \mathrm{E}+00$ & $4.30 \mathrm{E}-02$ \\
Gas & $6.30 \mathrm{E}-01$ & $1.00 \mathrm{E}+00$ & $6.30 \mathrm{E}-01$ \\
\hline
\end{tabular}


$================$ RISKIND Program Output, Version 1.11

Title : Case 3, Acute Healt Effects

Date/Time

: 04/29/97 10:25

Input File: c: Iriskind input`case3.inp

Output File: output lcase3.out

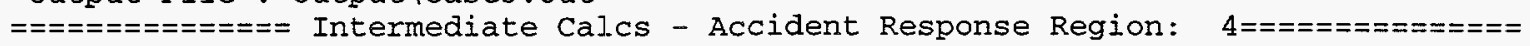

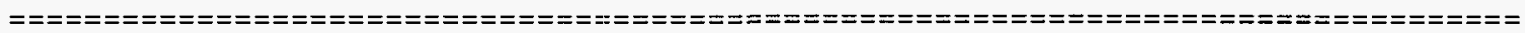

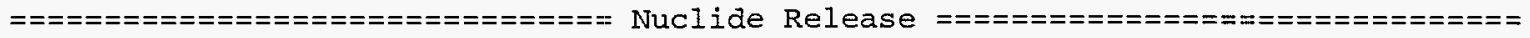

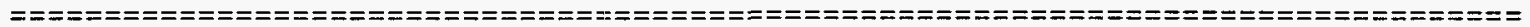

\begin{tabular}{|c|c|c|c|c|}
\hline $\begin{array}{l}\text { Nuclide } \\
\text { Name }\end{array}$ & $\begin{array}{c}\text { Release } \\
\text { Amount } \\
\text { [Ci] }\end{array}$ & \multicolumn{3}{|c|}{ 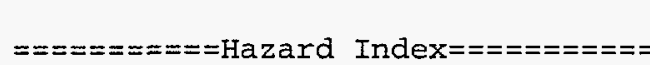 } \\
\hline $\mathrm{H}$ & $8.69 \mathrm{E}-02$ & $5.48 \mathrm{E}-09$ & $1.71 \mathrm{E}-05$ & $0.00 \mathrm{E}+00$ \\
\hline FE 55 & $2.78 E-02$ & $7.35 E-08$ & $1.97 \mathrm{E}-09$ & $0.00 E+00$ \\
\hline $\operatorname{co} 60$ & $2.00 \mathrm{E}+02$ & $4.35 E-02$ & $1.02 \mathrm{E}-02$ & 1. $35 E-01$ \\
\hline NI 63 & $4.98 E-02$ & $3.09 E-07$ & $5.95 \mathrm{E}-07$ & $0.00 E+00$ \\
\hline KR 85 & $2.77 \mathrm{E}+04$ & $1.09 E-03$ & $0.00 \mathrm{E}+00$ & $0.00 \mathrm{E}+00$ \\
\hline SR 90 & $1.06 \mathrm{E}+01$ & $1.37 E-02$ & $1.24 \mathrm{E}-02$ & $5.54 \mathrm{E}-05$ \\
\hline Y 90 & $1.06 \mathrm{E}+01$ & $8.83 E-05$ & $6.65 \mathrm{E}-08$ & $2.47 E-08$ \\
\hline RU106 & $1.21 \mathrm{E}+00$ & $5.74 \mathrm{E}-04$ & $7.89 \mathrm{E}-04$ & $1.51 \mathrm{E}-05$ \\
\hline RH106 & $1.21 \mathrm{E}+00$ & $4.13 E-06$ & $2.78 \mathrm{E}-09$ & $1.46 \mathrm{E}-11$ \\
\hline SB125 & $2.61 \mathrm{E}-01$ & $3.65 \mathrm{E}-06$ & $9.44 \mathrm{E}-07$ & $1.78 \mathrm{E}-05$ \\
\hline TE125M & $6.38 \mathrm{E}-02$ & $4.58 \mathrm{E}-07$ & $5.10 \mathrm{E}-06$ & $2.16 \mathrm{E}-08$ \\
\hline $\operatorname{cs} 134$ & $1.24 \mathrm{E}+02$ & $5.77 E-03$ & $1.14 \mathrm{E}-02$ & $2.20 \mathrm{E}-02$ \\
\hline $\operatorname{cs} 137$ & 1. $61 \mathrm{E}+03$ & $6.50 \mathrm{E}-02$ & $9.63 E-01$ & 8. $42 \mathrm{E}-01$ \\
\hline BA137M & $1.52 E+01$ & $1.44 \mathrm{E}-04$ & $1.05 E-10$ & $2.64 \mathrm{E}-09$ \\
\hline CE144 & $1.97 \mathrm{E}-02$ & $7.24 E-06$ & $2.30 E-08$ & $5.25 E-08$ \\
\hline PR144 & $1.97 \mathrm{E}-02$ & $1.39 \mathrm{E}-09$ & $5.81 \mathrm{E}-15$ & $1.47 \mathrm{E}-12$ \\
\hline PM147 & $1.40 E+00$ & $5.40 \mathrm{E}-05$ & $2.85 E-07$ & $7.19 \mathrm{E}-09$ \\
\hline SM151 & $7.64 \mathrm{E}-02$ & $2.25 \mathrm{E}-06$ & $4.88 E-08$ & $4.86 \mathrm{E}-10$ \\
\hline EU154 & $9.84 \mathrm{E}-01$ & $2.78 \mathrm{E}-04$ & $5.35 E-06$ & $5.13 E-04$ \\
\hline EU155 & $3.78 E-01$ & $1.54 \mathrm{E}-05$ & $2.00 E-07$ & $6.00 \mathrm{E}-06$ \\
\hline PU238 & $8.04 \mathrm{E}-01$ & $3.11 \mathrm{E}-01$ & $3.53 \mathrm{E}-04$ & $8.50 \mathrm{E}-07$ \\
\hline PU239 & $6.11 \mathrm{E}-02$ & $2.58 \mathrm{E}-02$ & $3.51 \mathrm{E}-05$ & $3.35 E-08$ \\
\hline PU240 & $9.57 \mathrm{E}-02$ & $4.05 E-02$ & $5.48 E-05$ & 1. $14 \mathrm{E}-07$ \\
\hline PU241 & $1.68 \mathrm{E}+01$ & $1.36 \mathrm{E}-01$ & $7.98 E-05$ & $5.58 \mathrm{E}-08$ \\
\hline AM2 41 & $3.82 \mathrm{E}-01$ & $1.67 \mathrm{E}-01$ & $2.20 \mathrm{E}-04$ & $1.51 \mathrm{E}-05$ \\
\hline CM2 44 & $7.76 \mathrm{E}-01$ & $1.89 \mathrm{E}-01$ & $1.27 \mathrm{E}-03$ & $5.03 \mathrm{E}-07$ \\
\hline CD113M & $5.10 \mathrm{E}-03$ & $7.67 \mathrm{E}-06$ & $6.78 E-05$ & $8.23 E-10$ \\
\hline sucat & $2.97 E+04$ & $1.00 E+00$ & $1.00 E+00$ & $1.00 \mathrm{E}+00$ \\
\hline
\end{tabular}

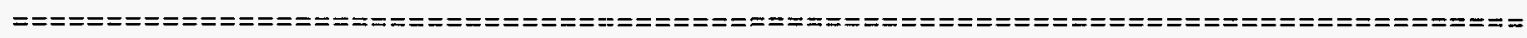

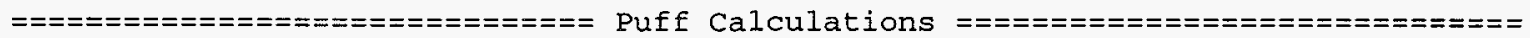

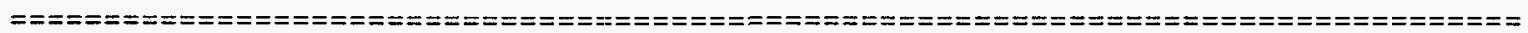

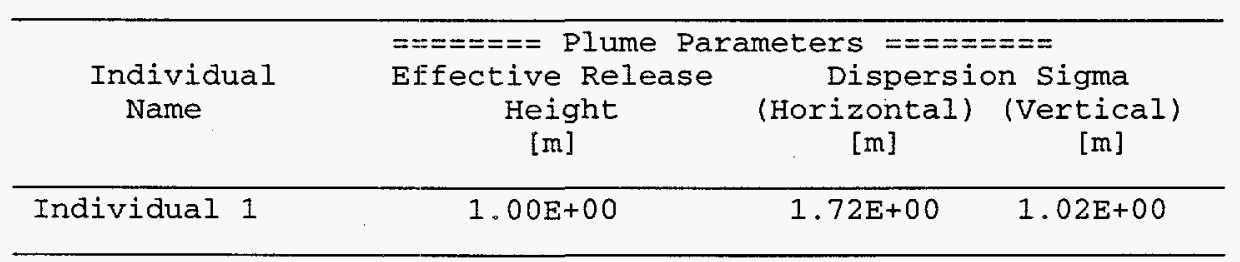




\begin{tabular}{ccccc}
\hline $\begin{array}{c}\text { Individual } \\
\text { Name }\end{array}$ & $\begin{array}{c}====\mathrm{Chi} / \mathrm{Q} \\
\mathrm{Air} \\
{[\mathrm{s} / \mathrm{m} 3]}\end{array}$ & $\begin{array}{c}===== \\
\text { Ground } \\
{[1 / \mathrm{m} 2]}\end{array}$ & $\begin{array}{c}\text { Depletion } \\
\text { Fraction }\end{array}$ & $\begin{array}{c}\text { Wet/Dry } \\
\text { Ratio }\end{array}$ \\
\hline $\begin{array}{c}\text { Individual 1 } \\
\text { Particulates }\end{array}$ & $1.02 \mathrm{E}-01$ & $1.02 \mathrm{E}-03$ & $9.12 \mathrm{E}-02$ & $0.00 \mathrm{E}+00$ \\
Ruthenium & $1.02 \mathrm{E}-01$ & $1.02 \mathrm{E}-03$ & $9.12 \mathrm{E}-02$ & $0.00 \mathrm{E}+00$ \\
Cesium & $1.02 \mathrm{E}-01$ & $1.02 \mathrm{E}-03$ & $9.12 \mathrm{E}-02$ & $0.00 \mathrm{E}+00$ \\
Iodine & $1.02 \mathrm{E}-01$ & $1.02 \mathrm{E}-03$ & $9.12 \mathrm{E}-02$ & $0.00 \mathrm{E}+00$ \\
Gases & $1.12 \mathrm{E}-01$ & $0.00 \mathrm{E}+00$ & $0.00 \mathrm{E}+00$ & $0.00 \mathrm{E}+00$ \\
\hline
\end{tabular}




\begin{tabular}{|c|c|c|}
\hline Individual Summary Results & Per Accident & \\
\hline $\begin{array}{l}\text { Committed Effective Dose Equivalent } \\
\text { Expected Genetic Effects } \\
\text { Expected Non-fatal Cancers } \\
\text { Expected Cancer Fatalities } \\
\text { Acute Risk (Expected fatalities) }\end{array}$ & $\begin{array}{l}2.62 \mathrm{E}+04 \\
6.81 \mathrm{E}+00 \\
5.24 \mathrm{E}+00 \\
1.00 \mathrm{E}+00 \\
1.00 \mathrm{E}+00\end{array}$ & rem \\
\hline
\end{tabular}

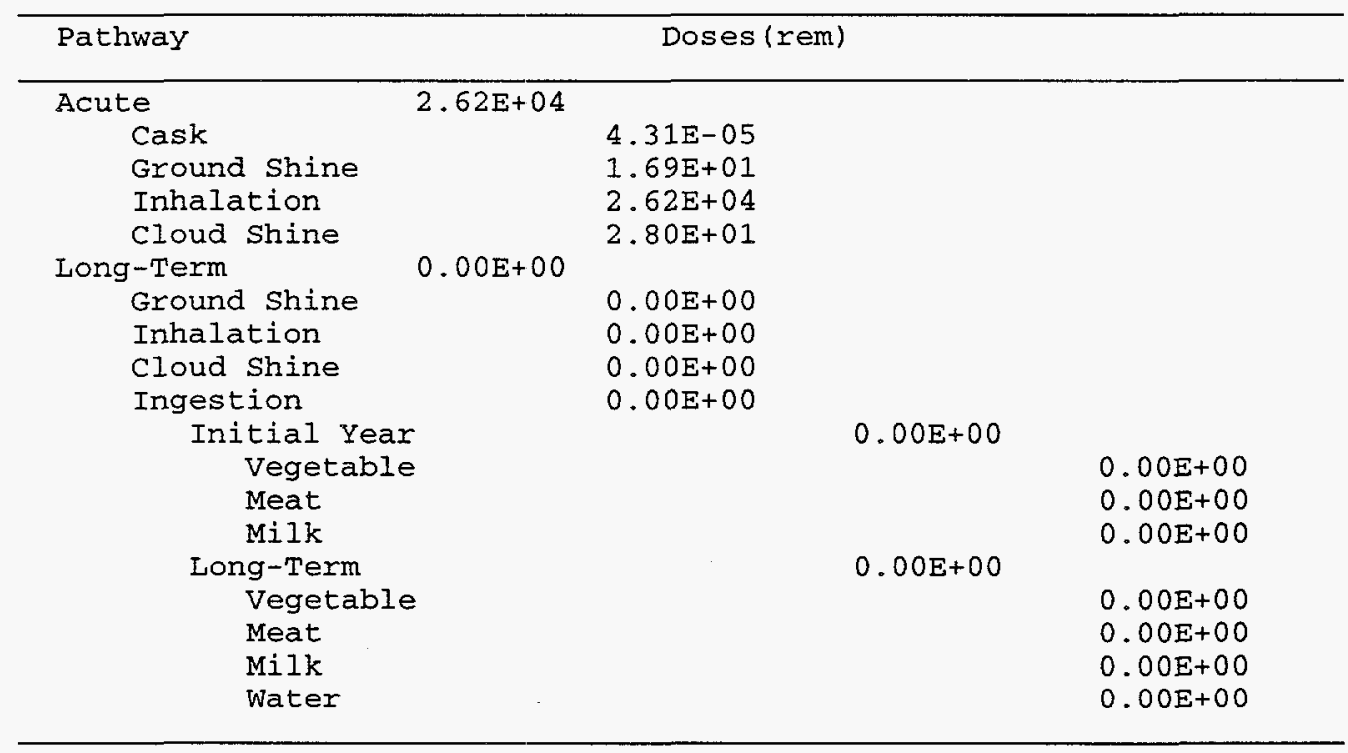

\begin{tabular}{lcccc}
\hline Exposure Parameter & Organ $\begin{array}{c}\text { Exposure } \\
\text { Marrow }\end{array}$ & Lung & Intestine & Gonads \\
\hline Long-Term Dose [rem] & $3.51 \mathrm{E}+04$ & $1.54 \mathrm{E}+04$ & $1.78 \mathrm{E}+03$ & $2.85 \mathrm{E}+03$ \\
Brief Dose [Gy] & $5.90 \mathrm{E}-01$ & $1.44 \mathrm{E}+01$ & $1.51 \mathrm{E}+01$ & 1 \\
Brief Exposure Time [d] & $1.00 \mathrm{E}+00$ & $1.00 \mathrm{E}+00$ & $1.00 \mathrm{E}+00$ \\
Brief Dose Rate [Gy/hr] & $2.54 \mathrm{E}-01$ & $1.05 \mathrm{E}+00$ & $9.21 \mathrm{E}-01$ \\
Prolonged Dose [Gy] & $3.83 \mathrm{E}+00$ & $5.06 \mathrm{E}+01$ & $1.54 \mathrm{E}+01$ \\
Prolong Exposure Time [d] & $3.00 \mathrm{E}+01$ & $3.65 \mathrm{E}+02$ & $7.00 \mathrm{E}+00$ \\
Prolong Dose Rate [Gy/hr] & $3.65 \mathrm{E}-02$ & $8.28 \mathrm{E}-01$ & $7.03 \mathrm{E}-01$ \\
Hazard & $2.99 \mathrm{E}-01$ & $1.02 \mathrm{E}+04$ & $8.44 \mathrm{E}+02$ \\
Acute Risk [Expected fatalities] & $2.59 \mathrm{E}-01$ & $1.00 \mathrm{E}+00$ & $1.00 \mathrm{E}+00$ \\
\hline
\end{tabular}




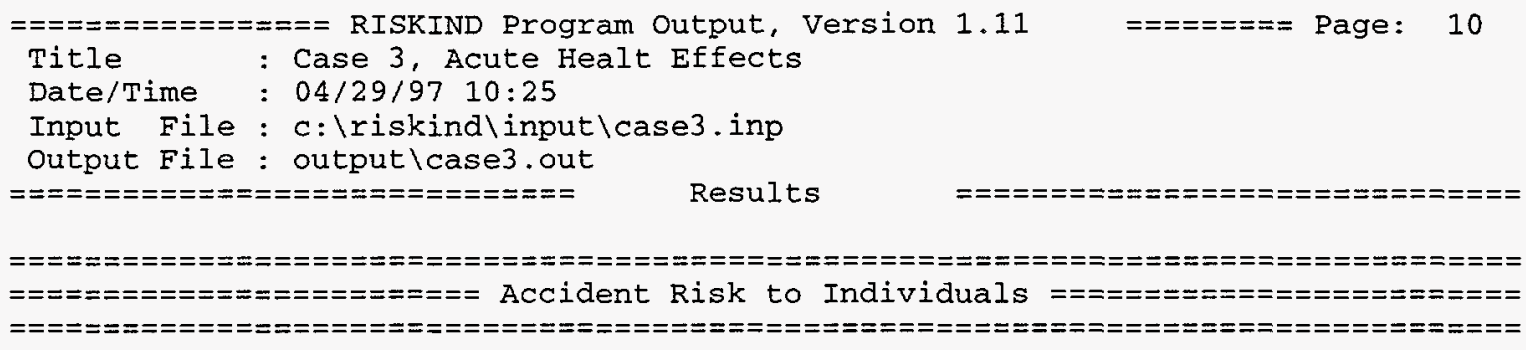

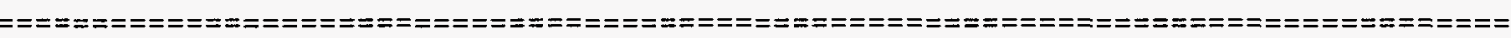

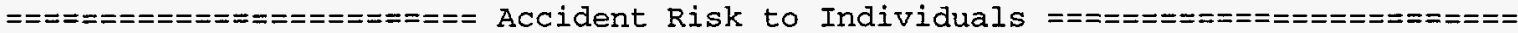

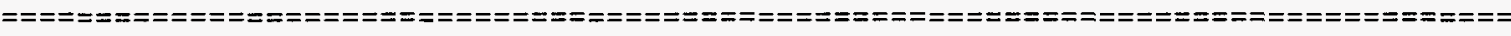

Individual Accident Dose Summary Results Consequences

\begin{tabular}{|c|c|c|c|}
\hline Acute & \multicolumn{3}{|c|}{ Total } \\
\hline $\begin{array}{c}\text { Risk } \\
\text { [Fatality] }\end{array}$ & $\begin{array}{l}\text { Expected } \\
\text { Non-Fatal } \\
\text { Cancer } \\
\text { Incidence }\end{array}$ & $\begin{array}{c}\text { Expected } \\
\text { Cancer } \\
\text { Fatalities }\end{array}$ & $\begin{array}{r}\text { Expected } \\
\text { Genetic } \\
\text { S Effects }\end{array}$ \\
\hline $2.62 \mathrm{E}+041.00 \mathrm{E}+00$ & $2.62 \mathrm{E}+04 \quad 5.24 \mathrm{E}+00$ & $1.00 \mathrm{E}+00$ & $6.81 E+00$ \\
\hline
\end{tabular}


$B-i$

APPENDIX B:

DOSE COMPARISON CASES 
$B-i i$ 


\section{CONTENTS}

B.1 Comparison with GENII ……............................................................................. B-1

B.1.1 Cs-137 Release (1 Ci) ....................................................................... B-1

B.1.1.1 RISKIND Output for Cs-137 Release ............................................. B-1

B.1.1.2 GENII Output for Cs-137 Release ..................................................... B-11

B.1.2 Spent Fuel Accident ............................................................................ B-27

B.1.2.1 RISKIND Output for Spent Fuel Accident ......................................... B-27

B.1.2.2 GENII Output for Spent Fuel Accident................................................ B-39

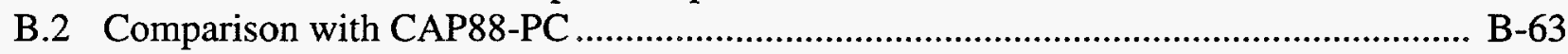

B.2.1 Cs-137 Release (1 Ci) ............................................................................ B-63

B.2.1.1 RISKIND Output for Cs-137 Release ……....................................... B-63

B.2.1.2 CAP88-PC Output for Cs-137 Release ............................................ B-72

B.2.2 Spent Fuel Accident ............................................................................. B-94

B.2.2.1 RISKIND Output for Spent Fuel Accident ......................................... B-94

B.2.2.2 CAP88-PC Output for Spent Fuel Accident ……................................... B-104 


\section{APPENDIX B: DOSE COMPARISON CASES}

\section{B.1 Comparison with GENII}

\section{B.1.1 Cs-137 Release (1 Ci)}

\section{B.1.1.1 RISKIND Output for Cs-137 Release}
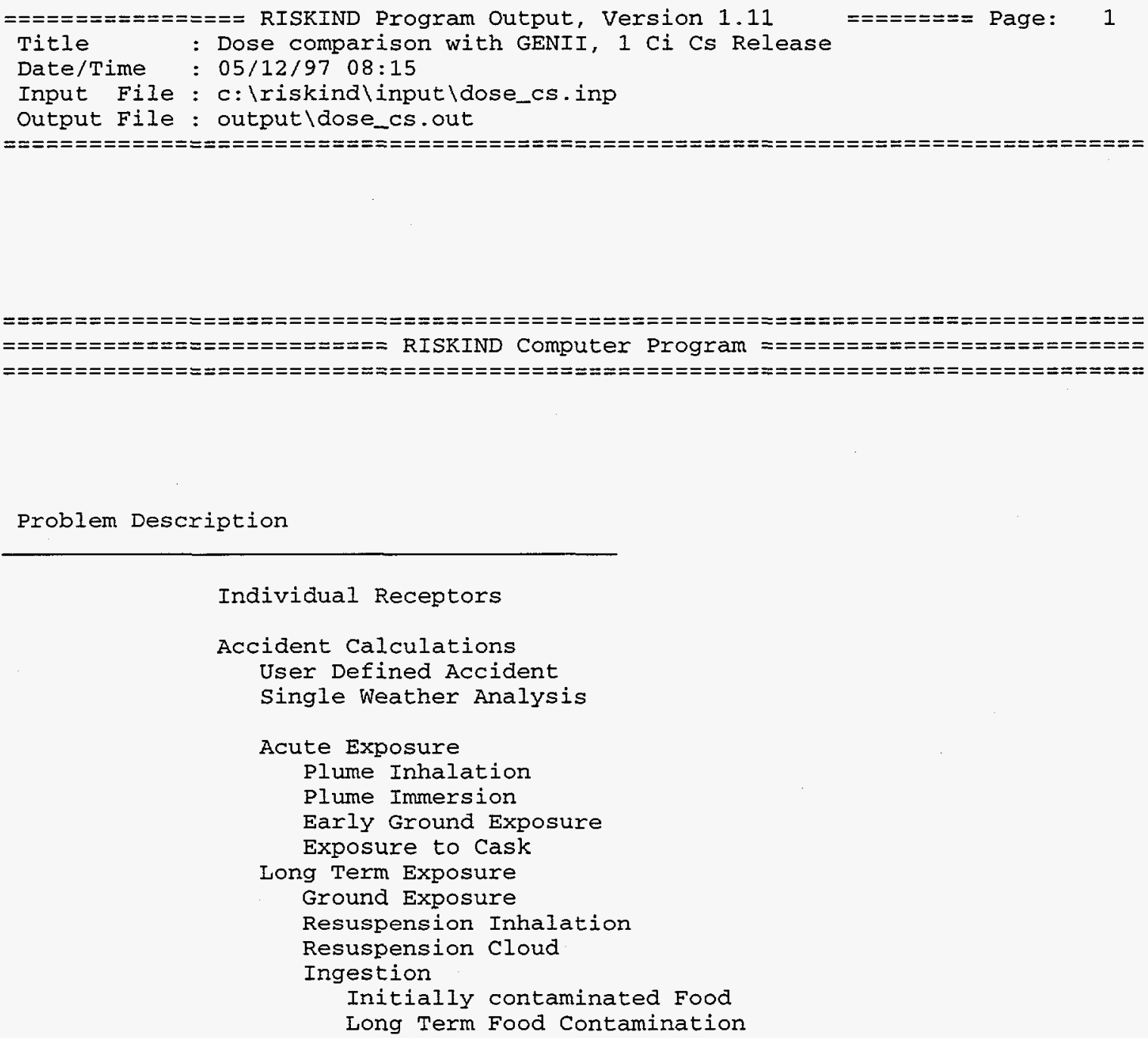


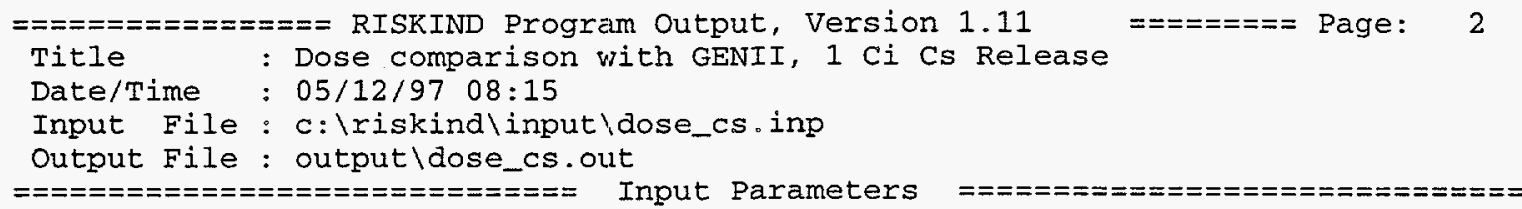

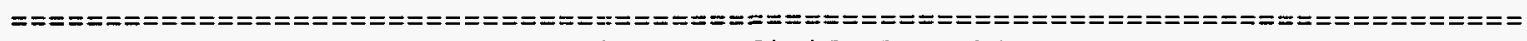

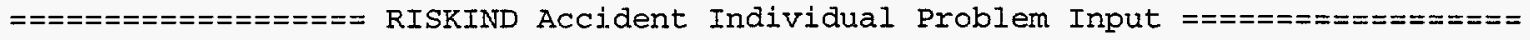

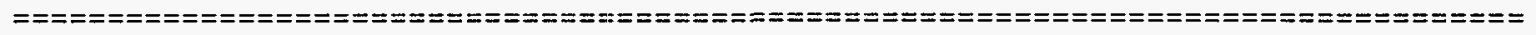

Individual Accident Parameters

State: US

Population Zone: Rural

Long-Term Exposure Duration [YEVD]: 1.00E+00 yr

Average Breathing Rate [BRTIND]: $8.00 \mathrm{E}+03 \mathrm{~m} 3 / \mathrm{yr}$ Individual type [INDTYPE]: Public

Risk Conversion Factors

Non-Fatal Cancers/rem: 1.0E-04

Fatal Cancers/rem: 5.0E-04

Genetic Effects/rem: 1.3E-04

\begin{tabular}{|c|c|c|c|c|c|c|}
\hline $\begin{array}{l}\text { Individual Name } \\
\text { [XNAME] }\end{array}$ & $\begin{array}{l}======= \\
\text { Down } \\
\text { Wind } \\
{[\mathrm{km}]}\end{array}$ & $\begin{array}{c}\text { Location } \\
\text { Cross } \\
\text { Wind } \\
\text { [km] } \\
\text { [XRECEP] }\end{array}$ & $\begin{array}{c}== \pm== \\
\text { Elevation } \\
{[\mathrm{m}]}\end{array}$ & $\begin{array}{c}\text { Acute } \\
\text { Exposure } \\
\text { Time } \\
\text { [hr] } \\
\text { [TEXT] }\end{array}$ & $\begin{array}{l}\text { Long Term } \\
\text { Exposure } \\
\text { [IRTP] }\end{array}$ & $\begin{array}{l}\text { Food } \\
\text { Ingestion } \\
\text { [IDFOOD] }\end{array}$ \\
\hline Individual 1 & $1.00 \mathrm{E}+00$ & $0.00 E+00$ & $0.00 \mathrm{E}+00$ & $2.00 \mathrm{E}+00$ & Yes & Yes \\
\hline
\end{tabular}

\begin{tabular}{|c|c|c|c|c|c|c|c|c|c|}
\hline \multirow[b]{3}{*}{ Individual Name } & \multirow{2}{*}{\multicolumn{2}{|c|}{$\begin{array}{c}\text { Shielding } \\
\text { Type }\end{array}$}} & \multirow{2}{*}{\multicolumn{2}{|c|}{$\begin{array}{l}\text { Long- } \\
\text { Term }\end{array}$}} & \multicolumn{5}{|c|}{$======$ Shielding Factors $====$} \\
\hline & & & & & Acute: & & Long & g-Tern & \\
\hline & Short & Long & In & out & Inh cld & Ext & $\operatorname{Inh}$ & $\operatorname{cld}$ & Ext \\
\hline Individual 1 & None & None & 0.00 & 0.50 & 1.001 .00 & 1.00 & 0.50 & 0.50 & 0.50 \\
\hline
\end{tabular}

Ingestion Parameters

\begin{tabular}{ccc}
\hline & $\begin{array}{c}\text { Individual } \\
\text { Consumption Rate } \\
{[\mathrm{kg} / \mathrm{d}]}\end{array}$ & $\begin{array}{c}\text { Contaminated } \\
\text { Fraction }\end{array}$ \\
\hline Food Type & {$[\mathrm{XIN}]$} & {$[\mathrm{PFIN}]$} \\
Meat & $3.00 \mathrm{E}-01$ & $1.00 \mathrm{E}+00$ \\
Milk & $8.50 \mathrm{E}-01$ & $1.00 \mathrm{E}+00$ \\
Vegetable & $1.60 \mathrm{E}+00$ & $1.00 \mathrm{E}+00$ \\
\hline
\end{tabular}




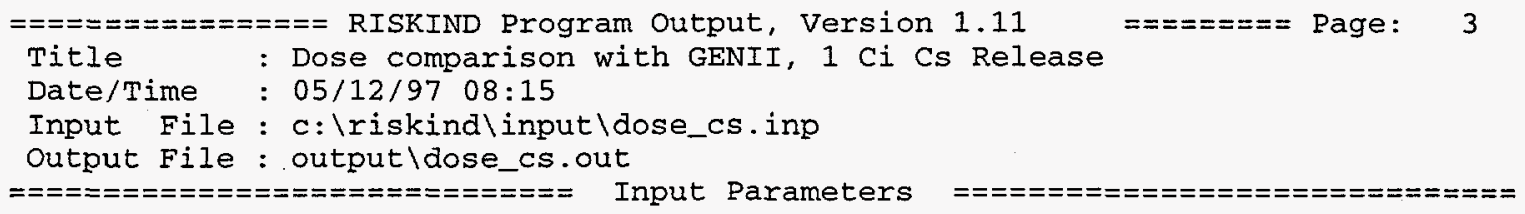

Meteorological Parameters

Dry deposition rates [VDEPNUC]

Particulates

Ruthenium

Cesium

Iodine

Gases

Rain fall rate [RAIN]:

Anemometer height [ANH] :

Ambient Temperature [TABK] :

Mixing height [DMIX] :

Wind at anemometer [WSM] :

Pasquill stability cat. [ITYPE]:

weather condition probability [METFREQ]: $1.00 \mathrm{D}+00$
$1.00 \mathrm{E}-03$

$1.00 \mathrm{E}-03$

$1.00 \mathrm{E}-02$

$0.00 E+00$

$0.00 \mathrm{E}+00$

10.00

283.00

1000.00

4.00

$+00$
$1.00 \mathrm{E}-03$

$$
\begin{array}{r}
\mathrm{m} / \mathrm{s} \\
\mathrm{m} / \mathrm{s} \\
\mathrm{m} / \mathrm{s} \\
\mathrm{m} / \mathrm{s} \\
\mathrm{m} / \mathrm{s} \\
\mathrm{mm} / \mathrm{h} \\
\mathrm{m} \\
\mathrm{K} \\
\mathrm{m} \\
\mathrm{m} / \mathrm{s}
\end{array}
$$

Transportation Mode [IMOD]: Dose at $2 \mathrm{~m}$ [TD2M] :

Measurement offset [TIOFF]: Gamma Fraction [FRAD(1)]: Neutron Fraction [FRAD(2)]: Cask Length [HSIZE]: Cask Radius [RSIZE]:
Truck

$10.00 \mathrm{mrem} / \mathrm{hr}$

0.00

0.60

0.40

5.46

0.56 $\mathrm{m}$

m 
$====\pi=== \pm========$ RISKIND Program Output, Version 1.11

$===ニ====$ Page:

Title : Dose comparison with GENII, 1 Ci Cs Release

Date/Time : 05/12/97 08:15

Input File: c: \riskind inputldose_cs.inp

output File : output $\backslash$ dose_cs.out

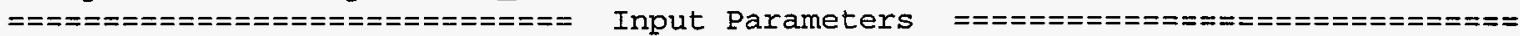

Long-Term Environmental Parameters

Removal half-life from soil [PHALF]: 50.00

Initial resuspension factor [SUFI] : 1.00E-05

Final Resuspension factor [SUFF]: 1.00E-09

Resus. factor decay halflife [RSALF] : 1.37E-01 $y r$
$1 / m$
$1 / m$
$y r$

Food Production Parameters

Food decontamination factor [DFACT] : 0.50

Cow's ingestion rate of grass [QA]: 50.00

Yield of pasture grass [YIELD_COW] : 7.00E-01

Yield of edible vegetation [YIELD_HUM]: $2.00 E+00$

Time to first harvest

Pasture grass [T_HARVEST_COW]: 1.00

Vegetation [T_HARVEST_HUM] : 1.00

Pasture grass grow time [T GROW COW]:

30.00

Vegetation grow time [T_GROW_HUM]: 60.00

Deposition retention fraction [F RETATN]:

0.20

Edible vegetation fraction [F_EDBL HUM]: 1.00

Edible pasture fraction [F_EDBL_COW]: 1.00

Weathering decay const. [DECAY WEATHER] : $4.95 \mathrm{E}-02$

Effective Surface Density [EFF_SURF_DEN]: 240.00

$\mathrm{kg} / \mathrm{d}$

$\mathrm{kg} / \mathrm{m} 2$

$\mathrm{kg} / \mathrm{m} 2$

days

days

days

days

$1 /$ day

$\mathrm{kg} / \mathrm{m} 2$ 


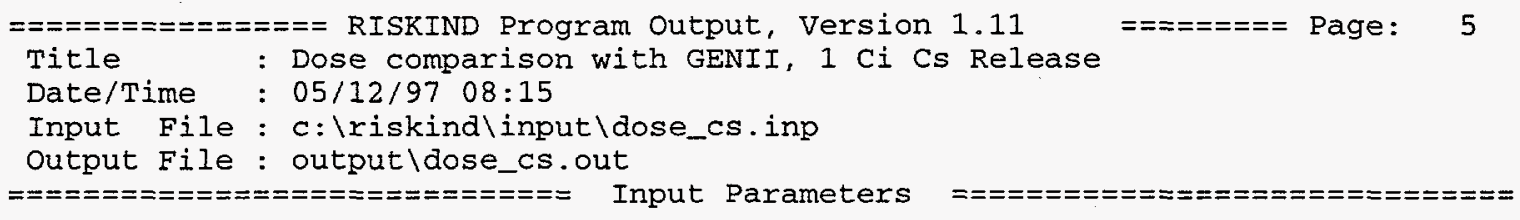

Nuclide Parameters

\begin{tabular}{|c|c|c|c|c|c|c|c|}
\hline \multirow[b]{2}{*}{$\begin{array}{l}\text { Nuclide } \\
\text { Name }\end{array}$} & \multicolumn{7}{|c|}{ Nuclide Inventory and DCFs } \\
\hline & $\begin{array}{c}\text { Inventory } \\
\text { Amount } \\
\text { [Ci] }\end{array}$ & $\begin{array}{c}======\mathrm{Do} \\
\text { Inhalation } \\
{[\mathrm{Sv} / \mathrm{Bq}]}\end{array}$ & $\begin{array}{l}\text { ose Convers } \\
\text { Ingestion } \\
\text { [Sv/Bq] }\end{array}$ & $\begin{array}{c}\text { sion Fact } \\
\text { Cloud } \\
{[\mathrm{Sv} / \mathrm{s}]} \\
{[\mathrm{Bq} / \mathrm{m} 3]}\end{array}$ & $\begin{array}{c}\text { rs }====== \\
\text { Ground } \\
{[\mathrm{Sv} / \mathrm{s}]} \\
{[\mathrm{Bq} / \mathrm{m} 2]}\end{array}$ & $\begin{array}{l}\text { Nucl. } \\
\text { Class }\end{array}$ & $\begin{array}{l}\text { Decay } \\
\text { Const. } \\
{[1 / y r]}\end{array}$ \\
\hline $\operatorname{cs137}$ & $1.00 E+00$ & $1.10 \mathrm{E}-08$ & $1.59 \mathrm{E}-08$ & $2.73 E-14$ & $5.54 E-16$ & $\mathrm{Cs}$ & $2.30 \mathrm{E}-02$ \\
\hline
\end{tabular}

Nuclide Food Transfer Parameters

\begin{tabular}{cccc}
$\begin{array}{c}\text { Nuclide } \\
\text { Name }\end{array}$ & $\begin{array}{c}\text { Soil-to-Plant } \\
\text { [unitless] }\end{array}$ & $\begin{array}{c}\text { Grass-to-Meat } \\
\text { [day/kg] }\end{array}$ & $\begin{array}{c}\text { Grass-to-Milk } \\
\text { [day/L] }\end{array}$ \\
\hline CS137 & $1.00 \mathrm{E}-02$ & $4.00 \mathrm{E}-03$ & $1.20 \mathrm{E}-02$
\end{tabular}

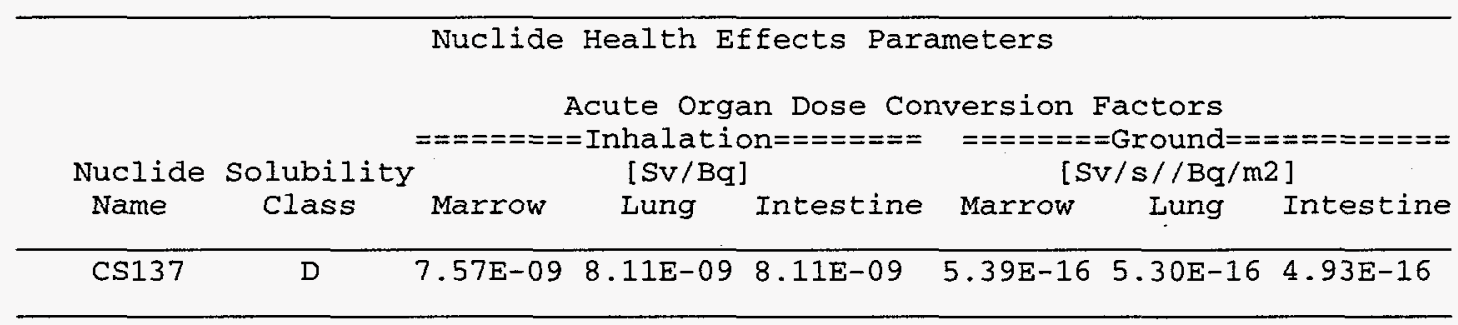


$=================$ RISKIND Program Output, Version 1.11

$==ニ=ニ=ニ==$ Page:

Title : Dose comparison with GENII, 1 Ci Cs Release

Date/Time : 05/12/97 08:15

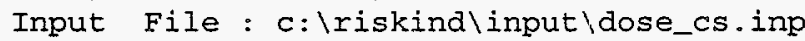

Output File : output $\backslash$ dose_cs.out

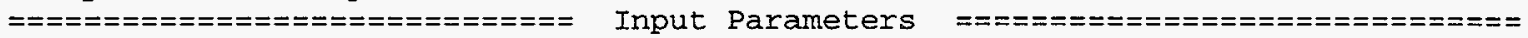

Nuclide Health Effects Parameters

Acute Organ Dose Conversion Factors

$========$ Cloudshine $========$

Name

列 $/ \mathrm{s} / \mathrm{Bq} / \mathrm{m} 3$

$\operatorname{CS} 137$

$2.59 \mathrm{E}-142.65 \mathrm{E}-14 \quad 2.48 \mathrm{E}-14$ 


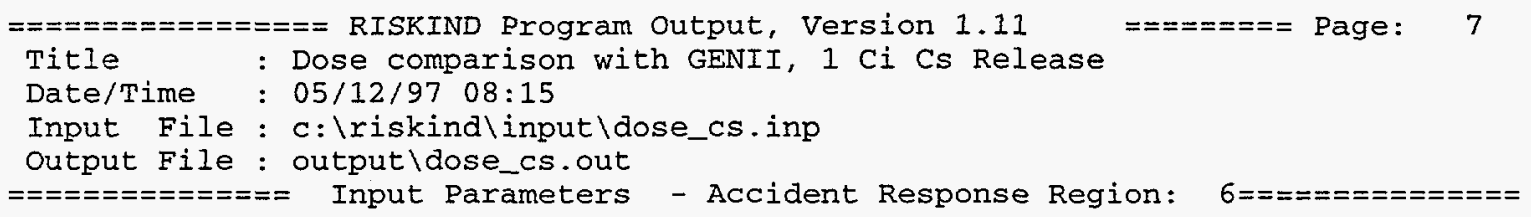

Accident Parameters

Physical Release Height [HS]: $10.00 \quad \mathrm{~m}$

Dispersion Model Coefficients [IDISPMOD] : Pasquill-Gifford

Accident Analysis Type: Risk Accident Rate [ACTA] : $1.00 \mathrm{E}+00 \quad 1 / \mathrm{km}$

Accident Response Region Determined By

$\begin{array}{rrr}\text { Accident Cask Velocity [VCASK] : } & 65.00 & \mathrm{~km} / \mathrm{h} \\ \text { Cask Impact Angle [ALPHA]: } & 90.00 & \text { Degrees } \\ \text { Cask Orientation Angle [BETA] : } & 90.00 & \text { Degrees } \\ \text { Impact Object Hardness [IHARD]: } & 1.00 & \\ \text { Flame Temperature [TFLAME]: } & 1.35 \mathrm{E}+03 & \mathrm{~K} \\ \text { Fire Duration [DFIRE] : } & 0.75 & \mathrm{hr} \\ \text { Fire Location [FLOCA]: } & 0.00 & \mathrm{~m}\end{array}$

Accident Response Region Parameters

\begin{tabular}{|c|c|c|c|c|}
\hline \multicolumn{3}{|c|}{$\begin{array}{r}\text { Response Region [IYOURS] : } \\
\text { Region Conditional Probability [FSEV] : } \\
\text { Heat Flux [HEATF] : } \\
\text { Loss of Cask Shielding Factor [SEXT] } \\
\text { Gamma: } \\
\text { Neutron: } \\
\text { Failure Rate [FAILS]: } \\
\text { Crud Spallation Rate [FSPAL]: } \\
\text { Crud Release Rate [FRCRUD]: }\end{array}$} & $\begin{array}{r}6 \\
2.33 \mathrm{E}-07 \\
0.00 \mathrm{E}+00 \\
1.00 \\
1.00 \\
1.00 \mathrm{E}+00 \\
0.00 \mathrm{E}+00 \\
1.00 \mathrm{E}+00\end{array}$ & $\mathrm{cal} / \mathrm{s}$ \\
\hline $\begin{array}{l}\text { Nuclide } \\
\text { Class } \\
\text { [NUTYPE] }\end{array}$ & $\begin{array}{l}\text { Conditional } \\
\text { Release } \\
\text { Fraction } \\
\text { [FRELS] }\end{array}$ & $\begin{array}{l}\text { Dispersion } \\
\text { Fraction } \\
\text { [FDISP] }\end{array}$ & $\begin{array}{l}\text { Rele } \\
\text { (F }\end{array}$ & $\begin{array}{l}\text { ased and Dispersed } \\
\text { Fraction } \\
\text { RELS*FAILS*FDISP) }\end{array}$ \\
\hline $\begin{array}{l}\text { Particulate } \\
\text { Ru } \\
\text { Cs } \\
\text { I } \\
\text { Gas }\end{array}$ & $\begin{array}{l}2.00 \mathrm{E}-06 \\
2.70 \mathrm{E}-05 \\
1.00 \mathrm{E}+00 \\
2.50 \mathrm{E}-03 \\
3.30 \mathrm{E}-01\end{array}$ & $\begin{array}{l}1.00 E+00 \\
1.00 E+00 \\
1.00 E+00 \\
1.00 E+00 \\
1.00 E+00\end{array}$ & & $\begin{array}{l}2.00 \mathrm{E}-06 \\
2.70 \mathrm{E}-05 \\
1.00 \mathrm{E}+00 \\
2.50 \mathrm{E}-03 \\
3.30 \mathrm{E}-01\end{array}$ \\
\hline
\end{tabular}


=="=="=========== RISKIND Program Output, Version 1.11

Title : Dose comparison with GENII, $1 \mathrm{CI}$ Cs Release

Date/Time : 05/12/97 08:15

Input File: c: Iriskind input\dose_cs.inp

Output File : output \dose_cs.out

$============$ Intermediate Cal.cs - Accident Response Region: $6==============$

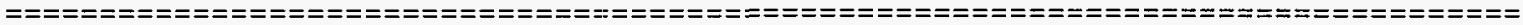

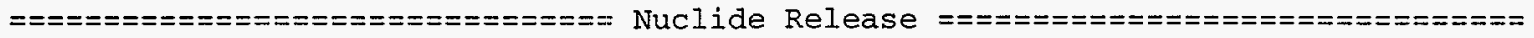

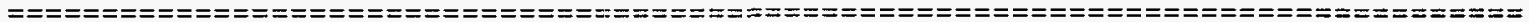

\begin{tabular}{ccccc}
\hline $\begin{array}{c}\text { Nuclide } \\
\text { Name }\end{array}$ & $\begin{array}{c}\text { Release } \\
\text { Amount } \\
\text { [Ci] }\end{array}$ & $\begin{array}{c}=======\text { Hazard Index }========= \\
\text { Inhalation Ingestion } \\
\text { Ground }\end{array}$ \\
\hline CS137 & $1.00 \mathrm{E}+00$ & $1.00 \mathrm{E}+00$ & $1.00 \mathrm{E}+00$ & $1.00 \mathrm{E}+00$ \\
\hline Total & $1.00 \mathrm{E}+00$ & $1.00 \mathrm{E}+00$ & $1.00 \mathrm{E}+00$ & $1.00 \mathrm{E}+00$
\end{tabular}

\begin{tabular}{|c|c|c|c|}
\hline $\begin{array}{l}\text { Individual } \\
\text { Name }\end{array}$ & $\begin{array}{c}\text { =:==:= }=\text { Plume Paran } \\
\text { Effective Release } \\
\text { Height } \\
\text { [m] }\end{array}$ & $\begin{array}{c}\text { meters }===== \\
\text { Dispersic } \\
\text { (Horizontal) } \\
\text { [m] }\end{array}$ & $\begin{array}{l}=== \\
\text { on Sigma } \\
\text { (Vertical) } \\
{[\mathrm{m}]}\end{array}$ \\
\hline Individual 1 & $1.00 E+01$ & $7.62 \mathrm{E}+01$ & $3.17 E+01$ \\
\hline $\begin{array}{l}\text { Individual } \\
\text { Name }\end{array}$ & $\begin{array}{cc}====\text { Chi/Q } & ====== \\
\text { Air } & \text { Ground } \\
{[\mathrm{s} / \mathrm{m} 3]} & {[1 / \mathrm{m} 2]}\end{array}$ & $\begin{array}{l}\text { Depletion } \\
\text { Fraction }\end{array}$ & $\begin{array}{l}\text { Wet/Dry } \\
\text { Ratio }\end{array}$ \\
\hline $\begin{array}{l}\text { Individual } 1 \\
\text { Particulates } \\
\text { Ruthenium } \\
\text { Cesium } \\
\text { Iodine } \\
\text { Gases }\end{array}$ & $\begin{array}{l}3.11 E-05 \\
3.11 E-05 \\
3.11 E-05 \\
2.89 E-05 \\
3.14 E-05\end{array}$ & $\begin{array}{l}7.94 \mathrm{E}-03 \\
7.94 \mathrm{E}-03 \\
7.94 \mathrm{E}-03 \\
7.67 \mathrm{E}-02 \\
0.00 \mathrm{E}+00\end{array}$ & $\begin{array}{l}0.00 E+00 \\
0.00 E+00 \\
0.00 E+00 \\
0.00 E+00 \\
0.00 E+00\end{array}$ \\
\hline
\end{tabular}




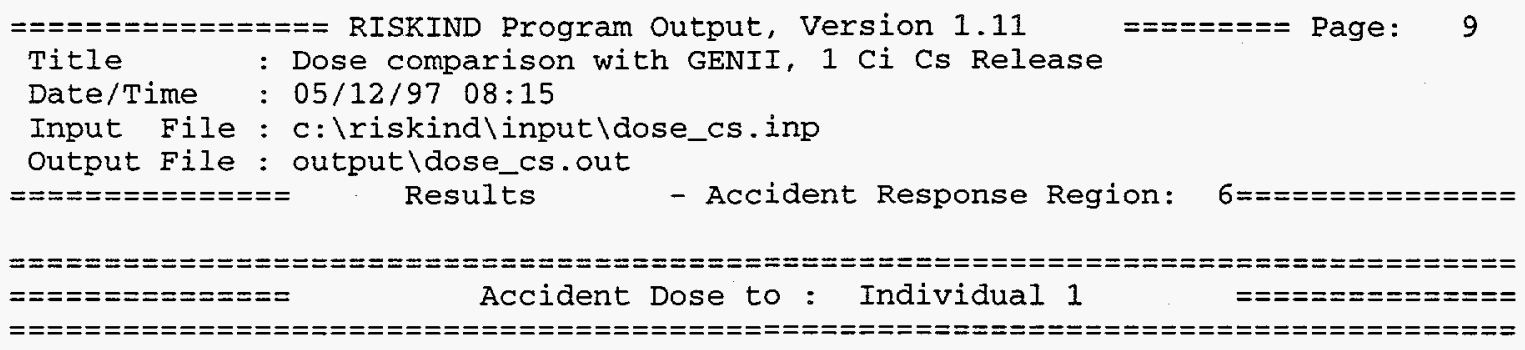

Individual Summary Results Per Accident

$\begin{array}{ll}\text { Committed Effective Dose Equivalent Risk } & 1.56 \mathrm{E}-01 \\ \text { Expected Genetic Effects } & 2.03 \mathrm{E}-05 \\ \text { Expected Non-fatal Cancers } & 1.56 \mathrm{E}-05 \\ \text { Expected Cancer Fatalities } & 7.81 \mathrm{E}-05 \\ \text { Acute Risk (Expected fatalities) } & 0.00 \mathrm{E}+00\end{array}$

\begin{tabular}{|c|c|c|c|c|}
\hline Pathway & & Doses (rem) & & \\
\hline Acute & $3.25 E-04$ & & & \\
\hline Cask & & $5.37 \mathrm{E}-10$ & & \\
\hline Ground Shine & & $4.59 \mathrm{E}-07$ & & \\
\hline Inhalation & & $3.21 \mathrm{E}-04$ & & \\
\hline Cloud Shine & & $3.14 E-06$ & & \\
\hline Long-Term & $1.56 \mathrm{E}-01$ & & & \\
\hline Ground Shine & & $9.87 \mathrm{E}-04$ & & \\
\hline Inhalation & & $9.88 \mathrm{E}-06$ & & \\
\hline Cloud Shine & & $9.67 E-08$ & & \\
\hline Ingestion & & $1.55 \mathrm{E}-01$ & & \\
\hline Initial Year & & & 1. $54 \mathrm{E}-01$ & \\
\hline Vegetable & & & & 5.09E-02 \\
\hline Meat & & & & $1.09 \mathrm{E}-02$ \\
\hline Milk & & & & $9.27 E-02$ \\
\hline Long-Term & & & $4.96 \mathrm{E}-04$ & \\
\hline Vegetable & & & & $1.94 E-04$ \\
\hline Meat & & & & $3.18 \mathrm{E}-05$ \\
\hline Milk & & & & $2.70 E-04$ \\
\hline Water & & & & $0.00 E+00$ \\
\hline
\end{tabular}

\begin{tabular}{lcccc}
\hline Exposure Parameter & Organ Exposure & Lung & Intestine & Gonads \\
& Marrow & & & \\
\hline Long-Term Dose [rem] & $1.53 \mathrm{E}-01$ & $1.48 \mathrm{E}-01$ & $1.41 \mathrm{E}-01$ & $7.61 \mathrm{E}+00$ \\
Brief Dose [Gy] Time [d] & $5.83 \mathrm{E}-08$ & $2.40 \mathrm{E}-06$ & $2.29 \mathrm{E}-06$ & \\
Brief Exposure Time & $1.00 \mathrm{E}+00$ & $1.00 \mathrm{E}+00$ & $1.00 \mathrm{E}+00$ \\
Brief Dose Rate [Gy/hr] & $1.81 \mathrm{E}-08$ & $1.54 \mathrm{E}-07$ & $1.10 \mathrm{E}-07$ \\
Prolonged Dose [Gy] & $6.09 \mathrm{E}-07$ & $2.37 \mathrm{E}-06$ & $2.37 \mathrm{E}-06$ \\
Prolong Exposure Time [d] & $3.00 \mathrm{E}+01$ & $3.65 \mathrm{E}+02$ & $7.00 \mathrm{E}+00$ \\
Prolong Dose Rate [Gy/hr] & $8.45 \mathrm{E}-10$ & $1.37 \mathrm{E}-07$ & $9.11 \mathrm{E}-08$ \\
Hazard & $0.00 \mathrm{E}+00$ & $0.00 \mathrm{E}+00$ & $0.00 \mathrm{E}+00$ \\
Acute Risk [Expected fatalities] & $0.00 \mathrm{E}+00$ & $0.00 \mathrm{E}+00$ & $0.00 \mathrm{E}+00$
\end{tabular}


$============= \pm==$ RISKIND Program Output, Version 1.11

$==\boldsymbol{=}=\mathbf{=}=\mathbf{=}$ Page:

Title

: Dose comparison with GENII, 1 Ci Cs Release

Date/Time : 05/12/97 08:15

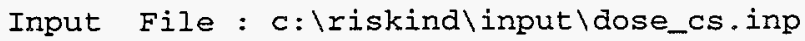

Output File : output \ase_cs.out

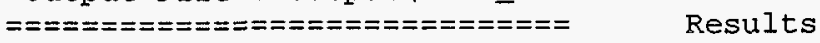

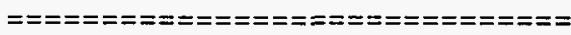

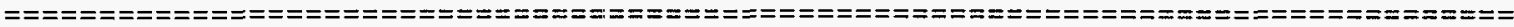

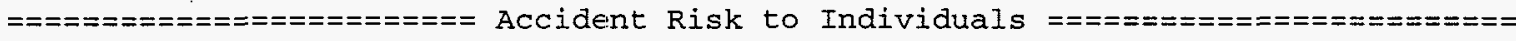

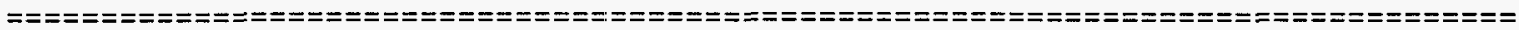

Individual Accident Dose Summary Results Dose Risks reported on a per $\mathrm{km}$ basis

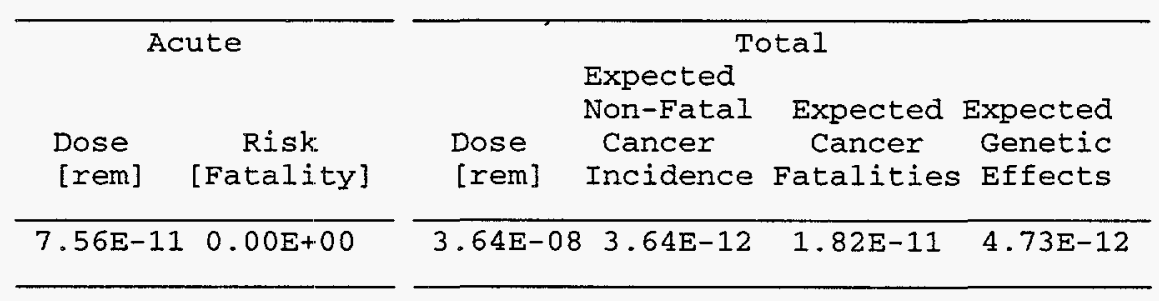




\section{B.1.1.2 GENII Output for Cs-137 Release}

$\begin{array}{lllllr}\text { Default value changed from } & 8.0 \mathrm{E}-01 \text { to } & 1.0 \mathrm{E}+00 \text { for parameter } & \text { FRACUT }(\mathrm{n}) \\ \text { Default value changed from } & 2.7 \mathrm{E}+02 \text { to } & 2.5 \mathrm{E}+02 \text { for parameter } & \text { RINH } \\ \text { Default value changed from } & 3.3 \mathrm{E}+02 \text { to } & 2.5 \mathrm{E}+02 \text { for parameter } & \text { RINHA }\end{array}$

GENII Dose Calculation Program

(Version 1.485 3-Dec-90)

Case title: Dose comparison with RISKIND, 1 Ci Cs release

Executed on: 05/08/97 at 09:37:31 $\quad$ Page A. 1

This is a far-field (wide-scale release, multiple site) scenario.

Release is acute

Individual dose

THE FOLLOWING TRANSPORT MODES ARE CONSIDERED

Air

THE FOLLOWING EXPOSURE PATHS ARE CONSIDERED:

Infinite plume, external

Ground, external

Inhalation uptake

Terrestrial foods ingestion

Animal product ingestion

THE FOLLOWING TIMES ARE USED:

Intake ends after (yr):

1.0

Dose calculations ends after $(y x):=50.0$

$=========$ FILENAMES AND TITLES OF FILES/LIBRARIES USED $======================$

Input file name: dose_cs.in

GENII Default Parameter Values w/ some RISKIND defaults (5/08/97 bb)

Radionuclide Master Library (11/28/90 RAP)

Food Transfer Factor Library - (RAP 29-Aug-88) (UPDATED LEACHING FA

External Dose Factors for GENII in person Sv/Yr per Bq/n 18 -May-90 $R$

Internal Dose Increments, Worst Case Solubilities, 12/3/90 PDR

$4.0 \mathrm{~m} / \mathrm{s}$ avg. wind speed, $100 \%$ persistence towards $\mathrm{s}$, class $\mathrm{D}, 6 / 6 / 94 \mathrm{bb}$

\begin{tabular}{|c|c|}
\hline & 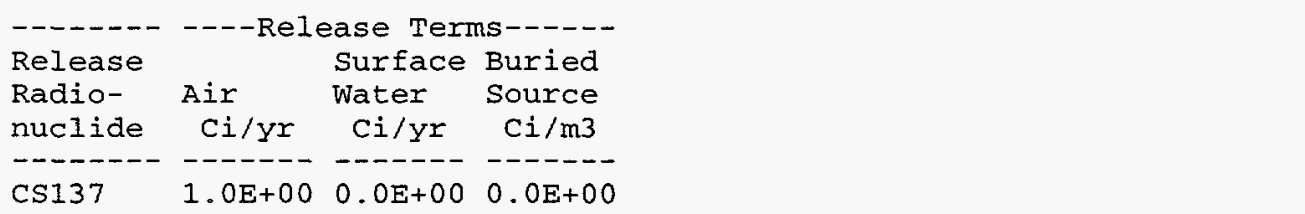 \\
\hline $\begin{array}{l}======== \\
\text { 1. } 0 E+03 \\
\text { 1. } 0 E+00 \\
1.0 E+01\end{array}$ & $\begin{array}{l}\text { AIR TRANSPORT }================================================= \\
\text { Joint frequency data input. } \\
\text { Maximum individual distance from release point }(\mathrm{m}) \\
\text { Maximum individual sector index (Wind Toward } \mathrm{S} \text { ) } \\
\text { Effective stack height }(\mathrm{m})\end{array}$ \\
\hline $\begin{aligned}= & ======== \\
& 1.0 \mathrm{E}+00 \\
& 4.4 \mathrm{E}+03\end{aligned}$ & $\begin{array}{l}\text { EXTERNAL EXPOSURE }============================================= \\
\text { Fraction of time spent in cloud } \\
\text { Hours of exposure to ground contamination }\end{array}$ \\
\hline
\end{tabular}




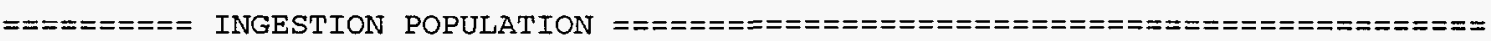

1 Atmospheric production definition: 1 - Use population-weighted chi/Q

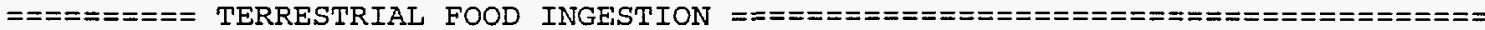

\begin{tabular}{|c|c|c|c|c|c|c|c|}
\hline & GROW & \multicolumn{2}{|c|}{ - - IREIGATION-- } & & PROD- & \multicolumn{2}{|c|}{--CONSUMPTION-- } \\
\hline FOOD & TIME & S RAT'E & TIME & YIELD & UCTION & HOLDUP & RATE \\
\hline TYPE & $d$ & * in/yr & mo/yr & $\mathrm{kg} / \mathrm{m} 2$ & $\mathrm{~kg} / \mathrm{yr}$ & $\mathrm{d}$ & $\mathrm{kg} / \mathrm{yr}$ \\
\hline----- & --1 & $----m$ & ----- & ----- & ------- & -- & \\
\hline Leaf Veg & 60 & 0.0 & 0.0 & 2.0 & & 0.0 & 1.91 \\
\hline
\end{tabular}

エニニニニニニニニニ

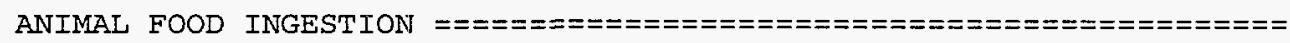

- - HUMAN--.. TOTAL DRINK CONSUMPTION RATE HOLDUP UCTION CONTAM

DIET GROW

-IRRIGATION--

FRAC- TIME S RATE TIME

FRACT. TION d

$\mathrm{kg} / \mathrm{yr}$ d $\mathrm{kg} / \mathrm{yr}$

-.- - -

--- - - -

* in/yr mo/yr

- ----- ----

0.00

0.00

0.0

1. $1 E+02$

0.0

Meat

Cow Milk

\subsection{0}

0.0

0.0

0.0

0.0

YIELD AGE

$\mathrm{kg} / \mathrm{m} 3 \mathrm{~d}$

$---\cdots-\cdots$

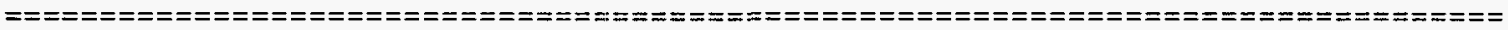

Input prepared by:

Date:

Input checked by:

Date: 


\section{$B-13$}

GENII Dose Calculation Program

(Version 1.485 3-Dec-90)

Case title: Dose comparison with RISKIND, $1 \mathrm{Ci}$ Cs release

Executed on: 05/08/97 at 09:37:31

Page A. 2

\begin{tabular}{|c|c|c|c|c|}
\hline Probability & $\begin{array}{c}E / Q \\
(\mathrm{sec} / \mathrm{m} 3)\end{array}$ & $\begin{array}{l}\mathrm{DOQ} \\
(\mathrm{m} 2\rangle\end{array}$ & $\begin{array}{l}\text { Travel } \\
\text { Time } \\
\text { (sec) }\end{array}$ & $\begin{array}{c}\text { Weighted } \\
\text { E/Q } \\
\text { (person-sec/m3) }\end{array}$ \\
\hline
\end{tabular}

Sector index: 1 $(\mathrm{sec} / \mathrm{m} 3)$

(m2)

Distance: 1000.0
0.5000
3. $2 E-05$
3. $2 \mathrm{E}-07$
3. $2 \mathrm{E}-07$
250 .
0.5000
3. $2 E-05$
3. $2 \mathrm{E}-07$
0.5000
3. $2 \mathrm{E}-05$
3. $2 \mathrm{E}-07$
0.5000
3. $2 \mathrm{E}-05$
$0.0 E+00$
250 .
250 .
0.0000
$0.0 \mathrm{E}+00$
50.
Population-
ighted
(person-sec/m3)




\section{$B-14$}

GENII Dose Calculation Program

(Version 1.485 3-Dec-90)

Case title: Dose comparison with RISKIND, $1 \mathrm{Ci}$ Cs release

Executed on: 05/08/97 at 09:37:35

Page B. 1

3. $2 \mathrm{E}-05$ Individual $\mathrm{E} / \mathrm{Q}$ 


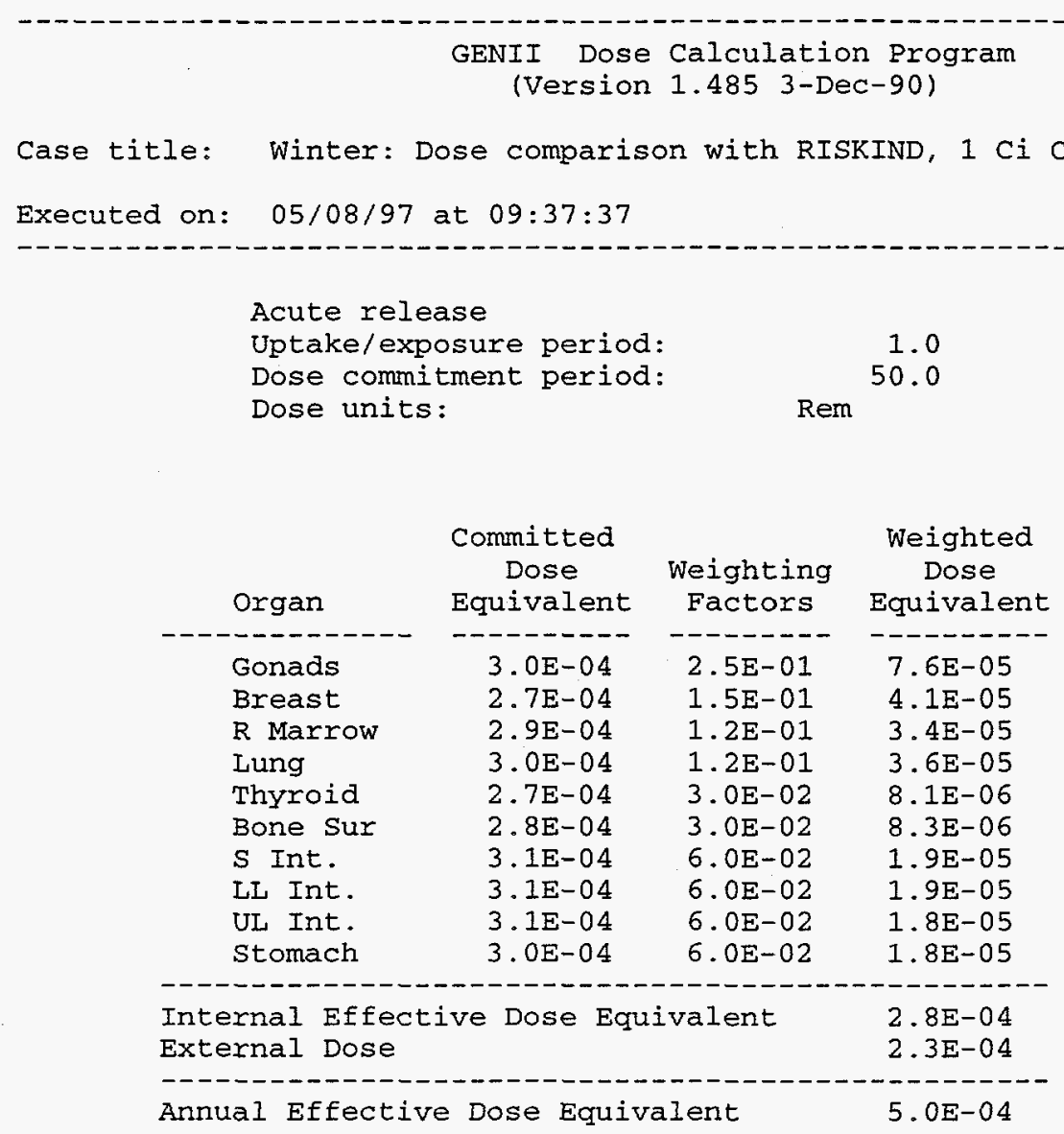

Controlling organ:

Controlling Pathway:

Controlling Radionuclide:

Total Inhalation EDE:

Total Ingestion EDE:
Page C. 1 
GENII Dose Calculation Program

(Version 1.4853 -Dec-90)

Case title: Winter: Dose comparison with RISKIND, 1 Ci Cs release

Executed on: $05 / 08 / 97$ at $09: 37: 37$

Page C. 2

Acute release

Uptake/exposure period:

Dose commitment period:

Dose units:

1.0

50.0

Rem

Dose Commitment Year

1

2

3

Internal
Intake
Year:

Internal
Annual
Dose

External

Annual

Dose

Annual

Dose
$:$
3
2
1

$2.5 \mathrm{E}-04+$

$0.0 E+00$
+

$+$

11

11

1

$2.5 E-04+2.4 E-0.5+2.4 E-06+\ldots=2.8 E-04$

$0.0 \mathrm{E}+00$

$0.0 \mathrm{E}+00 \quad \ldots$

$+2.4 \mathrm{E}-06+\ldots=2.8 \mathrm{E}-04$

11
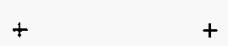

$+$

$+$
$2 \cdot 3 E-04$
$0.0 \mathrm{E}+00$
$0.0 E+00$
$\cdots$
$2.3 E-04$
11
11
| 1
|

$4.8 \mathrm{E}-04+2.4 \mathrm{E}-0.5+2.4 \mathrm{E}-06+\ldots$
$5.0 \mathrm{E}-04$

Cumulative

Dose

Maximum

4. 8E-04 Annual

Dose Occurred

In Year 1 


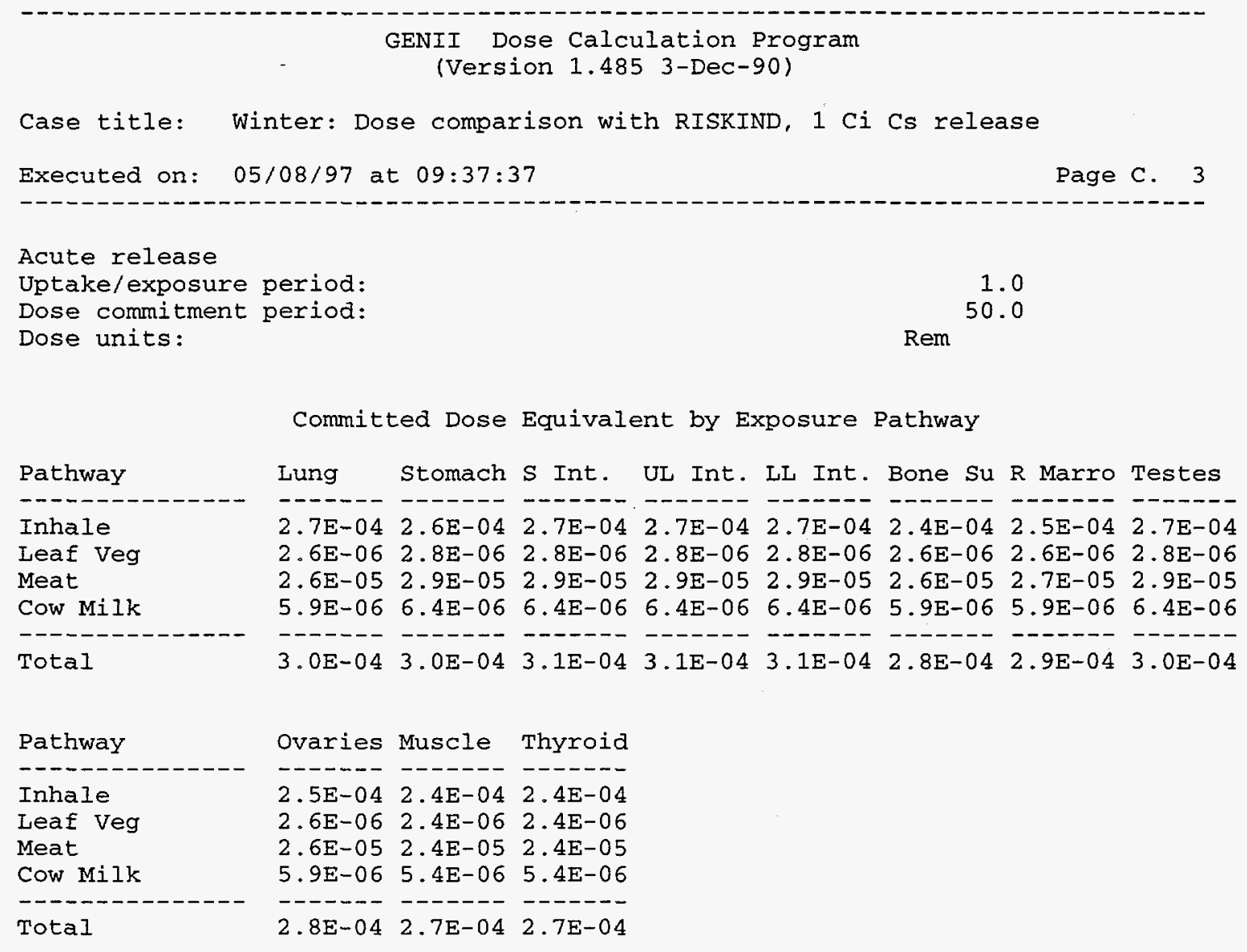

External Dose by Exposure Pathway

Pathway

\begin{tabular}{ll}
\hline Plume & $3.6 \mathrm{E}-06$ \\
Sur Soil & $2.2 \mathrm{E}-04$ \\
\hdashline------ \\
Total & $2.3 \mathrm{E}-04$
\end{tabular}


GENII Dose Calculation Program

(Version 1.485 3-Dec-90)

Case title: Spring: Dose comparison with RISKIND, 1 Ci Cs release

Executed on: $05 / 08 / 97$ at $09: 37: 38$

Page C. 4

Acute release

Uptake/exposure period:

Dose commitment period:

Dose units:

1.0

50.0

Rem

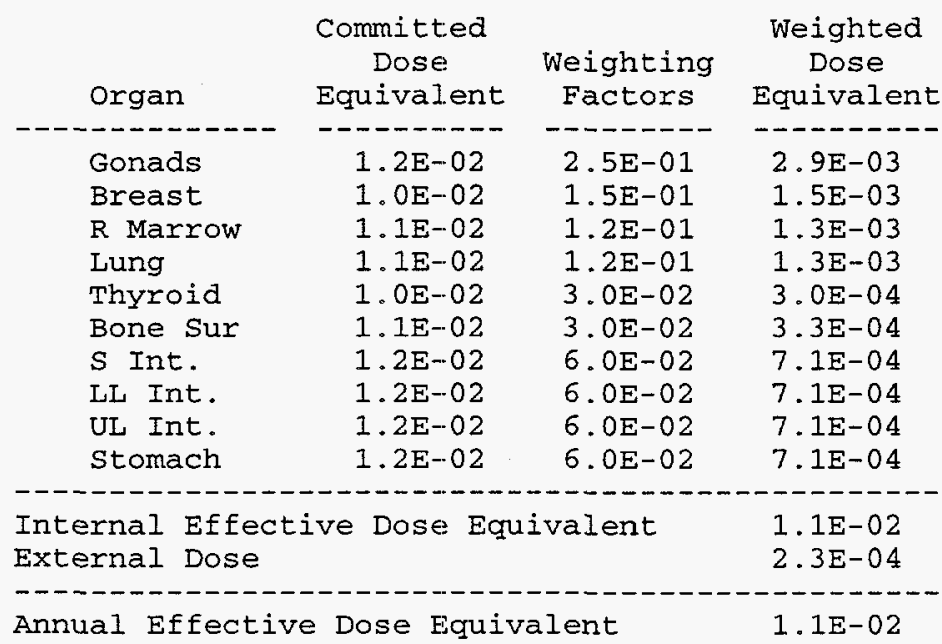

$\begin{array}{ll}\text { Controlling Organ: } & \text { S Int. } \\ \text { Controlling Pathway: } & \text { Ing } \\ \text { Controlling Radionuclide: } & \text { CSI37 } \\ - & \\ \text { Total Inhalation EDE: } & 2.4 \mathrm{E}-04 \\ \text { Total Ingestion EDE: } & 1.0 \mathrm{E}-02\end{array}$


GENII Dose Calculation Program

(Version 1.485 3-Dec-90)

Case title: Spring: Dose comparison with RISKIND, 1 Ci Cs release

Executed on: $05 / 08 / 97$ at $09: 37: 38$

Page C. 5

Acute release

Uptake/exposure period:

Dose commitment period:

Dose units :

1.0

Rem

Dose Commitment Year

1

2

3

$\begin{array}{ll}\text { Internal } & : \\ \text { Intake } & : \\ \text { Year: } & 3 \\ & 2 \\ & 1\end{array}$

\begin{tabular}{l|}
$:$ \\
3 \\
1
\end{tabular}

$+2$

Internal

Annual

Dose

External

Annual

Dose

Annual

Dose

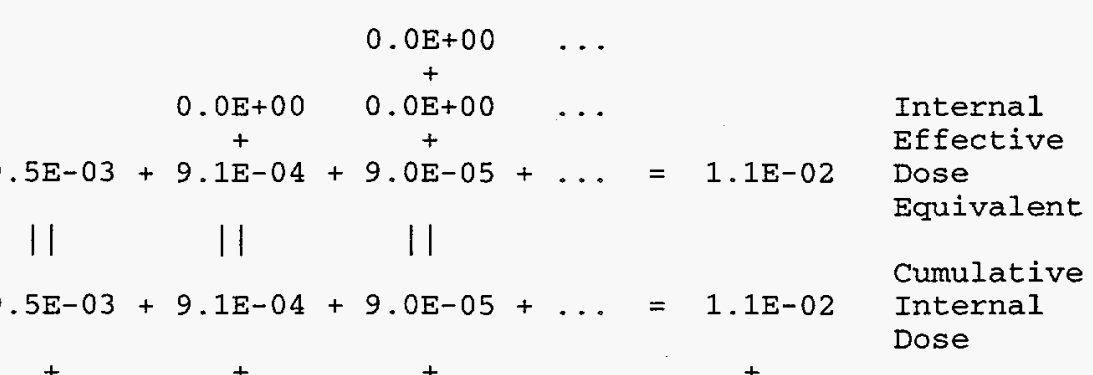

$2 \cdot 3 \mathrm{E}-04$

$0.0 E+00$

$0.0 E+00$

2. 3E-04

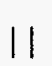

11

11

11

$9.8 \mathrm{E}-03+9.1 \mathrm{E}-04+9.0 \mathrm{E}-05+\ldots=1.1 \mathrm{E}-02$

umulative

Dose

$9.8 \mathrm{E}-03$

Maximum

Annual

Dose Occurred

In Yeax 1 


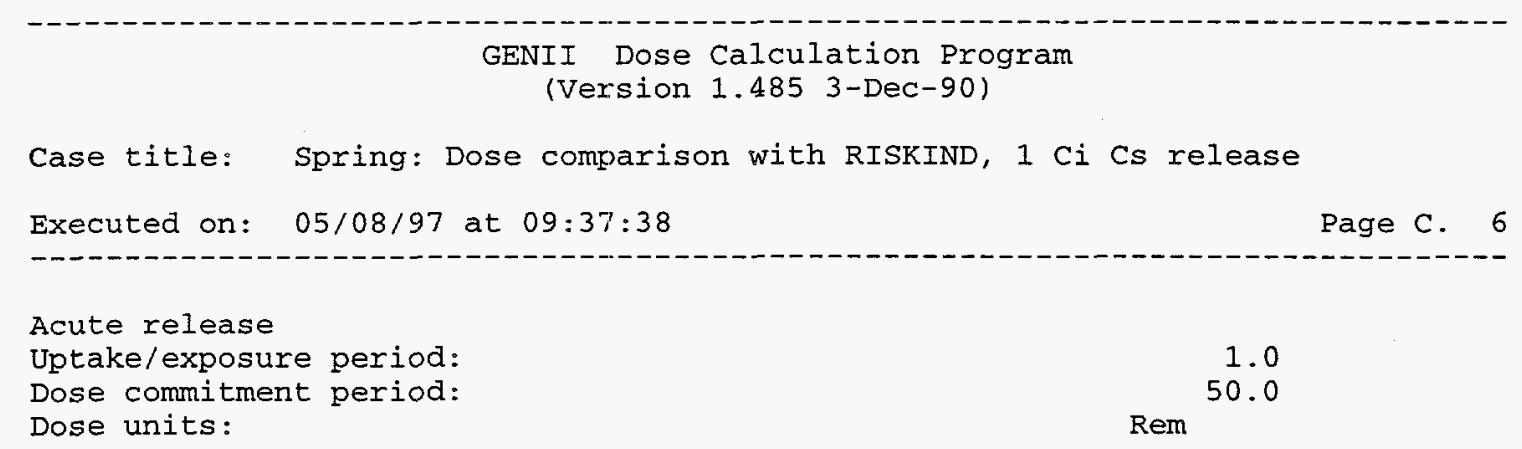

Committed Dose Equivalent by Exposure Pathway

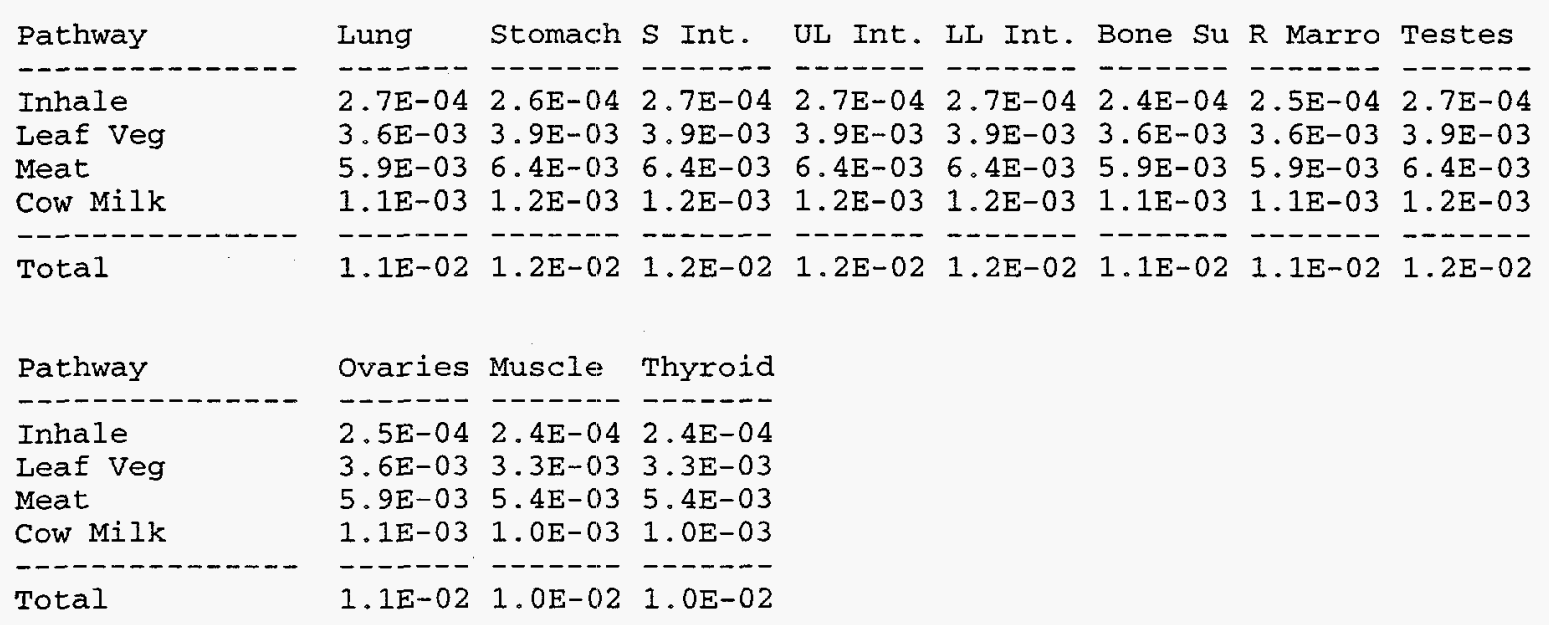

External Dose by Exposure Pathway

Pathway

$\begin{array}{ll}\text { Plume } & 3.6 \mathrm{E}-06 \\ \text { Sur Soil } & 2.2 \mathrm{E}-04 \\ -\mathrm{Dotal} & 2.3 \mathrm{E}-04\end{array}$


GENII Dose Calculation Program

(Version 1.485 3-Dec-90)

Case title: Summer: Dose comparison with RISKIND, I Ci Cs release

Executed on: 05/08/97 at 09:37:38

Page C. 7

Acute release

Uptake/exposure period:

Dose commitment period:

Dose units:

1.0

50.0

Rem

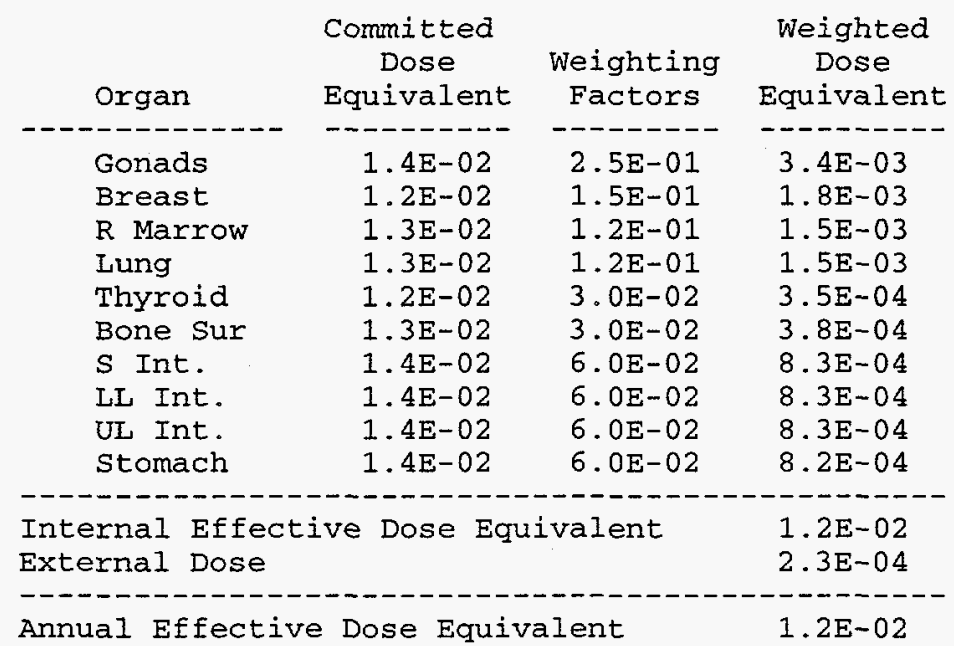

Controlling Organ:

s Int.

Controlling Pathway:

Ing

Controlling Radionuclide:

CS137

Total Inhalation EDE:

$2.4 \mathrm{E}-04$

Total Ingestion EDE:

$1.2 \mathrm{E}-02$ 
GENII Dose Calculation Program

(Version 1.485 3-Dec-90)

Case title: Summer: Dose comparison with RISKIND, 1 Ci Cs release

Executed on: $05 / 08 / 97$ at $09: 37: 38$

Page C. 8

Acute release

Uptake/exposure period:

Dose commitment period:

1.0

Dose units:

Rem

Dose Commitment Year

2

3

Internal
Intake
Year:

Internal
Annual
Dose

External

Annual

Dose

Annual

Dose

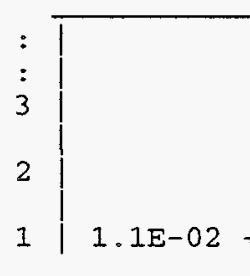

11

1. $1 \mathrm{E}-02$

$+$

$$
+
$$

$+$

11

$0.0 E+00$

$0 . \stackrel{+}{0}+00$

$+1.0 \mathrm{E}-04+\ldots$

$=1.2 \mathrm{E}-02$

| |

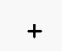

$2.3 E-04$

$0.0 \mathrm{E}+00$

$0.0 E+00$

11

| 1

1. $1 E-02$

$+1.1 \mathrm{E}-03$

1. OE-04

$-04+\ldots$
$=$

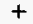

$2.3 E-04$

11

1.2E-02

1. $1 E-02$
Internal

Effective

Dose

Equivalent

Cumulative

Internal

Dose

Cumulative

Dose

Maximum

Annual

Dose Occurred

In Year 1 


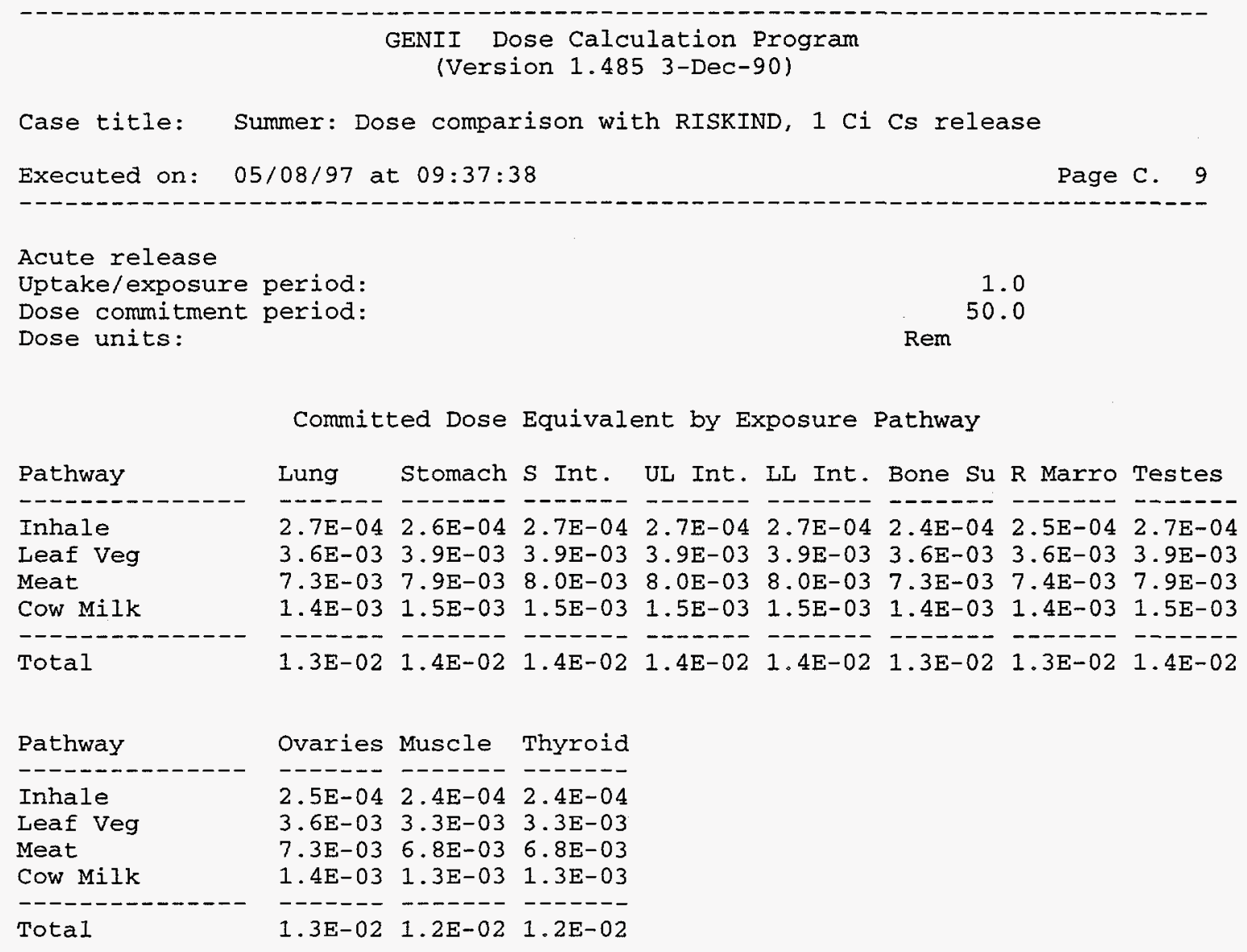

External Dose by Exposure Pathway

Pathway

\begin{tabular}{ll} 
Plume & $3.6 \mathrm{E}-06$ \\
Sur Soil & $2.2 \mathrm{E}-04$ \\
\hdashline$---1---$ \\
\hline Total & $2.3 \mathrm{E}-04$
\end{tabular}


GENII Dose Calculation Program

(Version 1.485 3-Dec-90)

Case title: Autumn: Dose comparison with RISKIND, 1 Ci Cs release

Executed on: $05 / 08 / 97$ at $09: 37: 39$

Page C. 10

Acute release

Uptake/exposure period:

Dose commitment period:

Dose units:

1.0

50.0

Rem

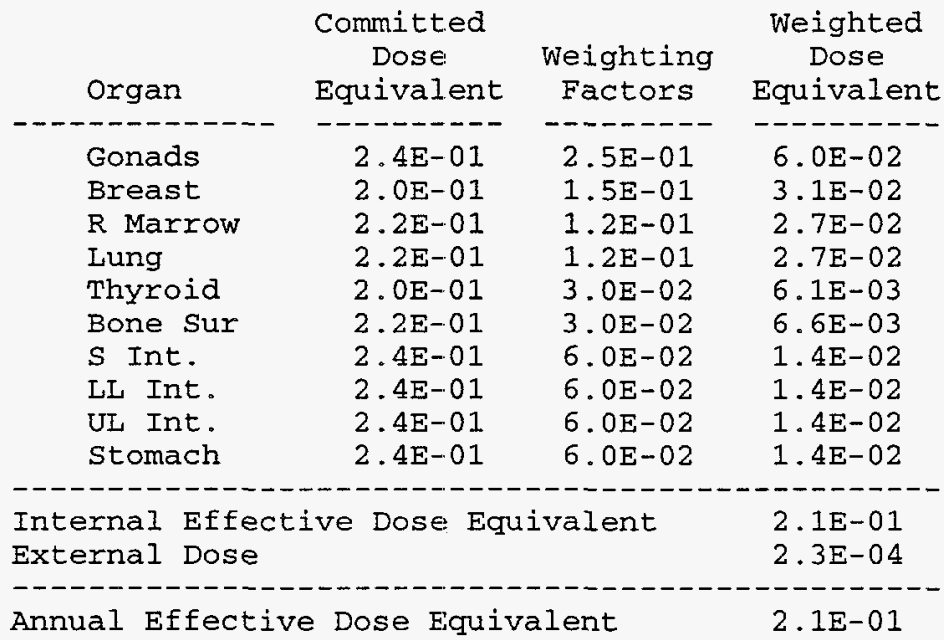

\begin{tabular}{ll} 
Controlling Oxgan: & S Int. \\
Controlling Pathway: & Ing \\
Controlling Radionuclide: & CS137 \\
\hline- & $-1 .-1 \mathrm{E}-04$ \\
Total Inhalation EDE: & $2.1 \mathrm{E}-01$ \\
Total Ingestion EDE: &
\end{tabular}


GENII Dose Calculation Program

(Version 1.485 3-Dec-90)

Case title: Autumn: Dose comparison with RISKIND, 1 Ci Cs release

Executed on: 05/08/97 at 09:37:39

Page C. 11

Acute release

Uptake/exposure period:

Dose commitment period:

1.

Dose units:

50.0

Rem

Dose Commitment Year

2

3

Internal Intake

Year:

\section{Internal \\ Annual \\ Dose}

External

Annual

Dose

Annual

Dose

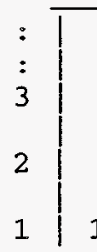

\begin{tabular}{l|l}
$:$ \\
3 \\
2 & 1
\end{tabular}

1. $9 \mathrm{E}-01$$$
0.0 E+00
$$

$$
+
$$$$
9 \mathrm{E}-02
$$

$$
0.0 \mathrm{E}+00
$$$$
0.0 \mathrm{E}+00
$$

.

$+$

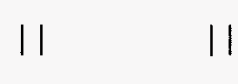

11

$1.9 E-01+1.9 E-02+$

1

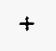

$2.3 E-04$

$0.0 E+00$

11

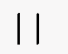

$1.9 E-01+1.9 E-02$
$.8 \mathrm{E}-03$

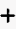

$+0$
$=2.1 \mathrm{E}-01$

I

Internal

Effective

Dose

Equivalent

Cumulative

Internal

Dose

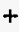

$2.3 E-04$

11

11

$2.1 E-01$

Cumulative

Dose

Maximum

1.9E-01 Annual Dose Occurred

In Year 1 


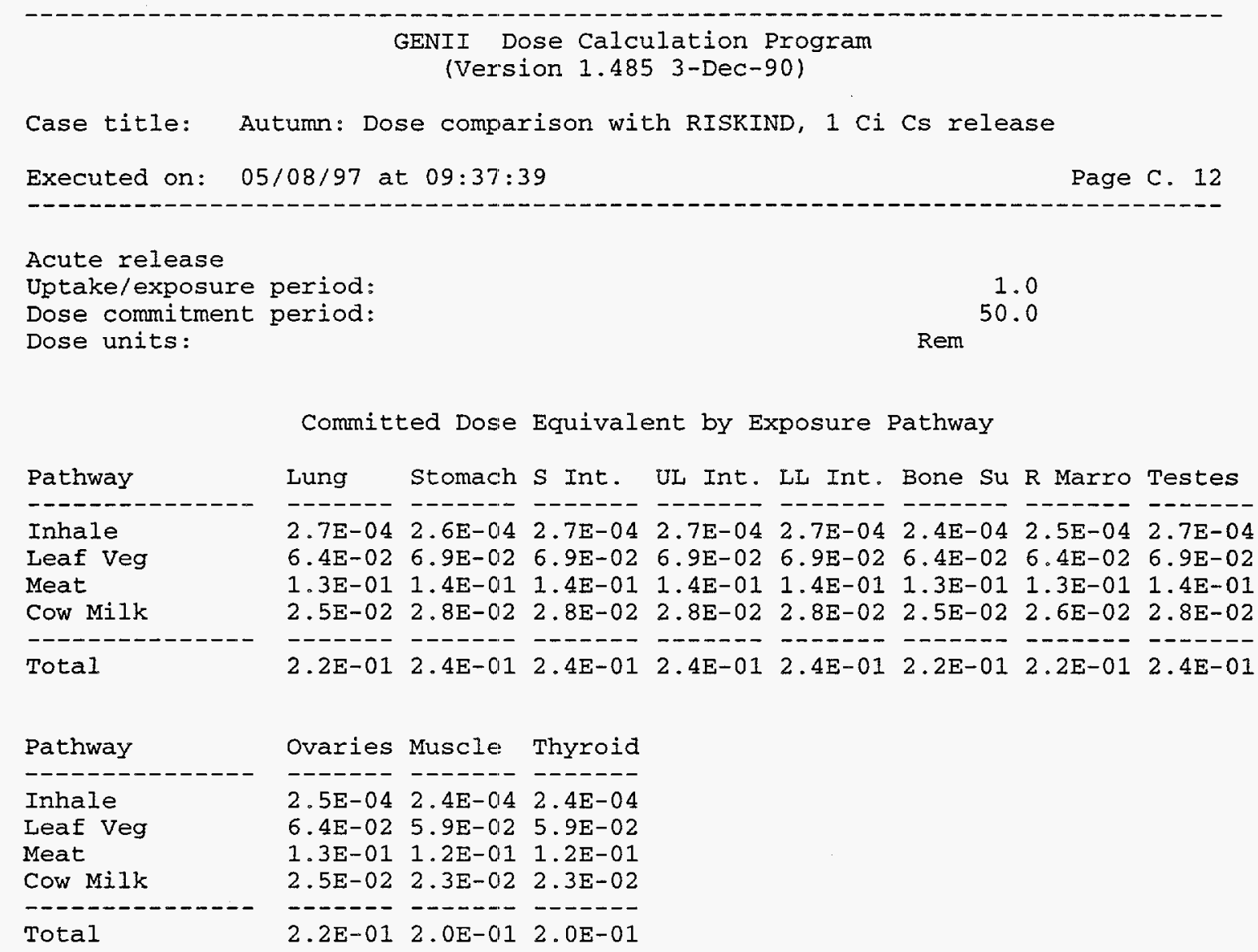

External Dose by Exposure Pathway

Pathway

\begin{tabular}{ll} 
Plume & $---1 .--$ \\
Sur Soil & $2.2 \mathrm{E}-06$ \\
\hdashline-04 \\
Total & $2.3 \mathrm{E}-04$
\end{tabular}




\section{B.1.2 Spent Fuel Accident}

\section{B.1.2.1 RISKIND Output for Spent Fuel Accident}

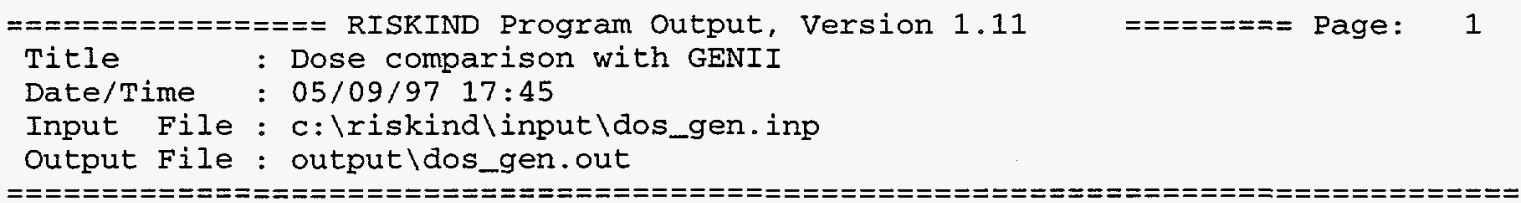

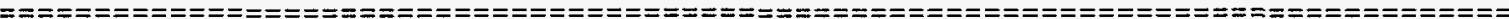

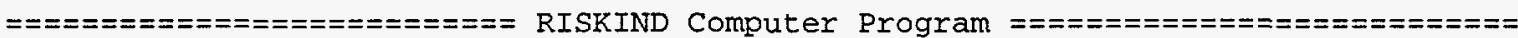

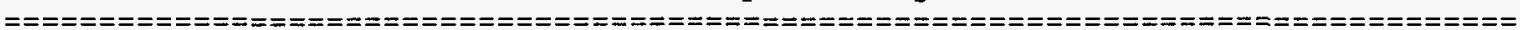

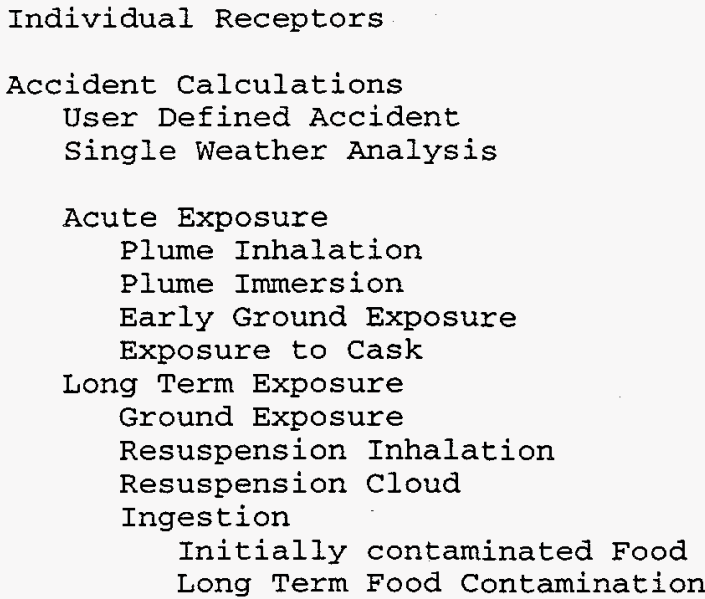

Note: * next to input description signifies

a data dependent default value 


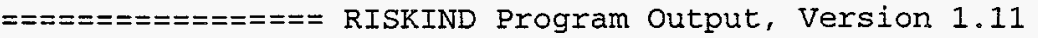

Title : Dose comparison with GENII

Date/Time : 05/09/97 17:45

Input File : c:\riskindlinput\dos_gen.inp

output File : output das_gen.out

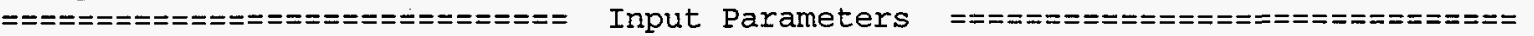

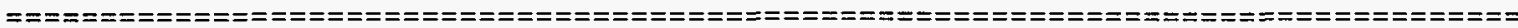

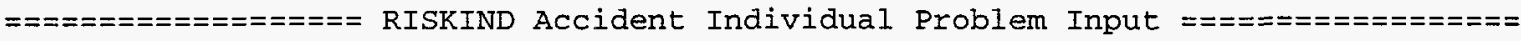

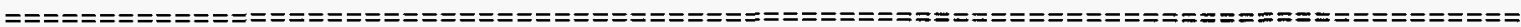

Individual Accident Parameters

State: US

Population Zone: Rural

Long-Term Exposure Duration [YEVD]: 1.00E+00

yr

Average Breathing Rate [BRTIND]: $8.00 \mathrm{E}+03 \mathrm{~m} 3 / \mathrm{yr}$

Individual type [INDTYPE]: Public

Risk Conversion Factors

Non-Fatal Cancers/rem: 1.0E-04

Fatal Cancers/rem: 5.0E-04

Genetic Effects/rem: 1.3E-04

\begin{tabular}{|c|c|c|c|c|c|c|}
\hline \multirow[b]{2}{*}{$\begin{array}{l}\text { Individual Name } \\
\text { [XNAME] }\end{array}$} & \multirow{2}{*}{$\begin{array}{l}====== \\
\text { Down } \\
\text { Wind } \\
{[\mathrm{km}]}\end{array}$} & \multirow{2}{*}{$\begin{array}{c}\text { Location } \\
\text { Cross } \\
\text { Wind } \\
\text { [km] } \\
\text { [XRECEP] }\end{array}$} & \multicolumn{3}{|c|}{$======\quad \begin{array}{c}\text { Acute } \\
\text { Exposure }\end{array}$} & \multirow[b]{2}{*}{$\begin{array}{l}\text { n Food } \\
\text { Ingestion } \\
\text { [IDFOOD] }\end{array}$} \\
\hline & & & $\begin{array}{c}\text { Elevation } \\
{[\mathrm{m}]}\end{array}$ & $\begin{array}{c}\text { Time } \\
\text { [hr] } \\
\text { [TEXT] }\end{array}$ & $\begin{array}{l}\text { Long Term } \\
\text { Exposure } \\
\text { [IRTP] }\end{array}$ & \\
\hline Individual 1 & $1.00 E+00$ & $00.00 \mathrm{E}+00$ & $0.00 E+002$ & $2.00 \mathrm{E}+00$ & Yes & Yes \\
\hline
\end{tabular}

\begin{tabular}{|c|c|c|c|c|c|c|c|c|c|c|}
\hline \multirow[b]{2}{*}{ Individual } & \multicolumn{2}{|c|}{$\begin{array}{l}\text { Shielding } \\
\text { Type }\end{array}$} & \multicolumn{2}{|c|}{$\begin{array}{l}\text { Long- } \\
\text { Term }\end{array}$} & \multicolumn{6}{|c|}{$\begin{array}{c}====\text { Shielding Factors }==== \\
\text { Acute: } \quad \text { Long-Term: }\end{array}$} \\
\hline & Short & Long & In & Out & Inh & cld & Ext & $\operatorname{Inh}$ & CId & Ext \\
\hline Individual 1 & None & None & 0.00 & 0.50 & 1.00 & 1.00 & 1.00 & 0.50 & 0.50 & 0.50 \\
\hline
\end{tabular}

Ingestion Parameters

\begin{tabular}{ccc}
\hline & $\begin{array}{c}\text { Individual } \\
\text { Consumption Rate } \\
{[\mathrm{kg} / \mathrm{d}]}\end{array}$ & $\begin{array}{c}\text { Contaminated } \\
\text { Fraction }\end{array}$ \\
\hline Food Type & {$[\mathrm{XIN}]$} & {$[\mathrm{PFIN}]$} \\
Meat & $3.00 \mathrm{E}-01$ & $1.00 \mathrm{E}+00$ \\
Milk & $8.50 \mathrm{E}-01$ & $1.00 \mathrm{E}+00$ \\
Vegetable & $1.60 \mathrm{E}+00$ & $1.00 \mathrm{E}+00$ \\
\hline
\end{tabular}




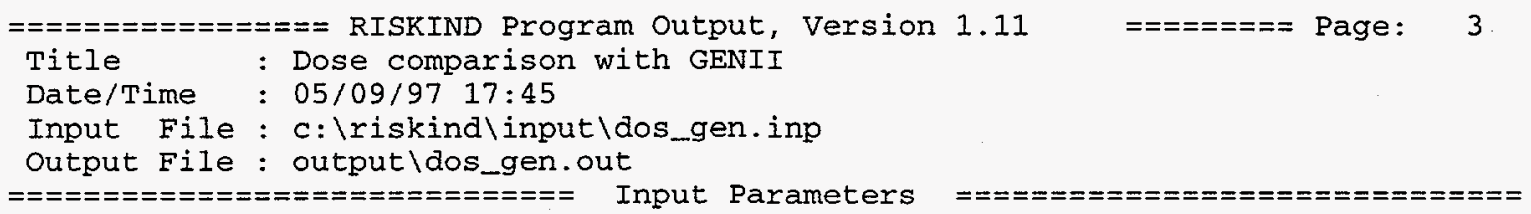

Meteorological Parameters

Dry deposition rates [VDEPNUC]

$\begin{array}{lrrr}\text { Particulates } & : & 1.00 \mathrm{E}-03 & \mathrm{~m} / \mathrm{s} \\ \text { Ruthenium } & : 1.00 \mathrm{E}-03 & \mathrm{~m} / \mathrm{s} \\ \text { Cesium } & : 1.00 \mathrm{E}-03 & \mathrm{~m} / \mathrm{s} \\ \text { Iodine } & : 1.00 \mathrm{E}-02 & \mathrm{~m} / \mathrm{s} \\ \text { Gases } & : 0.00 \mathrm{E}+00 & \mathrm{~m} / \mathrm{s} \\ \text { fall rate [RAIN] } & 0.00 \mathrm{E}+00 & \mathrm{~mm} / \mathrm{h} \\ \text { ter height [ANH] : } & 10.00 & \mathrm{~m} \\ \text { mperature [TABK] : } & 283.00 & \mathrm{~K} \\ \text { ng height [DMIX] : } & 1000.00 & \mathrm{~m} \\ \text { anemometer [WSM] : } & 4.00 & \mathrm{~m} / \mathrm{s}\end{array}$

Pasquil] stability cat [ITYPE]:

$\mathrm{D}$

Weather condition probability [METFREQ]: $1.00 \mathrm{E}+00$

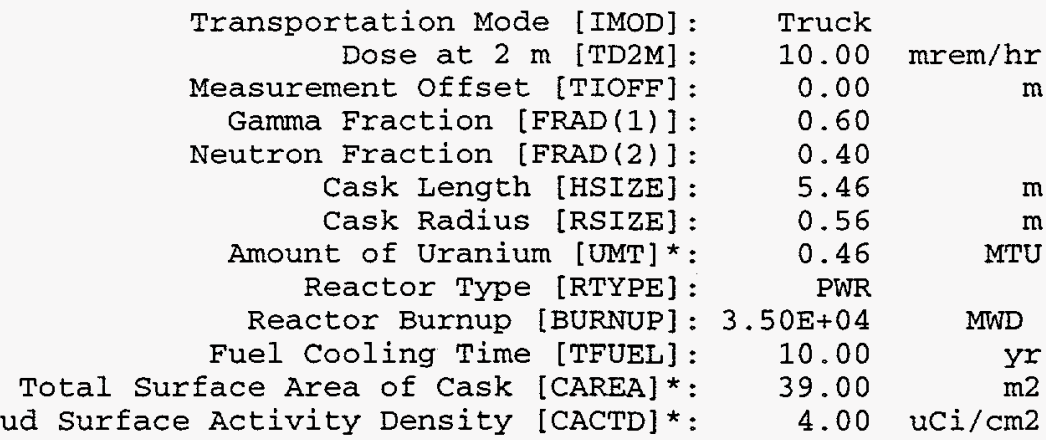




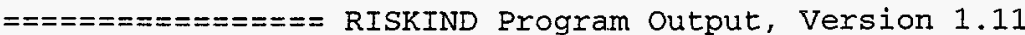

$==\boldsymbol{=}=\mathbf{=}=\mathbf{=}$ Page :

Title

: Dose comparison with GENII

Date/Time

: 05/09/97 17:45

Input File: c: \riskindlinput\dos_gen.inp

Output File : output \dos_gen.out

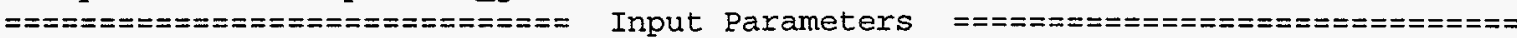

Long-Term Environmental Parameters

Removal half-life from soil [PHALF]: 50.00

Initial resuspension factor [SUFI]: $1.00 \mathrm{E}-05$

Final Resuspension factor [SUFF]: 1.00E-09

Resus. factor decay halflife [RSALF]: 1.37E-01

$\mathrm{yr}$
$1 / \mathrm{m}$
$1 / \mathrm{m}$
$\mathrm{yr}$

Food Production Parameters

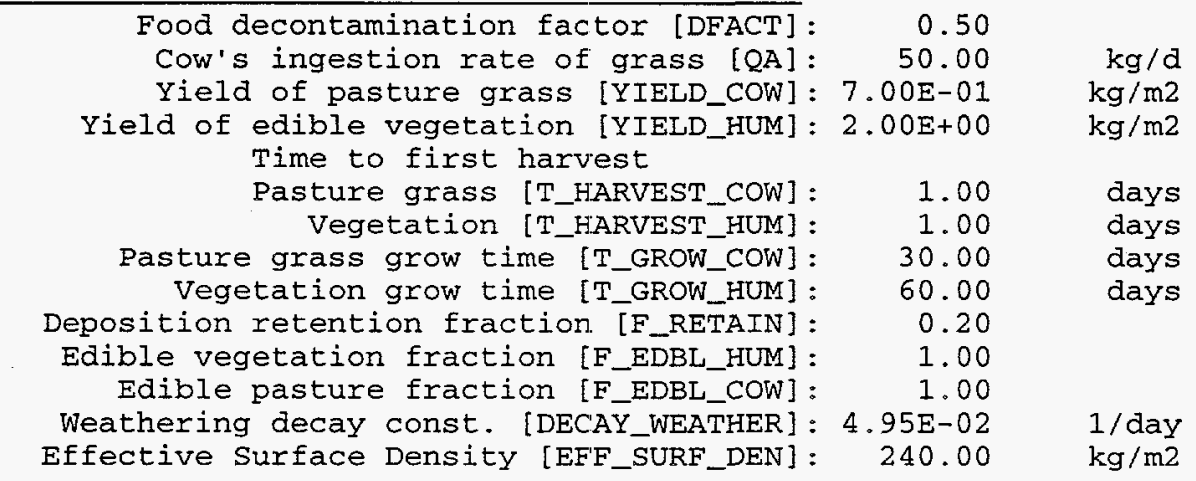




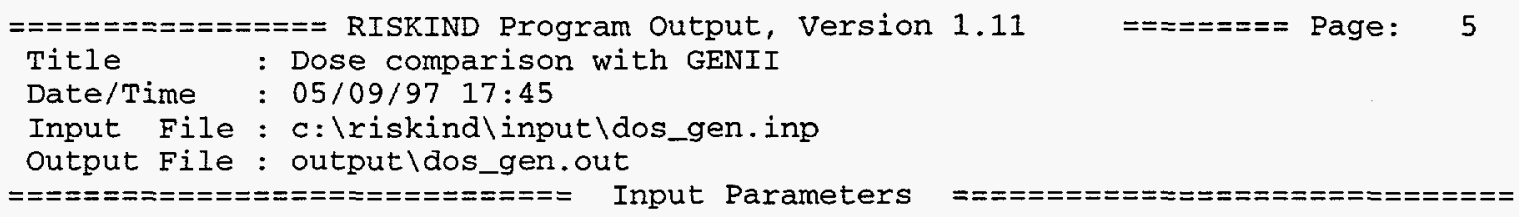

Nuclide Parameters

\begin{tabular}{|c|c|c|c|c|c|c|c|}
\hline \multirow[b]{2}{*}{$\begin{array}{l}\text { Nuclide } \\
\text { Name }\end{array}$} & \multicolumn{7}{|c|}{ Nuclide Inventory and DCFs } \\
\hline & $\begin{array}{c}\text { Inventory } \\
\text { Amount } \\
\text { [Ci] }\end{array}$ & $\begin{array}{c}=====D \\
\text { Inhalation } \\
\text { [Sv/Bq] }\end{array}$ & $\begin{array}{c}\text { Ingestion } \\
{[\mathrm{Sv} / \mathrm{Bq}]}\end{array}$ & $\begin{array}{c}\text { Cloud } \\
\text { [Sv/s] } \\
{[\mathrm{Bq} / \mathrm{m} 3]}\end{array}$ & $\begin{array}{c}\text { es }===== \\
\text { Ground } \\
{[\mathrm{Sv} / \mathrm{s}]} \\
{[\mathrm{Bq} / \mathrm{m} 2]}\end{array}$ & $\begin{array}{l}\text { Nucl. } \\
\text { Class }\end{array}$ & $\begin{array}{l}\text { Decay } \\
\text { Const. } \\
\text { [1/yr] }\end{array}$ \\
\hline $\mathrm{H} 3$ & $2.17 E+02$ & $1.73 \mathrm{E}-11$ & $1.73 E-11$ & $0.00 \mathrm{E}+00$ & $0.00 E+00$ & Particul & $5.60 E-02$ \\
\hline FE 55 & $1.07 \mathrm{E}+02$ & $7.26 \mathrm{E}-10$ & $1.64 E-10$ & $0.00 E+00$ & $0.00 E+00$ & Particul & $2.60 E-01$ \\
\hline CO 60 & 1. $10 \mathrm{E}+03$ & $5.91 E-08$ & $7.28 \mathrm{E}-09$ & $1.26 \mathrm{E}-13$ & $2.35 \mathrm{E}-15$ & Particul & $1.30 \mathrm{E}-01$ \\
\hline NI 63 & $1.88 \mathrm{E}+02$ & 1.70E-09 & $1.56 \mathrm{E}-10$ & $0.00 \mathrm{E}+00$ & $0.00 E+00$ & Particul & $6.90 \mathrm{E}-03$ \\
\hline $\mathrm{KR} \quad 85$ & $2.33 E+03$ & $1.03 E-11$ & $1.03 \mathrm{E}-11$ & $1.19 \mathrm{E}-16$ & $2.64 \mathrm{E}-18$ & Gas & $6.50 \mathrm{E}-02$ \\
\hline SR 90 & $2.77 \mathrm{E}+04$ & $3.53 E-07$ & $4.14 \mathrm{E}-08$ & $1.97 \mathrm{E}-16$ & $5.61 \mathrm{E}-18$ & Particul & $2.40 \mathrm{E}-02$ \\
\hline Y 90 & $2.77 \mathrm{E}+04$ & $2.28 \mathrm{E}-09$ & $2.91 \mathrm{E}-09$ & $1.90 \mathrm{E}-16$ & $5.33 E-18$ & Particul & $9.50 \mathrm{E}+01$ \\
\hline RU106 & $2.44 \mathrm{E}+02$ & $1.30 \mathrm{E}-07$ & $8.30 E-09$ & 1. $04 \mathrm{E}-14$ & $2.12 \mathrm{E}-16$ & $\mathrm{Ru}$ & $6.90 \mathrm{E}-01$ \\
\hline RH106 & $2.44 \mathrm{E}+02$ & $8.95 E-10$ & $8.95 E-10$ & $1.04 \mathrm{E}-14$ & $2.12 E-16$ & Ru & $7.30 E+05$ \\
\hline SB125 & $6.01 E+02$ & $3.75 \mathrm{E}-09$ & $9.85 E-10$ & $2.02 \mathrm{E}-14$ & $4.33 E-16$ & Particul & $2.50 E-01$ \\
\hline TE125M & $1.47 \mathrm{E}+02$ & $1.97 \mathrm{E}-09$ & $9.92 \mathrm{E}-10$ & $4.53 E-16$ & $3.61 \mathrm{E}-17$ & Particul & $4.40 E+00$ \\
\hline $\operatorname{cs} 134$ & $2.76 E+03$ & 1. $25 E-08$ & $1.98 E-08$ & $7.56 E-14$ & $1.52 \mathrm{E}-15$ & $\mathrm{Cs}$ & $3.40 E-01$ \\
\hline CS137 & $3.98 E+04$ & 1. $10 \mathrm{E}-08$ & $1.59 E-08$ & $2.73 E-14$ & $5.54 E-16$ & $\mathrm{Cs}$ & $2.30 E-02$ \\
\hline BA137M & $3.76 E+04$ & $2.49 E-09$ & $2.49 E-09$ & $2.88 E-14$ & $5.86 \mathrm{E}-16$ & Particul & $1.40 E+05$ \\
\hline CE144 & $6.45 E+01$ & $1.01 E-07$ & $5.71 E-09$ & $2.80 E-15$ & $5.83 E-17$ & Particul & $8.90 E-01$ \\
\hline PR144 & $6.45 E+01$ & 1. $17 \mathrm{E}-11$ & $3.15 \mathrm{E}-11$ & 1. $94 \mathrm{E}-15$ & $3.79 \mathrm{E}-17$ & Particul & $2.10 \mathrm{E}+04$ \\
\hline PM147 & $4.21 E+03$ & $1.06 \mathrm{E}-08$ & $2.83 E-10$ & $6.92 \mathrm{E}-19$ & $3.40 E-20$ & Particul & $2.60 E-01$ \\
\hline SM151 & $1.81 E+02$ & $8.10 E-09$ & $1.05 \mathrm{E}-10$ & $3.61 E-20$ & $5.02 \mathrm{E}-21$ & Particul & $7.70 E-03$ \\
\hline EU154 & $2.09 E+03$ & $7.73 E-08$ & $2.58 \mathrm{E}-09$ & $6.14 \mathrm{E}-14$ & $1.18 \mathrm{E}-15$ & Particul & $7.90 E-02$ \\
\hline EU155 & $7.69 \mathrm{E}+02$ & $1.12 E-08$ & $4.13 \mathrm{E}-10$ & $2.49 E-15$ & $5.90 \mathrm{E}-17$ & Particul & 1. $40 \mathrm{E}-01$ \\
\hline PU238 & $1.42 E+03$ & $1.06 \mathrm{E}-04$ & $8.65 E-07$ & $4.87 E-18$ & $8.37 E-19$ & Particul & $7.90 E-03$ \\
\hline PU239 & $1.65 E+02$ & $1.16 \mathrm{E}-04$ & $9.56 E-07$ & $4.24 E-18$ & $3.67 E-19$ & Particul & $2.90 E-05$ \\
\hline PU240 & $2.37 \mathrm{E}+02$ & $1.16 \mathrm{E}-04$ & $9.56 \mathrm{E}-07$ & $4.75 E-18$ & $8.02 E-19$ & Particul & $1.10 \mathrm{E}-04$ \\
\hline PU241 & $3.88 E+04$ & $2.23 E-06$ & $1.85 \mathrm{E}-08$ & $2.19 \mathrm{E}-19$ & $5.20 \mathrm{E}-21$ & Particul & $4.80 \mathrm{E}-02$ \\
\hline AM2 41 & $8.66 \mathrm{E}+02$ & $1.20 E-04$ & $9.84 E-07$ & $8.18 E-16$ & $2.74 \mathrm{E}-17$ & Particul & $1.60 \mathrm{E}-03$ \\
\hline CM244 & $8.95 \mathrm{E}+02$ & $6.70 \mathrm{E}-05$ & $5.45 \mathrm{E}-07$ & $4.91 \mathrm{E}-18$ & $8.78 E-19$ & Particul & $3.80 \mathrm{E}-02$ \\
\hline
\end{tabular}




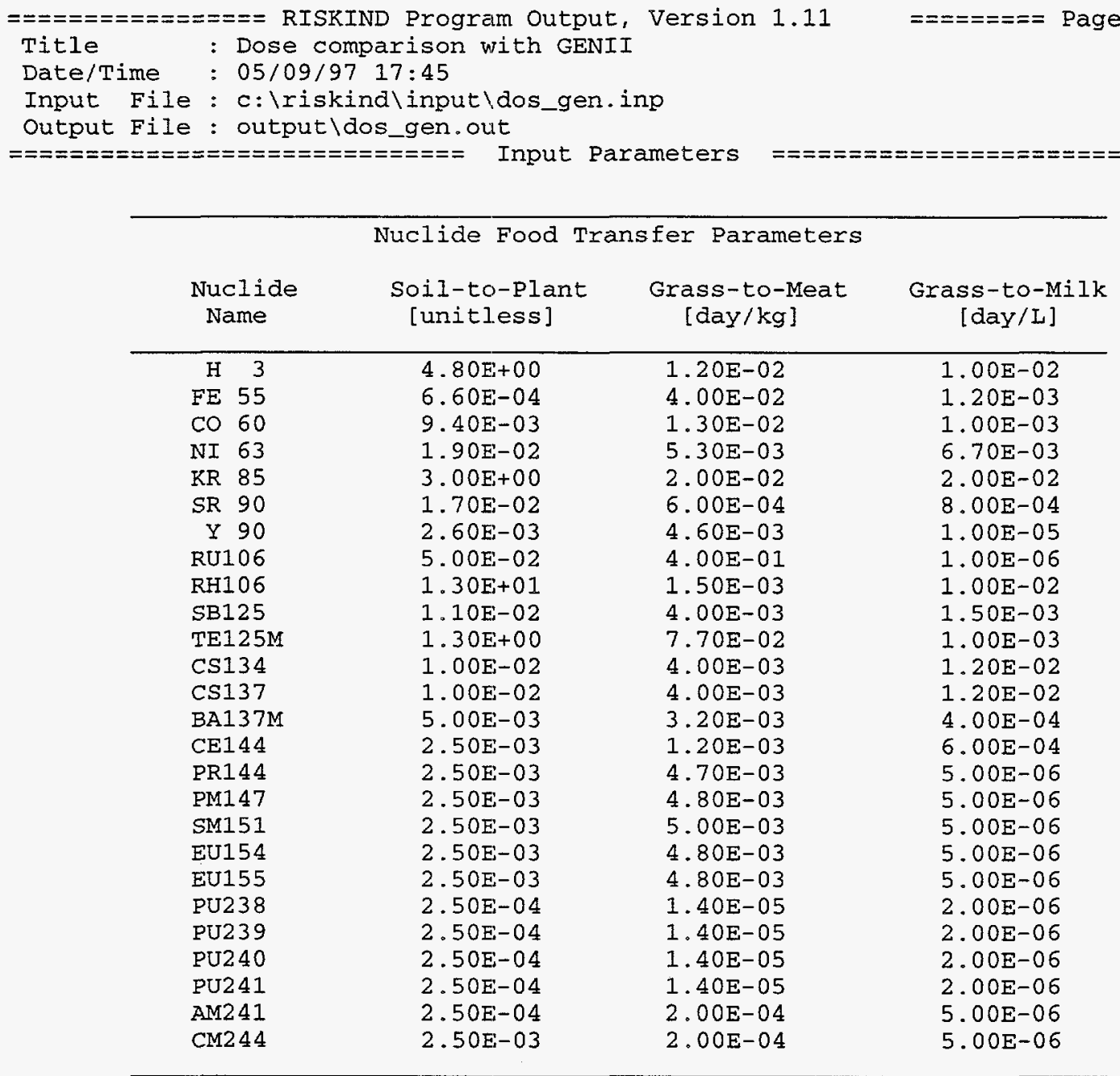




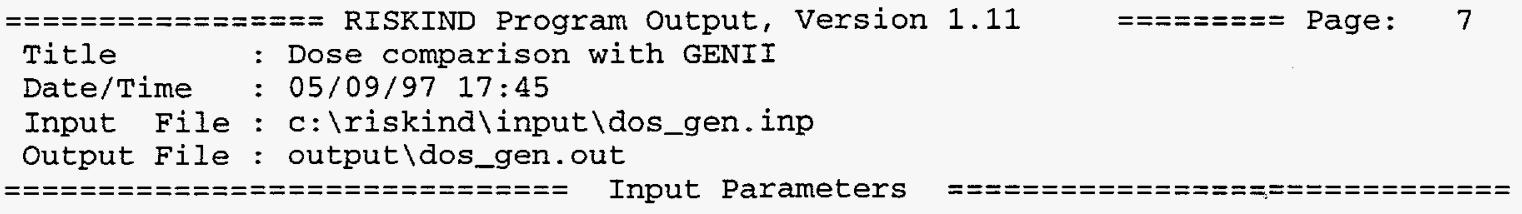

\begin{tabular}{|c|c|c|c|c|c|c|c|}
\hline \multirow{2}{*}{$\begin{array}{l}\text { Nuclide } \\
\text { Name }\end{array}$} & \multirow{2}{*}{$\begin{array}{l}\text { Solubility } \\
\text { Class }\end{array}$} & \multicolumn{6}{|c|}{ 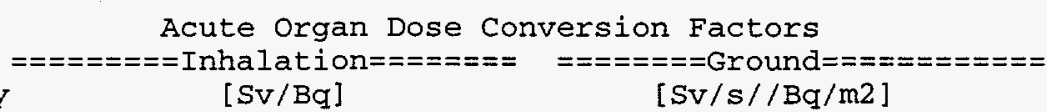 } \\
\hline & & Marrow & Lung & Intestine & Marrow & Lung & Intestine \\
\hline $\begin{array}{ll}\mathrm{H} & 3\end{array}$ & $D$ & $1.62 \mathrm{E}-11$ & $1.62 \mathrm{E}-11$ & $1.62 \mathrm{E}-11$ & $0.00 E+00$ & $0.00 \mathrm{E}+00$ & $0.00 \mathrm{E}+00$ \\
\hline FE 55 & $W$ & $1.65 E-10$ & $1.76 \mathrm{E}-10$ & $1.92 \mathrm{E}-10$ & $0.00 E+00$ & $0.00 E+00$ & $1.89 \mathrm{E}-19$ \\
\hline $\cos 60$ & $Y$ & $6.22 E-09$ & $1.24 \mathrm{E}-07$ & $5.95 E-09$ & $2.34 E-15$ & $2.27 E-15$ & $1.94 \mathrm{E}-15$ \\
\hline NI 63 & $Y$ & $1.05 E-12$ & $5.95 E-12$ & $4.59 \mathrm{E}-13$ & $0.00 E+00$ & $0.00 E+00$ & $0.00 \mathrm{E}+00$ \\
\hline $\mathrm{KR} 85$ & $\mathrm{D}$ & $0.00 E+00$ & $0.00 E+00$ & $0.00 \mathrm{E}+00$ & $2.43 E-18$ & $2.45 E-18$ & 1. $97 \mathrm{E}-18$ \\
\hline SR 90 & $Y$ & $1.08 E-09$ & $7.03 E-07$ & $1.70 \mathrm{E}-08$ & $4.77 E-18$ & $4.98 E-18$ & $0.00 E+00$ \\
\hline$Y 90$ & $\mathrm{Y}$ & 1. $51 \mathrm{E}-11$ & $9.19 E-09$ & $1.27 E-08$ & $4.57 E-18$ & $4.76 E-18$ & $0.00 E+00$ \\
\hline RU106 & $Y$ & $1.05 E-09$ & $6.76 E-07$ & $3.51 \mathrm{E}-08$ & $2.06 \mathrm{E}-16$ & $2.03 E-16$ & $1.80 \mathrm{E}-16$ \\
\hline RH106 & $Y$ & $2.58 E-10$ & $2.58 \mathrm{E}-10$ & $1.14 E-09$ & $2.06 E-16$ & $2.03 E-16$ & $1.80 \mathrm{E}-16$ \\
\hline SB125 & $W$ & $2.41 E-14$ & $7.30 \mathrm{E}-11$ & $3.24 \mathrm{E}-12$ & $4.05 E-16$ & $4.03 E-16$ & $3.79 \mathrm{E}-16$ \\
\hline TE125M & $W$ & $5.14 E-14$ & $1.05 \mathrm{E}-11$ & $2.38 E-12$ & $1.37 E-17$ & $1.77 \mathrm{E}-17$ & $1.78 \mathrm{E}-17$ \\
\hline $\operatorname{CS} 134$ & $\mathrm{D}$ & $1.08 E-08$ & $1.08 E-08$ & $1.27 E-08$ & $1.48 \mathrm{E}-15$ & $1.46 \mathrm{E}-15$ & 1. $34 \mathrm{E}-15$ \\
\hline $\operatorname{cs} 137$ & $D$ & $7.57 E-09$ & $8.11 E-09$ & $8.11 \mathrm{E}-09$ & $5.39 E-16$ & $5.30 \mathrm{E}-16$ & $4.93 E-16$ \\
\hline BA137M & $D$ & $2.73 E-11$ & $2.73 E-11$ & $0.00 E+00$ & $5.70 \mathrm{E}-16$ & $5.60 \mathrm{E}-16$ & $5.22 \mathrm{E}-16$ \\
\hline $\mathrm{CE} 144$ & $Y$ & $1.08 E-09$ & $5.68 \mathrm{E}-07$ & $3.24 E-08$ & $5.31 \mathrm{E}-17$ & $5.43 E-17$ & $1.83 \mathrm{E}-17$ \\
\hline PR144 & $Y$ & $1.92 \mathrm{E}-14$ & $9.46 \mathrm{E}-11$ & $2.16 \mathrm{E}-14$ & 3. $66 \mathrm{E}-17$ & $3.61 \mathrm{E}-17$ & $2.54 E-17$ \\
\hline PMI 47 & $\bar{Y}$ & $1.41 \mathrm{E}-10$ & $3.51 \mathrm{E}-08$ & $1.62 \mathrm{E}-09$ & 1. $86 \mathrm{E}-20$ & $2.20 E-20$ & $3.48 \mathrm{E}-21$ \\
\hline SM151 & $Y$ & $3.78 \mathrm{E}-12$ & $1.19 \mathrm{E}-11$ & $8.65 E-13$ & 1. $39 \mathrm{E}-21$ & 1. $01 \mathrm{E}-21$ & $4.45 \mathrm{E}-21$ \\
\hline EU154 & $Y$ & $2.46 \mathrm{E}-11$ & $1.57 \mathrm{E}-10$ & $9.19 \mathrm{E}-12$ & $1.16 \mathrm{E}-15$ & $1.14 \mathrm{E}-15$ & $1.03 E-15$ \\
\hline EU155 & $\mathrm{Y}$ & $3.78 \mathrm{E}-12$ & $2.54 \mathrm{E}-11$ & 1. $59 \mathrm{E}-12$ & $4.71 \mathrm{E}-17$ & $5.34 \mathrm{E}-17$ & $6.05 E-17$ \\
\hline PU238 & $Y$ & $2.97 E-07$ & $7.03 E-05$ & $2.97 E-08$ & $1.94 \mathrm{E}-19$ & $7.87 E-20$ & $7.35 E-19$ \\
\hline PU239 & $\bar{Y}$ & $2.70 \mathrm{E}-07$ & $6.76 \mathrm{E}-05$ & $2.70 E-08$ & $1.19 \mathrm{E}-19$ & $7.87 \mathrm{E}-20$ & $3.24 \mathrm{E}-19$ \\
\hline PU2 40 & $\bar{Y}$ & $2.70 E-07$ & $6.76 E-05$ & $2.70 \mathrm{E}-08$ & $1.88 \mathrm{E}-19$ & $7.81 \mathrm{E}-20$ & $7.02 \mathrm{E}-19$ \\
\hline PU241 & $Y$ & $2.97 E-10$ & $5.68 \mathrm{E}-08$ & $1.41 \mathrm{E}-10$ & $4.18 E-2 I$ & $4.36 \mathrm{E}-21$ & $0.00 \mathrm{E}+00$ \\
\hline $\mathrm{AM} 241$ & $\mathrm{~W}$ & $4.32 \mathrm{E}-06$ & $1.81 \mathrm{E}-05$ & $2.97 \mathrm{E}-08$ & $1.68 \mathrm{E}-17$ & $2.00 \mathrm{E}-17$ & $2.52 \mathrm{E}-17$ \\
\hline $\mathrm{CM} 244$ & $W$ & $4.59 E-06$ & $1.92 \mathrm{E}-05$ & $3.24 \mathrm{E}-08$ & $2.04 E-19$ & $9.00 E-20$ & $7.10 \mathrm{E}-19$ \\
\hline
\end{tabular}




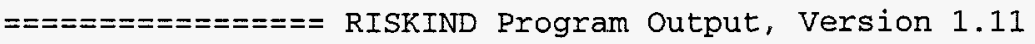

Title : Dose comparison with GENII

Date/Time : 05/09/97 17:45

Input File : c: \riskind $\backslash$ input $\backslash$ dos_gen.inp

Output File : outputidos_gen.out

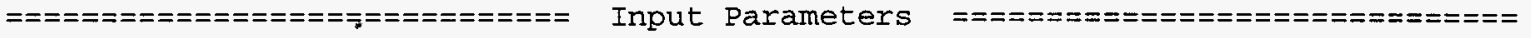

Nuclide Health Effects Parameters

A.cute Organ Dose Conversion Factors

$====== \pm==$ Cloudshine $=======$

Name Marrow Lung Intestine

$\begin{array}{rlll}\text { H } 3 & 0.00 \mathrm{E}+00 & 0.00 \mathrm{E}+00 & 0.00 \mathrm{E}+00 \\ \mathrm{FE} 55 & 0.00 \mathrm{E}+00 & 0.00 \mathrm{E}+00 & 9.85 \mathrm{E}-19 \\ \mathrm{CO} 60 & 1.23 \mathrm{E}-13 & 1.24 \mathrm{E}-13 & 1.11 \mathrm{E}-13 \\ \mathrm{NI} 63 & 0.00 \mathrm{E}+00 & 0.00 \mathrm{E}+00 & 0.00 \mathrm{E}+00 \\ \text { KR } 85 & 1.09 \mathrm{E}-16 & 1.14 \mathrm{E}-16 & 9.59 \mathrm{E}-17 \\ \text { SR } 90 & 1.68 \mathrm{E}-16 & 1.84 \mathrm{E}-16 & 0.00 \mathrm{E}+00 \\ \mathrm{Y} 90 & 1.62 \mathrm{E}-16 & 1.77 \mathrm{E}-16 & 0.00 \mathrm{E}+00 \\ \text { RU106 } & 9.76 \mathrm{E}-15 & 1.01 \mathrm{E}-14 & 8.99 \mathrm{E}-15 \\ \text { RH106 } & 9.76 \mathrm{E}-15 & 1.01 \mathrm{E}-14 & 8.99 \mathrm{E}-15 \\ \text { SB125 } & 1.88 \mathrm{E}-14 & 1.95 \mathrm{E}-14 & 1.82 \mathrm{E}-14 \\ \text { TE125M } & 1.86 \mathrm{E}-16 & 2.23 \mathrm{E}-16 & 4.10 \mathrm{E}-16 \\ \mathrm{CS134} & 7.19 \mathrm{E}-14 & 7.37 \mathrm{E}-14 & 6.84 \mathrm{E}-14 \\ \text { CS137 } & 2.59 \mathrm{E}-14 & 2.65 \mathrm{E}-14 & 2.48 \mathrm{E}-14 \\ \text { BA137M } & 2.73 \mathrm{E}-14 & 2.80 \mathrm{E}-14 & 2.61 \mathrm{E}-14 \\ \text { CE144 } & 2.55 \mathrm{E}-15 & 2.68 \mathrm{E}-15 & 7.73 \mathrm{E}-16 \\ \text { PR144 } & 1.88 \mathrm{E}-15 & 1.91 \mathrm{E}-15 & 1.52 \mathrm{E}-15 \\ \text { PM147 } & 4.46 \mathrm{E}-19 & 5.45 \mathrm{E}-19 & 1.55 \mathrm{E}-19 \\ \text { SM151 } & 1.13 \mathrm{E}-20 & 7.13 \mathrm{E}-21 & 3.91 \mathrm{E}-20 \\ \text { EU154 } & 5.87 \mathrm{E}-14 & 5.99 \mathrm{E}-14 & 5.54 \mathrm{E}-14 \\ \text { EU155 } & 1.85 \mathrm{E}-15 & 2.22 \mathrm{E}-15 & 2.42 \mathrm{E}-15 \\ \text { PU238 } & 1.68 \mathrm{E}-18 & 1.06 \mathrm{E}-18 & 3.77 \mathrm{E}-18 \\ \text { PU239 } & 2.67 \mathrm{E}-18 & 2.65 \mathrm{E}-18 & 3.50 \mathrm{E}-18 \\ \text { PU240 } & 1.66 \mathrm{E}-18 & 1.09 \mathrm{E}-18 & 3.69 \mathrm{E}-18 \\ \text { PU241 } & 1.75 \mathrm{E}-19 & 1.99 \mathrm{E}-19 & 0.00 \mathrm{E}+00 \\ \text { AM241 } & 5.21 \mathrm{E}-16 & 6.74 \mathrm{E}-16 & 8.00 \mathrm{E}-16 \\ \text { CM244 } & 1.46 \mathrm{E}-18 & 7.07 \mathrm{E}-19 & 3.57 \mathrm{E}-18\end{array}$




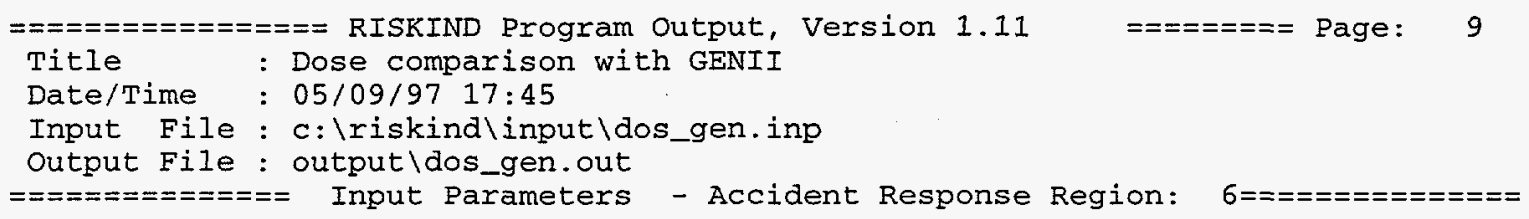

Accident Parameters

Physical Release Height [HS]: $10.00 \quad \mathrm{~m}$

Dispersion Model Coefficients [IDISPMOD]: Pasquill-Gifford

Accident Analysis Type: Risk

Accident Rate $[A C T A]: 1.00 \mathrm{E}+00 \quad 1 / \mathrm{km}$

Accident Response Region Determined By

$\begin{array}{rrr}\text { Accident Cask Velocity [VCASK] : } & 65.00 & \mathrm{~km} / \mathrm{h} \\ \text { Cask Impact Angle [ALPHA]: } & 90.00 & \text { Degrees } \\ \text { Cask Orientation Angle [BETA] : } & 90.00 & \text { Degrees } \\ \text { Impact Object Hardness [IHARD]: } & 1.00 & \\ \text { Flame Temperature [TFLAME] : } & 1.35 \mathrm{E}+03 & \mathrm{~K} \\ \text { Fire Duration [DFIRE] : } & 0.75 & \mathrm{hr} \\ \text { Fire Location [FLOCA] : } & 0.00 & \mathrm{~m}\end{array}$

Accident Response Region Parameters

Response Region [IYOURS]: 6

Region Conditional Probability [FSEV] : 2.33E-07

Heat Flux [HEATF] : $0.00 E+00$

Loss of Cask Shielding Factor [SEXT]

Gamma: $\quad 1.00$

Neutron: $\quad 1.00$

Failure Rate [FAILS]: 1.00E-01

Crud Spallation Rate [FSPAL]: 1.00E+00

Crud Release Rate [FRCRUD]: $1.00 \mathrm{E}+00$

\begin{tabular}{lccc}
\hline $\begin{array}{c}\text { Nuclide } \\
\text { Class } \\
\text { [NUTYPE] }\end{array}$ & $\begin{array}{c}\text { Conditional } \\
\text { Release } \\
\text { Fraction } \\
\text { [FRELS] }\end{array}$ & $\begin{array}{c}\text { Dispersion } \\
\text { Fraction } \\
\text { [FDISP] }\end{array}$ & $\begin{array}{c}\text { Released and Dispersed } \\
\text { Fraction } \\
\text { (FRELS*FAILS*FDISP) }\end{array}$ \\
\hline Particulate & $2.00 \mathrm{E}-06$ & $1.00 \mathrm{E}+00$ & $2.00 \mathrm{E}-07$ \\
Ru & $2.70 \mathrm{E}-05$ & $1.00 \mathrm{E}+00$ & $2.70 \mathrm{E}-06$ \\
Cs & $2.00 \mathrm{E}-04$ & $1.00 \mathrm{E}+00$ & $2.00 \mathrm{E}-05$ \\
I & $2.50 \mathrm{E}-03$ & $1.00 \mathrm{E}+00$ & $2.50 \mathrm{E}-04$ \\
Gas & $3.30 \mathrm{E}-01$ & $1.00 \mathrm{E}+00$ & $3.30 \mathrm{E}-02$ \\
\hline
\end{tabular}


$==============$ RISKIND Program Output, Version 1.11

Title

: Dose comparison with GENII

Date/Time : 05/09/97 17:45

Input File : c: \riskind

Output File : output ldos_gen.out

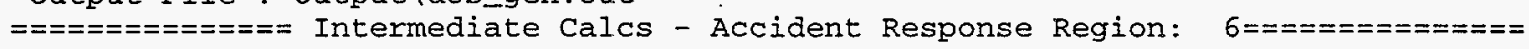

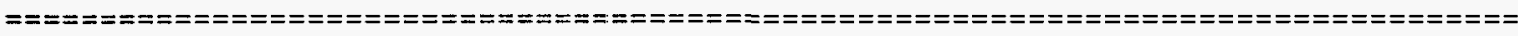

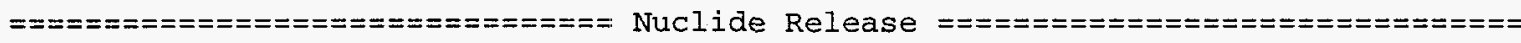

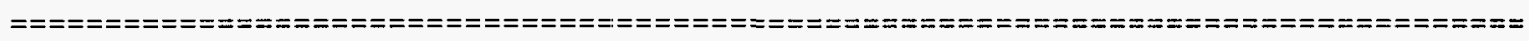

\begin{tabular}{|c|c|c|c|c|}
\hline $\begin{array}{l}\text { Nuclide } \\
\text { Name }\end{array}$ & $\begin{array}{c}\text { Release } \\
\text { Amount } \\
\text { [Ci] }\end{array}$ & $\begin{aligned}= & =====:==1 \\
& \text { Inhalation }\end{aligned}$ & $\begin{array}{l}\text { Hazard Ind } \\
\text { Ingestion }\end{array}$ & $\begin{aligned}== & ======= \\
& \text { Ground }\end{aligned}$ \\
\hline $\begin{array}{l}\text { CO } 60 \\
\text { SR } 90 \\
\text { CS134 } \\
\text { CS137 } \\
\text { PU238 } \\
\text { PU239 } \\
\text { PU2 } 40 \\
\text { PU2 } 41 \\
\text { AM2 } 41 \\
\text { CM2 } 44\end{array}$ & $\begin{array}{l}4.25 E-01 \\
5.55 E-03 \\
5.52 E-02 \\
7.95 E-01 \\
2.83 E-04 \\
3.30 E-05 \\
4.73 E-05 \\
7.77 E-03 \\
1.73 E-04 \\
1.79 E-04\end{array}$ & $\begin{array}{l}1.99 \mathrm{E}-01 \\
1.54 \mathrm{E}-02 \\
5.55 \mathrm{E}-03 \\
6.94 \mathrm{E}-02 \\
2.36 \mathrm{E}-01 \\
3.01 \mathrm{E}-02 \\
4.31 \mathrm{E}-02 \\
1.36 \mathrm{E}-01 \\
1.63 \mathrm{E}-01 \\
9.42 \mathrm{E}-02\end{array}$ & $\begin{array}{l}1.30 \mathrm{E}-01 \\
1.50 \mathrm{E}-02 \\
5.85 \mathrm{E}-02 \\
7.88 \mathrm{E}-01 \\
2.25 \mathrm{E}-04 \\
2.91 \mathrm{E}-05 \\
4.17 \mathrm{E}-05 \\
1.29 \mathrm{E}-04 \\
1.57 \mathrm{E}-04 \\
8.85 \mathrm{E}-04\end{array}$ & $\begin{array}{l}6.49 E-01 \\
2.13 E-05 \\
4.92 E-02 \\
3.01 E-01 \\
1.63 E-07 \\
8.39 E-09 \\
2.63 E-08 \\
2.73 E-08 \\
3.28 E-06 \\
1.07 E-07\end{array}$ \\
\hline Total & $1.29 E+00$ & $9.92 \mathrm{E}-01$ & $9.94 \mathrm{E}-01$ & $1.00 E+00$ \\
\hline
\end{tabular}

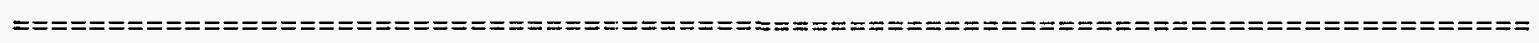

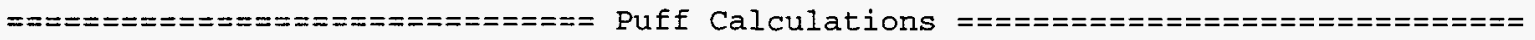

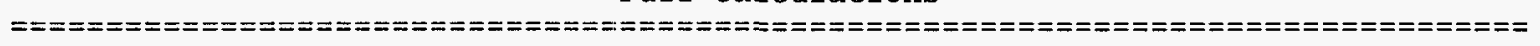

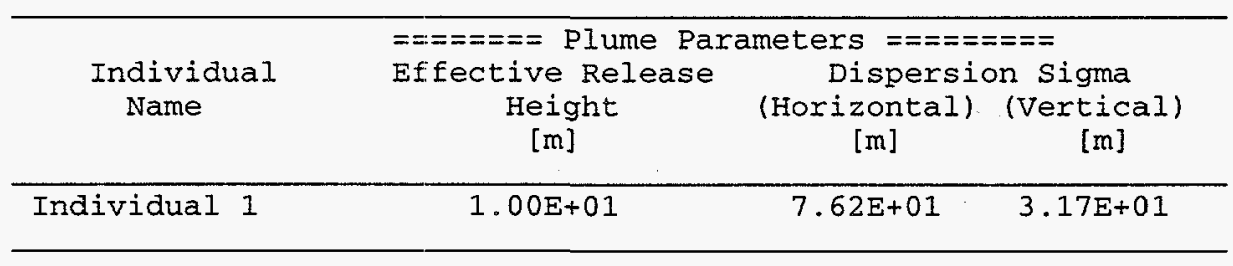

\begin{tabular}{ccccc}
\hline $\begin{array}{c}\text { Individual } \\
\text { Name }\end{array}$ & $\begin{array}{c}====\text { Chi/Q } \\
\text { Air } \\
{[\mathrm{s} / \mathrm{m} 3]}\end{array}$ & $\begin{array}{c}===== \\
\text { Ground } \\
{[1 / \mathrm{m} 2]}\end{array}$ & $\begin{array}{c}\text { Depletion } \\
\text { Fraction }\end{array}$ & $\begin{array}{c}\text { Wet/Dry } \\
\text { Ratio }\end{array}$ \\
\hline $\begin{array}{c}\text { Individual 1 } \\
\text { Particulates }\end{array}$ & $3.1 .1 \mathrm{E}-05$ & $3.11 \mathrm{E}-08$ & $7.94 \mathrm{E}-03$ & $0.00 \mathrm{E}+00$ \\
Ruthenium & $3.1 .1 \mathrm{E}-05$ & $3.11 \mathrm{E}-08$ & $7.94 \mathrm{E}-03$ & $0.00 \mathrm{E}+00$ \\
Cesium & $3.1 .1 \mathrm{E}-05$ & $3.11 \mathrm{E}-08$ & $7.94 \mathrm{E}-03$ & $0.00 \mathrm{E}+00$ \\
Iodine & $2.89 \mathrm{E}-05$ & $2.89 \mathrm{E}-07$ & $7.67 \mathrm{E}-02$ & $0.00 \mathrm{E}+00$ \\
Gases & $3.14 \mathrm{E}-05$ & $0.00 \mathrm{E}+00$ & $0.00 \mathrm{E}+00$ & $0.00 \mathrm{E}+00$ \\
\hline
\end{tabular}




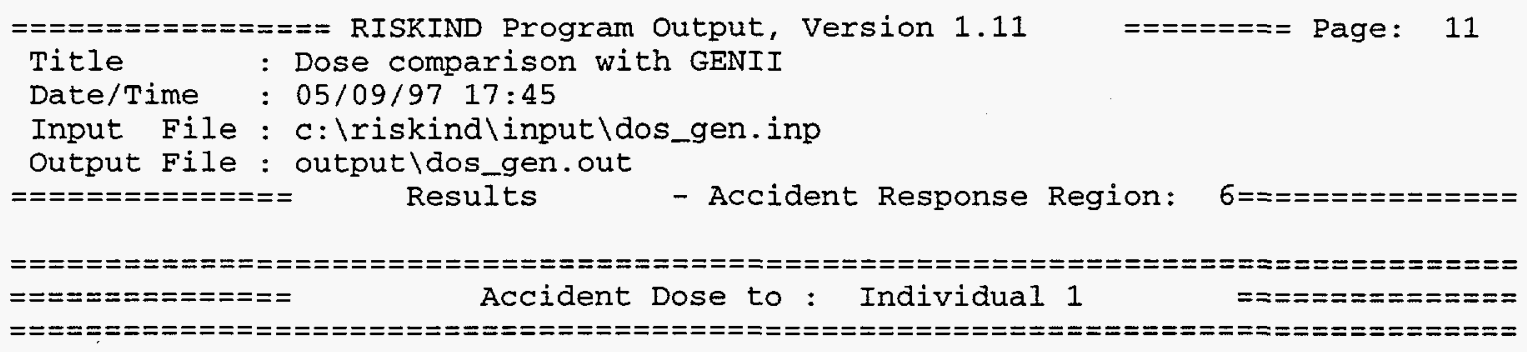

Individual Summary Results Per Accident

\begin{tabular}{lrr}
\hline Committed Effective Dose Equivalent Risk & $1.62 \mathrm{E}-01$ & rem \\
Expected Genetic Effects & $2.10 \mathrm{E}-05$ & \\
Expected Non-fatal Cancers & $1.62 \mathrm{E}-05$ & \\
Expected Cancer Fatalities & $8.09 \mathrm{E}-05$ \\
Acute Risk (Expected fatalities) & $0.00 \mathrm{E}+00$ \\
\hline
\end{tabular}

\begin{tabular}{|c|c|c|c|c|}
\hline Pathway & & Doses (rem) & & \\
\hline Acute & $3.69 E-03$ & & & \\
\hline Cask & & $5.37 E-10$ & & \\
\hline Ground Shine & & $1.26 \mathrm{E}-06$ & & \\
\hline Inhalation & & $3.68 E-03$ & & \\
\hline Cloud shine & & $9.15 \mathrm{E}-06$ & & \\
\hline Long-Term & $1.58 \mathrm{E}-01$ & & & \\
\hline Ground Shine & & $2.60 \mathrm{E}-03$ & & \\
\hline Inhalation & & 1. $13 \mathrm{E}-04$ & & \\
\hline Cloud Shine & & $2.77 \mathrm{E}-07$ & & \\
\hline Ingestion & & $1.55 \mathrm{E}-01$ & & \\
\hline Initial Year & & & $1.55 E-01$ & \\
\hline Vegetable & & & & $5.70 \mathrm{E}-02$ \\
\hline Meat & & & & 1. $64 \mathrm{E}-02$ \\
\hline Milk & & & & $8.17 E-02$ \\
\hline Long-Term & & & $4.98 E-04$ & \\
\hline Vegetable & & & & $2.15 \mathrm{E}-04$ \\
\hline Meat & & & & $4.70 \mathrm{E}-05$ \\
\hline Milk & & & & $2.37 E-04$ \\
\hline Water & & & & $0.00 E+00$ \\
\hline
\end{tabular}

\begin{tabular}{lcccc}
\hline Exposure Parameter & Organ $\begin{array}{c}\text { Exposure } \\
\text { Marrow }\end{array}$ & Lung & Intestine & Gonads \\
\hline Long-Term Dose [rem] & $1.59 E-01$ & $1.47 E-01$ & $1.60 E-01$ & $1.60 E+01$ \\
Brief Dose [Gy] Time [d] & $1.31 E-07$ & $2.25 E-06$ & $2.81 E-06$ & $1.00 E+00$ \\
Brief Exposure Tim [Gy/hr] & $1.00 E+00$ & $1.00 E+00$ & 1.007 \\
Brief Dose Rate [Gy] & $5.17 E-08$ & $1.74 E-07$ & $1.59 E-07$ \\
Prolonged Dose [d] & $6.89 E-07$ & $1.92 E-05$ & $2.85 E-06$ \\
Prolong Exposure Time [d] & $3.00 E+01$ & $3.65 E+02$ & $7.00 E+00$ \\
Prolong Dose Rate [Gy/hr] & $9.57 E-10$ & $1.21 E-07$ & $1.10 E-07$ \\
Hazard & $0.00 E+00$ & $0.00 E+00$ & $0.00 E+00$ \\
Acute Risk [Expected fatalities] & $0.00 E+00$ & $0.00 E+00$ & $0.00 E+00$ \\
\hline
\end{tabular}




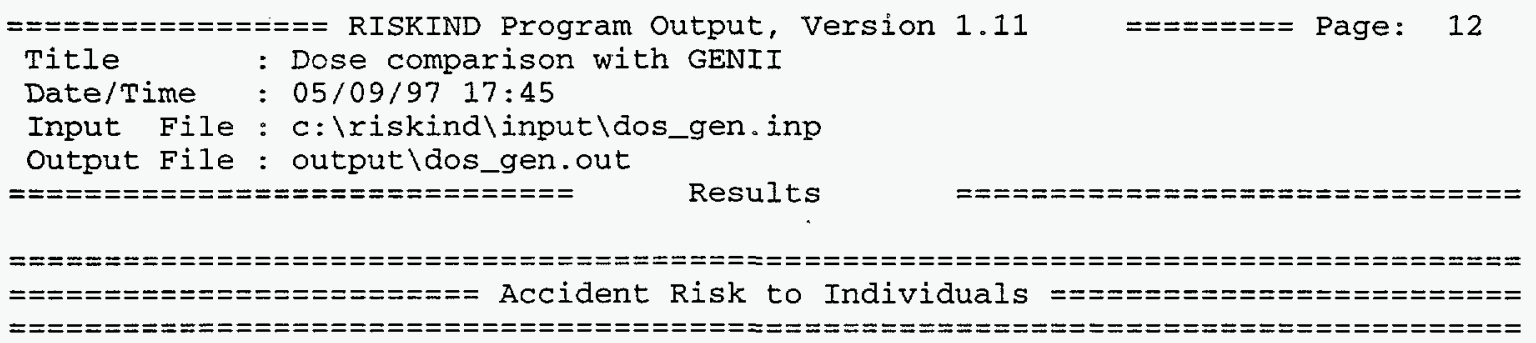

Individual Accident Dose Summary Results

Dose Risks reported on a per $\mathrm{km}$ basis

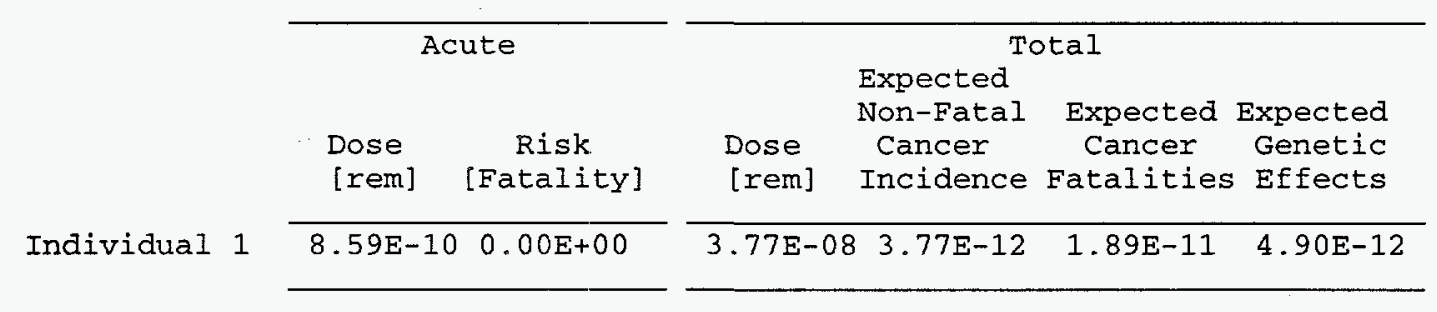




\section{B.1.2.2 GENII Output for Spent Fuel Accident}

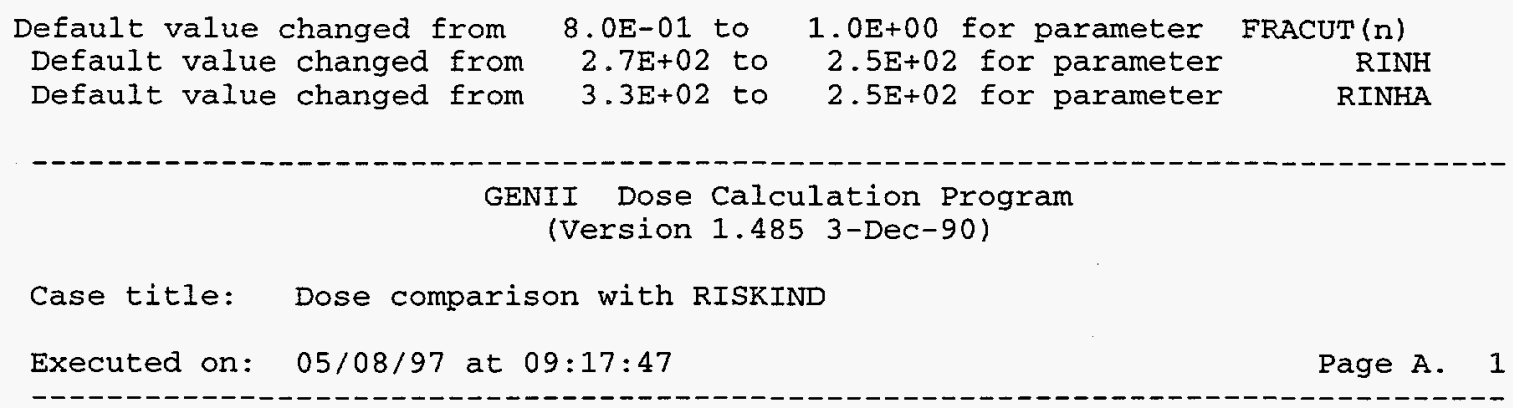

This is a far-field (wide-scale release, multiple site) scenario. Release is acute

Individual dose

THE FOLLOWING TRANSPORT MODES ARE CONSIDERED Air

THE FOLLOWING EXPOSURE PATHS ARE CONSIDERED:

Infinite plume, external

Ground; external

Inhalation uptake

Terrestrial foods ingestion

Animal product ingestion

THE FOLLOWING TIMES ARE USED:

Intake ends after ( $y r): \quad 1.0$

Dose calculations ends after $(y r): 50.0$

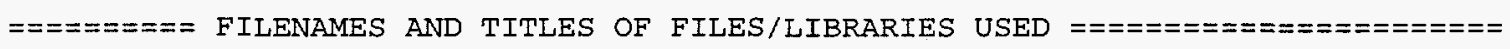

Input file name: dose_rkd.in

GENII Default Parameter Values w/ some RISKIND defaults $(5 / 08 / 97 \mathrm{bb})$

Radionuclide Master Library (11/28/90 RAP)

Food Transfer Factor Library - (RAP 29-Aug-88) (UPDATED LEACHING FA

External Dose Factors for GENII in person Sv/Yr per $\mathrm{Bq} / \mathrm{n}$ (8-May-90 $\mathrm{R}$

Internal Dose Increments, Worst Case Solubilities, 12/3/90 PDR

$4.0 \mathrm{~m} / \mathrm{s}$ avg. wind speed, $100 \%$ persistence towards $\mathrm{S}$, class D, $6 / 6 / 94 \mathrm{bb}$

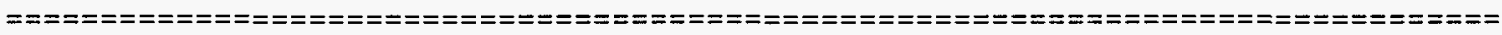

\begin{tabular}{|c|c|c|c|}
\hline Release & & Surface & Buried \\
\hline $\begin{array}{l}\text { Radio- } \\
\text { nuclide }\end{array}$ & $\begin{array}{l}\mathrm{Air} \\
\mathrm{Ci} / \mathrm{yr}\end{array}$ & $\begin{array}{c}\text { Water } \\
\text { Ci/yr }\end{array}$ & $\begin{array}{r}\text { Source } \\
\mathrm{Ci} / \mathrm{m} 3\end{array}$ \\
\hline & $\ldots-\cdots$ & ----- & --- \\
\hline CO60 & $4.3 E-01$ & $0.0 \mathrm{E}+00$ & $0.0 \mathrm{E}+00$ \\
\hline SR90 & $5.6 \mathrm{E}-03$ & $0.0 \mathrm{E}+00$ & $0.0 \mathrm{E}+00$ \\
\hline CS134 & $5.5 E-02$ & $0.0 E+00$ & $0.0 E+00$ \\
\hline $\operatorname{Cs} 137$ & $8.0 E-01$ & $0.0 \mathrm{E}+00$ & $0.0 E+00$ \\
\hline PU238 & $2.8 E-04$ & $0.0 \mathrm{E}+00$ & $0.0 E+00$ \\
\hline PU239 & $3.3 E-05$ & $0.0 E+00$ & $0.0 E+00$ \\
\hline PU240 & $4.7 E-05$ & $0.0 E+00$ & $0.0 E+00$ \\
\hline PU241 & $7.8 \pm-03$ & $0.0 E+00$ & $0.0 \mathrm{E}+00$ \\
\hline AM241 & 1. $7 E-04$ & $0.0 E+00$ & $0.0 E+00$ \\
\hline CM244 & $1.8 E-04$ & $0.0 \mathrm{E}+00$ & $0.0 \mathrm{E}+00$ \\
\hline
\end{tabular}

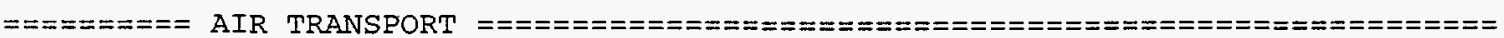
Joint frequency data input.

1. OE+03 Maximum individual distance from release point (m)

1.0E+00 Maximum individual sector index (Wind Toward $S$ ) 


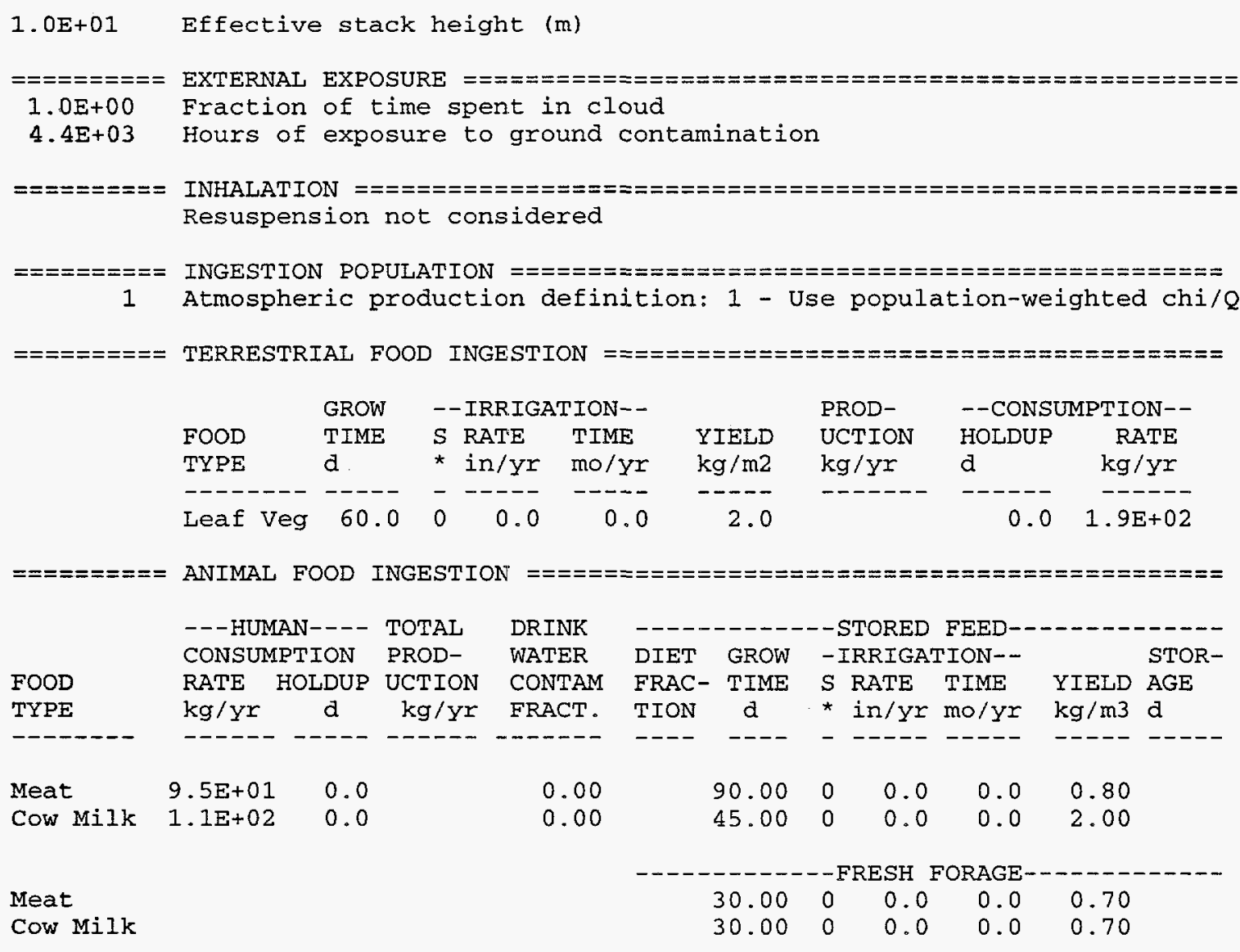

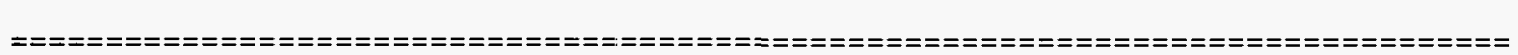

Input prepared by:

Date:

Input checked by:

Date: 


\section{$B-4 I$}

$--$

GENII Dose Calculation Program

(Version 1.485 3-Dec-90)

Case title: Dose comparison with RISKIND

Executed on: 05/08/97 at $09: 17: 47$

Page A. 2

\begin{tabular}{|c|c|c|c|c|c|}
\hline \multirow{2}{*}{$\begin{array}{l}\text { Sector index: } 1 \\
\text { Distance: } 1000.0\end{array}$} & Probability & $\begin{array}{c}E / Q \\
(\mathrm{sec} / \mathrm{m} 3)\end{array}$ & $\begin{array}{l}\mathrm{DOQ} \\
(\mathrm{m} 2)\end{array}$ & $\begin{array}{c}\text { Travel } \\
\text { Time } \\
\text { (sec) }\end{array}$ & $\begin{array}{c}\text { Population- } \\
\text { weighted } \\
\text { E/Q } \\
\text { (person-sec/m3) }\end{array}$ \\
\hline & $\begin{array}{l}0.5000 \\
0.5000 \\
0.5000 \\
0.5000 \\
0.0000\end{array}$ & $\begin{array}{l}3.2 \mathrm{E}-05 \\
3.2 \mathrm{E}-05 \\
3.2 \mathrm{E}-05 \\
3.2 \mathrm{E}-05 \\
0.0 \mathrm{E}+00\end{array}$ & $\begin{array}{l}3.2 \mathrm{E}-07 \\
3.2 \mathrm{E}-07 \\
3.2 \mathrm{E}-07 \\
3.2 \mathrm{E}-07 \\
0.0 \mathrm{E}+00\end{array}$ & $\begin{array}{r}250 . \\
250 . \\
250 . \\
250 . \\
0 .\end{array}$ & \\
\hline
\end{tabular}




\section{$B-42$}

GENII Dose Calculation Program

(Version 1.485 3-Dec-90)

Case title: Dose comparison with RISKIND

Executed on: $05 / 08 / 97$ at $09: 17: 51$

Page B. 1

3.2E-05 Individual $\mathrm{E} / \mathrm{Q}$ 


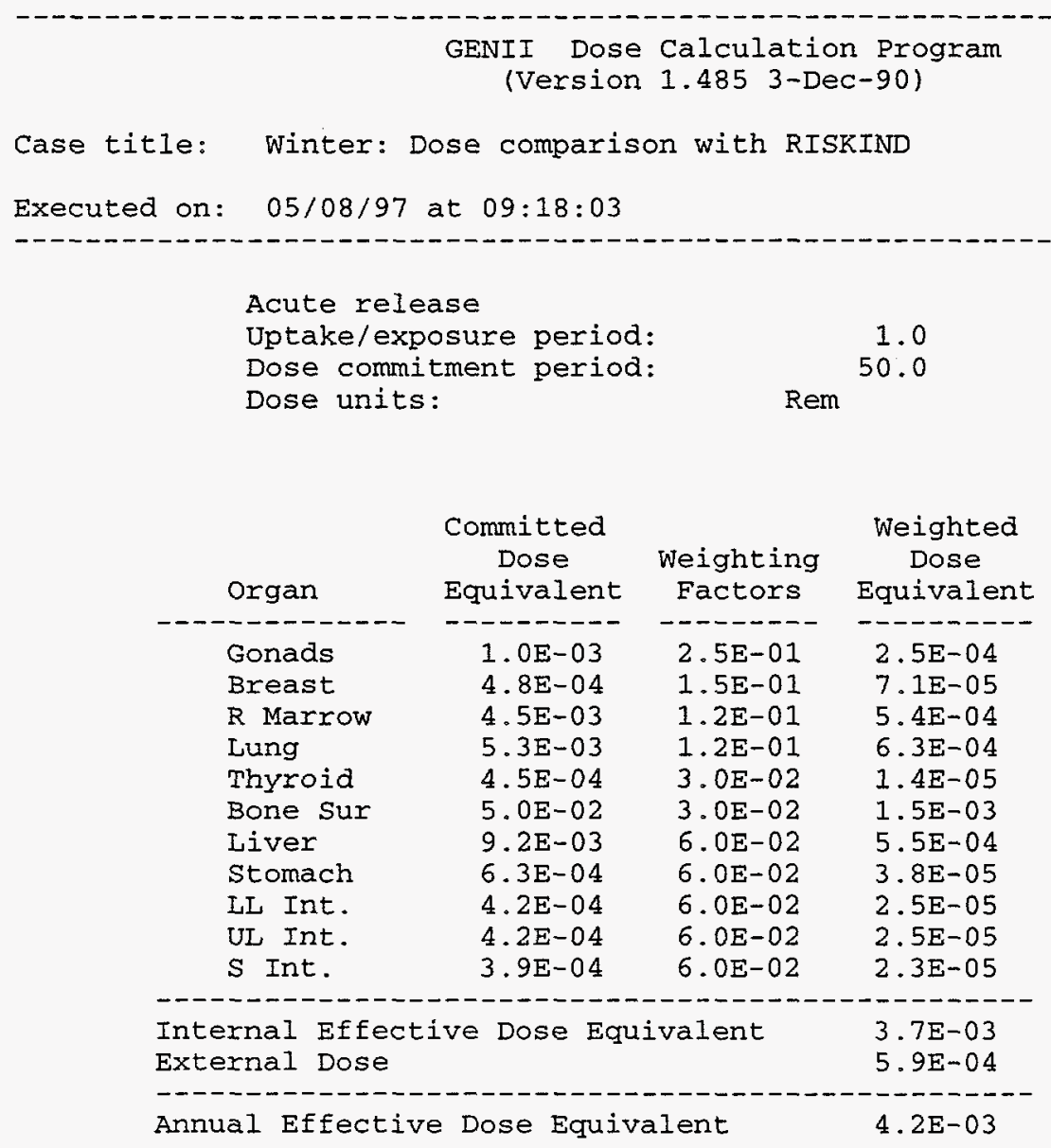

Controlling organ:

Controlling Pathway:

Bone sur

Controlling Radionuclide:

Inh

Total Inhalation EDE:

CO60

Total Ingestion EDE:

3. $6 \mathrm{E}-03$

$5.6 \mathrm{E}-05$

Page C. 1 
GENII Dose Calculation Program

(Version 1.485 3-Dec-90)

Case title: Winter: Dose comparison with RISKIND

Executed on: $05 / 08 / 97$ at $09: 18: 03$

Page C. 2

Acute release

Uptake/exposure period:

Dose commitment period:

Dose units:

1.0

50.0

Rem

Dose Commitment Year

2

3

Internal

Intake

Year:
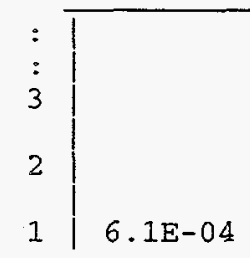

$$
0.0 \mathrm{E}+00
$$

$0.0 \mathrm{E}+00$

$0.0 \mathrm{E}+00$

$+$

$+2.5 \mathrm{E}-04+1.8 \mathrm{E}-04+\ldots=3.7 \mathrm{E}-03$

||

Internal

$$
11
$$

$$
11
$$

$$
\text { | }
$$

Annual

Dose

$$
\begin{aligned}
& 6.1 E-04+2.5 E-04+1.8 E-04+\ldots=3.7 E-03 \\
& 5.9 E-04 \\
& 0.0 E+00
\end{aligned}
$$

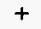

External

Annual

Dose

Annua 1

Dose

Cumulative

Dose

Maximum

1.2E-03 Annual

Dose Occurred

In Year 1 


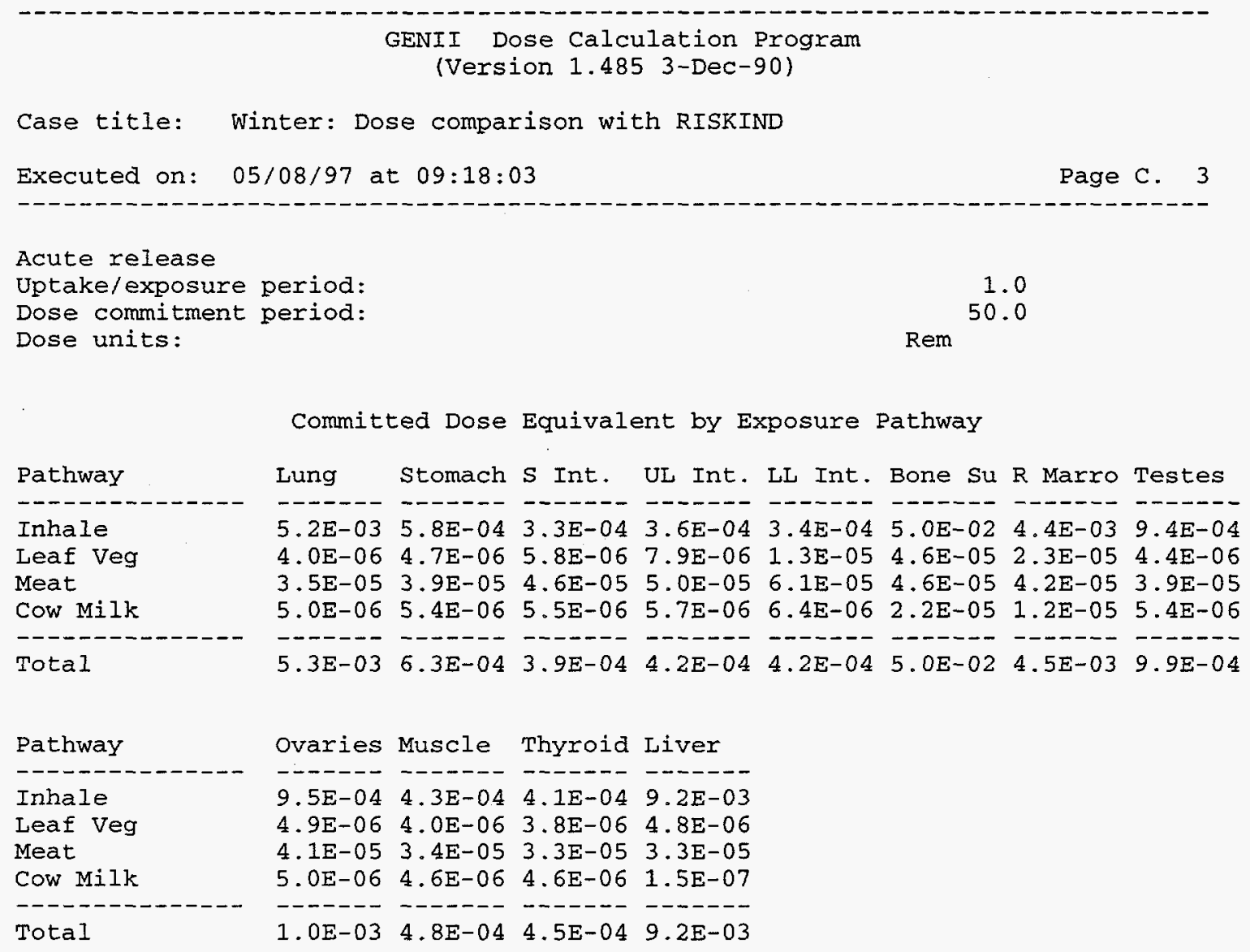

External Dose by Exposure Pathway

Pathway

\begin{tabular}{ll} 
Plume & $1.0 \mathrm{E}-05$ \\
Sur Soil & $5.8 \mathrm{E}-04$ \\
\hdashline$-1-0$ & ---- \\
Total & $5.9 \mathrm{E}-04$
\end{tabular}


GENII Dose Calculation Program

(Version 1.485 3-Dec-90)

Case title: Winter: Dose comparison with RISKIND

Executed on: 05/08/97 at 09:18:03

Page C. 4

Acute release

Uptake/exposure period:

Dose commitment period:

Dose units:

1.0

50.0

Rem

Committed Dose Equivalent by Radionuclide

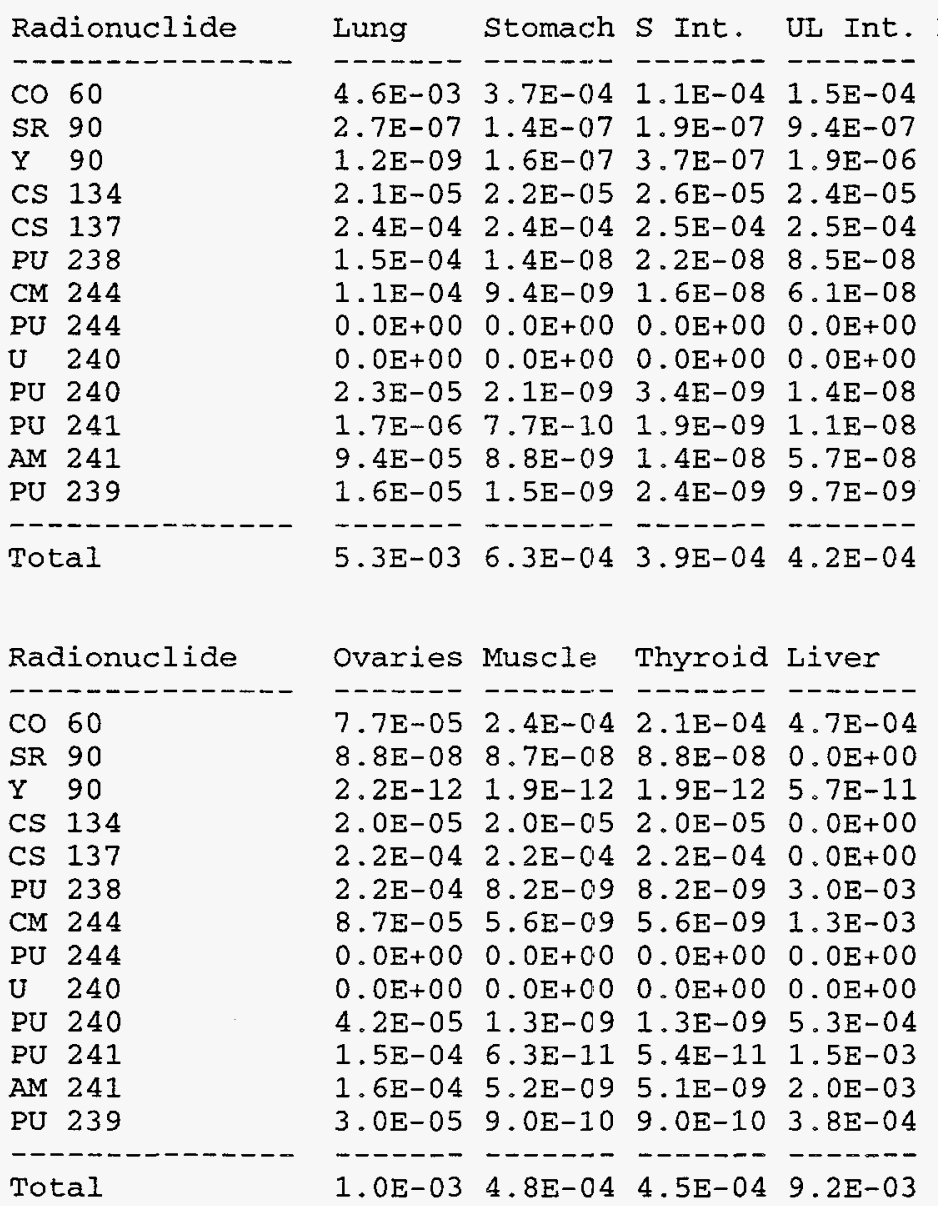




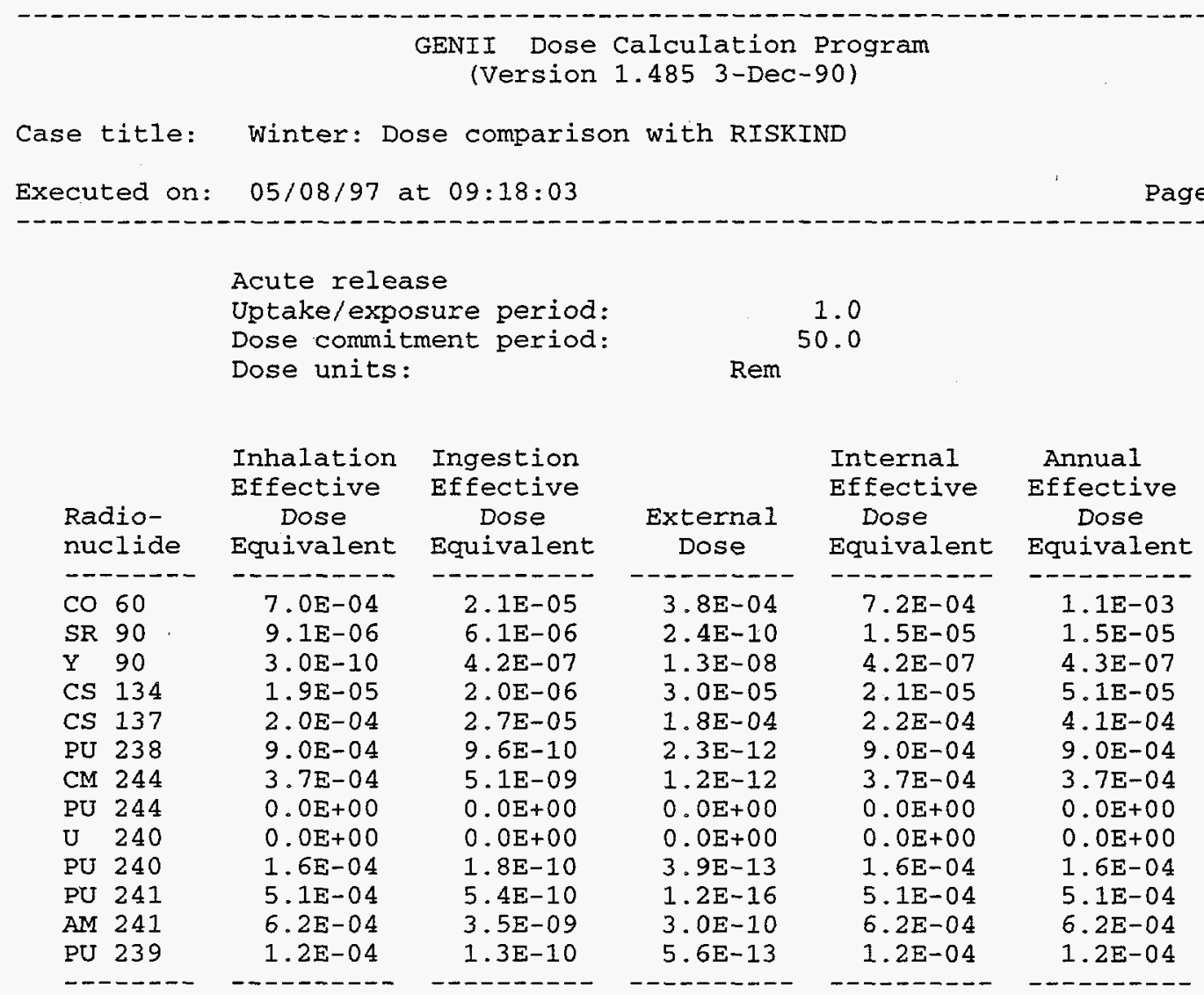


GENII Dose Calculation Program

(Version 1.485 3-Dec-90)

Case title: Spring: Dose comparison with RISKIND

Executed on: 05/08/97 at 09:18:04

Page C. 7

Acute release

Uptake/exposure period:

Dose commitment period:

Dose units:

50.0

Rem

Dose Commitment Year

1

2

3

$\begin{array}{lc}\text { Internal } & : \\ \text { Intake } & : \\ \text { Year: } & 3 \\ & 2 \\ & 1\end{array}$

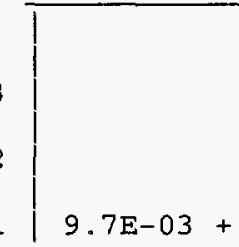

$\begin{array}{lll}0.0 E+00 & \ldots \\ + & 0.0 E+00 & \ldots\end{array}$

$.7 \mathrm{E}-03+1.3 \mathrm{E}-03+4.4 \mathrm{E}-04+\ldots=1.5 \mathrm{E}-02$

Internal

Effective

Dose

I| $|1|$

Internal

Annual

Dose

$9.7 E-03+1.3 E-03+4.4 E-04+\ldots=1.5 E-02$

Equivalent

External

Annual

Dose

Annual

Dose

$$
\text { 9.7 }
$$

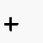

$$
\text { 5. } 9 \mathrm{E}-04
$$$$
0.0 E+00
$$

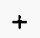

Cumulative

Internal

Dose

$$
11
$$

$$
11
$$

$0.0 E+00$

..

$5.9 E-04$

1. $0 \mathrm{E}-0$$$
11
$$$$
11
$$

1. 5E-02

Cumulative

Dose

$$
\text { 1. OE-02 }
$$

Maximum

Annual

Dose Occurred

In Year 1 
GENII Dose Calculation Program

(Version 1.485 3-DeC-90)

Case title: Spring: Dose comparison with RISKIND

Executed on: 05/08/97 at 09:18:04

Page C. 8

Acute release

Uptake/exposure period:

Dose commitment period:

Dose units:

1.0

50.0

Rem

Committed Dose Equivalent by Exposure Pathway

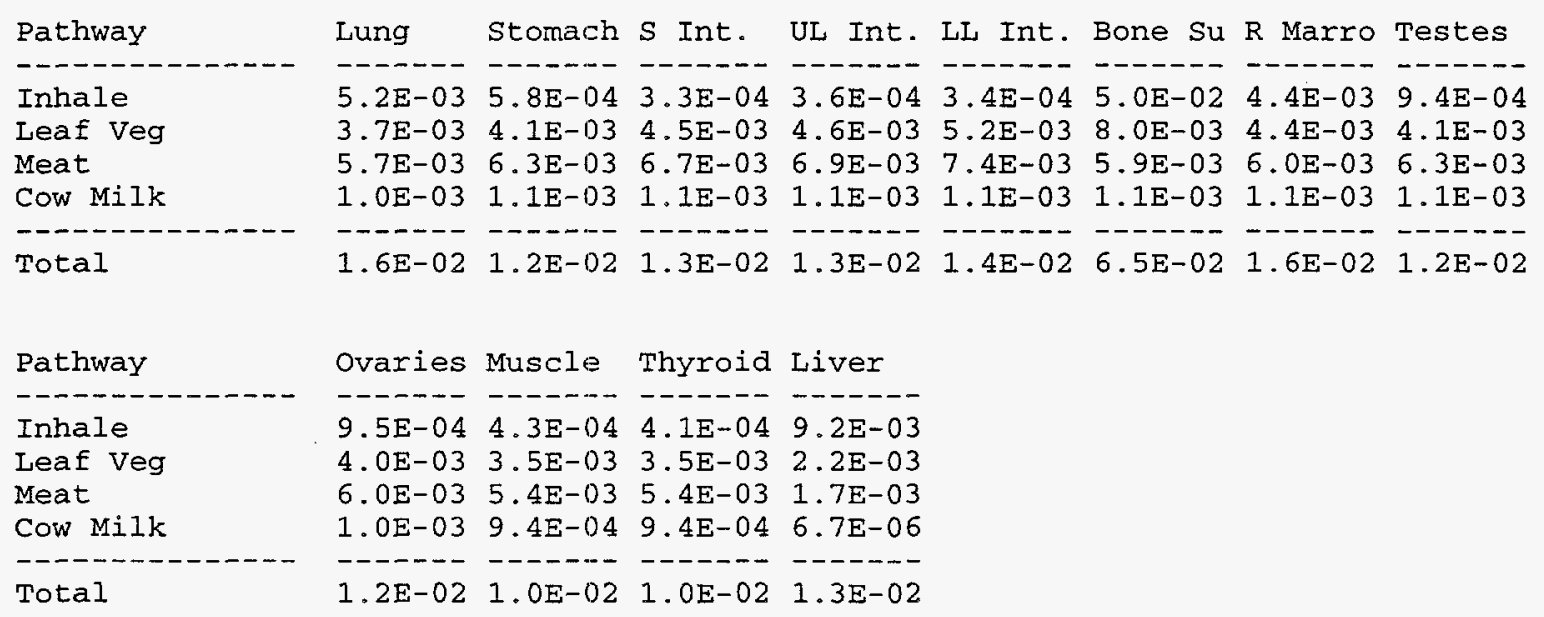

External Dose by Exposure Pathway

Pathway

\begin{tabular}{ll} 
Plume & $1.0 \mathrm{E}-05$ \\
Sur Soil & $5.8 \mathrm{E}-04$ \\
\hdashline Total & $--9 \mathrm{E}-04$
\end{tabular}




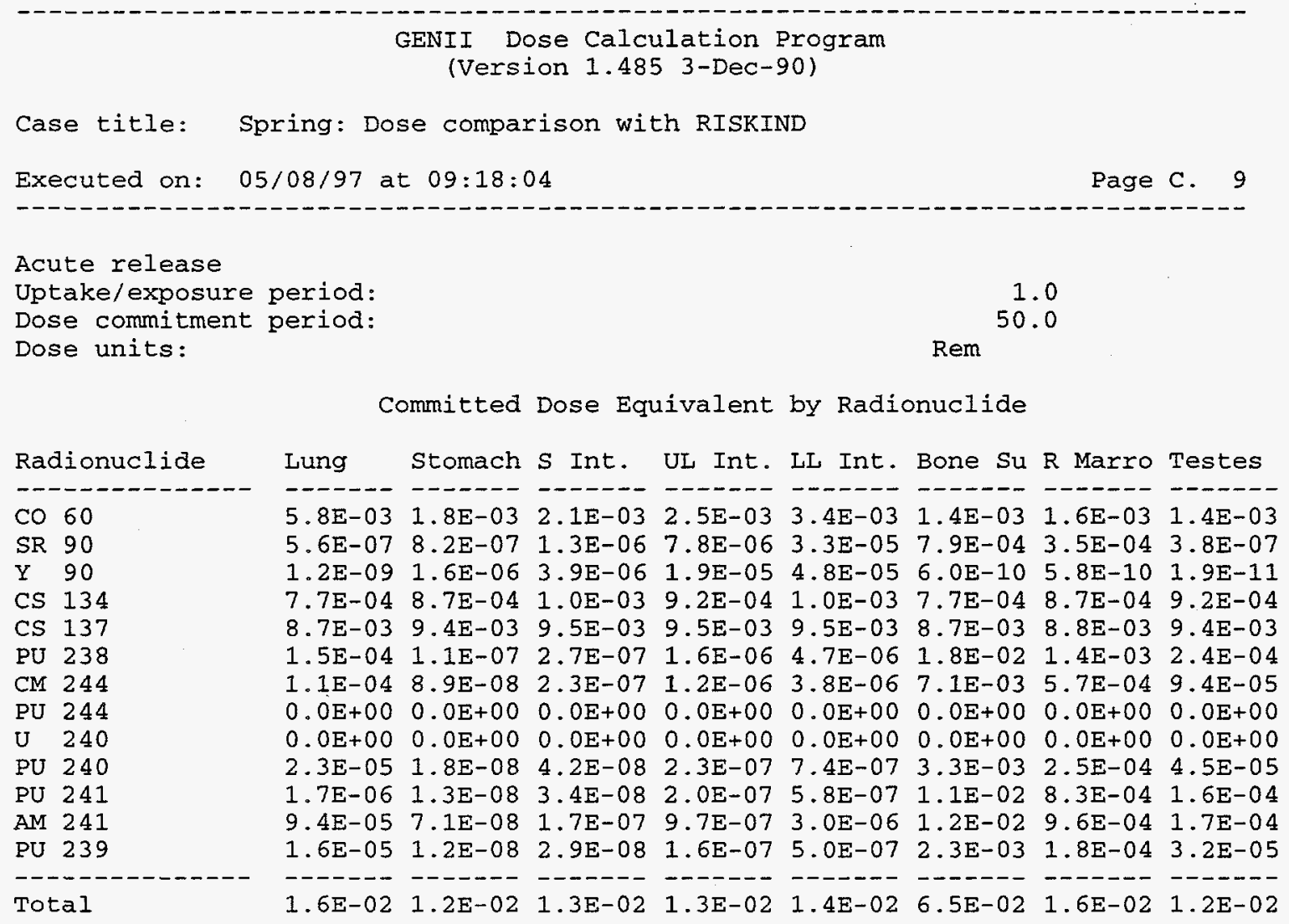

\begin{tabular}{|c|c|c|c|c|c|}
\hline Rad & dionuc & Ovaries & Muscle & Thy & $r$ \\
\hline & & - & -- & & \\
\hline $\mathrm{CO}$ & 60 & $1.8 E-03$ & $1.5 E-03$ & $1.4 \mathrm{E}-03$ & $3.6 \mathrm{E}-03$ \\
\hline SR & 90 & $3.8 \mathrm{E}-07$ & $3.8 E-07$ & $3.8 E-07$ & $.0 \mathrm{E}+00$ \\
\hline$Y$ & 90 & 2. $2 E-11$ & 1. $9 E-11$ & $1.9 \mathrm{E}-11$ & $5.7 E-10$ \\
\hline CS & 134 & $7.7 \mathrm{E}-04$ & $7.7 \mathrm{E}-04$ & $7.7 \mathrm{E}-04$ & $0.0 E+00$ \\
\hline CS & 137 & $8.7 E-03$ & $8.1 E-03$ & $8.1 E$ & $0.0 E+00$ \\
\hline PU & 238 & $2.4 \mathrm{E}-04$ & $8.8 E-09$ & $8.8 \mathrm{E}-09$ & $3.2 \mathrm{E}-03$ \\
\hline $\mathrm{CM}$ & 244 & $9.5 E-05$ & $6.1 E-09$ & $6.1 \mathrm{E}-09$ & $1.4 \mathrm{E}-03$ \\
\hline PU & 244 & $0.0 \mathrm{E}+00$ & $0.0 E+00$ & $0.0 E+00$ & $0.0 \mathrm{E}+00$ \\
\hline U & 240 & $0.0 E+00$ & $0.0 E+00$ & $0.0 \mathrm{E}+0$ & $0.0 E+00$ \\
\hline PU & 240 & $4.5 E-05$ & $1.4 \mathrm{E}-09$ & $1.4 \mathrm{E}-09$ & $5.7 \mathrm{E}-04$ \\
\hline PU & 241 & $1.6 \mathrm{E}-04$ & $6.6 \mathrm{E}-11$ & 5.5 & $1.6 \mathrm{E}-03$ \\
\hline$A M$ & 241 & $1.7 \mathrm{E}-04$ & $5.8 E-09$ & 5.5. & $2.2 E-03$ \\
\hline PU & & 3.2 & $7 E-10$ & & $0 E-04$ \\
\hline & & $2 E$ & $0 ?$ & Fח & 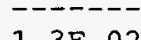 \\
\hline & & 1.2 & 32 & D & $3-0$ \\
\hline
\end{tabular}


GENII Dose Calculation Program

(Version 1.485 3-Dec-90)

Case title: Spring: Dose comparison with RISKIND

Executed on: 05/08/97 at 09:18:04

Page C. 10

Acute release

Uptake/exposure period:

Dose commitment period:

Dose units:

Inhalation Ingestion

Effective Effective

RadioDose

nuclide

-----.--

CO 60

SR 90

Y 90

CS 134

CS 137

PU 238

CM 244

PU 244

U 240

PU 240

PU 241

$\mathrm{AM} 241$

PU 239

\section{Equivalent Equivalent}

7. $0 \mathrm{E}-04$

9. $1 \mathrm{E}-06$

3. $0 \mathrm{E}-10$

1. $9 E-05$

2. $0 E-04$

9. $0 \mathrm{E}-04$

3. $7 E-04$

$0.0 \mathrm{E}+00$

$0.0 \mathrm{E}+00$

1. $6 \mathrm{E}-04$

5. $1 E-04$

6. $2 \mathrm{E}-04$

1. $2 \mathrm{E}-04$

$$
\text { Dosie }
$$

-

1. $8 \mathrm{E}-03$

5. $9 \mathrm{E}-05$

4. $3 \mathrm{E}-06$

8. $0 \mathrm{E}-04$

8. $2 \mathrm{E}-03$

$6.7 \mathrm{E}-05$

3. $3 E-05$

$0.0 E+00$

$0.0 E+00$

1. $2 \mathrm{E}-05$

3. $9 \mathrm{E}-05$

4. $7 E-05$

8. $6 \mathrm{E}-06$
1. 0

50.0

Rem

Internal

Effective

Dose

Dose

3. $8 E-04$

2. $4 E-10$

1. $3 E-08$

3. $0 \mathrm{E}-05$

1. $8 \mathrm{E}-04$

2. $3 E-12$

1. $2 E-12$

$0.0 E+00$

$0.0 E+00$

3. $9 E-13$

1. $2 \mathrm{E}-16$

3. $0 E-10$

5. $6 \mathrm{E}-13$

Equivalent

2. $5 \mathrm{E}-03$

$6.9 E-05$

4. $3 E-06$

8. $2 \mathrm{E}-04$

$8.4 \mathrm{E}-03$

9. $7 \mathrm{E}-04$

4. $0 E-04$

$0.0 E+00$

$0.0 E+00$

1. $8 \mathrm{E}-04$

5. $5 E-04$

$6.7 \mathrm{E}-04$

1. $3 \mathrm{E}-04$
Annual

Effective Dose

Equivalent

2. $8 \mathrm{E}-03$

$6.9 E-05$

4. $4 \mathrm{E}-06$

8. $5 E-04$

8. $6 \mathrm{E}-03$

9. $7 E-04$

4. $0 E-04$

$0.0 \mathrm{E}+00$

$0.0 E+00$

1. $8 \mathrm{E}-04$

5. $5 E-04$

$6.7 E-04$

1. $3 \mathrm{E}-04$

------




GENII Dose Calculation Program
(Version 1.485 3-Dec-90)

\begin{tabular}{|c|c|c|c|}
\hline Organ & $\begin{array}{l}\text { Committed } \\
\text { Dose } \\
\text { Equivalent }\end{array}$ & $\begin{array}{c}\text { Weighting } \\
\text { Factors }\end{array}$ & $\begin{array}{l}\text { Weighted } \\
\text { Dose } \\
\text { Equivalent }\end{array}$ \\
\hline -ー-ーーー-ーー & ------- & -------- & $----n--$ \\
\hline Gonads & 1. $4 \mathrm{E}-02$ & $2.5 E-01$ & $3.6 \mathrm{E}-03$ \\
\hline Breast & 1. $2 E-02$ & 1. $5 E-01$ & $1.8 \mathrm{E}-03$ \\
\hline $\mathrm{R}$ Marrow & $1.8 \mathrm{E}-02$ & 1. $2 E-01$ & $2.1 E-03$ \\
\hline Lung & $1.7 \mathrm{E}-02$ & 1. $2 \mathrm{E}-01$ & $2.1 E-03$ \\
\hline Thyroid & 1. $2 E-02$ & $3.0 E-02$ & $3.5 E-04$ \\
\hline Bone Sur & $6.6 \mathrm{E}-02$ & $3.0 E-02$ & 2. $.0 E-03$ \\
\hline LL Int. & $1.6 \mathrm{E}-02$ & $6.0 E-02$ & $9.7 E-04$ \\
\hline UL Int & 1. $5 \mathrm{E}-02$ & $6.0 \mathrm{E}-02$ & $8.9 E-04$ \\
\hline$S$ Int. & $1.5 E-02$ & $6.0 E-02$ & $8.7 E-04$ \\
\hline Stomach & $1.4 \mathrm{E}-02$ & $6.0 E-02$ & $8.3 E-04$ \\
\hline Liver & $1.3 \mathrm{E}-02$ & $6.0 E-02$ & $8.1 E-04$ \\
\hline \multirow{3}{*}{\multicolumn{3}{|c|}{$\begin{array}{l}\text { ernal Effe } \\
\text { ernal Dose }\end{array}$}} & \\
\hline & & & 1. $6 \mathrm{E}-02$ \\
\hline & & & $5.9 E-04$ \\
\hline \multicolumn{4}{|l|}{ 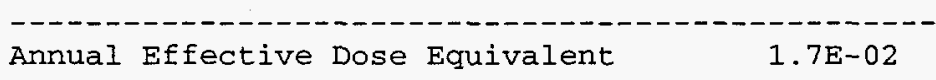 } \\
\hline
\end{tabular}

\begin{tabular}{ll} 
Controlling Organ: & Bone Sur \\
Controlling Pathway: & Ing \\
Controlling Radionuclide: & CS137 \\
\hline$-1-1.6 \mathrm{E}-03$ \\
Total Inhalation EDE: & $3.3 \mathrm{E}-02$ \\
Total Ingestion EDE: &
\end{tabular}


GENII Dose Calculation Program

(Version 1.485 3-Dec-90)

Case title: Summer: Dose comparison with RISKIND

Executed on: $05 / 08 / 97$ at $09: 18: 05$

Page C. 12

Acute release

Uptake/exposure period:

Dose commitment period:

Dose units:

1.0

50.0

Rem

Dose Commitment Year

2

3

Internal

Intake

Year:

$$
\begin{aligned}
& : \\
& 3 \\
& 2 \\
& 1
\end{aligned}
$$

Internal

Annual

Dose

External

Annual

Dose

Annual

Dose

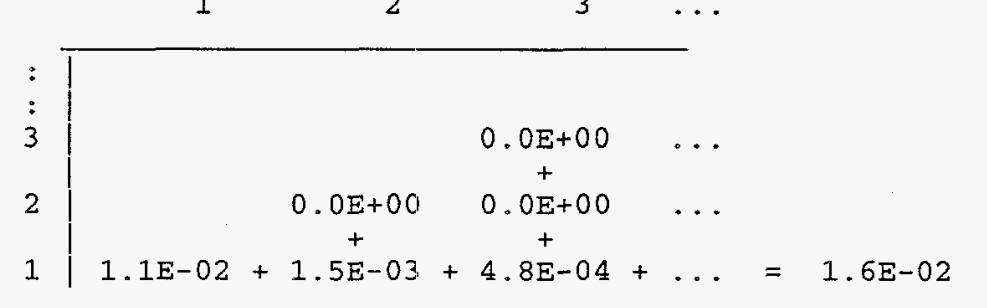

Internal

Effective

Dose

Equivalent

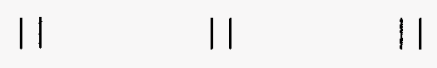

$1.1 \mathrm{E}-02+1.5 \mathrm{E}-03+4.8 \mathrm{E}-04+\ldots=1.6 \mathrm{E}-02$

Cumulative

Internal

Dose

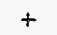

$+$

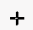

$+$

$5.9 \mathrm{E}-04 \quad 0.0 \mathrm{E}+0 \mathrm{O} \quad 0.0 \mathrm{E}+00 \quad \ldots \quad 5.9 \mathrm{E}-04$

11

11

11

11

$1.2 \mathrm{E}-02+1.5 \mathrm{E}-03+4.8 \mathrm{E}-04+\ldots=1.7 \mathrm{E}-02$

Cumulative

Dose

Maximum

1.2E-02 Annual

Dose Occurred

In Year 1 


\section{GENII Dose Calculation Program}

(Version 1.485 3-Dec-90)

Case title: Summer: Dose comparison with RISKIND

Executed on: 05/08/97 at 09:18:05

Page C. 13

Acute release

Uptake/exposure period:

Dose commitment period:

Dose units:

1.0

50.0

Rem

Committed Dose Equivalent by Exposure Pathway

\begin{tabular}{|c|c|c|c|c|c|c|c|c|}
\hline Pathway & Iung & Stomach & S Int. & UL Int. & LI Int. & Bone Su & R Marro & Testes \\
\hline le & $5.2 \boldsymbol{E}-03$ & $5.8 \mathrm{E}-04$ & $3.3 E-04$ & $3.6 E-04$ & $3.4 E-04$ & $5.0 \mathrm{E}-02$ & $4.4 E-03$ & $9.4 \mathrm{E}$ \\
\hline eaf Veg & $3.7 E-03$ & $4.1 E-03$ & $4.5 E-03$ & $4.6 E-03$ & $.2 \mathrm{E}$ & .03 & 03 & 03 \\
\hline eat & $7.2 \mathrm{E}-03$ & $7.8 \mathrm{E}-03$ & $8.4 E-03$ & $5 E-03$ & 03 & -03 & -03 & 03 \\
\hline ow Milk & 1. $2 E-03$ & $1.3 \mathrm{E}-03$ & $1.4 \mathrm{E}-03$ & 03 & 3 & 03 & -03 & 3. \\
\hline----- & ---- & -- & -- & & & & $\ldots$ & \\
\hline
\end{tabular}

Pathway

Ovaries Muscle Thyroid Liver

- - - - - - - - - - - -

Varies Muscle Thyroid Liver

Inhale

Leaf Veg

$9.5 \mathrm{E}-04 \quad 4.3 \mathrm{E}-04 \quad 4.1 \mathrm{E}-04 \quad 9.2 \mathrm{E}-03$

Meat

$4.0 \mathrm{E}-03 \quad 3.5 \mathrm{E}-03 \quad 3.5 \mathrm{E}-03 \quad 2.2 \mathrm{E}-03$

$\begin{array}{lllll}7.5 \mathrm{E}-03 & 6.8 \mathrm{E}-03 & 6.7 \mathrm{E}-03 & 2.1 \mathrm{E}-03\end{array}$

Cow Milk

$\begin{array}{llll}1.2 \mathrm{E}-03 & 1.1 \mathrm{E}-03 & 1.1 \mathrm{E}-03 & 8.6 \mathrm{E}-06\end{array}$

Total

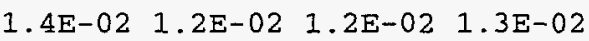

External Dose by Exposure Pathway

Pathway

$\begin{array}{ll}\text { Plume } & \\ \text { Sur Soil } & 1.0 \mathrm{E}-05 \\ ---1.8 \mathrm{E}-04 \\ \text { Total } & 5 .---- \\ & 5.9 \mathrm{E}-04\end{array}$


GENII Dose Calculation Program

(Version 1.485 3-Dec-90)

Case title: Summer: Dose comparison with RISKIND

Executed on: 05/08/97 at 09:18:05

Page C. 14

Acute release

Uptake/exposure period:

Dose commitment period:

Dose units:

$$
\text { Rem } \begin{array}{r}
1.0 \\
50.0
\end{array}
$$

Committed Dose Equivalent by Radionuclide

Radionuclide

CO 60

SR 90

Y 90

CS 134

CS 137

PU 238

CM 244

PU 244

U 240

PU 240

PU 241

AM 241

PU 239

Total

Radionuclide

CO 60

SR 90

Y 90

CS 134

CS 137

PU 238

CM 244

PU 244

U 240

PU 240

PU 241

AM 241

PU 239

- - - - - - - - - -

Total
Lung Stomach S Int. UL Int. LL Int. Bone Su R Marro Testes

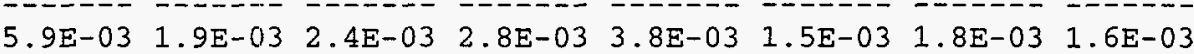

$\begin{array}{llllllll}5.6 \mathrm{E}-07 & 8.3 \mathrm{E}-07 & 1.3 \mathrm{E}-06 & 7.9 \mathrm{E}-06 & 3.4 \mathrm{E}-05 & 8.0 \mathrm{E}-04 & 3.5 \mathrm{E}-04 & 3.9 \mathrm{E}-07\end{array}$

1.2E-09 1.7E-06 3.9E-06 2.0E-05 $4.8 \mathrm{E}-05 \quad 6.0 \mathrm{E}-10 \quad 5.9 \mathrm{E}-10 \quad 2.0 \mathrm{E}-11$

$9.0 \mathrm{E}-041.0 \mathrm{E}-03 \quad 1.2 \mathrm{E}-03 \quad 1.1 \mathrm{E}-03 \quad 1.2 \mathrm{E}-03 \quad 8.9 \mathrm{E}-04 \quad 1.0 \mathrm{E}-03 \quad 1.1 \mathrm{E}-03$

1.0E-02 1.1E-02 1.1E-02 1.1E-02 1.1E-02 1.0E-02 1.0E-02 $1.1 \mathrm{E}-02$

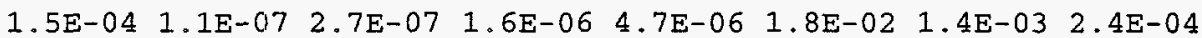

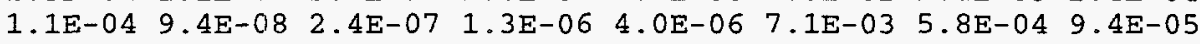

$\begin{array}{llllllll}0.0 E+00 & 0.0 E+00 & 0.0 E+00 & 0.0 E+00 & 0.0 E+00 & 0.0 E+00 & 0.0 E+00 & 0.0 E+00\end{array}$

$\begin{array}{llllllll}0.0 \mathrm{E}+00 & 0.0 \mathrm{E}+00 & 0.0 \mathrm{E}+00 & 0.0 \mathrm{E}+00 & 0.0 \mathrm{E}+00 & 0.0 \mathrm{E}+00 & 0.0 \mathrm{E}+00 & 0.0 \mathrm{E}+00\end{array}$

$2.3 E-05 \quad 1.8 E-08 \quad 4.2 E-08 \quad 2.3 E-07 \quad 7.4 E-07 \quad 3.3 E-03 \quad 2.5 E-04 \quad 4.5 E-05$

$\begin{array}{llllllll}1.7 \mathrm{E}-06 & 1.3 \mathrm{E}-0.8 & 3.4 \mathrm{E}-08 & 2.0 \mathrm{E}-07 & 5.8 \mathrm{E}-07 & 1.1 \mathrm{E}-02 & 8.3 \mathrm{E}-04 & 1.6 \mathrm{E}-04\end{array}$

$9.4 \mathrm{E}-05 \quad 7.1 \mathrm{E}-018 \quad 1.7 \mathrm{E}-07 \quad 9.7 \mathrm{E}-07 \quad 3.0 \mathrm{E}-06 \quad 1.2 \mathrm{E}-02 \quad 9.6 \mathrm{E}-04 \quad 1.7 \mathrm{E}-04$

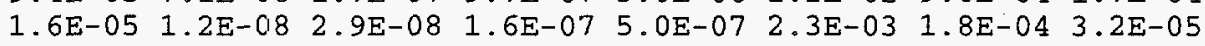

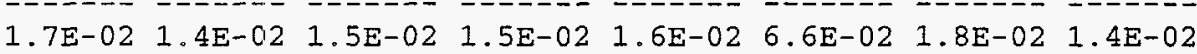

Ovaries Muscle Thyroid Liver

$2.1 \mathrm{E}-03 \quad 1.7 \mathrm{E}-03 \quad 1.5 \mathrm{E}-03 \quad 4.0 \mathrm{E}-03$

$3.9 \mathrm{E}-07 \quad 3.8 \mathrm{E}-07 \quad 3.9 \mathrm{E}-07 \quad 0.0 \mathrm{E}+00$

$2.3 \mathrm{E}-112.0 \mathrm{E}-112.0 \mathrm{E}-115.7 \mathrm{E}-10$

$8.9 \mathrm{E}-04 \quad 8.9 \mathrm{E}-04 \quad 8.9 \mathrm{E}-04 \quad 0.0 \mathrm{E}+00$

1. $0 \mathrm{E}-02 \quad 9.3 \mathrm{E}-03 \quad 9.3 \mathrm{E}-03 \quad 0.0 \mathrm{E}+00$

$2.4 \mathrm{E}-04 \quad 8.8 \mathrm{E}-09 \quad 8.8 \mathrm{E}-09 \quad 3.2 \mathrm{E}-03$

$9.5 \mathrm{E}-05 \quad 6.1 \mathrm{E}-09 \quad 6.1 \mathrm{E}-09 \quad 1.4 \mathrm{E}-03$

$0.0 E+00 \quad 0.0 E+00 \quad 0.0 E+00 \quad 0.0 E+00$

$0.0 \mathrm{E}+00 \quad 0.0 \mathrm{E}+00 \quad 0.0 \mathrm{E}+00 \quad 0.0 \mathrm{E}+00$

4.5E-05 1.4E-09 1.4E-09 5.7E-04

$1.6 \mathrm{E}-04 \quad 6.6 \mathrm{E}-11 \quad 5.5 \mathrm{E}-11 \quad 1.6 \mathrm{E}-03$

$1.7 E-04 \quad 5.8 E-09 \quad 5.5 E-09 \quad 2.2 E-03$

$3.2 \mathrm{E}-05 \quad 9.7 \mathrm{E}-10 \quad 9.7 \mathrm{E}-10 \quad 4.0 \mathrm{E}-04$

$\begin{array}{llll}1.4 \mathrm{E}-02 & 1.2 \mathrm{E}-02 & 1.2 \mathrm{E}-02 & 1.3 \mathrm{E}-02\end{array}$ 


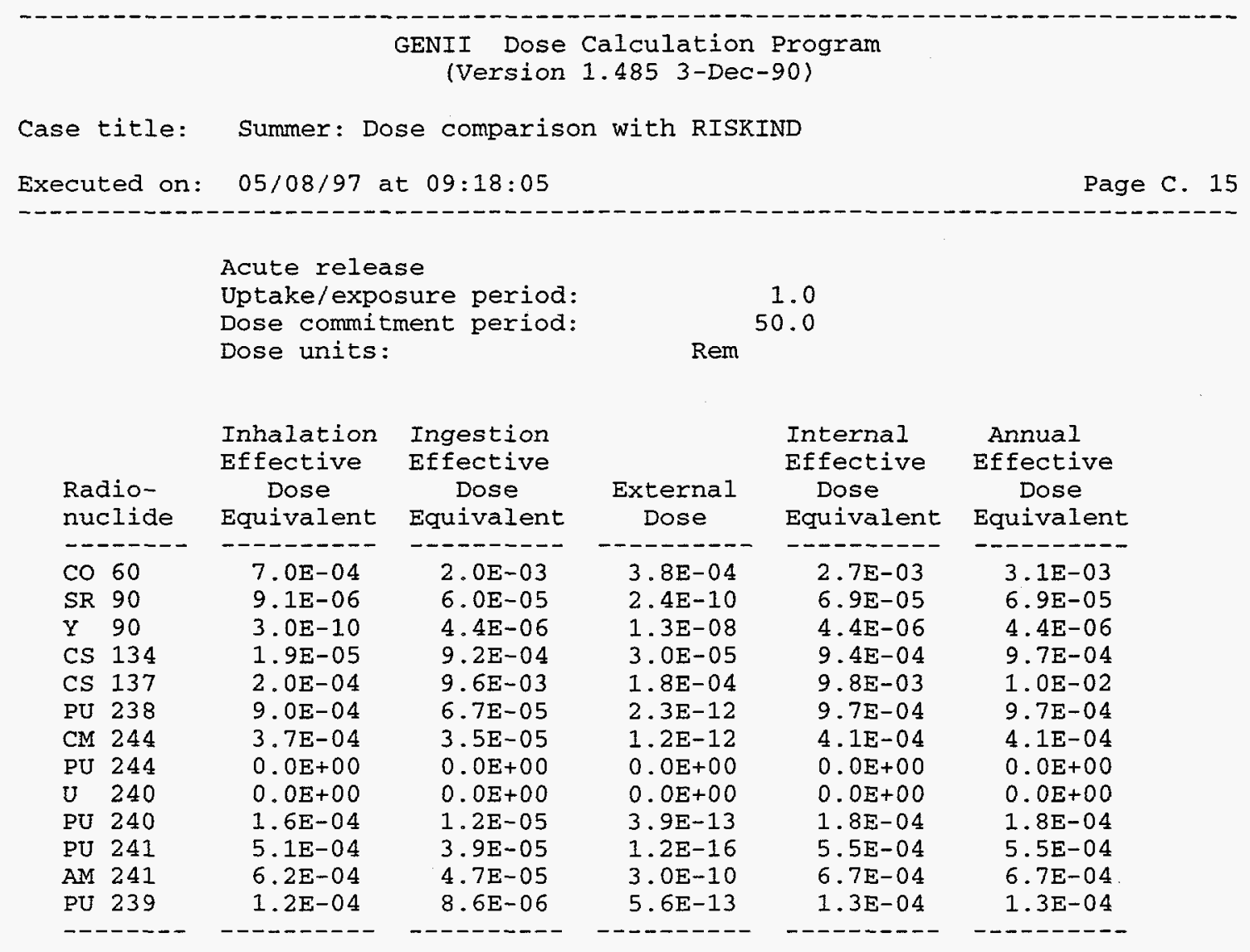


GENII Dose Calculation Program

(Version 1.485 3-Dec-90)

Case title: Autumn: Dose comparison with RISKIND

Executed on: $05 / 08 / 97$ at $09: 18: 06$

Page C. 16

Acute release

Uptake/exposure period:

Dose commitment period:

Dose units:

1.0

50.0

Rem

\begin{tabular}{|c|c|c|c|}
\hline organ & $\begin{array}{c}\text { Committed } \\
\text { Dose } \\
\text { Equivalent }\end{array}$ & $\begin{array}{l}\text { Weighting } \\
\text { Factors }\end{array}$ & $\begin{array}{c}\text { Weighted } \\
\text { Dose } \\
\text { Equivalent }\end{array}$ \\
\hline -ーーー-ー-ー-ー & -ー-ー- & - - - - - - & ------- \\
\hline Gonads & $2.4 E-01$ & $2.5 E-01$ & $5.9 E-02$ \\
\hline Breast & 2. $0 \mathrm{E}-01$ & 1. $5 E-01$ & 3. $0 \mathrm{E}-02$ \\
\hline R Marrow & $2.4 \mathrm{E}-01$ & $1.2 E-01$ & $2.8 \mathrm{E}-02$ \\
\hline Lung & $2.2 E-01$ & $1.2 \mathrm{E}-01$ & $2.6 \mathrm{E}-02$ \\
\hline Thyroid & 2. $.0 E-01$ & $3.0 \mathrm{E}-02$ & $6.0 \mathrm{E}-03$ \\
\hline Bone Sur & $3.4 E-01$ & $3.0 \mathrm{E}-02$ & $1.0 \mathrm{E}-02$ \\
\hline LL Int. & $2.8 E-01$ & $6.0 E-02$ & $1.7 E-02$ \\
\hline UL Int. & $2.6 \mathrm{E}-01$ & $6.0 E-02$ & $1.5 \mathrm{E}-02$ \\
\hline s Int. & $2.5 E-01$ & $6.0 E-02$ & 1. $5 \mathrm{E}-02$ \\
\hline Stomach & $2.3 E-01$ & $6.0 E-02$ & 1. $4 \mathrm{E}-02$ \\
\hline Liver & $8.2 E-02$ & $6.0 \mathrm{E}-02$ & $4.9 E-03$ \\
\hline ernal Effec & Je Dose Equ & valent & $2.3 E-01$ \\
\hline External Dose & & & $5.9 E-04$ \\
\hline
\end{tabular}

Controlling Organ:

Bone Sur

Controlling Pathway:

Ing

Controlling Radionuclide:

CS137

Total Inhalation EDE:

3. $6 \mathrm{E}-03$

Total Ingestion EDE:

$2.2 \mathrm{E}-01$ 
GENII Dose Calculation Program

(Version 1.485 3-DeC-90)

Case title: Autumn: Dose comparison with RISKIND

Executed on: 05/08/97 at 09:18:06

Page C. 17

Acute release

Uptake/exposure period:

Dose commitment period:

Dose units:

1.0

50.0

Rem

Dose Commitment Year

1

2

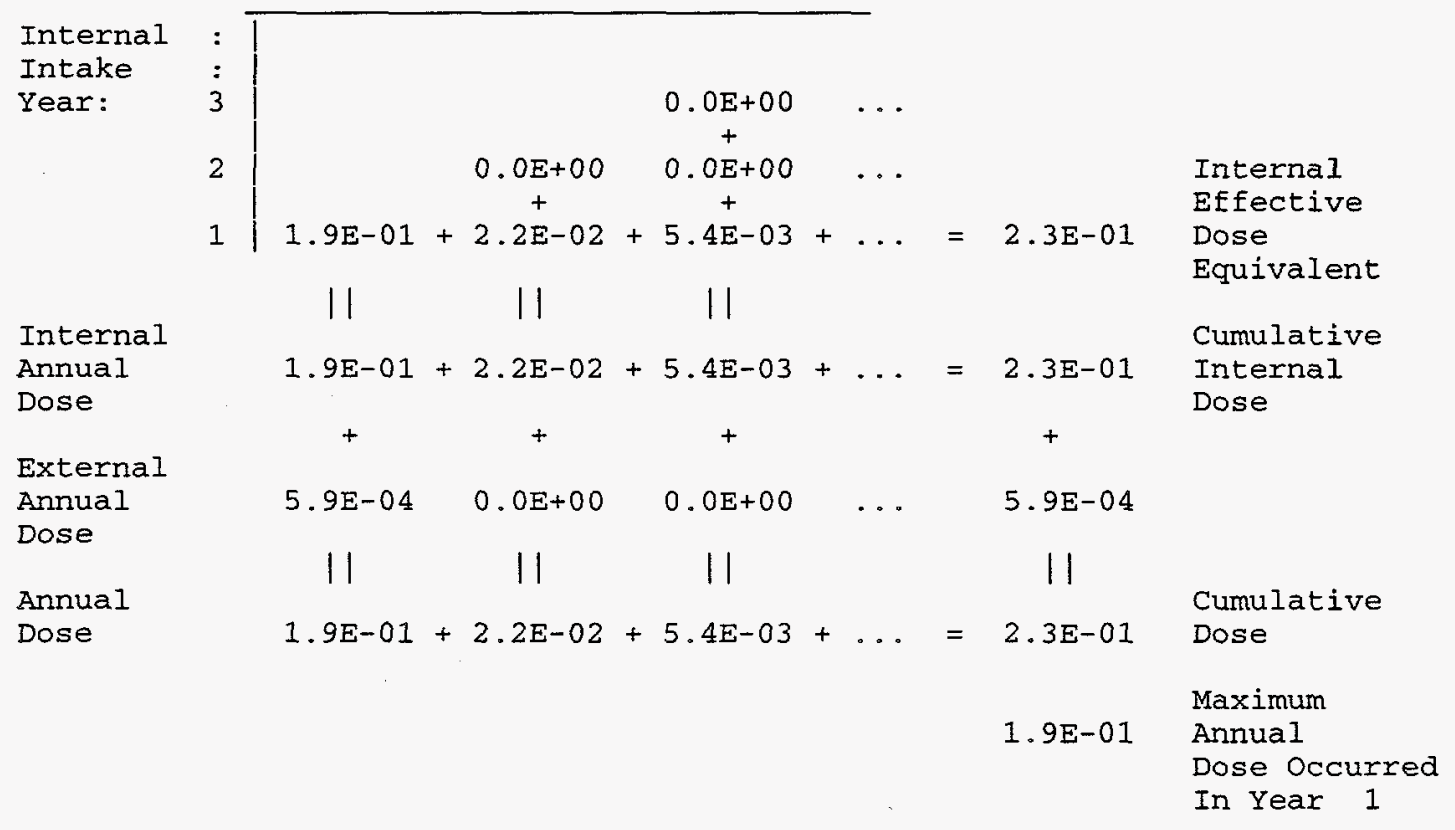


GENII Dose Calculation Program

(Version 1.485 3-Dec-90)

Case title: Autumn: Dose comparison with RISKIND

Executed on: $05 / 08 / 97$ at $09: 18: 06$

Page C. 18

Acute release

Uptake/exposure period:

Dose commitment period:

Dose units:

Rem $\begin{array}{r}1.0 \\ 50.0\end{array}$

Committed Dose Equivalent by Exposure Pathway

\begin{tabular}{|c|c|c|c|c|}
\hline athway & Lung & Stomach & S Int. & UL Int. \\
\hline hale & $5.2 E-03$ & $5.8 E-04$ & $3.3 E-04$ & $3.6 \mathrm{E}-04$ \\
\hline eaf Veg & $6.8 \mathrm{E}-02$ & $7.4 \mathrm{E}-02$ & $8.1 E-02$ & $8.3 E-02$ \\
\hline eat & $1.2 \mathrm{E}-01$ & $1.4 E-01$ & $1.5 \mathrm{E}-01$ & $1.5 \mathrm{E}-01$ \\
\hline ow Milk & $2.2 \mathrm{E}-02$ & $2.4 \mathrm{E}-02$ & $2.4 \mathrm{E}-02$ & $2.4 \mathrm{E}-02$ \\
\hline & 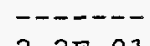 & $----\overline{1}$ & ------ & -ーー-ー- \\
\hline tal & $2.2 E-01$ & $2.3 E-01$ & $2.5 E-01$ & $2.6 E-01$ \\
\hline thway & Ovaries & Muscle & Thyroid & Liver \\
\hline e & 9 & 4 & 4 & 9 \\
\hline If Veg & 7. $3 \mathrm{E}-02$ & $6.4 \mathrm{E}-\mathrm{Cl} 2$ & $6.3 \mathrm{E}-02$ & 3. $8 \mathrm{E}-02$ \\
\hline & $1.3 E-01$ & $1.2 \mathrm{E}-\mathrm{OI}$ & 1. $2 \mathrm{E}-01$ & $3.6 E-02$ \\
\hline $\mathbf{M}$ & $2.2 \mathrm{E}-02$ & 2. $0 E-02$ & $2.0 \mathrm{E}-02$ & $1.4 \mathrm{E}-04$ \\
\hline & $--\cdots---$ & $--\cdots-\cdots$ & $----\cdots$ & -- \\
\hline & $2.3 E-01$ & 2. .0E-01 & $2.0 \mathrm{E}-01$ & $8.2 \mathrm{E}-02$ \\
\hline
\end{tabular}

External Dose by Exposure Pathway

Pathway

\begin{tabular}{|c|c|}
\hline $\begin{array}{l}\text { Plume } \\
\text { Sur Soil }\end{array}$ & $\begin{array}{l}1.0 \mathrm{E}-05 \\
5.8 \mathrm{E}-04\end{array}$ \\
\hline cotal & 5.9 \\
\hline
\end{tabular}


GENII Dose Calculation Program

(Version 1.485 3-Dec-90)

Case title: Autumn: Dose comparison with RISKIND

Executed on: $05 / 08 / 97$ at $09: 18: 06$

Page C. 19

Acute release

Uptake/exposure period:

Dose commitment period:

Dose units:

1.0

50.0

Rem

Committed Dose Equivalent by Radionuclide

Radionuclide

CO 60

SR 90

Y 90

CS 134

CS 137

PU 238

CM 244

PU 244

U 240

PU 240

PU 241

AM 241

PU 239

Total

Radionuclide

co 60

CO 60

SR 90

Y 90

CS 134

CS 137

PU 238

CM 244

PU 244

U 240

PU 240

PU 241

AM 241

PU 239

Total
Lung stomach $S$ Int. UL Int. LI Int. Bone Su R Marro Testes

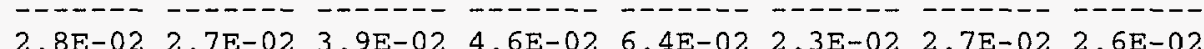

$\begin{array}{llllllll}5.8 E-06 & 1.3 E-05 & 2.0 E-05 & 1.3 E-04 & 5.6 E-04 & 1.2 E-02 & 5.2 E-03 & 5.6 E-06\end{array}$

$\begin{array}{llllllll}1.6 \mathrm{E}-09 & 3.2 \mathrm{E}-05 & 7.5 \mathrm{E}-05 & 3.8 \mathrm{E}-04 & 9.2 \mathrm{E}-04 & 1.2 \mathrm{E}-08 & 1.1 \mathrm{E}-08 & 3.8 \mathrm{E}-10\end{array}$

$\begin{array}{llllllll}1.4 \mathrm{E}-02 & 1.6 \mathrm{E}-02 & 1.8 \mathrm{E}-02 & 1.6 \mathrm{E}-02 & 1.8 \mathrm{E}-02 & 1.4 \mathrm{E}-02 & 1.6 \mathrm{E}-02 & 1.6 \mathrm{E}-02\end{array}$

$\begin{array}{llllllll}1.8 \mathrm{E}-01 & 1.9 \mathrm{E}-01 & 1.9 \mathrm{E}-01 & 1.9 \mathrm{E}-01 & 1.9 \mathrm{E}-01 & 1.8 \mathrm{E}-01 & 1.8 \mathrm{E}-01 & 1.9 \mathrm{E}-01\end{array}$

$\begin{array}{llllllll}1.5 E-04 & 1.8 E-06 & 4.4 E-06 & 2.6 E-05 & 7.8 E-05 & 3.8 E-02 & 3.1 E-03 & 5.3 E-04\end{array}$

$\begin{array}{llllllll}1.1 E-04 & 1.5 E-06 & 4.2 E-06 & 2.3 E-05 & 7.0 E-05 & 1.8 E-02 & 1.5 E-03 & 2.4 E-04\end{array}$

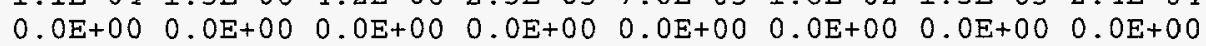

$\begin{array}{llllllllll}0.0 E+00 & 0.0 E+00 & 0.0 E+00 & 0.0 E+00 & 0.0 E+00 & 0.0 E+00 & 0.0 E+00 & 0.0 E+00\end{array}$

2.3E-05 2.8E-07 7.0E-07 $4.0 \mathrm{E}-06 \quad 1.3 \mathrm{E}-05 \quad 7.2 \mathrm{E}-03 \quad 5.6 \mathrm{E}-04 \quad 1.0 \mathrm{E}-04$

$\begin{array}{llllllll}1.7 E-06 & 2.2 E-07 & 5.6 E-07 & 3.3 E-06 & 9.7 E-06 & 2.3 E-02 & 1.8 E-03 & 3.4 E-04\end{array}$

$9.4 \mathrm{E}-05 \quad 1.1 \mathrm{E}-06 \quad 2.8 \mathrm{E}-06 \quad 1.6 \mathrm{E}-05 \quad 5.0 \mathrm{E}-05 \quad 2.7 \mathrm{E}-02 \quad 2.1 \mathrm{E}-03 \quad 3.8 \mathrm{E}-04$

$\begin{array}{llllllll}1.6 E-05 & 2.0 E-07 & 4.9 E-07 & 2.8 E-06 & 8.7 E-06 & 5.1 E-03 & 3.9 E-04 & 7.0 E-05\end{array}$

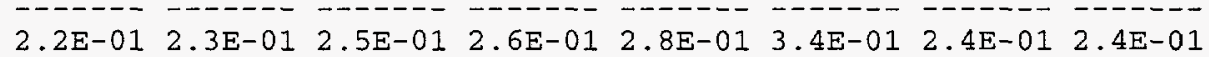

Ovaries Muscle Thyroid Liver

$3.4 E-02$ 2 $4 E-02$ 2 $2 E-026.1 E-02$

$\begin{array}{llll}5.6 \mathrm{E}-06 & 5.6 \mathrm{E}-06 & 5.6 \mathrm{E}-06 & 0.0 \mathrm{E}+00\end{array}$

$4.3 E-10 \quad 3.8 E-10 \quad 3.8 E-10 \quad 1.1 E-08$

1. $4 \mathrm{E}-02 \quad 1.4 \mathrm{E}-02 \quad 1.4 \mathrm{E}-02 \quad 0.0 \mathrm{E}+00$

$\begin{array}{llll}1.8 \mathrm{E}-01 & 1.6 \mathrm{E}-01 & 1.6 \mathrm{E}-01 & 0.0 \mathrm{E}+00\end{array}$

5.2E-04 1.9E-08 $1.9 \mathrm{E}-08 \quad 7.0 \mathrm{E}-03$

$2.4 \mathrm{E}-04 \quad 1.6 \mathrm{E}-08 \quad 1.6 \mathrm{E}-08 \quad 3.6 \mathrm{E}-03$

$0.0 \mathrm{E}+00 \quad 0.0 \mathrm{E}+00 \quad 0.0 \mathrm{E}+00 \quad 0.0 \mathrm{E}+00$

$0.0 \mathrm{E}+00 \quad 0.0 \mathrm{E}+00 \quad 0.0 \mathrm{E}+00 \quad 0.0 \mathrm{E}+00$

1. $0 \mathrm{E}-04$ 3. $3 \mathrm{E}-09 \quad 3.0 \mathrm{E}-09$ 1.3E-03

3. $4 \mathrm{E}-04 \quad 1.1 \mathrm{E}-10 \quad 8.0 \mathrm{E}-11 \quad 3.5 \mathrm{E}-03$

$3.7 E-04 \quad 1.6 E-08 \quad 1.2 E-08 \quad 4.8 E-03$

7.0E-05 2.1E-09 2.1E-09 8.9E-04

$2.3 E-012.0 E-01 \quad 2.0 E-01 \quad 8.2 E-02$ 
GENII Dose Calculation Program

(Version 1.485 3-Dec-90)

Case title: Autumn: Dose comparison with RISKIND

Executed on: 05/08/97 at 09:18:06

Page C. 20

Acute release

Uptake/exposure period:

Dose commitment period:

Dose units:

50.0

Rem

Inhalation Ingestion

Effective Effective

RadioDose

Effective
Dose

nuclide

Equivalent

Equivalent

$\mathrm{CO} 60$

7. $0 \mathrm{E}-04$

- - - - - - -

SR 90

Y 90

CS 134

CS 137

PU 238

CM 244

PU 244

U 240

PU 240

PU 241

AM 241

9. $1 E-06$

3. $4 \mathrm{E}-02$

3. $0 E-10$

1. $0 \mathrm{E}-03$

1. $9 E-05$

8. 4E:-05

1. $5 \mathrm{E}-02$

2. $O E-04$

9. $0 \mathrm{E}-04$

1. 7E-01

1. $2 \mathrm{E}-03$

3. $7 E-04$

$0.0 E+00$

$0.0 E+00$

1. $6 \mathrm{E}-04$

5. $1 \mathrm{E}-04$

6. $2 \mathrm{E}-04$

6. $4 E-04$

$0.0 E+00$

$0.0 E+00$

2. $2 E-04$

6. $8 \mathrm{E}-04$

8. $4 \mathrm{E}-04$

1. $2 \mathrm{E}-04$

1. $6 \mathrm{E}_{1}-04$

Externa1

Dose
$-----1$

2. $4 \mathrm{E}-10$

1. $3 \mathrm{E}-08$

3. $0 \mathrm{E}-05$

1. $8 \mathrm{E}-04$

2. $3 E-12$

1. $2 \mathrm{E}-12$

$0.0 E+0 O$

$0.0 \mathrm{E}+00$

$3.9 \mathrm{E}-13$

1. $2 \mathrm{E}-16$

3. $0 \mathrm{E}-10$

5. $6 \mathrm{E}-13$
Internal

Effective

Dose

Equivalent

----------

3. $4 \mathrm{E}-02$

1. $0 \mathrm{E}-03$

8. $4 \mathrm{E}-05$

1. $5 \mathrm{E}-02$

1. $7 \mathrm{E}-01$

2. $1 E-03$

1. $0 \mathrm{E}-03$

$0.0 \mathrm{E}+00$

$0.0 \mathrm{E}+00$

3. $9 \mathrm{E}-04$

1. $2 \mathrm{E}-03$

1. $5 \mathrm{E}-03$

2. $7 \mathrm{E}-04$
Annual

Effective

Dose

Equivalent

3. $5 \mathrm{E}-02$

1. $0 \mathrm{E}-03$

$8.4 \mathrm{E}-05$

1. $5 \mathrm{E}-02$

1. 7E-01

$2.1 \mathrm{E}-03$

1. $0 \mathrm{E}-03$

$0.0 E+00$

$0.0 \mathrm{E}+00$

3. $9 \mathrm{E}-04$

1. $2 \mathrm{E}-03$

1. $5 \mathrm{E}-03$

2. $7 \mathrm{E}-04$ 


\section{B.2 Comparison with CAP88-PC}

\section{B.2.1 Cs-137 Release (1 Ci)}

\section{B.2.1.1 RISKIND Output for Cs-137 Release}

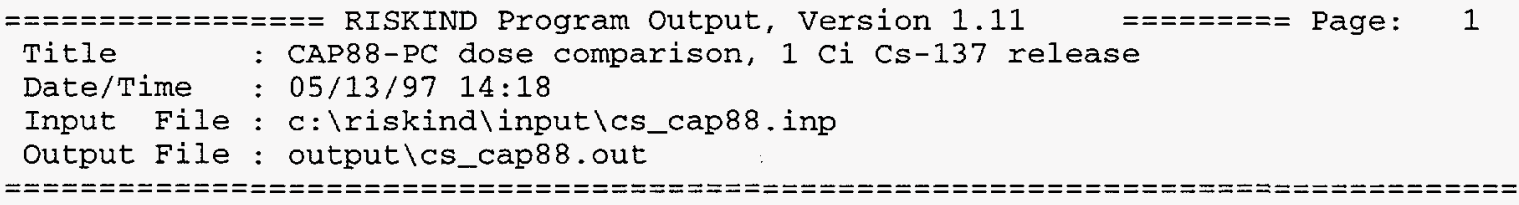

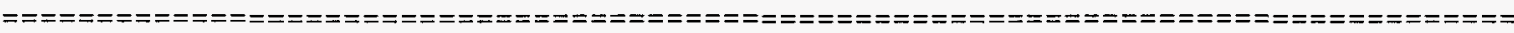

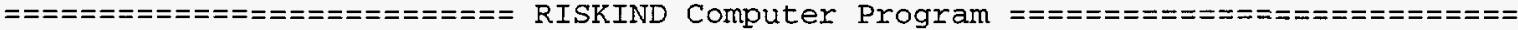

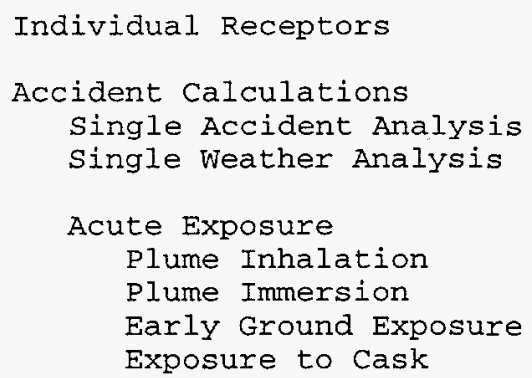

Note: * next to input description signifies

a data dependent default value 


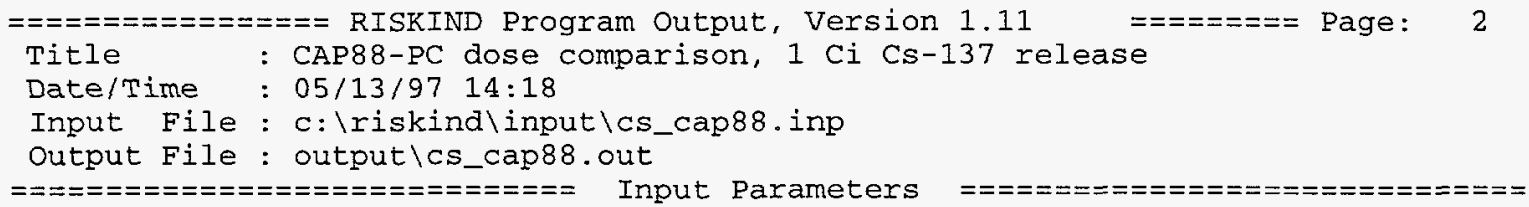

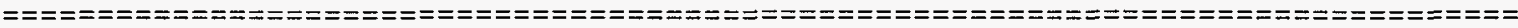

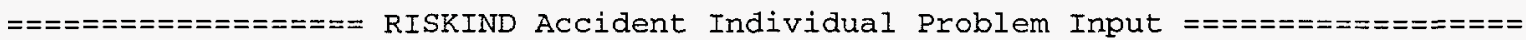

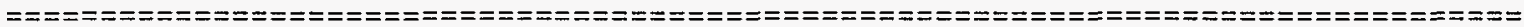

Individual Accident Parameters

State: ID

Population Zone: Rural

Average Breathing Rate [BRTIND]: 8.04E+03 $\mathrm{m} 3 / \mathrm{yr}$

Individual type [INDTYPE]: Public

Risk Conversion Factors

Non-Fatal Cancers/rem: 1.0E-04

Fatal Cancers/rem: 5.0E-04

Genetic Effects/rem: 1.3E-04

\begin{tabular}{|c|c|c|c|c|c|c|}
\hline $\begin{array}{l}\text { Individual Name } \\
\text { [XNAME] }\end{array}$ & $\begin{array}{c}====== \\
\text { Down } \\
\text { Wind } \\
{[\mathrm{km}]}\end{array}$ & $\begin{array}{c}\text { Location } \\
\text { Cross } \\
\text { wind } \\
\text { [km] } \\
\text { [XRECEP] }\end{array}$ & $\begin{array}{c}=\mathbf{=}=\mathbf{=}= \\
\text { Elevation } \\
{[\mathrm{m}]}\end{array}$ & $\begin{array}{c}\text { Acute } \\
\text { Exposure } \\
\text { Time } \\
\text { [hr] } \\
\text { [TEXI] }\end{array}$ & $\begin{array}{l}\text { Long Term } \\
\text { Exposure } \\
\text { [IRTP] }\end{array}$ & $\begin{array}{l}\text { Food } \\
\text { Ingestion } \\
\text { [IDFOOD] }\end{array}$ \\
\hline Receptor 1 & $1.50 E-01$ & $10.00 \mathrm{E}+00$ & $0.00 E+00$ & $1.00 \mathrm{E}+00$ & Non & No \\
\hline
\end{tabular}

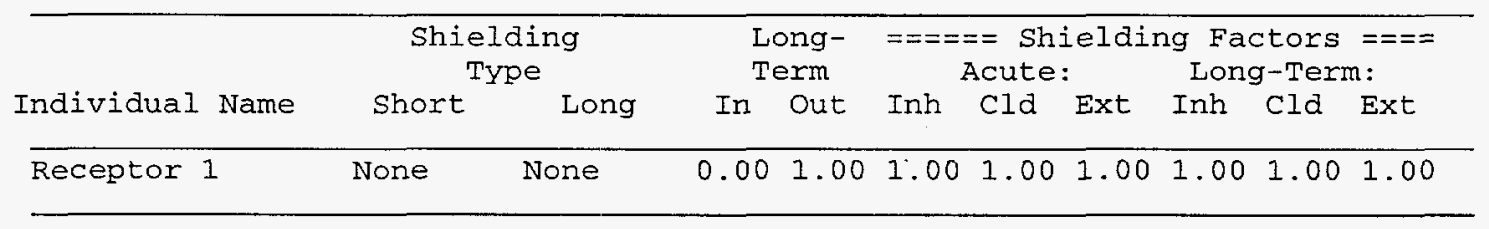




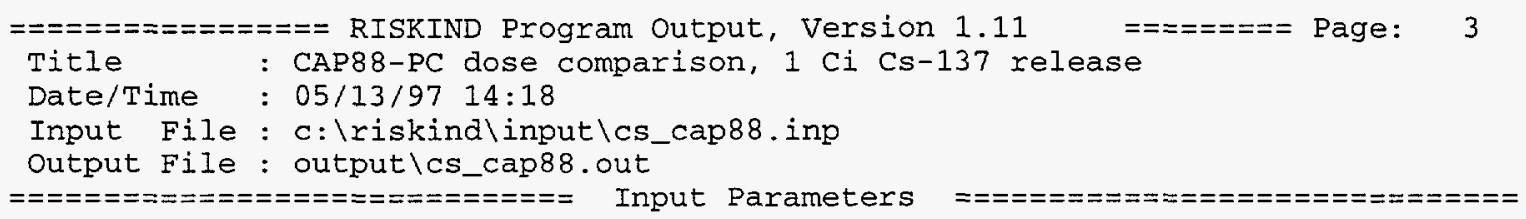

Meteorological Parameters

Dry deposition rates [VDEPNUC] Particulates Ruthenium

$: 1.00 \mathrm{E}-02$

$: 1.00 \mathrm{E}-02$

Cesium

$=1.00 \mathrm{E}-02$

Iodine

$: 1.00 \mathrm{E}-02$

Gases

$: 0.00 E+00$

Rain fall rate [RAIN]: $0.00 E+00$ Anemometer height [ANH]: 20.00 Ambient Temperature [TABK]: 288.00 Mixing height [DMIX]: 1000.00

wind at anemometer [WSM] : 4.37

pasquill stability cat. [ITYPE]:

4.37
$D$
$\mathrm{m} / \mathrm{s}$
$\mathrm{m} / \mathrm{s}$
$\mathrm{m} / \mathrm{s}$
$\mathrm{m} / \mathrm{s}$
$\mathrm{m} / \mathrm{s}$
$\mathrm{mm} / \mathrm{h}$
m
$\mathrm{K}$
m
$\mathrm{m} / \mathrm{s}$

Shipment Parameters

Transportation Mode [IMOD]: Dose at $1 \mathrm{~m}$ [TIDX] :

Truck

3.48 mrem $/ \mathrm{hr}$

Measurement of

0.00

0.69

Gamma Fraction [FRAD(1)]:

0.31

Neutron Fraction [FRAD (2)]: Cask Length [HSIZE]: Cask Radius [RSIZE]:

0.01

0.01

m

m

$\mathrm{m}$ 
$=================$ RISKIND Program Output, Version 1.11

$===ニ===$ Page:

Title : CAP88-PC dose comparison, $1 \mathrm{Ci}$ CS-137 release

Date/Time : 05/13/97 14:18

Input File : c:\riskind \input \cs_cap88.inp

Output File : outputlcs_cap88.out

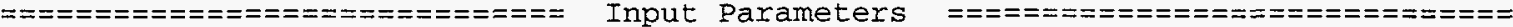

Nuclide Parameters

\begin{tabular}{|c|c|c|c|c|c|c|c|}
\hline \multirow{4}{*}{$\begin{array}{l}\text { Nuclide } \\
\text { Name }\end{array}$} & \multicolumn{6}{|c|}{ Nuclide Inventory and DCFs } & \multirow{4}{*}{$\begin{array}{l}\text { Decay } \\
\text { Const. } \\
{[1 / y r]}\end{array}$} \\
\hline & \multirow{4}{*}{$\begin{array}{c}\text { Inventory } \\
\text { Amount } \\
\text { [Ci] }\end{array}$} & \multicolumn{5}{|c|}{$======$ Dose Conversion Factors $======$} & \\
\hline & & & & Cloud & Ground & \multirow{3}{*}{$\begin{array}{l}\text { Nucl. } \\
\text { Class }\end{array}$} & \\
\hline & & Inhalation & Ingestion & {$[\mathrm{Sv} / \mathbf{s}]$} & {$[\mathrm{SV} / \mathrm{s}]$} & & \\
\hline & & & & & & & \\
\hline $\operatorname{CS137}$ & $1.00 \mathrm{E}+00$ & $1.10 E-08$ & $1.59 \mathrm{E}-08$ & $2.73 E-14$ & $5.54 \mathrm{E}-16$ & $\mathrm{Cs}$ & $2.30 E-0$ \\
\hline
\end{tabular}

Nuclide Health Effects Parameters

Acute Organ Dose Conversion Factors

$=======$ Inhalation $=======0=====$ Ground $===========$

$\begin{array}{lll}\text { Nuclide Solubility [Sv/Bq] } & {[\mathrm{Sv} / \mathrm{s} / / \mathrm{Bq} / \mathrm{m} 2]}\end{array}$

Name Class Marrow Lung Intestine Marrow Lung Intestine

$\begin{array}{lllllllll}\text { CS137 D } & 7.57 E-09 & 8.11 E-09 & 8.11 E-09 & 5.39 E-16 & 5.30 E-16 & 4.93 E-16\end{array}$




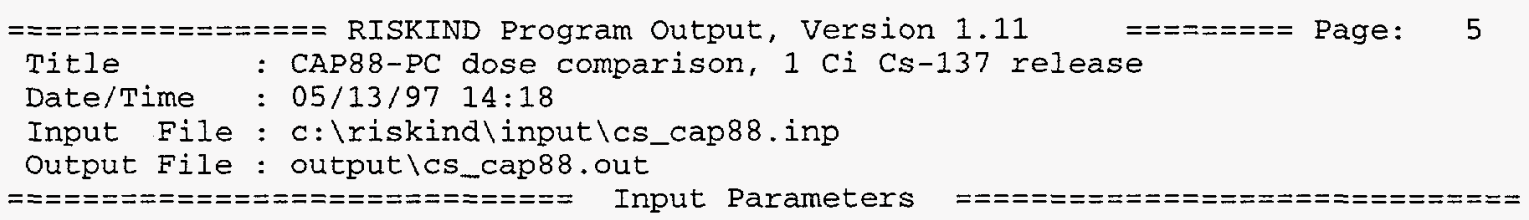

\section{Nuclide Health Effects Parameters}

Acute Organ Dose Conversion Factors $========$ Cloudshine $=======$

Name [Sv/s//Bq/m3]

Marrow Lung Intestine 

$==ニ=ニ=ニ=$ Page:

Title : CAP88-PC dose comparison, $1 \mathrm{Ci}$ Cs-137 release

Date/Time : 05/13/97 14:18

Input File : c: \riskind\input\cs_cap88.inp

Output File : output \cs_cap88.out

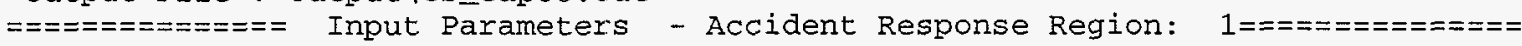

Accident Parameters

Physical Release Height [HS]: $20.00 \quad \mathrm{~m}$

Dispersion Model Coefficients [IDISPMOD]: Briggs

Accident Analysis Type: Consequence

Accident Response Region Parameters

Response Region [IYOURS]: 1

Response Regions Considered [NSV]: 20.00

Region Conditional Probability [FSEV]: $1.00 \mathrm{E}+00$

Heat F'lux [HEATF]: $0.00 \mathrm{E}+00$

$\mathrm{cal} / \mathrm{s}$

Loss of Cask Shielding Factor [SEXT]

Gamma: $\quad 2.00$

Neutron: 2.00

Failure Rate [FAILS]: $1.00 \mathrm{E}+00$

Crud Spallation R.ate [FSPAL]: $0.00 \mathrm{E}+00$

Crud Release Rate [FRCRUD]: 1.00E+00

\begin{tabular}{lccc}
\hline $\begin{array}{c}\text { Nuclide } \\
\text { Class } \\
\text { [NUTYPE] }\end{array}$ & $\begin{array}{c}\text { Conditional } \\
\text { Release } \\
\text { Fraction } \\
\text { [FRELS] }\end{array}$ & $\begin{array}{c}\text { Dispersion } \\
\text { Fraction } \\
\text { [FDISP] }\end{array}$ & $\begin{array}{c}\text { Released and Dispersed } \\
\text { Fraction } \\
\text { (FRELS*FAILS*FDISP) }\end{array}$ \\
\hline Particulate & $\begin{array}{c}1.00 \mathrm{E}+00 \\
\mathrm{Ru}\end{array}$ & $\begin{array}{c}1.00 \mathrm{E}+00 \\
\mathrm{CS}+00\end{array}$ & $1.00 \mathrm{E}+00$ \\
$\mathrm{I}$ & $1.00 \mathrm{E}+00$ & $1.00 \mathrm{E}+00$ & $1.00 \mathrm{E}+00$ \\
Gas & $1.00 \mathrm{E}+00$ & $1.00 \mathrm{E}+00$ & $1.00 \mathrm{E}+00$ \\
& $1.00 \mathrm{E}+00$ & $1.00 \mathrm{E}+00$ & $1.00 \mathrm{E}+00$ \\
\hline
\end{tabular}


$==============$ RISKIND Program Output, Version 1.11 ======== Page:

Title : CAP88-PC dose comparison, $1 \mathrm{Ci}$ Cs -137 release

Date/Time : 05/13/97 14:18

Input File : c:\riskind\input\cs_cap88.inp

Output File : output \cs_cap88.out

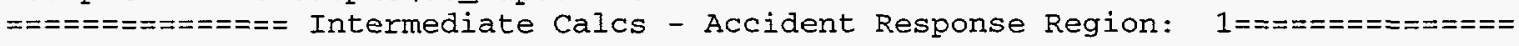

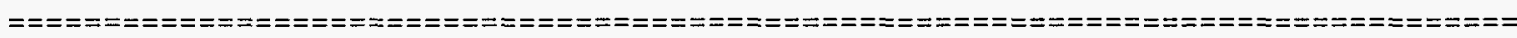

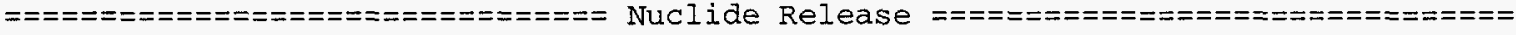

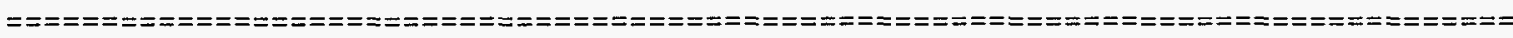

\begin{tabular}{ccccc}
\hline $\begin{array}{c}\text { Nuclide } \\
\text { Name }\end{array}$ & $\begin{array}{c}\text { Release } \\
\text { Amount }\end{array}$ & $\begin{array}{c}========\text { Hazard Index }========= \\
\text { Inhalation Ingestion }\end{array}$ Ground \\
\hline CS137 & $1.00 \mathrm{E}+00$ & $1.00 \mathrm{E}+00$ & $1.00 \mathrm{E}+00$ & $1.00 \mathrm{E}+00$ \\
\hline Total & $1.00 \mathrm{E}+00$ & $1.00 \mathrm{E}+00$ & $1.00 \mathrm{E}+00$ & $1.00 \mathrm{E}+00$
\end{tabular}

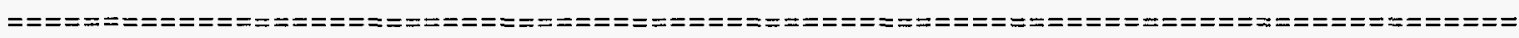

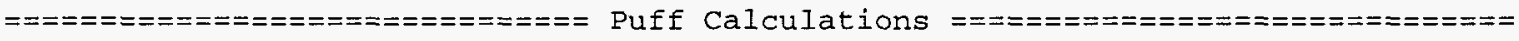

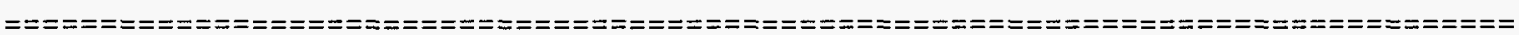

\begin{tabular}{cccc}
\hline $\begin{array}{c}\text { Individual } \\
\text { Name }\end{array}$ & $\begin{array}{c}======\text { Plume Parameters }======= \\
\text { Effective Release } \\
\text { Height } \\
{[\mathrm{m}]}\end{array}$ & $\begin{array}{c}\text { Dispersion Sigma } \\
\text { (Horizontal) } \\
{[\mathrm{m}]}\end{array}$ & $\begin{array}{c}\text { (Vertical) } \\
{[\mathrm{m}]}\end{array}$ \\
\hline Receptor 1 & $2.00 \mathrm{E}+01$ & $1.19 \mathrm{E}+01$ & $8.16 \mathrm{E}+00$ \\
\hline
\end{tabular}

\begin{tabular}{lllll}
\hline $\begin{array}{c}\text { Individual } \\
\text { Name }\end{array}$ & $\begin{array}{c}====\mathrm{Ch} / \mathrm{Q} \\
\mathrm{Air} \\
{[\mathrm{s} / \mathrm{m} 3]}\end{array}$ & $\begin{array}{c}===== \\
\text { Ground } \\
{[1 / \mathrm{m} 2]}\end{array}$ & $\begin{array}{c}\text { Depletion } \\
\text { Fraction }\end{array}$ & $\begin{array}{c}\text { Wet/Dry } \\
\text { Ratio }\end{array}$ \\
\hline $\begin{array}{c}\text { Receptor 1 } \\
\text { Particulates }\end{array}$ & $3.70 \mathrm{E}-05$ & $3.70 \mathrm{E}-07$ & $2.36 \mathrm{E}-04$ & $0.00 \mathrm{E}+00$ \\
Ruthenium & $3.70 \mathrm{E}-05$ & $3.70 \mathrm{E}-07$ & $2.36 \mathrm{E}-04$ & $0.00 \mathrm{E}+00$ \\
Cesium & $3.70 \mathrm{E}-05$ & $3.70 \mathrm{E}-07$ & $2.36 \mathrm{E}-04$ & $0.00 \mathrm{E}+00$ \\
Iodine & $3.70 \mathrm{E}-05$ & $3.70 \mathrm{E}-07$ & $2.36 \mathrm{E}-04$ & $0.00 \mathrm{E}+00$ \\
Gases & $3.70 \mathrm{E}-05$ & $0.00 \mathrm{E}+00$ & $0.00 \mathrm{E}+00$ & $0.00 \mathrm{E}+00$ \\
\hline
\end{tabular}




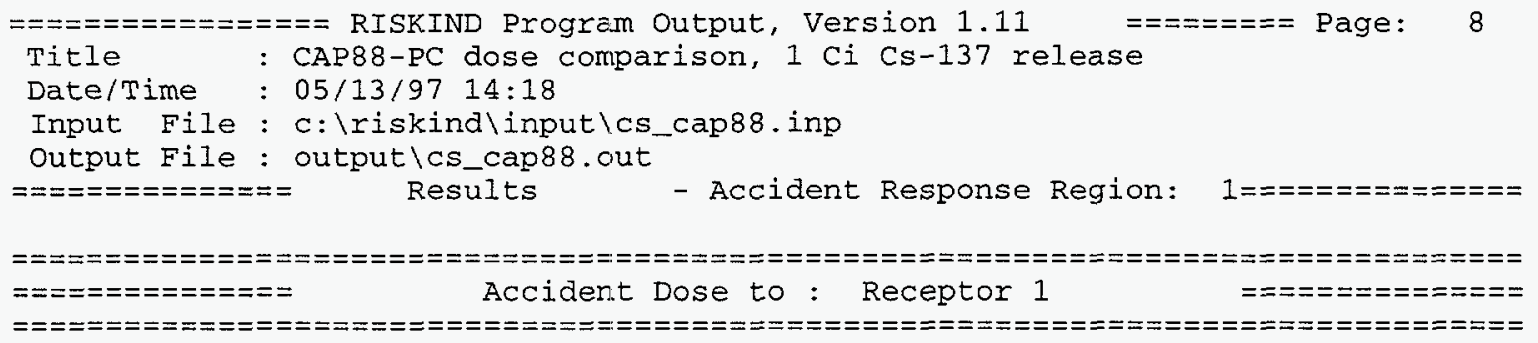

Individual Summary Results Per Accident

$\begin{array}{lll}\text { Committed Effective Dose Equivalent } & 3.90 \mathrm{E}-04 & \text { xem } \\ \text { Expected Genetic Effects } & 5.07 \mathrm{E}-08 & \\ \text { Expected Non-fatal Cancers } & 3.90 \mathrm{E}-08 \\ \text { Expected Cancer Fatalities } & 1.95 \mathrm{E}-07 \\ \text { Acute Risk (Expected fatalities) } & 0.00 \mathrm{E}+00\end{array}$

\begin{tabular}{|c|c|c|c|c|}
\hline Pathway & & Doses (rem) & & \\
\hline Acute & $3.90 \mathrm{E}-04$ & & & \\
\hline Cask & & $1.91 E-07$ & & \\
\hline Ground Shine & & $2.73 E-06$ & & \\
\hline Inhalation & & $3.84 \mathrm{E}-04$ & & \\
\hline Cloud Shine & & $3.74 \mathrm{E}-06$ & & \\
\hline Long-Term & $0.00 E+00$ & & & \\
\hline Ground Shine & & $0.00 \mathrm{E}+00$ & & \\
\hline Inhalation & & $0.00 \mathrm{E}+00$ & & \\
\hline Cloud Shine & & $0.00 \mathrm{E}+00$ & & \\
\hline Ingestion & & $0.00 \mathrm{E}+00$ & & \\
\hline Initial Year & & & $0.00 \mathrm{E}+00$ & \\
\hline Vegetable & & & & $0.00 E+00$ \\
\hline Meat & & & & $0.00 E+00$ \\
\hline Milk & & & & $0.00 E+00$ \\
\hline Long-Term & & & $0.00 \mathrm{E}+00$ & \\
\hline Vegetable & & & & $0.00 \mathrm{E}+00$ \\
\hline Meat & & & & $0.00 \mathrm{E}+00$ \\
\hline Milk & & & & $0.00 E+00$ \\
\hline Water & & & & $0.00 E+00$ \\
\hline
\end{tabular}

\begin{tabular}{|c|c|c|c|c|}
\hline Exposure Parameter & $\begin{array}{l}\text { Exposure } \\
\text { Marrow }\end{array}$ & Lung & Intestine & Gonads \\
\hline $\begin{array}{l}\text { Long-Term Dose [rem] } \\
\text { Brief Dose [Gy] } \\
\text { Brief Exposure Time [d] } \\
\text { Brief Dose Rate [Gy/hr] } \\
\text { Prolonged Dose [Gy] } \\
\text { Prolong Exposure Time [d] } \\
\text { Prolong Dose Rate [Gy/hr] } \\
\text { Hazard Risk [Expected fatalities] } \\
\text { Acute Risk }\end{array}$ & $\begin{array}{l}3.79 \mathrm{E}-04 \\
9.20 \mathrm{E}-08 \\
1.00 \mathrm{E}+00 \\
6.45 \mathrm{E}-08 \\
7.29 \mathrm{E}-07 \\
3.00 \mathrm{E}+01 \\
1.01 \mathrm{E}-09 \\
0.00 \mathrm{E}+00 \\
0.00 \mathrm{E}+00\end{array}$ & $\begin{array}{l}3.97 E-04 \\
2.89 E-06 \\
1.00 E+00 \\
2.27 E-07 \\
2.83 E-06 \\
3.65 E+02 \\
1.63 E-07 \\
0.00 E+00 \\
0.00 E+00\end{array}$ & $\begin{array}{l}3.17 \mathrm{E}-04 \\
2.76 \mathrm{E}-06 \\
1.00 \mathrm{E}+00 \\
1.72 \mathrm{E}-07 \\
2.83 \mathrm{E}-06 \\
7.00 \mathrm{E}+00 \\
1.09 \mathrm{E}-07 \\
0.00 \mathrm{E}+00 \\
0.00 \mathrm{E}+00\end{array}$ & $5.04 \mathrm{E}-04$ \\
\hline
\end{tabular}




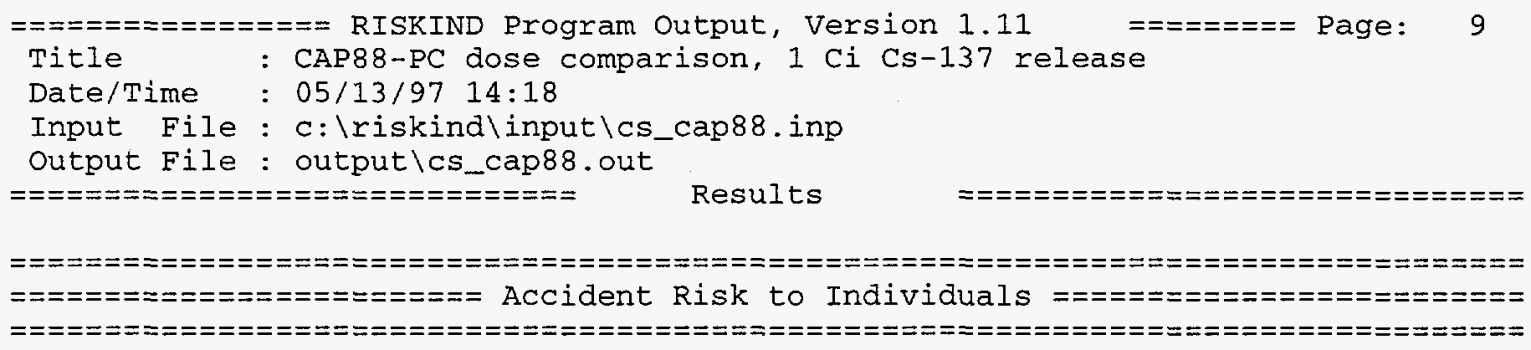

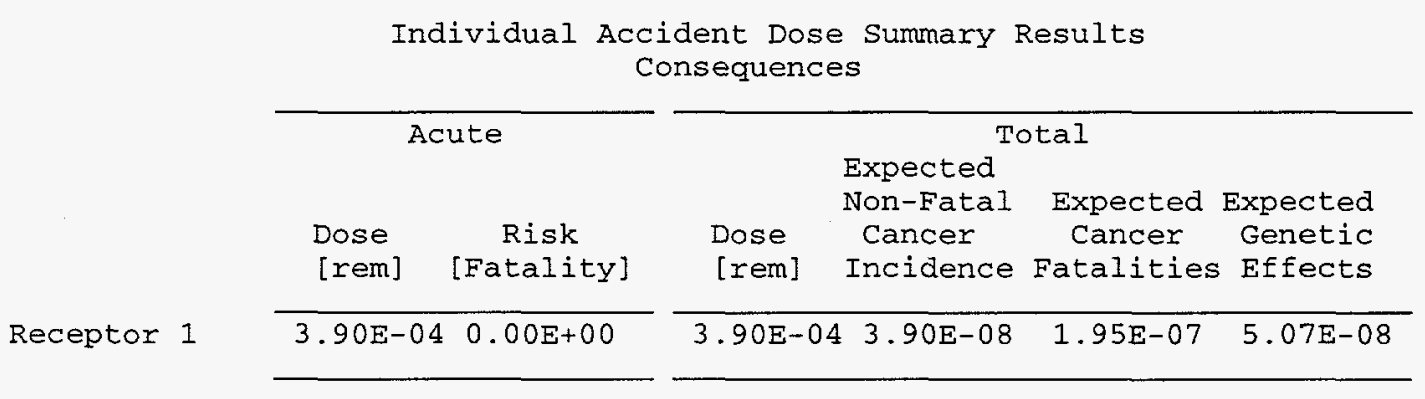




\title{
$B-72$
}

\section{B.2.1.2 CAP88-PC Output for Cs-137 Release}

\author{
C A P 8 - P C \\ Version 1.00 \\ Clean Air Act Assessment Package - 1988

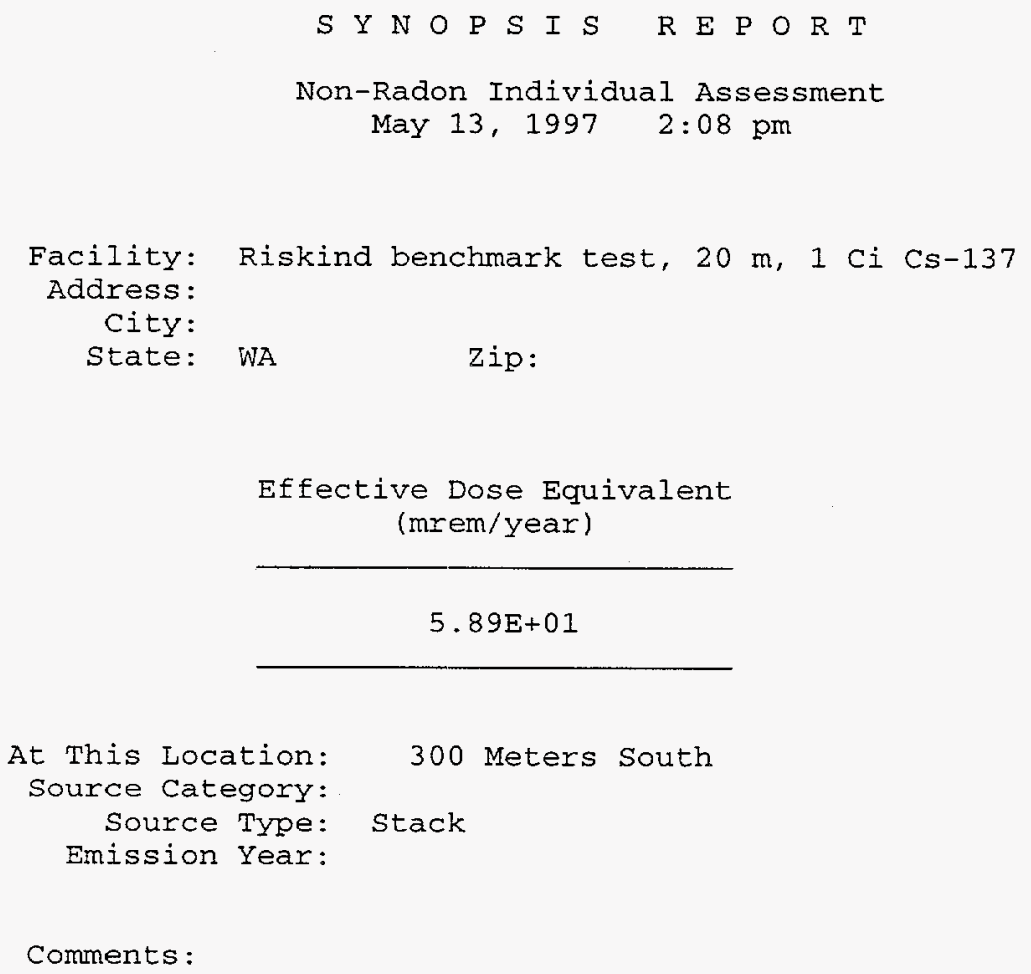


May $13,1997 \quad 2: 08 \mathrm{pm}$

SYNOPSIS

Page 1

MAXIMALLY EXPOSED INDIVIDUAL

Location of The Individual: 300 Meters South Lifetime Fatal Cancer Risk: 1.44E-03

ORGAN DOSE EQUIVALENT SUMMARY

Dose

Equivalent

Organ

(mrem/y)

GONADS

BREAST

R MAR

LUNGS

THYROID

ENDOST

RMNDR

EFFEC
$6.64 \mathrm{E}+01$

$6.29 E+01$

5. $36 \mathrm{E}+01$

$5.33 E+01$

$6.54 \mathrm{E}+01$

$5.44 \mathrm{E}+01$

5. $49 E+01$

$5.89 E+01$ 
RADIONUCLIDE EMISSIONS DURING THE YEAR

\begin{tabular}{|c|c|c|c|c|}
\hline Nuclide & Class & Size & $\begin{array}{c}\text { Source } \\
\# 1 \\
\mathrm{Ci} / \mathrm{Y}\end{array}$ & $\begin{array}{l}\text { TOTAL } \\
\mathrm{Ci} / \mathrm{Y}\end{array}$ \\
\hline CS -137 & D & 1.00 & 1. $O E+00$ & 1. $.0 E+00$ \\
\hline $\mathrm{BA}-137 \mathrm{M}$ & D & 1.00 & 1. $0 \mathrm{E}+00$ & 1. $.0 E+00$ \\
\hline
\end{tabular}

\section{SITE INFORMATION}

$\begin{array}{rr}\text { Temperature: } & 15 \text { degrees C } \\ \text { Precipitation: } & 0 \mathrm{~cm} / \mathrm{Y} \\ \text { Mixing Height: } & 1000 \mathrm{~m}\end{array}$


SOURCE INFORMATION

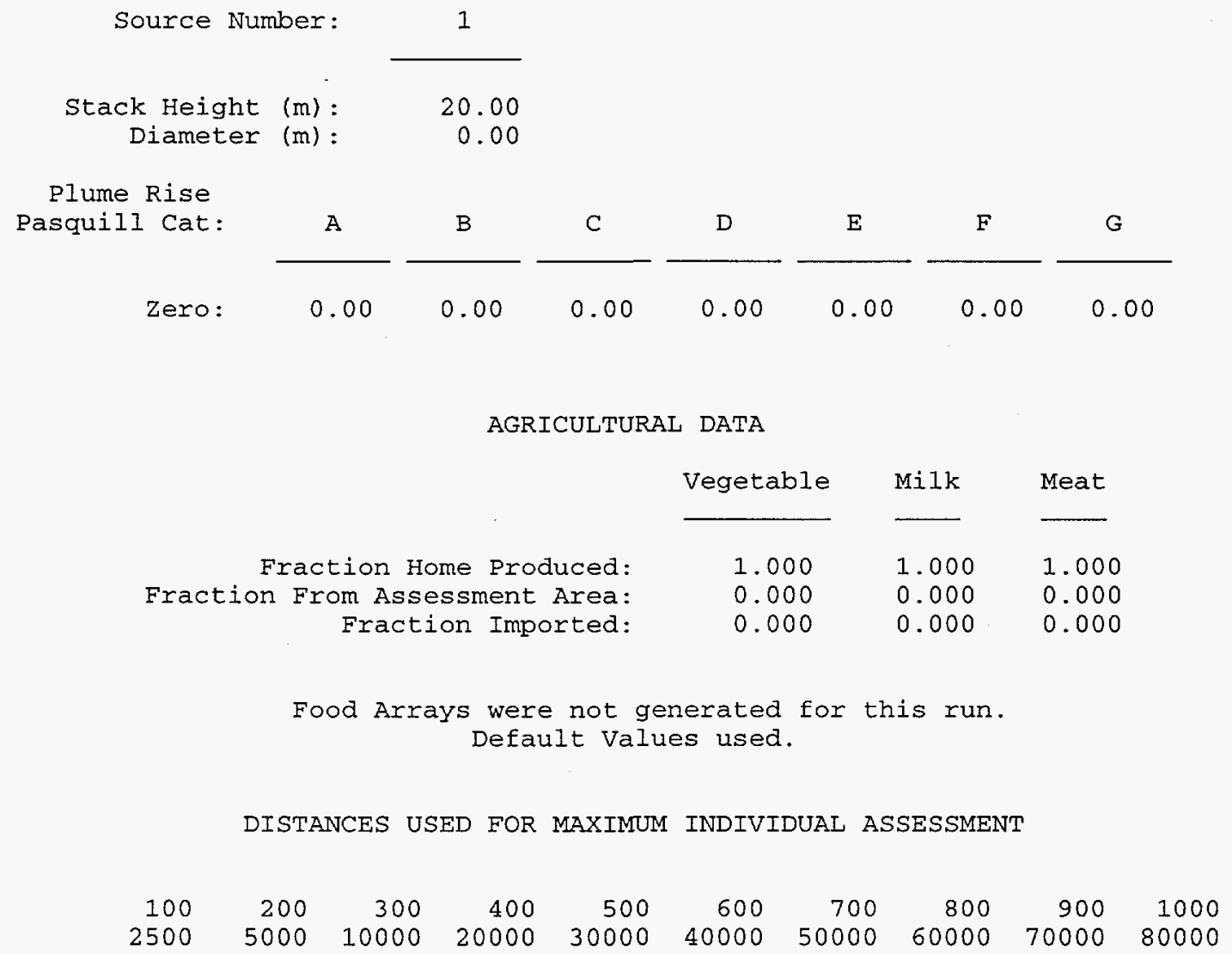

0.00

0.00

0.00

AGRICULTURAL DATA 
C A P $88-$ P C

Version 1.00

Clean Air Act Assessment Package - 1988

$D O S E$ A N D R I S K E Q U I V A L E N T S U M M A R I E Non-Radon Individual Assessment May 13, 1997 2:08 pm

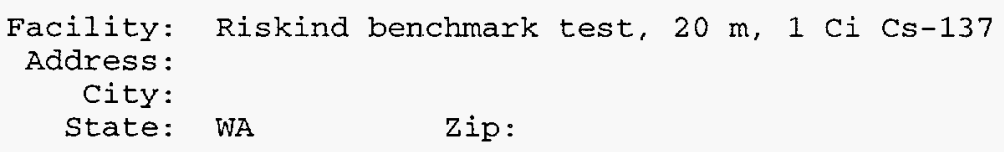


May 13, $1997 \quad 2: 08 \mathrm{pm}$

ORGAN DOSE EQUIVALENT SUMMARY

Selected Individual

Organ (mrem/y)

GONADS
BREAST
$R$ MAR
LUNGS
THYROID
ENDOST
RMNDR

EFFEC
$6.64 \mathrm{E}+01$

$6.29 \mathrm{E}+01$

$5.36 \mathrm{E}+01$

$5.33 E+01$

$6.54 \mathrm{E}+01$

$5.44 \mathrm{E}+01$

$5.49 E+01$

$5.89 E+01$

PATHWAY EFFECTIVE DOSE EQUIVALENT SUMMARY

Pathway

INGESTION

INHALATION

AIR IMMERSION

GROUND SURFACE

INTERNAL

EXTERNAL

TOTAL
Selected Individual $(\mathrm{mrem} / \mathrm{y})$
1. $33 E+01$
2. $92 E-01$
$2.61 \mathrm{E}-03$
4. $53 \mathrm{E}+01$
1. $36 \mathrm{E}+01$
$4.53 \mathrm{E}+01$
$5.89 E+01$ 
May 13, $19972: 08 \mathrm{pm}$

SUMMARY

Page 2

NUCLIDE EFFECTIVE DOSE EQUIVALENT SUMMARY

selected

Individual

Nuclide

(mrem/y)

CS -137

$\mathrm{BA}-137 \mathrm{M}$

1. $36 E+01$

4. $53 \mathrm{E}+01$

TOTAL

$5.89 E+01$ 


\begin{tabular}{lc} 
Cancer & $\begin{array}{c}\text { Selected Individual } \\
\text { Total Lifetime } \\
\text { Fatal Cancer Risk }\end{array}$ \\
\hline LEUKEMIA & $1.70 \mathrm{E}-04$ \\
BONE & $9.63 \mathrm{E}-06$ \\
THYROID & $2.97 \mathrm{E}-05$ \\
BREAST & $2.46 \mathrm{E}-04$ \\
LUNG & $2.64 \mathrm{E}-04$ \\
STOMACH & $1.55 \mathrm{E}-04$ \\
BOWEL & $7.39 \mathrm{E}-05$ \\
LIVER & $1.80 \mathrm{E}-04$ \\
PANCREAS & $1.10 \mathrm{E}-04$ \\
URINARY & $6.79 \mathrm{E}-05$ \\
OTHER & $1.35 \mathrm{E}-04$ \\
TOTAL & $1.44 \mathrm{E}-03$
\end{tabular}

PATHWAY RISK SUMMARY

Pathway

\section{INGESTION \\ INHALATION \\ AIR IMMERSION \\ GROUND SURFACE \\ INTERNAL \\ EXTERNAL}

TOTAL
Selected Individual

Total Lifetime

Fatal Cancer Risk
$3.48 \mathrm{E}-04$
7. $71 \mathrm{E}-06$
$6.25 \mathrm{E}-08$
$1.09 \mathrm{E}-03$
$3.56 E-04$
1. $09 \mathrm{E}-03$
$1.44 E-03$ 
NUCLIDE RISK SUMMARY

Nuclide

CS -137

$\mathrm{BA}-137 \mathrm{M}$

TOTAL
Selected Individual

Total Lifetime

Fatal Cancer Risk

3. $56 \mathrm{E}-04$

$1.09 \mathrm{E}-03$

$1.44 \mathrm{E}-03$ 
May 13, $1997 \quad 2: 08$ pm

SUMMARY

Page 5

INDIVIDUAL EFFECTIVE DOSE EQUIVALENT RATE (mrem/y)

(All Radionuclides and Pathways)

\begin{tabular}{|c|c|c|c|c|c|c|c|}
\hline \multirow[b]{2}{*}{ Direction } & \multicolumn{6}{|c|}{ Distance (m) } & \multirow[b]{2}{*}{700} \\
\hline & 100 & 200 & 300 & 400 & 500 & 600 & \\
\hline $\mathrm{N}$ & $0.0 E+00$ & $0.0 E+00$ & $0.0 E+00$ & $0.0 E+00$ & $0.0 E+00$ & $0.0 E+00$ & $0.0 E+00$ \\
\hline NNW & $0.0 E+00$ & $0.0 E+00$ & $0.0 E+00$ & $0.0 E+00$ & $0.0 E+00$ & $0.0 \mathrm{E}+00$ & $0.0 \mathrm{E}+00$ \\
\hline NW & $0.0 \mathrm{E}+00$ & $0.0 \mathrm{E}+00$ & $0.0 \mathrm{E}+00$ & $0.0 E+00$ & $0.0 E+00$ & $0.0 E+00$ & $0.0 \mathrm{E}+00$ \\
\hline WNW & $0.0 E+00$ & $0.0 \mathrm{E}+00$ & $0.0 \mathrm{E}+00$ & $0.0 \mathrm{E}+00$ & $0.0 E+00$ & $0.0 E+00$ & $0.0 E+00$ \\
\hline W & $0.0 \mathrm{E}+00$ & $0.0 \mathrm{E}+00$ & $0.0 \mathrm{E}+00$ & $0.0 E+00$ & $0.0 E+00$ & $0.0 E+00$ & $0.0 \mathrm{E}+00$ \\
\hline WSW & $0.0 \mathrm{E}+00$ & $0.0 \mathrm{E}+00$ & $0.0 \mathrm{E}+00$ & $0.0 E+00$ & $0.0 \mathrm{E}+00$ & $0.0 E+00$ & $0.0 E+00$ \\
\hline SW & $0.0 \mathrm{E}+00$ & $0.0 \mathrm{E}+00$ & $0.0 \mathrm{E}+00$ & $0.0 E+00$ & $0.0 E+00$ & $0.0 E+00$ & $0.0 E+00$ \\
\hline SSW & $0.0 \mathrm{E}+00$ & $0.0 \mathrm{E}+00$ & $0.0 \mathrm{E}+00$ & $0.0 E+00$ & $0.0 E+00$ & $0.0 E+00$ & $0.0 E+00$ \\
\hline$S$ & 1. $7 E+00$ & 4. $3 E+01$ & $5.9 \mathrm{E}+01$ & $5.3 E+01$ & $4.4 \mathrm{E}+01$ & $3.6 \mathrm{E}+01$ & $3.0 \mathrm{E}+01$ \\
\hline SSE & $0.0 E+00$ & $0.0 E+00$ & $0.0 E+00$ & $0.0 E+00$ & $0.0 E+00$ & $0.0 E+00$ & $0.0 E+00$ \\
\hline $\mathrm{SE}$ & $0.0 \mathrm{E}+00$ & $0.0 E+00$ & $0.0 E+00$ & $0.0 \mathrm{E}+00$ & $0.0 \mathrm{E}+00$ & $0.0 \mathrm{E}+00$ & $0.0 E+00$ \\
\hline ESE & $0.0 \mathrm{E}+00$ & $0.0 \mathrm{E}+00$ & $0.0 \mathrm{E}+00$ & $0.0 E+00$ & $0.0 \mathrm{E}+00$ & $0.0 E+00$ & $0.0 E+00$ \\
\hline$E$ & $0.0 \mathrm{E}+00$ & $0.0 E+00$ & $0.0 \mathrm{E}+00$ & $0.0 \mathrm{E}+00$ & $0.0 \mathrm{E}+00$ & $0.0 E+00$ & $0.0 E+00$ \\
\hline ENE & $0.0 E+00$ & $0.0 E+00$ & $0.0 E+00$ & $0.0 E+00$ & $0.0 E+00$ & $0.0 E+00$ & $0.0 \mathrm{E}+00$ \\
\hline $\mathrm{NE}$ & $0.0 E+00$ & $0.0 E+00$ & $0.0 \mathrm{E}+00$ & $0.0 \mathrm{E}+00$ & $0.0 \mathrm{E}+00$ & $0.0 E+00$ & $0.0 E+00$ \\
\hline NNE & $0.0 \mathrm{E}+00$ & $0.0 \mathrm{E}+00$ & $0.0 E+00$ & $0.0 E+00$ & $0.0 E+00$ & $0.0 E+00$ & $0.0 \mathrm{E}+00$ \\
\hline
\end{tabular}

Distance (m)

\begin{tabular}{|c|c|c|c|c|c|c|c|}
\hline Direction & 800 & 900 & 1000 & 2500 & 5000 & 10000 & 20000 \\
\hline$N$ & $0.0 \mathrm{E}+00$ & $0.0 \mathrm{E}+00$ & $0.0 \mathrm{E}+00$ & $0.0 \mathrm{E}+00$ & $0.0 E+00$ & $0.0 E+00$ & $0.0 \mathrm{E}+00$ \\
\hline NNW & $0.0 E+00$ & $0.0 E+00$ & $0.0 \mathrm{E}+00$ & $0.0 \mathrm{E}+00$ & $0.0 E+00$ & $0.0 E+00$ & $0.0 E+00$ \\
\hline NW & $0.0 \mathrm{E}+00$ & $0.0 \mathrm{E}+00$ & $0.0 E+00$ & $0.0 \mathrm{E}+00$ & $0.0 \mathrm{E}+00$ & $0.0 E+00$ & $0.0 E+00$ \\
\hline WNW & $0.0 E+00$ & $0.0 E+00$ & $0.0 E+00$ & $0.0 E+00$ & $0.0 E+00$ & $0.0 E+00$ & $0.0 E+00$ \\
\hline W & $0.0 \mathrm{E}+00$ & $0.0 E+00$ & $0.0 E+00$ & $0.0 E+00$ & $0.0 E+00$ & $0.0 E+00$ & $0.0 E+00$ \\
\hline WSW & $0.0 \mathrm{E}+00$ & $0.0 \mathrm{E}+00$ & $0.0 E+00$ & $0.0 E+00$ & $0.0 E+00$ & $0.0 E+00$ & $0.0 E+00$ \\
\hline SW & $0.0 \mathrm{E}+00$ & $0.0 E+00$ & $0.0 \mathrm{E}+00$ & $0.0 E+00$ & $0.0 E+00$ & $0.0 E+00$ & $0.0 E+00$ \\
\hline SSW & $0.0 \mathrm{E}+00$ & $0.0 \mathrm{E}+00$ & $0.0 E+00$ & $0.0 E+00$ & $0.0 \mathrm{E}+00$ & $0.0 E+00$ & $0.0 \mathrm{E}+00$ \\
\hline$S$ & $2.5 \mathrm{E}+01$ & $2.1 E+01$ & $1.8 \mathrm{E}+01$ & $4.2 E+00$ & 1. $5 E+00$ & $5.1 E-01$ & $1.8 \mathrm{E}-01$ \\
\hline SSE & $0.0 \mathrm{E}+00$ & $0.0 E+00$ & $0.0 \mathrm{E}+00$ & $0.0 E+00$ & $0.0 E+00$ & $0.0 E+00$ & $0.0 \mathrm{E}+00$ \\
\hline SE & $0.0 \mathrm{E}+00$ & $0.0 \mathrm{E}+00$ & $0.0 \mathrm{E}+00$ & $0.0 E+00$ & $0.0 E+00$ & $0.0 E+00$ & $0.0 \mathrm{E}+00$ \\
\hline ESE & $0.0 E+00$ & $0.0 E+00$ & $0.0 E+00$ & $0.0 E+00$ & $0.0 E+00$ & $0.0 E+00$ & $0.0 E+00$ \\
\hline$E$ & $0.0 \mathrm{E}+00$ & $0.0 E+00$ & $0.0 E+00$ & $0.0 E+00$ & $0.0 E+00$ & $0.0 \mathrm{E}+00$ & $0.0 \mathrm{E}+00$ \\
\hline ENE & $0.0 \mathrm{E}+00$ & $0.0 \mathrm{E}+00$ & $0.0 \mathrm{E}+00$ & $0.0 E+00$ & $0.0 E+00$ & $0.0 E+00$ & $0.0 \mathrm{E}+00$ \\
\hline $\mathrm{NE}$ & $0.0 \mathrm{E}+00$ & $0.0 \mathrm{E}+00$ & $0.0 \mathrm{E}+00$ & $0.0 E+00$ & $0.0 E+00$ & $0.0 E+00$ & $0.0 E+00$ \\
\hline NNE & $0.0 \mathrm{E}+00$ & $0.0 E+00$ & $0.0 \mathrm{E}+00$ & $0.0 E+00$ & $0.0 \mathrm{E}+00$ & $0.0 E+00$ & $0.0 E+00$ \\
\hline
\end{tabular}


INDIVIDUAL EFFECTIVE DOSE EQUIVALENT RATE (mrem/y)

(A11 Radionuclides and Pathways)

\begin{tabular}{|c|c|c|c|c|c|c|}
\hline \multirow[b]{2}{*}{ Direction } & \multicolumn{6}{|c|}{ Distance (m) } \\
\hline & 30000 & 40000 & 50000 & 60000 & 70000 & 80000 \\
\hline $\mathrm{N}$ & $0.0 \mathrm{E}+00$ & $0.0 E+00$ & $0.0 \mathrm{E}+00$ & $0.0 E+00$ & $0.0 E+00$ & $0.0 \mathrm{E}+00$ \\
\hline NNW & $0.0 \mathrm{E}+00$ & $0.0 E+00$ & $0.0 E+00$ & $0.0 E+00$ & $0.0 E+00$ & $0.0 E+00$ \\
\hline NW & $0.0 \mathrm{E}+00$ & $0.0 \mathrm{E}+00$ & $0.0 E+00$ & $0.0 E+00$ & $0.0 \mathrm{E}+00$ & $0.0 \mathrm{E}+00$ \\
\hline WNW & $0.0 \mathrm{E}+00$ & $0.0 \mathrm{E}+00$ & $0.0 E+00$ & $0.0 \mathrm{E}+00$ & $0.0 \mathrm{E}+00$ & $0.0 E+00$ \\
\hline$W$ & $0.0 \mathrm{E}+00$ & $0.0 \mathrm{E}+00$ & $0.0 E+00$ & $0.0 \mathrm{E}+00$ & $0.0 \mathrm{E}+00$ & $0.0 E+00$ \\
\hline WSW & $0.0 \mathrm{E}+00$ & $0.0 \mathrm{E}+00$ & $0.0 \mathrm{E}+00$ & $0.0 E+00$ & $0.0 \mathrm{E}+00$ & $0.0 E+00$ \\
\hline SW & $0.0 \mathrm{E}+00$ & $0.0 \mathrm{E}+00$ & $0.0 E+00$ & $0.0 E+00$ & $0.0 E+00$ & $0.0 E+00$ \\
\hline SSW & $0.0 \mathrm{E}+00$ & $0.0 \mathrm{E}+00$ & $0.0 E+00$ & $0.0 \mathrm{E}+00$ & $0.0 \mathrm{E}+00$ & $0.0 \mathrm{E}+00$ \\
\hline $\mathrm{S}$ & $9.4 \mathrm{E}-02$ & $6.0 \mathrm{E}-02$ & $4.2 \mathrm{E}-02$ & $3.1 E-02$ & $2.5 \mathrm{E}-02$ & $2.0 \mathrm{E}-02$ \\
\hline SSE & $0.0 E+00$ & $0.0 \mathrm{E}+00$ & $0.0 \mathrm{E}+00$ & $0.0 \mathrm{E}+00$ & $0.0 E+00$ & $0.0 E+00$ \\
\hline SE & $0.0 \mathrm{E}+00$ & $0.0 \mathrm{E}+00$ & $0.0 \mathrm{E}+00$ & $0.0 E+00$ & $0.0 \mathrm{E}+00$ & $0.0 E+00$ \\
\hline ESE & $0.0 E+00$ & $0.0 E+00$ & $0.0 \mathrm{E}+00$ & $0.0 E+00$ & $0.0 E+00$ & $0.0 E+00$ \\
\hline$E$ & $0.0 E+00$ & $0.0 \mathrm{E}+00$ & $0.0 \mathrm{E}+00$ & $0.0 \mathrm{E}+00$ & $0.0 \mathrm{E}+00$ & $0.0 E+00$ \\
\hline ENE & $0.0 E+00$ & $0.0 E+00$ & $0.0 \mathrm{E}+00$ & $0.0 \mathrm{E}+00$ & $0.0 \mathrm{E}+00$ & $0.0 \mathrm{E}+00$ \\
\hline $\mathrm{NE}$ & $0.0 E+00$ & $0.0 E+00$ & $0.0 \mathrm{E}+00$ & $0.0 \mathrm{E}+00$ & $0.0 \mathrm{E}+00$ & $0.0 E+00$ \\
\hline NNE & $0.0 E+00$ & $0.0 \mathrm{E}+00$ & $0.0 \mathrm{E}+00$ & $0.0 \mathrm{E}+00$ & $0.0 \mathrm{E}+00$ & $0.0 E+00$ \\
\hline
\end{tabular}




\begin{tabular}{|c|c|c|c|c|c|c|}
\hline 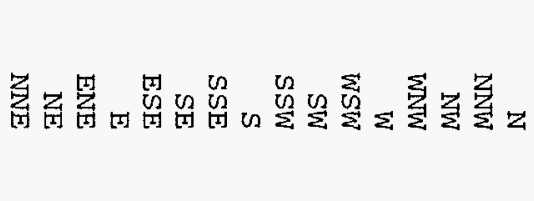 & 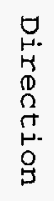 & & 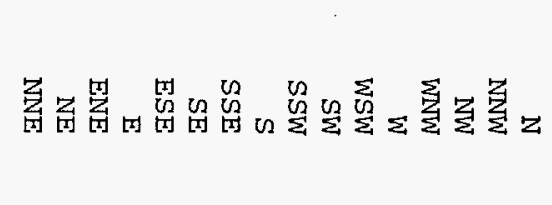 & 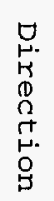 & & \\
\hline 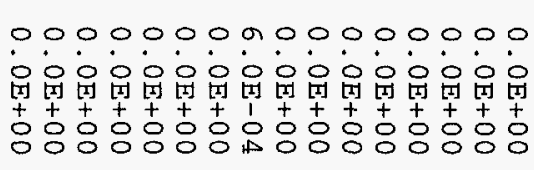 & $\begin{array}{l}\infty \\
:\end{array}$ & & 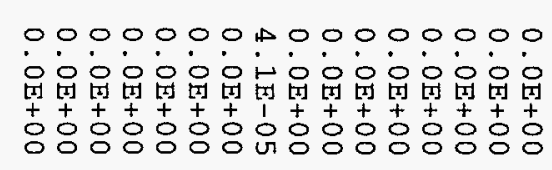 & $\vec{\circ}$ & & \\
\hline 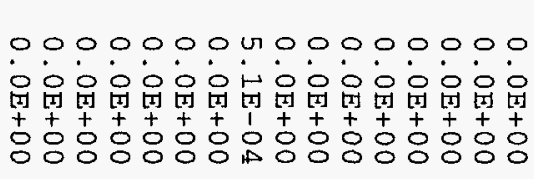 & $\stackrel{8}{\circ}$ & & 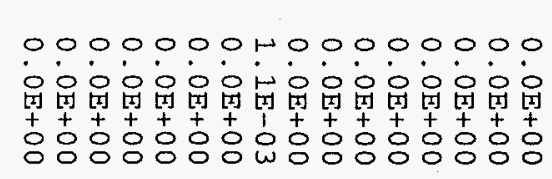 & $\stackrel{\tilde{O}}{\circ}$ & & गֶ. \\
\hline 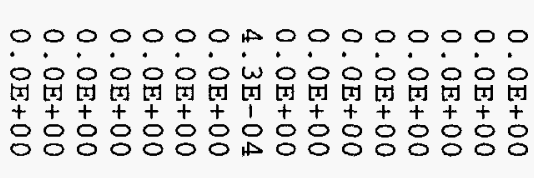 & $\stackrel{\leftrightarrow}{\circ}$ & & 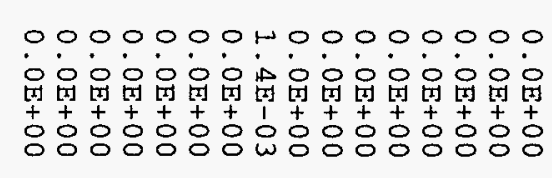 & $\stackrel{\omega}{\circ}$ & $\square$ & 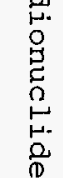 \\
\hline 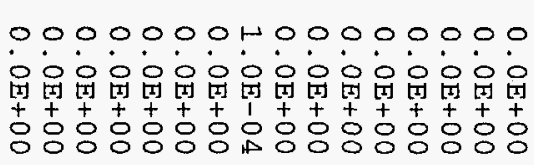 & $\begin{array}{l}N \\
\text { Ù } \\
0\end{array}$ & $\overline{\mathrm{g}}$ & 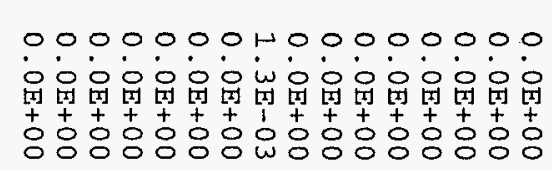 & 岁 & 五 & \\
\hline 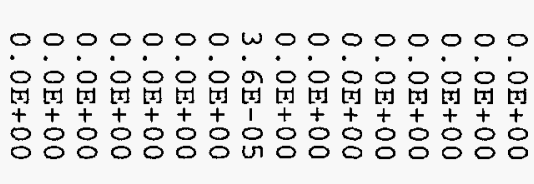 & $\begin{array}{l}\text { ज } \\
:\end{array}$ & & 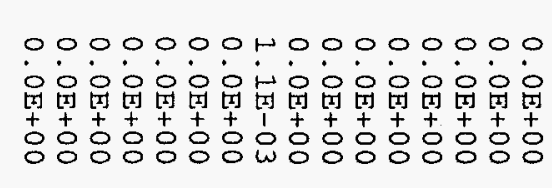 & $\stackrel{\sim}{\circ}$ & & \\
\hline 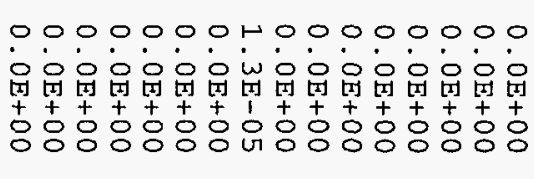 & $\begin{array}{l}\vec{\circ} \\
\stackrel{\circ}{\circ}\end{array}$ & & 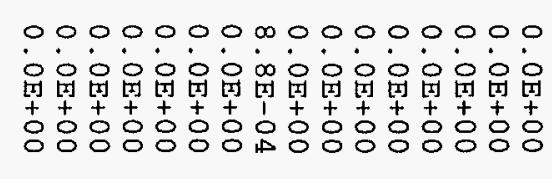 & 8 & & \\
\hline 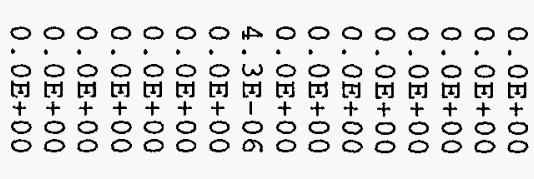 & $\begin{array}{l}\text { No } \\
: \\
:\end{array}$ & & 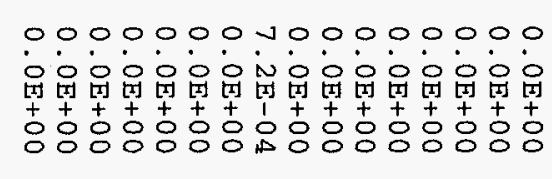 & & & \\
\hline
\end{tabular}


INDIVIDUAL LIFETIME RISK (deaths)

(All Radionuclides and Pathways)

\begin{tabular}{|c|c|c|c|c|c|c|}
\hline \multirow[b]{2}{*}{ Direction } & \multicolumn{6}{|c|}{ Distance $(\mathrm{m})$} \\
\hline & 30000 & 40000 & 50000 & 60000 & 70000 & 80000 \\
\hline $\mathrm{N}$ & $0.0 E+00$ & $0.0 \mathrm{E}+00$ & $0.0 E+00$ & $0.0 \mathrm{E}+00$ & $0.0 \mathrm{E}+00$ & $0.0 E+00$ \\
\hline NNWW & $0.0 E+00$ & $0.0 \mathrm{E}+00$ & $0.0 \mathrm{E}+00$ & $0.0 \mathrm{E}+00$ & $0.0 \mathrm{E}+00$ & $0.0 E+00$ \\
\hline NW & $0.0 E+00$ & $0.0 E+00$ & $0.0 \mathrm{E}+00$ & $0.0 \mathrm{E}+00$ & $0.0 E+00$ & $0.0 E+00$ \\
\hline WNW & $0.0 \mathrm{E}+00$ & $0.0 E+00$ & $0.0 \mathrm{E}+00$ & $0.0 \mathrm{E}+00$ & $0.0 \mathrm{E}+00$ & $0.0 \mathrm{E}+00$ \\
\hline W & $0.0 \mathrm{E}+00$ & $0.0 \mathrm{E}+00$ & $0.0 \mathrm{E}+00$ & $0.0 \mathrm{E}+00$ & $0.0 \mathrm{E}+00$ & $0.0 \mathrm{E}+00$ \\
\hline WSW & $0.0 \mathrm{E}+00$ & $0.0 \mathrm{E}+00$ & $0.0 \mathrm{E}+00$ & $0.0 \mathrm{E}+00$ & $0.0 \mathrm{E}+00$ & $0.0 \mathrm{E}+0 \mathrm{O}$ \\
\hline SW & $0.0 \mathrm{E}+00$ & $0.0 \mathrm{E}+00$ & $0.0 \mathrm{E}+00$ & $0.0 \mathrm{E}+00$ & $0.0 \mathrm{E}+00$ & $0.0 \mathrm{E}+00$ \\
\hline SSW & $0.0 \mathrm{E}+00$ & $0.0 \mathrm{E}+00$ & $0.0 \mathrm{E}+00$ & $0.0 \mathrm{E}+00$ & $0.0 \mathrm{E}+00$ & $0.0 E+00$ \\
\hline $\mathrm{s}$ & $2.3 E-06$ & $1.5 E-06$ & $1.0 \mathrm{E}-06$ & $7.7 \mathrm{E}-07$ & $6.0 \mathrm{E}-07$ & $4.9 E-07$ \\
\hline SSE & $0.0 E+00$ & $0.0 \mathrm{E}+00$ & $0.0 \mathrm{E}+00$ & $0.0 \mathrm{E}+00$ & $0.0 \mathrm{E}+00$ & $0.0 E+00$ \\
\hline SE & $0.0 E+00$ & $0.0 \mathrm{E}+00$ & $0.0 \mathrm{E}+00$ & $0.0 E+00$ & $0.0 \mathrm{E}+00$ & $0.0 E+00$ \\
\hline $\mathrm{ESE}$ & $0.0 E+00$ & $0.0 E+00$ & $0.0 \mathrm{E}+00$ & $0.0 \mathrm{E}+00$ & $0.0 \mathrm{E}+00$ & $0.0 E+00$ \\
\hline$E$ & $0.0 E+00$ & $0.0 E+00$ & $0.0 \mathrm{E}+00$ & $0.0 \mathrm{E}+00$ & $0.0 \mathrm{E}+00$ & $0.0 \mathrm{E}+00$ \\
\hline ENE & $0.0 \mathrm{E}+00$ & $0.0 \mathrm{E}+00$ & $0.0 E+00$ & $0.0 \mathrm{E}+00$ & $0.0 \mathrm{E}+00$ & $0.0 E+00$ \\
\hline $\mathrm{NE}$ & $0.0 \mathrm{E}+00$ & $0.0 \mathrm{E}+00$ & $0.0 \mathrm{E}+00$ & $0.0 \mathrm{E}+00$ & $0.0 \mathrm{E}+00$ & $0.0 E+00$ \\
\hline NNE & $0.0 E+00$ & $0.0 \mathrm{E}+00$ & $0.0 \mathrm{E}+00$ & $0.0 \mathrm{E}+00$ & $0.0 \mathrm{E}+00$ & $0.0 \mathrm{E}+00$ \\
\hline
\end{tabular}


May 13, $19972: 08 \mathrm{pm}$

GROUND-IEVEL CHI/Q VALUES FOR CS-137

CHI/Q TOWARD INDICATED DIRECTION (SEC/CUBIC METER)

\begin{tabular}{|c|c|c|c|c|c|c|c|}
\hline \multirow[b]{2}{*}{ Dir } & \multicolumn{7}{|c|}{ Distance (meters) } \\
\hline & 100 & 200 & 300 & 400 & 500 & 600 & 700 \\
\hline $\mathrm{N}$ & $0.000 E+00$ & $0.000 \mathrm{E}+00$ & $0.000 E+00$ & $0.000 E+00$ & $0.000 \mathrm{E}+00$ & $0.000 \mathrm{E}+00$ & $0.000 \mathrm{E}+00$ \\
\hline NNW & $0.000 E+00$ & $0.000 \mathrm{E}+00$ & $0.000 \mathrm{E}+00$ & $0.000 E+00$ & $0.000 E+00$ & $0.000 E+00$ & $0.000 \mathrm{E}+00$ \\
\hline NW & $0.000 E+00$ & $0.000 \mathrm{E}+00$ & $0.000 E+00$ & $0.000 E+00$ & $0.000 E+00$ & $0.000 E+00$ & $0.000 \mathrm{E}+00$ \\
\hline WNW & $0.000 E+00$ & $0.000 E+00$ & $0.000 E+00$ & $0.000 E+00$ & $0.000 E+00$ & $0.000 \mathrm{E}+00$ & $0.000 \mathrm{E}+00$ \\
\hline W & $0.000 E+00$ & $0.000 E+00$ & $0.000 E+00$ & $0.000 E+00$ & $0.000 E+00$ & $0.000 \mathrm{E}+00$ & $0.000 \mathrm{E}+00$ \\
\hline WSW & $0.000 \mathrm{E}+00$ & $0.000 E+00$ & $0.000 E+00$ & $0.000 E+00$ & $0.000 E+00$ & $0.000 \mathrm{E}+00$ & $0.000 \mathrm{E}+00$ \\
\hline SW & $0.000 E+00$ & $0.000 E+00$ & $0.000 E+00$ & $0.000 E+00$ & $0.000 E+00$ & $0.000 E+00$ & $0.000 \mathrm{E}+00$ \\
\hline SSW & $0.000 E+00$ & $0.000 E+00$ & $0.000 E+00$ & $0.000 E+00$ & $0.000 E+00$ & $0.000 E+00$ & $0.000 \mathrm{E}+00$ \\
\hline $\mathrm{S}$ & $1.058 E-06$ & $2.699 E-05$ & $3.698 \mathrm{E}-05$ & $3.349 E-05$ & $2.774 E-05$ & $2.264 E-05$ & $1.858 \mathrm{E}-05$ \\
\hline SSE & $0.000 \mathrm{E}+00$ & $0.000 E+00$ & $0.000 E+00$ & $0.000 E+00$ & $0.000 E+00$ & $0.000 E+00$ & $0.000 E+00$ \\
\hline SE & $0.000 \mathrm{E}+00$ & $0.000 E+00$ & $0.000 E+00$ & $0.000 E+00$ & $0.000 E+00$ & $0.000 E+00$ & $0.000 E+00$ \\
\hline ESE & $0.000 E+00$ & $0.000 E+00$ & $0.000 E+00$ & $0.000 E+00$ & $0.000 E+00$ & $0.000 E+00$ & $0.000 E+00$ \\
\hline$E$ & $0.000 E+00$ & $0.000 E+00$ & $0.000 E+00$ & $0.000 E+00$ & $0.000 E+00$ & $0.000 E+00$ & $0.000 E+00$ \\
\hline ENE & $0.000 E+00$ & $0.000 \mathrm{E}+00$ & $0.000 \mathrm{E}+00$ & $0.000 E+00$ & $0.000 E+00$ & $0.000 E+00$ & $0.000 \mathrm{E}+00$ \\
\hline NE & $0.000 E+00$ & $0.000 \mathrm{E}+00$ & $0.000 \mathrm{E}+00$ & $0.000 E+00$ & $0.000 E+00$ & $0.000 E+00$ & $0.000 E+00$ \\
\hline \multirow[t]{2}{*}{ NNE } & $0.000 E+00$ & $0.000 \mathrm{E}+00$ & $0.000 \mathrm{E}+00$ & $0.000 E+00$ & $0.000 E+00$ & $0.000 E+00$ & $0.000 \mathrm{E}+00$ \\
\hline & \multicolumn{7}{|c|}{ Distance (meters) } \\
\hline Dir & 800 & 900 & 1000 & 2500 & 5000 & 10000 & 20000 \\
\hline $\mathrm{N}$ & $0.000 \mathrm{E}+00$ & $0.000 E+00$ & $0.000 \mathrm{E}+00$ & $0.000 E+00$ & $0.000 E+00$ & $0.000 \mathrm{E}+00$ & $0.000 \mathrm{E}+00$ \\
\hline NNW & $0.000 \mathrm{E}+00$ & $0.000 \mathrm{E}+00$ & $0.000 E+00$ & $0.000 \mathrm{E}+00$ & $0.000 E+00$ & $0.000 E+00$ & $0.000 E+00$ \\
\hline NW & $0.000 \mathrm{E}+00$ & $0.000 \mathrm{E}+00$ & $0.000 E+00$ & $0.000 E+00$ & $0.000 E+00$ & $0.000 E+00$ & $0.000 E+00$ \\
\hline WNW & $0.000 \mathrm{E}+00$ & $0.000 \mathrm{E}+00$ & $0.000 \mathrm{E}+00$ & $0.000 E+00$ & $0.000 E+00$ & $0.000 \mathrm{E}+00$ & $0.000 E+00$ \\
\hline$w$ & $0.000 \mathrm{E}+00$ & $0.000 \mathrm{E}+00$ & $0.000 \mathrm{E}+00$ & $0.000 E+00$ & $0.000 E+00$ & $0.000 E+00$ & $0.000 E+00$ \\
\hline WSW & $0.000 \mathrm{E}+00$ & $0.000 \mathrm{E}+00$ & $0.000 E+00$ & $0.000 E+00$ & $0.000 E+00$ & $0.000 E+00$ & $0.000 E+00$ \\
\hline SW & $0.000 \mathrm{E}+00$ & $0.000 \mathrm{E}+00$ & $0.000 E+00$ & $0.000 E+00$ & $0.000 E+00$ & $0.000 E+00$ & $0.000 E+00$ \\
\hline SSW & $0.000 \mathrm{E}+00$ & $0.000 \mathrm{E}+00$ & $0.000 E+00$ & $0.000 E+00$ & $0.000 E+00$ & $0.000 E+00$ & $0.000 E+00$ \\
\hline S & $1.543 \mathrm{E}-05$ & $1.297 \mathrm{E}-05$ & $1.104 \mathrm{E}-05$ & $2.655 \mathrm{E}-06$ & $9.207 E-07$ & $3.222 E-07$ & $1.106 \mathrm{E}-07$ \\
\hline SSE & $0.000 \mathrm{E}+00$ & $0.000 \mathrm{E}+00$ & $0.000 E+00$ & $0.000 E+00$ & $0.000 E+00$ & $0.000 \mathrm{E}+00$ & $0.000 E+00$ \\
\hline SE & $0.000 \mathrm{E}+00$ & $0.000 \mathrm{E}+00$ & $0.000 E+00$ & $0.000 E+00$ & $0.000 \mathrm{E}+00$ & $0.000 \mathrm{E}+00$ & $0.000 E+00$ \\
\hline ESE & $0.000 \mathrm{E}+00$ & $0.000 \mathrm{E}+00$ & $0.000 E+00$ & $0.000 \mathrm{E}+00$ & $0.000 E+00$ & $0.000 E+00$ & $0.000 E+00$ \\
\hline $\mathrm{E}$ & $0.000 \mathrm{E}+00$ & $0.000 \mathrm{E}+00$ & $0.000 E+00$ & $0.000 \mathrm{E}+00$ & $0.000 \mathrm{E}+00$ & $0.000 \mathrm{E}+00$ & $0.000 E+00$ \\
\hline ENE & $0.000 \mathrm{E}+00$ & $0.000 \mathrm{E}+00$ & $0.000 E+00$ & $0.000 E+00$ & $0.000 E+00$ & $0.000 E+00$ & $0.000 E+00$ \\
\hline $\mathrm{NE}$ & $0.000 \mathrm{E}+00$ & $0.000 \mathrm{E}+00$ & $0.000 \mathrm{E}+00$ & $0.000 \mathrm{E}+00$ & $0.000 \mathrm{E}+00$ & $0.000 \mathrm{E}+00$ & $0.000 E+00$ \\
\hline NNE & $0.000 \mathrm{E}+00$ & $0.000 E+00$ & $0.000 E+00$ & $0.000 \mathrm{E}+00$ & $0.000 \mathrm{E}+00$ & $0.000 E+00$ & $0.000 E+00$ \\
\hline
\end{tabular}


GROUND-LEVEL CHI/Q VALUES FOR CS-137

CHI/Q TOWARD INDICATED DIRECTION (SEC/CUBIC METER)

\begin{tabular}{|c|c|c|c|c|c|c|}
\hline \multirow[b]{2}{*}{ Dir } & \multicolumn{6}{|c|}{ Distance (meters) } \\
\hline & 30000 & 40000 & 50000 & 60000 & 70000 & 80000 \\
\hline $\mathrm{N}$ & $0.000 E+00$ & $0.000 E+00$ & $0.000 E+00$ & $0.000 E+00$ & $0.000 E+00$ & $0.000 \mathrm{E}+00$ \\
\hline NNW & $0.000 E+00$ & $0.000 E+00$ & $0.000 E+00$ & $0.000 E+00$ & $0.000 E+00$ & $0.000 E+00$ \\
\hline $\mathrm{NW}$ & $0.000 E+00$ & $0.000 E+00$ & $0.000 E+00$ & $0.000 E+00$ & $0.000 E+00$ & $0.000 E+00$ \\
\hline WNW & $0.000 E+00$ & $0.000 E+00$ & $0.000 E+00$ & $0.000 E+00$ & $0.000 E+00$ & $0.000 \mathrm{E}+00$ \\
\hline W & $0.000 E+00$ & $0.000 E+00$ & $0.000 E+00$ & $0.000 E+00$ & $0.000 \mathrm{E}+00$ & $0.000 E+00$ \\
\hline WSW & $0.000 \mathrm{E}+00$ & $0.000 E+00$ & $0.000 E+00$ & $0.000 E+00$ & $0.000 E+00$ & $0.000 E+00$ \\
\hline SW & $0.000 \mathrm{E}+00$ & $0.000 E+00$ & $0.000 E+00$ & $0.000 E+00$ & $0.000 \mathrm{E}+00$ & $0.000 \mathrm{E}+00$ \\
\hline SSW & $0.000 \mathrm{E}+00$ & $0.000 E+00$ & $0.000 E+00$ & $0.000 \mathrm{E}+00$ & $0.000 E+00$ & $0.000 \mathrm{E}+00$ \\
\hline$S$ & $5.878 E-08$ & $3.760 E-08$ & $2.646 \mathrm{E}-08$ & $1.972 E-08$ & $1.549 E-08$ & 1. $253 E-08$ \\
\hline SSE & $0.000 E+00$ & $0.000 \mathrm{E}+00$ & $0.000 \mathrm{E}+00$ & $0.000 \mathrm{E}+00$ & $0.000 \mathrm{E}+00$ & $0.000 E+00$ \\
\hline $\mathrm{SE}$ & $0.000 \mathrm{E}+00$ & $0.000 E+00$ & $0.000 E+00$ & $0.000 E+.00$ & $0.000 E+00$ & $0.000 E+00$ \\
\hline ESE & $0.000 E+00$ & $0.000 E+00$ & $0.000 E+00$ & $0.000 E+00$ & $0.000 E+00$ & $0.000 E+00$ \\
\hline$E$ & $0.000 E+00$ & $0.000 E+00$ & $0.000 \mathrm{E}+00$ & $0.000 E+00$ & $0.000 \mathrm{E}+00$ & $0.000 E+00$ \\
\hline ENE & $0.000 E+00$ & $0.000 E+00$ & $0.000 E+00$ & $0.000 \mathrm{E}+00$ & $0.000 \mathrm{E}+00$ & $0.000 E+00$ \\
\hline $\mathrm{NE}$ & $0.000 E+00$ & $0.000 E+00$ & $0.000 E+00$ & $0.000 E+00$ & $0.000 \mathrm{E}+00$ & $0.000 E+00$ \\
\hline NNE & $0.000 E+00$ & $0.000 \mathrm{E}+00$ & $0.000 E+00$ & $0.000 E+00$ & $0.000 E+00$ & $0.000 \mathrm{E}+00$ \\
\hline
\end{tabular}


GROUND-LEVEL CHI/Q VALUES FOR BA-137M

CHI/Q TOWARD INDICATED DIRECTION (SEC/CUBIC METER)

\begin{tabular}{|c|c|c|c|c|c|c|c|}
\hline \multirow[b]{2}{*}{ Dir } & \multicolumn{7}{|c|}{ Distance (meters) } \\
\hline & 100 & 200 & 300 & 400 & 500 & 600 & 700 \\
\hline $\mathrm{N}$ & $0.000 \mathrm{E}+00$ & $0.000 \mathrm{E}+00$ & $0.000 E+00$ & $0.000 E+00$ & $0.000 E+00$ & $0.000 E+00$ & $0.000 E+00$ \\
\hline NNW & $0.000 \mathrm{E}+00$ & $0.000 E+00$ & $0.000 E+00$ & $0.000 \mathrm{E}+00$ & $0.000 E+00$ & $0.000 \mathrm{E}+00$ & $0.000 \mathrm{E}+00$ \\
\hline NW & $0.000 \mathrm{E}+00$ & $0.000 \mathrm{E}+00$ & $0.000 E+00$ & $0.000 E+00$ & $0.000 E+00$ & $0.000 E+00$ & $0.000 E+00$ \\
\hline WNW & $0.000 \mathrm{E}+00$ & $0.000 E+00$ & $0.000 E+00$ & $0.000 E+00$ & $0.000 E+00$ & $0.000 E+00$ & $0.000 E+00$ \\
\hline W & $0.000 \mathrm{E}+00$ & $0.000 E+00$ & $0.000 E+00$ & $0.000 E+00$ & $0.000 E+00$ & $0.000 E+00$ & $0.000 E+00$ \\
\hline WSW & $0.000 \mathrm{E}+00$ & $0.000 \mathrm{E}+00$ & $0.000 E+00$ & $0.000 E+00$ & $0.000 E+00$ & $0.000 E+00$ & $0.000 E+00$ \\
\hline SW & $0.000 \mathrm{E}+00$ & $0.000 E+00$ & $0.000 E+00$ & $0.000 E+00$ & $0.000 E+00$ & $0.000 E+00$ & $0.000 E+00$ \\
\hline SSW & $0.000 \mathrm{E}+00$ & $0.000 E+00$ & $0.000 E+00$ & $0.000 \mathrm{E}+00$ & $0.000 \mathrm{E}+00$ & $0.000 \mathrm{E}+00$ & $0.000 \mathrm{E}+00$ \\
\hline$S$ & $9.537 \mathrm{E}-07$ & $2.194 E-05$ & $2.711 E-05$ & $2.214 \mathrm{E}-05$ & $1.653 \mathrm{E}-05$ & $1.217 \mathrm{E}-05$ & $9.002 E-06$ \\
\hline SSE & $0.000 \mathrm{E}+00$ & $0.000 E+00$ & $0.000 E+00$ & $0.000 E+00$ & $0.000 E+00$ & $0.000 E+00$ & $0.000 \mathrm{E}+00$ \\
\hline $\mathrm{SE}$ & $0.000 \mathrm{E}+00$ & $0.000 \mathrm{E}+00$ & $0.000 \mathrm{E}+00$ & $0.000 E+00$ & $0.000 \mathrm{E}+00$ & $0.000 E+00$ & $0.000 \mathrm{E}+00$ \\
\hline ESE & $0.000 \mathrm{E}+00$ & $0.000 E+00$ & $0.000 \mathrm{E}+00$ & $0.000 \mathrm{E}+00$ & $0.000 \mathrm{E}+00$ & $0.000 E+00$ & $0.000 E+00$ \\
\hline$E$ & $0.000 \mathrm{E}+00$ & $0.000 \mathrm{E}+00$ & $0.000 \mathrm{E}+00$ & $0.000 \mathrm{E}+00$ & $0.000 \mathrm{E}+00$ & $0.000 E+00$ & $0.000 \mathrm{E}+00$ \\
\hline ENE & $0.000 \mathrm{E}+00$ & $0.000 E+00$ & $0.000 \mathrm{E}+00$ & $0.000 \mathrm{E}+00$ & $0.000 \mathrm{E}+00$ & $0.000 \mathrm{E}+00$ & $0.000 \mathrm{E}+00$ \\
\hline $\mathrm{NE}$ & $0.000 \mathrm{E}+00$ & $0.000 E+00$ & $0.000 E+00$ & $0.000 E+00$ & $0.000 \mathrm{E}+00$ & $0.000 E+00$ & $0.000 E+00$ \\
\hline \multirow[t]{2}{*}{ NNE } & $0.000 \mathrm{E}+00$ & $0.000 \mathrm{E}+00$ & $0.000 \mathrm{E}+00$ & $0.000 \mathrm{E}+00$ & $0.000 \mathrm{E}+00$ & $0.000 E+00$ & $0.000 \mathrm{E}+00$ \\
\hline & \multicolumn{7}{|c|}{ Distance (meters) } \\
\hline Dir & 800 & 900 & 1000 & 2500 & 5000 & 10000 & 20000 \\
\hline $\mathrm{N}$ & $0.000 \mathrm{E}+00$ & $0.000 E+00$ & $0.000 E+00$ & $0.000 E+00$ & $0.000 E+00$ & $0.000 E+00$ & $0.000 E+00$ \\
\hline NNW & $0.000 \mathrm{E}+00$ & $0.000 E+00$ & $0.000 E+00$ & $0.000 E+00$ & $0.000 \mathrm{E}+00$ & $0.000 E+00$ & $0.000 \mathrm{E}+00$ \\
\hline NW & $0.000 \mathrm{E}+00$ & $0.000 E+00$ & $0.000 \mathrm{E}+00$ & $0.000 \mathrm{E}+00$ & $0.000 \mathrm{E}+00$ & $0.000 E+00$ & $0.000 E+00$ \\
\hline WNW & $0.000 \mathrm{E}+00$ & $0.000 E+00$ & $0.000 E+00$ & $0.000 \mathrm{E}+00$ & $0.000 E+00$ & $0.000 E+00$ & $0.000 \mathrm{E}+00$ \\
\hline $\mathrm{W}$ & $0.000 \mathrm{E}+00$ & $0.000 E+00$ & $0.000 \mathrm{E}+00$ & $0.000 \mathrm{E}+00$ & $0.000 E+00$ & $0.000 \mathrm{E}+00$ & $0.000 \mathrm{E}+00$ \\
\hline WSW & $0.000 \mathrm{E}+00$ & $0.000 E+00$ & $0.000 E+00$ & $0.000 \mathrm{E}+00$ & $0.000 E+00$ & $0.000 E+00$ & $0.000 E+00$ \\
\hline SW & $0.000 E+00$ & $0.000 \mathrm{E}+00$ & $0.000 E+00$ & $0.000 \mathrm{E}+00$ & $0.000 E+00$ & $0.000 E+00$ & $0.000 E+00$ \\
\hline SSW & $0.000 E+00$ & $0.000 E+00$ & $0.000 E+00$ & $0.000 E+00$ & $0.000 E+00$ & $0.000 E+00$ & $0.000 \mathrm{E}+00$ \\
\hline S & $6.739 E-06$ & $5.110 \mathrm{E}-06$ & $3.923 \mathrm{E}-06$ & $1.996 \mathrm{E}-07$ & $5.204 E-09$ & $1.029 E-11$ & $1.129 \mathrm{E}-16$ \\
\hline SSE & $0.000 \mathrm{E}+00$ & $0.000 E+00$ & $0.000 E+00$ & $0.000 E+00$ & $0.000 \mathrm{E}+00$ & $0.000 E+00$ & $0.000 E+00$ \\
\hline$S E$ & $0.000 E+00$ & $0.000 E+00$ & $0.000 E+00$ & $0.000 \mathrm{E}+00$ & $0.000 \mathrm{E}+00$ & $0.000 E+00$ & $0.000 \mathrm{E}+00$ \\
\hline ESE & $0.000 E+00$ & $0.000 E+00$ & $0.000 E+00$ & $0.000 \mathrm{E}+00$ & $0.000 \mathrm{E}+00$ & $0.000 E+00$ & $0.000 \mathrm{E}+00$ \\
\hline$E$ & $0.000 \mathrm{E}+00$ & $0.000 E+00$ & $0.000 E+00$ & $0.000 E+00$ & $0.000 E+00$ & $0.000 E+00$ & $0.000 \mathrm{E}+00$ \\
\hline ENE & $0.000 E+00$ & $0.000 \mathrm{E}+00$ & $0.000 E+00$ & $0.000 E+00$ & $0.000 E+00$ & $0.000 E+00$ & $0.000 \mathrm{E}+00$ \\
\hline $\mathrm{NE}$ & $0.000 E+00$ & $0.000 E+00$ & $0.000 E+00$ & $0.000 \mathrm{E}+00$ & $0.000 E+00$ & $0.000 E+00$ & $0.000 E+00$ \\
\hline $\mathrm{NNE}$ & $0.000 \mathrm{E}+00$ & $0.000 \mathrm{E}+00$ & $0.000 E+00$ & $0.000 \mathrm{E}+00$ & $0.000 \mathrm{E}+00$ & $0.000 \mathrm{E}+00$ & $0.000 E+00$ \\
\hline
\end{tabular}


May 13, $19972: 08 \mathrm{pm}$

GROUND-LEVEL CHI/Q VALUES FOR BA-137M

CHI/Q TOWARD INDICATED DIRECTION (SEC/CUBIC METER)

\begin{tabular}{|c|c|c|c|c|c|c|}
\hline \multirow[b]{2}{*}{ Dir } & \multicolumn{6}{|c|}{ Distance (meters) } \\
\hline & 30000 & 40000 & 50000 & 60000 & 70000 & 80000 \\
\hline $\mathrm{N}$ & $0.000 E+00$ & $0.000 E+00$ & $0.000 E+00$ & $0.000 E+00$ & $0.000 E+00$ & $0.000 E+00$ \\
\hline NNW & $0.000 E+00$ & $0.000 E+00$ & $0.000 E+00$ & $0.000 E+00$ & $0.000 E+00$ & $0.000 E+00$ \\
\hline NW & $0.000 \mathrm{E}+00$ & $0.000 \mathrm{E}+00$ & $0.000 \mathrm{E}+00$ & $0.000 E+00$ & $0.000 E+00$ & $0.000 E+00$ \\
\hline WNW & $0.000 E+00$ & $0.000 E+00$ & $0.000 \mathrm{E}+00$ & $0.000 E+00$ & $0.000 E+00$ & $0.000 \mathrm{E}+00$ \\
\hline W & $0.000 E+00$ & $0.000 \mathrm{E}+00$ & $0.000 \mathrm{E}+00$ & $0.000 \mathrm{E}+00$ & $0.000 E+00$ & $0.000 E+00$ \\
\hline WSW & $0.000 E+00$ & $0.000 E+00$ & $0.000 \mathrm{E}+00$ & $0.000 E+00$ & $0.000 \mathrm{E}+00$ & $0.000 E+00$ \\
\hline SW & $0.000 E+00$ & $0.000 \mathrm{E}+00$ & $0.000 \mathrm{E}+00$ & $0.000 \mathrm{E}+00$ & $0.000 E+00$ & $0.000 \mathrm{E}+00$ \\
\hline SSW & $0.000 E+00$ & $0.000 E+00$ & $0.000 \mathrm{E}+00$ & $0.000 E+00$ & $0.000 E+00$ & $0.000 \mathrm{E}+00$ \\
\hline$S$ & $1.917 \mathrm{E}-21$ & $3.920 \mathrm{E}-26$ & $8.877 E-31$ & $2.357 \mathrm{E}-35$ & $0.000 \mathrm{E}+00$ & $0.000 \mathrm{E}+00$ \\
\hline SSE & $0.000 E+00$ & $0.000 \mathrm{E}+00$ & $0.000 E+00$ & $0.000 E+00$ & $0.000 E+00$ & $0.000 \mathrm{E}+00$ \\
\hline $\mathrm{SE}$ & $0.000 E+00$ & $0.000 \mathrm{E}+00$ & $0.000 E+00$ & $0.000 \mathrm{E}+00$ & $0.000 E+00$ & $0.000 \mathrm{E}+00$ \\
\hline ESE & $0.000 E+00$ & $0.000 \mathrm{E}+00$ & $0.000 \mathrm{E}+00$ & $0.000 E+00$ & $0.000 E+00$ & $0.000 \mathrm{E}+00$ \\
\hline$E$ & $0.000 \mathrm{E}+00$ & $0.000 \mathrm{E}+00$ & $0.000 \mathrm{E}+00$ & $0.000 \mathrm{E}+00$ & $0.000 E+00$ & $0.000 \mathrm{E}+00$ \\
\hline ENE & $0.000 E+00$ & $0.000 \mathrm{E}+00$ & $0.000 \mathrm{E}+00$ & $0.000 E+00$ & $0.000 E+00$ & $0.000 E+00$ \\
\hline $\mathrm{NE}$ & $0.000 E+00$ & $0.000 E+00$ & $0.000 \mathrm{E}+00$ & $0.000 E+00$ & $0.000 E+00$ & $0.000 \mathrm{E}+00$ \\
\hline NNE & $0.000 \mathrm{E}+00$ & $0.000 \mathrm{E}+00$ & $0.000 \mathrm{E}+00$ & $0.000 \mathrm{E}+00$ & $0.000 E+00$ & $0.000 \mathrm{E}+00$ \\
\hline
\end{tabular}


C A P $88-P$ C

Version 1.00

Clean Air Act Assessment Package - 1988

\author{
$D O S E A N D \quad R$ I S K C O N V E R S I O N F A C T O R S \\ Non-Radon Individual Assessment \\ May 13, $19972: 08 \mathrm{pm}$
}
Facility: Riskind benchmark test, $20 \mathrm{~m}, 1 \mathrm{Ci} \mathrm{Cs}-137$ Address :
City:
State:
WA
Zip:

Source Category:

Source Type: Stack

Emission Year:

Comments :

Dataset Name: Riskind 20m, Cs

Dataset Date: May 5, 1997 10:10 am

Wind File: WNDFILES $\backslash$ D4FRMN. WND 


\section{$B-91$}

May 13, $1997 \quad 2: 08 \mathrm{pm}$

FACTOR

Page 1

DOSE AND RISK FACTOR UNITS

The units for each type of dose rate conversion factor are shown below, by pathway:

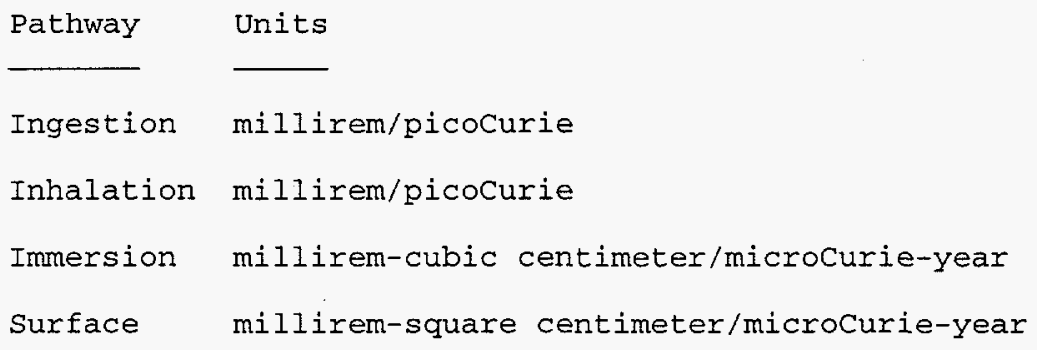

Risks for internal exposures (inhalation and ingestion) are the lifetime risk of premature death in a birth cohort of 100,000 people for a 1 picocurie/year intake rate, where the average lifetime is 70.7565 years. This is simplified to lifetime risk per 100,000 picocuries.

The units for each type of risk conversion factor are shown below, by pathway:

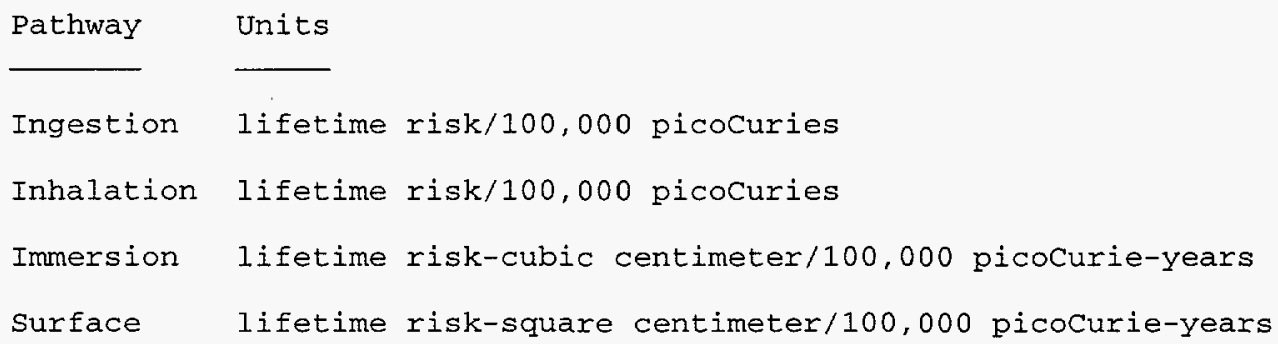




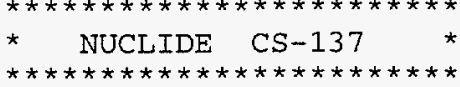

DOSE RATE CONVERSION FACTORS

\begin{tabular}{|c|c|c|c|c|}
\hline Organ & Ingestion & Inhalation & $\begin{array}{c}\text { Air } \\
\text { Immersion }\end{array}$ & $\begin{array}{l}\text { Ground } \\
\text { Surface }\end{array}$ \\
\hline GONADS & $4.404 \mathrm{E}-05$ & $2.925 E-05$ & $0.000 E+00$ & $0.000 E+00$ \\
\hline BREAST & $4.799 \mathrm{E}-05$ & $3.190 \mathrm{E}-05$ & $0.000 E+00$ & $0.000 E+00$ \\
\hline$R$ MAR & $4.365 E-05$ & $2.901 E-05$ & $0.000 E+00$ & $0.000 E+00$ \\
\hline LUNGS & $4.438 E-05$ & $3.262 \mathrm{E}-05$ & $0.000 E+00$ & $0.000 E+00$ \\
\hline THYROID & $5.080 \mathrm{E}-05$ & $3.378 \mathrm{E}-05$ & $0.000 E+00$ & $0.000 E+00$ \\
\hline ENDOST & $3.052 E-05$ & $2.029 E-05$ & $0.000 E+00$ & $0.000 E+00$ \\
\hline RMNDR & $4.950 \mathrm{E}-05$ & $3.291 \mathrm{E}-05$ & $0.000 E+00$ & $0.000 E+00$ \\
\hline EFFEC & $4.606 E-05$ & $3.099 E-05$ & $0.000 E+00$ & $0.000 E+00$ \\
\hline
\end{tabular}

\section{GENETIC EFFECT DOSE RATE CONVERSION FACTORS}

$\begin{array}{lllll}\text { TESTES } & 1.302 \mathrm{E}-03 & 8.650 \mathrm{E}-04 & 0.000 \mathrm{E}+00 & 0.000 \mathrm{E}+00 \\ \text { OVARIES } & 1.290 \mathrm{E}-03 & 8.550 \mathrm{E}-04 & 0.000 \mathrm{E}+00 & 0.000 \mathrm{E}+00 \\ \text { AVERAGE } & 1.296 \mathrm{E}-03 & 8.600 \mathrm{E}-04 & 0.000 \mathrm{E}+00 & 0.000 \mathrm{E}+00\end{array}$

\section{RISK CONVERSION FACTORS}

\begin{tabular}{|c|c|c|c|c|}
\hline Cancer & Ingestion & Inhalation & $\begin{array}{c}\text { Air } \\
\text { Immersion }\end{array}$ & $\begin{array}{l}\text { Ground } \\
\text { Surface }\end{array}$ \\
\hline LEUKEMIA & $1.378 \mathrm{E}-05$ & $9.158 \mathrm{E}-06$ & $0.000 \mathrm{E}+00$ & $0.000 \mathrm{E}+00$ \\
\hline BONE & $5.381 E-07$ & $3.578 E-07$ & $0.000 E+00$ & $0.000 \mathrm{E}+00$ \\
\hline THYROID & $2.301 E-06$ & $1.530 \mathrm{E}-06$ & $0.000 E+00$ & $0.000 E+00$ \\
\hline BREAST & $1.868 \mathrm{E}-05$ & 1. $242 E-05$ & $0.000 \mathrm{E}+00$ & $0.000 \mathrm{E}+00$ \\
\hline LUNG & $2.187 \mathrm{E}-05$ & $1.674 E-05$ & $0.000 \mathrm{E}+00$ & $0.000 \mathrm{E}+00$ \\
\hline STOMACH & $1.153 \mathrm{E}-05$ & $7.465 \mathrm{E}-06$ & $0.000 \mathrm{E}+00$ & $0.000 \mathrm{E}+00$ \\
\hline BOWEL & $4.723 E-06$ & $3.017 E-06$ & $0.000 \mathrm{E}+00$ & $0.000 \mathrm{E}+00$ \\
\hline IIVER & $1.667 \mathrm{E}-05$ & $1.109 E-05$ & $0.000 E+00$ & $0.000 \mathrm{E}+00$ \\
\hline PANCREAS & $1.079 E-05$ & $7.174 E-06$ & $0.000 \mathrm{E}+00$ & $0.000 \mathrm{E}+00$ \\
\hline URINARY & $6.303 E-06$ & $4.188 E-06$ & $0.000 E+00$ & $0.000 \mathrm{E}+00$ \\
\hline OTHER & $1.320 \mathrm{E}-05$ & $8.775 E-06$ & $0.000 E+00$ & $0.000 \mathrm{E}+00$ \\
\hline
\end{tabular}

GENETIC EFFECT RISK CONVERSION FACTORS

AVERAGE
$3.370 \mathrm{E}-10$
$2.236 \mathrm{E}-10$
$0.000 E+00$
$0.000 \mathrm{E}+00$ 
DOSE RATE CONVERSION FACTORS

\begin{tabular}{|c|c|c|c|c|}
\hline Organ & Ingestion & Inhalation & $\begin{array}{c}\text { Air } \\
\text { Imnersion }\end{array}$ & $\begin{array}{l}\text { Ground } \\
\text { Surface }\end{array}$ \\
\hline GONADS & $3.456 E-10$ & $5.090 E-11$ & $3.582 E+09$ & $7.141 E+05$ \\
\hline BREAST & $3.743 \mathrm{E}-10$ & $2.361 \mathrm{E}-10$ & $3.260 \mathrm{E}+09$ & $6.512 \mathrm{E}+05$ \\
\hline R MAR & $2.923 E-10$ & $2.177 E-10$ & $2.734 E+09$ & $5.439 E+05$ \\
\hline LUNGS & $4.594 E-10$ & $7.201 E-09$ & $2.686 E+09$ & $5.365 E+05$ \\
\hline THYROID & $4.051 E-11$ & $2.200 E-10$ & $3.367 E+09$ & $6.734 E+05$ \\
\hline ENDOST & $1.608 \mathrm{E}-10$ & $1.647 \mathrm{E}-10$ & $3.034 \mathrm{E}+09$ & $6.068 \mathrm{E}+05$ \\
\hline RMNDR & $7.704 E-09$ & $5.841 E-10$ & $2.702 E+09$ & $5.387 E+05$ \\
\hline EFFEC & $2.550 \mathrm{E}-09$ & $1.125 \mathrm{E}-09$ & $3.038 E+09$ & $6.059 \mathrm{E}+05$ \\
\hline
\end{tabular}

GENETIC EFFECT DOSE RATE CONVERSION FACTORS

$\begin{array}{lllll}\text { TESTES } & 7.174 \mathrm{E}-10 & 7.210 \mathrm{E}-10 & 1.074 \mathrm{E}+11 & 2.142 \mathrm{E}+07 \\ \text { OVARIES } & 1.037 \mathrm{E}-08 & 1.527 \mathrm{E}-09 & 7.304 \mathrm{E}+10 & 1.454 \mathrm{E}+07 \\ \text { AVERAGE } & 5.543 \mathrm{E}-09 & 1.124 \mathrm{E}-09 & 9.024 \mathrm{E}+10 & 1.798 \mathrm{E}+07\end{array}$

\section{RISK CONVERSION FACTORS}

\begin{tabular}{|c|c|c|c|c|}
\hline Cancer & Ingestion & Inhalation & $\begin{array}{c}\text { Air } \\
\text { Immersion }\end{array}$ & $\begin{array}{l}\text { Ground } \\
\text { Surface }\end{array}$ \\
\hline LEUKEMIA & $9.259 \mathrm{E}-11$ & $6.896 \mathrm{E}-11$ & $8.660 E+02$ & $1.723 \mathrm{E}-01$ \\
\hline BONE & $2.847 E-12$ & $2.916 \mathrm{E}-12$ & $5.370 \mathrm{E}+01$ & $1.074 \mathrm{E}-02$ \\
\hline THYROID & $1.842 E-12$ & $1.001 \mathrm{E}-11$ & $1.531 E+02$ & $3.063 E-02$ \\
\hline BREAST & $1.466 \mathrm{E}-10$ & $9.246 \mathrm{E}-11$ & $1.277 \mathrm{E}+03$ & $2.551 \mathrm{E}-01$ \\
\hline LUNG & $2.278 E-10$ & $2.678 E-09$ & $1.332 \mathrm{E}+03$ & $2.660 \mathrm{E}-01$ \\
\hline STOMACH & $9.421 \mathrm{E}-09$ & $3.193 \mathrm{E}-10$ & $8.060 E+02$ & $1.612 \mathrm{E}-01$ \\
\hline BOWEL & $1.587 \mathrm{E}-10$ & $1.215 \mathrm{E}-11$ & $4.011 E+02$ & $8.010 \mathrm{E}-02$ \\
\hline LIVER & $1.845 \mathrm{E}-10$ & $1.399 \mathrm{E}-10$ & $8.794 E+02$ & $1.751 \mathrm{E}-01$ \\
\hline PANCREAS & $1.049 E-09$ & $1.267 \mathrm{E}-10$ & $5.285 E+02$ & $1.050 \mathrm{E}-01$ \\
\hline URINARY & $1.079 \mathrm{E}-10$ & $2.521 \mathrm{E}-11$ & $3.301 E+02$ & $6.592 \mathrm{E}-02$ \\
\hline OTHER & $1.283 E-09$ & $1.550 \mathrm{E}-10$ & $6.465 E+02$ & 1. $284 \mathrm{E}-01$ \\
\hline
\end{tabular}

GENETIC EFFECT RISK CONVERSION FACTORS
AVERAGE
1. $441 \mathrm{E}-15$
$2.922 \mathrm{E}-16$
$2.346 \mathrm{E}+04$
$4.675 \mathrm{E}+00$ 


\section{B.2.2 Spent Fuel Accident}

\section{B.2.2.1 RISKIND Output for Spent Fuel Accident}

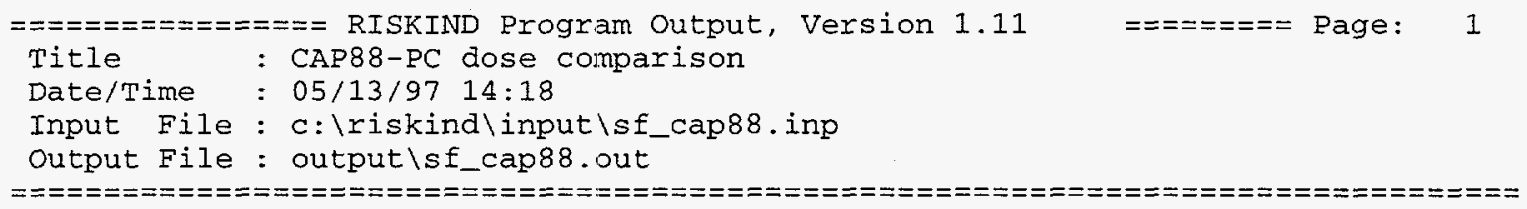

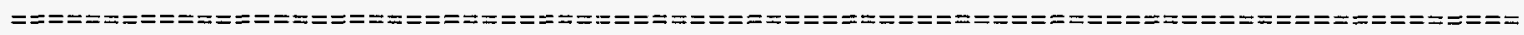

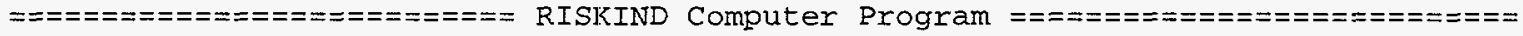

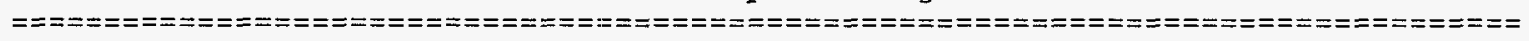

Problem Description

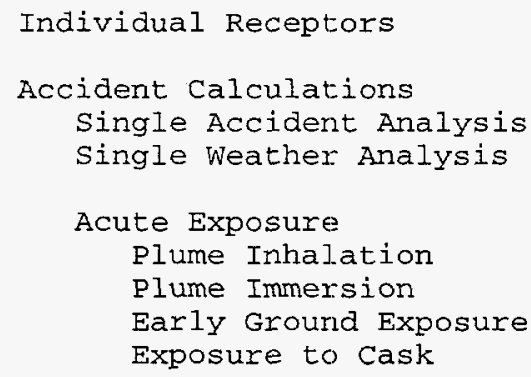




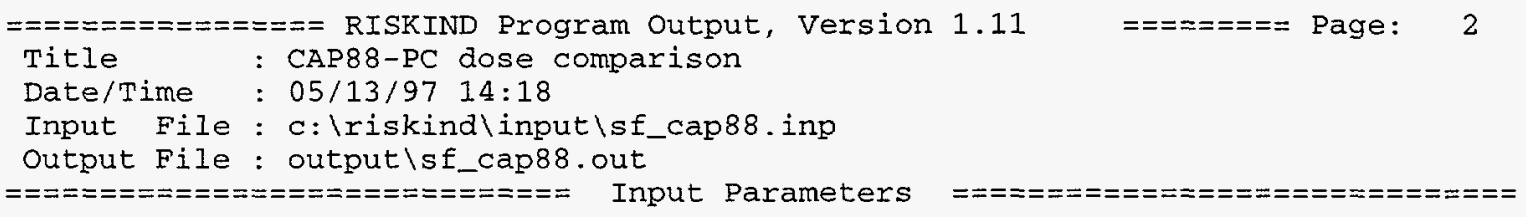

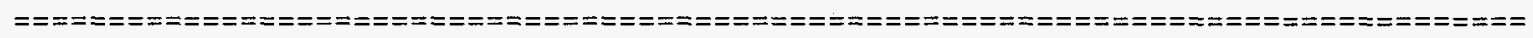

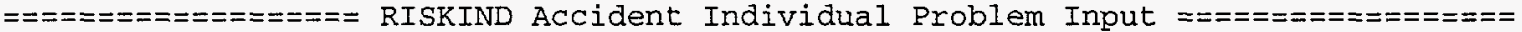

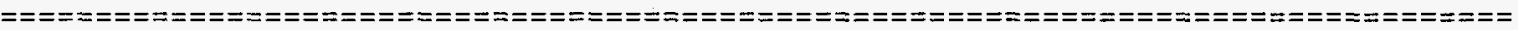

Individual Accident Parameters

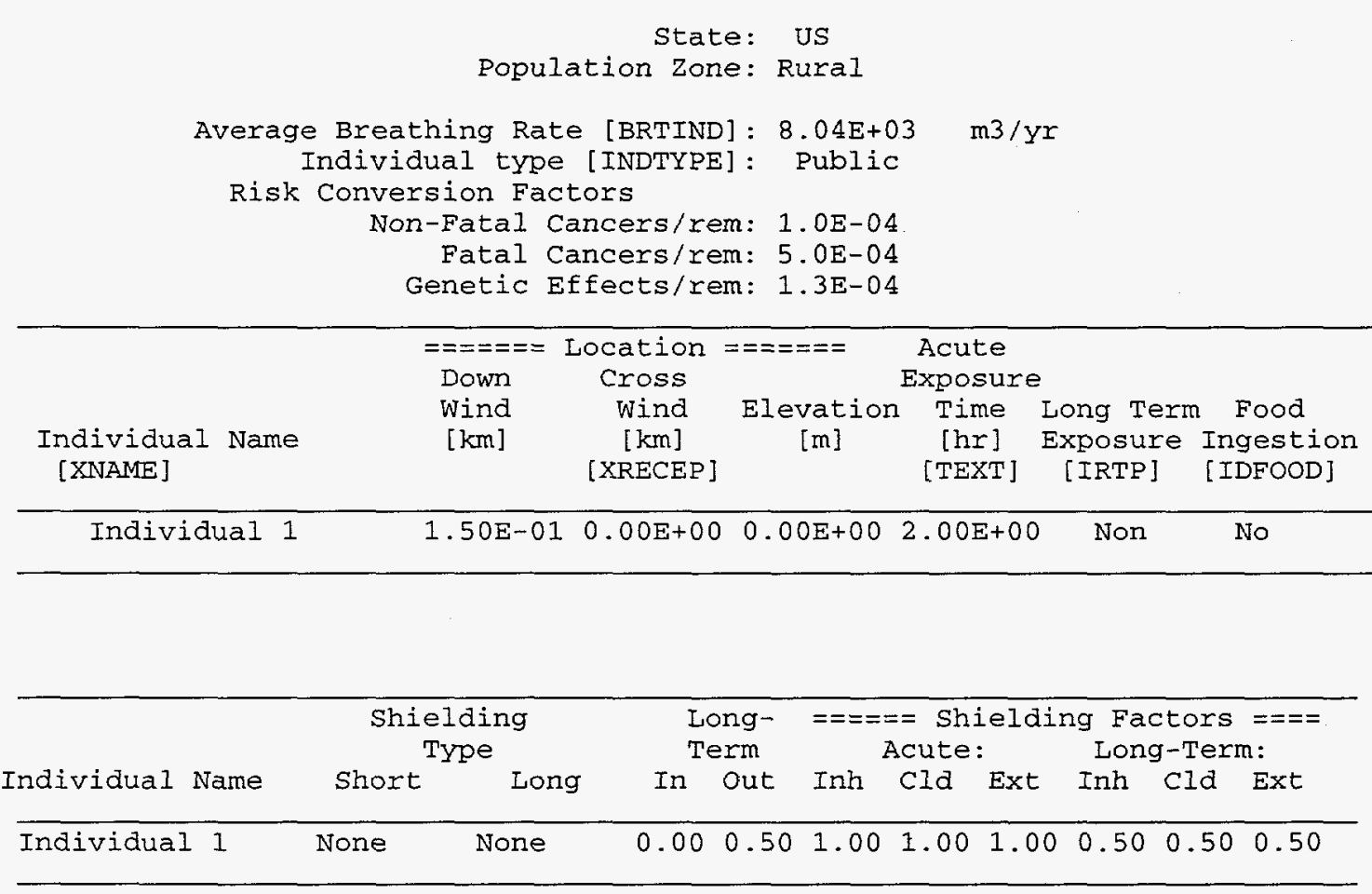




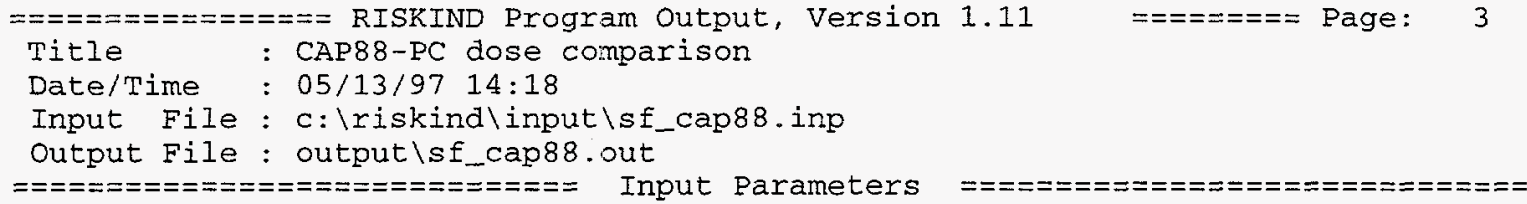

Meteorological Parameters

Dry deposition rates [VDEPNUC] Particulates Ruthenium

$: 1.00 \mathrm{E}-02$ Cesium : $1.00 \mathrm{E}-02$ Iodine : $1.00 \mathrm{E}-02$ Gases : $0.00 E+00$

Rain fall rate [RAIN]: $0.00 E+00$ Anemometer height [ANH] : 20.00 Ambient Temperature [TABK]: 288.00 Mixing height [DMIX]: 1000.00

Wind at anemometer [WSM] : 4.37 Pasquill stability cat. [ITYPE]: D

$$
\begin{array}{r}
\mathrm{m} / \mathrm{s} \\
\mathrm{m} / \mathrm{s} \\
\mathrm{m} / \mathrm{s} \\
\mathrm{m} / \mathrm{s} \\
\mathrm{m} / \mathrm{s} \\
\mathrm{mm} / \mathrm{h} \\
\mathrm{m} \\
\mathrm{K} \\
\mathrm{m} \\
\mathrm{m} / \mathrm{s}
\end{array}
$$

$$
\begin{array}{rrr}
\text { Transportation Mode [IMOD] : } & \text { Truck } \\
\text { Dose at } 1 \mathrm{~m} \text { [TIDX] : } & 3.48 & \mathrm{mrem} / \mathrm{hr} \\
\text { Measurement offiset [TIOFF] : } & 0.00 & \mathrm{~m} \\
\text { Gamma Fraction [FRAD(1)]: } & 0.60 & \\
\text { Neutron Fraction [FRAD(2)]: } & 0.40 & \\
\text { Cask Length [HSIZE] : } & 0.01 & \mathrm{~m} \\
\text { Cask Radius [RSIZE]: } & 0.01 & \mathrm{~m} \\
\text { Amount of Uranium [UMT]*: } & 0.46 & \mathrm{MTU} \\
\text { Reactor Type [RTYPE]: } & \text { PWR } & \\
\text { Reactor Burnup [BURNUP]: } & 3.50 \mathrm{E}+04 & \mathrm{MWD} \\
\text { Fuel Cooling Time [TFUEL] : } & 10.00 & \mathrm{yr} \\
\text { race Area of Cask [CAREA] : } & 39.00 & \mathrm{~m} 2 \\
\text { Activity Density [CACTD]*: } & 4.00 & \mathrm{uCi} / \mathrm{cm} 2
\end{array}
$$

Total Surface Area of Cask [CAREA] *: crud Surface Activity Density [CACTD]*: 


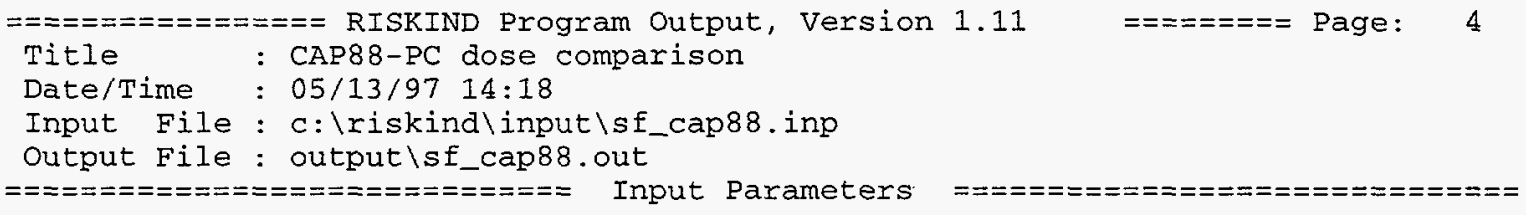

Nuclide Parameters

\begin{tabular}{|c|c|c|c|c|c|c|c|}
\hline \multirow[b]{2}{*}{$\begin{array}{l}\text { Nuclide } \\
\text { Name }\end{array}$} & \multicolumn{7}{|c|}{ Nuclide Inventory and DCFs } \\
\hline & $\begin{array}{c}\text { Inventory } \\
\text { Amount } \\
\text { [Ci] }\end{array}$ & $\begin{array}{c}\text { Inhalation } \\
{[\mathrm{Sv} / \mathrm{Bq}]}\end{array}$ & $\begin{array}{c}\text { Ingestion } \\
{[\mathrm{Sv} / \mathrm{Bq}]}\end{array}$ & $\begin{array}{l}\text { ion Fact } \\
\text { Cloud } \\
{[\mathrm{Sv} / \mathrm{s}]} \\
{[\mathrm{Bq} / \mathrm{m} 3]}\end{array}$ & $\begin{array}{c}\text { Cs }===== \\
\text { Ground } \\
{[\mathrm{Sv} / \mathrm{s}]} \\
{[\mathrm{Bq} / \mathrm{m} 2]}\end{array}$ & $\begin{array}{l}\text { Nucl. } \\
\text { Class }\end{array}$ & $\begin{array}{l}\text { Decay } \\
\text { Const. } \\
\text { [1/yr] }\end{array}$ \\
\hline $\mathrm{H} 3$ & $2.17 \mathrm{E}+02$ & $1.73 \mathrm{E}-11$ & $1.73 \mathrm{E}-11$ & $0.00 \mathrm{E}+00$ & $0.00 \mathrm{E}+00$ & Particul & $5.60 \mathrm{E}-02$ \\
\hline FE 55 & $1.07 \mathrm{E}+02$ & $7.26 \mathrm{E}-10$ & 1. $64 \mathrm{E}-10$ & $0.00 \mathrm{E}+00$ & $0.00 \mathrm{E}+00$ & Particul & $2.60 \mathrm{E}-01$ \\
\hline $\operatorname{co} 60$ & 1. $10 \mathrm{E}+03$ & $5.91 E-08$ & $7.28 \mathrm{E}-09$ & $1.26 E-13$ & $2.35 E-15$ & Particul & $1.30 \mathrm{E}-01$ \\
\hline NI 63 & $1.88 E+02$ & $1.70 E-09$ & 1. $56 \mathrm{E}-10$ & $0.00 \mathrm{E}+00$ & $0.00 E+00$ & Particul & $6.90 \mathrm{E}-03$ \\
\hline $\mathrm{KR} \quad 85$ & $2.33 E+03$ & $1.03 \mathrm{E}-11$ & $1.03 \mathrm{E}-11$ & $1.19 \mathrm{E}-16$ & $2.64 E-18$ & Gas & $6.50 \mathrm{E}-02$ \\
\hline SR 90 & $2.77 E+04$ & $3.53 E-07$ & $4.14 E-08$ & $1.97 E-16$ & $5.61 E-18$ & Particul & $2.40 E-02$ \\
\hline $\mathrm{Y} 90$ & $2.77 E+04$ & $2.28 \mathrm{E}-09$ & $2.91 \mathrm{E}-09$ & $1.90 \mathrm{E}-16$ & $5.33 E-18$ & Particul & $9.50 E+01$ \\
\hline RU106 & $2.44 \mathrm{E}+02$ & 1. $30 \mathrm{E}-07$ & $8.30 E-09$ & $1.04 \mathrm{E}-14$ & $2.12 \mathrm{E}-16$ & $\mathrm{Ru}$ & $6.90 \mathrm{E}-01$ \\
\hline RH106 & $2.44 E+02$ & $8.95 E-10$ & $8.95 E-10$ & 1. $04 E-14$ & $2.12 \mathrm{E}-16$ & $R u$ & $7.30 E+05$ \\
\hline SB125 & $6.01 E+02$ & $3.75 E-09$ & $9.85 E-10$ & $2,02 E-14$ & $4.33 E-16$ & Particul & $2.50 \mathrm{E}-01$ \\
\hline TE125M & $1.47 \mathrm{E}+02$ & $1.97 \mathrm{E}-09$ & $9.92 \mathrm{E}-10$ & $4.53 E-16$ & $3.61 E-17$ & Particul & $4.40 \mathrm{E}+00$ \\
\hline $\operatorname{CS} 134$ & $2.76 E+03$ & 1. $25 E-08$ & $1.98 E-08$ & $7.56 \mathrm{E}-14$ & $1.52 \mathrm{E}-15$ & $\mathrm{Cs}$ & $3.40 \mathrm{E}-0 \mathrm{I}$ \\
\hline $\operatorname{Cs} 137$ & $3.98 E+04$ & 1. $10 \mathrm{E}-08$ & $1.59 E-08$ & $2.73 \mathrm{E}-14$ & $5.54 \mathrm{E}-16$ & $\mathrm{Cs}$ & $2.30 E-02$ \\
\hline $\mathrm{BA} 137 \mathrm{M}$ & $3.76 \mathrm{E}+04$ & $2.49 \mathrm{E}-09$ & $2.49 \mathrm{E}-09$ & $2.88 E-14$ & $5.86 E-16$ & Particul & 1. $40 E+05$ \\
\hline $\mathrm{CE} 144$ & $6.45 E+01$ & $1.01 \mathrm{E}-07$ & $5.71 E-09$ & $2.80 \mathrm{E}-15$ & $5.83 E-17$ & Particul & $8.90 \mathrm{E}-01$ \\
\hline PR144 & $6.45 E+01$ & 1. $17 \mathrm{E}-11$ & 3. $15 \mathrm{E}-11$ & $1.94 \mathrm{E}-15$ & $3.79 E-17$ & Particul & $2.10 E+04$ \\
\hline PM147 & $4.21 E+03$ & $1.06 \mathrm{E}-08$ & $2.83 E-10$ & $6.92 \mathrm{E}-19$ & $3.40 E-20$ & Particul & $2.60 \mathrm{E}-01$ \\
\hline SM151 & $1.81 E+02$ & $8.10 \mathrm{E}-09$ & 1. $05 E-10$ & $3.61 E-20$ & $5.02 E-21$ & Particul & $7.70 \mathrm{E}-03$ \\
\hline EU154 & $2.09 E+03$ & $7.73 E-08$ & $2.58 E-09$ & $6.14 E-14$ & $1.18 \mathrm{E}-15$ & Particul & $7.90 \mathrm{E}-02$ \\
\hline EU155 & $7.69 E+02$ & $1.12 E-08$ & $4.13 E-10$ & $2.49 E-15$ & $5.90 \mathrm{E}-17$ & Particul & 1. $40 \mathrm{E}-01$ \\
\hline PU238 & 1. $42 \mathrm{E}+03$ & $1.06 \mathrm{E}-04$ & $8.65 \mathrm{E}-07$ & $4.87 E-18$ & $8.37 E-19$ & Particul & $7.90 \mathrm{E}-03$ \\
\hline PU239 & 1. $65 \mathrm{E}+02$ & $1.16 \mathrm{E}-04$ & $9.56 \mathrm{E}-07$ & $4.24 E-18$ & $3.67 \mathrm{E}-19$ & Particul & $2.90 \mathrm{E}-05$ \\
\hline PU2 40 & $2.37 E+02$ & $1.16 E-04$ & $9.56 \mathrm{E}-07$ & $4.75 E-18$ & $8.02 \mathrm{E}-19$ & Particul & 1.10E-04 \\
\hline PU241 & $3.88 E+04$ & $2.23 E-06$ & $1.85 \mathrm{E}-08$ & $2.19 E-19$ & $5.20 \mathrm{E}-21$ & Particul & $4.80 \mathrm{E}-02$ \\
\hline $\mathrm{AM} 241$ & $8.66 E+02$ & 1. $20 E-04$ & $9.84 E-07$ & $8.18 \mathrm{E}-16$ & $2.74 E-17$ & Particul & $1.60 E-03$ \\
\hline $\mathrm{CM} 244$ & $8.95 E+02$ & $6.70 \mathrm{E}-05$ & $5.45 E-07$ & $4.91 E-18$ & $8.78 E-19$ & Particul & $3.80 \mathrm{E}-02$ \\
\hline
\end{tabular}




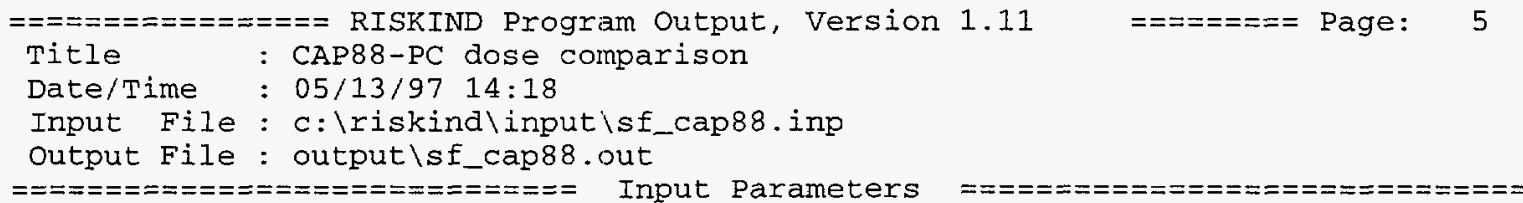

\begin{tabular}{|c|c|c|c|c|c|c|c|}
\hline \multirow{3}{*}{$\begin{array}{l}\text { Nuclide } \\
\text { Name }\end{array}$} & \multicolumn{7}{|c|}{ Nuclide Health Effects Parameters } \\
\hline & \multirow[t]{2}{*}{ Solubility } & \multicolumn{6}{|c|}{ 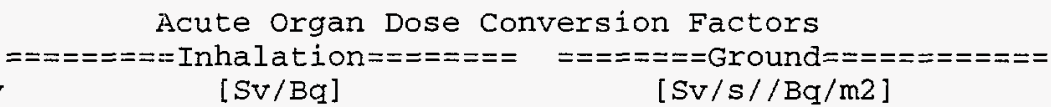 } \\
\hline & & Marrow & Lung & Intestine & Marrow & Lung & Intestine \\
\hline $\mathrm{H}$ & $\mathrm{D}$ & $1.62 \mathrm{E}-11$ & $1.62 \mathrm{E}-11$ & $1.62 \mathrm{E}-11$ & $0.00 \mathrm{E}+00$ & $0.00 E+00$ & $0.00 \mathrm{E}+00$ \\
\hline FE 55 & $W$ & 1. $65 E-10$ & $1.76 \mathrm{E}-10$ & $1.92 E-10$ & $0.00 E+00$ & $0.00 E+00$ & $1.89 \mathrm{E}-19$ \\
\hline co 60 & $Y$ & $6.22 \mathrm{E}-09$ & $1.24 \mathrm{E}-07$ & $5.95 E-09$ & $2.34 E-15$ & $2.27 \Xi-15$ & $1.94 \mathrm{E}-15$ \\
\hline NI 63 & $\mathrm{Y}$ & $1.05 \mathrm{E}-12$ & $5.95 E-12$ & $4.59 E-13$ & $0.00 E+00$ & $0.00 \mathrm{E}+00$ & $0.00 \mathrm{E}+00$ \\
\hline $\mathrm{KR} \quad 85$ & $\mathrm{D}$ & $0.00 \mathrm{E}+00$ & $0.00 E+00$ & $0.00 E+00$ & $2.43 E-18$ & $2.45 E-18$ & $1.97 \mathrm{E}-18$ \\
\hline SR 90 & $Y$ & $1.08 E-09$ & $7.03 E-07$ & $1.70 E-08$ & $4.77 E-18$ & $4.98 E-18$ & $0.00 \mathrm{E}+00$ \\
\hline Y 90 & $\mathrm{Y}$ & $1.51 E-11$ & $9.19 E-09$ & 1. $27 \mathrm{E}-08$ & $4.57 E-18$ & $4.76 E-18$ & $0.00 E+00$ \\
\hline RU106 & $\mathrm{Y}$ & $1.05 \mathrm{E}-09$ & $6.76 \mathrm{E}-07$ & $3.51 E-08$ & $2.06 \mathrm{E}-16$ & $2.03 E-16$ & 1. $80 \mathrm{E}-16$ \\
\hline RH106 & $\mathrm{Y}$ & $2.58 \mathrm{E}-10$ & $2.58 \mathrm{E}-10$ & $1.14 \mathrm{E}-09$ & $2.06 E-16$ & $2.03 E-16$ & $1.80 \mathrm{E}-16$ \\
\hline SB125 & $W$ & $2.41 \mathrm{E}-14$ & $7.30 \mathrm{E}-11$ & $3.24 \mathrm{E}-12$ & $4.05 E-16$ & $4.03 E-16$ & $3.79 E-16$ \\
\hline TE125M & W & $5.14 E-14$ & $1.05 E-11$ & $2.38 \mathrm{E}-12$ & $1.37 E-17$ & $1.77 E-17$ & $1.78 \mathrm{E}-17$ \\
\hline $\operatorname{CS} 134$ & $D$ & $1.08 E-08$ & $1.08 E-08$ & $1.27 E-08$ & $1.48 E-15$ & $1.46 \mathrm{E}-15$ & $1.34 \mathrm{E}-15$ \\
\hline $\operatorname{CS} 137$ & $\mathrm{D}$ & $7.57 E-09$ & $8.11 E-09$ & $8.11 \mathrm{E}-09$ & $5.39 E-16$ & $5.30 E-16$ & $4.93 E-16$ \\
\hline BAI 37M & D & $2.73 E-11$ & $2.73 E-11$ & $0.00 E+00$ & $5.70 E-16$ & $5.60 E-16$ & $5.22 E-16$ \\
\hline CE144 & $\mathrm{Y}$ & $1.08 E-09$ & $5.68 E-07$ & $3.24 E-08$ & $5.31 E-17$ & $5.43 E-17$ & $1.83 \mathrm{E}-17$ \\
\hline PR144 & $\mathrm{Y}$ & $1.92 \mathrm{E}-14$ & $9.46 \mathrm{E}-11$ & $2.16 \mathrm{E}-14$ & $3.66 \mathrm{E}-17$ & $3.61 \mathrm{E}-17$ & $2.54 \mathrm{E}-17$ \\
\hline PM1 47 & $Y$ & 1. $41 \mathrm{E}-10$ & $3.51 E-08$ & $1.62 \mathrm{E}-09$ & $1.86 \mathrm{E}-20$ & $2.20 \mathrm{E}-20$ & $3.48 E-21$ \\
\hline SM151 & $\mathrm{Y}$ & $3.78 E-12$ & $1.19 \mathrm{E}-11$ & $8.65 \mathrm{E}-13$ & $1.39 \mathrm{E}-21$ & $1.01 \mathrm{E}-21$ & $4.45 E-21$ \\
\hline EU154 & $\mathrm{Y}$ & $2.46 \mathrm{E}-11$ & $1.57 \mathrm{E}-10$ & $9.19 \mathrm{E}-12$ & $1.16 \mathrm{E}-15$ & $1.14 \mathrm{E}-15$ & $1.03 \mathrm{E}-15$ \\
\hline EU155 & $Y$ & $3.78 E-12$ & $2.54 E-11$ & 1. $59 \mathrm{E}-12$ & $4.71 E-17$ & $5.34 E-17$ & $6.05 E-17$ \\
\hline PU238 & $\mathrm{Y}$ & $2.97 \mathrm{E}-07$ & $7.03 E-05$ & $2.97 E-08$ & $1.94 E-19$ & $7.87 \mathrm{E}-20$ & $7.35 \mathrm{E}-19$ \\
\hline PU239 & $Y$ & $2.70 E-07$ & $6.76 E-05$ & $2.70 E-08$ & $1.19 \mathrm{E}-19$ & $7.87 E-20$ & $3.24 E-19$ \\
\hline PU240 & $\mathrm{Y}$ & $2.70 E-07$ & $6.76 \mathrm{E}-05$ & $2.70 \mathrm{E}-08$ & $1.88 \mathrm{E}-19$ & $7.81 \mathrm{E}-20$ & $7.02 \mathrm{E}-19$ \\
\hline PU2 41 & $Y$ & $2.97 \mathrm{E}-10$ & $5.68 E-08$ & $1.41 E-10$ & $4.18 E-21$ & $4.36 \mathrm{E}-21$ & $0.00 E+00$ \\
\hline AM2 41 & W & $4.32 E-06$ & $1.81 E-05$ & $2.97 E-08$ & $1.68 \mathrm{E}-17$ & $2.00 \mathrm{E}-17$ & $2.52 \mathrm{E}-17$ \\
\hline CM2 44 & $W$ & $4.59 E-06$ & $1.92 \mathrm{E}-05$ & $3.24 \mathrm{E}-08$ & $2.04 \mathrm{E}-19$ & $9.00 \mathrm{E}-20$ & 7. $10 E-19$ \\
\hline
\end{tabular}




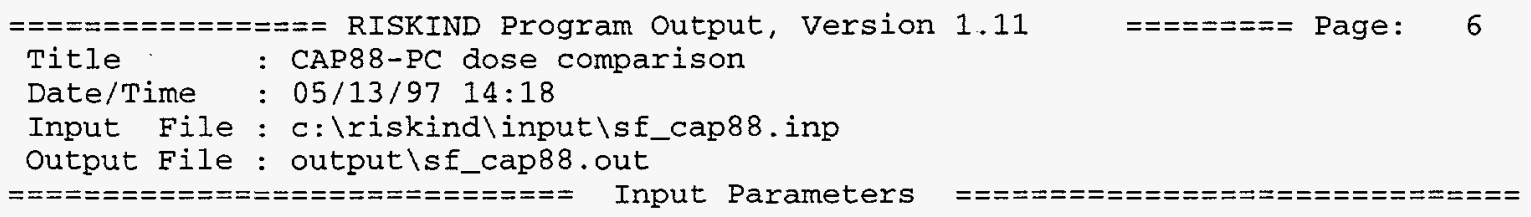

Nuclice Health Effects Parameters

Acute Organ Dose Conversion Factors

$=======$ Cloudshine $=======$

Name

$[\mathrm{Sv} / \mathrm{s} / / \mathrm{Bq} / \mathrm{m} 3]$

Marrow Lung Intestine

$\mathrm{H} 3 \quad 0.00 \mathrm{E}+00 \quad 0.00 \mathrm{E}+00 \quad 0.00 \mathrm{E}+00$

FE 55

$0.00 \mathrm{E}+00 \quad 0.00 \mathrm{E}+00 \quad 9.85 \mathrm{E}-19$

CO 60

NI 63

KR 85

SR 90

Y 90

RU106

RH106

$1.23 \mathrm{E}-13 \quad 1.24 \mathrm{E}-13 \quad 1.11 \mathrm{E}-13$

$0.00 \mathrm{E}+00 \quad 0.00 \mathrm{E}+00 \quad 0.00 \mathrm{E}+00$

$1.09 \mathrm{E}-16 \quad 1.14 \mathrm{E}-16 \quad 9.59 \mathrm{E}-17$

$1.68 \mathrm{E}-16 \quad 1.84 \mathrm{E}-16 \quad 0.00 \mathrm{E}+00$

$1.62 \mathrm{E}-16 \quad 1.77 \mathrm{E}-16 \quad 0.00 \mathrm{E}+00$

$9.76 \mathrm{E}-15 \quad 1.01 \mathrm{E}-14 \quad 8.99 \mathrm{E}-15$

$9.76 \mathrm{E}-15 \quad 1.01 \mathrm{E}-14 \quad 8.99 \mathrm{E}-15$

$1.88 \mathrm{E}-14 \quad 1.95 \mathrm{E}-14 \quad 1.82 \mathrm{E}-14$

$1.86 \mathrm{E}-16 \quad 2.23 \mathrm{E}-16 \quad 4.10 \mathrm{E}-16$

TE125M

CS134

CS137

$7.19 \mathrm{E}-14 \quad 7.37 \mathrm{E}-14 \quad 6.84 \mathrm{E}-14$

$2.59 \mathrm{E}-142.65 \mathrm{E}-142.48 \mathrm{E}-14$

$2.73 E-142.80 E-1422.61 E-14$

$2.55 \mathrm{E}-15 \quad 2.68 \mathrm{E}-15 \quad 7.73 \mathrm{E}-16$

$1.88 \mathrm{E}-15 \quad 1.91 \mathrm{E}-15 \quad 1.52 \mathrm{E}-15$

PR144

$4.46 \mathrm{E}-19 \quad 5.45 \mathrm{E}-19 \quad 1.55 \mathrm{E}-19$

1.13E-20 7.13E-21 3.91E-20

SM151

$5.87 \mathrm{E}-14 \quad 5.99 \mathrm{E}-14 \quad 5.54 \mathrm{E}-14$

$\begin{array}{lll}1.85 \mathrm{E}-15 & 2.22 \mathrm{E}-15 & 2.42 \mathrm{E}-15\end{array}$

EU155

PU238

$1.68 \mathrm{E}-18 \quad 1.06 \mathrm{E}-18 \quad 3.77 \mathrm{E}-18$

$2.67 E-18 \quad 2.65 E-18 \quad 3.50 E-18$

PU239

PU2 40

1. $66 \mathrm{E}-18 \quad 1.09 \mathrm{E}-18 \quad 3.69 \mathrm{E}-18$

$1.75 E-191.99 E-19 \quad 0.00 E+00$

AM2 41

5. $21 \mathrm{E}-16 \quad 6.74 \mathrm{E}-16 \quad 8.00 \mathrm{E}-16$

CM2 44

$1.46 \mathrm{E}-18 \quad 7.07 \mathrm{E}-19 \quad 3.57 \mathrm{E}-18$ 


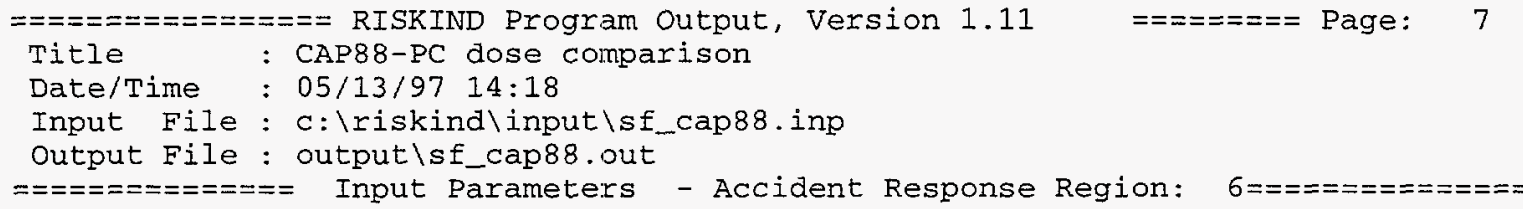

Accident Parameters

Physical Release Height [HS]: 20.00

m

Dispersion Model Coefficients [IDISPMOD]: Briggs

Accident Analysis Type: Consequence

Accident Response Region Parameters

Response Region [IYOURS] : 6

Region Conditional Probability [FSEV]: 2.33E-07

Heat Flux [HEATF]: $0.00 \mathrm{E}+00 \mathrm{cal} / \mathrm{s}$

Loss of Cask Shielding Factor [SEXT]

$\begin{aligned} \text { Gamma: } & 1.00 \\ \text { Neutron: } & 1.00\end{aligned}$

Failure Rate [FAILS]: 1.00E-01

Crud Spallation Rate [FSPAL]: 1.00E+00

Crud Release Rate [FRCRUD]: 1.00E+00

\begin{tabular}{lccc}
\hline $\begin{array}{c}\text { Nuclide } \\
\text { Class } \\
\text { [NUTYPE] }\end{array}$ & $\begin{array}{c}\text { Conditional } \\
\text { Release } \\
\text { Fraction } \\
\text { [FRELS] }\end{array}$ & $\begin{array}{c}\text { Dispersion } \\
\text { Fraction } \\
\text { [FDISP] }\end{array}$ & $\begin{array}{c}\text { Released and Dispersed } \\
\text { Fraction } \\
\text { (FRELS*FAILS*FDISP) }\end{array}$ \\
\hline Particulate & $2.00 E-06$ & $1.00 \mathrm{E}+00$ & $2.00 \mathrm{E}-07$ \\
Ru & $2.70 \mathrm{E}-05$ & $1.00 \mathrm{E}+00$ & $2.70 \mathrm{E}-06$ \\
CS & $2.00 \mathrm{E}-04$ & $1.00 \mathrm{E}+00$ & $2.00 \mathrm{E}-05$ \\
I & $2.50 \mathrm{E}-03$ & $1.00 \mathrm{E}+00$ & $2.50 \mathrm{E}-04$ \\
Gas & $3.30 \mathrm{E}-01$ & $1.00 \mathrm{E}+00$ & $3.30 \mathrm{E}-02$ \\
\hline
\end{tabular}




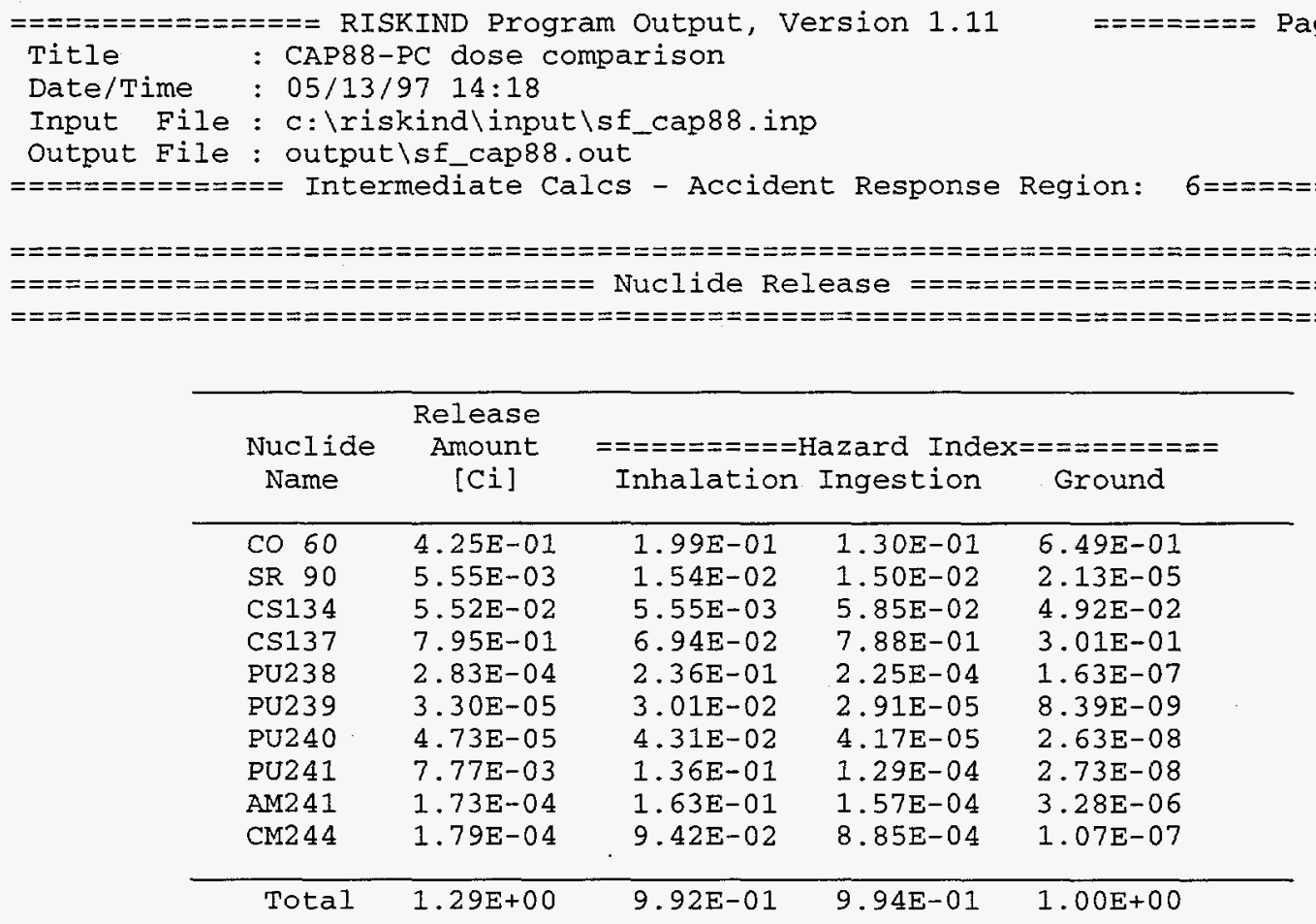

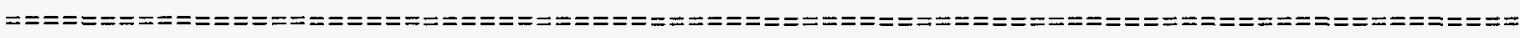

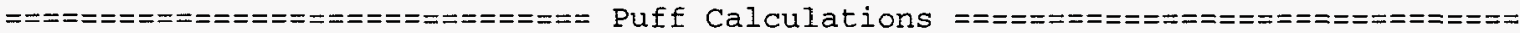

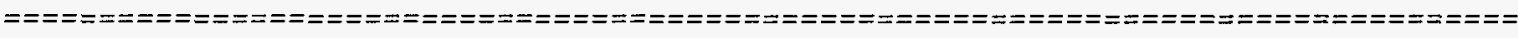

\begin{tabular}{|c|c|c|c|}
\hline $\begin{array}{l}\text { Individual } \\
\text { Name }\end{array}$ & $\begin{array}{c}======\text { Plume Para } \\
\text { Effective Release } \\
\text { Height } \\
{[\mathrm{m}]}\end{array}$ & $\begin{array}{c}\text { meters }==== \\
\text { Dispersi } \\
\text { (Horizontal) } \\
{[\mathrm{m}]}\end{array}$ & $\begin{array}{l}=== \\
\text { on Sigma } \\
\text { (Vertica1) } \\
{[\mathrm{m}]}\end{array}$ \\
\hline Individual 1 & $2.00 \mathrm{E}+01$ & $1.19 \mathrm{E}+01$ & $8.16 E+00$ \\
\hline $\begin{array}{l}\text { Individual } \\
\text { Name }\end{array}$ & $\begin{array}{cc}====\mathrm{Chi} / \mathrm{Q} & ====== \\
\operatorname{Air} & \text { Ground } \\
{[\mathrm{s} / \mathrm{m} 3]} & {[1 / \mathrm{m} 2]}\end{array}$ & $\begin{array}{c}\text { Depletion } \\
\text { Fraction }\end{array}$ & $\begin{array}{c}\text { Wet/Dry } \\
\text { Ratio }\end{array}$ \\
\hline $\begin{array}{l}\text { dividual } 1 \\
\text { Particulates } \\
\text { Ruthenium } \\
\text { Cesium } \\
\text { Iodine } \\
\text { Gases }\end{array}$ & $\begin{array}{l}3.70 E-05 \\
3.70 E-05 \\
3.70 E-05 \\
3.70 E-05 \\
3.70 E-05\end{array}$ & $\begin{array}{l}2.36 \mathrm{E}-04 \\
2.36 \mathrm{E}-04 \\
2.36 \mathrm{E}-04 \\
2.36 \mathrm{E}-04 \\
0.00 \mathrm{E}+00\end{array}$ & $\begin{array}{l}0.00 E+00 \\
0.00 E+00 \\
0.00 E+00 \\
0.00 E+00 \\
0.00 E+00\end{array}$ \\
\hline
\end{tabular}




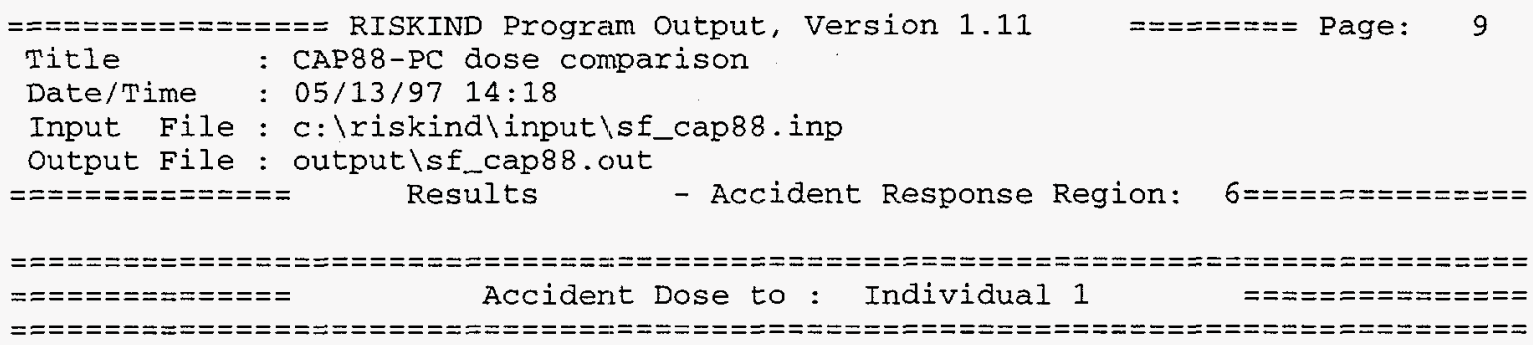

\section{Individual Summary Results Per Accident}

$\begin{array}{lll}\text { Committed Effective Dose Equivalent } & 4.42 \mathrm{E}-03 & \text { rem } \\ \text { Expected Genetic Effects } & 5.74 \mathrm{E}-07 \\ \text { Expected Non-fatal Cancers } & 4.42 \mathrm{E}-07 \\ \text { Expected Cancer Fatalities } & 2.21 \mathrm{E}-06 \\ \text { Acute Risk (Expected fatalities) } & 0.00 \mathrm{E}+00\end{array}$

\begin{tabular}{|c|c|c|c|c|}
\hline Pathway & & Doses (rem) & & \\
\hline Acute & $4.42 E-03$ & & & \\
\hline Cask & & $1.95 E-07$ & & \\
\hline Ground Shine & & $1.50 E-05$ & & \\
\hline Inhalation & & $4.39 E-03$ & & \\
\hline Cloud Shine & & $1.09 \mathrm{E}-05$ & & \\
\hline Long-Term & $0.00 E+00$ & & & \\
\hline Ground Shine & & $0.00 E+00$ & & \\
\hline Inhalation & & $0.00 E+00$ & & \\
\hline Cloud shine & & $0.00 \mathrm{E}+00$ & & \\
\hline Ingestion & & $0.00 E+00$ & & \\
\hline Initial Year & & & $0.00 E+00$ & \\
\hline Vegetable & & & & $0.00 E+00$ \\
\hline Meat & & & & $0.00 E+00$ \\
\hline Milk & & & & $0.00 E+00$ \\
\hline Long-Term & & & $0.00 E+00$ & \\
\hline Vegetable & & & & $0.00 E+00$ \\
\hline Meat & & & & $0.00 E+00$ \\
\hline Milk & & & & $0.00 E+00$ \\
\hline Water & & & & $0.00 E+00$ \\
\hline
\end{tabular}

\begin{tabular}{lcccc}
\hline Exposure Parameter & Organ $\begin{array}{c}\text { Exposure } \\
\text { Marrow }\end{array}$ & Lung & Intestine & Gonads \\
\hline Long-Term Dose [rem] & $5.13 \mathrm{E}-03$ & $6.49 \mathrm{E}-03$ & $4.20 \mathrm{E}-04$ & $6.65 \mathrm{E}-04$ \\
Brief Dose [Gy] & $2.91 \mathrm{E}-07$ & $2.82 \mathrm{E}-06$ & $3.48 \mathrm{E}-06$ & \\
Brief Exposure Time [d] & $1.00 \mathrm{E}+00$ & $1.00 \mathrm{E}+00$ & $1.00 \mathrm{E}+00$ \\
Brief Dose Rate [Gy/hr] & $1.29 \mathrm{E}-07$ & $2.73 \mathrm{E}-07$ & $2.48 \mathrm{E}-07$ \\
Prolonged Dose [Gy] & $8.25 \mathrm{E}-07$ & $2.29 \mathrm{E}-05$ & $3.41 \mathrm{E}-06$ \\
Prolong Exposure Time [d] & $3.00 \mathrm{E}+01$ & $3.65 \mathrm{E}+02$ & $7.00 \mathrm{E}+00$ \\
Prolong Dose Rate [Gy/hr] & $1.14 \mathrm{E}-09$ & $1.44 \mathrm{E}-07$ & $1.31 \mathrm{E}-07$ \\
Hazard Risk [Expected fatalities] & $0.00 \mathrm{E}+00$ & $0.00 \mathrm{E}+00$ & $0.00 \mathrm{E}+00$ \\
Acute Risk+00 & $0.00 \mathrm{E}+00$ & $0.00 \mathrm{E}+00$ \\
\hline
\end{tabular}




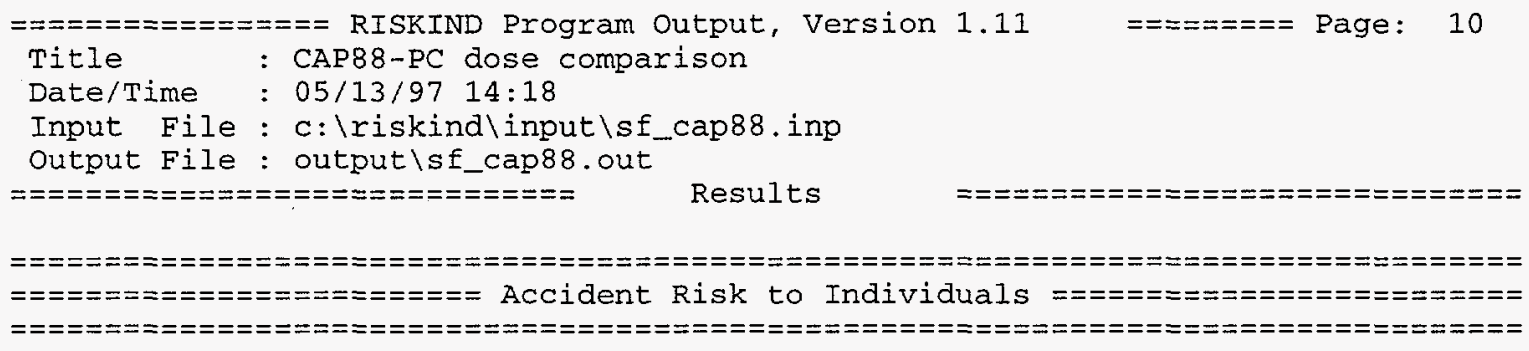

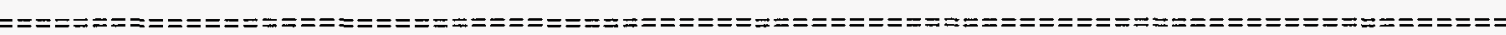

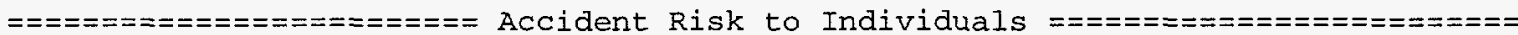

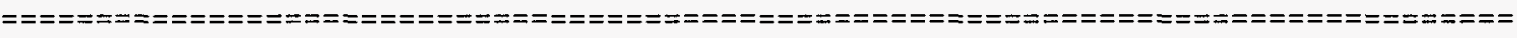

Individual Accident Dose Summary Results Consequences

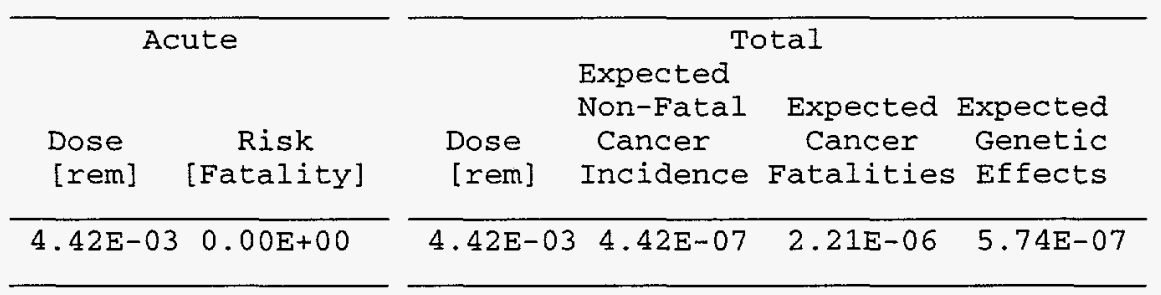




\title{
B.2.2.2 CAP88-PC Output for Spent Fuel Accident
}

\author{
C A P $88-\mathrm{P} C$ \\ Version 1.00 \\ Clean Air Act Assessment Package - 1988 \\ $S Y N O P S I S T E P O R T$ \\ Non-Radon Individual Assessment \\ May 13, 1997 2:07 pm \\ Facility: \\ Address: \\ City: \\ state: \\ WA \\ Zip: \\ Effective Dose Equivalent \\ (mrem/year) \\ $7.61 \mathrm{E}+01$ \\ At This Location: \\ Source Category: \\ Source Type: \\ Emission Year: \\ 300 Meters south \\ Stack \\ Comments : \\ Dataset Name: \\ Dataset Date: May 12, 1997 9:46 am \\ Wind File: WNDEILES $\backslash$ D FRMN. WND
}


May 13, $19972: 07 \mathrm{pm}$

SYNOPSIS

Page 1

MAXIMALLY EXPOSED INDIVIDUAL

Location of The Individual: 300 Meters South

Lifetime Fatal Cancer Risk: 1.82E-03

ORGAN DOSE EQUIVALENT SUMMARY

Dose

Equivalent

Organ

(mrem/y)

$\begin{array}{ll}\text { GONADS } & 8.20 \mathrm{E}+01 \\ \text { BREAST } & 7.63 \mathrm{E}+01 \\ \text { R MAR } & 7.00 \mathrm{E}+01 \\ \text { LUNGS } & 7.45 \mathrm{E}+01 \\ \text { THYROID } & 7.99 \mathrm{E}+01 \\ \text { ENDOST } & 1.13 \mathrm{E}+02 \\ \text { RMNDR } & 7.01 \mathrm{E}+01 \\ \text { EFFEC } & 7.61 \mathrm{E}+01\end{array}$




\section{B-106}

May 13, $1997 \quad 2: 07 \mathrm{pm}$

SYNOPSIS

Page 2

RADIONUCLIDE EMISSIONS DURING THE YEAR

\begin{tabular}{|c|c|c|c|c|}
\hline Nuclide & Class & Size & $\begin{array}{c}\text { Source } \\
\# 1 \\
\mathrm{Ci} / \mathrm{y}\end{array}$ & $\begin{array}{l}\text { TOTAL } \\
\mathrm{Ci} / \mathrm{Y}\end{array}$ \\
\hline $\mathrm{CO}-60$ & $Y$ & 1.00 & $4.3 E-01$ & $4.3 \mathrm{E}-01$ \\
\hline SR-90 & $\mathrm{D}$ & 1.00 & $5.5 \mathrm{E}-03$ & $5.5 \mathrm{E}-03$ \\
\hline CS -134 & D & 1.00 & $5.5 \mathrm{E}-02$ & $5.5 \mathrm{E}-02$ \\
\hline CS -137 & $D$ & 1.00 & 8.0E-01 & 8. $0 E-01$ \\
\hline$B A-137 M$ & D & 1.00 & 8.0E-01 & $8.0 E-01$ \\
\hline PU- 238 & $Y$ & 1.00 & $2.8 E-04$ & $2.8 E-04$ \\
\hline PU-239 & $Y$ & 1.00 & $3.3 E-05$ & $3.3 E-05$ \\
\hline$P U-240$ & $Y$ & 1.00 & $4.7 E-05$ & $4.7 \mathrm{E}-05$ \\
\hline PU-241 & $Y$ & 1.00 & $7.8 \mathrm{E}-03$ & $7.8 \mathrm{E}-03$ \\
\hline AM-241 & $W$ & 1.00 & $1.7 \mathrm{E}-04$ & $1.7 \mathrm{E}-04$ \\
\hline$C M-244$ & $W$ & 1.00 & $1.8 \mathrm{E}-04$ & $1.8 \mathrm{E}-04$ \\
\hline
\end{tabular}

SITE INFORMATION

$\begin{array}{rrl}\text { Temperature: } & 15 \text { degrees C } \\ \text { Precipitation: } & 0 \mathrm{~cm} / \mathrm{y} \\ \text { Mixing Height: } & 1000 \mathrm{~m}\end{array}$


SOURCE INFORMATION

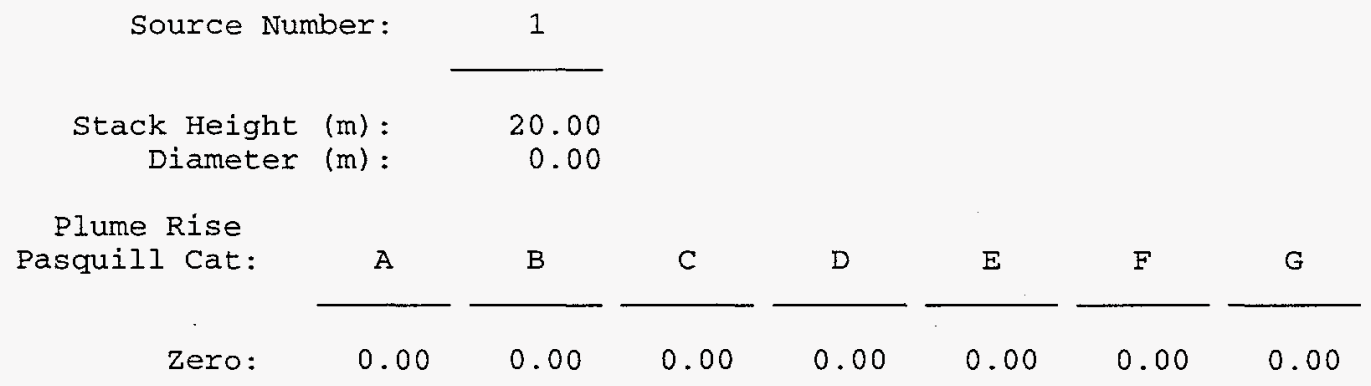

AGRICULTURAL DATA

$\begin{array}{crrrr} & \text { Vegetable } & \text { Milk } & \text { Meat } \\ \text { Fraction Home Produced: } & 1.000 & 1.000 & 1.000 \\ \text { Fraction From Assessment Area: } & 0.000 & 0.000 & 0.000 \\ \text { Fraction Imported: } & 0.000 & 0.000 & 0.000 \\ \text { Food Arrays were not generated for this run. } \\ \text { Default Values used. }\end{array}$

DISTANCES USED FOR MAXIMUM INDIVIDUAL ASSESSMENT

$\begin{array}{rrrrrrrrrr}100 & 200 & 300 & 400 & 500 & 600 & 700 & 800 & 900 & 1000 \\ 2500 & 5000 & 10000 & 20000 & 30000 & 40000 & 50000 & 60000 & 70000 & 80000\end{array}$


C A P $88-\mathrm{P}$ C

Version 1.00

Clean Air Act Assessment Package - 1988

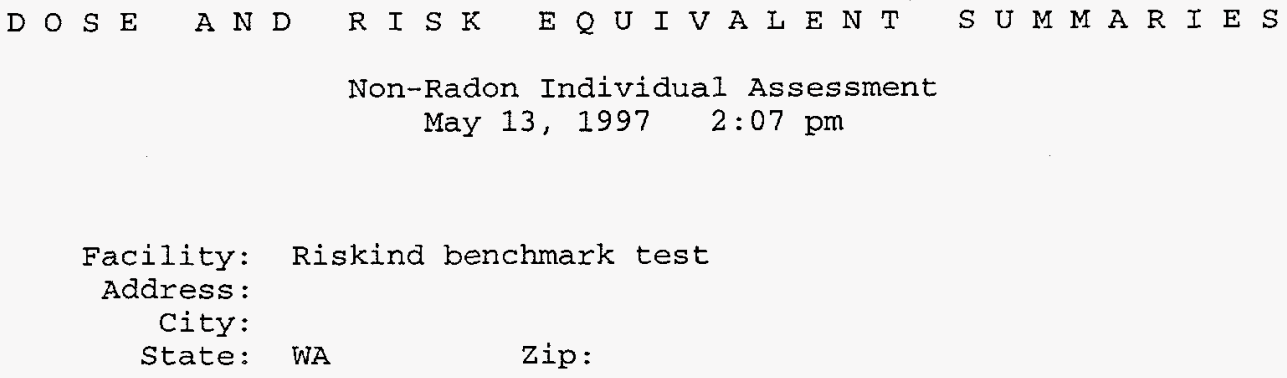


May 13, $19972: 07 \mathrm{pm}$

ORGAN DOSE EQUIVALENT SUMMARY

Selected

Individual

Organ

(mrem/y)

$\begin{array}{ll}\text { GONADS } & 8.20 \mathrm{E}+01 \\ \text { BREAST } & 7.63 \mathrm{E}+01 \\ \text { R MAR } & 7.00 \mathrm{E}+01 \\ \text { LUNGS } & 7.45 \mathrm{E}+01 \\ \text { THYROID } & 7.99 \mathrm{E}+01 \\ \text { ENDOST } & 1.13 \mathrm{E}+02 \\ \text { RMNDR } & 7.01 \mathrm{E}+01 \\ \text { EFFEC } & 7.61 \mathrm{E}+01\end{array}$

PATHWAY EFFECTIVE DOSE EQUIVALENT SUMMARY

Pathway

INGESTION

INHALATION

AIR IMMERSION

GROUND SURFACE

INTERNAL

EXTERNAL

TOTAL
Selected

Individual

(mrem/y)
1. $41 E+01$
3. $99 E+00$
$9.02 \mathrm{E}-03$
$5.80 E+01$
$1.81 \mathrm{E}+01$
$5.80 E+01$
$7.61 \mathrm{E}+01$ 
May 13, $19972: 07 \mathrm{pm}$

NUCLIDE EFFECTIVE DOSE EQUIVALENT SUMMARY

Nuclide

SR-90

CS- 134

CS -137

$\mathrm{BA}-137 \mathrm{M}$

PU-238

PU-239

PU-240

PU-241

AM-2 41

CM-244

TOTAL
Selected

Individual

(mrem/y)

2. $42 E+01$

$2.14 \mathrm{E}-01$

1. $72 \mathrm{E}+00$

$1.08 \mathrm{E}+01$

3. $60 \mathrm{E}+01$

9. $23 E-01$

1. $16 \mathrm{E}-01$

1. $66 \mathrm{E}-01$

4. 28E-01

9. $39 \mathrm{E}-01$

5. 13E-01

$7.61 \mathrm{E}+01$ 
CANCER RISK SUMMARY

\begin{tabular}{lc} 
Cancer & $\begin{array}{c}\text { Selected Individual } \\
\text { Total Lifetime } \\
\text { Fatal Cancer Risk }\end{array}$ \\
\cline { 2 - 2 } LEUKEMIA & $2.13 \mathrm{E}-04$ \\
BONE & $1.40 \mathrm{E}-05$ \\
THYROID & $3.63 \mathrm{E}-05$ \\
BREAST & $2.98 \mathrm{E}-04$ \\
LUNG & $3.58 \mathrm{E}-04$ \\
STOMACH & $1.92 \mathrm{E}-04$ \\
BOWEL & $9.43 \mathrm{E}-05$ \\
LIVER & $2.33 \mathrm{E}-04$ \\
PANCREAS & $1.35 \mathrm{E}-04$ \\
URINARY & $8.28 \mathrm{E}-05$ \\
OTHER & $1.65 \mathrm{E}-04$ \\
TOTAL & $1.82 \mathrm{E}-03$
\end{tabular}

PATHWAY RISK SUMMARY

Pathway

INGESTION

INHALATION

AIR IMMERSION

GROUND SURFACE

INTERNAL

EXTERNAL

TOTAL
Selected Individual Total Lifetime Fatal Cancer Risk
$3.65 E-04$
$6.36 \mathrm{E}-05$
$2.17 \mathrm{E}-07$
1. $39 E-03$
$4.29 \mathrm{E}-04$
1. $39 \mathrm{E}-03$
$1.82 \mathrm{E}-03$ 


\section{NUCLIDE RISK SUMMARY}

Nuclide

$\mathrm{CO}-60$

$\mathrm{SR}-90$

CS -134

CS -137

$\mathrm{BA}-137 \mathrm{M}$

PU -238

PU-239

PU-240

$\mathrm{PU}-241$

AM-241

CM-244

TOTAL
Selected Individual

Total Lifetime

Fatal Cancer Risk

$6.09 E-04$

3. $60 \mathrm{E}-06$

4. $36 \mathrm{E}-05$

$2.83 \mathrm{E}-04$

$8.63 \mathrm{E}-04$

7. $85 \mathrm{E}-06$

9. $08 \mathrm{E}-07$

1. $30 \mathrm{E}-06$

1. $63 \mathrm{E}-06$

4. $79 E-06$

$3.31 \mathrm{E}-06$

1. $82 \mathrm{E}-03$ 
INDIVIDUAL EFFECTIVE DOSE EQUIVALENT RATE (mrem/y) (All Radionuclides and Pathways)

\begin{tabular}{|c|c|c|c|c|c|c|c|}
\hline \multirow[b]{2}{*}{ Direction } & \multicolumn{6}{|c|}{ Distance (m) } & \multirow[b]{2}{*}{700} \\
\hline & 100 & 200 & 300 & 400 & 500 & 600 & \\
\hline $\mathrm{N}$ & $0.0 E+00$ & $0.0 \mathrm{E}+00$ & $0.0 E+00$ & $0.0 \mathrm{E}+00$ & $0.0 \mathrm{E}+00$ & $0.0 E+00$ & $0.0 E+00$ \\
\hline NNW & $0.0 E+00$ & $0.0 E+00$ & $0.0 E+00$ & $0.0 E+00$ & $0.0 E+00$ & $0.0 E+00$ & $0.0 E+00$ \\
\hline NW & $0.0 E+00$ & $0.0 \mathrm{E}+00$ & $0.0 E+00$ & $0.0 E+00$ & $0.0 \mathrm{E}+00$ & $0.0 E+00$ & $0.0 E+00$ \\
\hline WNW & $0.0 E+00$ & $0.0 \mathrm{E}+00$ & $0.0 E+00$ & $0.0 E+00$ & $0.0 \mathrm{E}+00$ & $0.0 E+00$ & $0.0 E+00$ \\
\hline$W$ & $0.0 E+00$ & $0.0 \mathrm{E}+00$ & $0.0 E+00$ & $0.0 \mathrm{E}+00$ & $0.0 \mathrm{E}+00$ & $0.0 E+00$ & $0.0 E+00$ \\
\hline WSW & $0.0 E+00$ & $0.0 \mathrm{E}+00$ & $0.0 E+00$ & $0.0 E+00$ & $0.0 E+00$ & $0.0 \mathrm{E}+00$ & $0.0 E+00$ \\
\hline SW & $0.0 \mathrm{E}+00$ & $0.0 \mathrm{E}+00$ & $0.0 E+00$ & $0.0 E+00$ & $0.0 E+00$ & $0.0 \mathrm{E}+00$ & $0.0 E+00$ \\
\hline SSW & $0.0 \mathrm{E}+00$ & $0.0 \mathrm{E}+00$ & $0.0 E+00$ & $0.0 E+00$ & $0.0 E+00$ & $0.0 \mathrm{E}+00$ & $0.0 E+00$ \\
\hline$S$ & $2.2 \mathrm{E}+00$ & $5.6 E+01$ & $7.6 \mathrm{E}+01$ & $6.9 \mathrm{E}+01$ & $5.7 E+01$ & $4.7 \mathrm{E}+01$ & $3.8 E+01$ \\
\hline SSE & $0.0 \mathrm{E}+00$ & $0.0 \mathrm{E}+00$ & $0.0 E+00$ & $0.0 \mathrm{E}+00$ & $0.0 E+00$ & $0.0 \mathrm{E}+00$ & $0.0 \mathrm{E}+00$ \\
\hline$S E$ & $0.0 \mathrm{E}+00$ & $0.0 E+00$ & $0.0 E+00$ & $0.0 E+00$ & $0.0 E+00$ & $0.0 \mathrm{E}+00$ & $0.0 \mathrm{E}+00$ \\
\hline ESE & $0.0 E+00$ & $0.0 \mathrm{E}+00$ & $0.0 E+00$ & $0.0 \mathrm{E}+00$ & $0.0 E+00$ & $0.0 E+00$ & $0.0 E+00$ \\
\hline$E$ & $0.0 E+00$ & $0.0 \mathrm{E}+00$ & $0.0 E+00$ & $0.0 E+00$ & $0.0 E+00$ & $0.0 E+00$ & $0.0 E+00$ \\
\hline ENE & $0.0 E+00$ & $0.0 E+00$ & $0.0 E+00$ & $0.0 \mathrm{E}+00$ & $0.0 \mathrm{E}+00$ & $0.0 E+00$ & $0.0 E+00$ \\
\hline $\mathrm{NE}$ & $0.0 E+00$ & $0.0 E+00$ & $0.0 E+00$ & $0.0 \mathrm{E}+00$ & $0.0 E+00$ & $0.0 E+00$ & $0.0 E+00$ \\
\hline NNE & $0.0 E+00$ & $0.0 E+00$ & $0.0 E+00$ & $0.0 E+00$ & $0.0 E+00$ & $0.0 E+00$ & $0.0 E+00$ \\
\hline
\end{tabular}

Distance $(\mathrm{m})$

\begin{tabular}{|c|c|c|c|c|c|c|c|}
\hline Direction & 800 & 900 & 1000 & 2500 & 5000 & 10000 & 20000 \\
\hline $\mathrm{N}$ & $0.0 E+00$ & $0.0 E+00$ & $0.0 E+00$ & $0.0 E+00$ & $0.0 E+00$ & $0.0 E+00$ & $0.0 E+00$ \\
\hline NNW & $0.0 \mathrm{E}+00$ & $0.0 E+00$ & $0.0 \mathrm{E}+00$ & $0.0 E+00$ & $0.0 E+00$ & $0.0 E+00$ & $0.0 E+00$ \\
\hline NW & $0.0 \mathrm{E}+00$ & $0.0 E+00$ & $0.0 \mathrm{E}+00$ & $0.0 E+00$ & $0.0 \mathrm{E}+00$ & $0.0 E+00$ & $0.0 E+00$ \\
\hline WNW & $0.0 E+00$ & $0.0 \mathrm{E}+00$ & $0.0 \mathrm{E}+00$ & $0.0 \mathrm{E}+00$ & $0.0 E+00$ & $0.0 E+00$ & $0.0 E+00$ \\
\hline$W$ & $0.0 E+00$ & $0.0 \mathrm{E}+00$ & $0.0 \mathrm{E}+00$ & $0.0 \mathrm{E}+00$ & $0.0 \mathrm{E}+00$ & $0.0 E+00$ & $0.0 E+00$ \\
\hline WSW & $0.0 E+00$ & $0.0 \mathrm{E}+00$ & $0.0 \mathrm{E}+00$ & $0.0 \mathrm{E}+00$ & $0.0 \mathrm{E}+00$ & $0.0 E+00$ & $0.0 E+00$ \\
\hline SW & $0.0 E+00$ & $0.0 \mathrm{E}+00$ & $0.0 \mathrm{E}+00$ & $0.0 E+00$ & $0.0 \mathrm{E}+00$ & $0.0 E+00$ & $0.0 E+00$ \\
\hline SSW & $0.0 \mathrm{E}+00$ & $0.0 \mathrm{E}+00$ & $0.0 \mathrm{E}+00$ & $0.0 E+00$ & $0.0 \mathrm{E}+00$ & $0.0 E+00$ & $0.0 \mathrm{E}+00$ \\
\hline$S$ & $3.2 E+01$ & $2.7 \mathrm{E}+01$ & $2.3 E+01$ & $5.5 E+00$ & $1.9 E+00$ & $6.6 \mathrm{E}-01$ & $2.3 E-01$ \\
\hline SSE & $0.0 E+00$ & $0.0 E+00$ & $0.0 \mathrm{E}+00$ & $0.0 E+00$ & $0.0 \mathrm{E}+00$ & $0.0 E+00$ & $0.0 E+00$ \\
\hline SE & $0.0 E+00$ & $0.0 \mathrm{E}+00$ & $0.0 \mathrm{E}+00$ & $0.0 E+00$ & $0.0 E+00$ & $0.0 E+00$ & $0.0 \mathrm{E}+00$ \\
\hline ESE & $0.0 \mathrm{E}+00$ & $0.0 \mathrm{E}+00$ & $0.0 \mathrm{E}+00$ & $0.0 E+00$ & $0.0 \mathrm{E}+00$ & $0.0 \mathrm{E}+00$ & $0.0 \mathrm{E}+00$ \\
\hline $\mathrm{E}$ & $0.0 E+00$ & $0.0 \mathrm{E}+00$ & $0.0 \mathrm{E}+00$ & $0.0 E+00$ & $0.0 \mathrm{E}+00$ & $0.0 E+00$ & $0.0 E+00$ \\
\hline ENE & $0.0 E+00$ & $0.0 E+00$ & $0.0 \mathrm{E}+00$ & $0.0 E+00$ & $0.0 E+00$ & $0.0 \mathrm{E}+00$ & $0.0 E+00$ \\
\hline $\mathrm{NE}$ & $0.0 E+00$ & $0.0 E+00$ & $0.0 E+00$ & $0.0 E+00$ & $0.0 E+00$ & $0.0 \mathrm{E}+00$ & $0.0 E+00$ \\
\hline NNE & $0.0 \mathrm{E}+00$ & $0.0 E+00$ & $0.0 \mathrm{E}+00$ & $0.0 E+00$ & $0.0 E+00$ & $0.0 \mathrm{E}+00$ & $0.0 E+00$ \\
\hline
\end{tabular}




\section{B-114}

May $13,19972: 07 \mathrm{pm}$

INDIVIDUAL EFFECTIVE DOSE EQUIVALENT RATE (mrem/y)

(AIl Radionuclides and Pathways)

\begin{tabular}{|c|c|c|c|c|c|c|}
\hline \multirow[b]{2}{*}{ Direction } & \multicolumn{6}{|c|}{ Distance (m) } \\
\hline & 30000 & 40000 & 50000 & 60000 & 70000 & 80000 \\
\hline $\mathrm{N}$ & $0.0 \mathrm{E}+00$ & $0.0 E+00$ & $0.0 E+00$ & $0.0 E+00$ & $0.0 E+00$ & $0.0 E+00$ \\
\hline NNW & $0.0 \mathrm{E}+00$ & $0.0 E+00$ & $0.0 E+00$ & $0.0 E+00$ & $0.0 E+00$ & $0.0 E+00$ \\
\hline NW & $0.0 \mathrm{E}+00$ & $0.0 E+00$ & $0.0 E+00$ & $0.0 \mathrm{E}+00$ & $0.0 E+00$ & $0.0 E+00$ \\
\hline WNW & $0.0 \mathrm{E}+00$ & $0.0 E+00$ & $0.0 E+00$ & $0.0 E+00$ & $0.0 \mathrm{E}+00$ & $0.0 E+00$ \\
\hline$W$ & $0.0 \mathrm{E}+00$ & $0.0 E+00$ & $0.0 \mathrm{E}+00$ & $0.0 E+00$ & $0.0 E+00$ & $0.0 E+00$ \\
\hline WSW & $0.0 \mathrm{E}+00$ & $0.0 \mathrm{E}+00$ & $0.0 \mathrm{E}+00$ & $0.0 \mathrm{E}+00$ & $0.0 \mathrm{E}+00$ & $0.0 E+00$ \\
\hline SW & $0.0 E+00$ & $0.0 E+00$ & $0.0 E+00$ & $0.0 \mathrm{E}+00$ & $0.0 \mathrm{E}+00$ & $0.0 E+00$ \\
\hline SSW & $0.0 \mathrm{E}+00$ & $0.0 \mathrm{E}+00$ & $0.0 E+00$ & $0.0 \mathrm{E}+00$ & $0.0 \mathrm{E}+00$ & $0.0 E+00$ \\
\hline $\mathrm{S}$ & $1.2 \mathrm{E}-01$ & $7.7 \mathrm{E}-02$ & $5.4 \mathrm{E}-02$ & $4.1 \mathrm{E}-02$ & $3.2 \mathrm{E}-02$ & $2.6 \mathrm{E}-02$ \\
\hline SSE & $0.0 E+00$ & $0.0 \mathrm{E}+00$ & $0.0 E+00$ & $0.0 \mathrm{E}+00$ & $0.0 E+00$ & $0.0 \mathrm{E}+00$ \\
\hline$S E$ & $0.0 E+00$ & $0.0 \mathrm{E}+00$ & $0.0 E+00$ & $0.0 \mathrm{E}+00$ & $0.0 E+00$ & $0.0 E+00$ \\
\hline ESE & $0.0 E+00$ & $0.0 \mathrm{E}+00$ & $0.0 E+00$ & $0.0 \mathrm{E}+00$ & $0.0 E+00$ & $0.0 E+00$ \\
\hline $\mathrm{E}$ & $0.0 E+00$ & $0.0 \mathrm{E}+00$ & $0.0 E+00$ & $0.0 E+00$ & $0.0 E+00$ & $0.0 E+00$ \\
\hline ENE & $0.0 E+00$ & $0.0 E+00$ & $0.0 E+00$ & $0.0 E+00$ & $0.0 E+00$ & $0.0 \mathrm{E}+00$ \\
\hline $\mathrm{NE}$ & $0.0 E+00$ & $0.0 E+00$ & $0.0 E+00$ & $0.0 \mathrm{E}+00$ & $0.0 E+00$ & $0.0 E+00$ \\
\hline NNE & $0.0 E+00$ & $0.0 E+00$ & $0.0 E+00$ & $0.0 \mathrm{E}+00$ & $0.0 E+00$ & $0.0 \mathrm{E}+00$ \\
\hline
\end{tabular}


May $13,1997 \quad 2: 07 \mathrm{pm}$

SUMMARY

Page 7

INDIVIDUAL LIFETIME RISK (deaths)

(All Radionuclides and Pathways)

\begin{tabular}{|c|c|c|c|c|c|c|c|}
\hline \multicolumn{8}{|c|}{ Distance (m) } \\
\hline Direction & 100 & 200 & 300 & 400 & 500 & 600 & 700 \\
\hline $\mathrm{N}$ & $0.0 E+00$ & $0.0 E+00$ & $0.0 E+00$ & $0.0 \mathrm{E}+00$ & $0.0 \mathrm{E}+00$ & $0.0 E+00$ & $0.0 E+00$ \\
\hline $\mathrm{NNNW}$ & $0.0 \mathrm{E}+00$ & $0.0 E+00$ & $0.0 \mathrm{E}+00$ & $0.0 E+00$ & $0.0 \mathrm{E}+00$ & $0.0 E+00$ & $0.0 \mathrm{E}+00$ \\
\hline NW & $0.0 \mathrm{E}+00$ & $0.0 E+00$ & $0.0 \mathrm{E}+00$ & $0.0 E+00$ & $0.0 \mathrm{E}+00$ & $0.0 E+00$ & $0.0 \mathrm{E}+00$ \\
\hline WNW & $0.0 E+00$ & $0.0 E+00$ & $0.0 \mathrm{E}+00$ & $0.0 E+00$ & $0.0 E+00$ & $0.0 \mathrm{E}+00$ & $0.0 \mathrm{E}+00$ \\
\hline W & $0.0 E+00$ & $0.0 E+00$ & $0.0 \mathrm{E}+00$ & $0.0 E+00$ & $0.0 E+00$ & $0.0 \mathrm{E}+00$ & $0.0 \mathrm{E}+00$ \\
\hline WSW & $0.0 E+00$ & $0.0 E+00$ & $0.0 \mathrm{E}+00$ & $0.0 E+00$ & $0.0 E+00$ & $0.0 E+00$ & $0.0 \mathrm{E}+00$ \\
\hline SW & $0.0 \mathrm{E}+00$ & $0.0 \mathrm{E}+00$ & $0.0 \mathrm{E}+00$ & $0.0 E+00$ & $0.0 E+00$ & $0.0 E+00$ & $0.0 E+00$ \\
\hline SSW & $0.0 \mathrm{E}+00$ & $0.0 \mathrm{E}+00$ & $0.0 \mathrm{E}+00$ & $0.0 \mathrm{E}+00$ & $0.0 E+00$ & $0.0 E+00$ & $0.0 \mathrm{E}+00$ \\
\hline $\mathrm{s}$ & $5.2 E-05$ & $1.3 E-03$ & $1.8 \mathrm{E}-03$ & $1.6 \mathrm{E}-03$ & $1.4 \mathrm{E}-03$ & $1.1 \mathrm{E}-03$ & $9.2 E-04$ \\
\hline $\mathrm{SSE}$ & $0.0 E+00$ & $0.0 E+00$ & $0.0 E+00$ & $0.0 \mathrm{E}+00$ & $0.0 E+00$ & $0.0 E+00$ & $0.0 E+00$ \\
\hline$S E$ & $0.0 E+00$ & $0.0 E+00$ & $0.0 E+00$ & $0.0 E+00$ & $0.0 E+00$ & $0.0 \mathrm{E}+00$ & $0.0 \mathrm{E}+00$ \\
\hline ESE & $0.0 E+00$ & $0.0 E+00$ & $0.0 E+00$ & $0.0 E+00$ & $0.0 E+00$ & $0.0 E+00$ & $0.0 E+00$ \\
\hline$E$ & $0.0 \mathrm{E}+00$ & $0.0 E+00$ & $0.0 \mathrm{E}+00$ & $0.0 E+00$ & $0.0 E+00$ & $0.0 \mathrm{E}+00$ & $0.0 E+00$ \\
\hline ENE & $0.0 \mathrm{E}+00$ & $0.0 E+00$ & $0.0 E+00$ & $0.0 E+00$ & $0.0 E+00$ & $0.0 \mathrm{E}+00$ & $0.0 E+00$ \\
\hline $\mathrm{NE}$ & $0.0 E+00$ & $0.0 E+00$ & $0.0 E+00$ & $0.0 E+00$ & $0.0 \mathrm{E}+00$ & $0.0 E+00$ & $0.0 E+00$ \\
\hline NNE & $0.0 E+00$ & $0.0 E+00$ & $0.0 E+00$ & $0.0 \mathrm{E}+00$ & $0.0 E+00$ & $0.0 \mathrm{E}+00$ & $0.0 \mathrm{E}+00$ \\
\hline \multicolumn{8}{|c|}{ Distance (m) } \\
\hline Direction & 800 & 900 & 1000 & 2500 & 5000 & 10000 & 20000 \\
\hline $\mathrm{N}$ & $0.0 \mathrm{E}+00$ & $0.0 E+00$ & $0.0 \mathrm{E}+00$ & $0.0 E+00$ & $0.0 E+00$ & $0.0 E+00$ & $0.0 E+00$ \\
\hline NNW & $0.0 E+00$ & $0.0 E+00$ & $0.0 E+00$ & $0.0 E+00$ & $0.0 E+00$ & $0.0 E+00$ & $0.0 E+00$ \\
\hline NW & $0.0 \mathrm{E}+00$ & $0.0 \mathrm{E}+00$ & $0.0 E+00$ & $0.0 \mathrm{E}+00$ & $0.0 E+00$ & $0.0 \mathrm{E}+00$ & $0.0 \mathrm{E}+00$ \\
\hline WNW & $0.0 \mathrm{E}+00$ & $0.0 E+00$ & $0.0 E+00$ & $0.0 E+00$ & $0.0 E+00$ & $0.0 E+00$ & $0.0 E+00$ \\
\hline$w$ & $0.0 E+00$ & $0.0 E+00$ & $0.0 \mathrm{E}+00$ & $0.0 E+00$ & $0.0 E+00$ & $0.0 E+00$ & $0.0 E+00$ \\
\hline WSW & $0.0 \mathrm{E}+00$ & $0.0 E+00$ & $0.0 E+00$ & $0.0 E+00$ & $0.0 E+00$ & $0.0 \mathrm{E}+00$ & $0.0 \mathrm{E}+00$ \\
\hline SW & $0.0 \mathrm{E}+00$ & $0.0 \mathrm{E}+00$ & $0.0 E+00$ & $0.0 E+00$ & $0.0 E+00$ & $0.0 \mathrm{E}+00$ & $0.0 E+00$ \\
\hline SSW & $0.0 E+00$ & $0.0 E+00$ & $0.0 E+00$ & $0.0 E+00$ & $0.0 E+00$ & $0.0 \mathrm{E}+00$ & $0.0 E+00$ \\
\hline $\mathrm{S}$ & $7.6 \mathrm{E}-04$ & $6.4 \mathrm{E}-04$ & $5.4 E-04$ & 1. $3 E-04$ & $4.5 E-05$ & $1.6 E-05$ & $5.4 \mathrm{E}-06$ \\
\hline SSE & $0.0 E+00$ & $0.0 E+00$ & $0.0 E+00$ & $0.0 E+00$ & $0.0 E+00$ & $0.0 E+00$ & $0.0 E+00$ \\
\hline $\mathrm{SE}$ & $0.0 E+00$ & $0.0 E+00$ & $0.0 E+00$ & $0.0 E+00$ & $0.0 \mathrm{E}+00$ & $0.0 E+00$ & $0.0 E+00$ \\
\hline ESE & $0.0 E+00$ & $0.0 E+00$ & $0.0 \mathrm{E}+00$ & $0.0 \mathrm{E}+00$ & $0.0 \mathrm{E}+00$ & $0.0 \mathrm{E}+00$ & $0.0 \mathrm{E}+00$ \\
\hline$E$ & $0.0 E+00$ & $0.0 E+00$ & $0.0 E+00$ & $0.0 E+00$ & $0.0 E+00$ & $0.0 E+00$ & $0.0 E+00$ \\
\hline ENE & $0.0 E+00$ & $0.0 \mathrm{E}+00$ & $0.0 E+00$ & $0.0 E+00$ & $0.0 E+00$ & $0.0 E+00$ & $0.0 E+00$ \\
\hline $\mathrm{NE}$ & $0.0 E+00$ & $0.0 E+00$ & $0.0 \mathrm{E}+00$ & $0.0 E+00$ & $0.0 E+00$ & $0.0 E+00$ & $0.0 \mathrm{E}+00$ \\
\hline NNE & $0.0 E+00$ & $0.0 E+00$ & $0.0 E+00$ & $0.0 \mathrm{E}+00$ & $0.0 E+00$ & $0.0 E+00$ & $0.0 E+00$ \\
\hline
\end{tabular}


INDIVIDUAI LIFETIME RISK (deaths)

(AlI Radionuclides and Pathways)

\begin{tabular}{|c|c|c|c|c|c|c|}
\hline \multirow[b]{2}{*}{ Direction } & \multicolumn{6}{|c|}{ Distance (m) } \\
\hline & 30000 & 40000 & 50000 & 60000 & 70000 & 80000 \\
\hline $\mathrm{N}$ & $0.0 E+00$ & $0.0 \mathrm{E}+00$ & $0.0 \mathrm{E}+00$ & $0.0 E+00$ & $0.0 E+00$ & $0.0 E+00$ \\
\hline NNW & $0.0 E+00$ & $0.0 \mathrm{E}+00$ & $0.0 \mathrm{E}+00$ & $0.0 E+00$ & $0.0 E+00$ & $0.0 E+00$ \\
\hline NW & $0.0 E+00$ & $0.0 \mathrm{E}+00$ & $0.0 E+00$ & $0.0 E+00$ & $0.0 E+00$ & $0.0 E+00$ \\
\hline WNW & $0.0 \mathrm{E}+00$ & $0.0 E+00$ & $0.0 \mathrm{E}+00$ & $0.0 E+00$ & $0.0 E+00$ & $0.0 \mathrm{E}+00$ \\
\hline$W$ & $0.0 E+00$ & $0.0 \mathrm{E}+00$ & $0.0 E+00$ & $0.0 E+00$ & $0.0 E+00$ & $0.0 \mathrm{E}+00$ \\
\hline WSW & $0.0 E+00$ & $0.0 \mathrm{E}+00$ & $0.0 \mathrm{E}+00$ & $0.0 E+00$ & $0.0 E+00$ & $0.0 E+00$ \\
\hline SW & $0.0 E+00$ & $0.0 E+00$ & $0.0 \mathrm{E}+00$ & $0.0 E+00$ & $0.0 E+00$ & $0.0 \mathrm{E}+00$ \\
\hline SSW & $0.0 E+00$ & $0.0 E+00$ & $0.0 \mathrm{E}+00$ & $0.0 E+00$ & $0.0 E+00$ & $0.0 \mathrm{E}+00$ \\
\hline$S$ & $2.9 E-06$ & $1.9 E-06$ & $1.3 E-06$ & $9.7 E-07$ & $7.6 E-07$ & $6.2 E-07$ \\
\hline SSE & $0.0 E+00$ & $0.0 E+00$ & $0.0 \mathrm{E}+00$ & $0.0 E+00$ & $0.0 \mathrm{E}+00$ & $0.0 E+00$ \\
\hline$S E$ & $0.0 E+00$ & $0.0 E+00$ & $0.0 \mathrm{E}+00$ & $0.0 E+00$ & $0.0 \mathrm{E}+00$ & $0.0 E+00$ \\
\hline ESE & $0.0 E+00$ & $0.0 E+00$ & $0.0 \mathrm{E}+00$ & $0.0 E+00$ & $0.0 \mathrm{E}+00$ & $0.0 \mathrm{E}+00$ \\
\hline$E$ & $0.0 E+00$ & $0.0 E+00$ & $0.0 E+00$ & $0.0 E+00$ & $0.0 E+00$ & $0.0 E+00$ \\
\hline ENE & $0.0 E+00$ & $0.0 E+00$ & $0.0 E+00$ & $0.0 E+00$ & $0.0 E+00$ & $0.0 E+00$ \\
\hline NE & $0.0 E+00$ & $0.0 E+00$ & $0.0 \mathrm{E}+00$ & $0.0 \mathrm{E}+00$ & $0.0 \mathrm{E}+00$ & $0.0 \mathrm{E}+00$ \\
\hline NNE & $0.0 E+00$ & $0.0 E+00$ & $0.0 \mathrm{E}+00$ & $0.0 \mathrm{E}+00$ & $0.0 E+00$ & $0.0 \mathrm{E}+00$ \\
\hline
\end{tabular}


APPENDIX C:

DEFINITIONS OF VARIABLES PRESENTED IN THE SPREADSHEET CALCULATIONS 


$$
C-i i
$$




\section{APPENDIX C:}

\section{DEFINITIONS OF VARIABLES PRESENTED \\ IN THE SPREADSHEET CALCULATIONS}

$\Delta \mathrm{h}$

$\lambda(i)$

$\lambda_{b}(i, j, k)$

$\lambda g$

$\lambda_{\mathrm{m}}(\mathrm{i}, \mathrm{j}, \mathrm{k})$

$\lambda_{\mathrm{r}}$

$\lambda_{\mathrm{ve}}$

$\lambda_{\mathrm{vw}_{\mathrm{w}}}$

$\lambda_{\mathrm{w}}(\mathrm{x}, \mathrm{y})$

$\rho$

$\sigma_{\theta}$

$\sigma_{\mathrm{y}}$

$\sigma_{y}^{\prime}$

$\sigma_{\mathrm{yo}}$

$\sigma_{\mathrm{z}}$

$\sigma_{z}^{\prime}$

$\sigma_{z 0}$

$\Psi$

a

$\mathrm{a}(\mathrm{i}, \mathrm{j}, \mathrm{k})$

$A_{\mathrm{ig}}$

$A_{\text {in }}$

Plume rise (m).

Radioactive decay constant for radionuclide $\mathrm{i}(1 / \mathrm{yr})$.

Biological removal constant for radionuclide $\mathrm{i}$ in subcompartment $\mathrm{j}$ of organ $\mathrm{k}$ $(1 / d)$.

Rate constant for environmental loss (1/yr).

Minimum decay constant (longest half-life) of radionuclide $i$ from all subcompartments $\mathrm{j}$ from organ $\mathrm{k}(1 / \mathrm{d})$; minimum value of $\lambda_{\mathrm{b}}(\mathrm{i}, \mathrm{j}, \mathrm{k})$ over all $\mathrm{j}$.

Resuspension decay constant (1/yr).

Effective decay constant, accounts for radioactive decay and weathering losses (1/d).

Decay constant for weathering losses (1/d).

Water exchange rate for water body at location $x, y(1 / y r)$.

Effective surface density of the soil $\left(\mathrm{kg} / \mathrm{m}^{2}\right)$.

Pasquill-Gifford dispersion parameter (unitless).

Effective horizontal dispersion coefficient adjusted for initial puff size and buoyancy-induced dispersion $(\mathrm{m})$.

Horizontal dispersion coefficient adjusted for initial puff size (m).

Initial value for the horizontal dispersion coefficient at the source location (m).

Effective vertical dispersion coefficient adjusted for initial puff size and buoyancy-induced dispersion (m).

Vertical dispersion coefficient adjusted for initial puff size (m).

Initial value for the vertical dispersion coefficient at the source location (m).

Angle subtended by the centerline and the edge of the cask, as viewed by the receptor (rad).

Briggs or Pasquill-Gifford dispersion parameter.

Fraction of radionuclide $\mathrm{i}$ originally absorbed in subcompartment $\mathrm{j}$ of organ $\mathrm{k}$ (unitless).

Fitted coefficients ( $i=0$ to 7 ) in the empirical formula for the shipping package gamma dose rate curve (unitless).

Fitted coefficients ( $\mathrm{i}=0$ to 7 ) in the empirical formula for the shipping package neutron dose rate curve (unitless). 
ALPHA Cask impact angle. The impact angle is the angle between the cask velocity (the direction along which the cask is traveling) and the plane of the surface struck (degree).

b

$\mathrm{B}_{\mathrm{v}}(\mathrm{i})$

BR

c

$\mathrm{C}_{\mathrm{a}}(\mathrm{i}, \mathrm{x}, \mathrm{y})$

$\mathrm{C}_{\mathrm{bI}}(\mathrm{i}, \mathrm{T})$

$\mathrm{C}_{\mathrm{bLT}}(\mathrm{i}, \mathrm{T})$

$\mathrm{C}_{\mathrm{g}}(\mathrm{i}, \mathrm{x}, \mathrm{y}, \mathrm{T})$

$\mathrm{C}_{\mathrm{ml}}(\mathrm{i}, \mathrm{T})$

$\mathrm{C}_{\mathrm{mLT}}(\mathrm{i}, \mathrm{T})$

$\mathrm{C}_{\mathrm{r}}(\mathrm{i}, \mathrm{x}, \mathrm{y}, \mathrm{T})$

$\mathrm{C}_{\mathrm{Vdep}}$ (i)

$\mathrm{C}_{\mathrm{vll}}(\mathrm{i}, \mathrm{x}, \mathrm{y}, \mathrm{T})$

$\mathrm{C}_{\mathrm{w}}(\mathrm{i}, \mathrm{x}, \mathrm{y}, \mathrm{T})$

$\mathrm{CF}_{\mathrm{b}}$

$\mathrm{CF}_{\mathrm{m}}$

$\mathrm{CF}_{\mathrm{y}}$

$\mathrm{CF}_{\mathrm{w}}$

d

$\mathrm{D}$

$\frac{\partial \mathrm{T}_{\mathrm{a}}}{\partial \mathrm{z}}+\ell$

$\mathrm{D}_{\text {AirLT }}$
Briggs or Pasquill-Gifford dispersion parameter.

Soil-to-plant transfer factor for radionuclide i (unitless).

Breathing rate for the receptor $\left(\mathrm{m}^{3} / \mathrm{yr}\right)$.

Briggs or Pasquill-Gifford dispersion parameter.

Time-integrated ground-level air concentration for radionuclide $\mathrm{i}\left(\mathrm{Ci}-\mathrm{s} / \mathrm{m}^{3}\right)$.

Concentration in meat for radionuclide $\mathrm{i}$ from initial deposition on vegetation (Ci/kg).

Time-integrated concentration in meat for radionuclide $i$, excluding from initial deposition on vegetation ( $\mathrm{Ci}-\mathrm{s} / \mathrm{kg}$ ).

Time-integrated ground concentration of radionuclide $\mathrm{i}$ at receptor location $\mathrm{x}, \mathrm{y}$ at time $\mathrm{T}$ following a release $\left(\mathrm{Ci}-\mathrm{s} / \mathrm{m}^{2}\right)$.

Concentration in milk for radionuclide $\mathrm{i}$ from initial deposition on vegetation $(\mathrm{Ci} / \mathrm{kg})$.

Time-integrated concentration in milk for radionuclide $i$, excluding from initial deposition on vegetation $(\mathrm{Ci}-\mathrm{s} / \mathrm{kg})$.

Time-integrated resuspended air concentration of radionuclide $i$ at receptor location $\mathrm{x}, \mathrm{y}$ after time $\mathrm{T}$ following release $\left(\mathrm{Ci}-\mathrm{s} / \mathrm{m}^{3}\right)$.

Vegetation concentration of radionuclide $\mathrm{i}$ at location $\mathrm{x}, \mathrm{y}$ from direct deposition from the passing plume $(\mathrm{Ci} / \mathrm{kg})$.

Long-term time-integrated vegetation concentration of radionuclide $i$ at receptor location $\mathrm{x}, \mathrm{y}$ after time $\mathrm{T}$ following release, excluding direct deposition ( $\mathrm{Ci}-\mathrm{s} / \mathrm{kg}$ ).

Time-integrated radionuclide $\mathrm{i}$ concentration in water body at location $\mathrm{x}, \mathrm{y}$ at time $\mathrm{T}$ after puff passage $\left(\mathrm{Ci}-\mathrm{yr} / \mathrm{m}^{3}\right)$.

Fraction of consumed meat that is contaminated (unitless).

Fraction of consumed milk that is contaminated (unitless).

Fraction of consumed vegetables that are contaminated (unitless).

Fraction of consumed water that is contaminated (unitless).

Receptor distance from cask surface for shape factor correction (m).

Reference distance (1 or $2 \mathrm{~m}$ ) for shape factor correction calculations $(\mathrm{m})$.

Potential temperature lapse rate $[0.002$ and 0.035 for stability classes $\mathrm{E}$ and $\mathrm{F}$ respectively] $(\mathrm{K} / \mathrm{m})$.

Dose to receptor from long-term external radiation exposure from resuspended contamination (rem). 
$\mathrm{D}_{\text {AirST }} \quad$ External dose to receptor from air submersion during plume passage (rem).

$\mathrm{D}_{50, \mathrm{~B}}(\mathrm{k}) \quad$ Median lethal dose, brief dose to organ $\mathrm{k}$ that produces the effect of interest in $50 \%$ of the population at risk (Gy).

$\mathrm{D}_{50, \mathrm{P}}(\mathrm{k}) \quad$ Median lethal dose, protracted dose to organ $\mathrm{k}$ that produces the effect of interest in $50 \%$ of the population at risk (Gy).

$D_{B}(i) \quad$ Brief dose to organ $\mathrm{i}(\mathrm{i}=$ bone, GI, or lung) (Gy).

$\mathrm{D}_{\text {GndLT }} \quad$ Dose to receptor from long-term external radiation exposure from ground contamination (rem).

$\mathrm{D}_{\text {GndST }}$

Short-term external dose from ground-deposited contamination (rem).

$\mathrm{D}_{\text {InhLT }}$

$\mathrm{D}_{\text {InhST }}$

Dose to receptor from long-term inhalation of resuspended contamination (rem).

$\mathrm{D}_{\text {MealLT }}(\mathrm{i})$

Short-term dose to receptor from inhalation during plume passage (rem).

$\mathrm{D}_{\text {MeatST }}(\mathrm{i})$

Long-term dose to receptor from ingestion of meat contaminated with radionuclide $i$, excluding that from initial deposition (rem).

$\mathrm{D}_{\text {MikLT }}(\mathrm{i}) \quad$ Long-term dose to receptor from ingestion of milk contaminated with radionuclide $i$, excluding that from initial deposition (rem).

$\mathrm{D}_{\text {MilkST }}$ (i) Short-term dose to receptor from ingestion of milk contaminated with radionuclide $\mathrm{i}$ (rem).

$\mathrm{D}_{\mathrm{p}}(\mathrm{i})$

$\mathrm{D}_{\mathrm{vegLT}}$

$\mathrm{D}_{\mathrm{vegST}}$

$\mathrm{D}_{\text {Water }}$

Protracted dose to organ i ( $\mathrm{i}=$ bone, GI, or lung) (Gy).

$\mathrm{DCF}_{\text {Air }}(\mathrm{i})$

Long-term dose to receptor from ingestion of contaminated vegetables (rem).

Short-term dose to receptor from ingestion of contaminated vegetables (rem).

Dose to receptor from ingestion of contaminated water (rem).

$\mathrm{DCF}_{\mathrm{Gnd}}(\mathrm{i})$

Dose conversion factor for air submersion for radionuclide $\mathrm{i}\left(\mathrm{Sv} / \mathrm{Bq}-\mathrm{s} / \mathrm{m}^{3}\right)$.

Dose conversion factor for external radiation from the ground for radionuclide $\mathrm{i}$ $\left(\mathrm{Sv} / \mathrm{Bq}-\mathrm{s} / \mathrm{m}^{2}\right)$.

$\mathrm{DCF}_{\mathrm{Ing}}(\mathrm{i}) \quad$ Dose conversion factor for ingestion for radionuclide $\mathrm{i}(\mathrm{Sv} / \mathrm{Bq})$.

$\mathrm{DCF}_{\text {Inh }}(\mathrm{i})$

Dose conversion factor for inhalation for radionuclide i ( $\mathrm{Sv} / \mathrm{Bq})$.

$\mathrm{DF}$

Decontamination factor, that is, the fraction of contamination remaining on vegetation after food preparation at time of consumption (unitless).

$\mathrm{DR}_{\mathrm{B}}(\mathrm{i}) \quad$ Average brief dose rate to organ $\mathrm{i}(\mathrm{i}=$ bone, $\mathrm{GI}$, or lung) $(\mathrm{Gy} / \mathrm{h})$.

$\mathrm{DR}_{\mathrm{i}}(\mathrm{r}) \quad$ Dose rate $(\mathrm{mrem} / \mathrm{h})$ from gamma radiation $(\mathrm{i}=\mathrm{g})$, neutron radiation $(\mathrm{i}=\mathrm{n})$, or both ( $i=0$ for the reference cask [before shape factor correction], $i=1$ after shape factor correction) at a distance $r$ meters from the cask surface.

$\mathrm{DR}_{\mathrm{p}}(\mathrm{i}) \quad$ Average protracted dose rate to organ $\mathrm{i}(\mathrm{i}=$ bone, GI, or lung) $(\mathrm{Gy} / \mathrm{h})$. 
$\mathrm{E}_{\mathrm{p}} \quad$ Release elevation, reference point for the release height $(0 \mathrm{~m})$.

$\mathrm{E}_{\mathrm{r}} \quad$ Receptor elevation $(\mathrm{m})$.

$\mathrm{E}_{\mathrm{vk}} \quad$ Fraction of foliar deposition reaching edible portions of vegetation type $\mathrm{k}$ (for human consumption, $\mathrm{k}=\mathrm{h}$, or pasture grass for animal consumption, $\mathrm{k}=\mathrm{a}$ ) (unitless)

$\mathrm{E}_{\mathrm{w}} \quad$ Water treatment efficiency, fraction of contamination removed by water treatment facilities before use $(0=$ no contamination removed, $1=$ all contamination removed) (unitless).

$f_{i} \quad$ Fraction of total dose rate due to gamma $(i=g)$ or neutron $(i=n)$ radiation where $f_{g}+f_{n}=1$.

$\mathrm{F}(\Psi, \mathrm{k}) \quad \int_{0}^{\Psi}\left(1-\mathrm{k}^{2} \sin ^{2} \theta\right)^{-1 / 2} \mathrm{~d} \theta,(\operatorname{rad})$.

$\mathrm{F}_{\mathrm{a}}(\mathrm{x}, \mathrm{y}) \quad$ Fraction of the water body at location $\mathrm{x}, \mathrm{y}$ covered by the passing puff, assumes puff travels full distance across the water body in the downwind direction (unitless), where

$F_{a}(x, y)=\left\{\begin{array}{c}1, \text { if } F_{w}(x, y) \geq 1 \\ F_{w}(x, y), \text { if } F_{w}(x, y)<1\end{array}\right.$

$\mathrm{F}_{\mathrm{b}}(\mathrm{i}) \quad$ Feed-to-meat transfer factor for radionuclide $\mathrm{i}(\mathrm{Ci} / \mathrm{kg}$ per $\mathrm{Ci} / \mathrm{d})$.

$\mathrm{F}_{\mathrm{m}}(\mathrm{i}) \quad$ Feed-to-milk transfer factor for radionuclide $\mathrm{i}(\mathrm{Ci} / \mathrm{kg}$ per $\mathrm{Ci} / \mathrm{d})$.

$\mathrm{F}_{\mathrm{r}} \quad$ Fraction of deposition retained on the plant (unitless).

$F_{w}(x, y) \quad$ When less than 1, fraction of the water body at location $x, y$ covered by the passing puff, assumes puff travels full distance across the water body in the downwind direction (unitless).

FE Final value of the resuspension factor (1/yr).

FI Initial value of the resuspension factor for fresh deposits $(1 / \mathrm{m})$.

h Physical release height $(\mathrm{m})$.

$\mathrm{H} \quad$ Effective release height (m).

$\mathrm{H}_{\mathrm{A}}(\mathrm{k}) \quad$ Lethality hazard for organ $\mathrm{k}$ (unitless).

HSIZE Length of user cask (m).

$1 \quad$ Normal adiabatic lapse rate of the atmosphere $(0.0098 \mathrm{~K} / \mathrm{m})$.

L Mixing layer height sometimes referred to as lid height (m).

$\mathrm{L}_{0} \quad$ Length of reference cask (m).

$\mathrm{L}_{1} \quad$ Length of user cask $(\mathrm{m})$.

$\mathrm{OF}_{\mathrm{in}} \quad$ Fraction of time spent indoors (unitless). 


\begin{tabular}{|c|c|}
\hline $\mathrm{OF}_{\text {out }}$ & Fraction of time spent outdoors (unitless). \\
\hline $\mathrm{p}$ & Power for height ratio (unitless). \\
\hline$P_{c}$ & Plume-path coefficient (unitless). \\
\hline$Q(d)$ & $\begin{array}{l}\text { Shape factor correction. Ratio of the external dose rates at a distance d meters } \\
\text { from the surfaces of the new cask and the reference cask (unitless). }\end{array}$ \\
\hline $\mathrm{Q}_{\mathrm{a}}$ & Animal feed ingestion rate $(\mathrm{kg} / \mathrm{d})$. \\
\hline $\mathrm{Q}_{\mathrm{h}}$ & Heat flux from radionuclide release area $(\mathrm{cal} / \mathrm{s})$. \\
\hline$Q_{x i}$ & Depleted source strength of nuclide $\mathrm{i}$ at distance $\mathrm{x}(\mathrm{Ci})$. \\
\hline $\mathrm{r}$ & $\begin{array}{l}\text { Distance in meters from the cask surface; } r=r_{0}+r_{1} \text {, where } r_{0} \text { is the distance from } \\
\text { the outer lateral surface of the vehicle and } r_{1} \text { is the distance between the cask } \\
\text { surface and the outer lateral surface of the vehicle. }\end{array}$ \\
\hline $\mathrm{R}_{0}$ & Radius of reference cask (m). \\
\hline $\mathrm{R}_{1}$ & Radius of user cask (m). \\
\hline $\mathrm{R}(\mathrm{i}, \mathrm{k}, \mathrm{t})$ & Time-integrated retention of radionuclide $\mathrm{i}$ in organ $\mathrm{k}$ after time $\mathrm{t}$ (unitless). \\
\hline RSIZE & Radius of user cask (m). \\
\hline $\mathrm{s}$ & Stability parameter $\left(\mathrm{s}^{-2}\right)$ \\
\hline $\mathrm{SF}_{\text {AirLT }}$ & $\begin{array}{l}\text { Long-term shielding factor for air immersion, from } 0 \text { for full shielding to } 1 \text { for no } \\
\text { shielding (unitless). }\end{array}$ \\
\hline $\mathrm{SF}_{\mathrm{AirST}}$ & $\begin{array}{l}\text { Short-term shielding factor for air immersion, from } 0 \text { for full shielding to } 1 \text { for no } \\
\text { shielding (unitless). }\end{array}$ \\
\hline $\mathrm{SF}_{\text {GndLT }}$ & $\begin{array}{l}\text { Long-term shielding factor for external ground radiation, from } 0 \text { for full shielding } \\
\text { to } 1 \text { for no shielding (unitless). }\end{array}$ \\
\hline $\mathrm{SF}_{\text {GndsT }}$ & $\begin{array}{l}\text { Short-term shielding factor for external ground radiation, from } 0 \text { for full shielding } \\
\text { to } 1 \text { for no shielding (unitless). }\end{array}$ \\
\hline $\mathrm{SF}_{\mathrm{InhLT}}$ & $\begin{array}{l}\text { Long-term shielding factor for resuspended contaminant inhalation, from } 0 \text { for } \\
\text { full shielding to } 1 \text { for no shielding (unitless). }\end{array}$ \\
\hline $\mathrm{SF}_{\text {InhST }}$ & $\begin{array}{l}\text { Short-term shielding factor for inhalation, from } 0 \text { for full shielding to } 1 \text { for no } \\
\text { shielding (unitless). }\end{array}$ \\
\hline $\mathrm{SF}_{\mathrm{kAir}}$ & Shielding factor afforded by shelter type $\mathrm{k}$ for air immersion (unitless). \\
\hline $\mathrm{SF}_{\mathrm{kGnd}}$ & Shielding factor afforded by shelter type $\mathrm{k}$ for external ground radiation (unitless). \\
\hline $\mathrm{SF}_{\mathrm{knh}}$ & Shielding factor afforded by shelter type $\mathrm{k}$ for inhalation (unitless). \\
\hline$t_{\mathrm{vk}}$ & $\begin{array}{l}\text { Time duration for growing season for vegetation type } k \text { (for human consumption, } \\
k=h \text {, or pasture grass for animal consumption, } k=a \text { ) }(d) \text {. }\end{array}$ \\
\hline
\end{tabular}


$t_{1}$

$\mathrm{t}_{2}$

$\mathrm{T}$

$\mathrm{T}_{\mathrm{a}}$

$\mathrm{T}_{\mathrm{a}}$

$T_{b}(i, j, k)$

$\mathrm{T}_{\text {Ext }}$

$\mathrm{T}_{\mathrm{v} k}$

$\mathrm{U}_{\mathrm{a}}$

$\mathrm{U}_{\mathrm{b}}$

$\mathrm{U}_{\mathrm{H}}$

$\mathrm{U}_{\mathrm{m}}$

$\mathrm{U}_{\mathrm{v}}$

$\mathrm{U}_{\mathrm{w}}$

V

$\mathrm{V}_{\mathrm{d}}$

VCASK

$\mathrm{W}_{\mathrm{c}}(\mathrm{x}, \mathrm{y})$

$\mathrm{W}_{\mathrm{d}}(\mathrm{x}, \mathrm{y})$

$\mathrm{X}$

$\mathrm{X}(\mathrm{k})$

$\mathrm{X}_{\mathrm{B}}(\mathrm{k})$

$\mathrm{X}_{\mathrm{p}}(\mathrm{k})$

$\mathrm{X}_{\text {Yvirt }}$

$\mathrm{X}_{\text {Zvirt }}$

Time since exposure; smaller of $1 \mathrm{~d}$ or the estimated half-life of a given radionuclide in the organ of interest for brief exposures, or the smaller of organ specific retention times or the estimated half-life of a given radionuclide in the organ of interest for protracted exposures (d).

Time since exposure, smaller of $365 \mathrm{~d}$ or estimated half-life of a given radionuclide in the organ of interest (d).

Time following accidental release (yr).

Ambient air temperature $(K)$ in plume rise calculations.

For resuspension calculations, time required for the resuspension factor to decrease from its initial to final value $(\mathrm{yr}) ; \mathrm{t}=\mathrm{T}_{\mathrm{a}}$ when:

$\mathrm{FE}=\mathrm{FI} \exp \left(-\lambda_{\mathrm{r}} \mathrm{T}_{\mathrm{a}}\right)$

Biological half-life of radionuclide $i$ in subcompartment $j$ of organ $k(d)$.

Short-term exposure time for receptor after plume passage (h).

Time from accidental release to first harvest of vegetation type $\mathrm{k}$ (for human consumption, $k=h$, or pasture grass for animal consumption, $k=a)(d)$.

Wind speed at measurement height $(\mathrm{m} / \mathrm{s})$.

Human consumption rate of meat $(\mathrm{kg} / \mathrm{d})$.

Average wind speed at the effective release height $(\mathrm{m} / \mathrm{s})$.

Human consumption rate of milk (kg/d).

Human consumption rate of vegetables $(\mathrm{kg} / \mathrm{d})$.

Human consumption rate of water (L/d).

Shape parameter for lethality risk calculations (unitless).

Deposition velocity $(\mathrm{m} / \mathrm{s})$.

Speed of the cask at the time of impact (miles per hour or mph).

Cross-wind width of the water body at location $x, y(m)$.

Effective mixing depth of the water body at location $x, y(m)$.

Downwind receptor distance from the accident release point $(\mathrm{m})$.

Ratio of acute dose to organ $\mathrm{k}$ to the median lethal dose $\left(\mathrm{D}_{50}(\mathrm{k})\right)$ to organ $\mathrm{k}$ (unitless).

Ratio of the brief acute dose to organ $k$ to the brief median lethal dose $\left(D_{50, \mathrm{~B}}(\mathrm{k})\right)$ to organ k (unitless).

Ratio of the protracted acute dose to organ $\mathrm{k}$ to the median lethal dose $\left(\mathrm{D}_{50, \mathrm{P}}(\mathrm{k})\right)$ to organ $\mathrm{k}$ (unitless).

Virtual distance from source location to virtual point source for $\sigma_{\mathrm{y}}$ calculation $(\mathrm{m})$.

Virtual distance from source location to virtual point source for $\sigma_{\mathrm{z}}$ calculation (m). 
Crosswind distance from the plume centerline $(\mathrm{m})$.

$\mathrm{Y}_{\mathrm{v} k}$

Yield density of vegetation type $k$ (for human consumption, $k=h$, or pasture grass for animal consumption, $\mathrm{k}=\mathrm{a})\left(\mathrm{kg} / \mathrm{m}^{2}\right)$.

z

Vertical distance above the release point $(\mathrm{m})$.

$\mathbf{Z}_{\mathrm{a}}$ Height of anemometer for wind speed measurement (m). 